GIULLIANA MONDELLI

\title{
INVESTIGAÇÃO GEOAMBIENTAL EM ÁREAS DE DISPOSIÇÃO DE RESÍDUOS SÓLIDOS URBANOS UTILIZANDO A TECNOLOGIA DO PIEZOCONE
}

\author{
Dissertação apresentada à Escola \\ Politécnica da Universidade de São \\ Paulo para obtenção do Título de \\ Mestre em Engenharia.
}

SÃO PAULO 


\section{FICHA CATALOGRÁFICA}

\section{Mondelli, Giulliana}

Investigação geoambiental em áreas de disposição de resíduos sólidos urbanos utilizando a tecnologia do piezocone I G. Mondelli. -- São Paulo, 2004.

$264 p$.

Dissertação (Mestrado) - Escola Politécnica da Universidade de São Paulo. Departamento de Engenharia de Estruturas e Fundações.

1.Geotecnia ambiental 2.Solos (Investigação; Métodos) 3.Solo tropical 4.Aterro sanitário (Contaminação) 5.Resíduos sólidos 6.Resíduos urbanos 7.Disposição no solo I.Universidade de São Paulo. Escola Politécnica. Departamento de Engenharia de Estruturas e Fundações II.t. 


\title{
INVESTIGAÇÃO GEOAMBIENTAL EM ÁREAS DE DISPOSIÇÃO DE RESÍDUOS SÓLIDOS URBANOS UTILIZANDO A TECNOLOGIA DO PIEZOCONE
}

\author{
Dissertação apresentada à Escola \\ Politécnica da Universidade de São \\ Paulo para obtenção do Título de \\ Mestre em Engenharia. \\ Área de Concentração: Engenharia \\ Geotécnica
}

Orientador: Heraldo Luiz Giacheti

SÃO PAULO

2004 
À minha Mãe, Sarah Catarina Axcar, a quem devo parte de tudo o que eu sou, me ensinando sempre que a honestidade e a competência ainda valem a pena;

Ao meu Pai, Antonio Mondelli, por ter me confiado e me encorajado a realizar meus desejos, inclusive este;

Aos meus irmãos, Nico e Mariana Mondelli, os quais sempre estiveram ao meu lado dando muito valor em tudo o que eu faço e na minha forma de ser;

Ao meu querido Rodrigo Dini Staliano, por todo companheirismo, compreensão e amor que tem me proporcionado;

Aos meus avós, Adib Miguel Axcar (in memoriam) e Elza Broggio Axcar, por todo carinho recebido durante toda minha vida;

A todos aqueles que um dia poderão usufruir das informações contidas aqui. 


\section{AGRADECIMENTOS}

Ao Prof. Dr. Heraldo Luiz Giacheti, por toda confiança depositada em mim durante todos esses anos de trabalho, assim como todas as oportunidades surgidas e adquiridas através de seu grande empenho como profissional, não perdendo nunca a esperança de tornar as coisas cada vez melhores.

À Prof́. Dr ${ }^{a}$. Maria Eugênia Gimenez Boscov, pela grande e admirável pessoa e profissional que é, e que também auxiliou e confiou em mim para a conclusão deste trabalho.

Ao Prof. Dr. Waldemar Coelho Hachich, por todo seu empenho para que este trabalho pudesse ser realizado junto à Escola Politécnica.

Ao Prof. Dr. Vagner Roberto Elis, do IAG-USP, por sua indispensável participação durante a realização deste projeto.

Ao Prof. Dr. Jorge Hamada, do Laboratório de Resíduos Sólidos da Unesp de Bauru, por sua disposição para sanar todas as dúvidas, além de suas importantíssimas sugestões.

À Prof ${ }^{a}$. Dr ${ }^{a}$. Elizabeth de Oliveira, pelas sugestões e por permitir a realização das análises químicas em seu laboratório, no Instituto de Química da USP.

Ao Prof. Dr. Eduardo Carlos Bianchi, por toda sua compreensão, comportando-se como um raro profissional que podemos encontrar hoje em dia.

À Prof $a$. Dr ${ }^{a}$. Anna Silvia P. Peixoto, por todo auxílio recebido durante a realização deste trabalho.

Ao Eng. Hermes Luiz Bolinelli Jr., pelo trabalho em conjunto, me ajudando muito na realização deste.

À Prof ${ }^{a}$. MSc. Mônica Machado Stuermer, por todas as dúvidas sanadas durante a realização dos ensaios geoambientais de laboratório.

Aos técnicos Antonio Carlos Heitzmann e Joaquim Costa Júnior, do Laboratório de Mecânica dos Solos da EPUSP, pela amizade e por suas preciosas colaborações durante a preparação e a realização dos ensaios. 
Ao técnico Alessandro de Souza, da Faculdade de Engenharia da Unesp de Bauru (FEB), por sua fundamental ajuda durante a coleta de uma das amostras indeformadas.

Ao colega MSc. Alexandre Lisboa Lago, pela sua contribuição com os ensaios geofísicos realizados no aterro de resíduos sólidos urbanos de Bauru.

Aos funcionários Mário Martins e Elias Alves Leite, do aterro de resíduos sólidos urbanos de Bauru, pela cordialidade recebida.

Aos técnicos Felisberto Batista dos Santos, Célia Regina Garcia e José Figueiredo (FEB), pela simpatia e por estarem sempre à disposição.

Ao funcionário Gilberto S. Castilho Filho, do Departamento de Água e Esgoto de Bauru, pelo ensinamento transmitido sobre manuseio de chorume.

Às secretárias Marly Coimbra (PEF), Djanira Amaral (FEB) e demais secretárias da SPG-EPUSP, pela paciência e por todas as informações e colaborações.

À Empresa Municipal de Desenvolvimento Urbano e Rural de Bauru (EMDURB), em especial à Eng ${ }^{a}$. Roberta Oliveira Lança e ao Eng. Antonio Carlos Duarte, pelo trabalho em conjunto com a Universidade.

Ao amigo Arnaldo Fabiano Corradini, pelos vários favores concedidos durante todos esses anos.

A todos os meus amigos do Colegial, com os quais até hoje eu posso contar, me proporcionando ainda momentos de alegria e lazer.

À minha psicóloga Keila C. M. Peraçoli, por ter ajudado a me tornar uma pessoa mais consciente e segura dos meus atos.

À minha funcionária Luiza Pereira, por todas as roupas lavadas durante todas minhas vindas e idas para Bauru e São Paulo.

Aos demais professores do PEF e da FEB, pelo conhecimento adquirido.

À FAPESP, pela bolsa concedida. 


\section{RESUMO}

O principal objetivo deste trabalho foi estudar a aplicabilidade da tecnologia do piezocone na investigação geoambiental de solos tropicais a partir da realização de ensaios nas áreas onde se encontram o aterro de resíduos sólidos urbanos de Bauru e o antigo lixão de Ribeirão Preto, ambos no Estado de São Paulo. Dentro deste contexto, outros ensaios de campo e de laboratório foram analisados para um melhor entendimento do caminhamento da pluma de contaminação e dos próprios resultados dos ensaios com piezocone realizados nestas áreas de disposição de resíduos.

A tecnologia do piezocone apresentou limitações quando empregada na área do antigo lixão de Ribeirão Preto, uma vez que o impenetrável do cone foi atingido antes do nível d'água, impossibilitando assim a identificação da posição deste, a estimativa da permeabilidade do solo e a coleta de amostras de água.

Os ensaios de eletrorresistividade de superfície permitiram a detecção do formato e do sentido do caminhamento da pluma de contaminação e foram fundamentais para a orientação dos locais onde foram realizados os ensaios de piezocone e amostragem de solo e água nas duas áreas estudadas.

Os resultados dos ensaios com o piezocone de resistividade (RCPTU) realizados no aterro de resíduos sólidos urbanos de Bauru mostraram que os valores de resistividade são fortemente afetados pelo grau de saturação, gênese, textura e tipo de argilo-mineral presente na fração fina do solo. Constatou-se que o ensaio RCPTU possibilitou identificar zonas com presença de poluentes, as quais foram confirmadas a partir da análise conjunta dos resultados dos ensaios de geofísica de superfície e das amostras de solo e água coletadas com os amostradores do sistema direct-push e dos poços de monitoramento.

Este trabalho apresenta ainda resultados preliminares de ensaios de laboratório, que foram úteis para avaliar a capacidade de retenção do solo que ocorre no entorno do aterro de resíduos sólidos urbanos de Bauru para os metais Ni, Zn, Cd e $\mathrm{Pb}$. Os resultados dos ensaios de adsorção em lote e de coluna indicam que a poluição no entorno deste aterro pode estar ocorrendo de forma lenta, destacando-se a importância da continuidade do monitoramento do aqüífero local. 


\begin{abstract}
The major purpose of this dissertation is to study the applicability of the piezocone technology for geoenvironmental site investigation of tropical soils. Two waste disposal sites were investigated: a deactivated dumpsite in Ribeirão Preto and a sanitary landfill in Bauru, in São Paulo State, Brazil. Other in situ and laboratory tests were carried out in these two areas for a better understanding of the leacheate plume and of the results gathered with piezocone tests.

The piezocone technology presented limitations to investigate Ribeirão Preto site, since groundwater level is deeper than the impenetrable to the cone. For reason, it was impossible to estimate permeability and no water samples using the direct-push technology were obtained.

Geophysical tests carried out at the two studied sites allowed to detect and delineate the shape of leachate plume. They were fundamental to guide and locate the piezocone tests, soil and water sampling and monitoring wells.

The resistivity piezocone tests (RCPTU) carried out in Bauru site showed that the resistivity values are very affected by degree of saturation, genesis, fabric and clay mineral type. Geophysical tests results, soil and water samples collected by direct-push technology and by monitoring wells supported the interpretation of RCPTU tests. These tests were able to identify polluted zones.

Preliminary laboratory tests were carried out to access retention of $\mathrm{Ni}, \mathrm{Zn}$, $\mathrm{Cd}$ and $\mathrm{Pb}$ by the soil from Bauru site. The results of leaching and batch equilibrium tests indicated that pollution around this site is taking place slowly, emphasizing the importance to continue monitoring groundwater.
\end{abstract}




\section{SUMÁRIO}

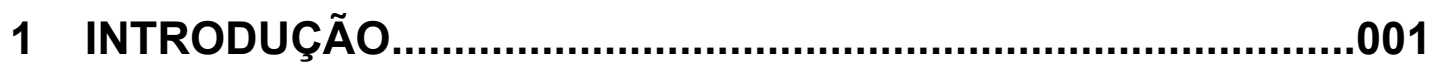

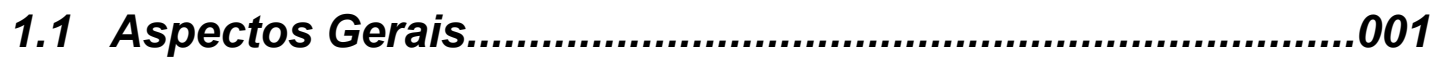

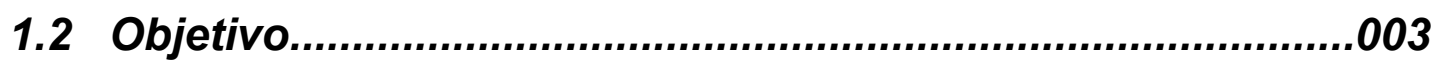

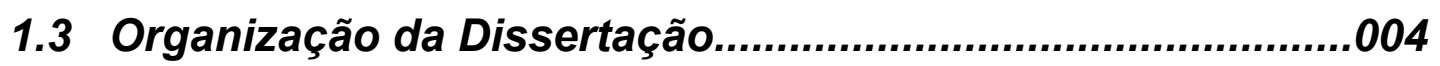

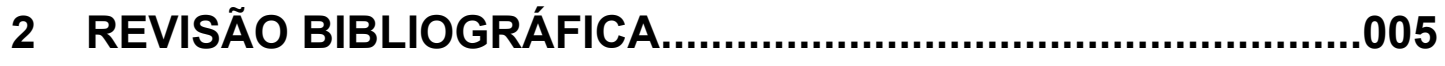

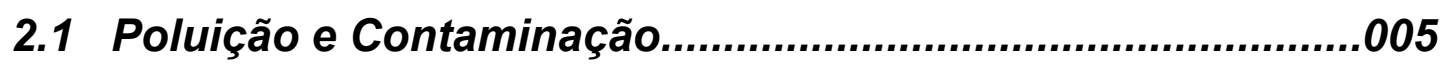

2.1.1 Valores de Qualidade do Solo e da Água Subterrânea...............007

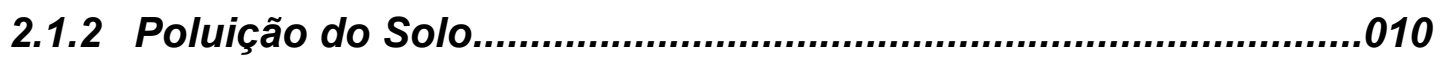

2.1.2.1 Propriedades do Solo......................................................................010

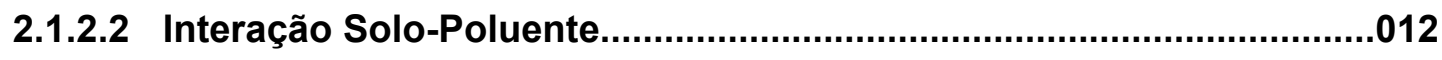

2.1.2.3 Atenuação e Transporte de Poluentes no Solo....................................024

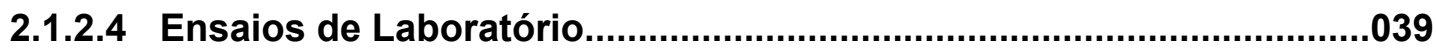

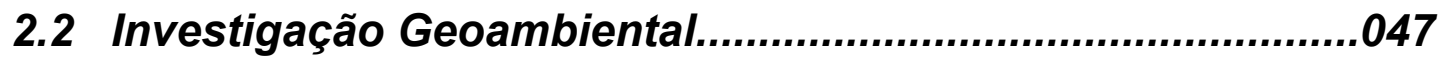

2.2.1 Métodos Geofísicos para a Investigação Geoambiental..............048

2.2.1.1 Geo-radar (Ground Penetrating Radar - GPR) .................................050

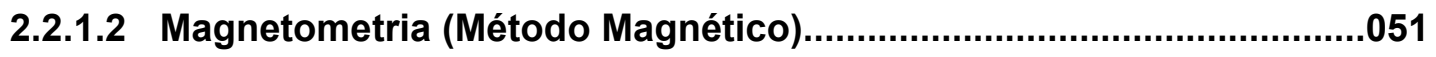


2.2.1.3 Eletromagnético indutivo (EM) 052

2.2.1.4 Eletrorresistividade (ER). 053

2.2.1.5 Potencialidades de Aplicação dos Métodos Geofísicos .060

2.2.1.6 Seleção do Método Geofísico 065

2.2.2 Tecnologia do Piezocone. .070

2.2.2.1 Aspectos Gerais .070

2.2.2.2 Identificação do Perfil Geotécnico 071

2.2.2.3 Interpretação Direta dos Resultados do CPT. .073

2.2.2.4 Estimativa de Parâmetros de Projeto .073

2.2.2.5 Dissipação de Poro-Pressão .074

2.2.2.6 Variações e Acessórios Incorporados ao Piezocone. .077

2.2.2.7 Piezocone de Resistividade (RCPTU) 078

2.2.2.8 Piezocone na Investigação Geotécnica de Solos Tropicais. .087

2.2.2.9 Tecnologia do Piezocone na Investigação Geoambiental. .088

2.2.3 Amostradores 090

2.2.3.1 Amostradores de Solo. .090

2.2.3.2 Amostradores de Água e/ou Gás 092

2.3 Poços para Monitoramento do Aqüífero Freático. 100 
3 MATERIAIS E MÉTODOS....................................................106

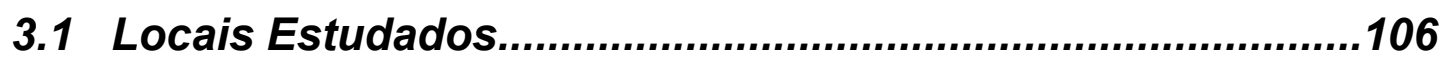

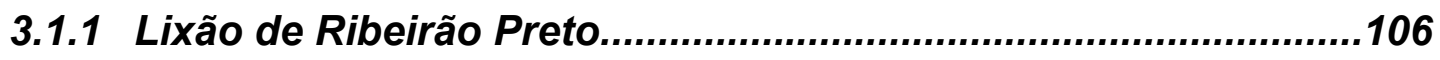

3.1.1.1 Aspectos Geológicos..................................................................107

3.1.1.2 Ensaios Realizados....................................................................

3.1.2 Aterro de Resíduos Sólidos Urbanos de Bauru...........................111

3.1.2.1 Descrição do Aterro.......................................................................111

3.1.2.2 Aspectos Geológicos.......................................................................114

3.1.2.3 Ensaios Realizados.......................................................................115

3.2 Caracterização do Solo do Aterro de Resíduos Sólidos Urbanos de Bauru...............................................................116

3.2.1 Amostras Coletadas no Entorno do Aterro................................116

3.2.1.1 Determinação dos Índices Físicos...............................................117

3.2.1.2 Análise Granulométrica Conjunta..................................................118

3.2.1.3 Limites de Consistência..........................................................................19

3.2.1.4 Adsorção de Azul de Metileno..........................................................120

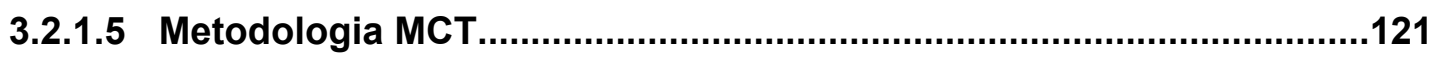

3.2.1.6 Compactação: Proctor na Energia Normal....................................126

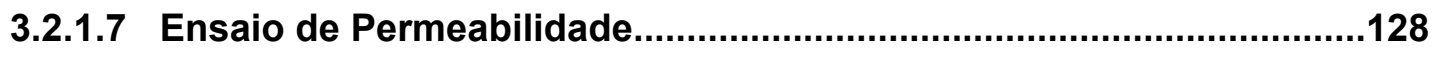

3.2.1.8 Ensaio de Compressão Edométrica..................................................129 
3.2.2 Resultados dos Ensaios Previamente Realizados para 0

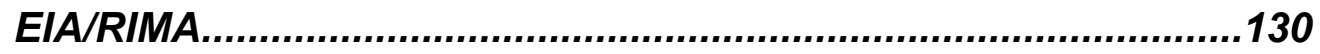

3.2.3 Perfil Típico que Ocorre no Local............................................131

3.3 Os Ensaios Realizados e Equipamentos Utilizados.............134

3.3.1 Sondagens de Eletrorresitividade de Superfície.........................134

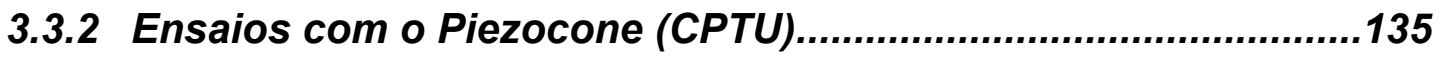

3.3.2.1 Descrição do Piezocone ....................................................................135

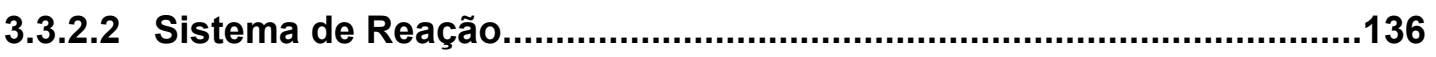

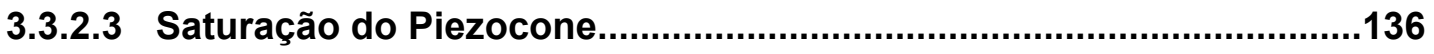

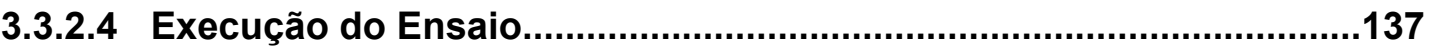

3.3.2.5 Ensaio de Dissipação de Poro-Pressão..............................................137

3.3.2.6 Tratamento de Dados e Interpretação dos Resultados........................137

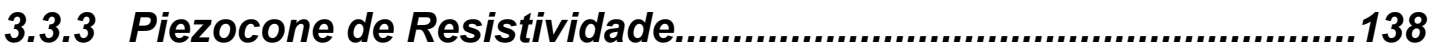

3.3.3.1 Sistema para Calibração e Checagem do Dispositivo para Medida da Resistividade. 138

3.3.3.2 Dispositivo para Medida da Resistividade........................................141

3.3.4 Amostragem de Água e Solo...................................................143

3.3.5 Instalação de Poços de Monitoramento Permanentes.................146

3.3.6 Avaliação Preliminar da Contaminação e da Atenuação do Solo do Aterro de Resíduos Sólidos de Bauru. 150 
3.3.7 Ensaios de Laboratório para a Avaliação da Retenção de Poluentes pelo Solo do Aterro de Resíduos Sólidos de Bauru. 151

3.3.7.1 Ensaios de Permeabilidade. .155

3.3.7.2 Ensaio de Coluna com Percolação de Solução Salina. .157

3.3.7.3 Ensaio de Coluna com Percolação de Solução de Metais. 160

3.3.7.4 Ensaio de Coluna com Percolação de Chorume mais Metais. 160

3.3.7.5 Ensaio de Adsorção em Lote ("Batch Test"). .161

4 RESULTADOS E DISCUSSÕES. 164

4.1 Lixão de Ribeirão Preto. 164

4.1.1 Sondagens Elétricas de Superfície. .164

4.1.2 Poços de Monitoramento. 171

4.1.3 Ensaios com o Piezocone (CPTU). 172

4.1.4 Avaliação da Contaminação da Área 174

4.2 Aterro de Resíduos Sólidos Urbanos de Bauru. 176

4.2.1 Sondagens Elétricas de Superfície. .176

4.2.2 Ensaios com o Piezocone (CPTU e RCPTU). 186

4.2.2.1 Calibração do Piezocone .186

4.2.2.2 Calibração do Dispositivo de Medida de Resistividade do Piezocone. 188 
4.2.2.3 Resultados dos Ensaios com o Piezocone (CPTU e RCPTU)............190

4.2.2.4 Identificação do Perfil Geotécnico........................................196

4.2.2.5 Definição da Posição do Nível D’Água....................................199

4.2.2.6 Coeficiente de Permeabilidade.........................................199

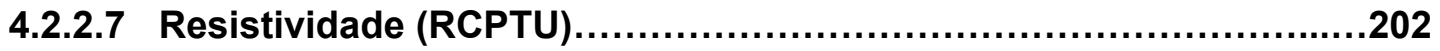

4.2.3 Ensaios de Caracterização Geotécnica e Geoambiental............212

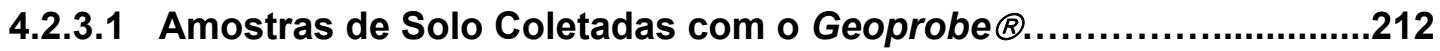

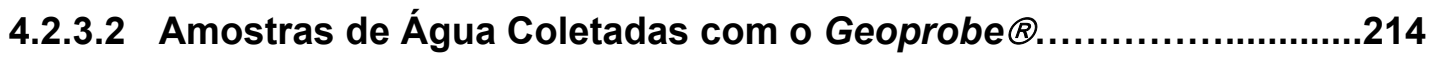

4.2.3.3 Poços de Monitoramento e Águas Superficiais........................215

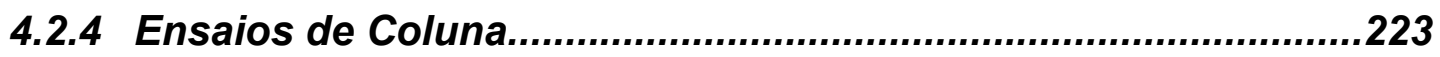

4.2.4.1 Ensaios de Permeabilidade........................................223

4.2.4.2 Ensaio de Coluna com Percolação de Solução Salina........................224

4.2.4.3 Ensaio de Coluna com Percolação de Solução de Metais................228

4.2.4.4 Ensaio de Coluna com Percolação de Chorume mais Metais.........230

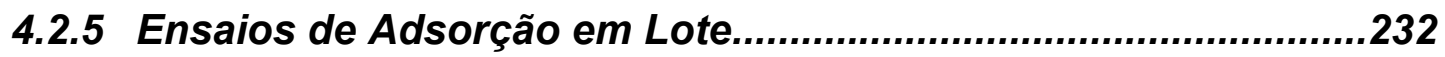

4.2.6 Avaliação da Contaminação no Aterro de Resíduos Sólidos Urbanos de Bauru.......................................................................241 
5 CONCLUSÕES E SUGESTÕES PARA CONTINUIDADE.........244

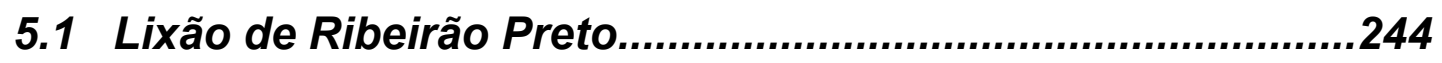

5.2 Aterro de Resíduos Sólidos Urbanos de Bauru....................245

5.3 Sugestões para Continuidade.............................................249

6 REFERÊNCIAS BIBLIOGRÁFICAS......................................251

ANEXO I: Ensaios CPTU Realizados no Antigo Lixão de Ribeirão Preto.

ANEXO II: Ensaios CPTU e RCPTU Realizados no Aterro de Resíduos Sólidos Urbanos de Bauru.

ANEXO III: Resultados das Dissipações do Excesso das Poro-pressões Realizadas em Algumas Sondagens RCPTU no Aterro de Resíduos Sólidos Urbanos de Bauru.

ANEXO IV: Resultados dos Ensaios de Permeabilidade e de Coluna Realizados com o Solo do Entorno do Aterro de Resíduos Sólidos Urbanos de Bauru.

ANEXO V: Resultados dos Ensaios de Adsorção em Lote ("Batch Tests") Realizados com o Solo do Entorno do Aterro de Resíduos Sólidos Urbanos de Bauru. 


\section{LISTA DE FIGURAS}

Figura 2.1. (a) Sílica tetraédrica sozinha, de GRIM (1959); (b) vista isométrica do tetraedro ou folha de sílica, de GRIM (1959); (c) representação esquemática da folha de sílica, de Lambe (1953); vista de cima da folha de sílica, de WARSHAW \& ROY, 1961 (HOLTZ \& KOVACS, 1981 apud SHARMA \& LEWIS, 1994).

Figura 2.2. (a) Alumínio (ou magnésio) octaédrico sozinho, de GRIM (1959); (b) vista isométrica da folha octaédrica, de GRIM (1959); (c) representação esquemática do octaédro ou da folha de alumínio (ou magnésio), de LAMBE (1953); vista de cima da folha octaédrica, de WARSHAW \& ROY, 1961 (HOLTZ \& KOVACS, 1981 apud SHARMA \& LEWIS, 1994)

Figura 2.3. Diagramas esquemáticos das estruturas da (a) caulinita e da (b) serpentina (MITCHELL, 1993 apud SHARMA \& LEWIS, 1994). .015

Figura 2.4. Representação do diagrama da estrutura da caulinita (MITCHELL, 1993 apud SHARMA \& LEWIS, 1994).

Figura 2.5. Diagramas esquemáticos da estrutura da haloisita: (a) $10 \hat{\mathrm{A}}$ e (b) $7 \hat{\mathrm{A}}$ (MITCHELL, 1993 apud SHARMA \& LEWIS, 1994). .016

Figura 2.6. Diagramas esquemáticos das estruturas de minerais esmectita: (a) montmorilonita; (b) saponitas (MITCHELL, 1993 apud SHARMA \& LEWIS, 1994). 017

Figura 2.7. Representação do diagrama da estrutura da montmorilonita (MITCHELL, 1993 apud SHARMA \& LEWIS, 1994)

Figura 2.8. Diagrama esquemático da estrutura da ilita, de LAMBE, 1953 (HOLTZ \& KOVACS, 1981 apud SHARMA \& LEWIS, 1994). .018

Figura 2.9. Diagramas esquemáticos das estruturas da (a) muscovita e ilita, e (b) vermiculita (MITCHELL, 1993 apud SHARMA \& LEWIS, 1994)...019

Figura 2.10. Posição dos argilo-minerais no ábaco da plasticidade de Casagrande (HOLTZ \& KOVACS, 1981 apud SHARMA \& LEWIS, 1994) .019

Figura 2.11. Distribuição dos íons adjacentes à superfície da argila, de acordo com o 
conceito da camada dupla (MITCHELL, 1993 apud SHARMA \& LEWIS, 1994). .021

Figura 2.12. Efeito da valência do cátion nas concentrações da camada dupla (MITCHELL, 1993 apud SHARMA \& LEWIS, 1994). .021

Figura 2.13. Coeficiente de permeabilidade dos argilo-minerais (ALBERTA ENVIRONMENT, 1985 apud SHARMA \& LEWIS, 1994) 023

Figura 2.14. Velocidade de advecção de um soluto através de um volume de solo (PINTO, 1991 apud BOSCOV, 1997).

Figura 2.15. Variação da velocidade em direção e magnitude dentro de um vazio (BOSCOV, 1997). 026

Figura 2.16. Variação espacial das linhas de fluxo em relação à direção do fluxo médio (BOSCOV, 1997).... 026

Figura 2.17. Evidência experimental da dispersão mecânica (BOSCOV, 1997)....027

Figura 2.18. Alguns modelos de equilíbrio isotérmico de adsorção (ISAAC, 1993 apud BOSCOV, 1997).

Figura 2.19. Ensaio de coluna (FREEZE \& CHERRY, 1979 apud BOSCOV, 1997)

Figura 2.20. Curva de saturação do poluente em função do volume de efluente (BEAR, 1979 apud BOSCOV, 1997). .040

Figura 2.21. Curva de saturação do poluente em função do tempo (FREEZE \& CHERRY, 1979 apud BOSCOV,1997). .041

Figura 2.22. Ensaio de difusão (BARONE et al., 1989 apud BOSCOV, 1997)........043

Figura 2.23. Situações inicial e final das concentrações no ensaio de difusão (BOSCOV, 1997). .044

Figura 2.24. Ensaio de adsorção em lote (EPA, 1992 apud BOSCOV, 1997). .045

Figura 2.25. Arranjo de campo - sondagem elétrica vertical Schlumberger (ELIS, 1999) .057

Figura 2.26. Disposição no campo do arranjo Dipolo-Dipolo - Caminhamento Elétrico (ELIS, 1999). .059

Figura 2.27. Sistema de plotagem da técnica do CE - arranjo Dipolo-Dipolo/Método da Eletrorresistividade (ELIS, 1999). .059

Figura 2.28. Seção de geo-radar indicando os limites da contaminação (atenuação do 
sinal) provocada pela infiltração de resíduos industriais (CETESB, 1999) .060

Figura 2.29. Mapa de isocondutividade apresentando os limites da pluma de contaminação proveniente de aterro industrial desativado (CETESB, 1999) 062

Figura 2.30. Resultado de sondagem elétrica vertical. (a) Externa à área de indústria suspeita de contaminação; (b) Realizada em local de infiltração de resíduos industriais (CETESB, 1999)....

Figura 2.31. Piezocone com inclinômetro, sensor de temperatura e acelerômetro (modificado de DAVIES \& CAMPANELLA, 1995a) .071

Figura 2.32. Carta de classificação de solos utilizando CPT elétrico (ROBERTSON et al., 1986).

Figura 2.33. Desenho esquemático de um RCPTU (DAVIES \& CAMPANELLA, 1995a) .083

Figura 2.34. Arranjo Werner (ELIS, 1993)..... 084

Figura 2.35. Desenho esquemático de um amostrador de solo com tubo de plástico para uso na investigação geoambiental (GIACHETI, 2001).

Figura 2.36. Condutividade hidráulica utilizando o sistema BAT (TORSTENSSON, 1984)

Figura 2.37. Sistema BAT para amostragem de água (TORSTENSSON, 1984; TORSTENSSON \& PETSONK, 1988).

Figura 2.38. Duplo engate rápido utilizado no UBC K-BAT (GIACHETI, 2001)..094 Figura 2.39. Desenho esquemático do sistema UBC K BAT (WILSON \& CAMPANELLA, 1997). .095

Figura 2.40. Sistema de amostragem de água Hydropunch ${ }^{\circledR}$ (http://www.conetec.com/Pdf/cpt_ground.pdf em 07/2002)..............096

Figura 2.41. Amostrador de água Geoprobe $\AA$ (GEOPROBE SYSTEMS, 1995) . .098

Figura 2.42. Disposiçao dos poços de monitoramento (CETESB, 1999)..................101

Figura 2.43. Perfil esquemático de poço de monitoramento (CETESB, 1999)........103

Figura 2.44. Perfil esquemático de poço de monitoramento (CETESB, 1999)........104

Figura 2.45. Tipos de poços para monitoramento em níveis distintos (CETESB, 
1999)

Figura 3.1. Localização de Ribeirão Preto no Estado de São Paulo e do antigo lixão da cidade (GIACHETI et al., 1999)..... 108

Figura 3.2. Localização dos ensaios realizados no lixão de Ribeirão Preto-SP (ELIS, 2003b). 110

Figura 3.3. Localização de Bauru no Estado de São Paulo e do aterro de resíduos sólidos urbanos da cidade (http://www.vidagua.org.br/imagens/ImgBauru/mapa_d5.gif em 2004) 112

Figura 3.4. Localização dos ensaios realizados no aterro de resíduos sólidos de Bauru. 115

Figura 3.5. Curvas granulométricas para as amostras coletadas de talude do entorno do aterro de resíduos sólidos de Bauru. 118

Figura 3.6. Carta da Classificação MCT-Posição das amostras ensaiadas. 122

Figura 3.7. Metodologia MCT - Ensaios mini-CBR e associados para amostra a 3.0 $\mathrm{m}$ - Energia Intermediária. 124

Figura 3.8. Metodologia MCT - Ensaios mini-CBR e associados para amostra a 3.7 $\mathrm{m}$ - Energia Intermediária. 125

Figura 3.9. Curva de Compactação Proctor (Energia Normal) para a profundidade de $1.7 \mathrm{~m}$ .126

Figura 3.10. Curva de Compactação Proctor (Energia Normal) para a profundidade de $3.0 \mathrm{~m}$. 127

Figura 3.11. Curva de Compactação Proctor (Energia Normal) para a profundidade de $3.7 \mathrm{~m}$.

Figura 3.12. Desenho esquemático do interior do permeâmetro utilizado no ensaio. 128

Figura 3.13. Curva de adensamento obtida para o entorno do aterro de resíduos sólidos de Bauru..... 130

Figura 3.14. Curvas granulométricas obtidas para amostras coletadas quando da elaboração do EIA/RIMA.

Figura 3.15. Localização dos perfis A e B no aterro de resíduos sólidos de Bauru. 
Figura 3.16. Perfil A representativo da região à oeste do aterro (transversal à estrada).......

Figura 3.17. Perfil $\mathrm{B}$ representativo da região à oeste do aterro (paralelo à estrada).

Figura 3.18. Tela de entrada do programa de aquisição de dados do piezocone de resistividade utilizado

Figura 3.19. Croqui de um dos poços instalados no aterro de resíduos sólidos de Bauru..

Figura 3.20. Curva de calibração entre condutividade elétrica e concentração de solução de $\mathrm{NaCl}$.

Figura 4.1. Interpretação da SEV 5, localizada à montante da cava de resíduos no lixão de Ribeirão Preto (ELIS, 2003b). 165

Figura 4.2. Interpretação da SEV 6, localizada dentro da cava de resíduos no lixão de Ribeirão Preto (ELIS, 2003b). 166

Figura 4.3. Mapa de fluxo subterrâneo definido através das SEVs e dos poços existentes (ELIS, 2003b).

Figura 4.4. Seções de resistividade modeladas para as Fases 1 e 2 da Linha C1 (ELIS, 2003b; 2004). 168

Figura 4.5. Seções de resistividade modeladas para as Fases 1 e 2 da Linha C4 (ELIS, 2003b; 2004).

Figura 4.6. Mapa de resistividade aparente do nível $30 \mathrm{~m}$ mostrando a pluma se desenvolvendo no sentido do fluxo subterrâneo, à nordeste (ELIS, 2003b). 170

Figura 4.7. Resultados das sondagens CPTU e das amostragens de solo realizadas na área do lixão de Ribeirão Preto. 173

Figura 4.8. Mapa de localização dos ensaios geofísicos realizados no aterro de resíduos sólidos urbanos de Bauru (LAGO, 2004).. 177

Figura 4.9. Interpretação da SEV 3, localizada à jusante da cava de resíduos no aterro de resíduos sólidos de Bauru (LAGO, 2004). 178

Figura 4.10. Interpretação da SEV 8, localizada dentro da cava de resíduos no aterro de resíduos sólidos de Bauru (LAGO, 2004)

Figura 4.11. Mapa de fluxo subterrâneo definido através das SEVs (LAGO, 
Figura 4.12. Seções de resistividade modeladas para as Fases 1 e 2 da Linha C2 (ELIS, 2004).

Figura 4.13. Seções de resistividade modeladas para as Fases 1 e 2 da Linha C4 (ELIS, 2004). 182

Figura 4.14. Mapa de resistividade aparente do nível teórico 15 m, Fase 1 (LAGO, 2004) 184

Figura 4.15. Mapa de resistividade aparente do nível teórico 30 m, Fase 1 (LAGO, 2004) 184

Figura 4.16. Conjunto com planta do aterro de resíduos sólidos de Bauru, linhas de isorresistividade e pontos de coleta de amostras de água para avaliação preliminar da contaminação 185

Figura 4.17. Calibração da célula de carga da resistência de ponta, no intervalo de 0 $35 \mathrm{MPa}$ 186

Figura 4.18. Calibração da célula de carga do atrito lateral, no intervalo de $0-0.5$ $\mathrm{MPa}$. 187

Figura 4.19. Calibração do transdutor de poro-pressão. 187

Figura 4.20. Calibração do sensor de resistividade - Faixa de valores 0 a 5000 ohm.m. 188

Figura 4.21. Calibração do sensor de resistividade - Faixa de valores 0 a 300 ohm.m.

Figura 4.22. Calibração do sensor de resistividade - Faixa de valores 0 a 5000 ohm.m.

Figura 4.23. Resultados do ensaio de piezocone CPTU 01 realizado à montante do aterro. 192

Figura 4.24. Resultados dos ensaios de piezocone CPTU 02 e RCPTU 12 realizados ao sul, fora do aterro

Figura 4.25. Resultados dos ensaios de piezocone CPTU 03, RCPTU 04, 05, 06 e 11 realizados à jusante do aterro e no entorno do poço de monitoramento temporário PT-1

Figura 4.26. Resultados dos ensaios de piezocone CPTU 04, RCPTU 01, 02,03 e 09 realizados à jusante do aterro e no entorno do poço de monitoramento 
temporário PT-2.

Figura 4.27. Resultados do ensaio de piezocone RCPTU 08 realizado à jusante e próximo ao aterro.

Figura 4.28. Resultados dos ensaios de piezocone RCPTU 14 e 15 realizados à jusante e próximos ao aterro. 194

Figura 4.29. Resultados do ensaio de piezocone RCPTU 07 realizado à jusante do aterro e próximo à erosão. 195

Figura 4.30. Resultados do ensaio de piezocone RCPTU 10 realizado à jusante do aterro e próximo à erosão.

Figura 4.31. Resultados dos ensaios de piezocone RCPTU 13 e 16 realizados na região de várzea, ao sul do aterro. 196

Figura 4.32. Curva de dissipação do excesso de poro-pressão obtida durante o ensaio RCPTU 05, saturado com glicerina, a $9.6 \mathrm{~m}$ de profundidade. .201

Figura 4.33. Curva de dissipação do excesso de poro-pressão obtida durante o ensaio RCPTU 08, saturado com graxa, a $8.06 \mathrm{~m}$ de profundidade. .201

Figura 4.34. Efeito da variação do grau de saturação na resistividade (DANIEL et al., 2002)

Figura 4.35. Mapa de resistividade do nível teórico $15 \mathrm{~m}$ do aterro de resíduos sólidos de Bauru. As regiões com valores de resistividade menores que 75 ohm.m indicam a contaminação da zona saturada. 205

Figura 4.36. Localização de Bauru na Bacia do Rio Tietê (INPE, 2002) 207

Figura 4.37. Precipitação ocorrida entre outubro de 2000 e julho de 2002 (INPE, 2002) .207

Figura 4.38. Precipitação acumulada mês a mês (INPE, 2002). 208

Figura 4.39. Valores de resistividade obtidos a partir dos ensaios RCPTU versus os valores de resistividade calculados a partir da Lei de Archie. 211

Figura 4.40. Variação da $\mathrm{DBO}_{5}$ nas amostras de água nos diversos pontos de amostragem 220

Figura 4.41. Variação da condutividade nas amostras de água nos diversos pontos de amostragem .220

Figura 4.42. Variação do coeficiente de permeabilidade versus volume de água percolado para corpo de prova confinado a $90 \mathrm{kPa}$. .224 
Figura 4.43. Variação do coeficiente de permeabilidade durante o ensaio de coluna com percolação de água e $\mathrm{NaCl}$.

Figura 4.44. Monitoramento das concentrações de $\mathrm{NaCl}$ dos efluentes .226

Figura 4.45. Monitoramento do $\mathrm{pH}$ dos efluentes da coluna com percolação de $\mathrm{NaCl}$ .227

Figura 4.46. Variação do coeficiente de permeabilidade em função da tensão confinante aplicada ao corpo de prova.

Figura 4.47. Variação do coeficiente de permeabilidade durante o ensaio de coluna com percolação de água e solução de metais. .228

Figura 4.48. Monitoramento das concentrações de metais pesados durante o ensaio de coluna com percolação de solução de metais.

Figura 4.49. Variação do coeficiente de permeabilidade durante o ensaio de coluna com percolação de água e chorume. .231

Figura 4.50. Monitoramento do $\mathrm{pH}$ dos efluentes da coluna com percolação de chorume acrescido de metais.

Figura 4.51. Determinação do tempo de equilíbrio para o Ni usando a solução de metais.

Figura 4.52. Determinação do tempo de equilíbrio para o Ni usando o chorume acrescido de metais

Figura 4.53. Monitoramento do $\mathrm{pH}$ durante o ensaio de adsorção realizado com a solução de metais

Figura 4.54. Monitoraento do $\mathrm{pH}$ durante o ensaio de adsorção realizado com o chorume acrescido de metais.

Figura 4.55. Monitoramento da condutividade durante o ensaio de adsorção realizado com a solução de metais. 236

Figura 4.56. Monitoramento da condutividade durante o ensaio de adsorção realizado com o chorume acrescido de metais. .236

Figura 4.57. Isoterma de adsorção do Zn obtida para a solução de metais .238

Figura 4.58. Isoterma de adsorção do Zn obtida para o chorume acrescido de metais. .238 


\section{LISTA DE FOTOS}

Foto 2.1. Equipamento e operação do geo-radar (CETESB, 1999).

Foto 2.2. Magnetômetro e sensores e o equipamento preparado para ensaio de campo (ELIS, 2003a).

Foto 2.3. Condutivímetro EM31 - profundidade de investigação: 3 e 6 m (CETESB, 1999). .052

Foto 2.4. Condutivímetro EM34 e seu modo de operação - profundidade de investigação: 7.5, 15, 30 e 60 m (CETESB, 1999)....

Foto 2.5. Resistivímetro de campo (CETESB, 1999). . .054

Foto 2.6. Dispositivo para medida da resistividade elétrica acoplado ao piezocone (GIACHETI, 2001).

Foto 2.7. Piezocone de resistividade com quatro eletrodos dispostos em arranjo Werner. .084

Foto2.8. Amostrador de solo utilizando o sistema direct push de coleta de amostras .090

Foto 2.9. Amostra coletada .091

Foto 2.10. Penetrômetro UBC K BAT ao lado de uma ponteira do sistema BAT (GIACHETI, 2001).

Foto 2.11. Dois tipos de filtros (aço inoxidável e PVC) do amostrador de água

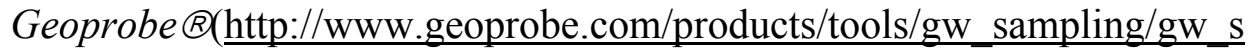
ampling tools menu.htm em 02/2004)

Foto 2.12. Poço de monitoramento temporário aberto com trado helicoidal motorizado.

Foto 2.13. Amostrador de água utilizado nos poços de monitoramento temporário.

Foto 3.1. Vista geral do lixão de Ribeirão Preto: borda da cava preenchida com resíduos. Notar o recalque na área dos resíduos (ELIS, 1999). 106

Foto 3.2. Lixão de Ribeirão Preto: chorume aflorando em uma das cavas (ELIS, 1999).

Foto 3.3. Foto aérea do local de implantação do aterro de resíduos sólidos de Bauru 
(EMDURB, 2002)

Foto 3.4. Vista geral do aterro de resíduos sólidos de Bauru (EMDURB, 2002)

Foto 3.5. Impermeabilização da base do aterro de resíduos sólidos de Bauru feita com CM-30 diluído (EMDURB, 2002).

Foto 3.6. Vista geral do talude localizado no entorno do aterro, de onde foram coletadas amostras deformadas e indeformadas 116

Foto 3.7. Amostra indeformada sendo coletada próximo ao pé do talude. 117

Foto 3.8. Caminhamento elétrico sendo executado no aterro de resíduos sólidos de Bauru. 134

Foto 3.9. Eletrodo cravado no solo do aterro de resíduos sólidos de Bauru. 135

Foto 3.10. Piezocone sem fio com filtro de cavidade, utilizado nas sondagens CPTU 135

Foto 3.11. Penetrômetro multi-função utilizado nos ensaios com piezocone. .136

Foto 3.12. Sistema de calibração do sensor de condutividade do piezocone de resistividade. 138

Foto 3.13. Instalação do piezocone de resistividade no reservatório. 140

Foto 3.14. Condutivímetro utilizado no Laboratório de Geotecnia de Solos Tropicais da Unesp de Bauru. 140

Foto 3.15. Sistema de aquisição de dados utilizado. 140

Foto 3.16. Piezocone de resistividade (RCPTU) utilizado no aterro de resíduos sólidos de Bauru....

Foto 3.17. Sondagem com piezocone de resistividade sendo realizada na área do aterro de resíduos sólidos de Bauru. 142

Foto 3.18. Sondagem com piezocone sendo realizada área do aterro de resíduos sólidos de Bauru. 142

Foto 3.19. Sondagem com piezocone sendo realizada área do lixão de Ribeirão Preto

Foto 3.20. Amostragem de água no aterro de resíduos sólidos de Bauru utilizando o

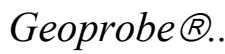
.144

Foto 3.21. Amostragem de solo no aterro de resíduos sólidos de Bauru utilizando o

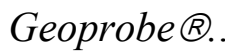
.144 
Foto 3.22. Amostragem de água no aterro de resíduos sólidos de Bauru utilizando poço temporário de monitoramento

Foto 3.23. Amostrador de água utilizado nos poços de monitoramento temporários 145

Foto 3.24. Instalação de poço de monitoramento no aterro de resíduos sólidos de Bauru.

Foto 3.25. Localização da caixa de armazenamento e recirculação do chorume, à jusante do aterro de resíduos sólidos de Bauru.

Foto 3.26. Detalhe do momento da coleta do chorume na caixa de armazenamento e recirculação.

Foto 3.27. Centrífuga utilizada no LMS-EPUSP para preparação das amostras de chorume a serem submetidas à análise química.

Foto 3.28. Amostra de solo do aterro de resíduos sólidos de Bauru sendo preparada para a realização do ensaio de permeabilidade 156

Foto 3.29. Corpo de prova já moldado dentro da célula de ensaio. 156

Foto 3.30. Detalhe do painel de controle utilizado no LMS-EPUSP para a aplicação de gradientes e confinantes durante a realização dos ensaios de permeabilidade e de coluna.

Foto 3.31. Reservatório utilizado para armazenamento de poluentes durante os ensaios de coluna (esquerda) ao lado do corpo de prova (direita) 158

Foto 3.32. Interface água/poluente utilizada durante os ensaios de coluna. 158

Foto 3.33. Condutivímetro utilizado para medir a condutividade elétrica da solução efluente dos ensaios de coluna no LMS-EPUSP.

Foto 3.34. Aparelho utilizado para medir o pH da solução efluente durante os ensaios de coluna no LMS-EPUSP

Foto 3.35. Vista geral do ensaio de coluna com percolação de salina. 160

Foto 3.36. Reservatório sendo cheio com o chorume. 161

Foto 3.37. Equipamento de rotação utilizado durante os ensaios de adsorção em lote.

Foto 4.1. Erosão localizada à jusante do aterro de resíduos sólidos de Bauru, onde é possível observar a heterogeneidade do solo que ocorre no local. 198 


\section{LISTA DE TABELAS}

Tabela 2.1. Valores orientadores para solos e águas subterrâneas no Estado de São Paulo (CETESB, 2001).

Tabela 2.2. Resumo das características principais dos métodos geofísicos (CETESB, 1999)

Tabela 2.3. Resumo das principais aplicações dos métodos geofísicos em áreas contaminadas (CETESB, 1999). .068

Tabela 2.4. Valores de resistividade elétrica de materiais conhecidos (ELIS, 1993)

Tabela 2.5. Resumo com valores típicos de resistividade (condutividade) com misturas de solo e fluidos (DAVIES \& CAMPANELLA, 1995a)......086

Tabela 3.1. Classificação da área do lixão de Ribeirão Preto (ZUQUETTE et al., 1994)

Tabela 3.2. Índices físicos obtidos para o entorno do aterro de resíduos sólidos de Bauru......

Tabela 3.3. Composição granulométrica obtida para o entorno do aterro de resíduos sólidos de Bauru.

Tabela 3.4. Limites de consistência obtidos para o entorno do aterro de resíduos de sólidos de Bauru

Tabela 3.5. Resultados obtidos para o ensaio de adsorção de azul de metileno para amostra de solo retirada a $3.0 \mathrm{~m}$

Tabela 3.6. Resultados obtidos para o ensaio de adsorção de azul de metileno para amostra de solo retirada a $3.7 \mathrm{~m}$

Tabela 3.7. Mini-CBR e associados - Energia Intermediária - Síntese de resultados

Tabela 3.8. Parâmetros de compactação (energia normal) obtidos para o entorno do aterro de resíduos sólidos de Bauru. 126

Tabela 3.9. Coeficientes de permeabilidade obtidos com a realização de ensaios com carga variável 128

Tabela 3.10. Índices físicos da amostra natural coletada a $1.7 \mathrm{~m}$ de profundidade em 
talude do entorno do aterro de resíduos sólidos de Bauru. 129

Tabela 3.11. Resultados dos ensaios de caracterização realizados quando da elaboração do EIA/RIMA

Tabela 3.12. Quadro resumo das de amostras de solo coletadas com o amostrador

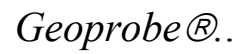
146

Tabela 3.13. Quadro resumo das amostras de água coletadas com amostrador Geoprobe ${ }^{\circledR}$...... 146

Tabela 3.14. Características dos poços de monitoramento permanentes instalados no aterro de resíduos sólidos de Bauru. 148

Tabela 3.15. Análise química realizada para o chorume do aterro de resíduos sólidos de Bauru. 152

Tabela 4.1. Dados da análise físico-química das águas dos poços do lixão de Ribeirão Preto (PEJON \& ZUQUETTE, 1991)..... .171

Tabela 4.2. Resultados dos ensaios realizados nas amostras de solo coletadas com o amostrador Geoprobe $\mathbb{R}$, sendo a granulometria obtida a partir da NBR 6502/95, e pH e a condutividade (C) obtidos a partir da água lixiviada pelo solo.

Tabela 4.3. Poços cujas amostras ultrapassaram os limites estabelecidos pela CETESB (2001) e pela Portaria $n^{0} 1.469$ do Ministério da Saúde......175

Tabela 4.4. Resumo dos resultados obtidos a partir dos ensaios de dissipação do excesso de poro-pressão gerada durante alguns ensaios RCPTU........200

Tabela 4.5. Aplicação da Lei de Archie para as amostras de solo e água coletadas através do Geoprobe ${ }^{\circledR}$. 210

Tabela 4.6. Resultados dos ensaios de caracterização geotécnica. 212

Tabela 4.7. Interpretação dos resultados dos ensaios de adsorção de azul de metileno a partir da proposta de LAUTRIN (1989) apud PEJON (1992) 213

Tabela 4.8. Resultados das determinações realizadas no campo para as amostras de água.

Tabela 4.9. Resultados das análises químicas realizadas nas amostras de água.......214

Tabela 4.10. Concentrações de metais pesados encontradas nas amostras de água e chorume. 
Tabela 4.11. Resultados da primeira campanha de análise das águas dos poços de monitoramento permanentes instalados no aterro de resíduos sólidos de Bauru. 216

Tabela 4.12. Resultados da segunda campanha de análise das águas dos poços de monitoramento permanentes instalados no aterro de resíduos sólidos de Bauru. 217

Tabela 4.13. Poços e amostras que ultrapassaram os limites estabelecidos pela CETESB (2001) e pela Portaria n ${ }^{0} 1.469$ do Ministério da Saúde......218

Tabela 4.14. Valores médios em diferentes épocas do ano para os parâmetros obtidos das águas superficiais e dos poços de monitoramento temporários.....222

Tabela 4.15. Determinação do coeficiente de distribuição $(\mathrm{Kd})$ e do fator de retardamento $(\mathrm{Rd})$ para os ensaios de adsorção em lote realizados com o solo do aterro de resíduos sólidos de Bauru. .239 


\section{SIGLAS E ABREVIATURAS}

\begin{tabular}{|c|c|c|}
\hline SIGLA & - & DESCRIÇÃO \\
\hline $\mathrm{ABEF}$ & - & Associação Brasileira de Engenharia de Fundações \\
\hline ABGE & - & Associação Brasileria de Geologia de Engenharia \\
\hline ABMS & - & Associação Brasileira de Mecânica dos Solos \\
\hline $\mathrm{ABNT}$ & - & Associação Brasileira de Normas Técnicas \\
\hline APL & - & Aqueous Phase Liquids \\
\hline ASCE & - & American Society of Civil Engineers \\
\hline ASTM & - & American Society for Testing and Materials \\
\hline CBR & - & Índice de Suporte Califórnia \\
\hline $\mathrm{CE}$ & - & Caminhamento Elétrico \\
\hline C. E. & - & Campo Experimental \\
\hline CEMPRE & - & Compromisso Empresarial para Reciclagem \\
\hline CETESB & - & Centro Tecnológico de Saneamento Básico \\
\hline CONAMA & - & Conselho Nacional do Meio Ambiente \\
\hline CPM & - & Cone Pressiométrico \\
\hline $\mathrm{CPT}$ & - & Ensaio de Penetração do Cone \\
\hline CPTU & - & Ensaio de Penetração do Piezocone \\
\hline EESC & - & Escola de Engenharia de São Carlos \\
\hline EIA & - & Estudo de Impacto Ambiental \\
\hline EM & - & Método Eletromagnético Indutivo \\
\hline EMDURB & - & Empresa Municipal de Desenvolvimento Urbano e Rural de Bauru \\
\hline EPA & - & Agência de Proteção Ambiental dos Estados Unidos \\
\hline EPUSP & - & Escola Politécnica da Universidade de São Paulo \\
\hline ER & - & Método da Eletrorresistividade \\
\hline FAPESP & - & Fundação de Amparo à Pesquisa do Estado de São Paulo \\
\hline FEB & - & Faculdade de Engenharia de Bauru - Unesp \\
\hline FIPAI & - & Fundação para o Incremento da Pesquisa e Aperfeiçoamento Industrial \\
\hline GPR & - & Ground Penetration Radar \\
\hline IAG & - & Instituto de Astronomia, Geofísica e Ciências Atmosféricas \\
\hline INPE & - & Instituto Nacional de Pesquisas Espaciais \\
\hline IPT & - & Instituto de Pesquisas Tecnológicas \\
\hline ISTG & - & In Situ Testing Group \\
\hline
\end{tabular}


LMS - Laboratório de Mecânica dos Solos

MCT - Miniatura - Compactação - Tropical

NAPL - Non-Aqueous Phase Liquid

ND

- Não Determinado

PEF - Departamento de Engenharia de Estruturas e Fundações

RCPTU - Piezocone de Resistividade

RIMA - Relatório de Impacto do Meio Ambiente

RSU - Resíduos Sólidos Urbanos

SBT - Soil Behavior Type

SEV - Sondagem Elétrica Vertical

SGI - Statens Geotekniska Institut

SPT - Sondagem de Simples Reconhecimento (Standard Penetration Test)

STI - Valores de Referência de Qualidade (S), Alerta (T) e Intervenção (I)

UBC - University of British Columbia

Unesp - Universidade Estadual Paulista

USP $\quad$ - Universidade de São Paulo 


\section{símBOLOS}

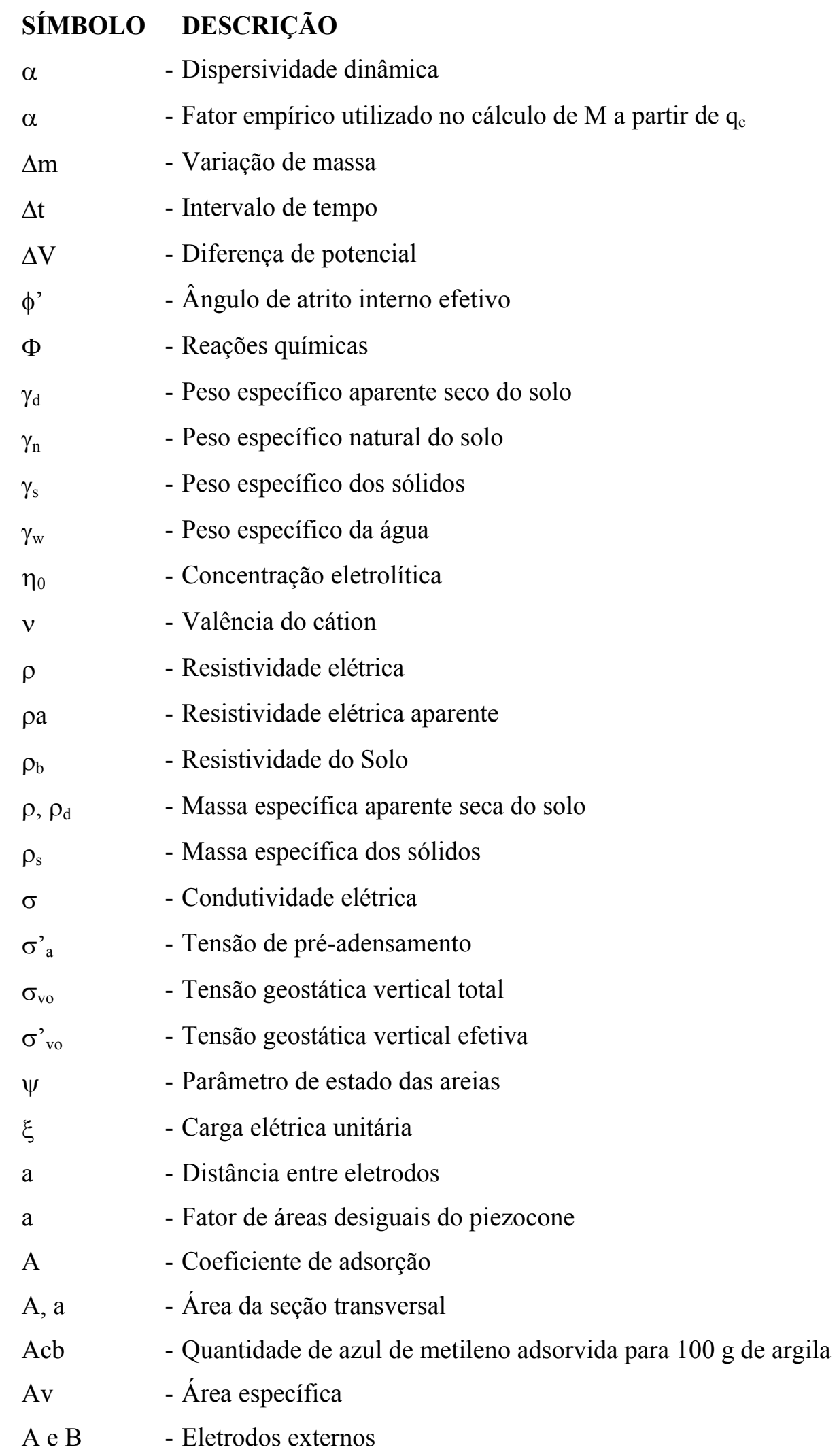




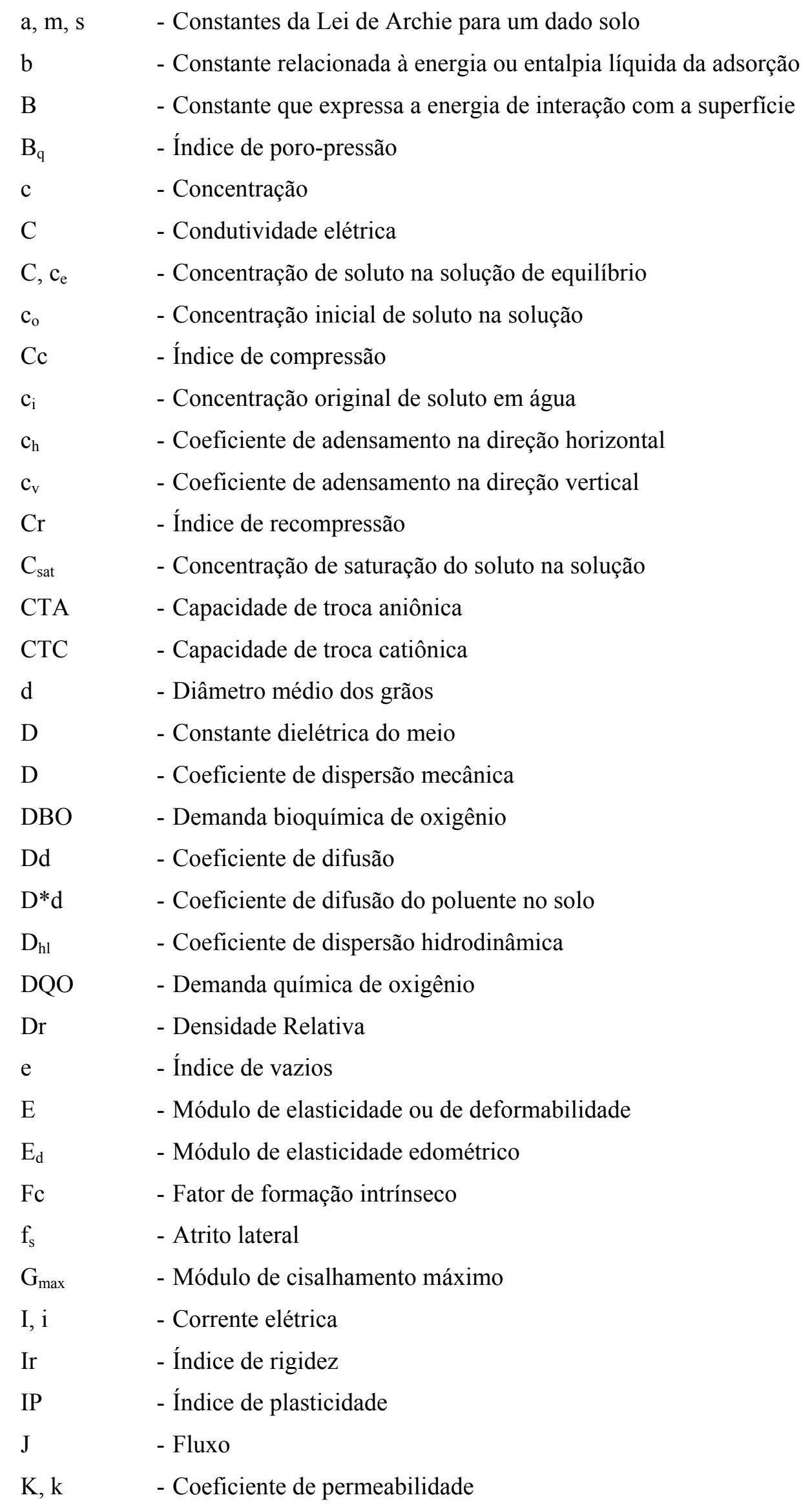




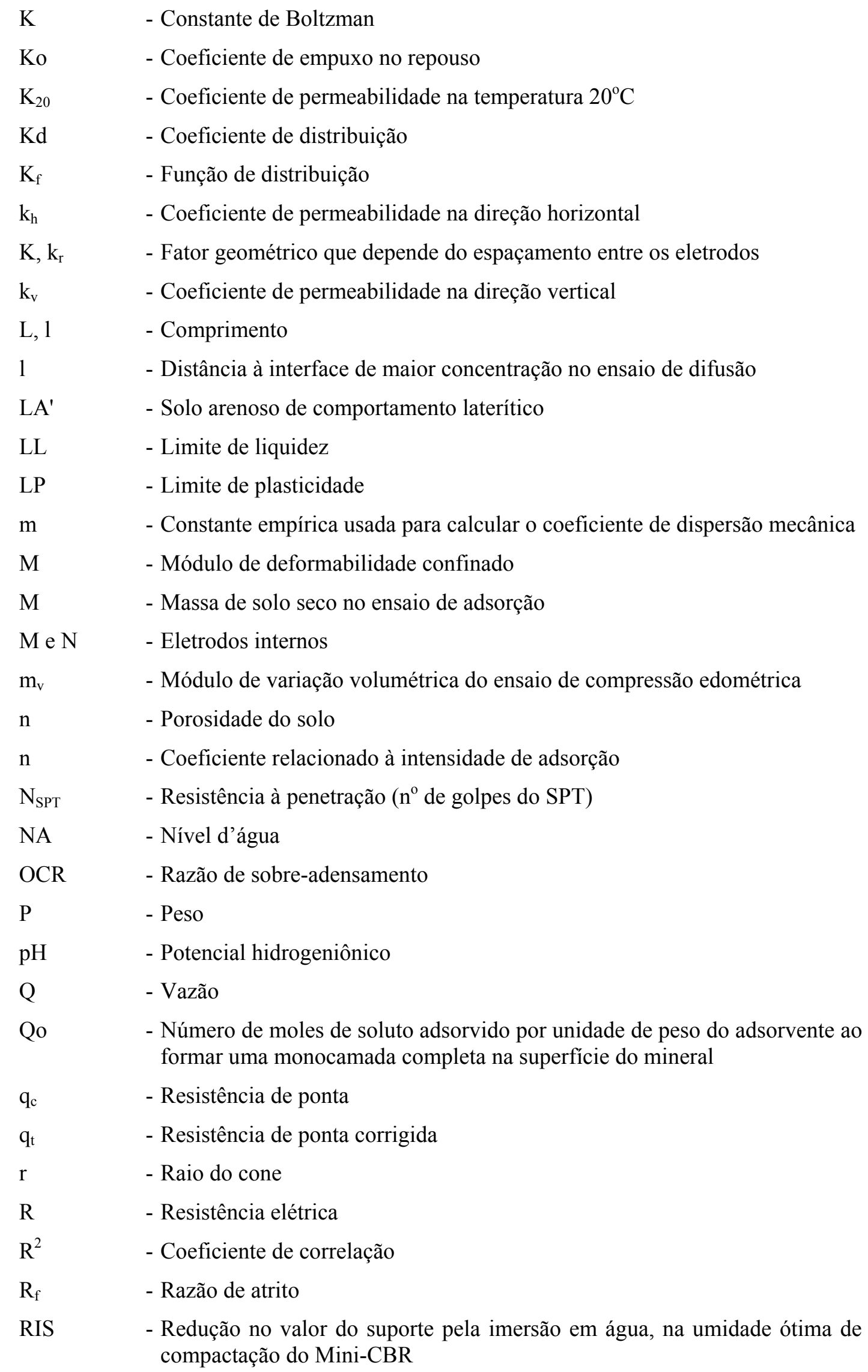




\begin{tabular}{|c|c|}
\hline RSS & - Razão solo-solução \\
\hline $\mathrm{S}$ & - Grau de adsorção \\
\hline $\mathrm{S}, \mathrm{Sr}$ & - Grau de saturação \\
\hline $\mathrm{S}$ & - Seção transversal do condutor \\
\hline $\mathrm{S}_{\mathrm{t}}$ & - Sensibilidade \\
\hline S.E. & - Superfície específica do argilo-mineral \\
\hline $\mathrm{t}$ & - Tempo \\
\hline $\mathrm{t}$ & - Espessura da camada dupla \\
\hline $\mathrm{T}$ & - Temperatura \\
\hline$T^{\prime \prime}$ & - Fator de tortuosidade \\
\hline$t_{0}$ & - Tempo inicial \\
\hline $\mathrm{T}^{*}$ & - Fator tempo \\
\hline $\mathrm{T}^{*}{ }_{50}$ & - Fator tempo correspondente a $50 \%$ da dissipação teórica \\
\hline$t_{50}$ & - Tempo correspondente a $U=0.5$ no ensaio de dissipação \\
\hline $\mathrm{u}$ & - Velocidade específica \\
\hline $\mathrm{U}$ & - Normalização do excesso de poro-presão \\
\hline $\mathrm{U}$ & - Volume do efluente \\
\hline $\mathrm{U}_{\mathrm{o}}$ & - Volume de vazios da coluna \\
\hline $\mathrm{U}$ & - Poro-pressão \\
\hline $\mathrm{U}_{1}$ & - Poro-pressão gerada na ponta do cone \\
\hline $\mathrm{U}_{2}$ & - Poro-pressão gerada imediatamente atrás da ponta do cone \\
\hline $\mathrm{U}_{3}$ & - Poro-pressão gerada imediatamente atrás da luva de atrito \\
\hline $\mathrm{u}_{\mathrm{o}}$ & - Poro-pressão estática \\
\hline $\mathrm{u}_{\mathrm{c}}$ & - Velocidade no ponto onde $\mathrm{c} / \mathrm{c}_{\mathrm{o}}=0.5$ no perfil de concentrações \\
\hline $\mathrm{u}_{\mathrm{i}}$ & - Poro-pressão medida no tempo $\mathrm{t}=0$ \\
\hline$u_{t}$ & - Poro-pressão medida no tempo $t$ \\
\hline $\mathrm{v}$ & - Velocidade de percolação \\
\hline V & - Volume do domínio delimitado numa certa região de fluxo \\
\hline $\mathrm{V}$ & - Volume da solução no frasco de adsorção \\
\hline $\mathrm{V}$ & - Voltagem \\
\hline VB & - Valor de azul de metileno consumido para $100 \mathrm{~g}$ de solo \\
\hline $\mathrm{V}_{\mathrm{s}}$ & - Volume de sólidos \\
\hline $\mathrm{V}_{\mathrm{v}}$ & - Volume de vazios \\
\hline $\mathrm{w}$ & - Teor de umidade do solo \\
\hline $\mathrm{w}_{\mathrm{ot}}$ & - Teor de umidade ótimo no ensaio de compactação \\
\hline $\mathrm{z}$ & - Direção de fluxo \\
\hline
\end{tabular}




\section{ERRATA}

\begin{tabular}{|c|c|c|c|}
\hline PÁGINA & LINHA & ONDE SE LÊ & LEIA-SE \\
\hline 004 & $13^{\mathrm{a}}$ & Capítulo 6 & Capítulo 5 \\
\hline 004 & $15^{\mathrm{a}}$ & Capítulo 7 & Capítulo 6 \\
\hline 005 & $27^{\mathrm{a}}$ & respectivos efluentes & respectivos efluentes e aerossóis \\
\hline 010 & $6^{\mathrm{a}}$ & a) Cor & Não considerar este ítem \\
\hline 022 & $17^{\mathrm{a}}$ & tamponamento & preenchimento \\
\hline 047 & $25^{\mathrm{a}}$ & sondagem & ensaio \\
\hline 049 & $15^{\mathrm{a}}$ & embasamento & topo rochoso \\
\hline 066 & $19^{\mathrm{a}}$ & alternativo & eficiente para a sua detecção \\
\hline 073 & $16^{\mathrm{a}}$ e $22^{\mathrm{a}}$ & De RUTIER & DE RUITER \\
\hline 074 & $12^{\mathrm{a}}$ & 1996 & 1998 \\
\hline 075 & $15^{\mathrm{a}}$ & Equação 3.8 & Equação 2.37 \\
\hline 113 & $1^{\mathrm{a}}$ & Foto 3.3 & $\begin{array}{l}\text { Acrescentar o sentido do norte }(\mathrm{N}) \text { na } \\
\text { foto, que é para a direita da mesma }\end{array}$ \\
\hline 133 & $1^{\mathrm{a}}$ & Figura 3.16 & Falta a camada de Arenito na figura \\
\hline 134 & $2^{\mathrm{a}}$ & 3.3.1 Sondagens de... & 3.3.1 Ensaios de ... \\
\hline 134 & $4^{\mathrm{a}}$ & sondagens elétricas & ensaios elétricos \\
\hline 141 & $11^{\mathrm{a}}$ & resistividade aparente & resistividade \\
\hline 164 & $3^{\mathrm{a}}$ & $\begin{array}{l}\text { 4.1.1 Sondagens } \\
\text { Elétricas de Superfície }\end{array}$ & $\begin{array}{c}\text { 4.1.1 Ensaios de Geofísica de } \\
\text { Superfície }\end{array}$ \\
\hline 168 & $3^{\mathrm{a}}$ & ... da linha $\mathrm{C} 1$ & $\begin{array}{l}\text {... da linha } \mathrm{C} 1 \text { seguidas do modelo } \\
\text { geoelétrico 2D para a Fase } 2\end{array}$ \\
\hline 169 & $1^{\mathrm{a}}$ & ... da linha C4 & $\begin{array}{l}\text {... da linha C4 seguidas do modelo } \\
\text { geoelétrico 2D para a Fase } 2\end{array}$ \\
\hline 175 & $18^{\mathrm{a}}$ & que um & que foi um \\
\hline 176 & $13^{\mathrm{a}}$ & $\begin{array}{l}\text { 4.2.1 Sondagens } \\
\text { Elétricas de Superfície } \\
\end{array}$ & $\begin{array}{c}\text { 4.2.1 Ensaios de Geofísica de } \\
\text { Superfície } \\
\end{array}$ \\
\hline 181 & $4^{\mathrm{a}}$ & $\ldots$ da linha $\mathrm{C} 2$ & $\begin{array}{l}\text {... da linha C2 seguidas do modelo } \\
\text { geoelétrico 2D para a Fase } 1\end{array}$ \\
\hline 182 & $1^{\mathrm{a}}$ & ... da linha $\mathrm{C} 4$ & $\begin{array}{l}\text {... da linha C4 seguidas do modelo } \\
\text { geoelétrico 2D para a Fase } 1\end{array}$ \\
\hline 234 & $17^{\mathrm{a}}$ & problema ocorreu & problema não ocorreu \\
\hline
\end{tabular}




\section{INTRODUÇÃO}

\subsection{Aspectos Gerais}

A proteção do meio ambiente, contra as consequencias adversas da disposição de resíduos, é um importante problema da atualidade e envolve duas questões fundamentais relacionadas à Geotecnia Ambiental. A primeira é a garantia de estabilidade dos locais usados para disposição dos resíduos. A segunda é a análise da migração de contaminantes, a partir dos locais onde os resíduos são dispostos, a qual será abordada neste trabalho.

Segundo TRESSOLDI \& CONSONI (1998), no Brasil, os requisitos para a proteção do meio ambiente envolvem muitas atividades técnicas e metodológicas da área da Geotecnia Ambiental, incluindo:

- Identificação e caracterização dos condicionantes geológicos, hidrogeológicos e geomorfológicos;

- Escolha do local de disposição e execução das investigações geológicas e hidrogeológicas;

- Definição e acompanhamento do monitoramento pré-operacional;

- Definição dos dispositivos de contenção e de coleta dos percolados e das plumas de contaminação;

- Definição dos tratamentos prévios dos resíduos, dos métodos e do projeto de disposição;

- Implementação e acompanhamento do monitoramento operacional e pósoperacional.

A seleção de novos locais para disposição de resíduos, aplicando critérios geológicos, hidrogeológicos e geotécnicos não soluciona os problemas de disposições efetuadas no passado, normalmente sem considerar qualquer critério e que, atualmente, são responsáveis por muitos impactos negativos, requerendo a 
implementação de medidas de remediação ou recuperação.

Os trabalhos para a remediação de áreas contaminadas por resíduos devem necessariamente, passar pela etapa inicial de diagnóstico, quando são coletadas informações sobre o meio ambiente atingido e sobre as características da contaminação. E efetuada a avaliação de impactos com base em indicadores ou fatores ambientais, são conduzidas investigações e monitoramento detalhados para melhor caracterizar e quantificar os impactos e para efetuar o estudo das alternativas de remediação.

Segundo DAVIES \& CAMPANELLA (1995b), a investigação ou caracterização geoambiental refere-se a uma representação sub e superficial do terreno, indicando de forma aproximada as suas condições in situ. E esta representação é geralmente obtida a partir de um programa de investigação que inclui tanto o reconhecimento superficial como o subsuperficial do terreno em questão.

Atualmente, este tipo de investigação inicia-se pela geofísica de superfície, técnica não invasiva que permite identificar a presença e a direção do fluxo de contaminantes no subsolo. Essa técnica vem sendo utilizada na fase de mapeamento preliminar, fornecendo informações necessárias para orientar a investigação através de métodos invasivos, como a sondagem a trado ou de simples reconhecimento (SPT), e também para identificar locais para implantação de poços de monitoramento do aqüífero freático.

Outra técnica invasiva mais recente é a sondagem com a utilização do piezocone (CPTU), o qual é uma ferramenta consagrada para a descrição contínua do perfil geotécnico, definição do nível d'água, assim como para estimativa de parâmetros mecânicos do solo.

Recentemente, sensores especiais têm sido incorporados no penetrômetro para detectar e medir propriedades geoambientais do solo, com destaque para o piezocone de resistividade (RCPTU) em conjunto com amostradores "direct push" para a coleta de amostras de solo, água e gás, o que faz com que este ensaio seja uma ferramenta ideal para a caracterização ambiental do solo, uma vez que ele reduz a exposição do operador com o solo contaminado, não causa grandes perturbações no terreno e, até mesmo, novos estudos estão sendo realizados para que ele permita que os contaminantes químicos sejam determinados in situ e em tempo real, sem 
amostragem, e assim, sem a posterior análise química em laboratório.

O conjunto de ensaios realizados com o piezocone associado a diversos dispositivos especiais é chamado de Tecnologia do Piezocone (DAVIES \& CAMPANELLA, 1995a). Hoje, toda esta tecnologia está sendo comercializada e empregada em vários países, devido à sua veloz evolução e à grande importância que tem sido dada às questões ambientais atualmente.

As pesquisas no Brasil utilizando piezocone de resistividade estão no início e, portanto, é necessário, no atual estágio de conhecimento, a obtenção de valores de referência para a avaliação da presença de contaminantes em diferentes tipos de solos, o que representa um grande desafio no Brasil, pela sua extensão e variedade de tipos de solos existentes.

\subsection{Objetivo}

O principal objetivo deste trabalho é estudar a aplicação da tecnologia do piezocone na investigação geoambiental de solos tropicais a partir da realização de ensaios nas áreas onde se encontram o aterro de resíduos sólidos urbanos de Bauru e o antigo lixão de Ribeirão Preto, ambos no Estado de São Paulo. Dentro deste contexto, outros ensaios como a eletrorresistividade de superfície, as análises químicas das amostras coletadas por amostradores especiais e pelos poços de monitoramento, além de ensaios geoambientais laboratório, poderão contribuir para um melhor entendimento do camininhamento da pluma de contaminação e dos próprios resultados obtidos a partir dos ensaios com o piezocone realizados nestas áreas de disposição de resíduos.

É importante salientar que este trabalho só pôde ser desenvolvido com a participação de profissionais de diferentes áreas do conhecimento. Ou seja, muito do que é apresentado aqui é fruto de um trabalho em equipe, o que possibilitou que muitas questões pudessem ser abordadas, demonstrando a importância da integração de diferentes especialidades para o entendimento do problema da disposição de resíduos em solos, um dos temas de suma importância em Geotecnia Ambiental. 


\subsection{Organização da Dissertação}

O trabalho se inicia com uma ampla Revisão Bibliográfica (Capítulo 2), descrevendo os principais assuntos estudados durante a realização do projeto, como algumas noções básicas sobre Engenharia Ambiental, interação solo-contaminante, transporte de poluentes no solo, metodologias dos ensaios de Geofísica, Piezocone de Resistividade (RCPTU), amostradores de solo e água aplicados à Tecnologia do Piezocone e poços de monitoramento.

Já o Capítulo 3, Materiais e Métodos, apresenta a descrição dos locais estudados, seguida da metodologia aplicada nos ensaios realizados nestes locais.

O Capítulo 4 traz os resultados de todos estes ensaios, seguidos de uma discussão sobre eles, além de uma discussão geral sobre o que cada um destes ensaios contribuíram para o entendimento da contaminação dos locais estudados.

No Capítulo 6 tem-se as conclusões e algumas sugestões para continuidade desta pesquisa.

O Capítulo 7 apresenta as referências bibliográficas consultadas e citadas durante todo o texto.

Nos Anexos, são apresentados os resultados das campanhas de ensaios CPTU realizados no lixão de Ribeirão Preto, ensaios CPTU e RCPTU realizados no aterro de resíduos sólidos urbanos de Bauru, ensaios de dissipação de poro-pressão realizados no aterro de resíduos sólidos urbanos de Bauru, ensaios de coluna realizados em laboratório com o solo do aterro de resíduos sólidos urbanos de Bauru e ensaios de adsorção em lote realizados em laboratório com o solo do aterro de resíduos sólidos urbanos de Bauru. 


\section{REVISÃO BIBLIOGRÁFICA}

\subsection{Poluição e Contaminação}

Antes de iniciar o estudo sobre a contaminação do subsolo (incluindo com este também a contaminação do lençol freático), é de grande importância que se faça a distinção entre os conceitos de poluição e de contaminação, já que ambos são às vezes utilizados como sinônimos. A contaminação refere-se à transmissão de substâncias ou microrganismos nocivos à saúde pela água. A ocorrência da contaminação não implica necessariamente um desequilíbrio ecológico. Assim, a presença na água de organismos patogênicos prejudiciais ao homem não significa que o meio ambiente aquático esteja ecologicamente desequilibrado. De maneira análoga, a ocorrência de poluição não implica necessariamente riscos à saúde de todos os organismos que fazem uso dos recursos hídricos afetados. Por exemplo, a introdução de calor extensivo nos corpos de água pode causar profundas alterações ecológicas no meio sem que isso signifique necessariamente restrições ao seu consumo pelo homem (BRAGA et al., 2002).

A contaminação do subsolo pode ocorrer devido a diversos tipos de despejo, com diferentes objetivos, situações e resíduos. São citadas a seguir algumas situações que podem provocar a contaminação do subsolo:

- Poluição do solo rural, devido ao emprego de fertilizantes sintéticos e defensivos;

- Despejo de águas residuárias no solo, podendo se caracterizar por um possível sistema de tratamento ou como método apropriado de disposição final;

- Poluição do solo urbano, proveniente dos resíduos gerados pelas atividades econômicas que são típicas das cidades, como a indústria, o comércio e os serviços, além dos provenientes do grande número de residências presentes em áreas relativamente restritas;

- Poluição do solo provocada por resíduos industriais e seus respectivos efluentes, 
podendo ser citados aqui os óleos, detergentes, pesticidas, hidrocarbonos aromáticos, solventes, além de demais resíduos perigosos, os quais serão definidos adiante.

O presente trabalho fará referência ao terceiro item, no que diz respeito aos locais de disposição final de resíduos sólidos urbanos. Segundo BOSCOV \& ABREU (2000), o conceito de aterro sanitário vem evoluindo concomitantemente ao de disposição de resíduos. A tendência atual é definir aterro sanitário como uma forma de disposição de resíduos sólidos no solo, particularmente resíduos sólidos urbanos, que, fundamentada em critérios de engenharia e normas operacionais específicas, permite o confinamento seguro em termos de poluição ambiental e proteção à saúde pública, minimizando os impactos ambientais (IPT, 1995 e ABNT, 1984).

A ABNT (1984) define os resíduos sólidos urbanos (RSU) como sendo os resíduos sólidos gerados num aglomerado urbano, exceto os resíduos industriais perigosos, hospitalares sépticos, e de aeroportos e portos.

Hoje, dá-se o nome de aterro sanitário a um sistema devidamente preparado para a disposição dos RSU, englobando, sempre que necessário, determinados componentes e práticas operacionais, tais como: divisão em células, compactação dos resíduos, cobertura, sistema de impermeabilização, sistema de drenagem para líquidos e gases, tratamento de chorume, monitoramento geotécnico e geoambiental, entre outros (BOSCOV \& ABREU, 2000). Distinguem-se assim os aterros sanitários de outras formas de disposição de resíduos sólidos urbanos, como os aterros controlados e os lixões. Nos aterros controlados, os resíduos são cobertos com solo, e eventualmente, compactados; não existe impermeabilização de base, sistema de drenagem e tratamento de chorume ou gases gerados. Já os lixões são descargas a céu aberto, sem quaisquer medidas de proteção ao meio ambiente e à saúde pública.

É importante ressaltar que existem casos de sistemas de disposição de RSU que não se encaixam exatamente nas definições descritas acima. Ás vezes, pode ocorrer de um sistema ter mais componentes que um aterro controlado, mas menos componentes que um aterro sanitário, seguindo aí perfeitamente a sua definição.

À fase líquida da massa aterrada, que percola através desta removendo materiais dissolvidos e suspensos, é dado o nome de chorume ou lixiviado. $\mathrm{Na}$ 
maioria dos locais de disposição de resíduos, o chorume é composto pelo líquido que entra na massa aterrada de lixo advindo de fontes externas, tais como sistemas de drenagem superficial, chuva, lençol freático, nascentes e aqueles resultantes da decomposição do lixo (CALÇAS, 2001).

\subsubsection{Valores de Qualidade do Solo e da Água Subterrânea}

A CETESB (2001), à exemplo de países com tradição na questão do monitoramento da qualidade de solos e águas subterrâneas e no controle de áreas contaminadas, publicou uma lista preliminar de valores orientadores para proteção da qualidade dos solos e das águas subterrâneas, os quais, sempre que possível, foram estabelecidos com base em dados nacionais e em avaliação de risco à saúde humana.

Estes valores de referência de qualidade foram estabelecidos para serem utilizados como instrumento ágil e de fácil aplicação no suporte às decisões para as ações de prevenção e controle da poluição dos solos e das águas subterrâneas. A Tabela 2.1 apresenta os valores de referência de qualidade, alerta e intervenção para os solos e os valores de intervenção para as águas subterrâneas no Estado de São Paulo.

Segundo a CETESB (1999), a proposta da criação de três valores distintos (STI) foi feita pelo Ministério de Planejamento Territorial e Meio Ambiente da Holanda em 1994, e a definição de cada um desses valores é descrita a seguir:

- Valor de Referência de Qualidade (S): indica o limite de qualidade para um solo considerado limpo ou a qualidade natural das águas subterrêneas a ser utilizado em ações de prevenção da poluição do solo e das águas subterrâneas e no controle de áreas contaminadas. Foi estabelecido com base em análises químicas dos diversos tipos de solos do Estado de São Paulo;

- Valor de Alerta (T): indica uma possível alteração da qualidade natural dos solos. Será utilizado em caráter preventivo e quando excedido no solo, deverá ser exigido o monitoramento das águas subterrâneas, identificando-se e controlandose as fontes de poluição. Foi derivado para os metais, com base em revisão bibliográfica sobre fitotoxicidade.

- Valor de Intervenção (I): indica o limite de contaminação do solo e das águas 
subterrâneas, acima do qual, existe risco potencial à saúde humana. Será utilizado em caráter corretivo no gerenciamento de áreas contaminadas e, quando excedido, requer alguma forma de intervenção na área avaliada, de forma a interceptar as vias de exposição, devendo ser efetuada uma avaliação de risco caso a caso. Foi derivado com base em modelo matemático de avaliação de risco, considerando diversas vias de exposição em três cenários de uso e ocupação do solo. Para as águas subterrâneas, considerou-se como valor de intervenção os padrões de potabilidade da Portaria 36 de 1990, atualizados pela Portaria 1.469 de 29/12/2000, ambas do Ministério da Saúde.

Observa-se aqui que os valores de intervenção para as águas subterrâneas podem ser muito rigorosos quando aplicados às águas do entorno de um local de disposição de resíduos, uma vez estes foram determinados a partir dos padrões de potabilidade para o consumo humano do Ministério da Saúde. Acredita-se assim na necessidade de uma norma brasileira que regulamente estes valores considerando um futuro tratamento desta água, como traz a Resolução do CONAMA $n^{\circ}$ 20, de 18/06/1986, no caso de águas superficiais. Nota-se ainda inexistência de limites para alguns parâmetros importantes na avaliação da poluição e da contaminação das águas subterrâneas na Portaria 1.469 do Ministério da Saúde, como a DBO (Demanda Bioquímica de Oxigênio), DQO (Demanda Química de Oxigênio), alcalinidade, condutividade etc. 
Tabela 2.1. Valores orientadores para solos e águas subterrâneas no Estado de São Paulo (CETESB, 2001).

\begin{tabular}{|c|c|c|c|c|c|c|}
\hline \multirow{4}{*}{ Substância } & \multicolumn{6}{|c|}{ VALORES ORIENTADORES } \\
\hline & \multicolumn{5}{|c|}{ Solos (mg.kg-1) } & \multirow{3}{*}{\begin{tabular}{|c|}
$\begin{array}{c}\text { Águas } \\
\text { Subting.17) }\end{array}$ \\
Intervençàc
\end{tabular}} \\
\hline & \multirow[b]{2}{*}{ Referencia } & \multirow[b]{2}{*}{ Alerta } & \multicolumn{3}{|c|}{ Intervençào } & \\
\hline & & & $\begin{array}{l}\text { Agricola } \\
\text { APMax }\end{array}$ & Residencial & Industrial & \\
\hline Aluminio & - & - & - & - & - & $200^{4}$ \\
\hline Antimônio & $<0,5$ & 2.0 & 5,0 & 10,0 & 25 & $5^{1+1}$ \\
\hline Arsếnio: & 3,50 & 15 & 25 & 50 & 100 & $10^{\circ}$ \\
\hline Bário & 75 & 150 & 300 & 400 & 700 & $700^{(1)}$ \\
\hline Cadmio & $<0,5$ & 3 & 10 & 15 & 40 & 50 \\
\hline Chumbo & 17 & 100 & 200 & 350 & 1200 & $10 \%$ \\
\hline Cobalto & 13 & 25 & 40 & 80 & 100 & $30^{50}$ \\
\hline Cobre & 35 & 60 & 100 & 500 & 700 & $2000^{(i)}$ \\
\hline Cromo & 40 & 75 & 300 & 700 & 1000 & 50.0 \\
\hline Ferro & - & - & - & - & - & 3004 \\
\hline Manganès & - & - & - & - & - & $100 \%$ \\
\hline Mercúrio & 0,05 & 0,5 & 2,5 & 5 & 25 & 110 \\
\hline Molibdénio & $<25$ & 30 & 50 & 100 & 120 & $250^{25}$ \\
\hline Niquel & 13 & 30 & 50 & 200 & 300 & 50.0 \\
\hline Prata & 0,25 & 2 & 25 & 50 & 100 & 50 in \\
\hline Selênio & 0.25 & 5 & - & - & - & $10^{6}$ \\
\hline Venádio & 275 & - & - & - & - & - \\
\hline Zinco & 60 & 300 & 500 & 1000 & 1500 & $5000^{(2)}$ \\
\hline Benzeno & 0,25 & - & 0,6 & 1,5 & 3,0 & 5 \\
\hline Tolueno & 0,25 & - & 30 & 40 & 140 & $170 / 7$ \\
\hline Xilenos & 0,25 & - & 3,0 & 6,0 & 15 & 30041 \\
\hline Estireno & 0,05 & - & 15 & 35 & 80 & 2060 \\
\hline Naftaleno & 0,20 & - & 15 & 60 & 90 & 10008 \\
\hline Diclorobenzeno & 0,02 & - & 2,0 & 7,0 & 10,0 & $40^{\circ 5}$ \\
\hline Hexaclorobenzeno & 0,0005 & - & 0,1 & 1,0 & 1,5 & 110 \\
\hline Tetracioroetileno & 0,10 & - & 1.0 & 1,0 & 10 & $40^{\circ}$ \\
\hline Tricloroetileno & 0,10 & - & 5,0 & 10 & 30 & 70.0 \\
\hline 1,1,1 Tricioroetano & 0,01 & - & 8,0 & 20 & 50 & $600^{\circ}$ \\
\hline 1.2 Dicioroetano & 0.5 & - & 0.5 & 1,0 & 2,0 & $10^{6}$ \\
\hline Clareto de Vinila & 0,05 & - & 0.1 & 0,2 & 0,7 & $5^{10}$ \\
\hline Pentaciorofenol & 0,01 & - & 2,0 & 5,0 & 15,0 & 910 \\
\hline 2,4,6 Triclorofenol & 0,2 & - & 1,0 & 5,0 & 6,0 & $200^{(1 / 2}$ \\
\hline Fend & 0,3 & - & 5,0 & 10,0 & 15,0 & $0,1^{a j}$ \\
\hline Aldrin e Dieldrin & 0,00125 & - & 0.5 & 1,0 & 5,0 & $0,03^{\text {가 }}$ \\
\hline DDT & 0,0025 & - & 0.5 & 1,0 & 5,0 & $2^{11}$ \\
\hline Endrin & 0,00375 & - & 0,5 & 1,0 & 5,0 & $0,6^{15}$ \\
\hline Lindano (d-BHC) & 0,00125 & - & 0,5 & 1,0 & 5,0 & $2^{111}$ \\
\hline
\end{tabular}

(1) Padrão de potabilidade da Portaria 1.469 do Ministério da Saúde para substâncias que apresentam risco à saúde.

(2) Padrão de potabilidade da Portaria 1.469 do Ministério da Saúde para aceitação de consumo (critério organolétptico).

(3) Padrão de potabilidade da Portaria 36 do Ministério da Saúde.

(4) Comunidade Econômica Européia.

(5) Com base no valor de intervenção para solos no cenário agrícola/Área de Proteção Máxima (APMax).

- não estabelecido. 


\subsubsection{Poluição do Solo}

\subsubsection{Propriedades do Solo}

Algumas propriedades do solo são extremamente importantes para sua utilização como local de disposição de resíduos, como as que serão relatadas a seguir.

\section{a) Cor}

Como característica mais prontamente perceptível, é, em muitos casos, utilizada popularmente e mesmo em classificações científicas, para denominar e identificar os solos. Em termos técnicos, a cor é descrita por comparação com escalas padronizadas.

\section{b) Textura/Granulometria}

Descreve a proporção de partículas de dimensões distintas componentes do solo. Quando apresentada na forma de curvas gronulométricas, a qual é a base de classificação mais conhecida dos solos (areia, argila etc.), explica, também, algumas das principais propriedades físicas e químicas dos solos. Assim, por exemplo, a drenabilidade, a permeabilidade e a aeração de um solo serão mais acentuadas se as dimensões das partículas que o formam forem maiores. Já os solos com partículas menores favorecem a resistência à erosão, à retenção de água e de nutrientes, pelas propriedades coloidais que lhes estão associadas.

\section{c) Microbiologia do Solo}

A porção orgânica e particularmente sua parcela em decomposição é importante por dar origem ao húmus. Ao húmus cabe a função de agente granulador (formação de torrões) dos solos produtivos. A matéria orgânica tem a elevadíssima capacidade de reter nutrientes e água, muito superior, por exemplo, à existente na caulinita, a argila predominante em nossos solos. Deste modo, a matéria orgânica pode ter um efeito atenuador da nocividade de alguns elementos minerais sobre as 
plantas, como o alumínio e o manganês, por vezes presentes em teores indesejáveis nos solos tropicais (BRAGA et al., 2002).

\section{d) Estrutura}

É o modo como as partículas do solo se arranjam: em agregados ou torrões. Produtos da decomposição de matéria orgânica, juntamente com alguns componentes minerais, como o óxido de ferro e frações argilosas, promovem a agregação das partículas. A presença de umidade e ressecamento, com consequente inchamento e encolhimento, acaba por dar origem aos torrões do solo, com tamanho e forma variados e característicos, que podem ser granulares (esféricos ou arredondados), angulares (com faces planas e dimensões aproximadamente iguais), laminares (faces planas e dimensão horizontal bem maior) e prismáticos (faces planas e dimensão vertical bem maior). A estrutura de um solo explica, em boa parte, seu comportamento mecânico (capacidade de suporte de cargas, resistência ao cisalhamento ou escorregamento), conferindo-lhe o que se denomina consistência, ou seja, a capacidade de resistir a um esforço destinado a rompê-lo e que, podemos avalia-la pressionando os torrões entre os dedos (BRAGA et al., 2002).

\section{e) Capacidade de Troca Iônica}

Os argilo-minerais presentes na fração argila dos solos, bem como a matéria orgânica e alguns óxidos, podem apresentar cargas elétricas. Essas cargas elétricas desempenham importante papel nas trocas químicas entre as partículas sólidas e a solução aquosa que as envolve, repelindo ou absorvendo íons e radicais, configurando o que se denomina capacidade de troca ionica do solo (BRAGA et al., 2002). Se houver excesso de cargas negativas, o solo é trocador de cátions, propriedade esta que pode ser medida (capacidade de troca cationica - CTC). Se o excesso for de cargas positivas, mede-se a sua capacidade de troca aniônica (CTA). A CTC pode ocorrer nos óxidos e hidróxidos de metais devido à dissociação de $\mathrm{H}^{+}$, enquanto que o contrário, ou seja, a protonação dos óxidos ou das hidroxilas causam a CTA, no caso de meio ácido. Os argilo-minerais são apenas trocadores de cátions, devido ao fenômeno da substituição isomórfica, o qual ocorre durante a formação da 
molécula do mineral, ocorrendo a substituição de um tipo de átomo por outro, na estrutura molecular do mineral.

A CTC é dada em miliequivalentes/100 gramas (meq / 100g), sendo calculada através da razão entre a deficiência de carga da fórmula estrutural do argilo-mineral, por seu peso atômico total, incluindo já aí o cátion trocável.

\section{f) Potencial Hidrogeniônico (pH)}

Segundo BRAGA et al. (2002), solos de zonas de alta pluviosidade tendem a apresentar valores mais baixos do $\mathrm{pH}$ em conseqüência do processo de lixiviação das bases dos horizontes superiores, pela infiltração e percolação das águas. As condições climáticas predominantes em nosso país fazem com que quase a totalidade dos solos apresente $\mathrm{pH}$ inferior a 7, como é o caso do Estado de São Paulo.

\subsubsection{Interação Solo-Poluente}

Um entendimento adequado dos argilo-minerais em relação às suas interações com a água e os resíduos é o que será discutido e apresentado neste ítem, de acordo com SHARMA \& LEWIS (1994).

Os argilo-minerais são substâncias cristalinas muito pequenas, que fazem parte da fração argila dos solos (geralmente partículas menores que $2 \mu \mathrm{m}$ ) e têm a forma de placas. Estas placas são formadas por diversas folhas de cristais, as quais são de dois tipos básicos: (1) sílica tetraédrica e (2) magnésio ou alumínio octaédrico.

Como mostrado na Figura 2.1 (a), uma sílica tetraédrica sozinha é constituída por 4 átomos de oxigênio que envolvem um único átomo de sílicio. A Figura 2.1 (b) mostra que os átomos de oxigênio da base se combinam para formar uma estrutura foleada, e a Figura 2.1 (c) mostra uma representação comum da folha tetraédrica. A Figura 2.1 (d) apresenta uma vista de cima da folha de sílica. 


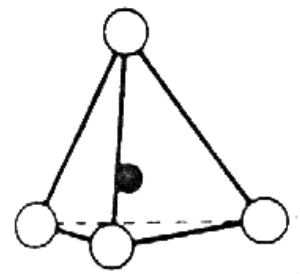

(a)

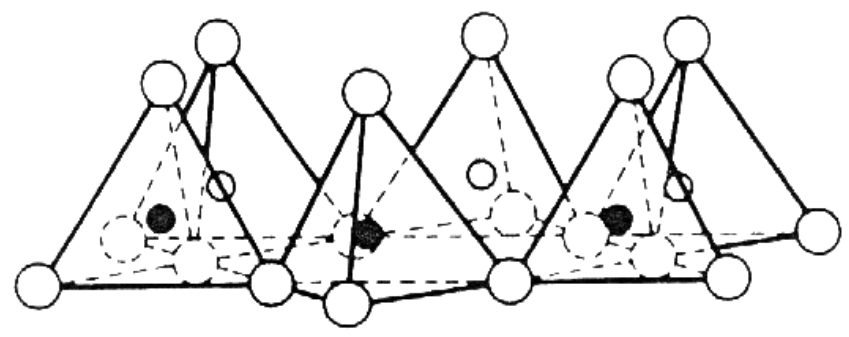

(b)

$\bigcirc$ e $\quad y=$ Oxigênios $\quad O$ e $=$ Silícios

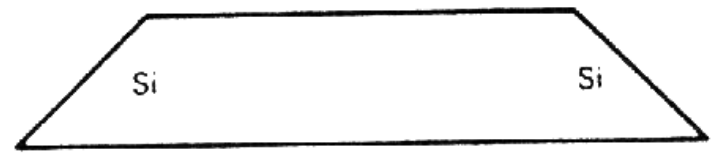

(c)

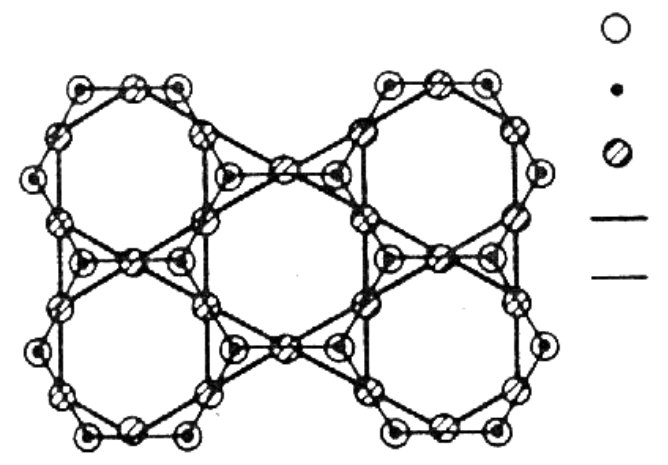

Oxigênios no plano mais acima

- Silícios

Oxigênios ligados formando a rede

Contorno da sílica tetraédrica

Contorno da rede hexagonal de sílica em duas dimensões; também indica os vínculos entre os silícios e os oxigênios em um plano mais baixo.

(d)

Figura 2.1. (a) Sílica tetraédrica sozinha, de GRIM (1959); (b) vista isométrica do tetraedro ou folha de sílica, de GRIM (1959); (c) representação esquemática da folha de sílica, de Lambe (1953); vista de cima da folha de sílica, de WARSHAW \& ROY, 1961 (HOLTZ \& KOVACS, 1981 apud SHARMA \& LEWIS, 1994).

Já o magnésio, ou alumínio octaédrico, como mostrado na Figura 2.2 (a), é constituído por 6 oxigênios, ou hidrogênios, que envolvem um único alumínio, magnésio, metal, ou outro átomo. A Figura 2.2 (b) mostra uma folha octaédrica, a Figura 2.2 (c) mostra uma representação esquemática da folha, e a Figura 2.2 (d) apresenta uma vista de cima da folha octaédrica e revela a fração de diferentes átomos na folha. 


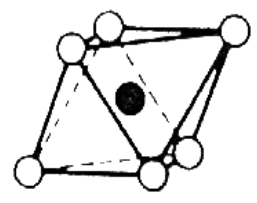

(a)

e $\because=$ Hidróxidos ou oxigênios

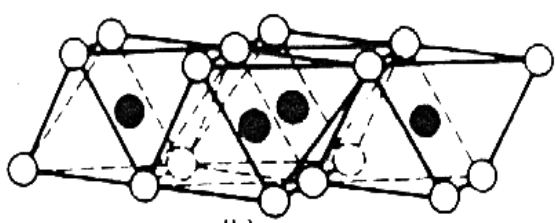

(b)

Alumínios, magnésios, etc.

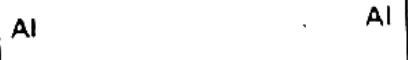

(c)

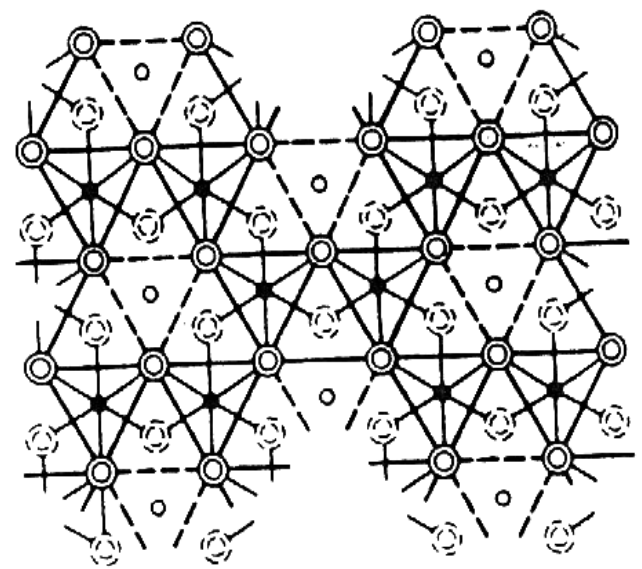

(d)
Hidróxidos no plano mais acima

- Alumínios

- Posições vazias do octaédro, que podem ser preenchidas por brucita

(Q) Hidróxidos no plano mais baixo Contorno do alumínio octaédrico paralelo ao plano mais baixo de hidróxidos Contorno dos vazios do octaédro paralelo ao plano mais baixo de hidróxidos Vínculos entre os alumínios e os hidróxidos (6 para cada alumínio)

Figura 2.2. (a) Alumínio (ou magnésio) octaédrico sozinho, de GRIM (1959); (b) vista isométrica da folha octaédrica, de GRIM (1959); (c) representação esquemática do octaédro ou da folha de alumínio (ou magnésio), de LAMBE (1953); vista de cima da folha octaédrica, de WARSHAW \& ROY, 1961 (HOLTZ \& KOVACS, 1981 apud SHARMA \& LEWIS, 1994).

Estas duas estruturas básicas foleadas são unidas entre si, de uma única forma e com certos cátions, de modo a formar diferentes argilo-minerais. A seguir, diversos argilo-minerais serão abordados. 


\section{a) Caulinita - Serpentina}

Como mostrado na Figura 2.3, estes minerais constituem camadas alternadas de sílica tetraédrica e folhas octaédricas, e são chamadas de argilo-minerais 1:1. Se a folha octaédrica é de alumínio ou gibsita, o mineral é caulinita. Por outro lado, se a camada octaédrica é de brucita, o mineral é serpentina. A estrutura atômica da caulinita é mostrada na Figura 2.4 e sua fórmula estrutural é $(\mathrm{OH})_{8} \mathrm{Si}_{4} \mathrm{Al}_{4} \mathrm{O}_{10}$ (MITCHELL, 1993). Cada camada tem cerca de 7,2 Â $\left(1 \hat{\mathrm{A}}=10^{-8} \mathrm{~cm}\right)$ de espessura; um típico cristal de caulin pode ter de 70 a 100 camadas. Camadas sucessivas de folhas são unidas por uma ligação de hidrogênio, a qual é muito forte, evitando hidratação. Já entre as camadas não existe nenhuma ligação.

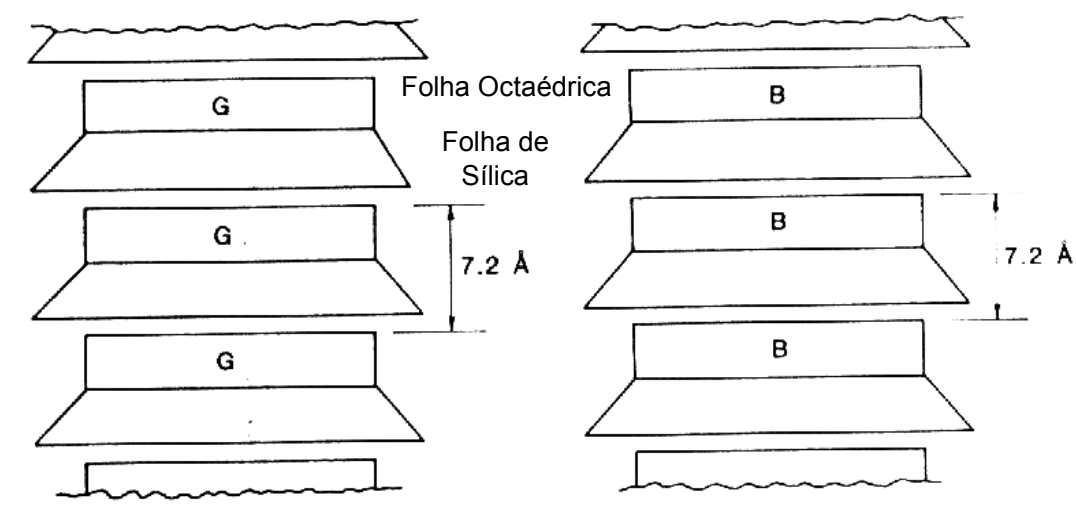

(a)

(b)

Figura 2.3. Diagramas esquemáticos das estruturas da (a) caulinita e da (b) serpentina (MITCHELL, 1993 apud SHARMA \& LEWIS, 1994).

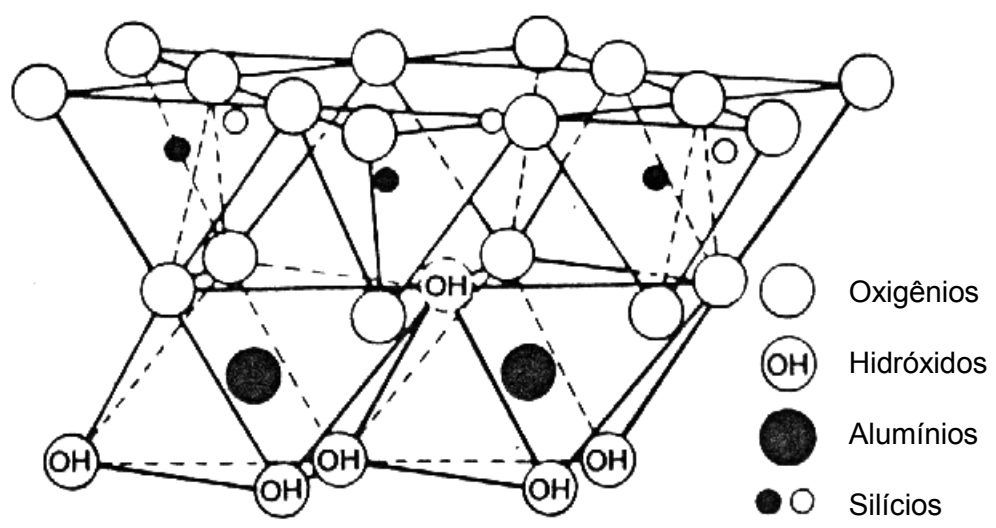

Figura 2.4. Representação do diagrama da estrutura da caulinita (MITCHELL, 1993 apud SHARMA \& LEWIS, 1994). 


\section{b) Haloisita}

Outro argilo-mineral 1:1 é a haloisita. Ela difere da caulinita no sentido de que quando ela é formada, ela é hidratada entre as camadas por alguma razão. Isto resulta numa distorcida ou aleatória formação das camadas. A Figura 2.5 mostra um mineral de haloisita hidratado e não hidratado. É interessante notar que a água pode ser facilmente removida por entre as camadas por aquecimento ou ar seco. Contudo, a haloisita não será re-hidratada caso adiciona-se mais água. Este fato pode ser de interessante aplicação na engenharia no sentido de que os resultados de ensaios de compactação podem diferir entre amostras secas e amostras ensaiadas com o teor de umidade natural.

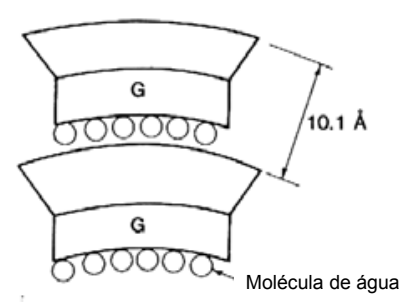

CAMADA HIDRATADA

(a)

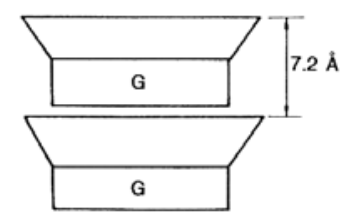

FORMA NÃO HIDRATADA

(b)

Figura 2.5. Diagramas esquemáticos da estrutura da haloisita: (a) $10 \hat{\mathrm{A}}$ e (b) $7 \hat{\mathrm{A}}$ (MITCHELL, 1993 apud SHARMA \& LEWIS, 1994).

\section{c) Montmorilonita}

A montmorilonita é um argilo-mineral do grupo da esmectita. Como mostrado na Figura 2.6, a saponita é um outro argilo-mineral deste grupo. O mineral é composto por duas folhas de sílica e uma folha de alumínio (ou gibsita) e assim, é chamado de mineral 2:1. A ligação entre as sucessivas camadas é fraca, pois é realizada pelas forças de van der Waals. Além disso, existe uma rede deficiente de 
carga negativa na folha octaédrica. Por isso, a água ou outros líquidos polares e íons trocáveis podem entrar e separar as camadas. Devido à grande afinidade que a montmorilonita tem com a água, solos que contêm este mineral sofrem expansão devido ao aumento do teor de água. A Figura 2.7 apresenta um desenho da estrutura da montmorilonita.

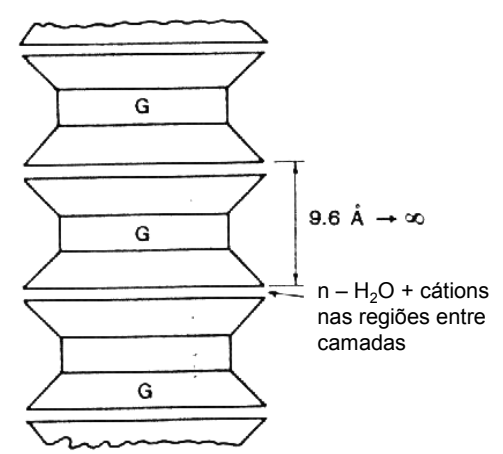

(a)

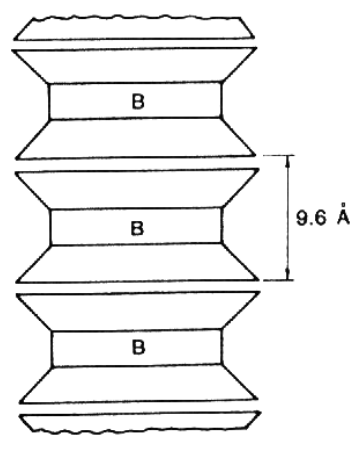

(b)

Figura 2.6. Diagramas esquemáticos das estruturas de minerais esmectita: (a) montmorilonita; (b) saponitas (MITCHELL, 1993 apud SHARMA \& LEWIS, 1994).

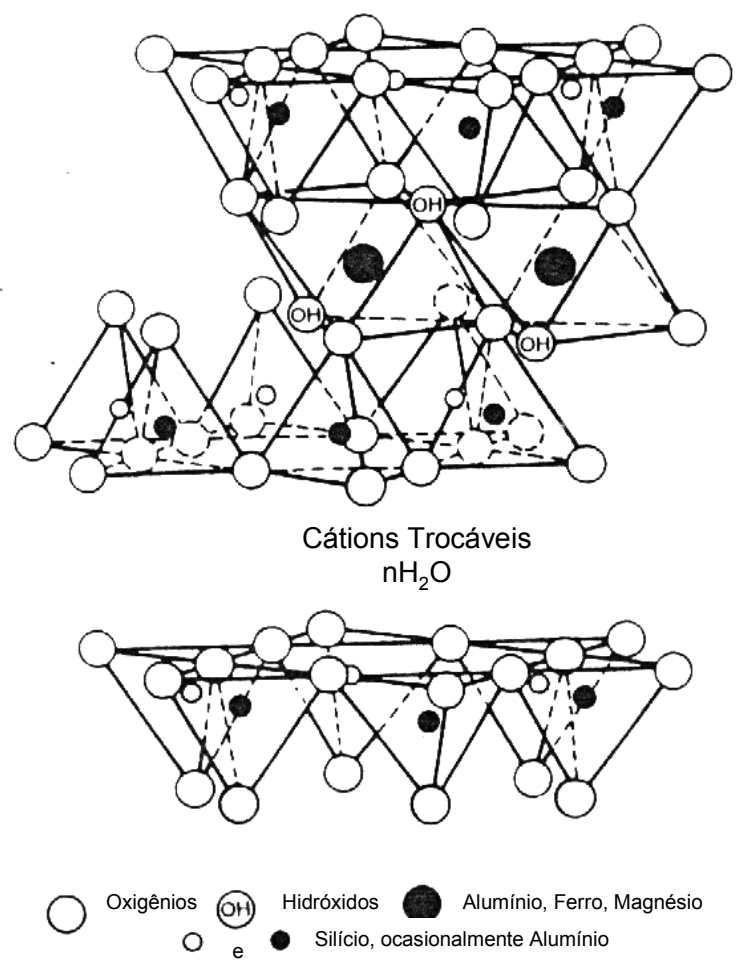

Figura 2.7. Representação do diagrama da estrutura da montmorilonita (MITCHELL, 1993 apud SHARMA \& LEWIS, 1994). 


\section{d) Ilita}

Como mostrada na Figura 2.8, a ilita tem uma estrutura 2:1, similar à da montmorilonita, mas a ligação entre suas camadas é feita por átomos de potássio. Por isso, sua estrutura é estável e não está sucetível à expansão, devido ao aumento do teor de água.

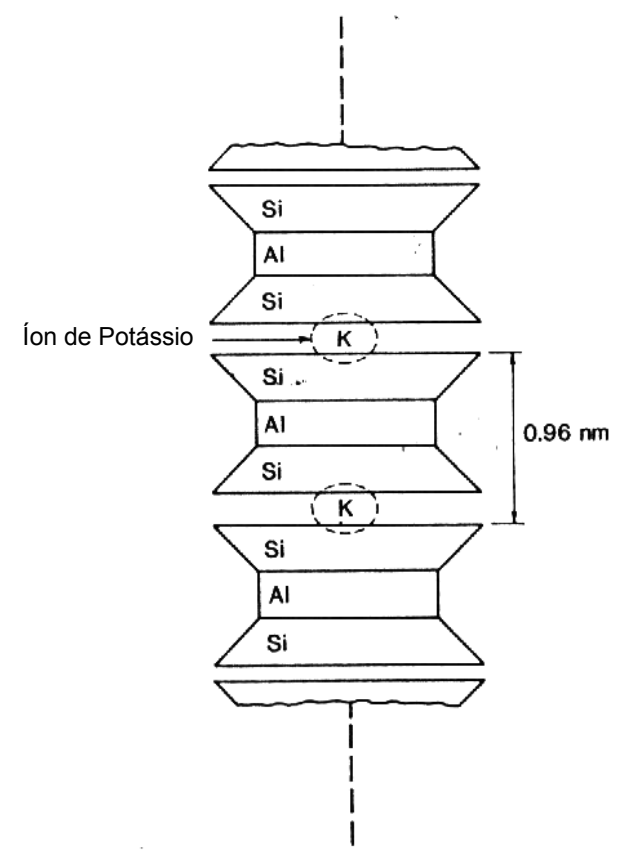

Figura 2.8. Diagrama esquemático da estrutura da ilita, de LAMBE, 1953 (HOLTZ \& KOVACS, 1981 apud SHARMA \& LEWIS, 1994).

\section{e) Clorita}

A clorita é outro mineral comumente encontrado nos solos argilosos. Ela é constituída por repetidas camadas constituídas de uma sílica, um alumínio ou uma brucita ou gibsita, outra sílica, e entre uma ou outra camada uma folha de gibsita ou de brucita. Por essa razão é chamada de mineral 2:1:1 e é significativamente menos ativa que a montmorilonita (mineral 2:1), mas tem apenas duas intercamadas de água (HOLTZ \& KOVACS, 1981). As estruturas de alguns outros minerais deste tipo são mostradas na Figura 2.9. 


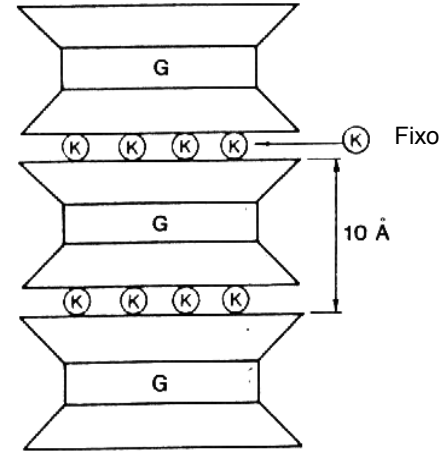

(a)

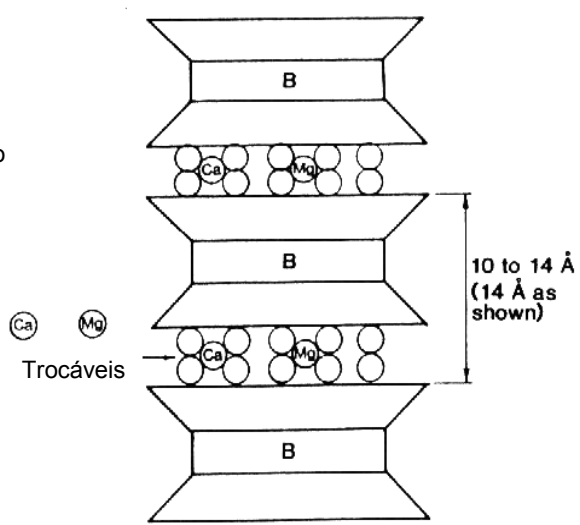

(b)

Figura 2.9. Diagramas esquemáticos das estruturas da (a) muscovita e ilita, e (b) vermiculita (MITCHELL, 1993 apud SHARMA \& LEWIS, 1994).

Os argilo-minerais podem ser identificados por técnicas como difração de raios-X e análise térmica diferencial (Diferential Thermal Analisys - DTA). Estas técnicas são de difícil interpretação. Uma simples aproximação da engenharia para identificar argilo-minerais é usada pelos Limites de Atterberg (Figura 2.10). Como mostrado nesta figura, um gráfico do índice de plasticidade (IP) em função do limite de liquidez (LL) pode indicar a presença de montmorilonitas, ilitas, caulinitas, ou haloisitas no solo.

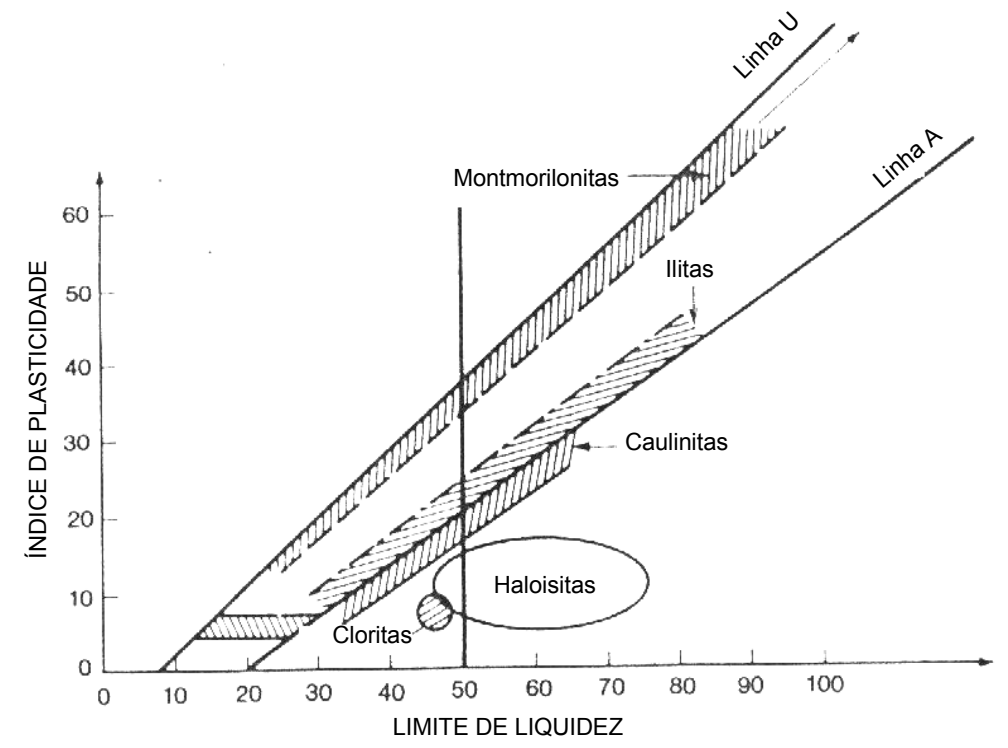

Figura 2.10. Posição dos argilo-minerais no ábaco da plasticidade de Casagrande (HOLTZ \& KOVACS, 1981 apud SHARMA \& LEWIS, 1994). 


\section{f) Interação Argilo-minal - Água}

Como visto, as superfícies dos argilo-minerais são negativamente carregadas. Devido a esta eletronegatividade, os cátions são firmemente segurados nas superfícies desses minerais. $\mathrm{O}$ excesso de cátions (mais que o necessário para neutralizar as cargas negativas) e seus ânions associados, estão presentes como sais precipitados. Estes sais se movem dentro da solução quando os argilo-minerais entram em contato com a água. Devido à alta concentração de cátions adsorvidos, existe uma tendência dos cátions se dissiparem; isto tende a igualar as concentrações completamente (MITCHELL, 1993). Desde que os ânions sejam excluídos dos campos de força negativos, suas concentrações aumentarão com a distância da partícula. A Figura 2.11 apresenta a distribuição dos íons adjacentes à surperfície dos argilo-minerais. A carga distribuída adjacente à superfície negativa forma uma parte importante do sistema argilo-mineral - água. A superfície carregada e a carga distribuída adjacente juntas são chamadas de difusão da camada dupla. A espessura desta camada (t) pode ser obtida através da seguinte expressão (MITCHELL, 1976, 1993):

$$
\mathrm{t}=\frac{(D \cdot K \cdot T)^{0.5}}{\left(8 \cdot \pi \cdot \eta_{0} \cdot \xi^{2} \cdot v^{2}\right)^{0.5}}
$$

onde:

$\mathrm{D}=$ constante dielétrica do meio;

$\mathrm{K}=$ constante de Boltzman $=1,38 \times 10^{-16} \mathrm{erg} / \mathrm{K}$;

$\mathrm{T}=$ temperatura;

$\eta_{0}=$ concentração eletrolítica;

$\xi=$ carga elétrica unitária $=16 \times 10^{-20}$ coulomb ou $4,8 \times 10^{-10} \mathrm{esu}$;

$v=$ valência do cátion. 

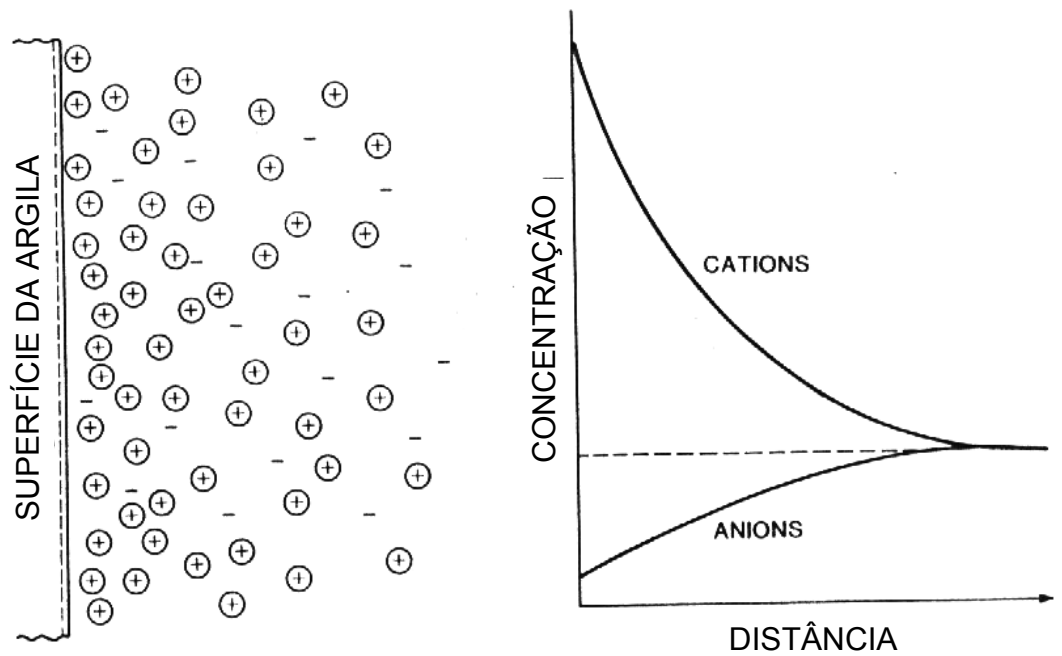

Figura 2.11. Distribuição dos íons adjacentes à superfície da argila, de acordo com o conceito da camada dupla (MITCHELL, 1993 apud SHARMA \& LEWIS, 1994).

A Figura 2.12 mostra como o efeito da valência do cátion altera o valor da espessura e das concetrações da camada dupla.

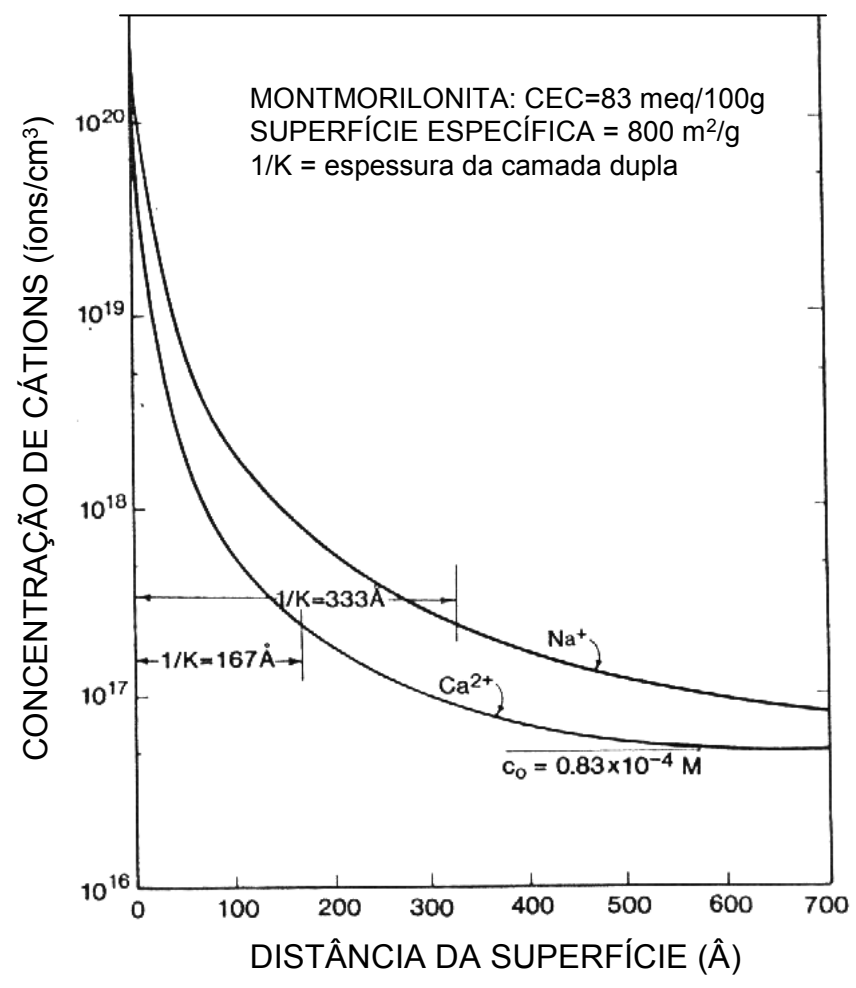

Figura 2.12. Efeito da valência do cátion nas concentrações da camada dupla (MITCHELL, 1993 apud SHARMA \& LEWIS, 1994). 
Os valores da constante dielétrica, que indicam a habilidade de um material conduzir um campo elétrico em relação ao vácuo, são tabelados para diversos hidrocarbonos e podem ser encontrados em SHARMA \& LEWIS (1994) ou em DRAGUN (1988).

\section{g) Interação Solo - Resíduo}

Como os contaminantes provenientes da disposição de resíduos infiltram-se através da superfície natural dos solos, eles podem influenciar as propriedades fundamentais dos solos. Uma das mais importantes propriedades de interesse é a condutividade hidráulica, ou permeabilidade. A condutividade hidráulica das argilas pode ser afetada pelas substâncias químicas dos resíduos através das seguintes maneiras:

- Dissolução dos minerais do solo: ácidos e bases existentes nos líquidos infiltrantes podem causar uma redução de certos minerais do solo por dissolução. Por exemplo, alumínio, carbonatos, óxidos de ferro e metais podem ser dissolvidos por ácidos, e a sílica, por bases. Os finos resultantes deste processo podem migrar com os fluidos infiltrantes, resultando em um decréscimo do coeficiente de permeabilidade devido ao tamponamento dos poros do solo. Em longo prazo, contudo, esta migração dos finos pode resultar num aumento da permeabilidade devido ao carreamento e à formação de canais no interior do solo;

- Mudanças na estrutura do solo: podem ocorrer devido à troca de cátions ou à substituição da água adsorvida por fluidos orgânicos percoláveis. Cátions como $\mathrm{Na}^{+}, \mathrm{K}^{+}, \mathrm{Ca}^{++}, \mathrm{Mg}^{++}$são atraídos pelas cargas negativas. Dependendo do cátion e dos argilo-minerais, estes cátions ocupam os espaços entre as folhas dos argilominerais. A rede elétrica de forças entre as faces dessas folhas são então afetadas pela concentração e valência dos cátions na água adsorvida. Um aumento na concentração ou na valência do cátion (por exemplo, a substituição de $\mathrm{Na}^{+}$por $\mathrm{Ca}^{++}$) resultarão na diminuição das forças repulsivas da rede. Isto causará a floculação das partículas do solo e o aumento do coeficiente de permeabilidade comparado com a estrutura do solo dispersa. Este efeito é mostrado na Figura 2.13 para a montmorilonita, ilita, e caulinita. A figura mostra que quando a 
concentração de $\mathrm{Ca}^{++}$é aumentada, o coeficiente de permeabilidade é também aumentado, devido à tendência das partículas sofrerem floculação e revelarem um tipo de abertura na estrutura do solo. Por outro lado, se todas as cargas negativas disponíveis na superfície dos argilo-minerais são ocupadas por cátions de $\mathrm{Na}^{+}$, as partículas se dispersam, resultando num baixo coeficiente de permeabilidade. A Figura 2.13 também mostra que a montmorilonita é afetada mais que a ilita e a caulinita pela troca de cátions, pois ela tem maior superfície de área disponível para que ocorram mais trocas de cátions; o que significa dizer que ela tem alta capacidade de troca cationnica (YOUNG \& WARKENTIN, 1975);

- Precipitação: o coeficiente de permeabilidade também pode ser afetado pela precipitação de metais pesados, sais e carbonatos. Com mudanças na temperatura, no $\mathrm{pH}$ e na concentração do soluto, esta precipitação pode ser reversível (ALBERTA ENVIRONMENT, 1985). O processo de precipitação pode resultar no bloqueamento dos poros do solo, além de reduzir o coeficiente de permeabilidade.

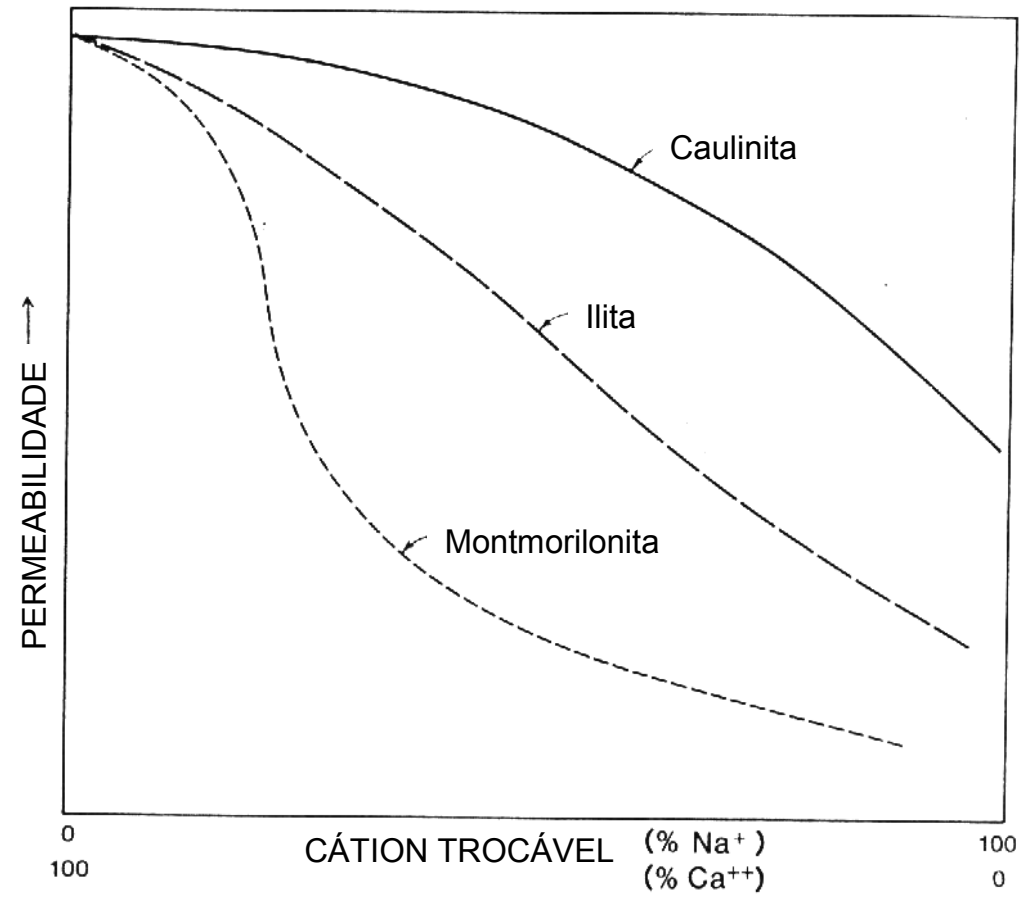

Figura 2.13. Coeficiente de permeabilidade dos argilo-minerais (ALBERTA

ENVIRONMENT, 1985 apud SHARMA \& LEWIS, 1994). 


\subsubsection{Atenuação e Transporte de Poluentes no Solo}

Como descrito QASIM \& CHIANG (1994), a atenuação é um processo físico, químico e/ou biológico, que causa um decaimento transitório ou permanente na concentração de contaminantes dos resíduos aterrados durante um determinado tempo ou distância percorrida.

Os mecanismos de atenuação natural de poluentes pelo solo podem ser classificados em físicos, químicos e biológicos. CALÇAS (2001) fez uma breve revisão sobre as formas de atenuação através destes mecanismos e BOSCOV (1997) detalhou os principais mecanismos envolvidos no transporte de um soluto em um meio poroso. O que será mostrado a seguir é um resumo conceitual de todos os mecanismos envolvidos na atenuação de poluentes pelo solo, inclusive o transporte de poluentes (o qual não deixa de ser uma forma de atenuação) com base nas revisões já realizadas por BOSCOV (1997) e CALÇAS (2001).

\section{a) Mecanismos Físicos}

\section{Advecção}

A advecção é o processo pelo qual o soluto é carregado pela água em movimento, mantendo-se constante a concentração da solução. Solutos não reativos são transportados a uma velocidade média igual à velocidade específica ou de fluxo da água, $u=v / n$, sendo $v$ a velocidade de percolação, aproximação ou descarga (ou ainda, velocidade de Darcy) e $n$ a porosidade do solo, conforme esquematizado na Figura 2.14.
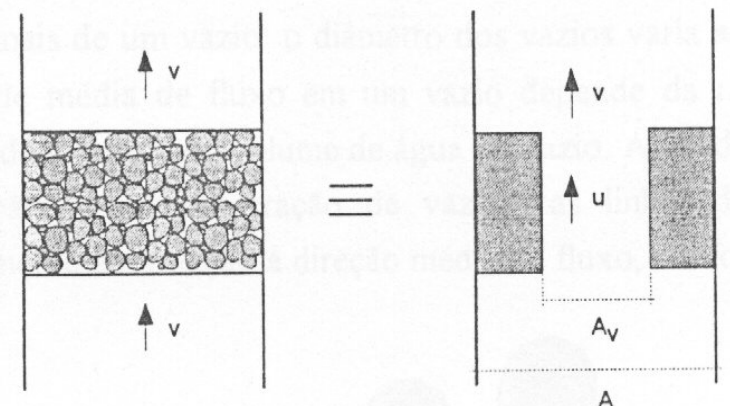

$Q=v A=u A_{v}$

$A_{v}=n A$

$\mathrm{u}=\mathrm{v} / \mathrm{n}$

Figura 2.14. Velocidade de advecção de um soluto através de um volume de solo (PINTO, 1991 apud BOSCOV, 1997). 
A advecção pode ser considerada como um fluxo químico causado por um gradiente hidráulico: a água dos vazios contendo soluto escoa sob a ação de um gradiente hidráulico e carrega consigo partículas de soluto (MITCHELL, 1991).

O fluxo por advecção, que corresponde ao transporte de soluto de um ponto a outro do domínio pela percolação de água, pode ser expresso por:

$$
\mathrm{J}=n \cdot c \cdot u
$$

onde $c$ é a concentração, a qual é definida como a quantidade de massa do soluto por unidade de volume de poros, ou seja:

$$
\mathrm{c}=\frac{\Delta m}{n \cdot V}
$$

onde:

$\mathrm{V}=$ volume do domínio delimitado numa certa região de fluxo;

$\Delta \mathrm{m}=$ variação de massa

A variação de massa pode ser escrita como função do fluxo de massa (J), o qual agora é dado por:

$$
\mathrm{J}=\frac{\Delta m}{A \cdot \Delta t}=\frac{\Delta m}{V} \cdot v
$$

onde:

$\Delta \mathrm{m}=$ variação de massa dentro do domínio no intervalo de tempo $\Delta \mathrm{t}$;

A = área da seção transversal ao fluxo do domínio;

$\Delta \mathrm{t}=$ intervalo de tempo.

\section{Dispersão Mecânica ou Hidráulica}

A dispersão mecânica ou hidráulica é a mistura mecânica que ocorre durante a advecção; é causada inteiramente pelo movimento do fluido. Deve ser explicada na 
escala microscópica, dentro do volume de vazios (FREEZE \& CHERRY, 1979; BEAR, 1979). A velocidade da água varia tanto em magnitude como em direção através de qualquer seção transversal de um vazio, conforme ilustrado na Figura 2.15; é nula na superficie dos grãos e máxima em algum ponto interno, à semelhança da distribuição parabólica de velocidades em um tubo capilar reto.

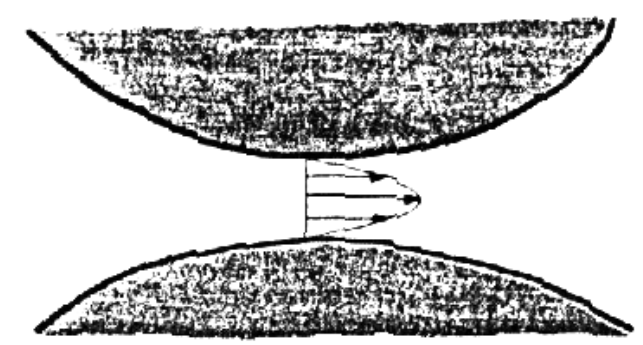

Figura 2.15. Variação da velocidade em direção e magnitude dentro de um vazio (BOSCOV, 1997).

As velocidades também são diferentes em diferentes vazios ou em diferentes segmentos longitudinais de um vazio: o diâmetro dos vazios varia ao longo das linhas de fluxo, e a velocidade média de fluxo em um vazio depende da razão entre a área superficial e rugosidade relativas ao volume de água no vazio. Além disso, por causa da tortuosidade, ramificação e interpenetração de vazios, as linhas de fluxo microscópicas variam espacialmente em relação à direção média do fluxo, conforme mostra a Figura 2.16.

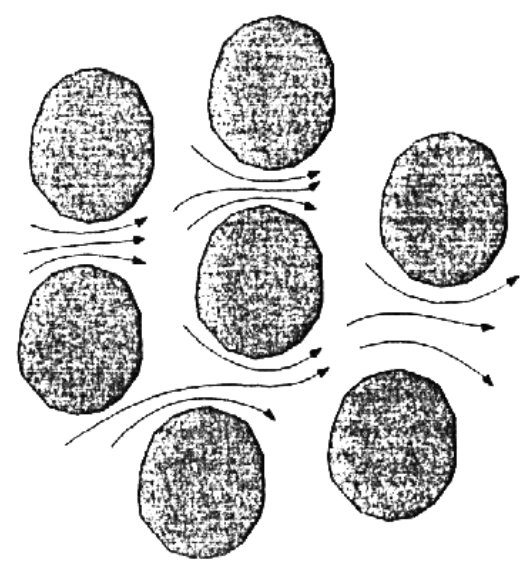

Figura 2.16. Variação espacial das linhas de fluxo em relação à direção do fluxo médio (BOSCOV, 1997). 
Considere-se o fluxo permanente vertical de água pura com velocidade $v$ pela coluna de solo granular homogêneo apresentada na Figura 2.17. A partir de um tempo $t_{0}$ passa-se a alimentar a coluna com uma solução de concentração $c_{0}$. Se houvesse apenas advecção, as partículas de soluto atingiriam a base da coluna após um intervalo de tempo igual a $L / u$; observa-se, no entanto, que a concentração da solução na base da amostra de solo em função do tempo segue a curva indicada na figura, denominada curva de saturação. Algumas partículas caminham mais rapidamente e outras mais lentamente que a velocidade média de fluxo $u$, devido ao fenômeno da dispersão mecânica.
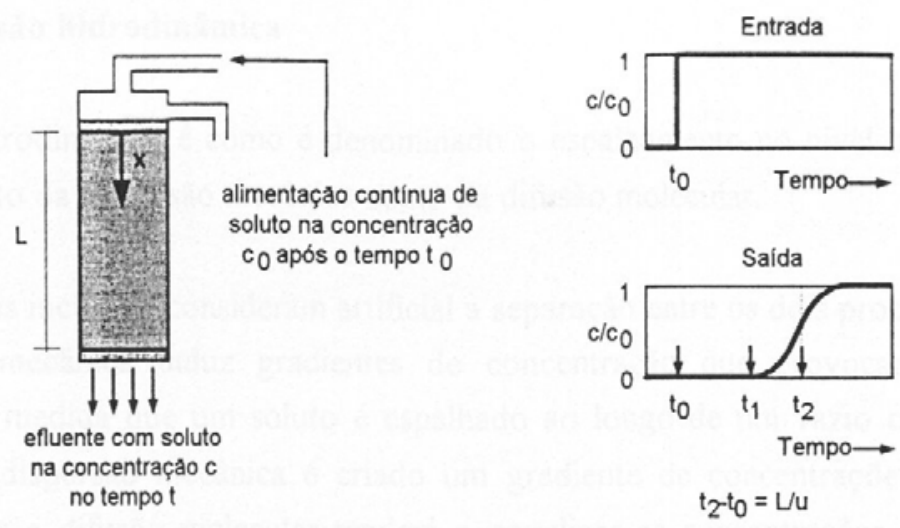

Figura 2.17. Evidência experimental da dispersão mecânica (BOSCOV, 1997).

\section{Difusão Molecular}

Um fenômeno de transporte de massa, simultâneo à dispersão mecânica, é a difusão molecular, que resulta de variações na concentração de soluto na fase líquida. É o processo pelo qual os constituintes iônicos ou moleculares se movem devido a sua energia térmica-cinética na direção do gradiente de concentração e em sentido oposto ao mesmo. O processo de difusão também é chamado de auto-difusão, difusão molecular e difusão iônica. A difusão molecular causa um fluxo adicional de partículas de soluto no nível microscópico das regiões de maior para as de menor concentração.

A difusão molecular é considerada como um fenômeno regido pela Primeira Lei de Fick, ou seja, considera-se que a massa de substância em difusão que passa por uma dada seção transversal por unidade de tempo é proporcional ao gradiente de concentração. A Primeira Lei de Fick foi desenvolvida em 1855 por Adolf Fick para 
descrever o fluxo químico de sais dissolvidos através de membranas separando soluções com diferentes concentrações de sal (BARBOSA, 1994), e pode ser expressa por:

$$
\mathrm{J}=-D d \cdot \frac{\partial c}{\partial l}
$$

onde:

Dd = coeficiente de difusão em solução;

1 = distância à interface de maior concentração.

A tortuosidade e outros fenômenos que eventualmente podem modificar o fluxo difusional no solo em relação ao fluxo em solução livre estão compreendidos no fator tortuosidade, T”, ou w, que é um coeficiente empírico sempre menor que 1. Segundo FREEZE \& CHERRY (1979), T" se encontra entre 0,01 a 0,5. Assim, pode-se expressar o coeficiente de difusão do poluente no solo como função do coeficiente de difusão do poluente em água por meio do fator tortuosidade:

$$
\mathrm{D} * \mathrm{~d}=D d \cdot T^{\prime \prime}
$$

onde:

$\mathrm{D}^{*} \mathrm{~d}=$ coeficiente de difusão do poluente no solo;

Dd = coeficiente de difusão do poluente na água;

$\mathrm{T}^{\prime \prime}=$ fator de tortuosidade.

Deste modo, a Primeira Lei de Fick pode ser expressa, no caso de difusão molecular em solos, por:

$$
\mathrm{J}=-n \cdot D * d \cdot \frac{\partial c}{\partial z}
$$

onde, $\mathrm{z}=$ direção do fluxo. 


\section{Dispersão Hidrodinâmica}

A dispersão hidrodinâmica é como é denominado o espalhamento no nível macroscópico resultante tanto da dispersão mecânica como da difusão molecular.

A dispersão hidrodinâmica pode também ser definida como o fenômeno pelo qual o soluto tende a se espalhar para fora do caminho que era esperado que seguisse de acordo com a hidráulica advectiva do sistema de escoamento. O líquido com soluto ocupa inicialmente uma região determinada com uma interface abrupta separando-a da região sem soluto. Devido a dispersão hidrodinâmica, uma zona de transição cada vez mais larga vai sendo criada, através da qual a concentração de soluto varia do valor inicial para a do líquido ao redor.

O processo de dispersão mecânica é anisotrópico, ou seja, dependente da direção, mesmo que o meio poroso seja isotrópico com respeito às propriedades de textura e condutividade hidráulica, porque a dispersão é mais forte na direção do fluxo (dispersão longitudinal) que nas direções normais ao fluxo (dispersão transversal). A baixas velocidades, no entanto, onde a difusão molecular é o

mecanismo dispersivo dominante, os coeficientes de dispersão longitudinal e transversal são aproximadamente iguais.

O fluxo devido à dispersão hidrodinâmica é dado por:

$$
\mathrm{J}=-n \cdot D_{h l} \cdot \frac{\partial c}{\partial z}
$$

onde:

$\mathrm{D}_{\mathrm{hl}}=D^{*} d+D$

$\mathrm{D}_{\mathrm{hl}}=$ coeficiente de dispersão hidrodinâmica;

$\mathrm{D}=$ coeficiente de dispersão mecânica:

$$
\mathrm{D}=\alpha \cdot u
$$

$\alpha=$ dispersividade dinâmica ou dispersividade (característica do meio poroso), de dimensão [L]. 
Para alguns autores (TAYLOR, 1953 apud BEAR, 1972; SCHEIDEGGER, 1957 apud BEAR, 1972), a forma mais correta de expressar o coeficiente de dispersão mecânica é $\alpha . \mathrm{u}^{\mathrm{m}}$, onde $m$ é uma constante determinada empiricamente com valor entre 1 e 2. Estudos laboratoriais citados por FREEZE \& CHERRY (1979) indicam que para finalidades práticas $m$ pode ser considerado geralmente igual a 1 para materiais geológicos granulares.

PERKINS \& JOHNSTON (1963) apud BARBOSA (1994) apresentaram a seguinte relação empírica, obtida experimentalmente em amostras homogêneas de solo:

$$
\alpha=1.75 \cdot d \quad(\mathrm{~m})
$$

onde $\mathrm{d}=$ diâmetro médio dos grãos do solo (m).

\section{Filtração}

A filtração é aplicável quando a solução contém partículas suspensas de diversos tamanhos, como, por exemplo, o chorume. Neste caso, as partículas acumulam-se nos vazios e a permeabilidade do solo diminui. Deste modo, é possível que ocorra a redução da migração do chorume devido à redução da permeabilidade. Segundo QASIM \& CHIANG (1994), a extensão do processo resultante como forma de atenuação é de difícil estimativa.

\section{Diluição}

A diluição é o processo de diminição da concentração dos constituintes do lixiviado, quando este entra em contato com as águas subterrâneas. O grau de diluição é proporcional ao fluxo de água em relação ao fluxo do lixiviado, e depende também da textura do solo: quanto menor o tamanho dos grãos, menor será o fluxo e, conseqüentemente, menor o grau de diluição. Segundo BAGCHI (1990) apud QASIM \& CHIANG (1994), parâmetros como cloretos, nitratos, sulfatos e dureza, encontrados no chorume de sistemas de disposição de resíduos, são atenuados basicamente pelo efeito da diluição, e não pelo solo. 


\section{Volatização}

A volatização é o processo pelo qual uma substância química evapora. Isso ocorre principalmente na zona não-saturada e na superfície do nível d'água.

\section{b) Mecanismos Químicos}

\section{Precipitação / Dissolução}

Precipitação e dissolução, como já definidos no item 2.1.2.1, são reações importantes que podem controlar os níveis e os limites da quantidade total de poluentes na solução, quando esta percola através do solo. Os níveis de poluentes são normalmente governados pela solubilidade da fase sólida. Particularmente, as reações de precipitação/dissolução são importantes na migração de metais. Por outro lado, a atenuação dos efeitos nos metais é bastante influenciada pelo pH do sistema (equilíbrio químico de reações).

\section{Complexação}

A complexação, ou quelação, é a denominação dada para a formação de complexos inorgânicos-orgânicos. Embora este mecanismo de atenuação ocorra, a extensão de seus efeitos é desconhecida e de difícil previsão.

\section{Reações de Redox}

São reações de oxidação e redução que afetam bastante a solubilidade dos poluentes. Por exemplo, ferro e manganês no estado oxidado são muito pouco solúveis, enquanto a atenuação de outros metais em um ambiente redutor e na presença de sulfeto em quantidade suficiente é mais favorável devido à queda de solubilidade.

\section{c) Adsorção}

Adsorção é um mecanismo físico-químico no qual uma substância é acumulada numa interface entre fases. Quando substâncias contidas em um líquido 
se acumulam em uma interface sólido-líquido, denomina-se adsorvato a substância que está sendo removida da fase líquida e adsorvente a fase sólida na qual a acumulação ocorre.

A adsorção ocorre porque há forças que atraem o adsorvato da solução para a superficie do adsorvente; essas forças de atração podem ser fisicas e químicas (forças eletrostáticas como: atração e repulsão eletrostática segundo a Lei de Coulomb, interações dipolo-dipolo, forças de London-van der Waals e pontes de hidrogênio).

A diferença entre adsorção fisica e química não é muito distinta. A primeira tem forças e energias de ligação mais fracas, opera a longas distâncias e é mais reversível. Na adsorção química, segundo ISAAC (1993), a atração entre adsorvente e adsorvato aproxima-se daquela de uma ligação covalente entre átomos, com menor comprimento e maior energia de ligação. A EPA (1992) considera a adsorção química uma ligação química real, geralmente covalente, entre uma molécula e átomos superficiais, na qual a molécula pode perder sua identidade quando os átomos são rearranjados, formando novos compostos.

A adsorção também pode ser explicada termodinamicamente como o fato de que o adsorvato tem menor energia livre na superficie sólida do que na solução.

A desadsorção é a liberação de substâncias previamente adsorvidas. Isto ocorre quando a concentração afluente de uma determinada substância diminui, ou quando ocorre o chamado "deslocamento cromatográfico", provocado pela competição com outra substância mais fortemente adsorvida.

Um dos modelos mais utilizados de equilíbrio isotérmico de adsorção é o de Langmuir, de 1915, válido para camadas simples. Adota como hipóteses: energia de adsorção constante e uniforme na superfície do adsorvente, adsorção máxima correspondente a uma monocamada saturada de moléculas de soluto na superfície do adsorvente, e que não haja transmigração do adsorvato no plano da superficie. A isoterma de Langmuir pode ser expressa por:

$$
\mathrm{S}=\frac{Q^{0} \cdot b \cdot C}{1+b \cdot C}
$$

onde: 
$\mathrm{S}=$ número de moles adsorvido por unidade de peso de adsorvente à concentração $\mathrm{C}$, ou concentração de soluto na parte sólida;

$\mathrm{C}=$ concentração de soluto na solução no equilíbrio;

$\mathrm{Q}^{0}=$ número de moles de soluto adsorvido por unidade de peso do adsorvente ao formar uma monocamada completa na superfície;

$\mathrm{b}=$ constante relacionada à energia ou entalpia líquida da adsorção.

A curva $1 / S$ em função de $1 / C$ é uma reta de declividade $1 /\left(b \cdot Q^{0}\right)$ e intercepto $1 / Q^{0}$, conforme mostrado na Figura 2.18.

B.E.T.

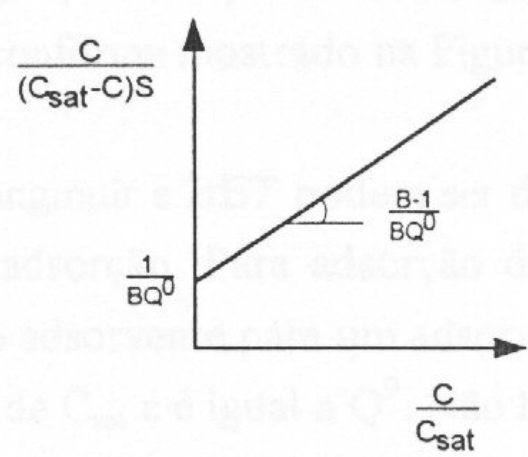

Freundlich

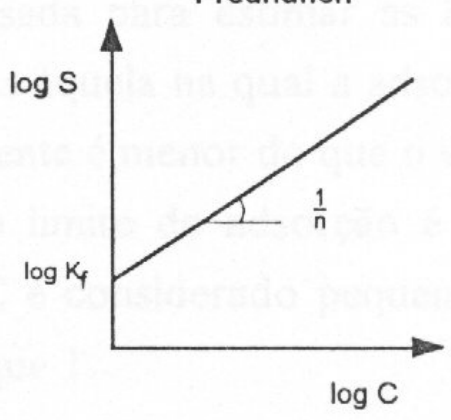

Langmuir

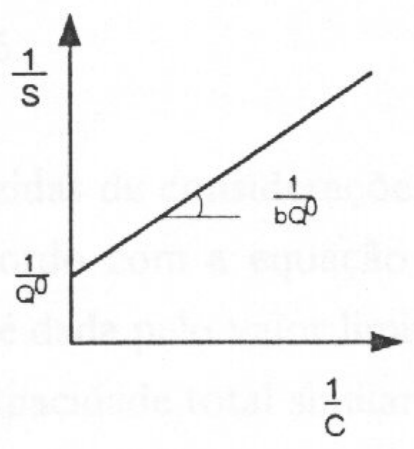

Linear

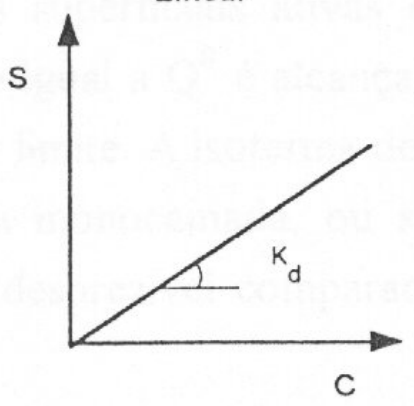

Figura 2.18. Alguns modelos de equilíbrio isotérmico de adsorção (ISAAC, 1993 apud BOSCOV, 1997).

Para adsorção de quantidades muito pequenas de soluto, isto é, quando b. $C<<1$, a adsorção específica é proporcional à concentração final de adsorvato na 
solução, o que pode ser expresso por:

$$
\mathrm{S}=Q^{0} \cdot b \cdot C
$$

Para grandes quantidades adsorvidas de soluto, isto é, quando $b . C>>1$, temse:

$$
\mathrm{S}=Q^{0}
$$

O modelo de Brunauer, Emmett e Teller (BET) representa a adsorção em multicamadas. Adota como hipóteses: energia de adsorção constante e uniforme na superfície do adsorvente, que haja formação de várias camadas de moléculas de adsorvato na superficie do adsorvente, que a equação de Langmuir se aplique a cada camada; e que uma dada camada não precise estar completamente formada para que se iniciem as camadas subseqüentes. Considerando-se que as camadas seguintes à primeira têm energia de adsorção iguais, a equação de BET é:

$$
\mathrm{S}=\frac{B \cdot C \cdot Q^{0}}{\left(C_{s a t}-C\right) \cdot\left[1+(B-1) \cdot \frac{C}{C_{s a t}}\right]}
$$

onde:

$\mathrm{C}_{\text {sat }}=$ concentração de saturação do soluto na solução a uma dada temperatura; $\mathrm{B}=$ constante que expressa a energia de interação com a superfície.

A curva $C /\left[\left(C_{\text {sat }}-C\right)\right.$.S $\left.S\right]$ em função de $(C) /\left(C_{\text {sat }}\right)$ é uma reta de declividade (B1) $/\left(B . Q^{0}\right)$ e intercepto $1 / B . Q^{0}$, conforme mostrado na Figura 2.18 .

Outro modelo é o de Freundlich ou de van Bemmclen, basicamente empírico, de 1926. Representa um caso especial para energias superficiais heterogêneas, no qual a constante $b$ varia como uma função do cobrimento da superfície (S) devido estritamente a variações no calor de adsorção. A equação de Freundlich pode ser expressa por: 


$$
\mathrm{S}=K_{f} \cdot C^{\frac{1}{n}}
$$

ou

$$
\log \mathrm{S}=\log K_{f}+\frac{1}{n} \cdot \log C
$$

onde:

$\mathrm{n}=$ coeficiente relacionado com a energia ou a intensidade de adsorção $(\mathrm{n}>1)$;

$\mathrm{K}_{\mathrm{f}}=$ função de distribuição (proporcional a RTnbe ${ }^{\Delta \mathrm{H} / \mathrm{RT}}$ ).

A forma logarítmica resulta em uma reta com declividade $1 / \mathrm{n}$ e intercepto igual a $\log \mathrm{K}_{\mathrm{f}}$ para $\mathrm{C}=1(\log \mathrm{C}=0)$, conforme representado na Figura 2.18; o valor do intercepto é um indicador da capacidade de adsorção, e a declividade, da intensidade de adsorção. A equação de Freundlich geralmente se ajusta bem à de Langmuir para variações moderadas de concentração. Porém, não se reduz a uma expressão linear para concentrações muito baixas e não se ajusta bem para altas concentrações, uma vez que $n$ deve atingir algum limite quando a superfície estiver totalmente coberta.

O modelo mais simples de adsorção, também apresentado na Figura 2.18, é a isoterma linear, ou seja:

$$
\mathrm{S}=K_{d} \cdot C
$$

onde $\mathrm{Kd}=$ coeficiente de distribuição.

Os modelos que representam os processos de reações por um coeficiente constante, em princípio, são válidos para reações rápidas e reversíveis.

A mudança de massa de soluto por unidade de volume no domínio devido à adsorção pode ser expressa por:

$$
\frac{\partial(n c)}{\partial t}=-\rho \frac{\partial S}{\partial t}=\Phi
$$


O grau de adsorção S é normalmente uma função da concentração da solução. A velocidade de adsorção, $\partial \mathrm{S} / \partial \mathrm{c}$, pode ser expressa por:

$$
\frac{\partial S}{\partial t}=\frac{\partial S}{\partial c} \frac{\partial c}{\partial t}
$$

onde $\partial \mathrm{S} / \partial \mathrm{c}=$ divisão do soluto entre as fases líquida e sólida.

Sendo o modelo linear o mais correntemente utilizado dada sua simplicidade, a divisão do soluto entre as fases líquida e sólida pode ser expressa por:

$$
\frac{\partial S}{\partial c}=\frac{d S}{d c}=K d
$$

Kd é uma representação válida da divisão de soluto entre líquido e sólidos apenas se as reações que causam a divisão forem rápidas e reversíveis, e apenas se a isoterma for linear. Felizmente, muitos contaminantes de interesse no estudo de água subterrânea atendem a esses requisitos.

A transferência de massa de soluto entre fases por adsorção, relativamente ao movimento da água, é expressa por:

$$
\frac{u}{u_{c}}=1+\frac{\rho}{n} \cdot K d
$$

onde:

$\mathrm{u}_{\mathrm{c}}=$ velocidade do ponto onde $\mathrm{c} / \mathrm{c}_{0}=0.5$ no perfil de concentrações;

$\rho=$ massa específica aparente do solo.

Essa expressão é denominada equação de retardamento; $(1+\rho / n \mathrm{Kd})$, fator de retardamento, e u/ $\mathrm{u}_{\mathrm{c}}$, velocidade relativa. Segundo RITTER (1994), Kd varia normalmente de valores próximos a zero até $10^{3} \mathrm{ml} / \mathrm{g}$ ou maiores; se for nulo, a zona ocupada por contaminante não é afetada por reações químicas; para Kd igual a 1 $\mathrm{ml} / \mathrm{g}$, o ponto de concentração média estará retardado por um fator entre 5 e 11 em 
relação ao movimento da água; para Kd maior do que 10, o soluto é essencialmente imóvel.

Quando uma pluma de contaminantes avança ao longo das linhas de fluxo do lençol subterrâneo, a frente é retardada como resultado da transferência de parte da massa de soluto para a fase sólida, conforme indicado na equação 2.22. Se a alimentação for descontinuada, os poluentes serão transferidos de volta à fase líquida à medida que água com concentrações mais baixas flui através da área previamente contaminada. Se as reações forem totalmente reversíveis, toda evidência de contaminação será eventualmente removida do sistema quando ocorrer a completa desadsorção. FREEZE \& CHERRY (1979) lembram que os contaminantes não podem ser permanentemente isolados na zona subsuperficial, por mais que o retardamento seja forte; em algumas situações, no entanto, quando transferidos para a fase sólida do material poroso por adsorção ou precipitação, podem ser considerados fixos para a escala de tempo de interesse.

Algumas substâncias, por outro lado, não reagem suficientemente rápido com o meio poroso para se aceitar a hipótese de que as reações sejam imediatas. Como é muito dificil obter informações sobre velocidades de reação entre solutos e meio poroso, utiliza-se por simplicidade a equação de retardamento, o que pode levar a erros consideráveis nas previsões sobre migração de contaminantes em sistemas onde fatores cinéticos são importantes.

Acima da franja capilar, onde normalmente existe uma fase contínua gasosa em parte dos vazios, reações podem ocasionar transferência de parte da massa do contaminante da fase da solução para a fase gasosa.

\section{d) Mecanismos Microbiológicos}

A decomposição biológica de componentes orgânicos do chorume ocorre na estrutura do subsolo, sendo aeróbia ou anaeróbia, dependendo da presença do oxigênio molecular. Sob condições aeróbias, a matéria orgânica carbonácea, a amônia, o sulfeto, o fósforo, o ferro e o manganês são convertidos em dióxido de carbono, nitrato, sulfato, fosfato e formas oxidadas de ferro e manganês. Sob condições anaeróbias, a matéria orgânica carbonácea é decomposta em ácidos orgânicos, dióxido de carbono, metano e outros compostos orgânicos complexos. 
A desnitrificação e a redução de metais são outras reações da atividade anaeróbia.

Em geral, a atividade microbiana provoca a imobilização pela conversão de compostos orgânicos e inorgânicos em massa celular, e através da precipitação de compostos inorgânicos. Neste caso, também pode haver mobilização de compostos orgânicos pela solubilização e fragmentação em partículas menores e a solubilização de metais por reações de redução e a liberação sob condições ácidas (ácido carbônico e outros ácidos orgânicos).

\section{e) Mecanismos Combinados de Transporte}

Levando-se em conta todos os fenômenos citados, aplica-se a Lei de Conservação da Massa para o domínio estudado. Um certo tempo será necessário para que o domínio seja totalmente percorrido por partículas ou íons do poluente. A quantidade de íons por volume unitário varia, portanto, com o tempo e com o espaço. A diferença entre o fluxo de soluto que entra no domínio e o fluxo de soluto que sai do domínio deve ser igual à variação de concentração do soluto no intervalo de tempo considerado, ou seja:

$$
\frac{\partial(n c)}{\partial t}=-\frac{\partial J}{\partial z}
$$

Para o fluxo por advecção, lembrando-se que n e u são constantes em um meio homogêneo:

$$
\frac{\partial J}{\partial z}=-n u \frac{\partial c}{\partial z}
$$

Para o fluxo por dispersão hidrodinâmica, lembrando-se que $\mathrm{n}$ é constante para um meio homogêneo:

$$
\frac{\partial J}{\partial z}=n D_{h l} \frac{\partial^{2} c}{\partial z^{2}}
$$


A equação (2.25) também é conhecida como a Segunda Lei de Fick.

Considerando as duas parcelas, advecção e dispersão hidrodinâmica, e também as reações químicas, tem-se a equação da advecção-dispersão.O transporte de poluentes inertes dissolvidos na água em um solo homogêneo isotrópico saturado em fluxo unidimensional pode ser descrito por:

$$
\frac{\partial c}{\partial t}=D_{h l} \frac{\partial^{2} c}{\partial z^{2}}-u \frac{\partial c}{\partial z} \pm \Phi
$$

A equação (2.26) indica o fluxo total de massa de soluto (J) de uma substância, constituindo a soma dos fluxos difusivo, dispersivo e advectivo. A parcela $\pm \Phi$ refere-se às reações químicas, ou fontes e sorvedouros. Quando considera-se apenas as reações químicas devidas à adsorção, a equação (2.26) fica:

$$
\left(1+\frac{\rho \cdot K d}{n}\right) \frac{\partial c}{\partial t}=D_{h l} \frac{\partial^{2} c}{\partial z^{2}}-u \frac{\partial c}{\partial z}
$$

\subsubsection{Ensaios de Laboratório}

Em pesquisas de transporte de poluentes em solos, além de ensaios para determinação de parâmetros (como os descritos logo a seguir de acordo com BOSCOV, 1997), são normalmente realizados ensaios de permeabilidade e de compatibilidade.

BOSCOV (1997) observa que os equipamentos de laboratório para ensaios com poluentes devem ser constituídos de materiais que adsorvam quantidades desprezíveis de soluto e que sejam quimicamente inertes (CRITTENDEN et al., 1986; EPA, 1992; BARONE et al., 1989; STOCKMEYER, 1993; BARBOSA, 1994). A autora também lembra que na análise de percolados compostos por vários solutos, os parâmetros determinados para cada soluto testado isoladamente podem não representar adequadamente o efeito combinado dos contaminantes (BARONE et al., 1989). 


\section{a) Ensaio de Coluna ou de Dispersão}

Uma coluna cilíndrica é preenchida com solo e satur

ada com água. Estabelece-se um regime de fluxo permanente de água através da coluna. Em um certo instante $\mathrm{t}=0$, um soluto não reativo com concentração $\mathrm{c}_{0}$ é introduzido na extremidade de montante da coluna. A solução começa a desalojar a coluna de água original. Mede-se a concentração de saída $\mathrm{c}=\mathrm{c}(\mathrm{t})$ no final da coluna com diversos intervalos de tempo. Um esquema ilutrativo da montagem do ensaio de coluna está apresentado na Figura 2.19.

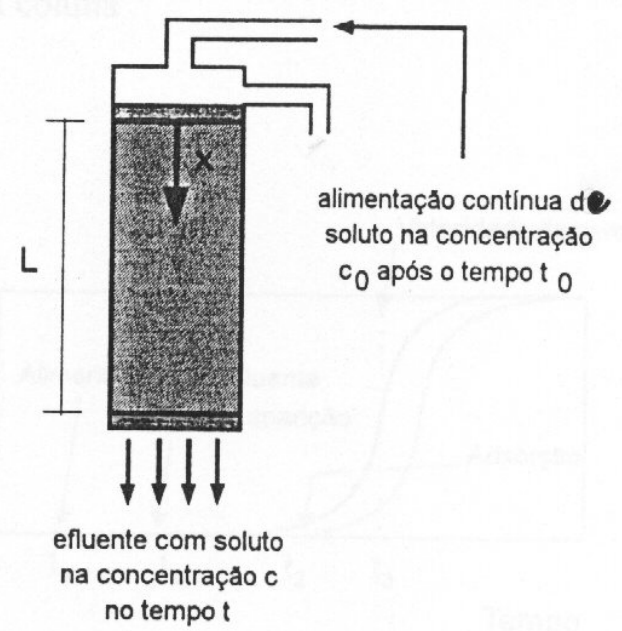

Figura 2.19. Ensaio de coluna (FREEZE \& CHERRY, 1979 apud BOSCOV, 1997).

A representação gráfica da concentração de saída c ou da relação $\mathrm{c} / \mathrm{c}_{0} \mathrm{em}$ função do tempo t ou do volume de efluente $U$ é chamada de curva de saturação do poluente ("breakthrough curve"). Dois modos de representar a curva de saturação estão apresentados nas Figuras 2.20 e 2.21. A concentração inicial do soluto na água é considerada igual a $\mathrm{c}_{\mathrm{i}}$ na Figura 2.20, e nula na Figura 2.21.

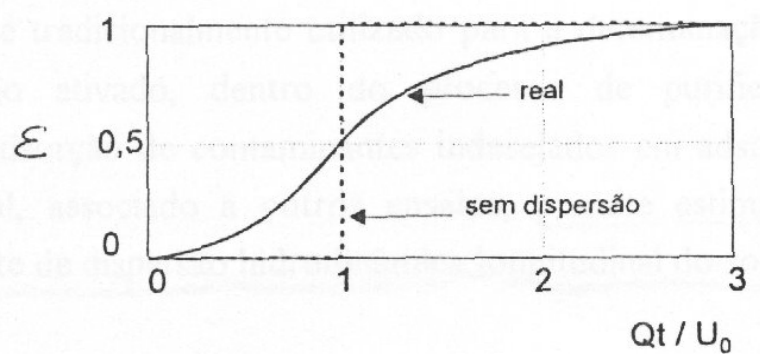

Figura 2.20. Curva de saturação do poluente em função do volume de efluente (BEAR, 1979 apud BOSCOV, 1997). 


$$
\xi(\mathrm{U})=\frac{c(t)-c_{i}}{c_{0}-c_{i}}
$$

onde:

$\mathrm{c}_{\mathrm{i}}=$ concentração original do soluto na água;

$\mathrm{c}_{0}=$ concentração do soluto na solução de alimentação;

$c(t)=$ concentração do soluto no efluente no tempo t, após o escoamento do volume $\mathrm{U}$;

$\mathrm{Q}=$ vazão constante;

$\mathrm{U}_{0}=$ volume de vazios da coluna;

$\mathrm{U}=$ volume de efluente;

$\mathrm{t}=$ tempo.

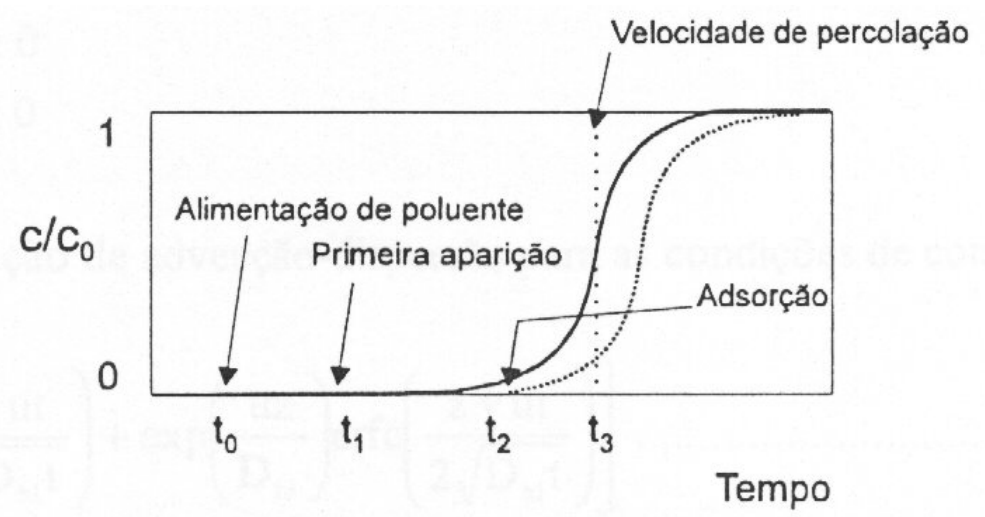

Figura 2.21. Curva de saturação do poluente em função do tempo (FREEZE \& CHERRY, 1979 apud BOSCOV,1997).

Se o transporte fosse apenas advectivo, a frente de soluto passaria pela coluna no tempo $t_{3}$ relativo à velocidade $u$, e a curva de saturação seria uma função degrau. A dispersão hidrodinâmica faz com que soluto apareça na saída em um tempo $\mathrm{t}_{1}$ menor que $t_{2}$. Por outro lado, havendo adsorção do soluto pelo solo, a curva será retardada e o soluto atingirá a base da coluna no tempo $t_{2}$.

O ensaio de coluna é tradicionalmente utilizado para a determinação da capacidade de adsorção do carvão ativado, dentro do processo de purificação da água de abastecimento por adsorção de contaminantes indesejados em adsorventes sólidos. 
$\mathrm{Na}$ Geotecnia Ambiental, associado a outros ensaios, permite estimar a capacidade de adsorção e o coeficiente de dispersão hidrodinâmica longitudinal do solo.

O procedimento e a interpretação do ensaio são mais simples quando o solo é granular. Pode-se desprezar o fator de retardamento relativo à adsorção; além disso, há maior facilidade em atingir um grau de saturação elevado; SCAPERDAS (1994) recomenda saturação de no mínimo $90 \%$ para que a hipótese de solo saturado seja utilizada sem erro considerável.

Outra simplificação usual é empregar solução de cloreto de sódio; o sal, além de não reativo, apresenta relação bem definida entre concentração e condutividade elétrica. Pode-se determinar a concentração de soluto ao longo da coluna, por meio de transdutores posicionados dentro do solo e previamente calibrados para fornecer a concentração do fluido intersticial pela medida da resistividade. Para calcular $\mathrm{D}_{\mathrm{hl}}$, utiliza-se a curva $\mathrm{c} / \mathrm{c}_{0}$ em função do tempo do transdutor implantado no meio da amostra.

\section{b) Ensaio de Difusão}

A aparelhagem do ensaio consiste basicamente de uma célula de acrílico (BARBOSA, 1994) ou Plexiglas (BARONE, 1989), com diâmetro interno de 6,74 cm e altura de $11 \mathrm{~cm}$; uma base ou placa circular impermeável; e tampa superior com orificio de $0,5 \mathrm{~cm}$ de diâmetro para drenagem e coleta de amostra. Um esquema ilustrativo está representado na Figura 2.22.

No caso de utilização de amostras indeformadas, o corpo de prova deve ser moldado com dimensões próximas das desejadas e pressionado para dentro do cilindro por meio de um equipamento de compressão, por exemplo, uma prensa de ensaio de compressão triaxial (BARONE et al., 1989) ou um equipamento de compressão hidráulica (BARBOSA, 1994), para evitar distorção. Uma vez posicionada a amostra de solo, fixa-se a base sob a célula e sela-se o contato com silicone. A parte superior do cilindro é enchida lentamente com a solução de ensaio, de modo a formar uma camada de $6 \mathrm{~cm}$ de altura sobre o solo. Fecha-se a célula com a tampa superior; o contato entre ambas deve ser vedado para garantir estanqueidade. O orifício é fechado com uma pequena rolha de borracha, a qual só é removida para coletar amostras de fluido do reservatório durante o ensaio. A solução é agitada 
continuamente para manter uma concentração uniforme através do reservatório, por meio de uma pá agitadora de Teflon conectada a um motor de $6 \mathrm{rpm}$. O ensaio deve ser realizado a temperatura controlada.

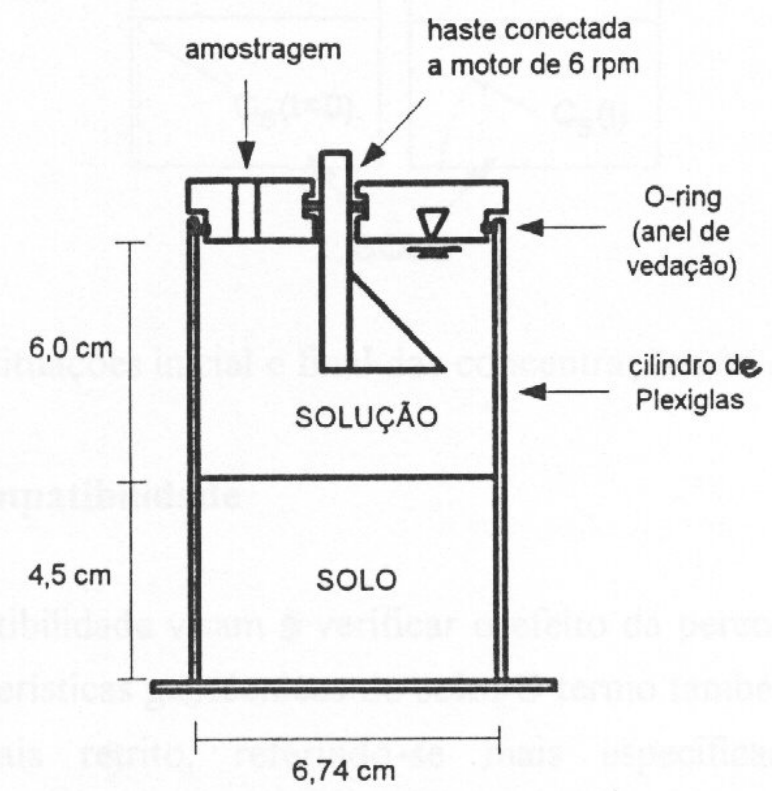

Figura 2.22. Ensaio de difusão (BARONE et al., 1989 apud BOSCOV, 1997).

Durante o período de ensaio, coletam-se amostras de solução a intervalos regulares de tempo para monitoramento da concentração da solução. No trabalho de BARONE et al. (1989), as amostras de $0.1 \mathrm{ml}$ eram retiradas a cada 2 dias por meio de uma pipeta; BARBOSA (1994) coletava amostras de $4 \mathrm{ml}$ a cada 24 horas com uma seringa.

Ao final do ensaio (15 dias, BARONE et al., 1989; 6 a 9 dias, BARBOSA, 1994), a amostra de solo é seccionada em discos de $1 \mathrm{~cm}$ de espessura para determinação da distribuição vertical das concentrações por meio de análise química da solução intersticial. O fluido intersticial é extraído de cada fatia por meio de aparelho pneumático à pressão de $25 \mathrm{MPa}$ por aproximadamente 3 horas, à temperatura de $(22 \pm 1)^{\circ} \mathrm{C}$; supõe-se que sob essa pressão não haja remoção de água da camada dupla. Quando a quantidade de solo remanescente permite, faz-se ainda a análise dos cátions adsorvidos em cada profundidade.

Para o cálculo do coeficiente de difusão, são utilizadas as curvas de concentração do fluido no reservatório em função do tempo, e a concentração do 
fluido intersticial do solo em função da profundidade de solo. Na Figura 2.23 estão representadas as curvas de concentração do fluido no reservatório e do fluido intersticial do solo em função da profundidade nos instantes inicial e final do ensaio.

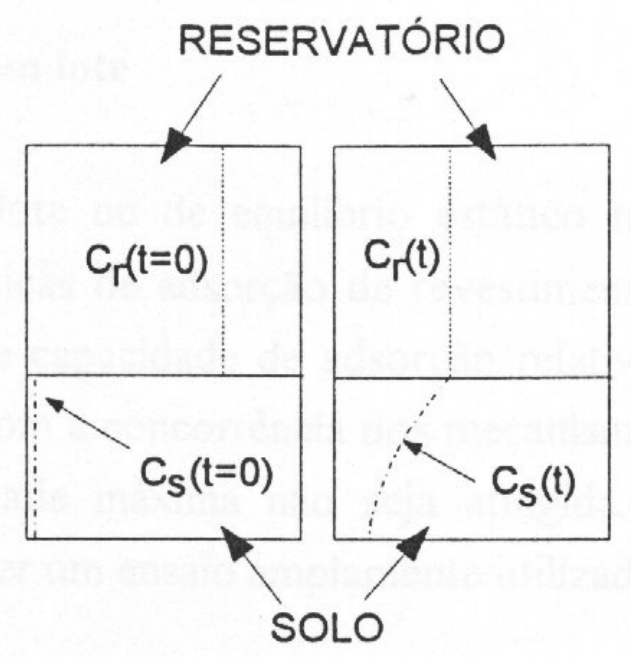

Figura 2.23. Situações inicial e final das concentrações no ensaio de difusão (BOSCOV, 1997).

\section{c) Ensaio de Adsorção em Lote ("Batch Equilibrium Test")}

Uma solução aquosa contendo soluto com composição e concentração conhecidas é misturada a uma massa de adsorvente por um período de tempo determinado. A seguir, a solução é separada do adsorvente e analisada quimicamente para determinação da mudança na concentração de soluto. A quantidade de soluto adsorvida pelo adsorvente é, por hipótese, a diferença entre a concentração inicial de soluto, antes do contato com o adsorvente, e a concentração final, após o tempo de mistura.

Muitos parâmetros experimentais podem afetar a adsorção de um dado constituinte químico pelo solo. Para solutos inorgânicos, os parâmetros são, entre outros: tempo de contato ou de equilíbrio, temperatura, método de mistura, razão solo/solução, teor de umidade do adsorvente, $\mathrm{pH}$ da solução, hidrólise, e presença de outros produtos químicos dissolvidos na solução. Para solutos orgânicos, além dos parâmetros já mencionados, acrescentam-se: carbono orgânico dissolvido, 
volatilidade do adsorvato, fotodegradação, biodegradação e estabilidade do composto.

O ensaio em lote permite a estimativa da adsorção de um produto químico em solução por um adsorvente em condições de equilíbrio; e a geração de isotermas de adsorção, as quais indicam como a adsorção varia com a concentração de soluto na solução.

Duas técnicas podem ser utilizadas: na primeira, volumes iguais de uma mesma solução são aplicados a diferentes massas de adsorvente; na segunda, volumes iguais de soluções com diferentes concentrações são misturados a amostras de adsorvente de mesma massa.

A aparelhagem consta de frascos de reação, equipamento para agitação e equipamento para separação das fases. Um esquema simplificado da montagem do ensaio de adsorção em lote está apresentado na Figura 2.24.

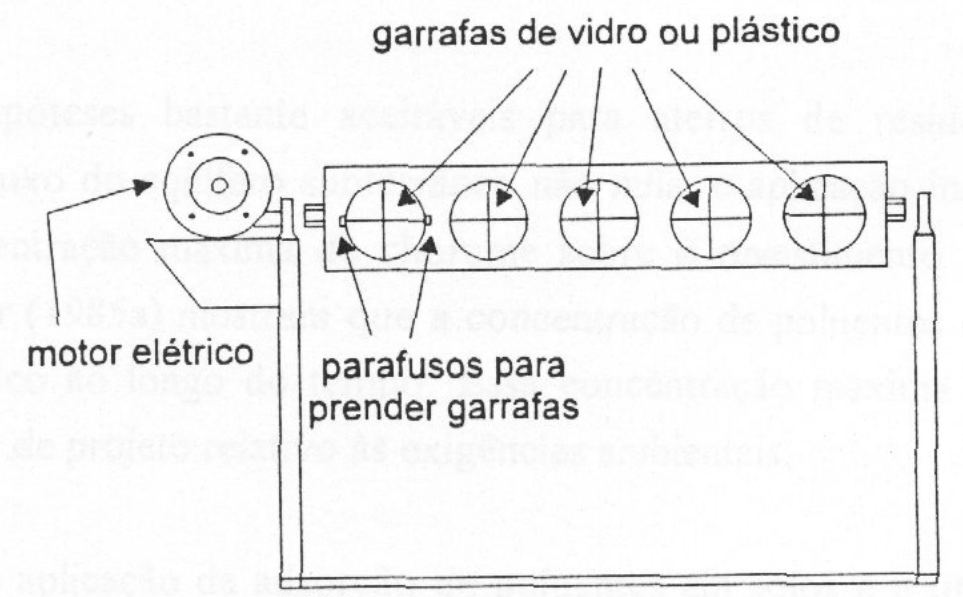

Figura 2.24. Ensaio de adsorção em lote (EPA, 1992 apud BOSCOV, 1997).

Em um frasco, denominado "branco", só é colocada a amostra de solução, sem adsorvente. No final do ensaio, a diferença entre a concentração inicial da solução e a concentração final no frasco "branco" indica se houve adsorção ou desadsorção em outras superficies que não a do adsorvente, e fornece informações sobre a instabilidade do soluto. A EPA recomenda a utilização de três frascos "brancos".

A adsorção em cada frasco é calculada por: 


$$
\mathrm{A}(\%)=\frac{c_{0}-c}{c_{0}} \cdot 100
$$

onde:

A = coeficiente de adsorção;

$\mathrm{c}_{0}=$ concentração inicial da solução;

c = concentração final da solução corrigida em função do frasco "branco".

Os ensaios são levados até o tempo de equilíbrio, definido como o intervalo mínimo de tempo necessário para garantir que a variação na concentração seja menor ou igual a 5\%. O tempo de equilíbrio é determinado experimentalmente.

\section{d) Ensaios de Compatibilidade}

Os ensaios de compatibilidade visam verificar o efeito da percolação de poluentes nas propriedades e características geotécnicas do solo. O termo também pode ser empregado em um sentido mais restrito, referindo-se mais especificamente a ensaios de permeabilidade, realizados com esse objetivo (BARBOSA, 1994).

São realizados ensaios de granulometria, limites de Atterberg, permeabilidade, resistência ao cisalhamento (normalmente, resistência à compressão simples) e, eventualmente, pressão de expansão, antes e depois da percolação da solução.

Recomenda-se a execução desses ensaios como procedimento mínimo no estudo de transporte de poluentes em solos, visto que a percolação de uma solução pelo solo pode alterar suas características geotécnicas. 


\subsection{Investigação Geoambiental}

A investigação geoambiental é um tema recente que vem sendo abordado no campo das Geociências e da Geotecnia. Existem diferentes interpretações para o significado da investigação e caracterização geoambiental. Esta pode ser entendida como "o campo de estudo que faz a ligação entre geologia, geotecnia, engenharia ambiental e ciências correlatas, para dar origem a uma área de interesse que inclui todas as preocupações ambientais dentro do meio geológico natural ou modificado" (DAVIES \& CAMPANELLA, 1995b).

Segundo a EPA (1989), os principais fatores que devem ser considerados na investigação geoambiental são:

- perfil geotécnico;

- posição do nível d'água;

- condutividade hidráulica; e

- composição química e fonte(s)/receptor(es) de contaminantes, potenciais ou existentes.

A presença de contaminantes no solo tem levado a mudanças nas técnicas de investigação e caracterização do subsolo, procurando incluir a identificação do tipo, quantidade e como se dará o caminhamento do mesmo através da formação de uma pluma de contaminação. Para se obter todas essas informações são necessárias que na investigação do subsolo, utilizem-se técnicas que permitam amostrar solo, água e/ou gás.

Para que um programa de investigação in situ seja mais eficiente, tem-se utilizado a geofísica para a determinação dos locais onde deve ser realizado um estudo mais detalhado, incluindo as amostragens. A combinação de uma campanha de campo utilizando ensaios geofísicos de superfície, ensaios com o piezocone de resistividade e amostragens de água, têm proporcionado uma rápida e econômica caracterização geoambiental do subsolo naqueles países que detêm essa tecnologia. 


\subsubsection{Métodos Geofísicos para a Investigação Geoambiental}

Devido à crescente preocupação com a proteção ambiental, tem sido necessário desenvolver novas técnicas e procedimentos para investigação, caracterização e monitoramento geoambiental do subsolo. Alguns métodos geofísicos - principalmente os elétricos - vêm sendo utilizados para esse fim e tem levado a resultados promissores (VOGELSANG, 1995). Esses trabalhos foram realizados, em sua grande maioria, utilizando-se de sondagens elétricas verticais e caminhamento eletromagnético para mapeamento e monitoramento da pluma de contaminação.

Mais recentemente, a aplicação desses e de outros métodos elétricos têm fornecido informações importantes com respeito a estrutura dos depósitos de resíduos como, por exemplo, o volume de rejeitos e o perfil vertical do aterro, definição do sentido de fluxo subterrâneo, bem como as relações envolvendo a quantidade de resíduos introduzida no meio e as características geológicas, geotécnicas e hidrogeológicas locais (CARPENTER et al., 1990; ELIS \& ZUQUETTE, 1996; 1997).

Novos métodos e técnicas têm sido avaliados, principalmente na determinação e monitoramento da pluma de contaminação como, por exemplo, o TEM - Transient Eletromagnetics, ou Eletromagnético Domínio do Tempo e GPR Ground Penetrating Radar, ou Radar de Penetração no Solo. A técnica desenvolvida mais recentemente para esse tipo de estudo é a associação do piezocone a sensores geofísicos (BRATTON et al., 1995) com destaque especial para o piezocone de resistividade.

A CETESB (1999) define os métodos geofísicos como técnicas indiretas de investigação das estruturas de subsuperfície através da aquisição e da interpretação de dados instrumentais, caracterizando-se, portanto, como métodos não invasivos ou não destrutivos.

Essa metodologia permite avaliar as condições geológicas locais através dos contrastes das propriedades físicas dos materiais de subsuperfície, por exemplo condutividade ou resistividade elétrica, permissividade dielétrica, magnetismo, densidade, etc., que podem ter como origem as diferenciações litológicas e outras heterogeneidades naturais ou não. 
Uma das principais vantagens da aplicação das técnicas geofísicas em relação aos métodos tradicionais de investigação de subsuperfície como, por exemplo, as sondagens, é a rapidez na avaliação de grandes áreas com custo relativamente menor. Além disso, os levantamentos geofísicos propiciam a execução de perfis contínuos, possibilitando a identificação com maior precisão das variações laterais decorrentes das mudanças litológicas ou originadas pela presença da contaminação subterrânea.

No diagnóstico ambiental de áreas contaminadas, a realização de levantamentos geofísicos tem por objetivo básico a identificação da presença da contaminação subterrânea, além da definição das feições geológicas e hidrogeológicas dos locais investigados.

As características do meio geológico, além da natureza da contaminação, podem determinar o comportamento dos contaminantes em subsuperfície. Nesse contexto, a interpretação dos dados geofísicos pode contribuir para a obtenção de informações sobre a litologia, estratigrafia, profundidade do nível d'água, profundidade do embasamento, presença de falhas ou fraturas, existência de aqüíferos importantes, caminhos preferenciais de propagação subterrânea e outras feições geológicas de interesse.

$\mathrm{Na}$ avaliação da presença da contaminação em profundidade, o emprego dos métodos geofísicos está voltado, especificamente, à localização de valas contendo resíduos, investigação da contaminação disseminada no solo e nas águas subterrâneas, detecção de tambores e tanques enterrados e determinação de vazamentos em tanques ou dutos.

A aplicação de dois ou mais métodos geofísicos distintos aumenta a precisão das interpretações, sendo que a natureza dos contaminantes e a geologia local são os fatores decisivos na seleção das técnicas geofísicas a serem utilizadas.

Os desvios significativos do padrão normal das medidas geofísicas, que são as anomalias, podem, do ponto de vista ambiental, apontar a presença de contaminantes em subsuperfície. A interpretação das anomalias é fundamental, pois pode indicar a intensidade da contaminação presente, proporcionando, assim, dados importantes para as atividades de diagnóstico, monitoramento da propagação dos contaminantes e acompanhamento da recuperação de uma área contaminada.

Dessa forma, as informações derivadas dos levantamentos geofísicos são 
úteis para a locação dos poços de monitoramento, como também podem fornecer estimativas de área e volume para as atividades de remoção e remediação de solos contaminados. Além disso, podem ser aplicadas para reduzir o risco de perfuração de tanques e tambores enterrados contendo resíduos, ou de dutos e galerias subterrâneas.

A realização dos levantamentos geofísicos pode ser efetuada nas diferentes etapas de atividades estabelecidas para o gerenciamento de áreas contaminadas:

- Na etapa de investigação confirmatória, as técnicas geofísicas são utilizadas para localizar os pontos de amostragem mais adequados, através da determinação de anomalias que representam os locais com maiores concentrações de contaminantes (hot spots);

- Quando da investigação detalhada e para remediação, os métodos geofísicos podem ser empregados para o mapeamento e monitoramento da propagação da contaminação;

- Na fase de remediação de áreas contaminadas, estes métodos podem ser aplicados na avaliação da eficiência dos trabalhos de recuperação pela confirmação das reduções das concentrações dos contaminantes.

Existe uma variedade de métodos geofísicos que podem ser utilizados nos estudos ambientais, porém os principais métodos, que comumente são aplicados à investigação da contaminação do solo e da água subterrânea são: o geo-radar (GPR), o eletromagnético indutivo (EM), a eletrorresistividade (ER) e a magnetometria (CETESB, 1999). A seguir, é apresentado um breve resumo de cada uma dessas técnicas com base na CETESB (1999). Maiores detalhes destes e de outros métodos geofísicos podem ser conferidos em ELIS (2003a).

\subsubsection{Geo-radar (Ground Penetrating Radar - GPR)}

Segundo ELIS (2003a), o radar produz uma onda eletromagnética de alta frequência (10-1000 MHz) que é transmitida ao solo, onde a propagação do sinal depende das propriedades elétricas dos materiais existentes. O equipamento é composto basicamente de uma unidade de processamento e duas antenas, uma de emissão do sinal eletromagnético e outra de recepção dos sinais refletidos (Foto 2.1). A influência dominante nos sinais de Geo-Radar está representada pelo coeficiente dielétrico e pela condutividade elétrica apresentada pelos materiais. Nas camadas de 
solo, essas propriedades elétricas são normalmente associadas com o volume de água contido, de forma que variação do teor de umidade causam reflexões da onda eletromagnética gerada pelo radar. Em rochas, o radar é sensível a mudanças no tipo rochoso e nas fraturas, preenchidas ou não com água. Dessa forma, mudanças das propriedades elétricas do meio geológico fazem com que parte do sinal transmitido seja refletido. O sinal refletido é detectado por um receptor onde é amplificado, digitalizado e armazenado, para ser processado e transformado em registro (radargrama).

Aplica-se esta técnica na caracterização geológica e hidrogeológica, localização de resíduos enterrados, localização de dutos e galerias subterrâneas, cubagem em aterros e lixões e detecção de contaminação orgânica ou inorgânica.

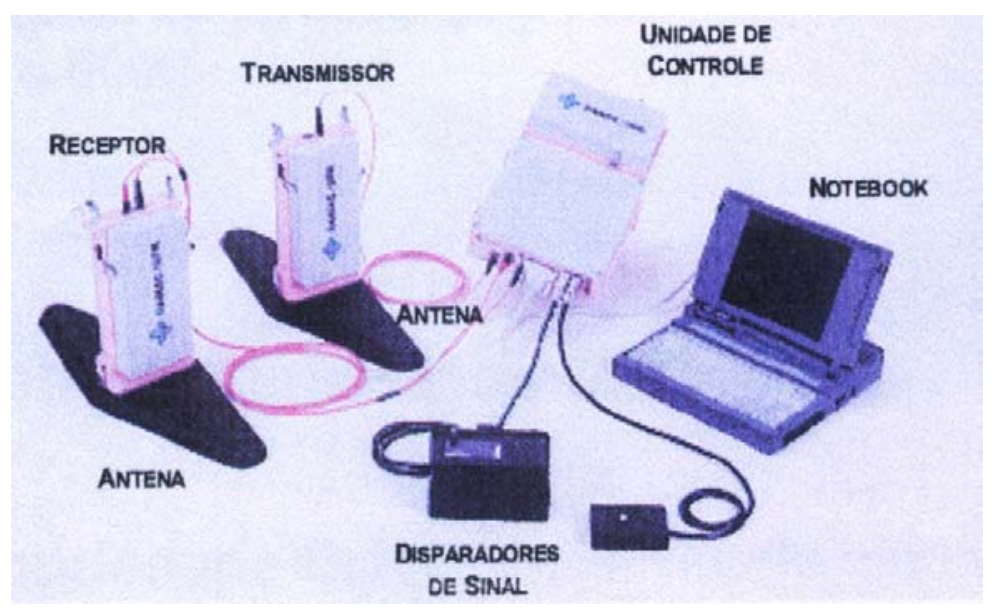

Foto 2.1. Equipamento e operação do geo-radar (CETESB, 1999).

\subsubsection{Magnetometria (Método Magnético)}

Os ensaios magnéticos em estudos ambientais podem ser feitos com um magnetômetro para determinação do campo magnético total (magnetômetro de prótons), pois é um instrumento de fácil utilização e que realiza medidas rápidas que são simples de processar (ELIS, 2003a). Na Foto 2.2 é apresentado um magnetômetro e um esquema de como o equipamento pode ser usado no campo. $\mathrm{O}$ princípio é a determinação de anomalias de materiais ferromagnéticos. Aplica-se esta técnica na localização de tanques, tambores e resíduos metálicos ferrosos enterrados. 


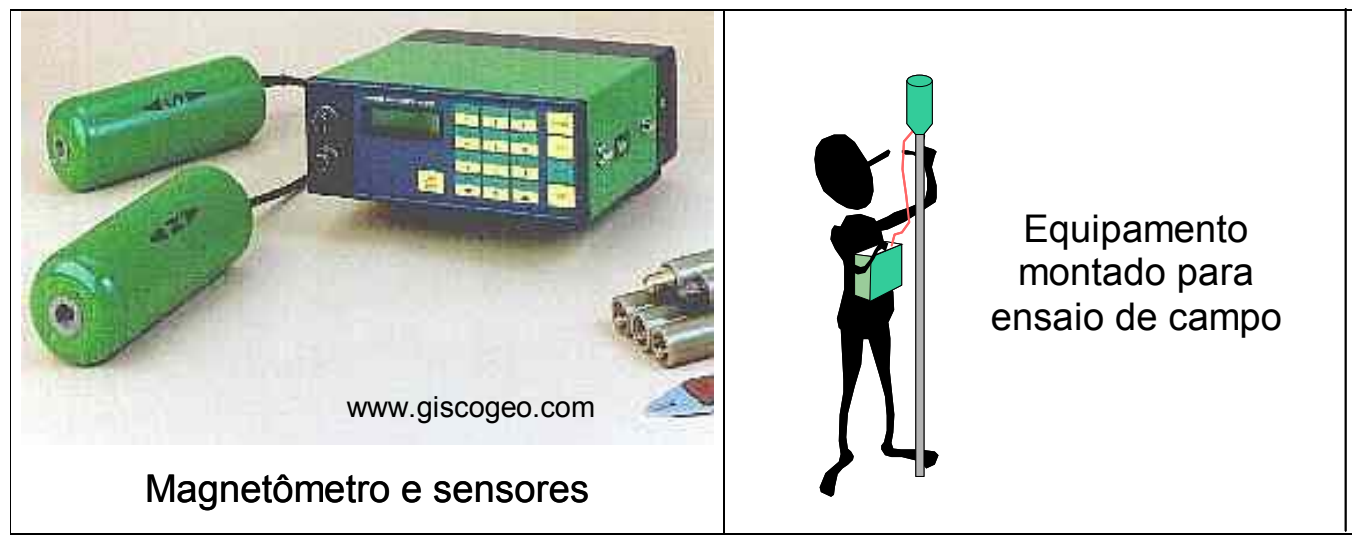

Foto 2.2. Magnetômetro e sensores e o equipamento preparado para ensaio de campo (ELIS, 2003a).

\subsubsection{Eletromagnético indutivo (EM)}

Nesta técnica, a propriedade física determinada é a condutividade elétrica. $\mathrm{O}$ ensaio é realizado através da introdução de campo eletromagnético no subsolo. Aplica-se esta técnica na definição das condições hidrogeológicas naturais, localização de resíduos, tambores e tanques enterrados, galerias subterrâneas e delimitação de plumas de contaminação inorgânica.

Os ensaios de campo são realizados geralmente por caminhamentos, que, devido a praticidade de operação e transporte dos equipamentos, são realizados com muita rapidez (Fotos 2.3 e 2.4). Como as profundidades de investigação são prédeterminadas, os equipamentos são bastante limitados para a execução de sondagens.

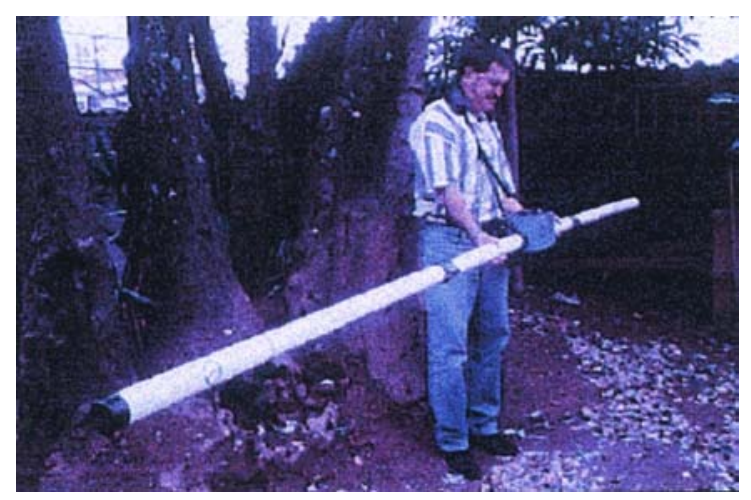

Foto 2.3. Condutivímetro EM31 - profundidade de investigação: 3 e 6 m (CETESB, 1999). 

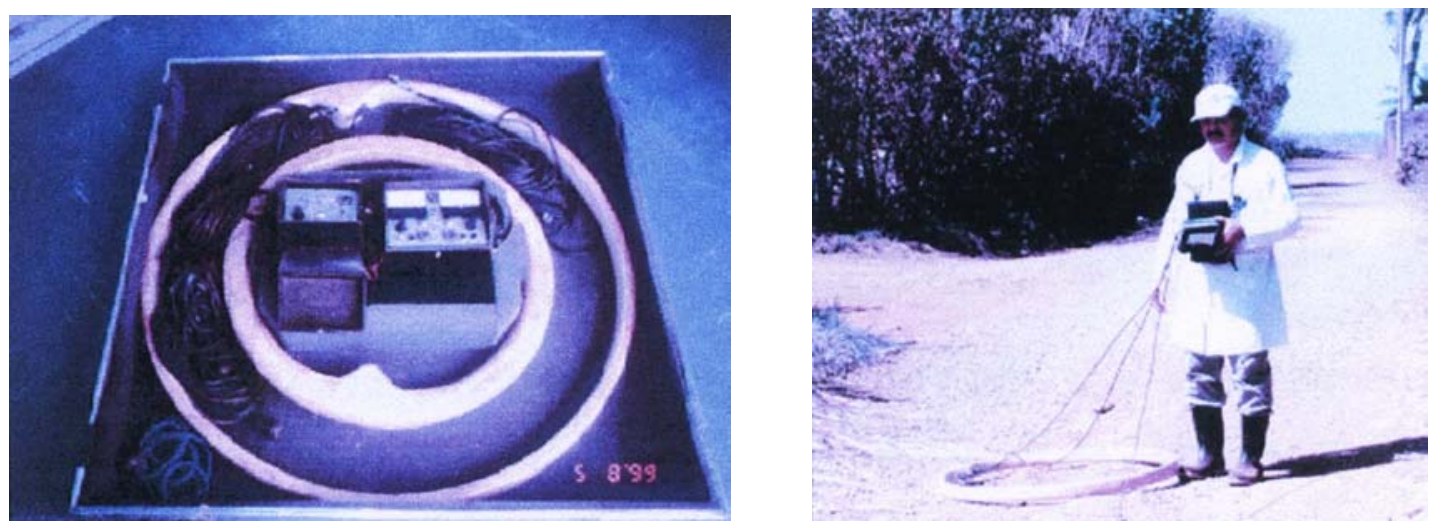

Foto 2.4. Condutivímetro EM34 e seu modo de operação - profundidade de investigação: 7.5, 15, 30 e 60 m (CETESB, 1999).

Os dados de condutividade podem ser plotados em perfis, em função da distância, e um conjunto de perfis permite a confecção de mapas. A interpretação desses dados é qualitativa porém, existem em desenvolvimento softwares para quantificação desses dados. No caso deste trabalho, os resultados foram convertidos em resistividade para uniformização.

\subsubsection{Eletrorresistividade (ER)}

Nesta técnica, a propriedade física determinada é a resistividade elétrica. O ensaio é realizado por aplicação de corrente no solo. Aplica-se esta técnica na caracterização hidrogeológica, determinação dos estratos geológicos, localização de resíduos enterrados e mapeamento de plumas de contaminantes inorgânicos (Foto 2.5). Como esta foi a técnica utilizada nesta pesquisa, ela será detalhada a seguir, segundo ELIS (1999). 


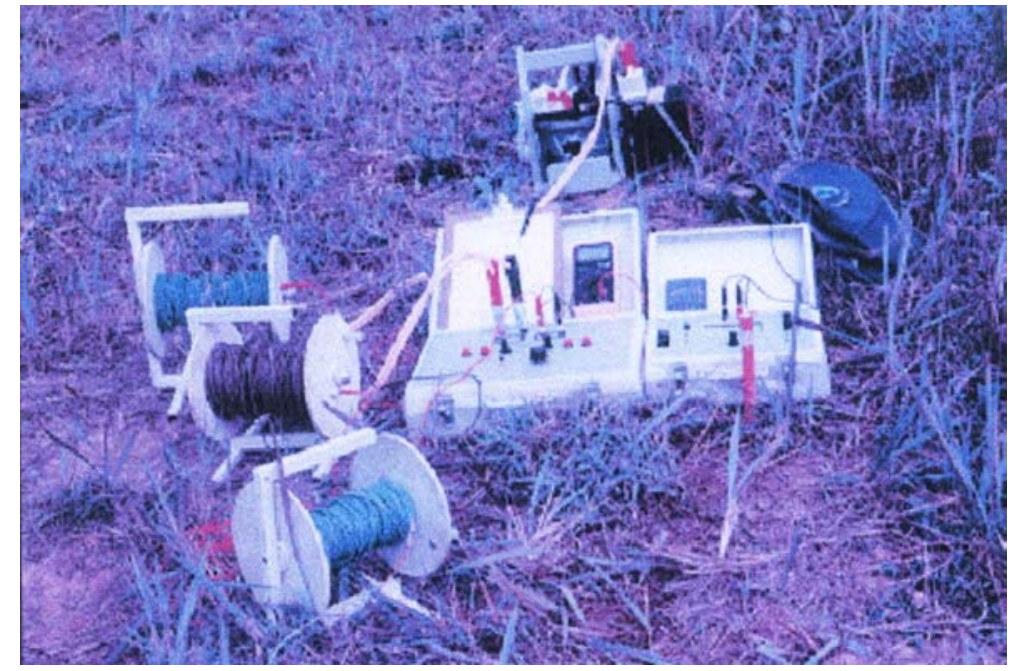

Foto 2.5. Resistivímetro de campo (CETESB, 1999).

\section{a) Princípios da Técnica}

Os diferentes tipos de materiais existentes apresentam como uma de suas propriedades fundamentais o parâmetro físico resistividade elétrica, o qual reflete suas principais características servindo para caracterizar seu estado e até identificálo.

Da Física Elementar, tem-se que a relação entre a resistividade e a resistência de um condutor homogêneo, de forma cilíndrica ou prismática, é dada pela fórmula:

$$
\mathrm{R}=(\rho . \mathrm{L}) / \mathrm{S} \quad(\mathrm{ohm})
$$

onde:

$\mathrm{L}=$ comprimento;

$\mathrm{S}=$ seção transversal do condutor;

$\rho=$ coeficiente que depende da natureza e do estado físico do corpo considerado e recebe o nome de resistividade.

Deste modo, pode-se definir a resistividade elétrica desse corpo como:

$$
\rho=(\text { R.S }) / \mathrm{L} \quad \text { (ohm.m) }
$$


De maneira simplista, a resistividade pode ser definida como sendo uma medida da dificuldade que a corrente elétrica encontra na sua passagem em um determinado material, e isso está ligado aos mecanismos pelos quais a corrente elétrica se propaga.

Nas rochas, estes mecanismos são caracterizados por sua condutividade " $\sigma$ ", que numericamente pode ser expressa como o inverso da resistividade:

$$
\sigma=1 / \rho(\mathrm{ohm} / \mathrm{m})
$$

Estes mecanismos de propagação das correntes elétricas podem ser do tipo condutividade eletrônica ou iônica. A classificação destes tipos de condutividade pode ser sintetizada da seguinte maneira:

- Condutividade eletrônica: metais e semicondutores; e

- Condutividade iônica: eletrólitos sólidos (dielétricos) e eletrólitos líquidos.

A condutividade eletrônica se deve ao transporte de elétrons na matriz da rocha, sendo a sua resistividade governada pelo modo de agregação dos minerais e do grau de impurezas (é o caso de certos minerais metálicos e dos xistos grafitosos). A condutividade iônica deve-se ao deslocamento dos íons existentes na água contida nos poros e fissuras da rocha.

A resistividade das rochas que possuem condutividade iônica é função decrescente da quantidade de água e da natureza dos sais dissolvidos, e da porosidade total comunicante (a água contida em vacúolos isolados tem pouca importância). Praticamente, todas as rochas possuem poros em proporção maior ou menor, os quais podem estar ocupados total ou parcialmente por eletrólitos; em conjunto elas se comportam como condutores iônicos, de resistividades muito variáveis.

Se ao introduzir uma corrente elétrica (I) através dos eletrodos A e B, e entre os eletrodos $\mathrm{M}$ e $\mathrm{N}$ medir a diferença de potencial criada $(\Delta \mathrm{V})$, resulta que as medidas pertinentes serão utilizadas para o cálculo da resistividade aparente ( $\rho$ a) pela fórmula: 


$$
\rho \mathrm{a}=(\mathrm{K} . \Delta \mathrm{V}) / \mathrm{I} \quad(\text { ohm.m) }
$$

sendo $\mathrm{K}$ um fator geométrico que só depende do espaçamento entre os quatro eletrodos, calculado da seguinte maneira:

$$
\mathrm{K}=\pi \cdot(\mathrm{AM} \cdot \mathrm{AN}) / \mathrm{MN}
$$

Como na prática o subsolo não pode ser considerado um meio homogêneo, a quantia medida representa uma "média" ponderada de todas as resistividades verdadeiras em um volume de material em uma subsuperfície relativamente grande. Portanto, ao efetuar-se as medições pertinentes obtem-se uma resistividade aparente

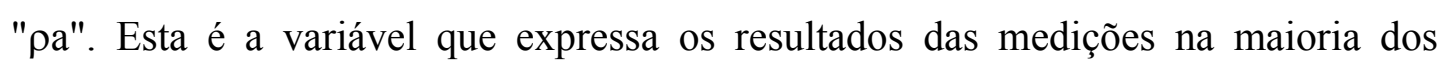
métodos geoelétricos e é a que se toma como base para a interpretação final.

\section{b) Técnica de Sondagem Elétrica Vertical - Arranjo Schlumberger}

A técnica de sondagem elétrica vertical (SEV) caracteriza-se por uma série de determinações de resistividade aparente, efetuadas com um dispositivo eletródico e com separação crescente entre os eletrodos de emissão e recepção. Esse procedimento permite a observação dos valores de resistividade aparente, em um ponto fixo, a profundidades cada vez maiores, através da separação crescente entre os eletrodos A e B de corrente.

Os valores de resistividade aparente obtidos nas SEVs são representados, em relação às distâncias entre os eletrodos de corrente, através de uma curva construída sobre uma base bi-logarítmica. Esse gráfico é normalmente denominado de curva de sondagem elétrica vertical e é o que se toma como base para interpretação quantitativa do ensaio.

$\mathrm{O}$ arranjo de campo Schlumberger é o mais utilizado em SEVs, devido à qualidade das curvas de campo, facilidade e rapidez na execução do ensaio e menor susceptibilidade às variações laterais de resistividade e ruídos, como correntes naturais no subsolo.

O arranjo compreende uma configuração que utiliza quatro eletrodos, sendo dois para injetar a corrente (A e B) e dois para a leitura de diferença de potencial (M 
e N), todos dispostos no terreno de acordo com um mesmo alinhamento. A principal característica desse arranjo é que a distância $\mathrm{MN}$ deve ser bastante pequena em relação a $\mathrm{AB}$, procurando sempre satisfazer a relação $\mathrm{MN} \leq(\mathrm{AB} / 5)$ (Figura 2.25). $\mathrm{Na}$ prática, quando o sinal $\Delta \mathrm{V}$ medido torna-se muito fraco, aumenta-se a distância $\mathrm{MN}$, isto é, adota-se um primeiro intervalo $\mathrm{MN}$ e realizam-se várias medidas com diferentes $\mathrm{AB}$, depois aumenta-se $\mathrm{MN}$, que se conserva constante para outra série de deslocamentos de $\mathrm{AB}$, e assim por diante, evitando deslocar ao mesmo tempo os eletrodos de corrente e de potencial e mantendo a relação $\mathrm{MN} \leq(\mathrm{AB} / 5)$. Este procedimento recebe a denominação de "embreagem" e permite uma checagem da qualidade dos dados obtidos durante o processo de campo.

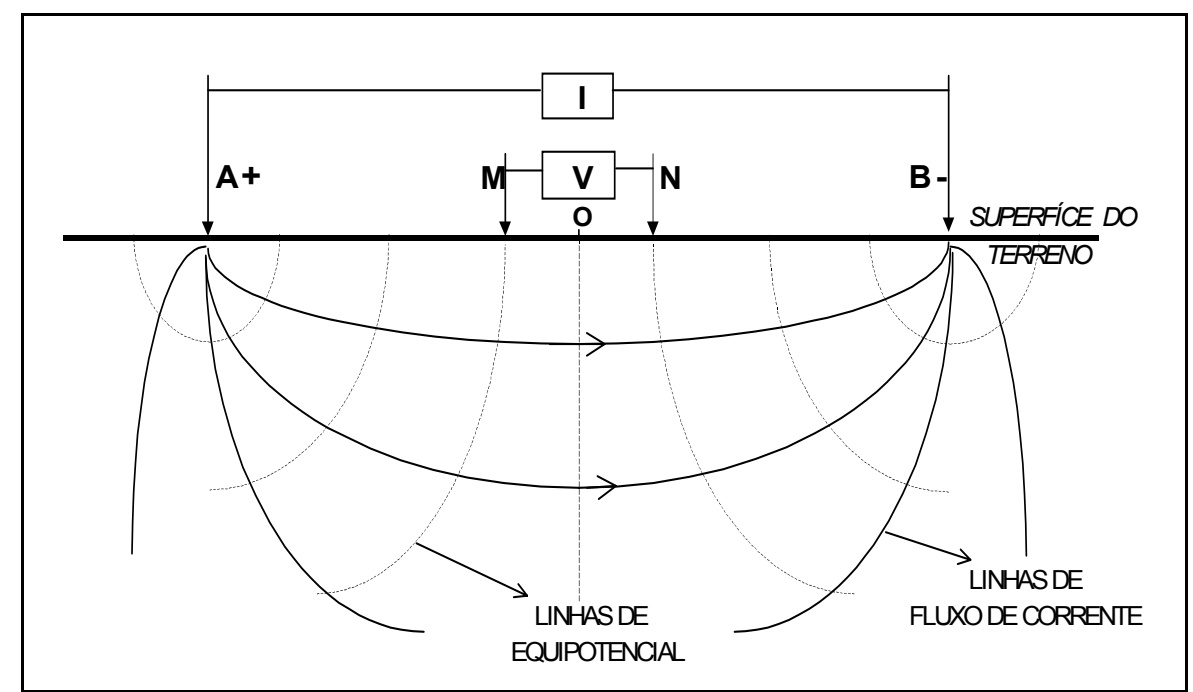

Figura 2.25. Arranjo de campo - sondagem elétrica vertical Schlumberger (ELIS, 1999).

O ponto de atribuição do ensaio é sempre localizado no centro geométrico do arranjo. Os valores de resistividade aparente obtidos são plotados em relação aos valores da distância $\mathrm{AB} / 2$, fornecendo a curva de resistividade aparente, a qual é passível de interpretação quantitativa. A interpretação de uma SEV objetiva determinar a distribuição espacial dos estratos com diferentes resistividades no subsolo, partindo dos dados de resistividade aparente medidos na superfície. A seguir, é feita a interpretação do significado geológico dos estratos, com diferentes 
resistividades. A interpretação da curva de SEV baseia-se em leis físicomatemáticas, o que a torna um processo trabalhoso e de difícil execução. Inicialmente, as curvas obtidas em campo são interpretadas pelo método da superposição e ponto auxiliar de Ebert (IPT, 1988), através de modelos matemáticos convencionais - ábacos ou curvas padrão - disponíveis, para obter-se um modelo inicial. Posteriormente, o refinamento do modelo encontrado é feito através de softwares específicos, a partir do método das aproximações sucessivas ou de inversão usando regressão em cadeia.

\section{c) Técnica do Caminhamento Elétrico - Arranjo Dipolo-Dipolo}

As investigações pelo caminhamento elétrico (CE) são realizadas ao longo de perfis e os resultados obtidos se relacionam entre si através de um estudo em mapas a uma ou mais profundidades determinadas, ou através de seções com várias profundidades de investigação. Devido ao caráter de detalhe e precisão dos resultados a serem obtidos, o arranjo utilizado nesta pesquisa foi o Dipolo-Dipolo.

A Figura 2.26 ilustra a disposição no campo dos eletrodos de emissão de corrente e de recepção de potencial na realização da técnica do CE - arranjo de campo dipolo-dipolo. No desenvolvimento deste arranjo de campo, pode-se utilizar simultaneamente vários dipolos de recepção dispostos ao longo da linha a ser levantada. Cada dipolo refere-se a um nível de investigação, podendo, dependendo do caráter da pesquisa, estudar as variações horizontais de um parâmetro físico ao longo de um perfil com um ou até cinco dipolos, com uma e cinco profundidades de investigações, respectivamente.

Nesse tipo de arranjo, a profundidade teórica atingida em cada nível investigado pode ser tomada como sendo $\mathrm{R} / 2$ (metros).

O ensaio é desenvolvido ao longo de perfis previamente estaqueados, com espaçamento constante, em função das profundidades de investigação requeridas, pois tanto o espaçamento entre os dipolos como o número de dipolos utilizados regulam as profundidades de investigação atingidas. 


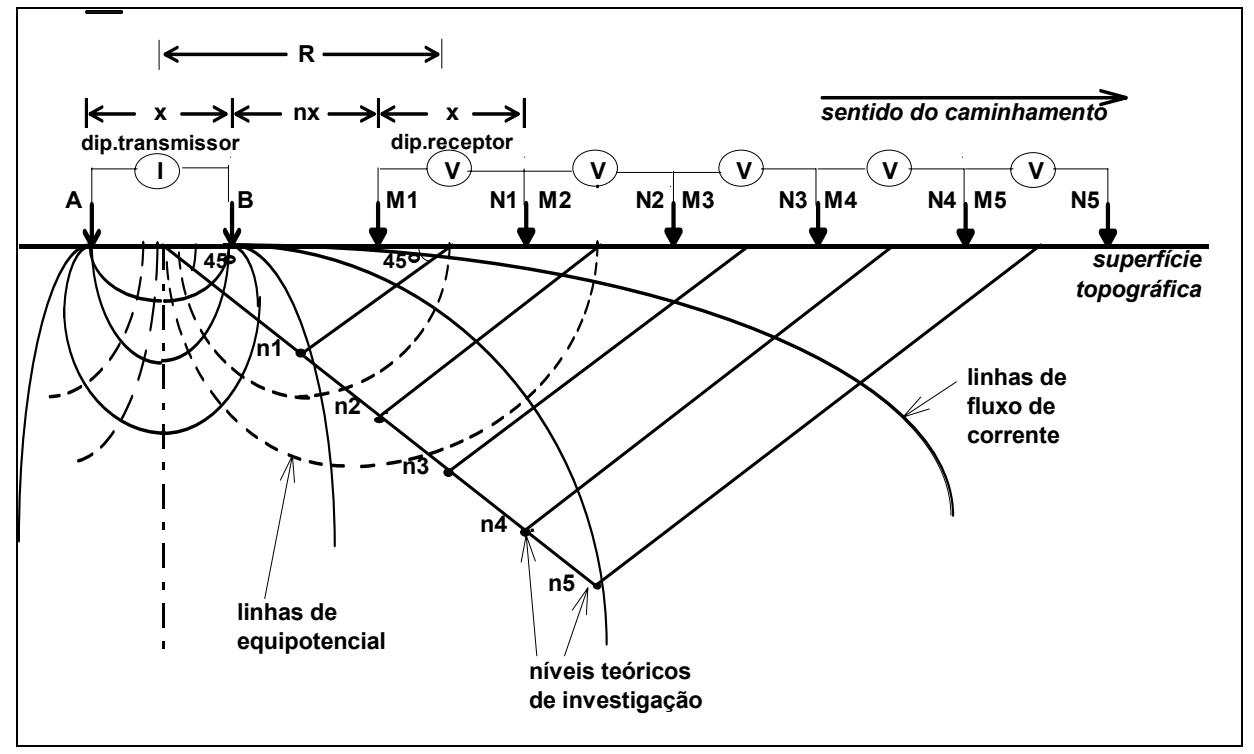

Figura 2.26. Disposição no campo do arranjo Dipolo-Dipolo - Caminhamento Elétrico (ELIS, 1999).

Após realizada a disposição do arranjo no terreno, fixados os níveis de investigações, e obtidas as leituras pertinentes, todo o arranjo é deslocado para a estaca seguinte e efetuadas as leituras correspondentes, continuando este procedimento sucessivamente até atingir o final do perfil a ser investigado.

O sistema de plotagem dos parâmetros físicos obtidos é efetuado considerando como ponto de atribuição das leituras uma projeção de $45^{\circ}$ a partir dos centros dos dipolos $\mathrm{AB}$ e $\mathrm{MN}$, até atingir o ponto médio entre os centros destes dipolos.

Após a plotagem de todos os parâmetros geoelétricos obtidos em um perfil, tem-se uma seção geoelétrica aparente (Figura 2.27).

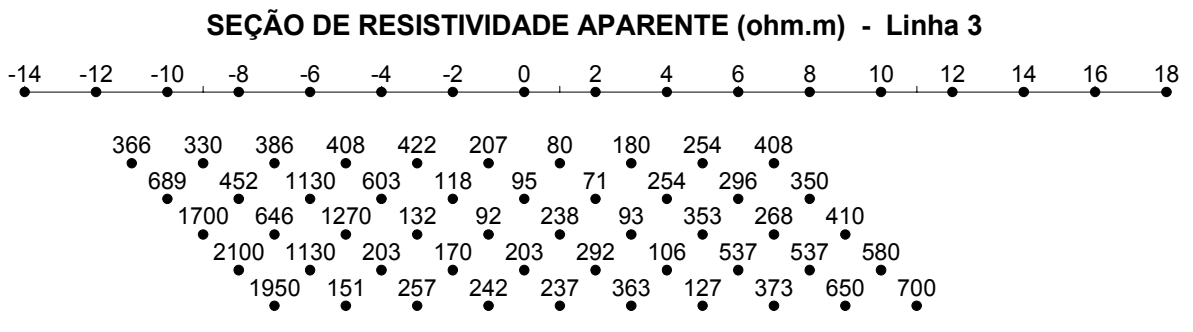

Figura 2.27. Sistema de plotagem da técnica do CE - arranjo Dipolo-Dipolo/Método da Eletrorresistividade (ELIS, 1999). 


\subsubsection{Potencialidades de Aplicação dos Métodos Geofísicos}

A seguir, estão relacionadas as potencialidades dos métodos geofísicos citados anteriormente, conforme a CETESB (1999):

\section{a) Geo-radar (GPR)}

Para as sondagens utilizando o geo-radar, destacam-se os seguintes aspectos:

- Realização de perfis ao longo de linhas, produzindo seções contínuas e instantâneas (Figura 2.28);

- A faixa de velocidade varia de 0.5 a $2.0 \mathrm{~km} / \mathrm{h}$ para perfis detalhados e velocidades superiores a $8.0 \mathrm{~km} / \mathrm{h}$ em perfis de reconhecimento;

- Os registros gráficos podem ser, freqüentemente, interpretados no campo;

Seção de geo-radar em área contaminada por infiltração de resíduos industriais

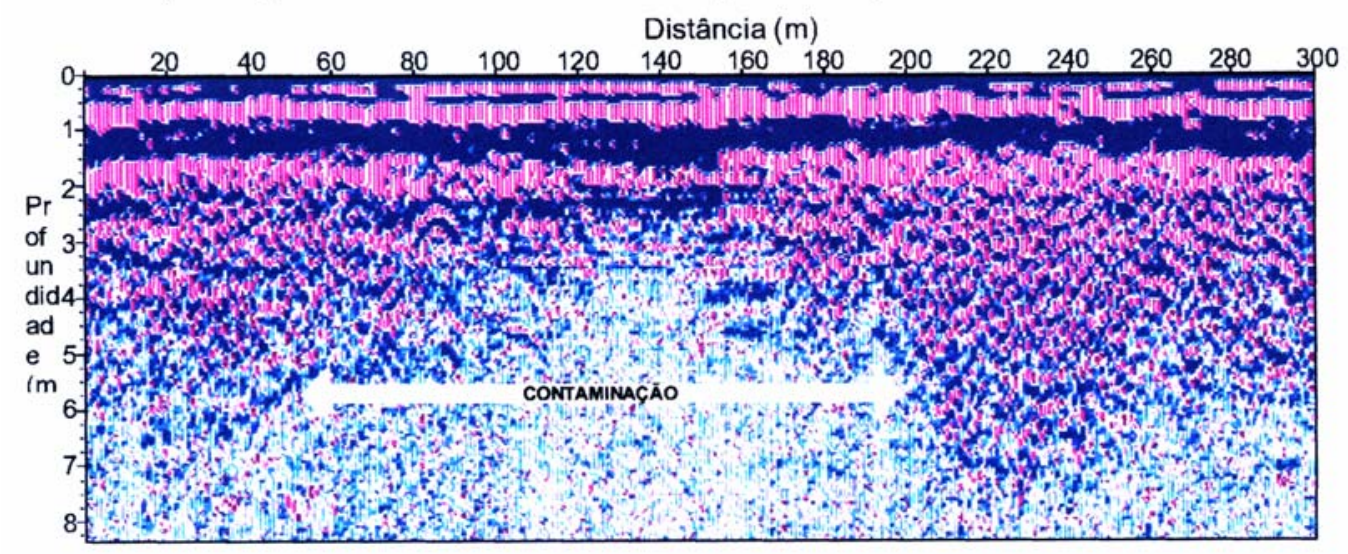

Figura 2.28. Seção de geo-radar indicando os limites da contaminação (atenuação do sinal) provocada pela infiltração de resíduos industriais (CETESB, 1999).

- Boa definição para corpos de poucos centímetros a 1 metro, dependendo da antena a ser utilizada;

- Adequação do equipamento às condições locais através da mudança de antenas (freqüência): altas freqüências obtêm melhor definição; baixas freqüências fornecem maior profundidade de investigação;

- Profundidades aproximadas e relativas são facilmente estabelecidas, assumindose simples condições e técnicas de interpretação;

- Possibilidade de detecção de contaminação por compostos orgânicos;

- Utilização do método em áreas urbanas; 
- Aplicabilidade sobre a água, concreto, asfalto ou qualquer outro tipo de superfície (exceção feita às superfícies metálicas e à água do mar);

- Uma ampla variedade de técnicas de processamento pode ser aplicada aos dados de radar, para aperfeiçoar a interpretação e apresentação;

- Capacidade de detecção de dutos ou galerias subterrâneas de qualquer tipo de material;

- Possibilidade de identificação de vazamentos em tubulações.

\section{b) Magnetometria (Método Magnético)}

Para método magnético, destacam-se os seguintes aspectos:

- Os magnetômetros respondem aos metais ferrosos (aço e ferro);

- Tambores individuais podem ser detectados a profundidade de até $6 \mathrm{~m}$;

- Um conjunto de tambores ou grandes tanques podem ser identificados de 6 a 20 $\mathrm{m}$ de profundidade;

- Os magnetômetros atingem maiores profundidades que os detectores de metal;

- A interpretação dos dados é empregada para estimar o número e a profundidade de tambores enterrados;

- Obtêm-se respostas contínuas ao longo das linhas de investigação;

- Os levantamentos podem ser executados acoplando o equipamento a veículos para cobertura de grandes locais.

\section{c) Eletromagnético Indutivo (EM)}

Para a técnica eletromagnética indutiva, destacam-se os seguintes aspectos:

- Rápida aquisição de dados, resultando em levantamentos de alta densidade e definição;

- Instrumentos de registros contínuos podem aumentar a velocidade, densidade e definição dos levantamentos, permitindo a cobertura total do local investigado;

- Os limites da pluma de condutividade do solo ou das águas subterrâneas podem ser detectados e medidos (Figura 2.29);

- A faixa de profundidade de aquisição de dados varia de 0.75 a $60 \mathrm{~m}$, aproximadamente, dependendo do equipamento utilizado; 
- As leituras são realizadas diretamente em unidades de condutividade elétrica (miliSiemens/m), possibilitando o uso direto dos dados de campo, e correlacionando-os à condutividade de amostras do solo e da água subterrânea;

- Capacidade de mapear variações das diferentes porções hidrogeológicas;

- A direção de fluxo da pluma de contaminação pode ser determinada através dos mapas e seções de isocondutividade;

- Medidas levantadas em épocas diferentes podem fornecer taxas da migração dos contaminantes no solo e na água subterrânea, contribuindo para o monitoramento local;

- Possibilidade de mapear minerações abandonadas, estimar seus volumes e detectar resíduos enterrados;

- Deteç̧ão e mapeamento de dutos metálicos enterrados.

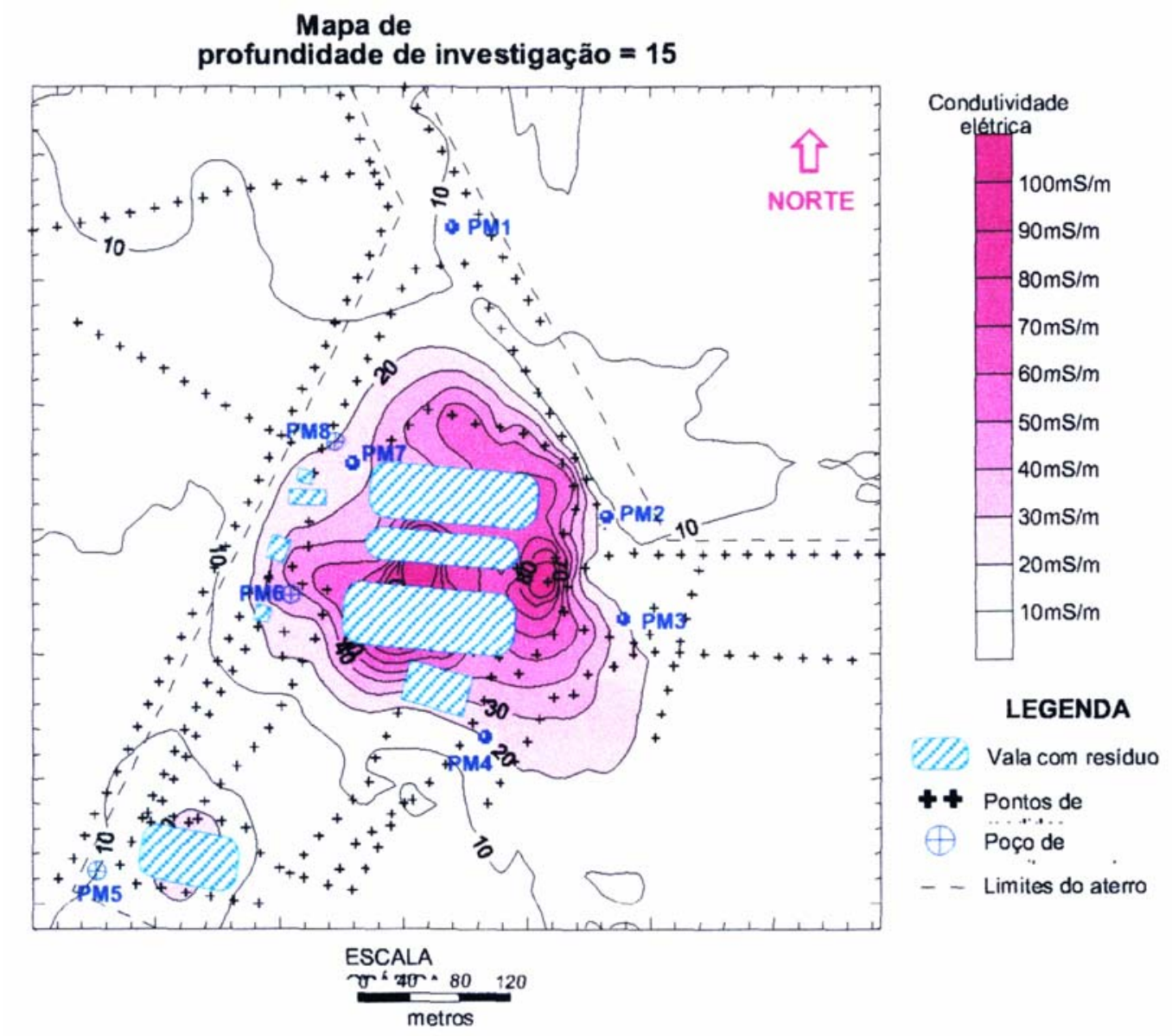

Figura 2.29. Mapa de isocondutividade apresentando os limites da pluma de contaminação proveniente de aterro industrial desativado (CETESB, 1999). 


\section{d) Eletrorresistividade (ER)}

- Sondagem elétrica: visa identificar a resistividade das rochas em diferentes profundidades, sob um mesmo ponto do terreno. Fundamenta-se na aplicação de correntes elétricas em dois eletrodos metálicos, que são cravados no solo com a aferição dessa mesma corrente em dois outros eletrodos cravados em pontos diferentes do terreno. Pela diferença de potencial observada entre os eletrodos de aplicação e os de aferição da corrente elétrica, pode-se calcular a resistividade das rochas existentes sob o ponto de observação e inferir-se sobre o tipo e/ou condições dessas rochas, bem como sobre a espessura das camadas formadas. Conhecendo-se o subsolo da região, pode-se ainda detectar alterações causadas por elementos estranhos, como poluentes, bem como o seu caminhamento, posicionamento, concentração, etc.

- Caminhamento elétrico: valem as mesmas técnicas e princípios das sondagens elétricas. Enquanto nas sondagens mede-se a resistividade das rochas em várias profundidades sob um mesmo ponto da superfície, no caminhamento elétrico mede-se a resistividade a uma profundidade aproximadamente constante, em vários pontos de um perfil do terreno. Assim, desloca-se um arranjo fixo de quatro eletrodos pelo terreno, fazendo-se uma medida em cada ponto predeterminado. Esse procedimento permite, por exemplo, o rastreamento de determinadas substâncias que compõem uma pluma de poluição.

Desta forma, para a técnica da eletrorresistividade, destacam-se os seguintes aspectos:

- A técnica de caminhamento pode ser empregada para detectar e mapear as plumas de contaminação, e também as variações na hidrogeologia local;

- Através da técnica de sondagem elétrica vertical (SEV) é possível estimar a profundidade, espessura e resistividade das camadas em subsuperfície, além da profundidade aproximada do nível d'água (Figura 2.30); 

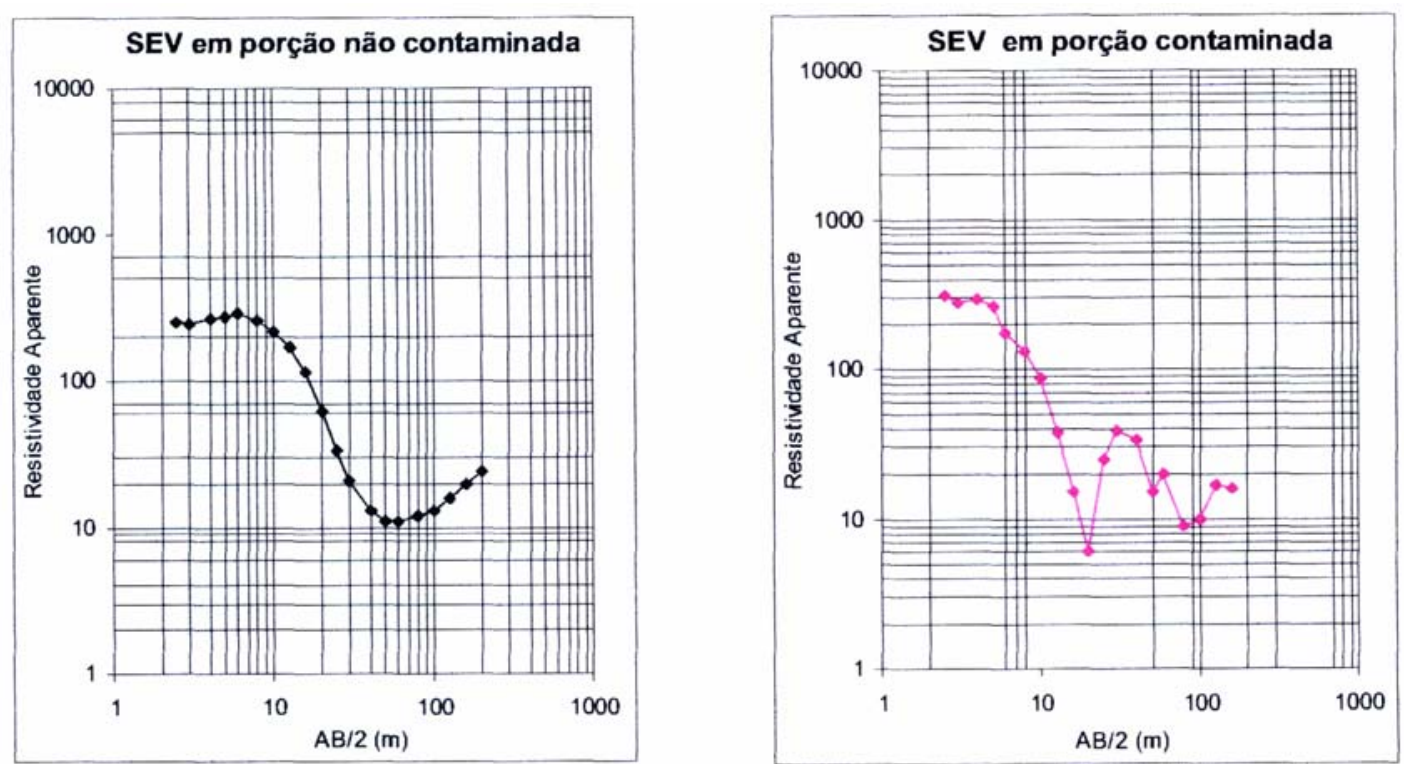

Figura 2.30. Resultado de sondagem elétrica vertical. (a) Externa à área de indústria suspeita de contaminação; (b) Realizada em local de infiltração de resíduos industriais (CETESB, 1999).

- Os dados de caminhamento, ou sondagem elétrica, podem ser avaliados qualitativamente ou semiquantitativamente no campo;

- Os dados de resistividade podem fornecer a provável composição geológica de uma camada ou estimar a condutividade específica da pluma;

- A profundidade de aterros ou de locais de descarte de resíduos pode, muitas vezes, ser estimada;

- Dos métodos apresentados é aquele que atinge maior profundidade de investigação (superior a $100 \mathrm{~m}$ ), dependendo fundamentalmente da abertura dos eletrodos de corrente, da geologia local e da corrente elétrica injetada no solo.

A Tabela 2.2, a seguir, apresenta um resumo das principais características dos métodos geofísicos estudados. 
Tabela 2.2. Resumo das características principais dos métodos geofísicos (CETESB, 1999).

\begin{tabular}{|c|c|c|c|c|}
\hline & Geo-radar & Eletromagnético & Eletrorresistividade & Magnetométrico \\
\hline $\begin{array}{l}\text { Profundidade } \\
\text { de investigação }\end{array}$ & $\begin{array}{l}\text { Até } 30 \text { metros } \\
\text { Depende de: } \\
\begin{array}{l}\text { Antenas } \\
\text { utilizadas }\end{array} \\
\text { - Geologia } \\
\text { local }\end{array}$ & $\begin{array}{l}\text { Até } 60 \text { metros, } \\
\text { depende de: } \\
\text { - Equipamento } \\
\text { - Geologia } \\
\text { local }\end{array}$ & $\begin{array}{l}100 \text { metros ou mais, } \\
\text { depende de: } \\
\text { - Abertura dos } \\
\text { eletrodos } \\
\text { - Corrente injetada } \\
\text { no solo } \\
\text { - Geologia local }\end{array}$ & $\begin{array}{l}\text { Até } 20 \text { metros, } \\
\text { Depende de: } \\
\text { Quantidade } \\
\text { de material } \\
\text { ferroso } \\
\text { enterrado }\end{array}$ \\
\hline $\begin{array}{l}\text { Suscetibilidade } \\
\text { às } \\
\text { interferências }\end{array}$ & $\begin{array}{ll}\text { - } & \begin{array}{l}\text { Rede } \\
\text { elétrica }\end{array} \\
\text { - Objetos } \\
\text { metálicos } \\
\text { próximos }\end{array}$ & $\begin{array}{l}\text { - Rede elétrica } \\
\text { - Objetos } \\
\text { metálicos } \\
\text { próximos }\end{array}$ & $\begin{array}{l}\text { Mau contato dos } \\
\text { eletrodos com o } \\
\text { solo }\end{array}$ & $\begin{array}{l}\text { - Linhas de alta } \\
\text { tensão } \\
\text { - Qualquer } \\
\text { objeto } \\
\text { metálico } \\
\text { próximo }\end{array}$ \\
\hline $\begin{array}{c}\text { Características } \\
\text { mais } \\
\text { destacadas }\end{array}$ & $\begin{array}{l}\text { Método } \\
\text { de maior } \\
\text { definição }\end{array}$ & $\begin{array}{l}\text { - Detecção de } \\
\text { contaminante } \\
\text { s } \\
\text { disseminados } \\
\text { no solo } \\
\text { - Determinação } \\
\text { rápida de } \\
\text { variações } \\
\text { laterais }\end{array}$ & $\begin{array}{l}\text { Determinação da } \\
\text { resistividade em } \\
\text { profundidade } \\
\text { - Grande } \\
\text { profundidade de } \\
\text { investigação. }\end{array}$ & $\begin{array}{l}\text { Detecção e } \\
\text { quantificação } \\
\text { de objetos } \\
\text { metálicos }\end{array}$ \\
\hline
\end{tabular}

\subsubsection{Seleção do Método Geofísico}

Segundo a CETESB (1999), para a seleção de um método geofísico a ser empregado, o ideal é ter conhecimento da geologia local, das características físicoquímicas das águas subterrâneas e do contaminante, do tipo de descarte efetuado e invólucro utilizado e da proximidade de edificações e instalações.

Dentre os aspectos mencionados, dois deles são preponderantes e decisivos na escolha do método o geofísico a ser empregado, que são:

- O tipo de contaminação;

- O ambiente geológico onde está disposto o contaminante. 


\section{a) Tipo de Contaminação}

Descrevem-se, a seguir, os melhores métodos geofísicos a serem utilizados de acordo com o tipo de contaminação a ser investigado, conforme consta no manual da CETESB (1999). A Tabela 2.3 apresenta um resumo com as melhores situações para aplicação dos métodos geofísicos citados.

- Resíduos metálicos: possuem alta condutividade elétrica e ainda, se forem ferrosos, também são altamente magnéticos. Dessa forma, os dois métodos geofísicos mais apropriados são: o eletromagnético indutivo (EM) e o magnetométrico. Em áreas de interferências elétricas intensas, o magnetômetro será mais adequado; em contrapartida, se o resíduo estiver disseminado no solo, o método eletromagnético fornecerá melhores resultados. Além desses métodos, o geo-radar tem se mostrado eficiente para a detecção desse tipo de material, com a vantagem de apresentar alta definição dos dados e menor suscetibilidade às interferências urbanas graças à blindagem das antenas;

- Resíduos inorgânicos: produzem anomalias de alta condutividade (baixa resistividade), em relação ao meio onde está localizado. Assim, para a detecção desses resíduos é mais viável o emprego de métodos eletromagnéticos indutivos (EM) e do geo-radar. Além destes, a eletrorresistividade também pode ser utilizada como método alternativo. Dentre os métodos aqui apontados, o georadar leva vantagem, devido à continuidade dos seus perfis e da alta resolução obtida. Exemplos: a definição dos limites de valas com resíduos ou de lixões;

- Pluma inorgânica na água subterrânea (ions e sais dissolvidos): os contaminantes inorgânicos em contato com a água subterrânea aumentam a concentração de íons livres, elevando a condutividade elétrica do meio. Para a determinação desses contrastes de condutividade, o método eletromagnético indutivo (EM) é mais indicado que a eletrorresistividade, principalmente pela rapidez de execução do levantamento e pela precisão na determinação de variações laterais. O geo-radar pode ser empregado para este tipo de investigação como alternativa, uma vez que os limites da pluma inorgânica podem ser determinados pela atenuação das ondas eletromagnéticas. Exemplos: mapeamento das plumas de contaminação a partir de aterros mal controlados ou 
devido à infiltração de resíduos industriais;

- Resíduos orgânicos e plumas orgânicas: possuem baixa condutividade elétrica e pequeno coeficiente dielétrico, apresentando, assim, pequeno contraste com as propriedades elétricas do meio geológico onde estão dispostos, dificultando, portanto, sua detecção. O geo-radar é, dentre os métodos geofísicos, o que tem apresentado os melhores resultados para identificação de contaminação por organoclorados, e, principalmente, por hidrocarbonetos (combustíveis). Em condições muito especiais, podem ser empregados os métodos de eletrorresistividade e eletromagnético, a fim de se mapear as anomalias resistivas (baixa condutividade elétrica).

- Rejeitos de mineração: os rejeitos de mineração proporcionam anomalias condutivas, tanto no solo como nas águas subterrâneas. Assim, o método mais indicado para identificar essa contaminação é o eletromagnético indutivo, tendo como vantagem, em relação à eletrorresistividade, a agilidade do levantamento e a maior capacidade de detecção dos contaminantes disseminados no solo e na água subterrânea. De forma alternativa, o geo-radar pode ser empregado para a detecção desse tipo de contaminação, graças a atenuação do sinal provocada pela alta condutividade dos rejeitos. 
Tabela 2.3. Resumo das principais aplicações dos métodos geofísicos em áreas contaminadas (CETESB, 1999).

\begin{tabular}{|c|c|c|c|c|}
\hline$i-\cdot+-\cdot$ & Geo-radar & Eletromagnético & Eletrorresistividade & Magnetométrico \\
\hline $\begin{array}{c}\text { Caracterização } \\
\text { geológica e } \\
\text { hidrogeológica } \\
\text { de locais }\end{array}$ & 1. Adequado & 2. Alternativo & 1.Adequado & 3. Não se utiliza \\
\hline $\begin{array}{l}\text { Mapeamento de } \\
\text { pluma de } \\
\text { contaminação } \\
\text { inorgânica }\end{array}$ & 2. Alternativo & 1. Adequado & 2. Altemativo & 3. Não se utiliza \\
\hline $\begin{array}{l}\text { Localização de } \\
\text { valas de } \\
\text { residuos e } \\
\text { determinação } \\
\text { dos limites de } \\
\text { aterros e lixões }\end{array}$ & 1. Adequado & 1. Adequado & 2. Alternativo & $\begin{array}{l}\text { 3. Não se utiliza } \\
\text { (só se houver } \\
\text { presença de } \\
\text { materiais } \\
\text { metálicos) }\end{array}$ \\
\hline $\begin{array}{c}\text { Investigação de } \\
\text { residuos } \\
\text { orgânicos e } \\
\text { pluma orgânica }\end{array}$ & 1. Adequado & $\begin{array}{l}\text { 2. Alternativo } \\
\text { (em condições } \\
\text { especiais) }\end{array}$ & $\begin{array}{l}\text { 2. Alternativo } \\
\text { (em condiçōes } \\
\text { especiais) }\end{array}$ & 3. Não se utiliza \\
\hline $\begin{array}{c}\text { Detecção de } \\
\text { objetos } \\
\text { metálicos } \\
\text { enterrados }\end{array}$ & 1. Adequado & 2. Alternativo & 3. Não se utiliza & 1. Adequado \\
\hline
\end{tabular}

\section{b) Influência do Meio Geológico na Detecção da Contaminação}

O material geológico, no qual está localizado o resíduo ou o contaminante, atua, sobremaneira, na aplicabilidade e na eficiência dos métodos geofísicos que se baseiam na condutividade ou resistividade elétrica. Na seqüência, são relacionados os tipos dos materiais geológicos que podem influenciar na detecção da contaminação através do emprego desses métodos, segundo a CETESB (1999).

- Argilas: devido à alta condutividade elétrica apresentada por elas, o contraste 
entre o valor da condutividade natural do meio (background) e a condutividade dos contaminantes inorgânicos pode ser pequeno, podendo mascarar a detecção da contaminação. Em contrapartida, com a presença de compostos orgânicos, os contrastes de condutividade poderão ser salientados. Além disso, a presença de argila atenua a propagação dos campos e ondas eletromagnéticas, reduzindo a profundidade de investigação dos métodos eletromagnéticos indutivos (EM) e do geo-radar;

- Rochas arenosas: quanto maior é a resistividade desse tipo de material, maior será a profundidade de penetração dos campos e ondas eletromagnéticas no terreno. Assim, nesse tipo de ambiente, os métodos eletromagnéticos indutivos e o geo-radar detectarão de forma marcante os contrastes nas propriedades físicas provocadas pelos contaminantes inorgânicos ou metálicos. Como método alternativo, também poderá ser utilizado o método de eletrorresistividade, lembrando-se que, quanto maior a resistividade do meio geológico, maior será a dificuldade de propagação das correntes elétricas;

- Sedimentos não consolidados e materiais intemperizados: são representados pelas areias, cascalhos e seixos, que freqüentemente apresentam maior resistividade e menor teor de argila em relação aos materiais mais compactados. Assim, esse tipo de meio favorece a aplicação dos métodos de eletrorresistividade, eletromagnético indutivo e o geo-radar na investigação de contaminantes de alta condutividade;

- Rochas fraturadas: a contaminação orgânica e inorgânica presente nestes meios é de difícil identificação por métodos geofísicos de superfície. Nestes casos, os métodos geofísicos têm se mostrado eficientes na detecção das fraturas como caminhos preferenciais para os contaminantes. Para a investigação da contaminação em si, os melhores resultados têm sido determinados por perfilagens eletromagnéticas e de resistividade, pois essas técnicas possibilitam a detecção de forma direta do contaminante localizado nas fraturas;

- Áreas cársticas: nestas, existe grande variação das propriedades físicas do meio, o que dificulta a detecção da contaminação. Nesses locais, a aplicação dos 
métodos geofísicos deverá ser utilizada para caracterizar o meio geológico no qual os contaminantes possam se propagar. Dentre os métodos abordados, o georadar é aquele que tem se mostrado mais eficiente para a detecção de cavidades, decorrente da alta definição e continuidade das seções obtidas.

\subsubsection{Tecnologia do Piezocone}

\subsubsection{Aspectos Gerais}

O piezocone é um ensaio de penetração quasi-estática in situ que permite identificar e avaliar o perfil e os parâmetros geotécnicos do solo (LUNNE et al., 1997). Nos Estados Unidos, o procedimento está normalizado de acordo com a ASTM D3441 (1986), tanto para o ensaio com medida de poro-pressões (CPTU), como para o ensaio sem essa medida (CPT).

Nesse ensaio, uma ponteira em forma cônica (Figura 2.31), que é conectada à extremidade de um conjunto de hastes, é introduzida no solo a uma velocidade constante igual a $2 \mathrm{~cm} / \mathrm{seg}$, que é aproximadamente igual a $1 \mathrm{~m} / \mathrm{min}$. O cone tem um vértice de $60^{\circ}$ e um diâmetro típico de $35.68 \mathrm{~mm}$ (que corresponde a uma área de 10 $\mathrm{cm}^{2}$ ). O diâmetro das hastes é igual ou menor do que o diâmetro do cone. Durante o ensaio, a resistência à penetração da ponta do cone é medida constantemente. Também é medida a resistência à penetração de uma luva de atrito que é alojada logo atrás do cone.

Os penetrômetros eletrônicos possuem células de carga que registram a resistência de ponta $\left(\mathrm{q}_{\mathrm{c}}\right)$ e o atrito lateral $\left(\mathrm{f}_{\mathrm{s}}\right)$. Valores da poro-pressão $(\mathrm{U})$ atrás do cone durante a penetração são determinados através de um transdutor de pressão. Alguns piezocones possuem múltiplos transdutores de pressão, permitindo determinar também a poro-pressão na ponta $\left(\mathrm{U}_{1}\right)$, atrás da ponta $\left(\mathrm{U}_{2}\right)$ e atrás da luva de atrito $\left(\mathrm{U}_{3}\right)$.

O procedimento de ensaio CPT e CPTU é o mesmo, com exceção da preparação do piezo-elemento. Essa preparação consiste na desaeração do elemento de filtro poroso e do próprio cone. O sistema de reação utilizado para penetração 
consiste em um sistema hidráulico, normalmente com capacidade entre 100 a 200 $\mathrm{kN}$, geralmente montado sobre carretas ou carroceria de caminhões.

Em um piezocone eletrônico os sinais são normalmente transmitidos através de um cabo que passa pelo interior das hastes de cravação do cone. Os dados são digitalizados, e normalmente gravados a cada 25 ou $50 \mathrm{~mm}$ de variação da profundidade. Esses sistemas de aquisição de dados permitem a apresentação, em tempo real dos resultados obtidos durante a penetração, utilizando gráficos da variação da resistência de ponta $\left(\mathrm{q}_{\mathrm{c}}\right)$, o atrito lateral $\left(\mathrm{f}_{\mathrm{s}}\right)$ e a poro-pressão $(\mathrm{U})$ com a profundidade. Durante uma interrupção da penetração é possível monitorar a dissipação da poro-pressão com o tempo.
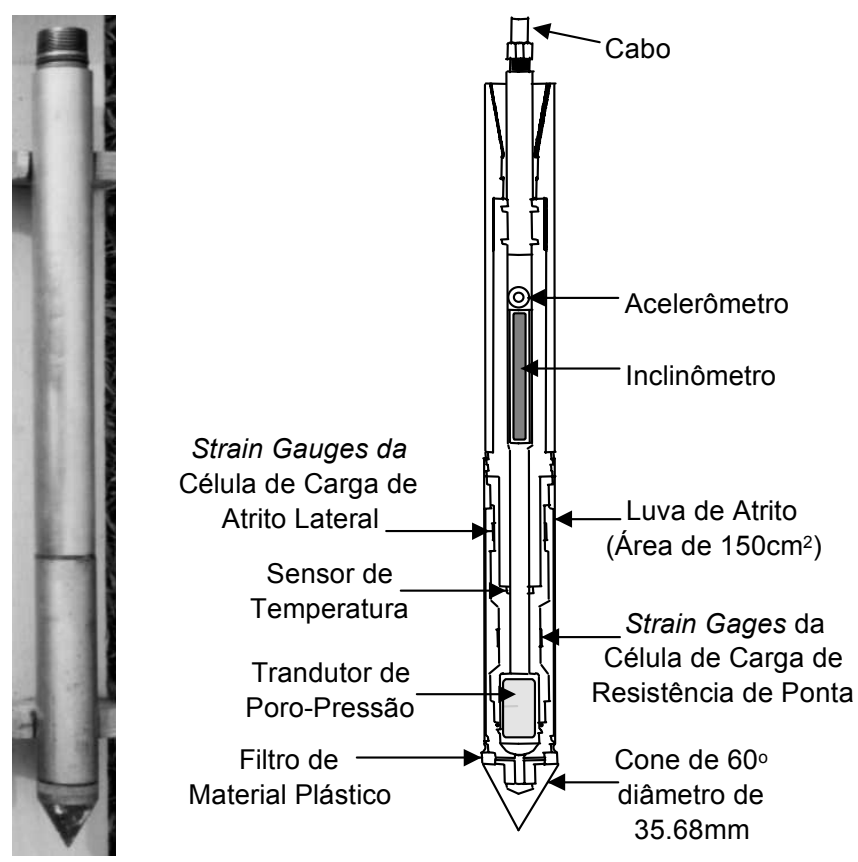

Figura 2.31. Piezocone com inclinômetro, sensor de temperatura e acelerômetro (modificado de DAVIES \& CAMPANELLA, 1995a).

\subsubsection{Identificação do Perfil Geotécnico}

Uma das principais aplicações do piezocone é para a identificação do perfil geotécnico a partir do emprego de cartas de classificação. A experiência tem demonstrado que tipicamente a resistência de ponta $\left(\mathrm{q}_{\mathrm{c}}\right)$ é alta em areias e baixa em argilas e o atrito lateral $\left(\mathrm{f}_{\mathrm{s}}\right)$ é baixo em areias e alto em argilas. 
DOUGLAS \& OLSEN (1981) foram os pioneiros a propor uma carta de classificação de solos a partir da resistência de ponta $\left(\mathrm{q}_{\mathrm{c}}\right)$ e razão de atrito $\left(\mathrm{R}_{\mathrm{f}}\right)$ determinado com cones elétricos. Uma das cartas de classificação mais utilizadas é a proposta por ROBERTSON et al. (1986), apresentada na Figura 2.32. Esta carta utiliza a resistência de ponta corrigida $\left(q_{T}\right)$ e a razão de atrito corrigida $\left(R_{f}=q_{T} / f_{S}\right.$ $\times 100$ ). A carta mostra, além da classificação dos solos, a tendência de variação da densidade relativa (Dr), do histórico de tensões (OCR), da sensibilidade (St) e do índice de vazios (e). O piezocone permite ainda que se classifique o solo utilizando a informação de poro-pressão, através do índice de poro-pressão $(\mathrm{Bq})$. Este recurso é interessante especialmente para solos moles, onde os valores de resistência de ponta são baixos e a geração de poro-pressão é elevada.
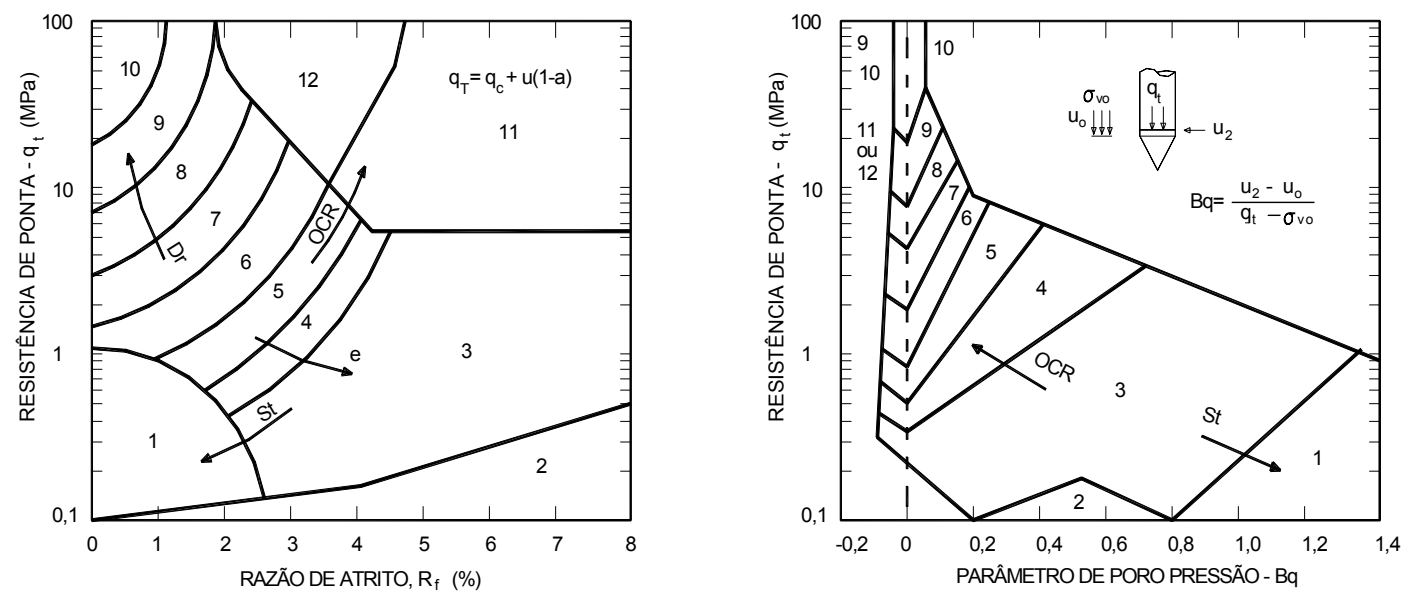

\begin{tabular}{c|c}
\hline SBT & Tipo de comportamento do solo \\
\hline 1 & Solos finos sensíveis \\
\hline 2 & Solos orgânicos \\
\hline 3 & Argila \\
\hline 4 & Argila siltosa a argila \\
\hline 5 & Silte argiloso a argila siltosa \\
\hline 6 & Silte arenoso a silte argiloso \\
\hline 7 & Areia siltosa a silte arenoso \\
\hline 8 & Areia a areia siltosa \\
\hline 9 & Areia \\
\hline 10 & Areia pedregulhosa a areia \\
\hline 11 & Solo fino muito rijo $*$ \\
\hline 12 & Areia a areia pedregulhosa $*$ \\
& Pré-adensado ou cimentado
\end{tabular}

Figura 2.32. Carta de classificação de solos utilizando CPT elétrico (ROBERTSON et al., 1986). 
A resistência de ponta e o atrito lateral aumentam com a profundidade devido à tensão de confinamento. Portanto, os dados obtidos pelo CPT necessitam de correções, especialmente para as sondagens mais profundas. Por exemplo, em uma camada espessa de argila pré-adensada, a resistência do cone aumentará com a profundidade, resultando em mudanças aparentes na classificação (ROBERTSON, 1998). Assim, uma outra carta de classificação com base em dados obtidos em sondagens CPTU foi proposta por ROBERTSON (1990) e é recomendada para sondagens com profundidade superior a $30 \mathrm{~m}$.

\subsubsection{Interpretação Direta dos Resultados do CPT}

Uma forma de interpretação de resultados de sondagens CPT é correlacionar empiricamente $q_{c}$ e $f_{s}$ medidos com o comportamento observado em fundações, prática que tem sido utilizada, especialmente no Brasil, provavelmente pela dificuldade de considerar os diversos fatores que afetam o comportamento de solos residuais não-saturados. Os métodos empíricos desenvolvidos para a previsão do comportamento de fundações, como por exemplo o de AOKI \& VELLOSO (1975) são, em geral, para valores de $q_{c}$ e $f_{s}$ obtidos utilizando-se o cone mecânico. De RUTIER (1971) recomenda que não se corrija o valor de $q_{c}$ obtido com cone elétrico no caso de aplicação de métodos originados de dados de cone mecânico, como no caso de capacidade de carga de estacas. Entretanto, quando se utiliza um cone elétrico, as pesquisas realizadas mostram que os valores de atrito lateral medidos com o cone mecânico são da ordem do dobro daqueles medidos utilizando-se o cone elétrico. De RUTIER (1971) atribui tal diferença à resistência extra desenvolvida no bordo inferior da luva de atrito do cone de Begemann, a qual é incluída no registro de atrito lateral.

\subsubsection{Estimativa de Parâmetros de Projeto}

Com base nos valores de $q_{c}, f_{s}$ e $U$ medidos, é possível estimar os parâmetros de resistência, compressibilidade e permeabilidade do solo. Esta forma de análise de resultados de sondagens CPT ou CPTU é conhecida como abordagem indireta de interpretação. Para a obtenção desses parâmetros existem inúmeras propostas na 
literatura internacional, a maioria foi desenvolvida para solos sedimentares, sendo poucos os estudos existentes para avaliar o comportamento de solos residuais.

No caso de areias, os seguintes parâmetros podem ser estimados: densidade relativa (Dr), parâmetro de estado das areias $(\psi)$, coeficiente de empuxo no repouso (Ko), ângulo de atrito interno efetivo ( $\left.\phi^{\prime}\right)$, módulos de deformabilidade (E), edométrico $\left(E_{d}\right)$ e de cisalhamento máximo $\left(G_{\max }\right)$. Já, para as argilas, os seguintes parâmetros podem ser estimados: resistência não drenada $\left(\mathrm{s}_{\mathrm{u}}\right)$, razão de préadensamento (OCR), sensibilidade $\left(S_{t}\right)$, módulos (E, $E_{d}$ e $\left.G_{\max }\right)$, coeficiente de adensamento $\left(c_{h}\right.$ e $\left.c_{v}\right)$ e permeabilidade $\left(k_{h}\right.$ e $\left.k_{v}\right)$. Embora alguns parâmetros listados acima possam ser interpretados segundo uma abordagem teórica, a maioria deles foram obtidos através de correlações com resultados de ensaios de laboratório e/ou ensaios específicos de campo (QUARESMA et al., 1996). Recomenda-se sua utilização em estimativas para posterior confirmação, quando necessário, utilizando ensaios específicos de campo ou de laboratório.

\subsubsection{Dissipação do Excesso de Poro-Pressão}

O ensaio de dissipação do excesso de poro-pressão pode ser facilmente conduzido em qualquer profundidade através de uma interrupção no processo de penetração do piezocone. Com o sistema paralisado, monitora-se a dissipação das poro-pressões em função do tempo, obtendo-se assim uma estimativa da condutividade hidráulica do solo e a influência de algum gradiente hidráulico no aqüífero ou na camada analisada (CAMPANELLA et al., 1998 apud MARQUES, 2002).

O período de dissipação do excesso das pressões é fixado para todas as camadas e em outros casos, a dissipação é mantida até alcançar uma porcentagem pré-determinada da pressão hidrostática ou da poro-pressão de equilíbrio (por exemplo, 50\%).

Quando realizado o ensaio de dissipação, a normalização do excesso de poropressão pode ser expressa através da seguinte equação:

$$
\mathrm{U}=\frac{u_{t}-u_{0}}{u_{i}-u_{0}}
$$


onde:

$\mathrm{u}_{\mathrm{t}}=$ poro-pressão medida no tempo $t$;

$\mathrm{u}_{\mathrm{i}}=$ poro-pressão medida no tempo $t=0$;

$\mathrm{u}_{0}=$ poro-pressão estática.

Assim, pode-se então obter o gráfico de U versus tempo, do qual é determinado o valor de $t_{50}$ (tempo correspondente a $U=0.5$ ), que possibilita o cálculo do coeficiente de adensamento horizontal $\left(c_{h}\right)$ através da seguinte expressão:

$$
\mathrm{c}_{\mathrm{h}}=\frac{T_{50}^{*} \cdot r^{2} \cdot \sqrt{I_{r}}}{t_{50}}
$$

onde:

$\mathrm{T}_{50} *$ = fator de tempo correspondente a $50 \%$ da dissipação teórica (valor igual a 0.245, segundo TEH \& HOULSBY, 1991);

$\mathrm{r}=$ raio do cone $=1.784 \mathrm{~cm}$;

$\mathrm{I}_{\mathrm{r}}=$ índice de rigidez do solo (na falta deste valor, adotar 100).

O valor do coeficiente de adensamento permite o cálculo dos fatores de tempo $\left(\mathrm{T}^{*}\right)$ para cada instante do ensaio (Equação 3.8), possibilitando assim a obtenção da curva U versus T*. Esta curva, obtida com os dados do ensaio, pode ser comparada com a curva teórica de dissipação dada por TEH \& HOULSBY (1991) para que se tenha uma idéia da validade do ensaio.

$$
\mathrm{T}=\frac{c_{h} \cdot t}{r^{2} \cdot \sqrt{I_{r}}}
$$

Para a obtenção do coeficiente de permeabilidade vertical $\left(\mathrm{k}_{\mathrm{v}}\right)$ do solo na profundidade em que o ensaio de dissipação foi realizado, é necessário corrigir o $\mathrm{c}_{\mathrm{h}}$ para $c_{v}$, que é possível através da seguinte expressão, considerando a compressibilidade do solo isotrópica: 


$$
\mathrm{c}_{\mathrm{v}}=c_{h} \cdot \frac{k_{v}}{k_{h}}
$$

onde $\mathrm{o}$ valor de $\mathrm{k}_{\mathrm{h}} / \mathrm{k}_{\mathrm{v}}$ pode ser estimado como $1.2 \pm 0.2$ para argilas sem acamamento, segundo BALIGH \& LEVADOUX (1980) apud ROBERTSON \& CAMPANELLA (1986).

Com o coeficiente de adensamento vertical determinado, torna-se possível estimar o coeficiente de permeabilidade vertical:

$$
\mathrm{k}_{\mathrm{v}}=c_{v} \cdot \frac{1}{M} \cdot \gamma_{w}
$$

onde M é o módulo confinado drenado do solo.

CAMPANELLA et al. (1995) citam uma correlação para o módulo confinado drenado (M) realizada por MITCHELL \& GARDNER em 1975:

$$
\mathrm{M}=1 / \mathrm{m}_{\mathrm{v}}=\alpha \cdot \mathrm{q}_{\mathrm{c}}
$$

onde:

$\mathrm{m}_{\mathrm{v}}=$ módulo de variação volumétrica do ensaio de compressão edométrica;

$\mathrm{q}_{\mathrm{c}}=$ resistência de ponta do cone;

$\alpha=$ fator empírico geralmente variando entre 1.5 a 4.0 (sendo este valor conservador, pois pode atingir o valor de $11 \mathrm{em}$ areias normalmente adensadas e de até $30 \mathrm{em}$ areias pré-adensadas).

VÉSIC (1970) propôs para o valor de $\alpha$ a seguinte expressão:

$$
\alpha=2 *\left(1+\mathrm{Dr}^{2}\right)
$$

onde Dr é a densidade relativa. 
Em CAMPANELLA et al. (1995) também podem ser encontradas propostas para a estimativa de $\mathrm{M}$ para diferentes tipos de solos a partir de resultados de sondagens com o piezocone.

\subsubsection{Variações e Acessórios Incorporados ao Piezocone}

\section{a) Inclinômetros}

A verticalidade durante a penetração do piezocone é fator importante para garantir a qualidade dos resultados, assim como, para evitar a quebra do hasteamento e a possível perda do aparelho devido a um desvio brusco. Isso pode ocorrer em perfis com solos estratificados ou quando se encontra um fragmento de rocha. Para a verificação da verticalidade, incorporou-se aos piezocones um sensor de desvio, que permite monitorar a inclinação à medida que o ensaio vai sendo realizado.

\section{b) Sensor de Temperatura}

Um dos sensores incorporados ao piezocone é o de temperatura. Inicialmente, os sensores de temperatura foram utilizados para correções na calibração ou para definir zonas com diferentes níveis de temperatura. Atualmente, esses sensores têm sido utilizados como recurso complementar na investigação geoambiental, especialmente para auxiliar a identificação de certos contaminantes químicos ou biológicos.

\section{c) Sensor de pH}

Outro sensor de grande importância na investigação geoambiental é o de $\mathrm{pH}$, que é capaz de identificar se a área de contaminação é ácida ou básica (OLIE et al., 1992 apud BURNS \& MAYNE, 1998). A utilização deste sensor tem permitido o mapeamento do $\mathrm{Ph}$ como uma função da profundidade e o monitoramento do progresso de remediação em terrenos com resíduos ácidos.

As medidas de $\mathrm{pH}$ são sensíveis às variações da temperatura e sendo assim, o sensor de $\mathrm{pH}$ é montado ao lado do sensor de temperatura, possibilitando a medida do $\mathrm{pH}$ já corrigido. 


\section{d) Outros Acessórios}

Diversos outros acessórios têm sido desenvolvidos para serem utilizados em conjunto com o piezocone. Pode-se destacar, aqui, o módulo para medida de tensões laterais e o cone pressiométrico (CPM), os quais permitem realizar um ensaio específico ao mesmo tempo e no mesmo furo de uma sondagem CPT. Têm-se, também, dispositivos para estimativa in situ da densidade ou porosidade do solo, baseados em medidas por radioisotopos. Entretanto, as maiores novidades têm surgido para aplicação ambiental e incluem medidas da constante dielétrica, do potencial de redox e fluorescência induzida por laser. LUNNE et al. (1997), BRANDL \& ROBERTSON (1996), BURNS \& MAYNE (1998) e ROBERTSON (1998) apresentam cada acessório e as variações do piezocone.

\subsubsection{Piezocone de Resistividade (RCPTU)}

O ensaio de resistividade no solo consiste em aplicar uma corrente elétrica no mesmo e medir a facilidade (ou dificuldade) com que a corrente elétrica flui dentro dele. Essa resposta depende da combinação do teor de umidade do solo, da concentração de íons solúveis e do tipo de solo. Solos úmidos possuem resistividade menor do que solos secos. Solos finos (argilas) possuem resistividades menores do que solos grossos (areias). Solos com alta salinidade possuem baixa resistividade. Dessa maneira pode-se concluir que a resistividade do solo é influenciada pela porosidade, pela permeabilidade, pela porcentagem de íons no fluido contido nos poros e também pelos argilo-minerais.

Assim, deve-se deduzir que, ao se realizar um ensaio com o piezocone de resistividade, está se fazendo a medida da resistividade do solo, acima do nível d'água, influenciada pelo teor de umidade. Espera-se, nessa situação, condutividades baixas e resistividades altas. Por outro lado, abaixo do nível d'água, os valores de condutividade/resistividade são constantes e influenciados pela salinidade da água. $\mathrm{O}$ parâmetro resistividade varia entre largos limites, mesmo para um único tipo de rocha, como apresentado na Tabela 2.4, de ELIS (1993). 
Tabela 2.4. Valores de resistividade elétrica de materiais conhecidos (ELIS, 1993).

\begin{tabular}{|c|c|}
\hline Material & Resistividade (ohm.m ) \\
\hline Ar & $\infty$ \\
\hline Águas doces superficiais & $10-10^{3}$ \\
\hline Água marinha & 0.2 \\
\hline Argilas & $10-10^{2}$ \\
\hline Areias & $10^{2}-10^{4}$ \\
\hline Areia saturada com água mineral & $10^{-1}-10$ \\
\hline Aluvião & $10-10^{3}$ \\
\hline Conglomerados & $10-10^{4}$ \\
\hline Arenitos & $10-10^{8}$ \\
\hline Margas arenosas & $10-10^{2}$ \\
\hline Calcários & $10^{2}-10^{4}$ \\
\hline Basaltos & $10^{2}-10^{5}$ \\
\hline Granitos & $10^{2}-10^{5}$ \\
\hline Xixtos & $10-10^{3}$ \\
\hline Gnaisses & $10^{2}-10^{4}$ \\
\hline & \\
\hline
\end{tabular}

A determinação da resistividade nas rochas pode ser realizada em laboratório, através de testemunhos das rochas. Quando a resistividade é determinada no campo, deve-se considerar que as diferentes camadas de rochas possuem resistividades diferentes e sendo assim, mede-se uma resistividade aparente. O mesmo ocorre quando se está analisando o solo, que não é um meio homogêneo.

Além do uso de inclinômetros e sensores de temperatura, o piezocone de resistividade (Foto 2.6) é um outro desenvolvimento da tecnologia do piezocone, relativamente recente (CAMPANELLA \& WEEMEES, 1990). Este recurso permite medir continuamente a resistência a um fluxo de corrente elétrica aplicada ao solo.

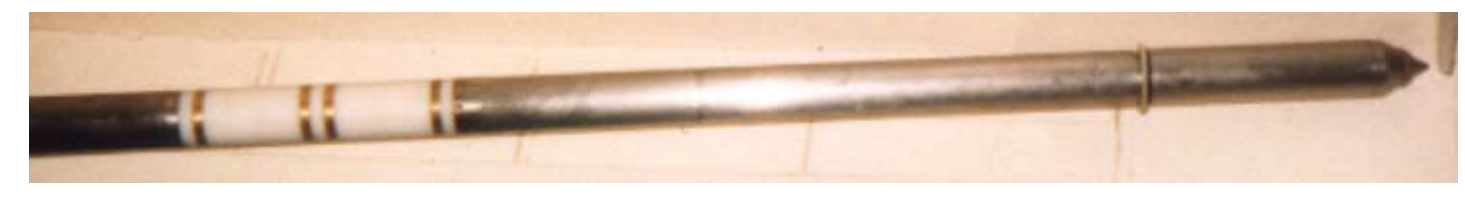

Foto 2.6. Dispositivo para medida da resistividade elétrica acoplado ao piezocone (GIACHETI, 2001).

Assim, é possível detectar a presença de certas substâncias ou se suas 
concentrações presentes no lençol freático estão acima de um determinado valor de referência. Esses valores de referência são estabelecidos a partir da experiência de campo ou a partir de ambientes geológicos similares. Em áreas em que valores de referência são excedidos, pode-se então efetuar uma avaliação complementar através da coleta, em profundidades discretas, de amostras da água subterrânea, para uma posterior análise química. A combinação de ensaios RCPTU com uma amostragem discreta de águas subterrâneas proporciona um meio rápido e econômico de realizar caracterizações geoambientais de campo.

Os resultados de ensaios RCPTU mostram grandes intervalos para os valores da resistividade (condutividade), variando de 0.01 ohm.m $\left(10^{6} \mu \mathrm{s} / \mathrm{cm}\right)$ até 100 ohm.m $(10 \mu \mathrm{s} / \mathrm{cm})$. A resistividade é bastante sensível, tanto a sais dissolvidos, como a contaminantes orgânicos de baixa solubilidade. Em países que costumam utilizar esses ensaios, o custo é praticamente o mesmo de ensaios com o piezocone padrão (CPTU), acrescido de mais ou menos 10 a 20\% para considerar a depreciação do aparelho e, também, para levar em conta a necessidade de tratamento adicional de dados (DAVIES \& CAMPANELLA, 1995a).

\section{a) Fundamentos do Ensaio RCPTU}

Segundo CAMPANELLA \& WEEMEES (1990), a resistividade elétrica dos solos é determinada, primeiramente, medindo-se a resistência elétrica. Isso é feito a partir da medida da voltagem, através de um par de eletrodos alimentados com uma freqüência de corrente conhecida. Essa resistência é calculada a partir da Lei de Ohm.

$$
R=\frac{V}{i}
$$

onde:

$\mathrm{R}=$ Resistência;

$\mathrm{i}=$ Corrente elétrica;

$\mathrm{V}=$ Voltagem.

Entretanto, a resistência medida não é uma propriedade intrínseca do 
material, mas uma função da área da seção transversal e do comprimento do material que conduz corrente. Assim, a resistividade $(\rho)$ pode ser definida como:

$$
\rho=\frac{a}{l} \cdot R=\frac{1}{C}
$$

onde:

$\rho=$ Resistividade (ohm.m);

$\mathrm{a}=$ Área de seção transversal $\left(\mathrm{m}^{2}\right)$;

$1=$ Comprimento $(\mathrm{m})$;

$\mathrm{R}=$ Resistência (ohm);

$\mathrm{C}=$ Condutividade.

Para o caso de um par de eletrodos num meio condutor homogêneo e isotrópico existe uma relação linear entre resistência e resistividade:

$$
\rho=k_{r} \cdot R
$$

onde $\mathrm{k}_{\mathrm{r}}$ é a constante do aparelho, função da geometria do par de eletrodos.

A medida da resistividade é uma função da resistividade tanto do fluido presente nos poros como das partículas sólidas. O mecanismo de condução de corrente elétrica dominante é a transferência de carga através da condução eletrolítica, isto é, movimento físico de íons em resposta à aplicação de um campo elétrico. Em geral, quanto mais íons presentes no fluido dos poros, menor será a resistividade e maior será a condutividade (CAMPANELLA \& WEEMEES, 1990).

Outro fator a considerar é a viscosidade desse fluido, que afeta a condutividade de um íon específico em um eletrólito. Por sua vez, o fator mais importante que afeta a viscosidade e, por conseguinte, a condutividade, é a temperatura do referido fluido.

Solos contaminados são normalmente um sistema multifásico composto de partículas sólidas do solo, APL (Aqueous Phase Liquids), NAPL (Non-Aqueous phase liquid) e ar. A medida do módulo de resistividade do solo é o resultado da condução (ou falta de condução), através dos componentes mencionados acima e da 
interação de um com outro. A dificuldade é identificar qual componente provoca mudanças na resistividade.

De acordo com URISH (1981) apud DANIEL (1997), a resistividade do solo $\left(\rho_{\mathrm{b}}\right)$, englobando o conjundo sólidos, ar e fluido, pode ser influenciada pelos seguintes aspectos:

- Grau de saturação (Sr);

- Composição iônica do líquido ( $\rho_{\mathrm{f}}$ - resistividade do fluido);

- Porosidade (n);

- Temperatura;

- Forma dos poros;

- Capacidade de troca catiônica (CTC).

A fórmula de ARCHIE (1942) é uma das leis mais simples que relaciona diferentes componentes do solo para determinação da resistividade elétrica. Ela leva em consideração os três primeiros fatores citdos acima, sendo dada por:

$$
F_{C}=\frac{\rho_{b}}{\rho_{f}}=a \cdot n^{-m} \cdot S r^{-s}
$$

onde:

$\mathrm{Fc}=$ Fator de formação intrínseco, que depende da geometria dos poros;

$a$ = Fator de escala da equação, que depende da mineralogia do solo. Para solos normalmente adensados, adota-se $\mathrm{a} \cong 1$;

$\mathrm{m}=$ Constante que depende do tipo do solo. Para areias, $\mathrm{m} \cong 1.5$ e para uma série de argilas, $\mathrm{m}=1.8$ a 3.0 (JACKSON et al., 1978 apud WEEMES, 1990);

$\mathrm{s}=$ Expoente que também depende da mineralogia do solo, que ARCHIE estimou como sendo igual a 2.0 e DUNLAP et al. (1949) sugeriu valores de 1.0 a 2.5 (DANIEL, 1997).

\section{b) Descrição do Dispositivo para Medida da Resistividade}

Durante a sondagem RCPTU, os eletrodos não respondem exclusivamente a uma única camada, a menos que essa camada esteja completamente dentro do espaçamento entre eles. Para um espaçamento entre eletrodos ser sensível a uma 
camada, esse deve ser menor que a espessura da camada. Um pequeno espaçamento de eletrodos possibilita detectar camadas finas com contraste de resistividade. Um maior espaçamento permite medir a resistividade média para uma maior penetração do campo elétrico dentro do solo, não perturbado. Isso resulta em uma medida mais precisa da determinação da resistividade do solo em um meio homogêneo (WEEMEES, 1990).

O dispositivo apresentado na Figura 2.33 e na Foto 2.6 é composto por um arranjo de quatro eletrodos, do tipo Schlumberger, onde a corrente é fornecida pelos dois eletrodos mais externos e a diferença de potencial é lida pelos dois eletrodos internos. Como descrito no item 2.2.1.4, a principal característica deste arranjo é que a distância entre os dois eletrodos internos (MN) deve ser bastante pequena em relação à distância dos dois eletrodos externos $(\mathrm{AB})$, procurando satisfazer a relação $\mathrm{MN} \leq \mathrm{AB} / 5$.

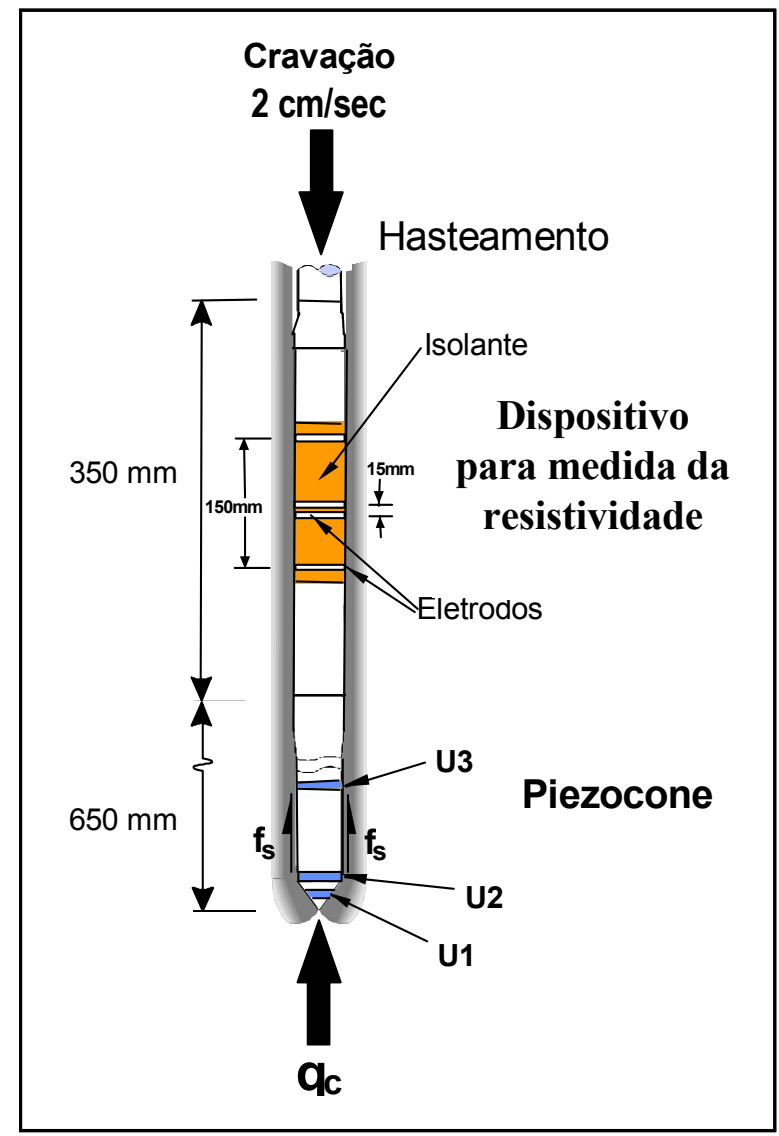

Figura 2.33. Desenho esquemático de um RCPTU (DAVIES \& CAMPANELLA, 1995a). 
Existem também os dispositivos compostos pelo arranjo Werner, onde a única diferença em relação ao arranjo Schlumberger é a distância entre os quatro eletrodos, que é igual entre todos eles (distância “a”). A Figura 2.34 apresenta um desenho esquemático deste tipo de arranjo e a Foto 2.7 mostra um piezcone de resistividade com este tipo de arranjo.

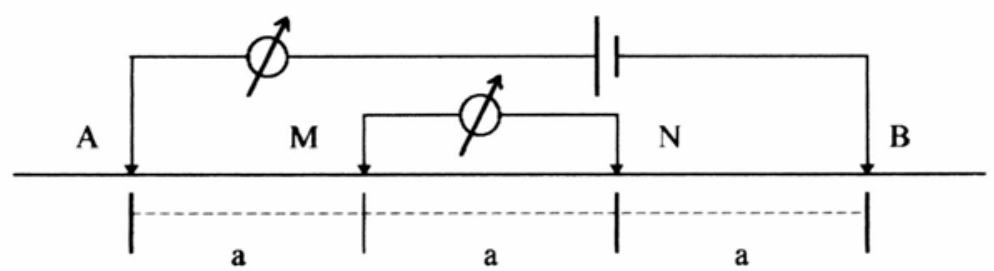

Figura 2.34. Arranjo Werner (ELIS, 1993).

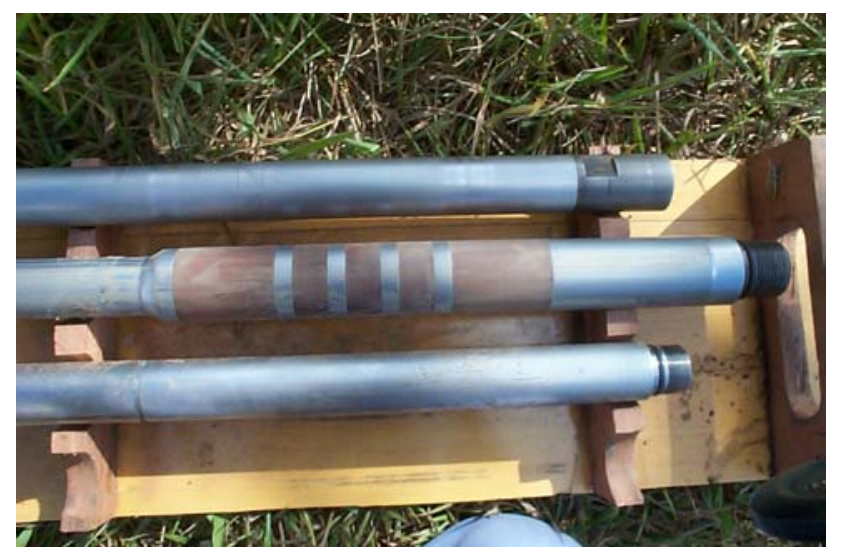

Foto 2.7. Piezocone de resistividade com quatro eletrodos dispostos em arranjo

Werner.

\section{c) Calibração do RCPTU}

Segundo WEEMEES (1990), o RCPTU mede a resistência elétrica entre eletrodos, a qual está relacionada com a resistividade do meio penetrado e a geometria dos mesmos. A resistência medida aumentaria se os eletrodos fossem posicionados mais distantes ou se a área de sua superfície diminuísse. A resistividade é um parâmetro do solo fundamental e, conseqüentemente, seu valor não depende da geometria dos eletrodos. 
Para transformar resistência para resistividade, uma calibração de laboratório deve ser feita para ambos os pares de eletrodos de entrada e saída. Para minimizar os efeitos de borda, o RCPTU é colocado em um reservatório com água que envolva totalmente o módulo. Esse reservatório é preenchido com água. Adiciona-se, então cloreto de potássio $(\mathrm{KCl})$, pouco a pouco, e mede-se a condutividade para diferentes concentrações. Essa condutividade é medida com um condutímetro portátil e os valores são comparados com a condutividade (resistividade) medida pelo RCPTU.

\section{d) Procedimento de Ensaio}

Os preparativos envolvidos no ensaio RCPTU são similares àqueles de qualquer outro ensaio CPT (ROBERTSON \& CAMPANELLA, 1988). O único procedimento adicional é a conexão de um gerador de sinal no sistema de aquisição de dados para controlar o nível de corrente e a freqüência para as medidas de resistência elétrica. Os dados são obtidos usando um sistema de aquisição de dados capaz de registrar, simultaneamente, a resistência de ponta, o atrito lateral, a poropressão, a temperatura, a inclinação e a resistividade elétrica, normalmente a intervalos de profundidade que variam de 10 a $50 \mathrm{~mm}$.

\section{d) Resultados Típicos}

A Tabela 2.5, elaborada por DAVIES \& CAMPANELLA (1995a), apresenta valores típicos de resistividade medidos com o RCPTU e os correspondentes valores da resistividade do fluido presente nos poros. 
Tabela 2.5. Resumo com valores típicos de resistividade (condutividade) com misturas de solo e fluidos (DAVIES \& CAMPANELLA, 1995a).

\begin{tabular}{|c|c|c|c|c|}
\hline Tipo de material & $\begin{array}{l}\text { Resistividade } \\
\text { do solo } \\
\rho_{b}, \text { ohm-m }\end{array}$ & $\begin{array}{l}\text { Resistividade } \\
\text { do fluido } \\
\text { } \text { pf }_{\text {f }} \text { ohm-m }\end{array}$ & $\begin{array}{c}\text { Condutividade } \\
\text { do solo } \\
\mu \mathrm{S} / \mathrm{cm}\end{array}$ & $\begin{array}{c}\text { Condutividade } \\
\text { do fluido } \\
\mu \mathrm{S} / \mathrm{cm}\end{array}$ \\
\hline Água do mar & --- & 0.2 & --- & 50000 \\
\hline Água potável & --- & $>15$ & --- & $<665$ \\
\hline $\begin{array}{l}\text { C. E. Fazenda McDonald - Argila } \\
\text { (Richmond) }\end{array}$ & 1.5 & 0.3 & 6700 & 33300 \\
\hline $\begin{array}{l}\text { C. E. Laing Bridge - Argila } \\
\text { (Richmond) }\end{array}$ & 20 & 7 & 500 & 1430 \\
\hline C. E. Colebrook - Argila (Langley) & 25 & 18.2 & 400 & 550 \\
\hline C. E.TC@ 232 - Argila (Langley) & 8 & --- & 1250 & --- \\
\hline C. E. Strong Pit - Argila (Abbotsford) & 35 & --- & 285 & --- \\
\hline C. E. Kidd 2 - Argila (Richmond) & 14 & 12.5 & 715 & 800 \\
\hline $\begin{array}{l}\text { C. E. Fazenda Mc Donald - Areia } \\
\text { (Richmond) }\end{array}$ & $5-20$ & $1.5-6$ & $2000-500$ & $6700-1670$ \\
\hline $\begin{array}{l}\text { C. E. Laing Bridge - Areia } \\
\text { (Richmond) }\end{array}$ & $5-40$ & $1.5-10$ & $2000-250$ & $6700-1000$ \\
\hline C. E. Colebrook - Areia (Langley) & 70 & & 143 & \\
\hline C. E. Strong Pit site - Areia & 115 & & 89 & \\
\hline C. E. Kidd 2 (Richmond) - Areia & $1.5-40$ & $0.5-21$ & $6700-225$ & $20000-475$ \\
\hline Chorume típico de aterro sanitário & $1-30$ & $.5-10$ & $10000-330$ & $20000-1000$ \\
\hline $\begin{array}{c}\text { Área de barragem de rejeito (metais) } \\
\text { Com chorume de sulfeto oxidado }\end{array}$ & $0.01-20$ & $005-15$ & $1000000-500$ & $2000000-670$ \\
\hline $\begin{array}{c}\text { Área de barragem de rejeito (metal) } \\
\text { Sem chorume de sulfeto oxidado }\end{array}$ & $20-100$ & $15-50$ & $145-100$ & $665-200$ \\
\hline $\begin{array}{l}\text { Areia e pedregulho contaminados com } \\
\text { arsênico }\end{array}$ & $1-10$ & $.5-4$ & $10000-1000$ & $20000-2500$ \\
\hline $\begin{array}{l}\text { Área industrial - Contaminantes } \\
\text { inorgânicos em areias }\end{array}$ & $0.5-1.5$ & $0.3-0.5$ & $20000-6500$ & $33000-20000$ \\
\hline $\begin{array}{c}\text { Área industrial - Areias e siltes } \\
\text { contaminados por creosoto }\end{array}$ & $200-1000$ & $75-450$ & $50-10$ & $135-22$ \\
\hline $\begin{array}{c}\text { Área industrial - Contaminantes } \\
\text { orgânicos em areia }\end{array}$ & 125 & --- & 80 & --- \\
\hline $\begin{array}{c}\text { Área do BC Place - Parte 2- } \\
\text { Vancouver (gasômetro) }\end{array}$ & $200-300$ & --- & $50-33$ & --- \\
\hline $\begin{array}{c}\text { Área do BC Place- Parte } 2 \text { (resíduos de } \\
\text { madeira) }\end{array}$ & $300-600$ & --- & $33-66$ & --- \\
\hline
\end{tabular}

C.E. = Campo experimental 
Como a condutividade (C) é o inverso da resistividade (R), é fácil converter uma na outra de acordo com a seguinte expressão:

$$
\mathrm{C}(\mu \mathrm{s} / \mathrm{cm})=10.000 / \mathrm{R}(\mathrm{ohm} . \mathrm{m})
$$

Os resultados da Tabela 2.5 mostram que a faixa de variação da resistividade (condutividade) é muito grande, cerca de $0.01 \mathrm{ohm} . \mathrm{m}(1000000 \mu \mathrm{s} / \mathrm{cm})$ para cerca de $100 \mathrm{ohm} . \mathrm{m}(10 \mu \mathrm{s} / \mathrm{cm})$, sendo bastante sensível, tanto a sais dissolvidos como a contaminantes orgânicos de baixa solubilidade.

\subsubsection{Piezocone na Investigação Geotécnica de Solos Tropicais}

No Brasil, o ensaio de penetração estático com o cone mecânico (cone de atrito ou cone de Begemman) tem sido utilizado há muito tempo nos mais diferentes tipos de solos e desempenharam um importante papel para a elaboração de métodos empíricos para a estimativa da capacidade de carga de estacas a partir de correlações com provas de carga, como aquele proposto por AOKI \& VELLOSO (1975), largamente empregado na prática de projeto de fundações.

O piezocone foi introduzido no Brasil para investigação off-shore para a obtenção de informações necessárias a prospeção de petróleo. A sua aplicação em projetos geotécnicos tem sido basicamente para obtenção de parâmetros mecânicos de solos moles, especialmente do Rio de Janeiro.

Atualmente, são reconhecidas mundialmente as vantagens de utilização do piezocone como ferramenta para identificação detalhada do perfil geotécnico. A utilização do CPTU para esse fim no Brasil foi apresentada por DANZIGER et al. (1998), onde foram discutidos resultados de ensaios com o piezocone realizados na Rodovia Presidente Dutra, comparando-os com aqueles obtidos em sondagens de simples reconhecimento (SPT).

Estes autores concluíram que o piezocone permite um melhor detalhamento do perfil geotécnico, conforme defende CAMPANELLA et al. (1985), e é um recurso poderoso para complementar as informações obtidas nas sondagens SPT. Entretanto, estudos realizados por GIACHETI (2001) em solos tropicais do interior 
de São Paulo mostram limitações dos métodos utilizados para classificação de solos a partir dos ensaios CPT. É importante lembrar que os ábacos de classificação do tipo do solo a partir do CPT ou CPTU, como aquele sugerido por ROBERTSON et al. (1986), foram desenvolvidos para os solos de países de clima temperado da América do Norte e da Europa.

MARQUES (2002) mostra que a identificação do perfil geotécnico a partir de resultados de ensaios com o piezocone baseados neste ábaco apresentou limitações quando empregado para classificar texturalmente os solos existentes nas áreas das cidades de Bauru, Campinas e São Carlos, evidenciando a necessidade de uma adaptação no ábaco para que este possa contemplar solos tropicais. Como isso exige uma maior quantidade de dados, GIACHETI (2001) propõe a utilização de amostradores solo especiais que se adaptam aos equipamentos do CPT, de modo a coletar amostras nas profundidades em que os resultados apresentaram mudanças de comportamento do solo.

GIACHETI (2001) acrescenta que a maior dificuldade para interpretação pelo método indireto de ensaios com o piezocone está associada à hipótese inicial de interpretação desses ensaios, a qual estabelece penetração drenada para areias e nãodrenado para argilas. Para solos tropicais, essa subdivisão imposta nem sempre é possível, pois tais solos apresentam comportamento coesivo-friccional fortemente influenciado por suas características genéticas e pela sucção matricial. Esse fato deve ser o principal motivo para que a interpretação de ensaios CPT seja realizada por métodos diretos.

SCHNAID et al. (1998) sugerem que ensaios com o cone sísmico (SCPT) podem ser utilizados para avaliação do tipo de solo a partir da relação entre $G_{\max } / q_{c}$. Esta recomendação está de acordo com as conclusões de GIACHETI \& CARVALHO (1994), que mostraram as diferenças de comportamento de horizontes lateríticos e não lateríticos a partir das limitações das formulações desenvolvidas para solos sedimentares para a estimativa de $G_{\max }$ a partir de valores de $N_{S P T}$ e $q_{c}$.

\subsubsection{Tecnologia do Piezocone na Investigação Geoambiental}

Devido à preocupação com a questão ambiental, as áreas de disposição de resíduos têm merecido especial atenção por parte dos órgãos públicos e instituições 
de pesquisa relacionadas ao meio ambiente, no sentido de avaliar o nível de poluição causado por estes resíduos e procurar estabelecer procedimentos para minimizar seus impactos nocivos. Dentro desse contexto, a geofísica tem se mostrado uma das principais ferramentas para a caracterização geoambiental do subsolo. Entretanto, para atender todas as necessidades de um bom programa de investigação e caracterização é necessário que este programa seja complementado com a utilização de algumas técnicas invasivas que permitam a amostragem de água, gás e solo.

Os valores correspondentes à resposta da penetração do piezocone no terreno $\left(\mathrm{q}_{\mathrm{c}}, \mathrm{f}_{\mathrm{s}}\right.$ e $\left.\mathrm{U}\right)$ podem auxiliar na identificação dos poluentes presentes no solo. Entretanto, o emprego de sensores especiais anexados ao piezocone é um recurso mais interessante para esse fim. E um dos dispositivos que pode ser utilizado é o de resistividade (RCPTU), o qual permite detectar a presença de contaminantes orgânicos ou inorgânicos, livres ou dissolvidos na água subterrânea (CAMPANELLA et al., 1994). Esta técnica complementa os resultados de uma sondagem geofísica de superfície.

Amostras de águas subterrâneas podem ser obtidas com a utilização de amostradores especiais introduzidos no mesmo furo aberto pelo processo de cravação do piezocone. Além disso, é possível monitorar o processo de amostragem e estimar a condutividade hidráulica dos solos. As principais vantagens dessa técnica, conhecida como direct-push, são: não escavar material contaminado; reduzir o contado do operador com esse material; e permitir a obtenção de amostras representativas não perturbadas pelo processo de amostragem. Já a principal desvantagem desta técnica é que ela é restrita a solos moles, onde a penetração é possível.

GIACHETI (2001) lembra que em países tropicais, existe um vasto campo para pesquisa visando a adequação desta tecnologia para investigação e caracterização geoambiental. Acretida-se que, com o passar do tempo, o maior rigor e preocupação com as questões ambientais levará à aplicação desta tecnologia, também em países em desenvolvimento. 


\subsubsection{Amostradores}

Para uma análise geoquímica e especialmente para uma avaliação do tipo e da quantidade de contaminantes presentes, faz-se necessária a amostragem de solo, água e/ou gás. Quando possível, o recurso mais interessante é amostrar água, pois é nela que se concentra a maioria dos contaminantes. Além disso, a sua amostragem é mais fácil. Diversos são os dispositivos existentes atualmente para amostragem de solo, água e/ou gás e para monitoramento das águas subterrâneas. A seguir, serão descritos os mais utilizados deles.

\subsubsection{Amostradores de Solo}

Na Foto 2.8 é apresentado um amostrador de solo que é utilizado como acessório importante na tecnologia do piezocone. As amostras de solo são coletadas utilizando tubos plásticos de parede fina (Foto 2.9). A vantagem do emprego dessa técnica é a produção de poucos resíduos e a redução da exposição dos operários ao contaminante.

O amostrador, da marca Geoprobe ${ }^{\circledR}$, consiste de um tudo de PVC rígido e transparente, com uma ponteira cônica maciça e outra de PVC flexível, ambas instaladas na extremidade inferior.

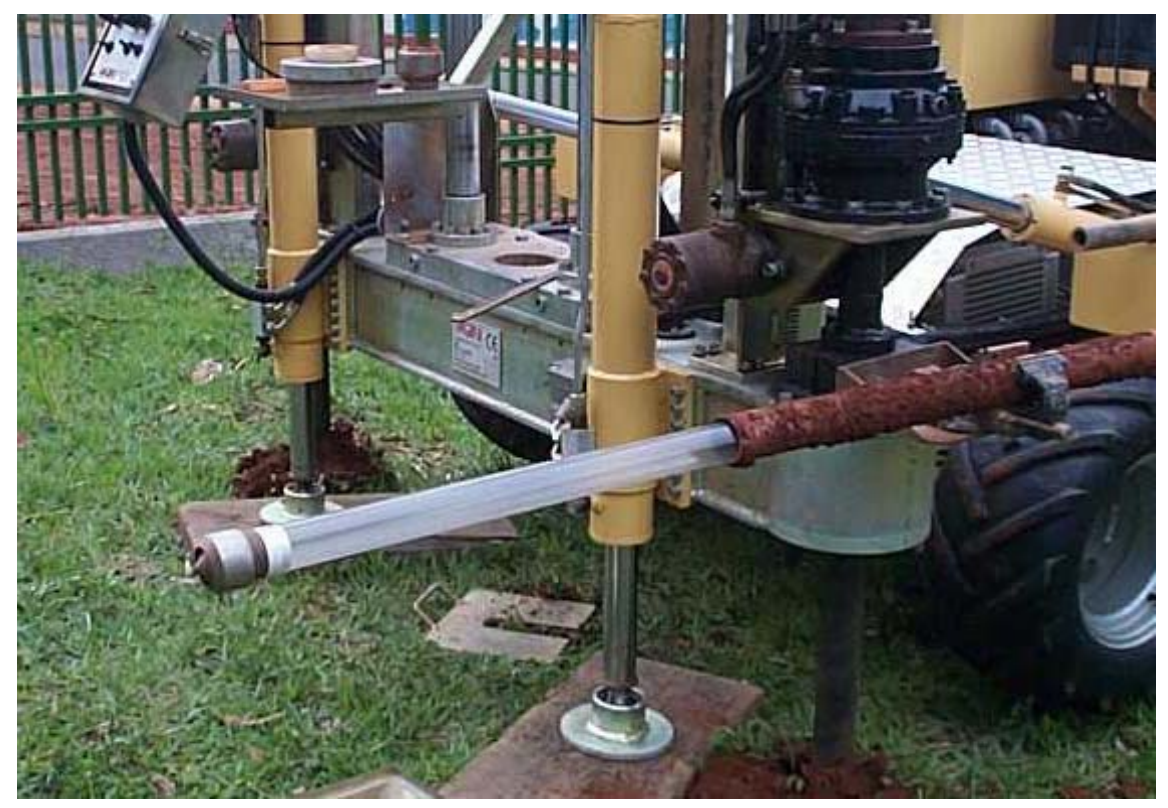

Foto2.8. Amostrador de solo utilizando o sistema direct-pusch de coleta de amostras. 


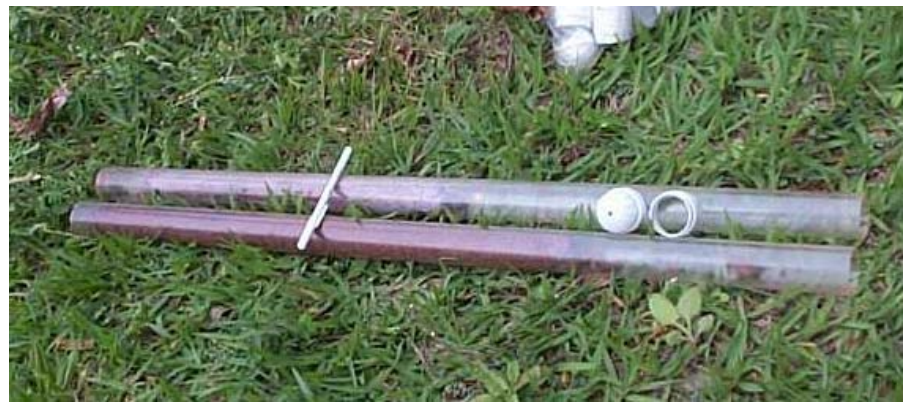

Foto 2.9. Amostra coletada.

Primeiramente, o amostrador é cravado, com o mesmo equipamento utilizado para o ensaio CPTU, até a cota de amostragem, quando a ponteira cônica é destravada. Logo após, o conjunto haste-amostrador é empurrado até a cota final de amostragem. Nessa operação, a ponteira cônica é empurrada pelo solo para dentro do amostrador e a de PVC, que é oca e assim permite a entrada do solo, permanece na extremidade. Terminado este procediemento, o amostrador é puxado para a superfície, sendo que nesta etapa a ponteira de PVC flexível é fechada pelo peso próprio do solo, impedindo que o mesmo caia dentro do furo (Figura 2.35).

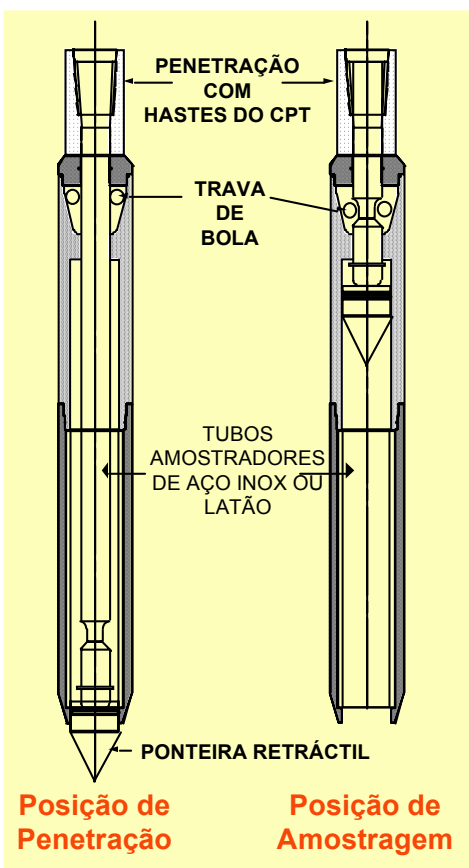

Figura 2.35. Desenho esquemático de um amostrador de solo com tubo de plástico para uso na investigação geoambiental (GIACHETI, 2001). 


\subsubsection{Amostradores de Água e/ou Gás}

\section{a) Sistema BAT}

O sistema de monitoramento de água subterrânea, denominado BAT, inicialmente desenvolvido na Suécia por Bengt-Arne Tortensson, razão de seu nome, é um dispositivo composto de um único piezômetro, facilmente instalado no subsolo.

O penetrômetro BAT possibilita a realização da amostragem discreta de água subterrânea no próprio local, assim como é possível, também, a medida da poropressão. Utilizando-se esse sistema, pode-se medir a condutividade hidráulica de solos saturados (Figura 2.36).

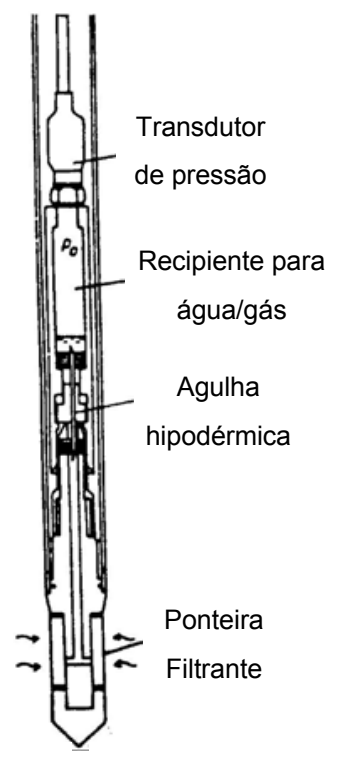

Figura 2.36. Condutividade hidráulica utilizando o sistema BAT (TORSTENSSON, 1984).

O kit para amostragem permite a obtenção tanto de gás como de fluido presentes nos poros. Utiliza-se para tanto um tubo de ensaio esterilizado, selado e com vácuo no seu interior. O emprego desse kit permite que se obtenha uma amostra, conectando-se esse tubo de ensaio à ponteira filtro, Figura 2.37 (a). $\mathrm{O}$ gradiente de pressão criado entre o tubo de ensaio e o fluido/gás que preenche os poros em torno da ponteira é o responsável pela amostragem. Esse tubo de ensaio é colocado dentro 
do furo, utilizando-se um conjunto de pesos, cabos, além do dispositivo com a agulha de duas pontas, conforme ilustrado na Figura 2.37 (b). Ao término da amostragem, iça-se o tubo, o qual se fecha automaticamente quando é desconectado da agulha, devido à existência de um septo. A amostra no interior do tubo, Figura 2.37 (c) poderá ser ensaiada no próprio local onde, em geral, mede-se a condutividade, o $\mathrm{pH}$ e a temperatura. Em seguida, a amostra é enviada para o laboratório onde serão realizados outros ensaios químicos específicos.
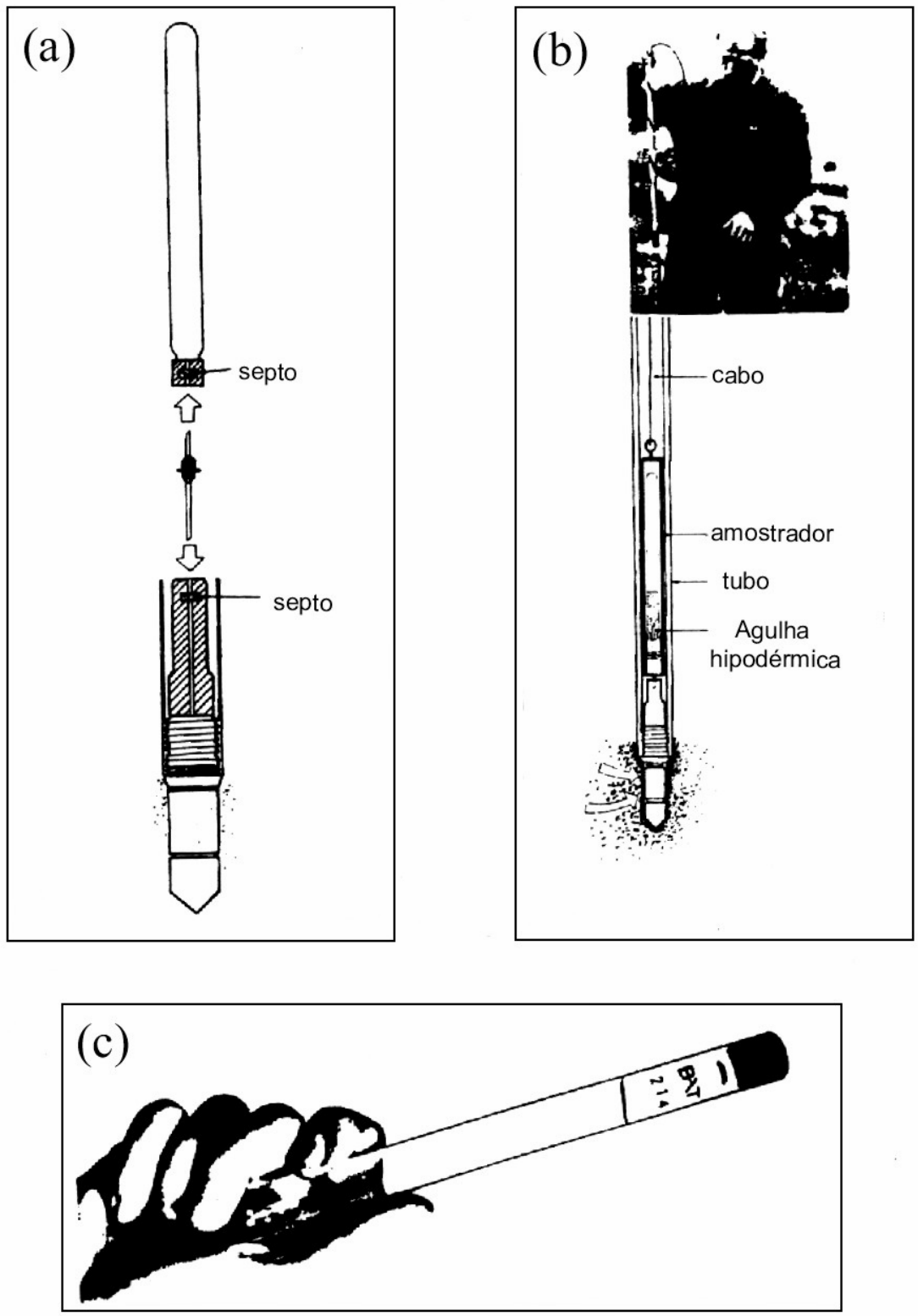

Figura 2.37. Sistema BAT para amostragem de água (TORSTENSSON, 1984;

TORSTENSSON \& PETSONK, 1988). 


\section{b) Sistema UBC K BAT}

Devido à pequena quantidade de líquido que passará pela agulha quando se utiliza o sistema BAT convencional, o ISTG UBC adaptou um sistema duplo engaterápido em latão (Figura 2.38), para substituir o sistema tradicional de agulha/septo. Esse engate rápido é uma válvula auto-vedante especial, fabricada para trabalhar de modo que, quando a parte superior entra em contato com a inferior, essa última abre primeiro e assim o vácuo aplicado no tubo de ensaio não se perde antes do início do ensaio de permeabilidade. Esse novo dispositivo permite uma rápida entrada de água quando se faz ensaios em areias.

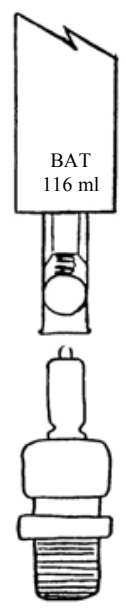

Figura 2.38. Duplo engate rápido utilizado no UBC K-BAT (GIACHETI, 2001).

Na Figura 2.39, tem-se o desenho esquemático do penetrômetro UBC K BAT. Uma das alterações foi a posição do elemento filtrante para $125 \mathrm{~mm}$ atrás da ponta do amostrador. A principal vantagem dessa mudança é poder utilizar o sistema em materiais mais densos. Outra modificação foi aumentar o diâmetro do amostrador para $50 \mathrm{~mm}$. Isso permite que o novo penetrômetro seja cravado num pré-furo do piezocone, que tem $44 \mathrm{~mm}$ de diâmetro, reduzindo o nível de perturbação provocado no solo e aumentando o contado entre a parede do elemento filtrante e o material ensaiado. Na Foto 2.10, tem-se o penetrômetro UBC K BAT ao lado da ponteira filtro do sistema BAT convencional. 


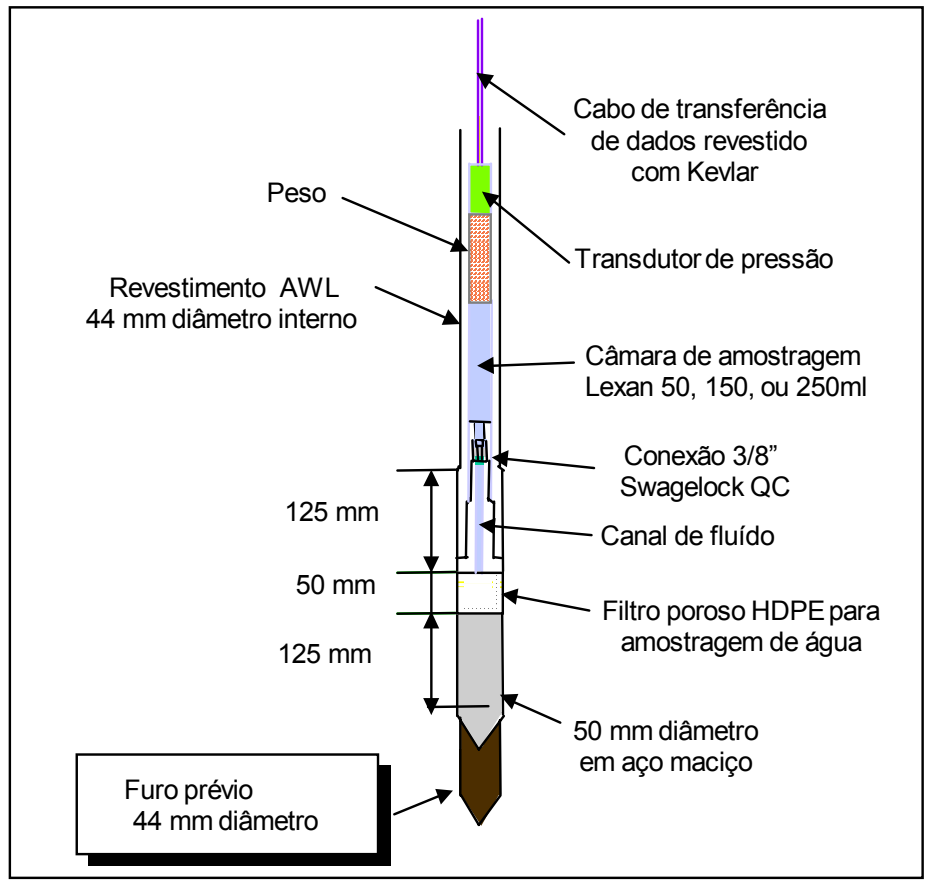

Figura 2.39. Desenho esquemático do sistema UBC K BAT (WILSON \& CAMPANELLA, 1997).

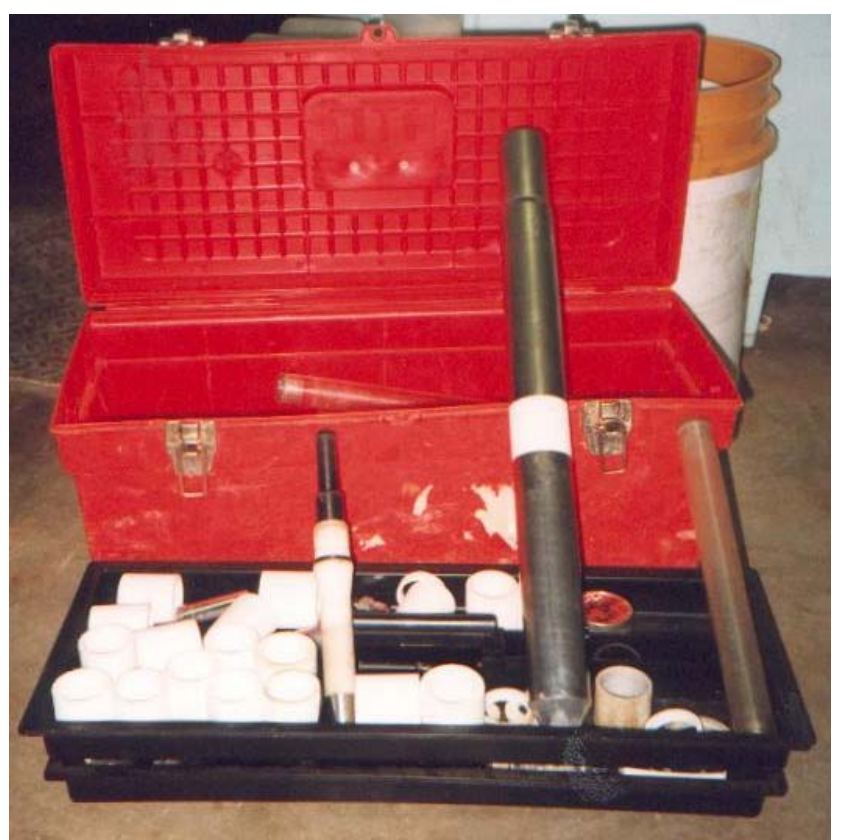

Foto 2.10. Penetrômetro UBC K BAT ao lado de uma ponteira do sistema BAT (GIACHETI, 2001). 


\section{c) Hydropunch $\mathbb{R}$}

O Hydropunch $\circledast$ é um amostrador de água subterrânea que, como os outros amostradores, pode ser cravado no terreno até a profundidade desejada para ser realizada a amostragem. Então é cravada apenas a haste do amostrador, o que permite que a água o peencha hidrostaticamente. $\mathrm{O}$ amostrador é de aço inoxidável, o que permite que sejam realizadas várias amostragens em um mesmo furo. Para que a água seja levada à superfície, um "balde" de cerca de 3/4" a 1/2" é abaixado através da cavidade da haste do cone até alcançar a amostra (Figura 2.40). Estas medidas são utilizadas para amostras que contêm hidrocarbonos, enquanto que para água nãovoláteis e de maior volume requerido, um tubo de $1 / 4$ " é descido até a amostra e então realiza-se a retirada da amostra com a ajuda de um bombeamento peristáltico ou a gás (http://www.conetec.com/Pdf/cpt ground.pdf em 07/2002).

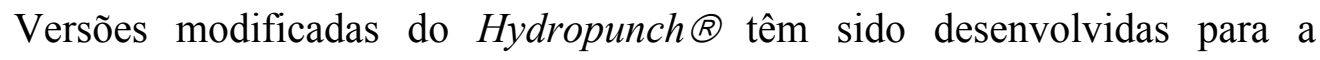
instalação de poços de monitoramento em longo prazo. Estas incluiem técnicas inovadoras para lacrar e rebocar o amostrador dentro solo, depois que este é empurrado para a profundidade desejada (BRANDL \& ROBERTSON, 1996).

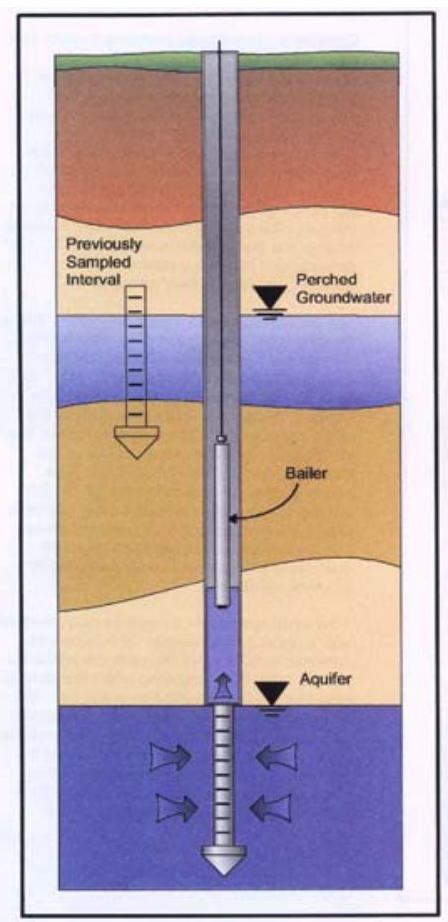

Figura 2.40. Sistema de amostragem de água Hydropunch $®$ (http://www.conetec.com/Pdf/cpt ground.pdf em 07/2002). 


\section{d) Sistema Geoprobe ${ }^{\circledR}$-Amostragem de Água}

O sistema Point 15 tem sido designado tanto para investigação de subsolo quanto à coleta de amostras de águas subterrâneas. A amostra de água pode ser coletada no mesmo instante, ou após dias ou semanas. A instalação do sistema necessita de hastes que permitam a cravação e o armazenamento da amostra por um longo tempo de uso. Este sistema permite que se possa retirar várias amostras ao longo do tempo não necessitando a realização de novas perfurações.

O sistema Point 15 utiliza, como material na haste, aço inoxidável ou tubo de 80" de PVC (38mm), envolvendo o sistema, e utiliza como ponteira uma combinação de metais para resistir a uma maior profundidade de cravação. O sistema é envolvido com Neoprene para prevenir infiltração de fluidos até a profundidade desejada. A coleta é feita com tubos de polipropileno de 3/8", com micro-válvula de pé, a qual permite extração de pequenas quantidades de água até a profundidade de $20 \mathrm{~m}$. Permite ainda a identificação da posição do nível d'água.

É um processo rápido, sem geração de resíduos, e quando realizado em maiores quantidades, permite a estimativa da permeabilidade e o estabelecimento das direções de fluxo. Em terrenos pouco permeáveis o tempo de recarga é longo, o que dificulta a coleta. É mais adequado para medições rápidas (até 24 horas). Pode ser utilizado como sistema de monitoramento por longo período porém, tem custo elevado.

O procedimento utilizado para amostragem de água consta, inicialmente, da cravação do amostrador até a cota onde se deseja iniciar a amostragem da água, Figura 2.41 (a), utilizando o mesmo penetrômetro que é usado para cravar o piezocone. No aterro de resíduos sólidos de Bauru, essa profundidade foi determinada com base nos resultados de resistividade e estratigrafia obtidas através do ensaio RCPTU. Atingida a profundidade desejada, inicia-se a inserção do filtro e separação da ponteira cônica, Figura 2.41 (b). O filtro está mostrado na Foto 2.11. Inicia-se, então, a coleta de água dentro do filtro por bombeamento, Figura 2.41 (c). O tempo de execução dessa etapa depende da permeabilidade do solo e pode ser praticamente imediata para solos arenosos, ou demorar horas para solos argilosos. Terminada a coleta, recomenda-se completar o furo com calda de cimento, Figura $2.41(\mathrm{~d})$. 


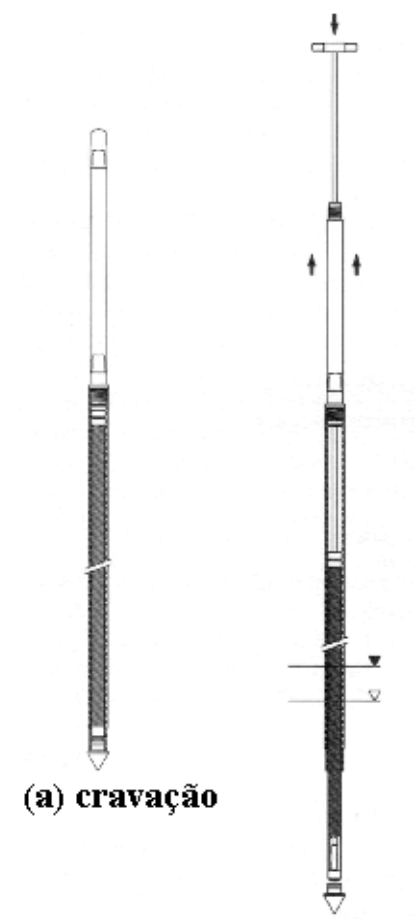

(b) separação

(c) amostragem

(d) injeção

Figura 2.41. Amostrador de água Geoprobe $®(G E O P R O B E$ SYSTEMS, 1995).

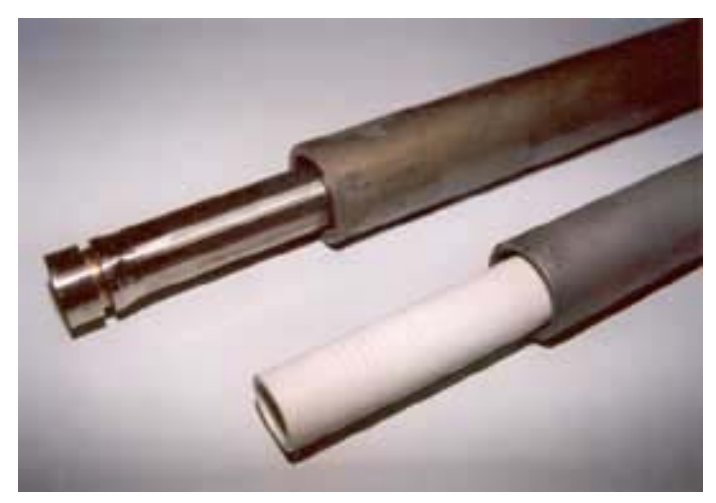

Foto 2.11. Dois tipos de filtros (aço inoxidável e PVC) do amostrador de água Geoprobe $\mathbb{A}$ (http://www.geoprobe.com/products/tools/gw_sampling/gw_sampling to ols_menu.htm em 02/2004).

\section{e) Poços de Monitoramento Temporário}

Poços de monitoramento temporário, abertos a trado, conforme ilustrado na Foto 2.12 , possibilitam a coleta de água utilizando um amostrador de água igual 
aquele mostrado na Foto 2.13. Esse equipamento consiste de um tubo PVC rígido e transparente, Foto 2.13 (a). Na extremidade inferior é ajustada uma luva, Foto 2.13 (b), na qual é acoplada uma tampa flexível, Foto 2.13 (c). Quando o conjunto é imerso na água, Foto 2.13 (d), essa tampa permite a entrada da água e, ao ser puxado o amostrador para a superfície, o peso próprio da água fecha a tampa, permitindo assim, a coleta da água. Terminada a coleta, a água é armazenada num recipiente devidamente limpo, o qual é acondicionado em um local devidamente refrigerado, e assim, ser transportado para o laboratório.

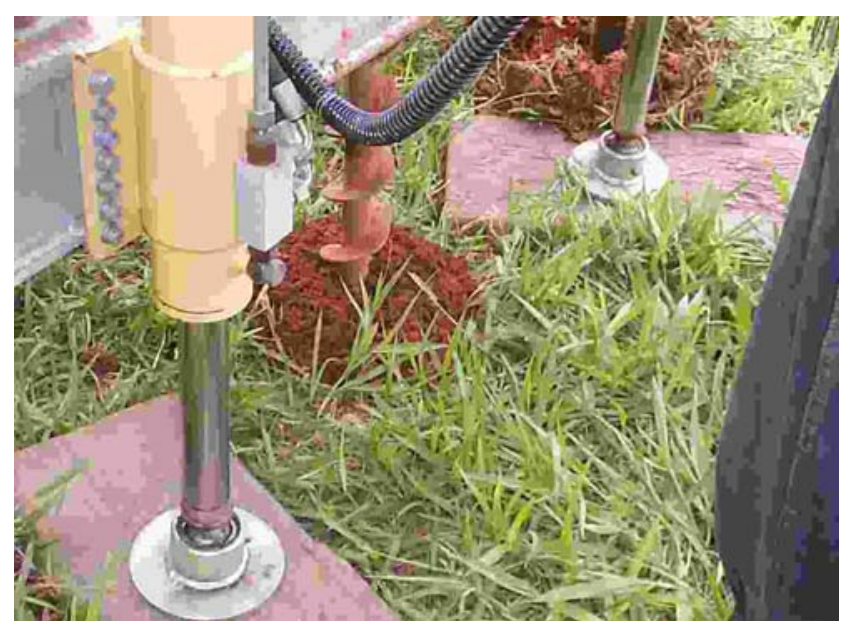

Foto 2.12. Poço de monitoramento temporário aberto com trado helicoidal motorizado.
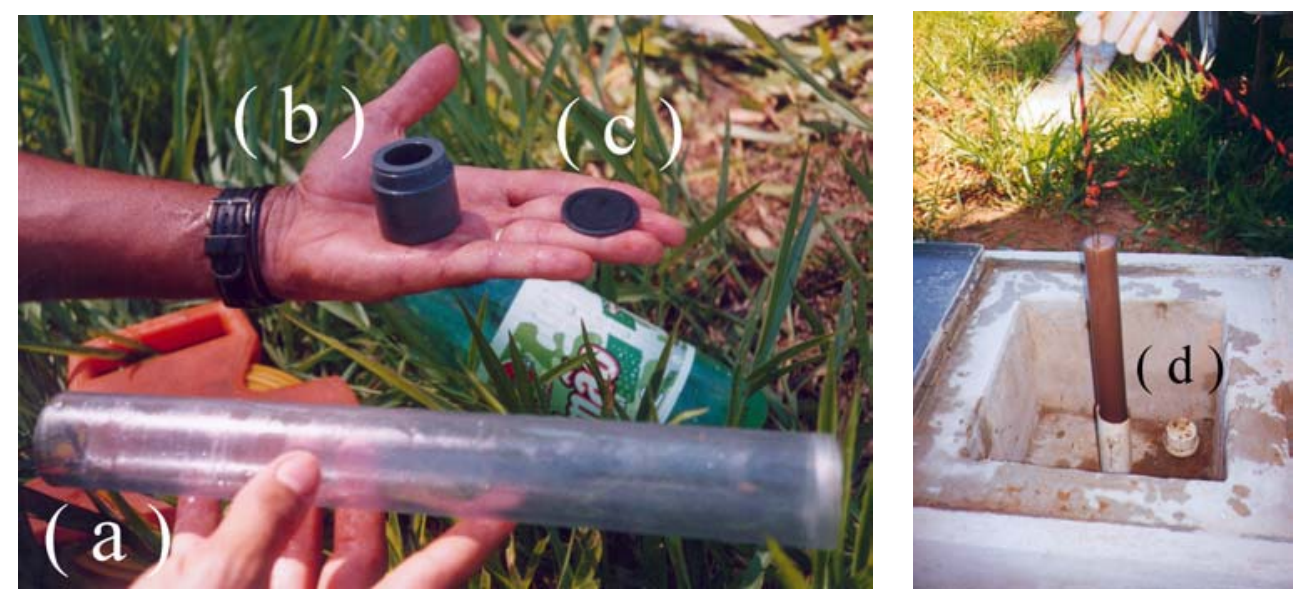

Foto 2.13. Amostrador de água utilizado nos poços de monitoramento temporário. 


\subsection{Poços para Monitoramento do Aqüífero Freático}

LaGREGA et al. (1994) lembra que os poços de monitoramento freqüentemente servem para um propósito adicional e igualmente importante ao da medida da pressão piezométrica, a qual é geralmente obtida através de piezômetros. Segundo os autores, um poço de monitoramento corretamente instalado permite a coleta de amostras de águas subterrâneas representativas para análises químicas em laboratório, ou até mesmo a medida de propriedades químicas especificas da água subterrânea in situ, como pH e condutividade. Os poços de monitoramento também podem ser utilizados na medida da condutividade hidráulica através de um ensaio de permeabilidade num único poço, ou através de um certo numero de poços de monitoramento e de bombeamento.

É importante ressaltar que o monitoramento do aquífero se faz necessário durante toda a vida útil de um aterro (ou local de disposição de resíduos), inclusive depois de desativado. Ele permite que alguns parâmetros sejam acompanhados em tempo real, além de poder dar a informação de que um certo tipo de remediação escolhido esteja funcionando adequadamente.

Quanto à localização dos poços de monitoramento, a CETESB (1999), com base na Norma Construção de Poços de Monitoramento de Aqüífero Freático de 1988, assim como na NBR 13895, diz que o poço de montante deve ser locado próximo à área de disposição, mas a uma distancia segura da influencia do efluente, enquanto os poços de jusante, que devem ser no mínimo três, devem ser distribuídos próximos à área de disposição, para que a pluma possa ser identificada o mais breve possível, no caso do lixiviado atingir o lençol. Entretanto, a localização exageradamente próxima dos poços aumenta o risco de contaminação direta dos mesmos. A Figura 2.42 apresenta de forma sistemática o que a CETESB exige para a locação de poços de monitoramento numa área de disposição de resíduos. 

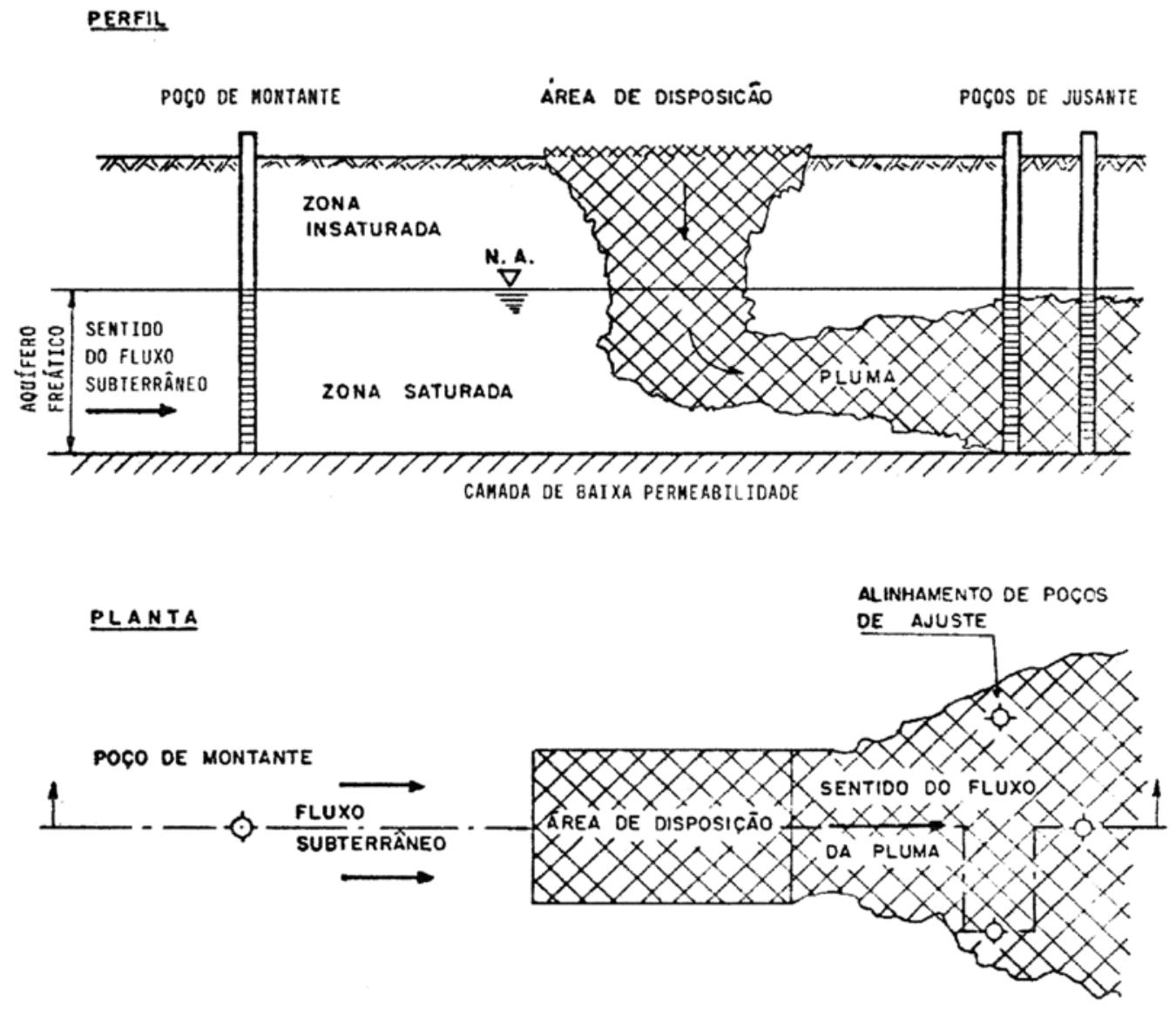

Figura 2.42. Disposiçao dos poços de monitoramento (CETESB, 1999).

HAMADA et al. (2002) criticam os sistemas atualmente exigidos pelos órgãos ambientais, que constam de poços de monitoramento instalados à montante (referencial) e outros à jusante com o intuito de monitorar o lençol freático com base na superfície potenciométrica. Desta forma os poços de monitoramento que atingem o lençol freático superficialmente, satisfazem as condições legais, mas podem ser inconsistentes quanto à sua real função. Os autores lembram que a NBR 10157, por exemplo, não especifica condicionantes geológicos e o potencial uso dos aqüíferos. Como descrito nessa norma, existe uma preocupação somente com a qualidade da água existente no aqüífero mais alto (superficial). Sendo assim, os autores sugerem o emprego da geofísica, em especial o caminhamento elétrico, que tem demonstrado grande potencial, fornecendo uma avaliação das áreas de disposição de resíduos quanto às características do meio físico (nível d'água, fluxo subterrâneo, espessura 
da cobertura inconsolidada, presença de fraturas) e quanto às relações entre os resíduos e local de disposição. Além de técnicas de investigação invasivas, tais como a sondagem SPT e o piezocone, que são limitadas quanto às características do subsolo e à profundidade, porém, permitem um detalhamento maior de informações.

Os poços de monitoramento, conforme mostra as Figuras 2.43 e 2.44 e o que diz a CETESB (1999), - com base na Norma Construção de Poços de Monitoramento de Aqüífero Freático de 1988, assim como na NBR 13895 - são constituídos basicamente dos seguintes elementos:

- Revestimento interno: pode ser de aço inoxidável, ferro fundido ou plástico. É encaixado no interior da perfuração, com a função de revestir a parede da mesma;

- Filtro: tem a propriedade de permitir a entrada de água e de impedir a penetração de algumas impurezas plásticas do poço. O filtro mais comum é do tipo ranhurado;

- Pré-filtro: ocupa o espaço anular, entre o filtro e a parede de perfuração. É constituído de areia lavada de grãos quartzosos ou pedrisco de quartzo (inertes e resistentes);

- Proteção sanitária: tem a função de evitar que a água superficial contamine o poço através da infiltração pelo espaço anular. É o conjunto formado pelo selo sanitário e pela laje de proteção (piso de cimento com pequeno declive ao redor da boca do poço);

- Tampão: a extremidade superior do tubo deve ser protegida contra a penetração de substâncias indesejáveis, que podem alterar os resultados da análise. É necessário instalar um tampão removível com chave. Na extremidade inferior do tubo, um tampão fixo, de preferência rosqueado, tem a função de evitar a entrada do material sólido no tubo;

- Caixa de proteção: o tubo de revestimento sobressai ao nível do terreno aproximadamente $0.2 \mathrm{~m}$ para evitar a penetração de água superficial e de elementos estranhos no poço. A caixa de proteção de alvenaria ou tubo de aço deve ter dimensões apenas suficientes para envolver a parte saliente do tubo de revestimento. Uma tampa na parte superior permite o acesso ao poço. Essa tampa pode manter-se fechada a chave para melhor proteção do poço; 

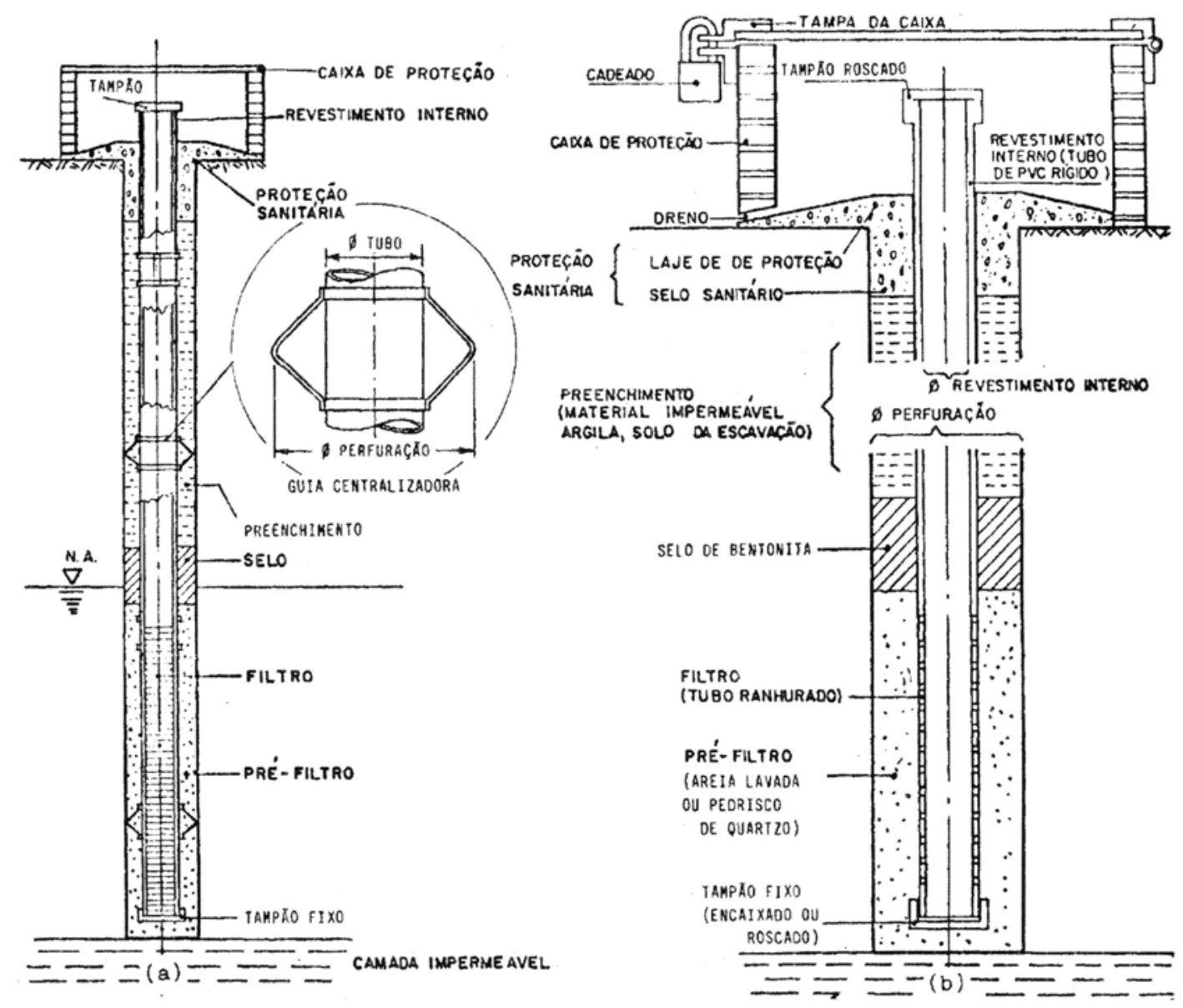

Figura 2.43. Perfil esquemático de poço de monitoramento (CETESB, 1999).

- Selo: obturador com a função de vedar o espaço anular em torno do tubo de revestimento, acima do limite máximo de variação do nível do aqüífero, evitando a contaminação do poço por líquidos percolados pelo espaço anular. Serve também para delimitar a camada de interesse dentro da zona saturada. O material vedante (bentonita, cimento) deve obstruir uma pequena parte do espaço anular, o suficiente para impedir a passagem de água de um nível para o outro;

- Preenchimento: o espaço anular entre a parede de perfuração e o tubo de revestimento deve ser preenchido por material impermeável (argila, solo de escavação) em toda a extensão não saturada, a fim de fixar o tubo de revestimento e dificultar a penetração de líquidos provenientes da superfície;

- Guias centralizadoras: dispositivos salientes, distribuídos ao longo do tubo de 
revestimento, fixados por seu lado externo. Tem a função de mantê-lo centrado em relação ao eixo do poço.

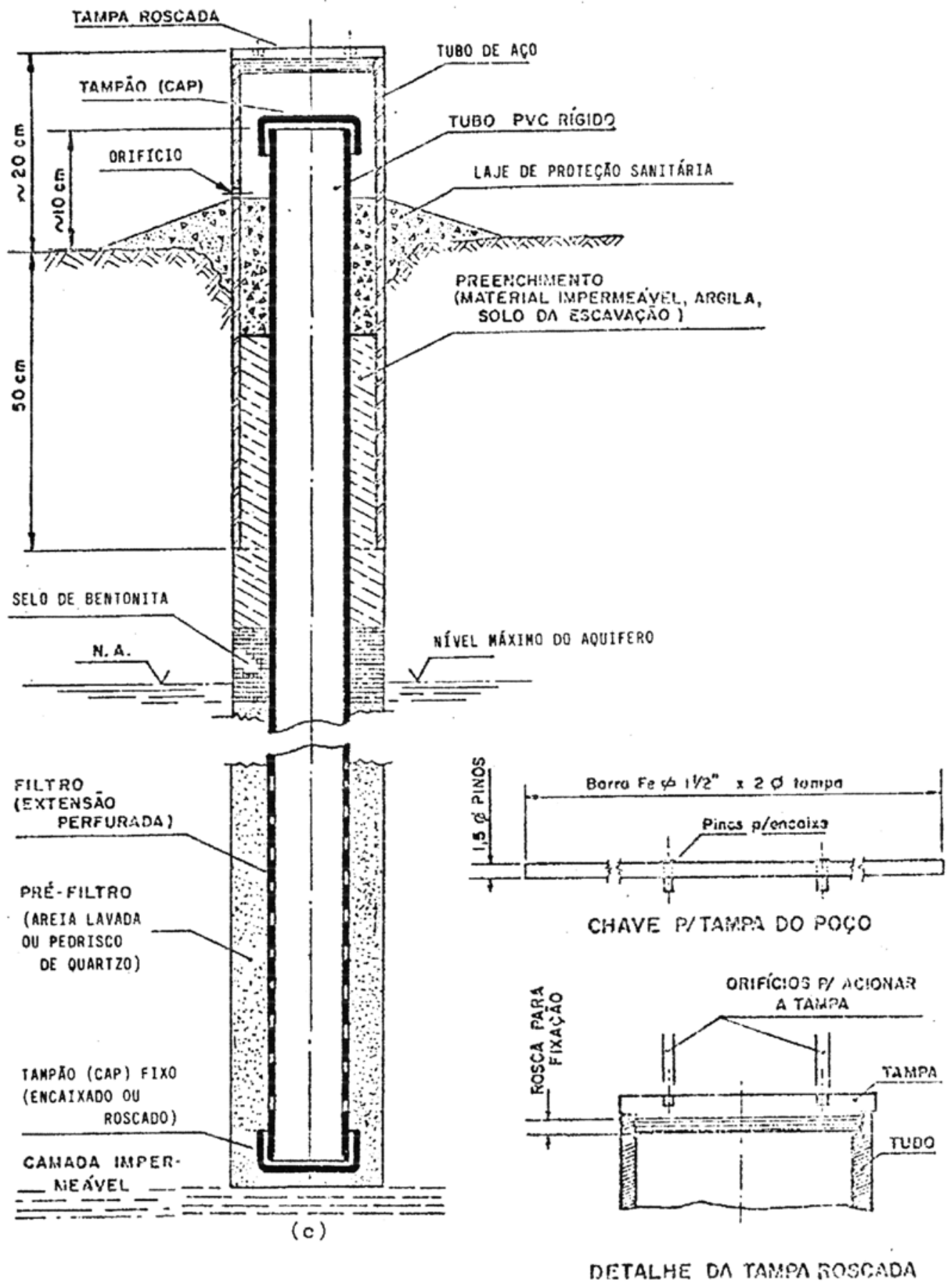

Figura 2.44. Perfil esquemático de poço de monitoramento (CETESB, 1999). 
É possível que a avaliação e a coleta das amostras de água sejam realizadas em diferentes níveis, como mostra os tipos de poços da Figura 2.45, descritos a seguir:

- Bateria de poços: é utilizada para monitoramento puntiforme nos locais de zona saturada espessa. A bateria de poços constitui-se de um grupo de poços locados bem próximos uns dos outros, não alinhados, com profundidades variáveis e com filtros curtos (1 a 3 m), dispostos em profundidades distintas. Esses poços são dimensionados para, em conjunto, interceptarem o fluxo subterrâneo em toda extensão ou em segmentos apropriados do aqüífero freático;

- Poço tipo multinivel: consiste em tubos de comprimentos variáveis, munidos de filtros curtos, introduzidos em uma perfuração (exemplo: três tubos de diâmetro nominal de $50 \mathrm{~mm}$ ), complementados com pré-filtro e selo, delimitando o campo de ação de cada filtro.

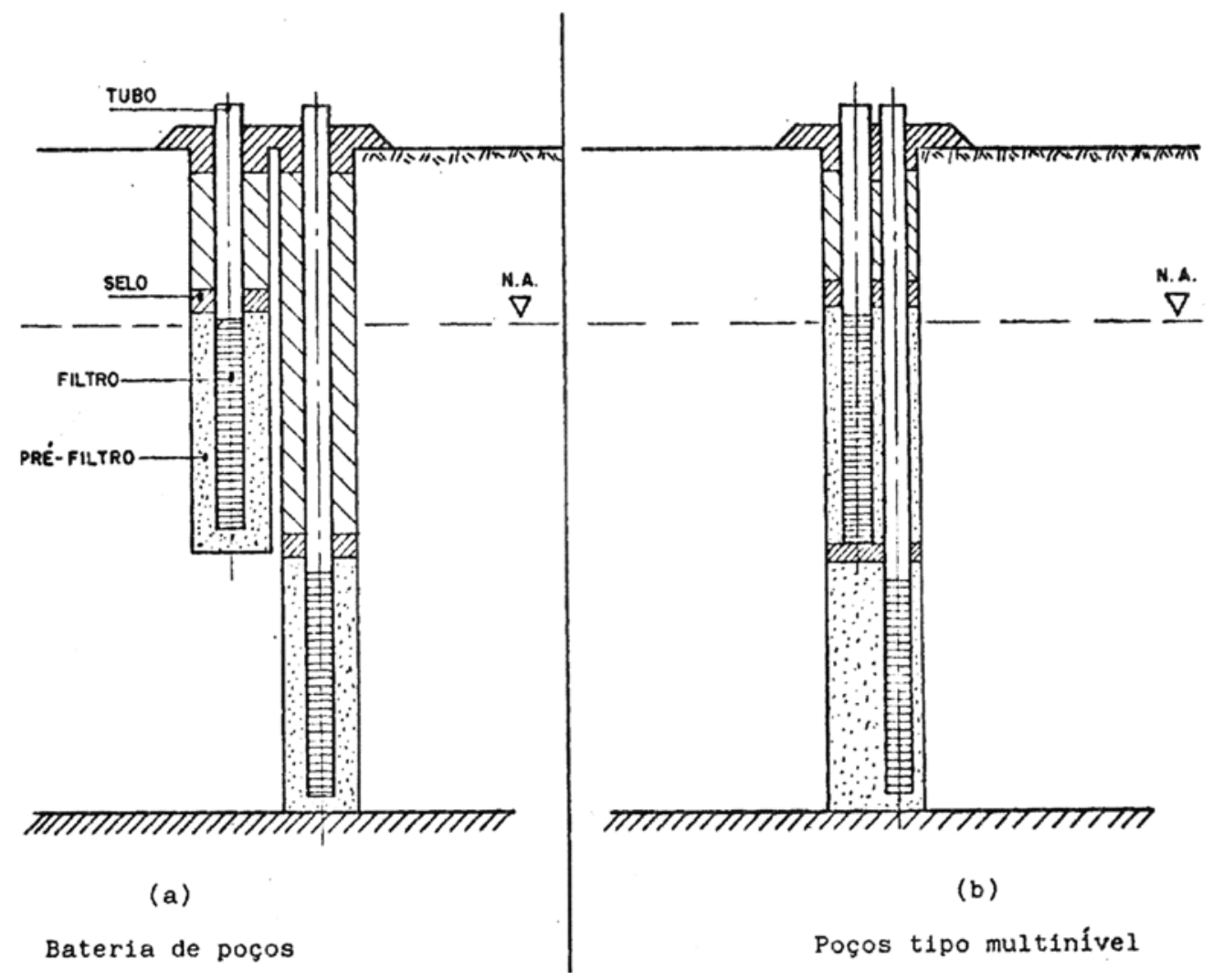

Figura 2.45. Tipos de poços para monitoramento em níveis distintos (CETESB, 1999). 


\section{MATERIAIS E MÉTODOS}

\subsection{Locais Estudados}

\subsubsection{Lixão de Ribeirão Preto}

O lixão desativado de Ribeirão Preto está situado à sudeste da cidade, às margens da rodovia que liga Ribeirão Preto a Serrana, como mostra a Figura 3.1. Nesse local, foram dispostos tanto resíduos sólidos comuns como aqueles provenientes de serviços de saúde produzidos pela cidade de Ribeirão Preto entre 1974 e 1990, totalizando cerca de $600.000 \mathrm{~m}^{3}$ de rejeitos dispostos em duas cavas alongadas de cerca de $300 \mathrm{~m}$ de comprimento por 40 a $60 \mathrm{~m}$ de largura (ZUQUETTE et al., 1990). As Fotos 3.1 e 3.2, a seguir, apresentam a borda de uma das cavas e também o chorume aflorando de uma delas, respectivamente.

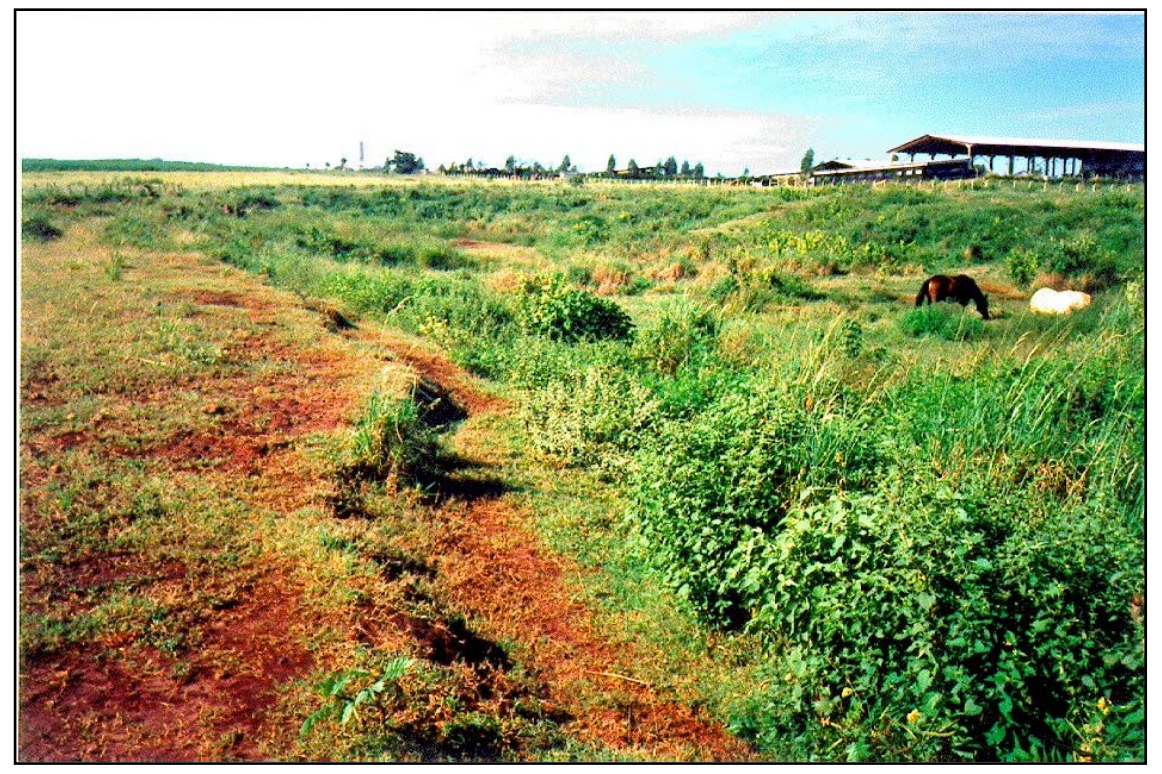

Foto 3.1. Vista geral do lixão de Ribeirão Preto: borda da cava preenchida com resíduos. Notar o recalque na área dos resíduos (ELIS, 1999). 


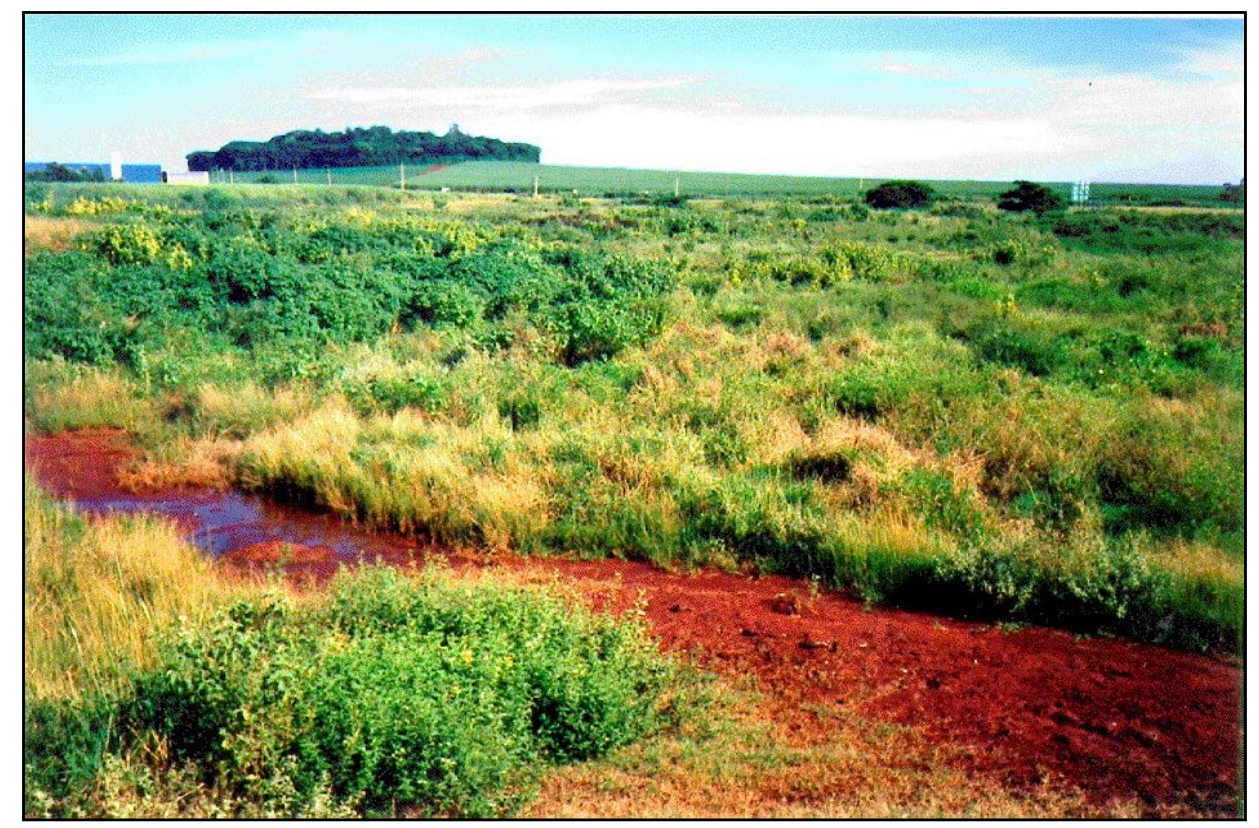

Foto 3.2. Lixão de Ribeirão Preto: chorume aflorando em uma das cavas (ELIS, 1999).

\subsubsection{Aspectos Geológicos}

A área caracteriza-se como um divisor de águas superficiais tendo como substrato rochoso os arenitos não silicificados da Formação Botucatu e recobertos por materiais inconsolidados constituídos na parte inferior por residuais dos arenitos e na superior enriquecida por materiais argilosos retrabalhados e oriundos das áreas mais elevadas topograficamente, constituídas pelos magmatitos (basaltos) da Formação Serra Geral. Quanto ao coeficiente de permeabilidade os materiais inconsolidados da porção superior apresentam valores da ordem de $10^{-7}$ a $10^{-8} \mathrm{~m} / \mathrm{s} \mathrm{e}$ da inferior de $10^{-6} \mathrm{~m} / \mathrm{s}$; o nível d'água está em profundidades em torno de $20 \mathrm{~m}$ (PEJON \& ZUQUETTE, 1991). Considerando as características geológicogeotécnicas utilizadas por ZUQUETTE et al. (1994) para classificação de áreas quanto à adequação para depósitos de resíduos, pode-se relacionar alguns atributos da área em questão que a classificam como restritiva. 


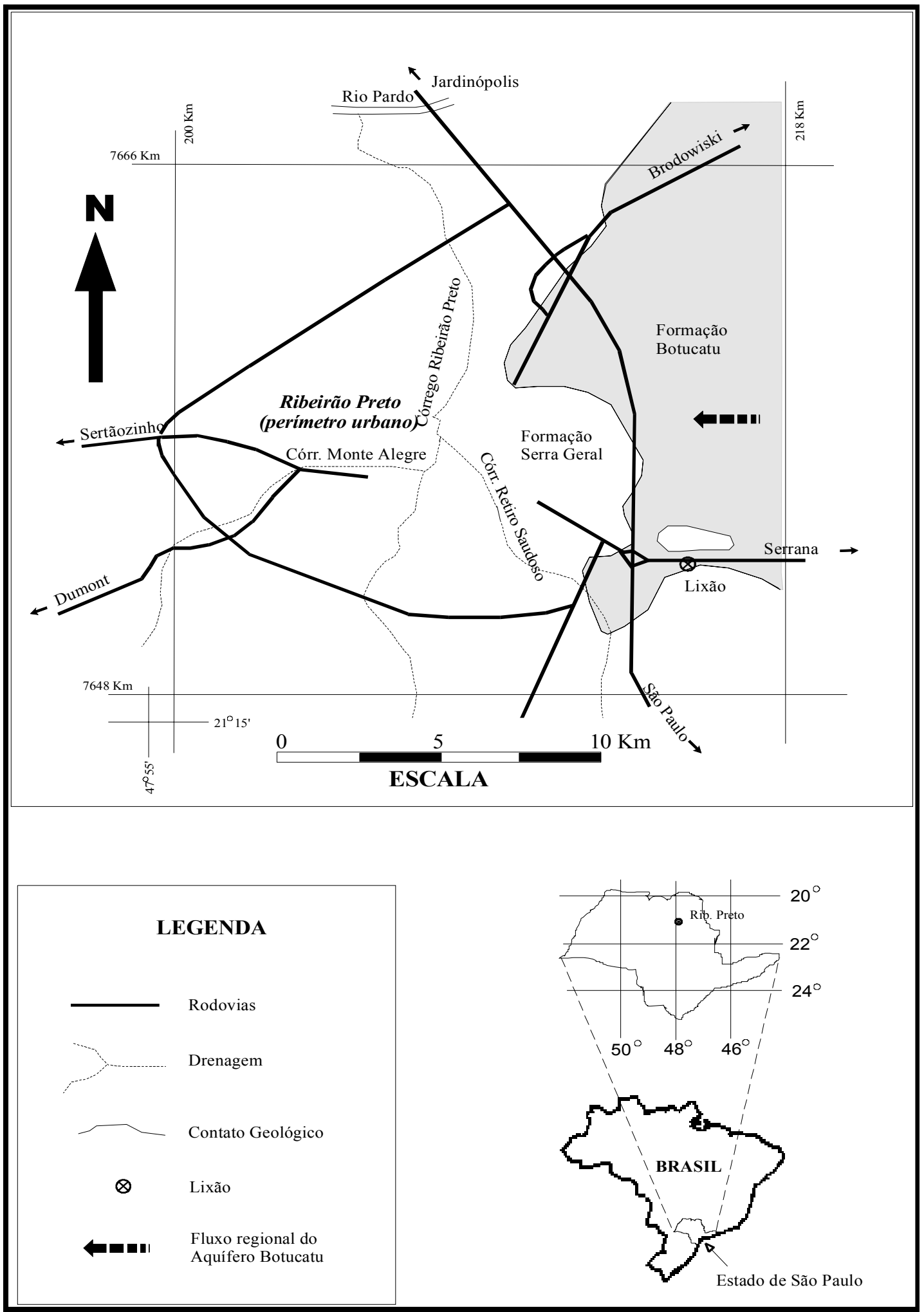

Figura 3.1. Localização de Ribeirão Preto no Estado de São Paulo e do antigo lixão da cidade (GIACHETI et al., 1999). 
Tabela 3.1. Classificação da área do lixão de Ribeirão Preto (ZUQUETTE et al., 1994).

\begin{tabular}{|c|c|c|}
\hline Atributo & Característica no local & Característica adequada \\
\hline $\begin{array}{c}\text { Profundidade da zona } \\
\text { saturada (sob a base dos } \\
\text { resíduos) }\end{array}$ & $7 \mathrm{a} 10 \mathrm{~m}$ & $>15 \mathrm{~m}$ \\
\hline $\begin{array}{c}\text { Capacidade de troca } \\
\text { catiônica (CTC) }\end{array}$ & $5 \mathrm{a} 7 \mathrm{meq} / 100 \mathrm{~g}$ & $\begin{array}{c}>15 \mathrm{meq} / 100 \mathrm{~g} \text { (valores entre } 5 \mathrm{e} \\
15 \mathrm{meq} / 100 \mathrm{~g} \text { são considerados } \\
\text { moderadamente adequados) }\end{array}$ \\
\hline Divisor topográfico & $\mathrm{Sim}$ & Não \\
\hline Área de recarga & $\mathrm{Sim}$ & Não \\
\hline
\end{tabular}

\subsubsection{Ensaios Realizados}

Nesta área, novos ensaios de geofísica de superfície são apresentados por ELIS (2003b), que também a estudou em 1999. Esta nova campanha de ensaios foi realizada em duas épocas distintas, sendo uma após o período das chuvas (04/2001 Fase 1) e outra após um período de estiagem (08/2001 - Fase 2). Os ensaios foram conduzidos basicamente em quatro perfis de direção E-W (Linhas C1 a C4), os quais estão localizados na Figura 3.1. Foram realizados os seguintes ensaios por ELIS (2003b):

- Caminhamento elétrico (resistividade e polarização induzida) com dipolo de 10 metros e 5 profundidades teóricas de investigação (10 a 30 metros), nas Linhas C1 a C4 (Fases 1 e 2);

- Caminhamento eletromagnético, com o equipamento EM34, utilizando os cabos de referência de 10 e 20 metros, investigando as profundidades teóricas de 7.5, 15 e 30 metros. Estações de medida a cada 10 metros (Fase 1);

- Uma linha de Ground Penetrating Radar (GPR), com antena de 25MHz, na Linha C4 (Fase 1);

- Potencial espontâneo, com o técnica de potenciais, e estações a cada 10 metros nas Linhas C1 a C4 (Fase 2);

- GPR, com antena de 50MHz, com intervalo de medidas de 0.5 metros, nas Linhas C1, C3 e C4 (Fase 2);

- Magnetometria, com estações a cada 10 metros, nas Linhas C1 a C4 (Fase 2). 
Na Figura 3.2 estão também localizados os poços de monitoramento e os pontos de ensaios de sondagem elétrica vertical (SEVs) realizadas por ELIS (1999), além das 3 sondagens CPTU realizadas no local, com amostragem de solos usando o sistema Geoprobe $\circledast$. É importante ressaltar que a tecnologia do piezocone apresentou limitações quando empregada nesta área, uma vez que o impenetrável do cone foi atingido antes do nível d'água, impossibilitando assim a identificação da posição desse nível d'água, a estimativa da permeabilidade do solo e a coleta de amostras de água, o que fez com que a continuidade da pesquisa sobre o emprego da tecnologia do piezocone neste local ficasse prejudicada.
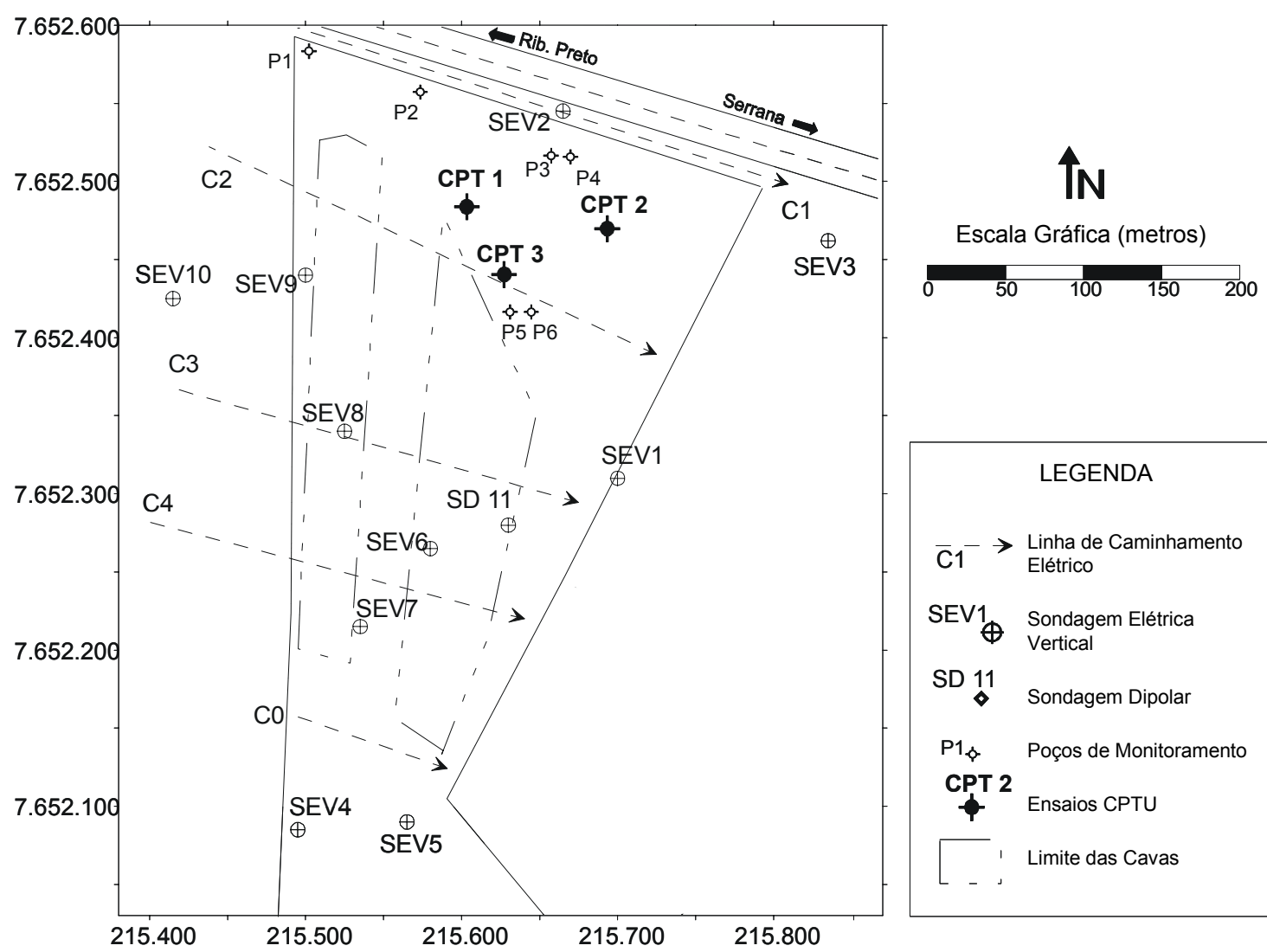

Figura 3.2. Localização dos ensaios realizados no lixão de Ribeirão Preto-SP (ELIS, 2003b). 


\subsubsection{Aterro de Resíduos Sólidos Urbanos de Bauru}

O local estudado é um aterro sanitário, situado a cerca de $1000 \mathrm{~m}$ de importante drenagem e de áreas de pastagens cujas sedes estão instaladas num raio superior a 2000 m (Figura 3.3 e Foto 3.3). Neste contexto, também é importante destacar a predominância de ventos na direção Leste (E) e Sudeste (SE), leves e próximos à superfície, com períodos ocasionais de ventos fortes (por volta de $10 \mathrm{~m} / \mathrm{s}$ ), o que permite uma maior facilidade no manejo dos resíduos. Esses ventos sopram no sentido contrário ao da cidade.

O crescimento urbano em direção ao aterro encontra barreiras representadas pelas instalações de transmissão e administração da energia elétrica do Estado, dentre outros. Além disso, tanto a Zona de Expansão Urbana como a Zona de Interesse Urbano estão muito distantes do local de implantação desse aterro.

\subsubsection{Descrição do Aterro}

O aterro sanitário em questão foi projetado para uma vida útil estimada em 10 anos (Foto 3.4). Além da área disponível de $300.000 \mathrm{~m}^{2}$, também possui uma área contígua que poderá ser usada para futuras expansões ou eventuais emergências. Atualmente, o aterro encontra-se na sua terceira e última camada prevista em projeto. As áreas de cada camada (ou patamar) são: $1^{\circ}$ Patamar: $24.858 \mathrm{~m}^{2}, 2^{\circ}$ Patamar: $76.516 \mathrm{~m}^{2}$ e $3^{\circ}$ Patamar: $90.276 \mathrm{~m}^{2}$.

Para a estimativa da vida útil do aterro, foi considerado no projeto um volume total de $958.250 \mathrm{~m}^{3}$, dos quais $766.600 \mathrm{~m}^{3}$ correspondem ao volume ocupado pelos resíduos ( $80 \%$ do total). Considerando-se a massa específica dos resíduos ali dispostos em torno de $700 \mathrm{~kg} / \mathrm{m}^{3}$ e a produção diária de $140.000 \mathrm{kgf}$ (valores adotados), chega-se à vida útil aproximada de 10 anos acima informada. Deve-se ressaltar que para essa estimativa não foi considerada a possibilidade de expansão na área contígua ou a viabilidade de aumento da quantidade de patamares. Para impermeabilização da base do aterro aplicou-se CM-30 diluído (Foto 3.5). 


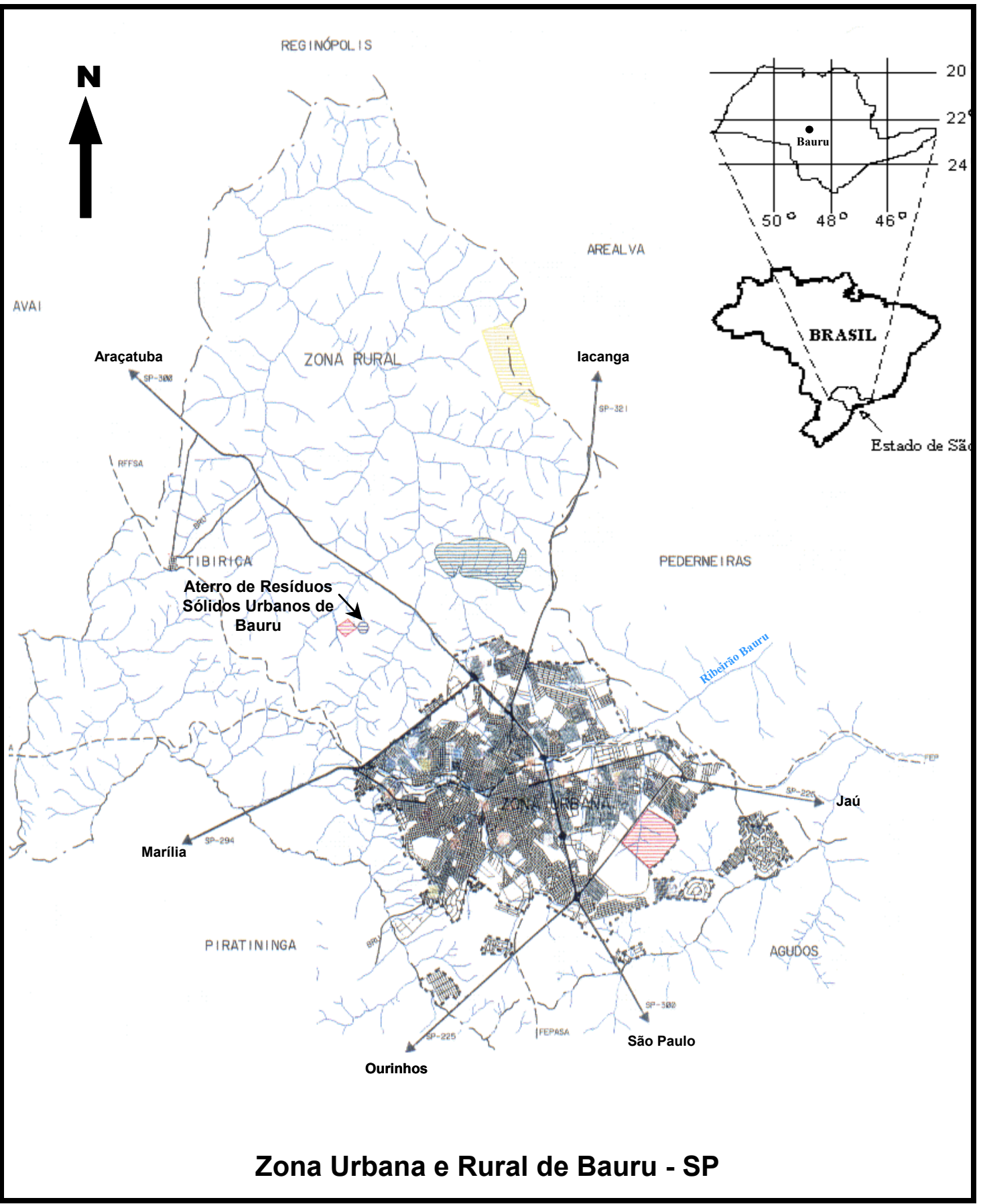

Figura 3.3. Localização de Bauru no Estado de São Paulo e do aterro de resíduos sólidos urbanos da cidade (http://www.vidagua.org.br/imagens/ImgBauru/mapa_d5.gif em 02/2004). 


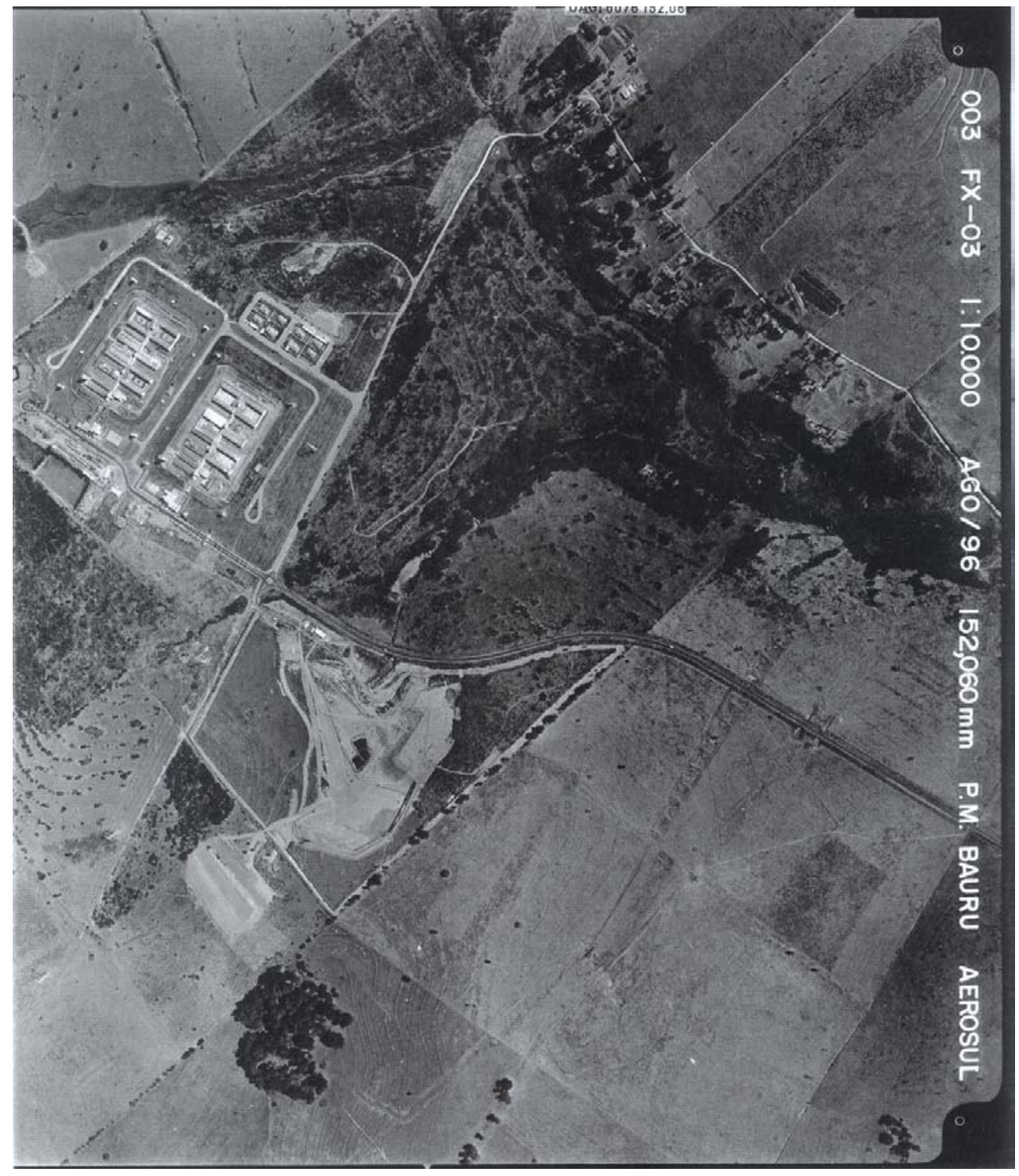

Foto 3.3. Foto aérea do local de implantação do aterro de resíduos sólidos de Bauru (EMDURB, 2002).

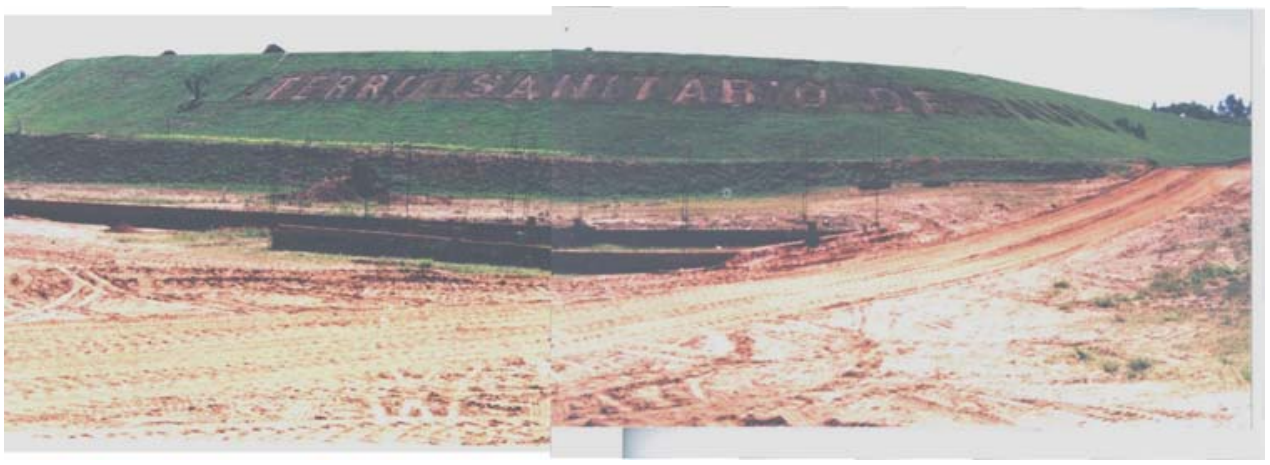

Foto 3.4. Vista geral do aterro de resíduos sólidos de Bauru (EMDURB, 2002). 


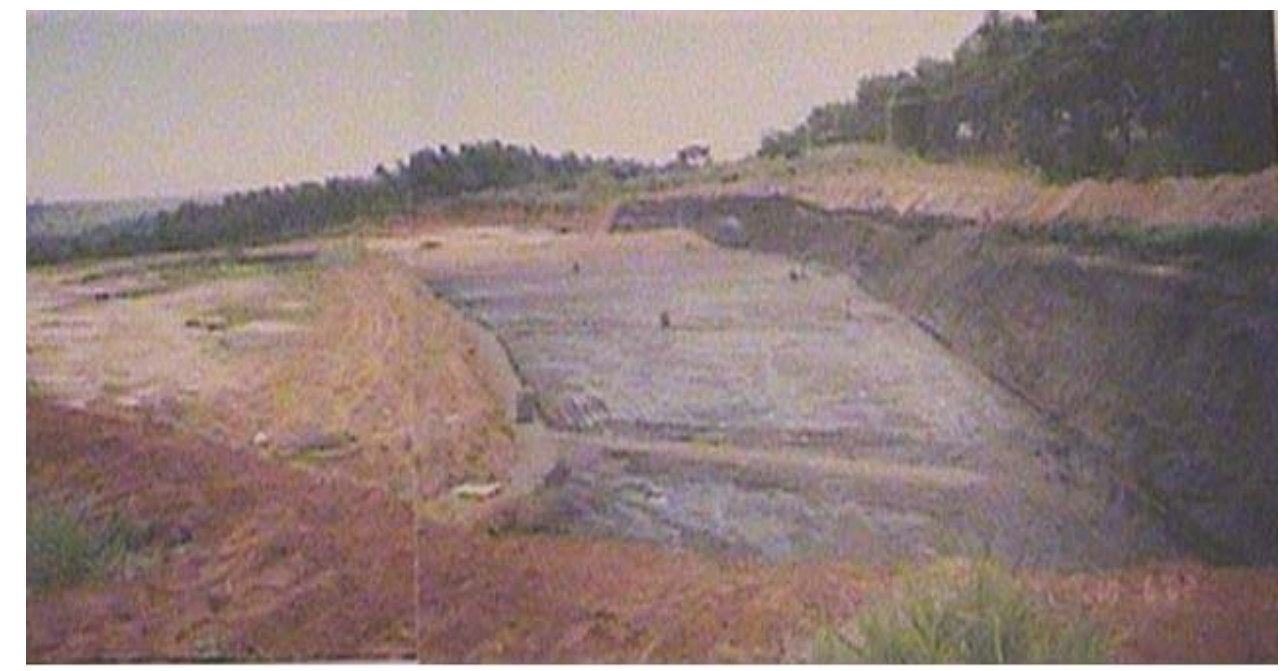

Foto 3.5. Impermeabilização da base do aterro de resíduos sólidos de Bauru feita com CM-30 diluído (EMDURB, 2002).

\subsubsection{Aspectos Geológicos}

O aterro está sobre uma área caracterizada geologicamente por arenitos do Grupo Bauru (Formações Marília e Adamantina). $O$ solo superficial nas proximidades é constituído ora por uma camada de aluvião de areia fina, siltoargilosa de cor acinzentada, seguida de solo coluvionar, e ora do próprio coluvião composto por areia argilosa, marrom-avermelhada. Abaixo dessas camadas é encontrado o solo de alteração de arenito sobre a rocha inalterada (EIA/RIMA, 1992).

O solo da área do aterro possui textura de areia fina a média argilosa. Segundo a classificação MCT, é classificado como solo arenoso de comportamento laterítico (LA'), possuindo elevada capacidade de suporte, elevado módulo de resiliência, baixa permeabilidade, pequena contração por perda de umidade, razoável coesão e pequena expansibilidade por imersão em água quando devidamente compactado, segundo NOGAMI \& VILLIBOR (1995).

O lençol freático localiza-se a uma profundidade no mínimo superior a $5 \mathrm{~m}$ da cota da base do aterro de resíduos. Na época de implantação do aterro foram executadas 20 sondagens de simples reconhecimento (SPT), além de ensaios de caracterização, os quais serão discutidos adiante. 


\subsubsection{Ensaios Realizados}

Para o desenvolvimento deste trabalho, foram realizadas duas campanhas de ensaios elétricos de superfície por LAGO (2004), uma campanha de ensaios CPTU e três campanhas de ensaios RCPTU, duas delas com coleta de solos e água. Também foram instalados poços de monitoramento permanentes no aterro, a partir da análise dos resultados dos ensaios elétricos de superfície realizados. A localização desses ensaios e desses poços encontra-se na Figura 3.4.

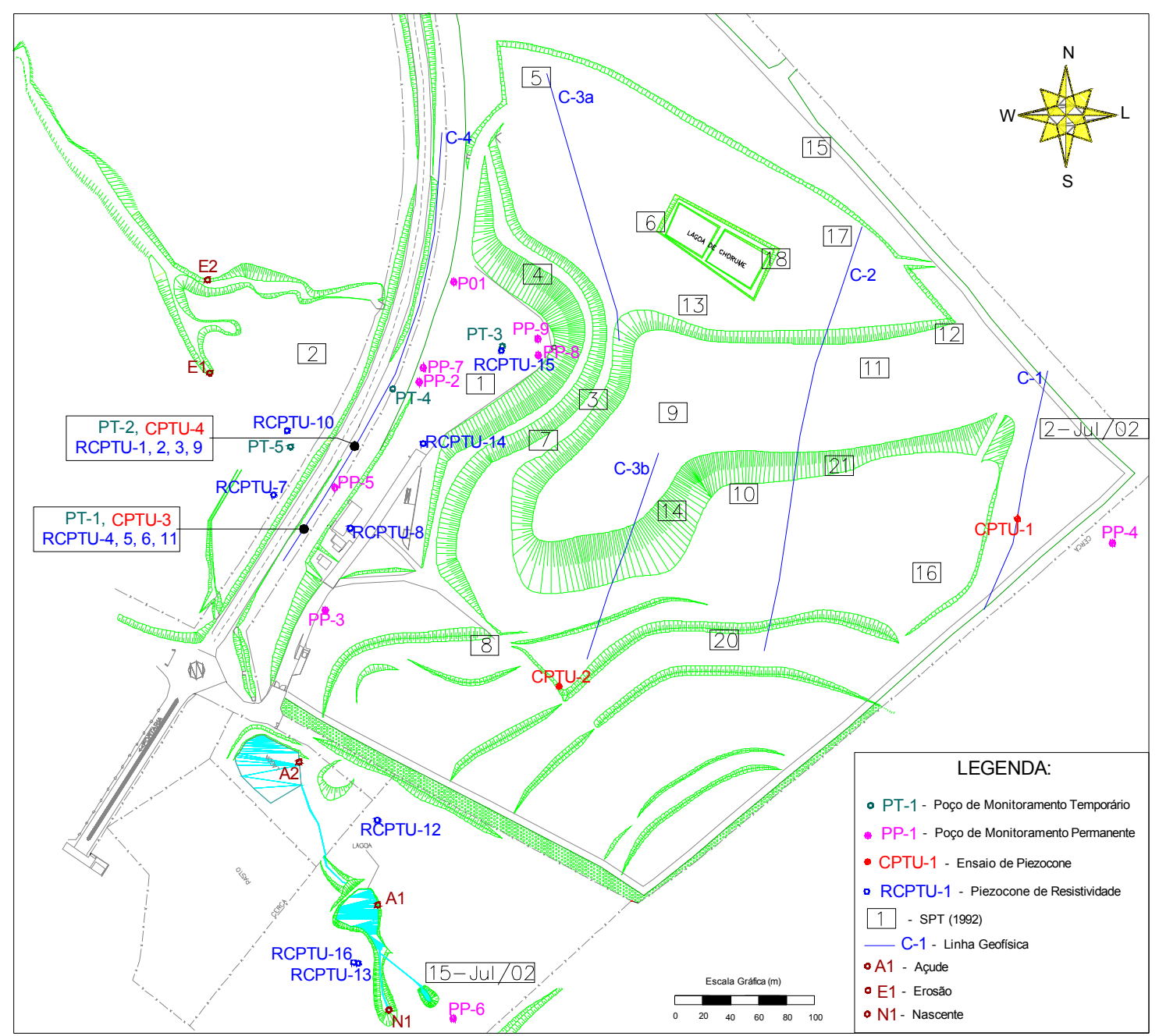

Figura 3.4. Localização dos ensaios realizados no aterro de resíduos sólidos de Bauru. 


\subsection{Caracterização do Solo do Aterro de Resíduos Sólidos Urbanos de Bauru}

Com o objetivo de obter amostras representativas para o desenvolvimento de ensaios de laboratório e para o conhecimento do perfil natural do terreno, foi realizado um estudo de caracterização do solo do aterro de resíduos sólidos urbanos de Bauru, englobando ensaios geotécnicos de laboratório e um levantamento dos resultados de ensaios SPT e de laboratório realizados quando da elaboração do Estudo de Impacto Ambiental - Relatório de Impacto do Meio Ambiente (EIARIMA), de 1992, antes da implantação do aterro.

\subsubsection{Amostras Coletadas no Entorno do Aterro}

Foram realizados ensaios geotécnicos de laboratório com amostras coletadas a $1.7 \mathrm{~m}, 3.0 \mathrm{~m}, 3.7 \mathrm{~m}$ e $7.0 \mathrm{~m}$ de um talude já existente, situado ao norte do aterro. Os ensaios foram realizados no Laboratório de Mecânica dos Solos da Unesp de Bauru com o objetivo de caracterizar o solo que é representativo daquele que ocorre na região onde se o aterro foi implantado. A Foto 3.6 mostra uma vista geral do talude onde as amostras foram retiradas e a Foto 3.7 mostra o momento da coleta de uma das amostras indeformadas utilizadas nos ensaios.

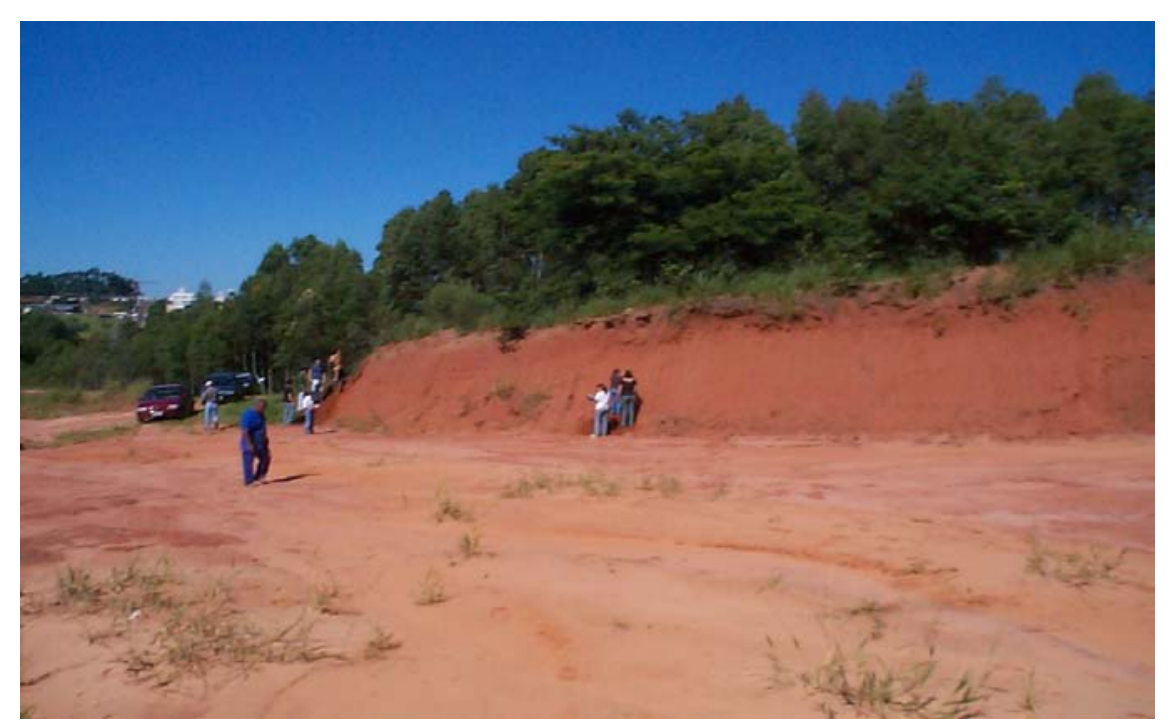

Foto 3.6. Vista geral do talude localizado no entorno do aterro, de onde foram coletadas amostras deformadas e indeformadas. 


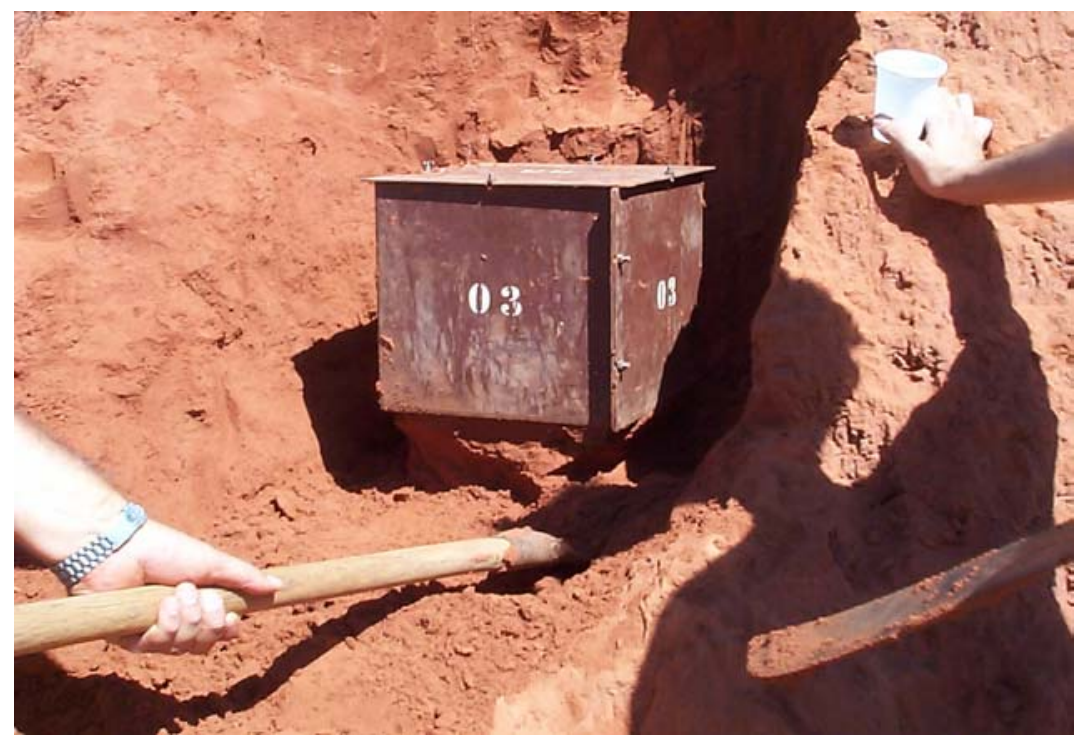

Foto 3.7. Amostra indeformada sendo coletada próximo ao pé do talude.

\subsubsection{Determinação dos Índices Físicos}

Os índices físicos determinados a partir das amostras coletadas foram o teor de umidade $(w)$, o peso específico dos sólidos $\left(\gamma_{\mathrm{s}}\right)$ e o peso específico natural $\left(\gamma_{\mathrm{n}}\right)$. A partir destes, foram calculados o peso específico aparente seco $\left(\gamma_{\mathrm{d}}\right)$, o índice de vazios (e), o grau de saturação (S) e a porosidade (n).

O teor de umidade foi determinado utilizando-se uma estufa elétrica. Para tanto, as amostras deformadas foram acondicionadas em recipiente selado que foi armazenado em depósito portátil para impedir as variações térmicas até que fosse feita a determinação da massa. Foram realizadas três determinações para cada amostra a fim de possibilitar o cálculo de um valor médio para a umidade.

$\mathrm{O}$ peso específico dos sólidos $\left(\gamma_{\mathrm{s}}\right)$ foi determinado a partir das amostras deformadas, utilizando-se o método do picnômetro (NBR 6508). Pelo menos três determinações foram feitas para cada amostra.

O peso específico natural foi determinado pelo método da balança hidrostática, no qual uma amostra indeformada, e coberta por parafina, é submersa num recipiente com água (NBR 10838).

Os índices físicos obtidos são apresentados na Tabela 3.2, a seguir. 
Tabela 3.2. Índices físicos obtidos para o entorno do aterro de resíduos sólidos de Bauru.

\begin{tabular}{|c|c|c|c|c|c|c|c|}
\hline Prof. (m) & $\mathbf{w ~ ( \% )}$ & $\gamma_{\mathbf{n}}\left(\mathbf{k N} / \mathbf{m}^{\mathbf{3}}\right)$ & $\gamma_{\mathbf{s}}\left(\mathbf{k N} / \mathbf{m}^{\mathbf{3}}\right)$ & $\gamma_{\mathbf{d}}\left(\mathbf{k N} / \mathbf{m}^{\mathbf{3}}\right)$ & $\mathbf{e}$ & $\mathbf{S ~ ( \% )}$ & $\mathbf{n} \mathbf{( \% )}$ \\
\hline $\mathbf{1 . 7}$ & 11.4 & 16.4 & 27.0 & 14.7 & 0.834 & 36.9 & 45.5 \\
\hline $\mathbf{3 . 0}$ & 5.9 & 17.0 & 26.8 & 16.1 & 0.669 & 23.6 & 40.1 \\
\hline $\mathbf{3 . 7}$ & 8.0 & 17.0 & 28.4 & 15.7 & 0.804 & 28.3 & 44.6 \\
\hline $\mathbf{7 . 0}$ & 7.5 & 15.4 & 28.0 & 14.3 & 0.955 & 22.0 & 48.8 \\
\hline
\end{tabular}

\subsubsection{Análise Granulométrica Conjunta}

Para a realização do ensaio de granulometria conjunta as amostras deformadas foram preparadas de acordo com a NBR 6457. A curva granulométrica foi determinada através da realização conjunta dos ensaios de peneiramento e de sedimentação, conforme preconiza a NBR 7181. No ensaio de sedimentação, o hexametafosfato de sódio foi utilizado como defloculante.

A Figura 3.5 apresenta as curvas granulométricas obtidas para cada amostra coletada nas quatro diferentes profundidades. Já a Tabela 3.3 apresenta a classificação textural de cada uma das amostras, de acordo com a escala da NBR 6502, de 1995.

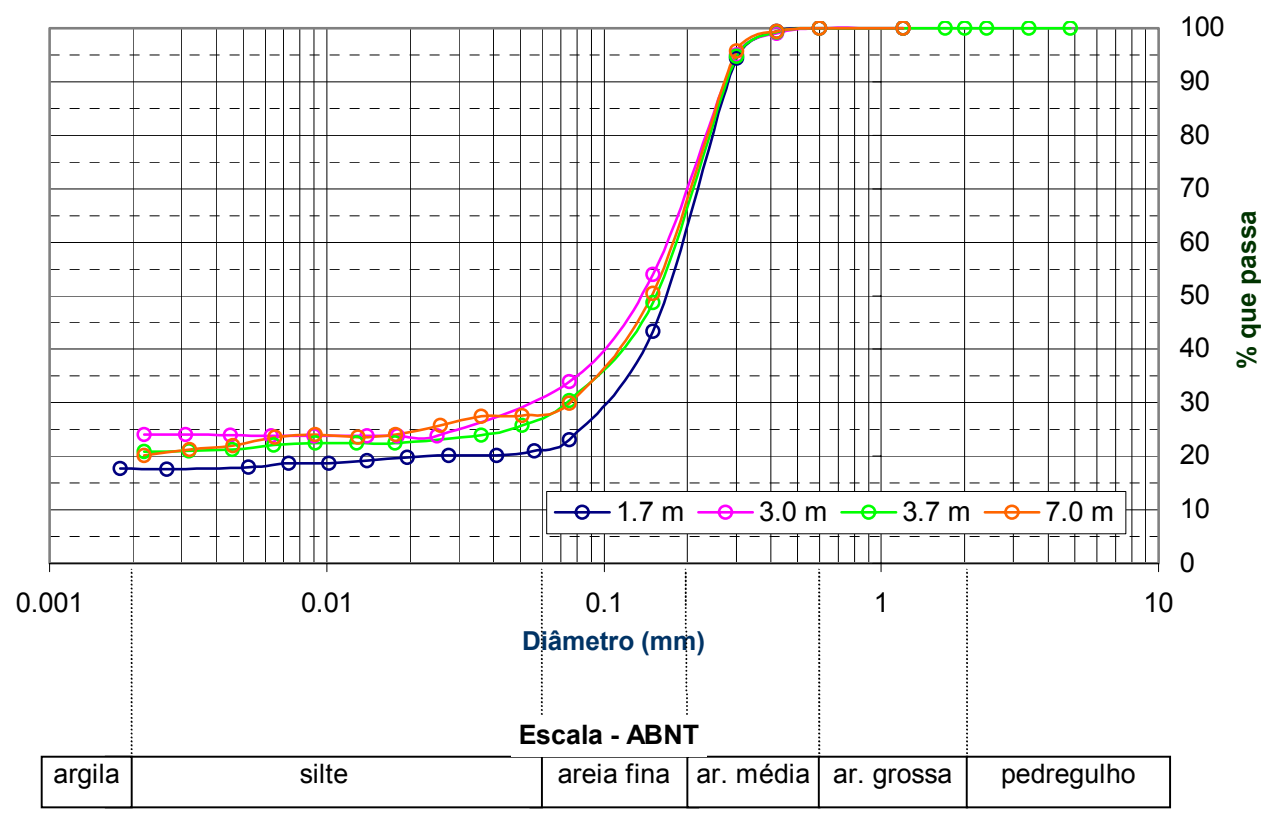

Figura 3.5. Curvas granulométricas para as amostras coletadas de talude do entorno do aterro de resíduos sólidos de Bauru. 
Tabela 3.3. Composição granulométrica obtida para o entorno do aterro de resíduos sólidos de Bauru.

\begin{tabular}{|c|c|c|c|c|c|c|}
\hline $\begin{array}{c}\text { Prof. } \\
(\mathbf{m})\end{array}$ & $\begin{array}{c}\text { Ar. Grossa } \\
(\mathbf{\%})\end{array}$ & $\begin{array}{c}\text { Ar. Média } \\
(\mathbf{\%})\end{array}$ & $\begin{array}{c}\text { Ar. Fina } \\
(\mathbf{\%})\end{array}$ & $\begin{array}{c}\text { Silte } \\
\mathbf{( \% )}\end{array}$ & $\begin{array}{c}\text { Argila } \\
\mathbf{( \% )}\end{array}$ & $\begin{array}{c}\text { Classificação } \\
\text { Textural }\end{array}$ \\
\hline $\mathbf{1 . 7}$ & 0.0 & 37.5 & 41.5 & 3.5 & 17.5 & $\begin{array}{c}\text { Areia Argilosa } \\
\text { Marrom-Vermelha }\end{array}$ \\
\hline $\mathbf{3 . 0}$ & 0.0 & 28.0 & 40.0 & 8.0 & 24.0 & $\begin{array}{c}\text { Areia Argilosa } \\
\text { Marrom-Vermelha }\end{array}$ \\
\hline $\mathbf{3 . 7}$ & 0.0 & 32.5 & 40.5 & 5.5 & 21.5 & $\begin{array}{c}\text { Areia Argilosa } \\
\text { Marrom-Vermelha }\end{array}$ \\
\hline $\mathbf{7 . 0}$ & 0.0 & 32.0 & 40.5 & 7.5 & 20.0 & $\begin{array}{c}\text { Areia Argilosa } \\
\text { Marrom-Vermelha }\end{array}$ \\
\hline
\end{tabular}

\subsubsection{Limites de Consistência}

O limite de liquidez (LL) e o limite de plasticidade (LP) foram determinados com o material que passou pela peneira 40 , conforme preconizam as normas NBR 6459 e NBR 7180. Esses ensaios foram realizados para todas as amostras deformadas coletadas.

Os valores dos limites de liquidez (LL) e de plasticidade (LP), bem como dos índices de plasticidade $(I P)$ se encontram na Tabela 3.4.

Tabela 3.4. Limites de consistência obtidos para as amostra coletadas no entorno do aterro de resíduos sólidos de Bauru.

\begin{tabular}{|c|c|c|c|}
\hline Prof. (m) & LL (\%) & LP (\%) & IP (\%) \\
\hline $\mathbf{1 . 7}$ & 22.3 & 16.2 & 6.1 \\
\hline $\mathbf{3 . 0}$ & 27.0 & 22.0 & 5.0 \\
\hline $\mathbf{3 . 7}$ & 26.2 & 16.2 & 10.0 \\
\hline $\mathbf{7 . 0}$ & 27.0 & 16.6 & 10.4 \\
\hline
\end{tabular}




\subsubsection{Adsorção de Azul de Metileno}

O azul de metileno é um corante orgânico que apresenta a composição $\mathrm{C}_{16} \mathrm{H}_{18} \mathrm{~N}_{3} \mathrm{SCl} .3 \mathrm{H}_{2} \mathrm{O}$ e é denominado em Química como "cloridrato de metiltiamina". Caracteriza-se como um corante catiônico, ou seja, em solução aquosa que se apresenta dissociada em ânions de cloreto e em cátions de azul de metileno $\left(\mathrm{C}_{16} \mathrm{H}_{18}\right.$ $\mathrm{N}_{3} \mathrm{~S}^{+}$). $\mathrm{O}$ ensaio pode ser feito pelo método do colorímetro ou pelo método do papel filtro, sendo esse último adotado neste estudo.

Inicialmente, preparou-se uma suspensão adicionando-se 2 a $4 \mathrm{~g}$ de solo em $10 \mathrm{ml}$ de água destilada. Esta suspensão foi mantida em constante agitação, enquanto alguns mls de solução de azul de metileno iam sendo adicionados a ela, e dela era obtida uma gota num papel filtro. Este procedimento ocorreu até que surgisse uma auréola azul clara em torno da mancha azul escura no papel filtro.

O ensaio de adsorsão de azul de metileno permite que se calcule a quantidade de azul de metileno consumida para cada 100 gramas de solo (VB), a capacidade de troca de cátions (CTC) e a superfície específica dos argilo-minerais (S.E.) e a quantidade de azul de metileno adsorvido por 100 gramas de argila (Acb). Detalhes sobre esse ensaio podem ser obtidos em PEJON (1992) e os resultados obtidos estão apresentados nas Tabelas 3.5 e 3.6.

Tabela 3.5. Resultados obtidos para o ensaio de adsorção de azul de metileno para amostra de solo retirada a $3.0 \mathrm{~m}$.

\begin{tabular}{|c|c|c|c|c|}
\hline Prof. (m) & \multicolumn{2}{|l|}{ Azul de Metileno } & \multicolumn{2}{|l|}{ Amostra de Solo } \\
\hline \multirow[t]{2}{*}{3.0} & Quantidade Última (ml) & 14 & Massa $(\mathrm{g})$ & 2.61 \\
\hline & Quantidade Penúltima (ml) & 12 & Temp. Ambiente $\left({ }^{\circ} \mathrm{C}\right)$ & 26 \\
\hline CTC & \multicolumn{4}{|c|}{$2.5 \mathrm{meq} / 100 \mathrm{~g}$} \\
\hline VB & \multicolumn{4}{|c|}{$0.81 \mathrm{~g} / 100 \mathrm{~g}$} \\
\hline S.E. & \multicolumn{4}{|c|}{$19.7 \mathrm{~m}^{2} / \mathrm{g}$} \\
\hline Acb & \multicolumn{4}{|c|}{$3.38 \mathrm{~g} / 100 \mathrm{~g}$} \\
\hline $\begin{array}{c}\text { Interpretação - } \\
\text { LAUTRIN (1989) }\end{array}$ & \multicolumn{4}{|c|}{ Caulinita - Pouco Ativa } \\
\hline
\end{tabular}


Tabela 3.6. Resultados obtidos para o ensaio de adsorção de azul de metileno para amostra de solo retirada a $3.7 \mathrm{~m}$.

\begin{tabular}{|c|c|c|c|c|}
\hline Prof. (m) & \multicolumn{2}{|l|}{ Azul de Metileno } & \multicolumn{2}{|l|}{ Amostra de Solo } \\
\hline \multirow{2}{*}{3.7} & Quantidade Última (ml) & 25 & Massa (g) & 2.54 \\
\hline & Quantidade Penúltima (ml) & 22 & Temp. Ambiente $\left({ }^{\circ} \mathrm{C}\right)$ & 26 \\
\hline CTC & \multicolumn{4}{|c|}{$4.6 \mathrm{meq} / 100 \mathrm{~g}$} \\
\hline VB & \multicolumn{4}{|c|}{$1.48 \mathrm{~g} / 100 \mathrm{~g}$} \\
\hline S.E. & \multicolumn{4}{|c|}{$36.1 \mathrm{~m}^{2} / \mathrm{g}$} \\
\hline Acb & \multicolumn{4}{|c|}{$6.88 \mathrm{~g} / 100 \mathrm{~g}$} \\
\hline $\begin{array}{c}\text { Interpretaçãa - } \\
\text { LAUTRIN (1989) }\end{array}$ & \multicolumn{4}{|c|}{ Caulinita - Normal } \\
\hline
\end{tabular}

\subsubsection{Metodologia MCT}

\section{a) Classificação}

Os ensaios de compactação Mini-MCV e de perda por imersão, conforme proposto por NOGAMI \& VILLIBOR (1995), foram realizados nas quatro amostras de solo retiradas a 1.7, 3.0, 3.7 e $7.0 \mathrm{~m}$ de profundidade. Os resultados desses ensaios permitem a classificação dos solos no sistema de classificação MCT, desenvolvido para utilização dos solos tropicais em pavimentação.

As amostras de solo ensaiadas pertencem ao Grupo LA', como mostra a Carta de Classificação MCT da Figura 3.6. Segundo a classificação MCT, os solos pertencentes a esse grupo são areias argilosas, colapsíveis e com permeabilidade relativamente baixa, possuindo uma boa capacidade de suporte quando compactados. 


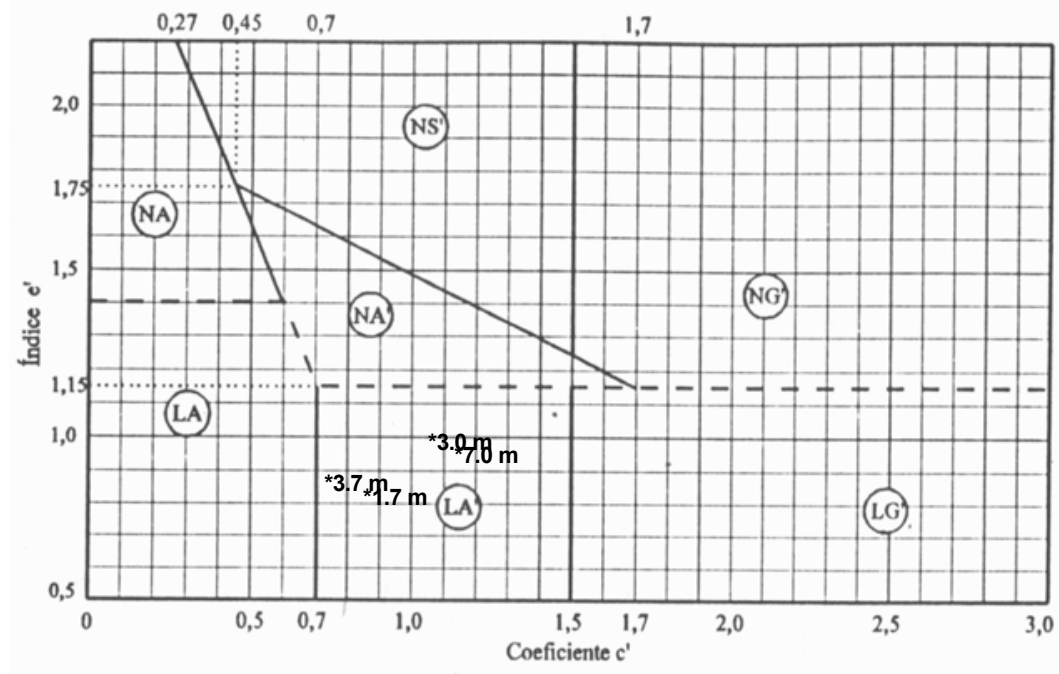

L= LATERÍTICO

$\mathrm{N}=\mathrm{NÃO}$ LATERÍTICO

$A=$ AREIA

$\mathrm{A}^{\prime}=$ ARENOSO

$\mathrm{G}^{\prime}=\mathrm{ARGILOSO}$

S'= SILTOSO

Figura 3.6. Carta de Classificação MCT- Posição das amostras ensaiadas.

\section{b) Mini-CBR e Associados}

Ensaios de Mini-Proctor, Mini-CBR, expansão e retração foram realizados nas amostras de solo retiradas a 3.0 e a $3.7 \mathrm{~m}$ de profundidade, conforme proposto por NOGAMI \& VILLIBOR (1995). A energia de compactação utilizada foi a intermediária. O ensaio de expansão foi feito com sobrecarga e o de retração sem sobrecarga. Os resultados desses ensaios suplementam os da classificação MCT e permitem uma melhor previsão do comportamento de solos tropicais compactados, especialmente para uso em pavimentação.

Nas Figuras 3.7 e 3.8 tem-se uma síntese dos resultados dos ensaios MiniCBR e associados. Constam nessas figuras as curvas de Mini-Proctor, Mini-CBR, expansão e retração. Na Tabela 3.8, tem-se uma síntese dos resultados dos ensaios realizados para cada amostra. 
Tabela 3.7. Mini-CBR e associados - Energia Intermediária - Síntese de resultados.

\begin{tabular}{|c|c|c|}
\hline Parâmetros & $\mathbf{3 . 0} \mathbf{~ m}$ & $\mathbf{3 . 7} \mathbf{~ m}$ \\
\hline$\rho_{d \max }\left(\mathrm{g} / \mathrm{cm}^{3}\right)$ & 2.05 & 1.93 \\
\hline$w_{o t}(\%)$ & 10.6 & 12.8 \\
\hline $\begin{array}{c}\text { CBR na umidade ótima sem } \\
\text { imersão (\%) }\end{array}$ & 17.0 & 22.0 \\
\hline $\begin{array}{c}\text { RIS- Redução no valor de } \\
\text { suporte pela imersão em água, } \\
\text { na } w_{o t} \text { de compactação (\%) }\end{array}$ & 97.8 & 50.0 \\
\hline Expansão na umidade ótima (\%) & 0.00 & 0.35 \\
\hline Retração na umidade ótima (\%) & 0.00 & 1.00 \\
\hline
\end{tabular}

A partir destes resultados, observa-se que os valores de RIS são elevados, acima de $50 \%$, o que é uma peculiaridade dos solos lateríticos arenosos, segundo NOGAMI \& VILLIBOR (1995).

Observa-se também a baixa expansão das amostras ensaiadas na umidade ótima, que também é uma característica dos solos lateríticos arenosos, sendo a expansão apreciável apenas no ramo seco das curvas de compactação.

Os valores de expansão e contração, apresentados na Tabela 3.7, estão coerentes com os resultados obtidos a parir dos ensaios de adsorção de azul de metileno, quando a amostra coletada a $3.7 \mathrm{~m}$ de profundidade apresentou maior superfície específica que a amostra coletada a $3.0 \mathrm{~m}$, que pode ser a razão da maior expansão e contração observadas. 

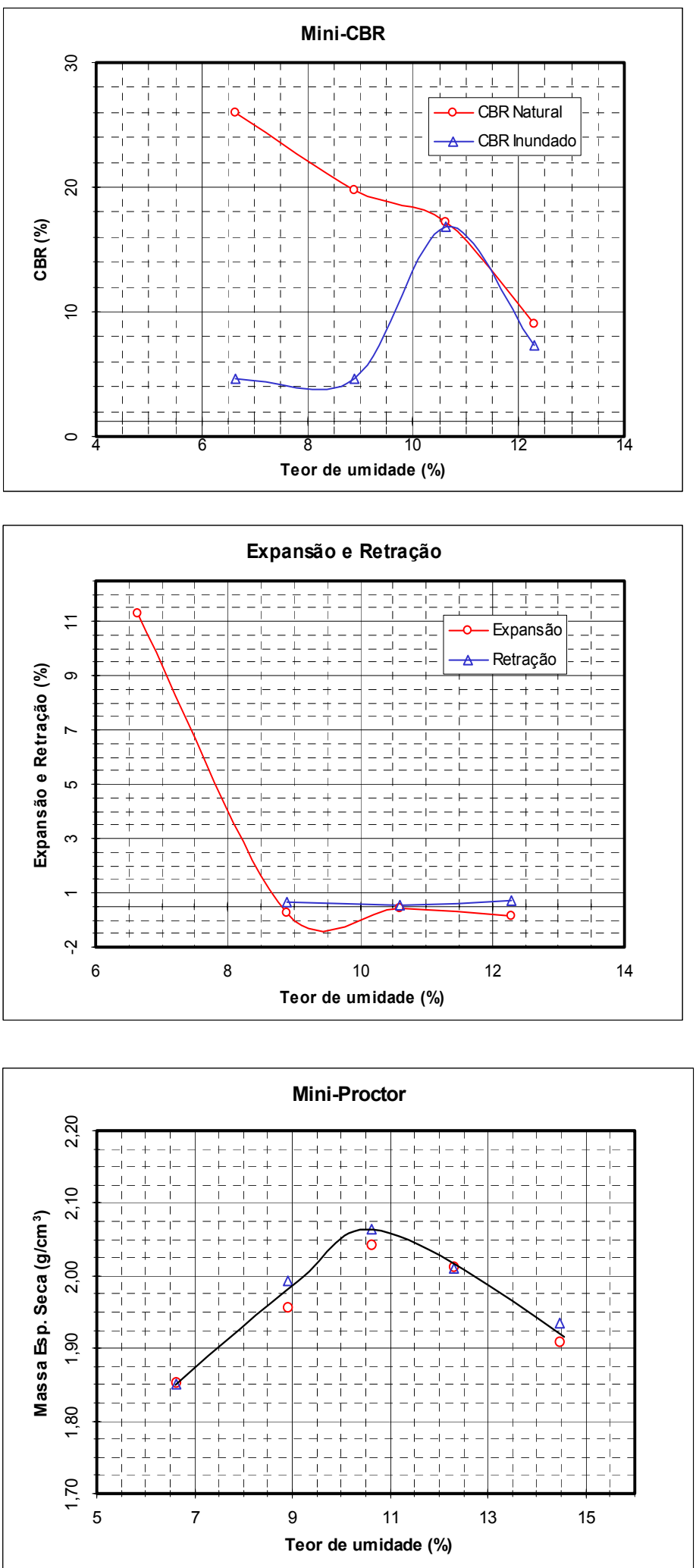

Figura 3.7. Metodologia MCT - Ensaios mini-CBR e associados para amostra a 3.0 m - Energia Intermediária. 

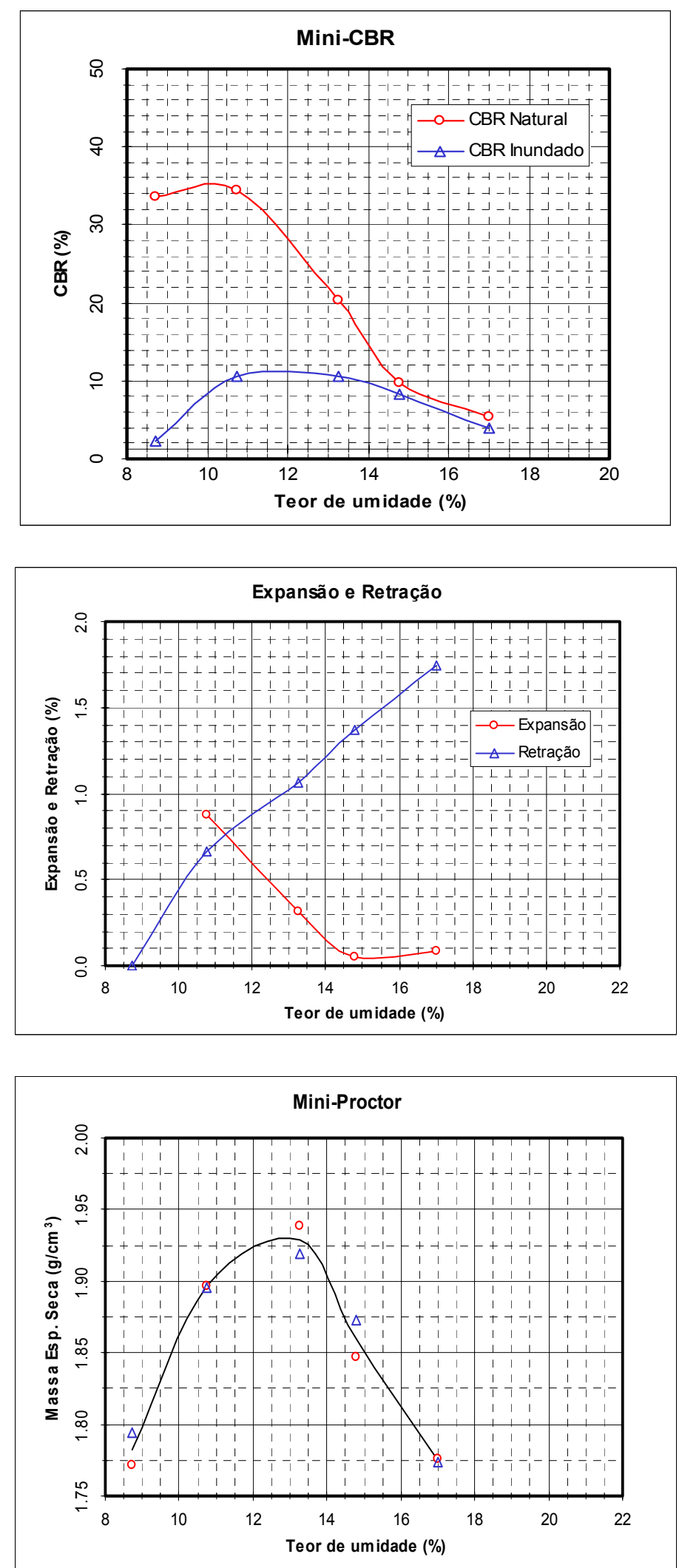

Figura 3.8. Metodologia MCT - Ensaios mini-CBR e associados para amostra a 3.7 $\mathrm{m}$ - Energia Intermediária. 


\subsubsection{Compactação: Proctor na Energia Normal}

O ensaio normal de compactação (Proctor Normal) foi realizado conforme preconiza a NBR 7182/86, com a reutilização das amostras.

Nas Figuras 3.9, 3.10 e 3.11 tem-se as curvas de compactação para as amostras retiradas a $1.7,3.0$ e $3.7 \mathrm{~m}$ de profundidade, respectivamente. Na Tabela 3.8 estão apresentados os valores do peso específico aparente seco $\left(\gamma_{d \max }\right)$ e o correspondente valor da umidade ótima $\left(w_{o t}\right)$.

Tabela 3.8. Parâmetros de compactação (energia normal) obtidos para o entorno do aterro de resíduos sólidos de Bauru.

\begin{tabular}{|c|c|c|}
\hline Prof. (m) & $\gamma_{d \max }\left(\mathbf{g} / \mathbf{c m}^{\mathbf{3}}\right)$ & $\boldsymbol{w}_{\text {ot }}(\mathbf{\%})$ \\
\hline 1.7 & 1.93 & 11.6 \\
\hline 3.0 & 1.86 & 11.9 \\
\hline 3.7 & 1.89 & 12.8 \\
\hline
\end{tabular}

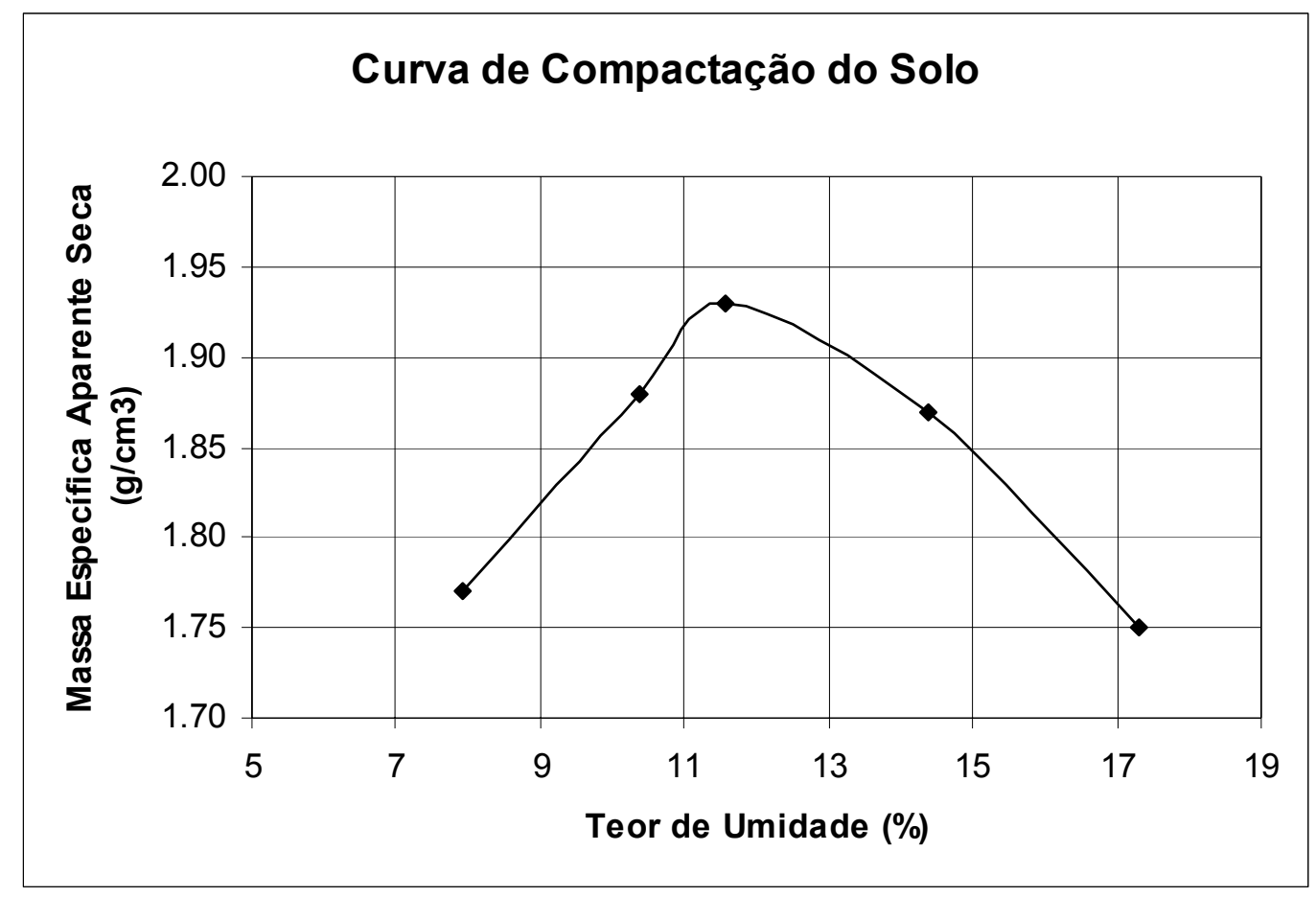

Figura 3.9. Curva de Compactação Proctor (Energia Normal) para a profundidade de $1.7 \mathrm{~m}$. 


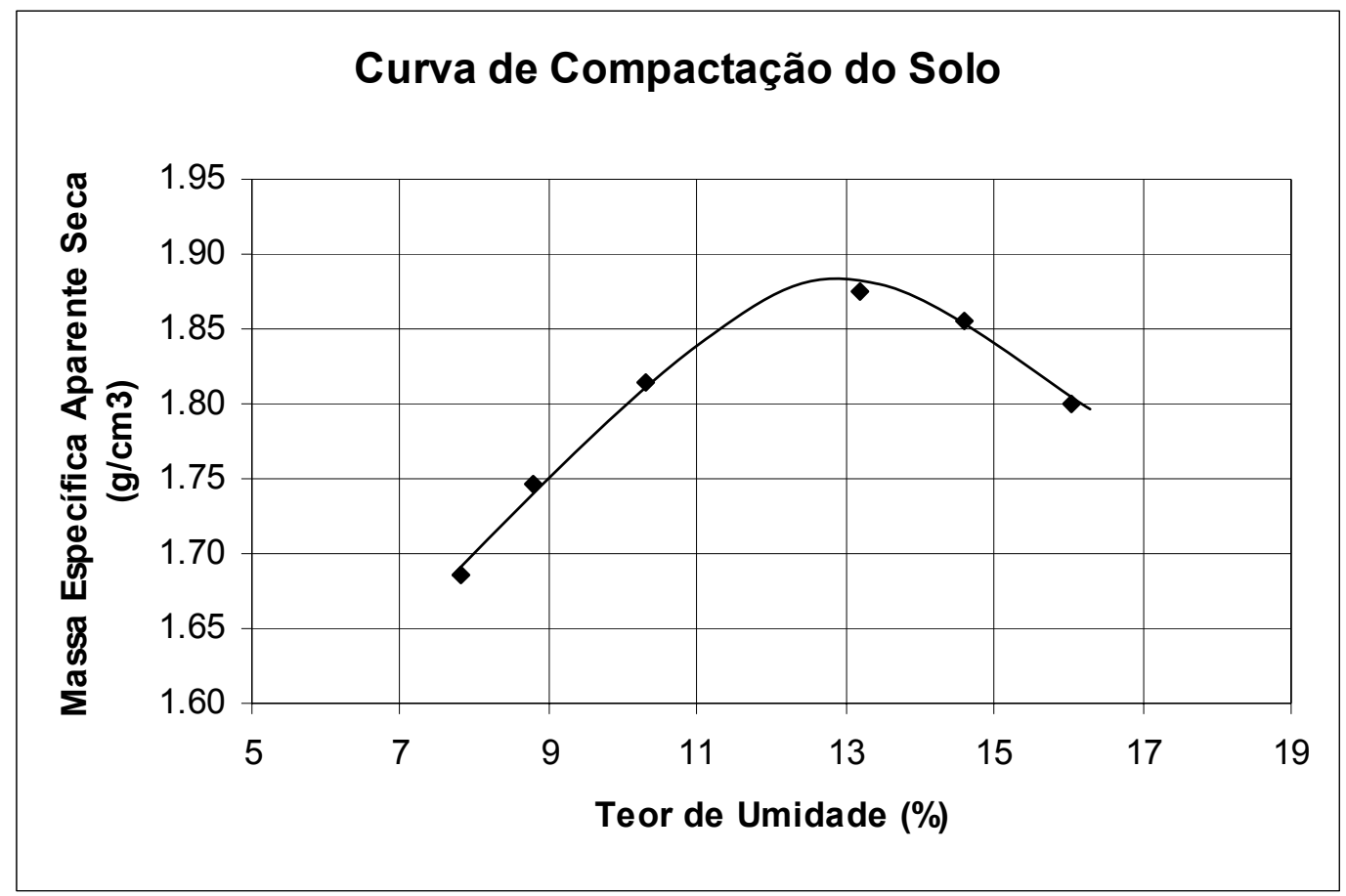

Figura 3.10. Curva de Compactação Proctor (Energia Normal) para a profundidade de $3.0 \mathrm{~m}$.

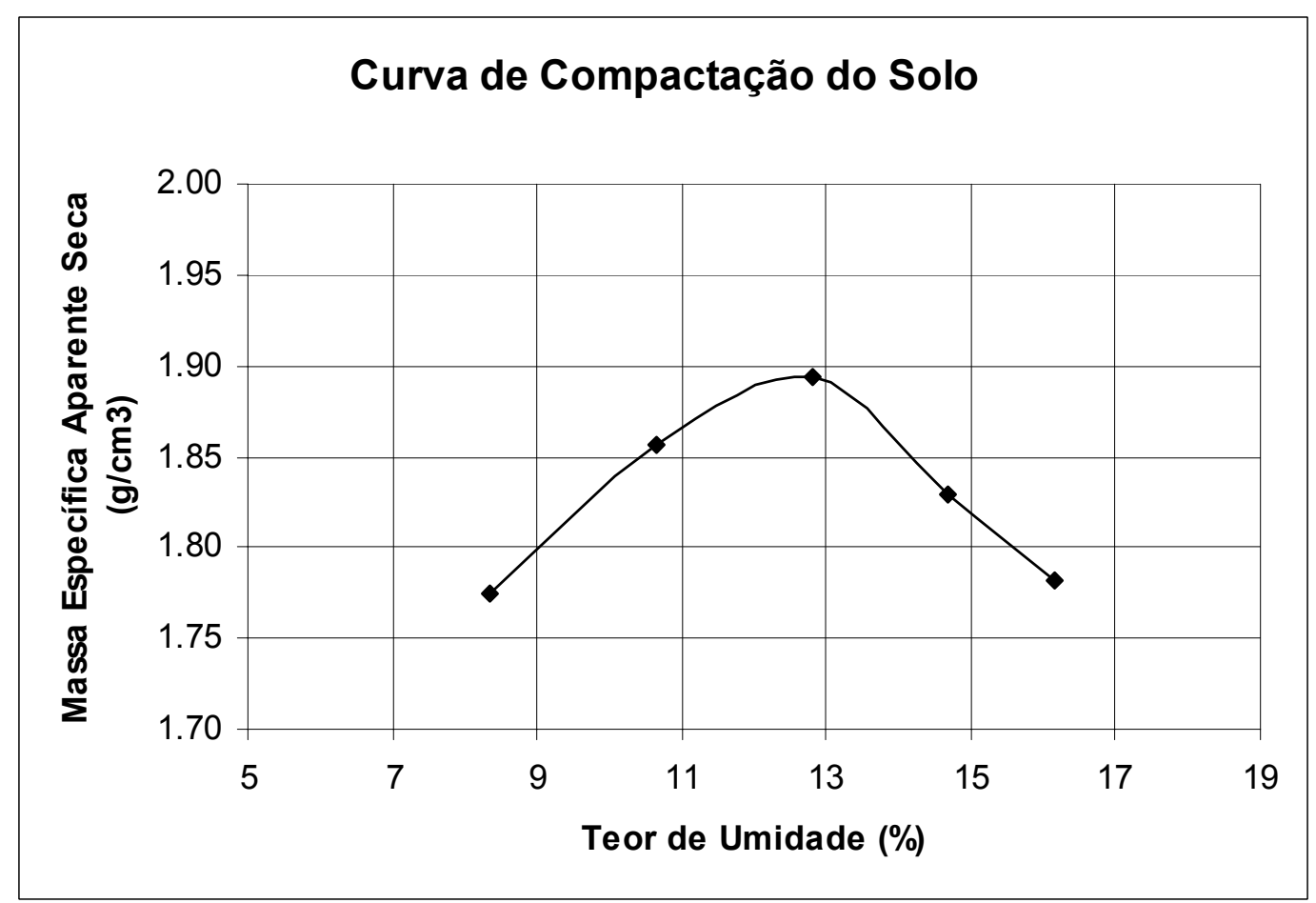

Figura 3.11. Curva de Compactação Proctor (Energia Normal) para a profundidade de $3.7 \mathrm{~m}$. 


\subsubsection{Ensaio de Permeabilidade}

O ensaio de permeabilidade realizado nas amostras de $1.7 \mathrm{~m}$ e de $3.0 \mathrm{~m}$ de profundidade do solo do aterro de resíduos sólidos de Bauru foi o de carga variável.

Inicialmente, prepararam-se os corpos de prova com $50 \mathrm{~mm}$ de diâmetro e 80 mm de altura, e mediram-se as umidades, as dimensões exatas e os pesos. Foi então realizada a impermeabilização do corpo de prova, seguindo o critério mostrado na Figura 3.12. A saturação do corpo de prova foi realizada a partir de processos de circulação de água durante algum tempo e também foi determinado o diâmetro interno do tubo de carga. Fizeram-se duas marcas de referência ao lado do tubo de carga a ser utilizado, que determinariam o inicio e o fim do ensaio. Permitiu-se que a água percolasse pelo corpo de prova até atingir a marca inferior, repetindo-se algumas vezes. O ensaio foi iniciado quando o menisco d'água estava na marca superior, contando-se o tempo até ele atingir a marca inferior. Repetiu-se mais algumas vezes este procedimento e determinou-se a umidade após o término do ensaio.

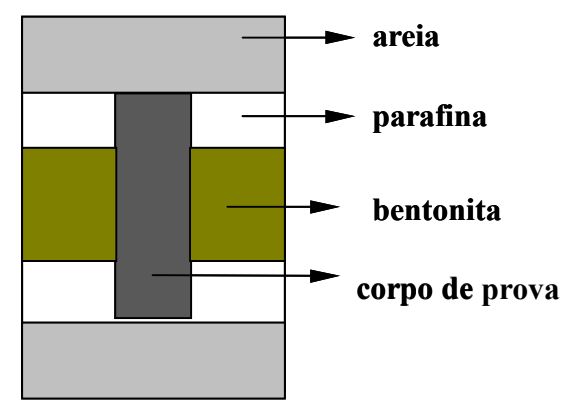

Figura 3.12. Desenho esquemático do interior do permeâmetro utilizado no ensaio.

Os coeficientes de permeabilidade corrigidos para a temperatura de $20^{\circ} \mathrm{C}$ são apresentados na Tabela 3.9, a seguir, para as duas amostras ensaiadas.

Tabela 3.9. Coeficientes de permeabilidade obtidos com a realização de ensaios com carga variável.

\begin{tabular}{|c|c|c|}
\hline Profundidade (m) & $\mathbf{1 . 7}$ & $\mathbf{3 . 0}$ \\
\hline $\mathbf{K}_{\mathbf{2 0}}(\mathbf{m} / \mathbf{s})$ & $2.5 \times 10^{-7}$ & $4.5 \times 10^{-7}$ \\
\hline
\end{tabular}




\subsubsection{Ensaio de Compressão Edométrica}

O ensaio de compressão edométrica (ou de adensamento) foi realizado utilizando-se uma prensa previamente ajustada e calibrada. Um corpo de prova talhado da amostra indeformada retirada de $1.7 \mathrm{~m}$ de profundidade foi submetido a uma série de ensaios em sua umidade natural.

O equipamento para o ensaio consta essencialmente de uma prensa de carregamento e de um anel para colocação da amostra (indeformada). Este anel tem a função de impedir a deformação lateral do corpo de prova, contendo duas pedras porosas, que permitem a drenagem, além de uma base e um cabeçote rígido, através do qual as cargas são transmitidas. O anel tem diâmetro cerca de três vezes a altura, com o objetivo de reduzir o efeito de atrito lateral.

O carregamento é feito por etapas, mantendo-se as cargas por tempo necessário para estabilização das deformações, quando elas são então elevadas para o dobro do seu valor anterior.

$\mathrm{Na}$ Tabela 3.10, a seguir, são mostrados os índices físicos da amostra ensaiada.

Tabela 3.10. Índices físicos da amostra natural coletada a $1.7 \mathrm{~m}$ de profundidade em talude do entorno do aterro de resíduos sólidos de Bauru.

\begin{tabular}{|l|c|}
\hline Massa específica natural $\mathbf{( g / \mathbf { c m } ^ { 3 } )}$ & 1.552 \\
\hline Teor de umidade $\mathbf{( \% )}$ & 11.41 \\
\hline Massa específica seca $\mathbf{( g / \mathbf { c m } ^ { 3 } )}$ & 1.393 \\
\hline Massa específica dos sólidos $\mathbf{( g / \mathbf { c m } ^ { \mathbf { 3 } } )}$ & 2.90 \\
\hline Índice de vazios & 1.081 \\
\hline Grau de saturação (\%) & 30.6 \\
\hline
\end{tabular}

A curva de variação do índice de vazios versus o log da pressão aplicada é apresentada na Figura 3.13 para a amostra ensaiada. A partir dos resultados deste ensaio obteve-se os seguintes parâmetros:

- Índice de Compressão $(\mathrm{Cc})=0.32$;

- Índice de Recompressão $(\mathrm{Cr})=0.97$;

- Tensão de Pré-Adensamento ( $\sigma$ ’a) $=95 \mathrm{kPa}$. 


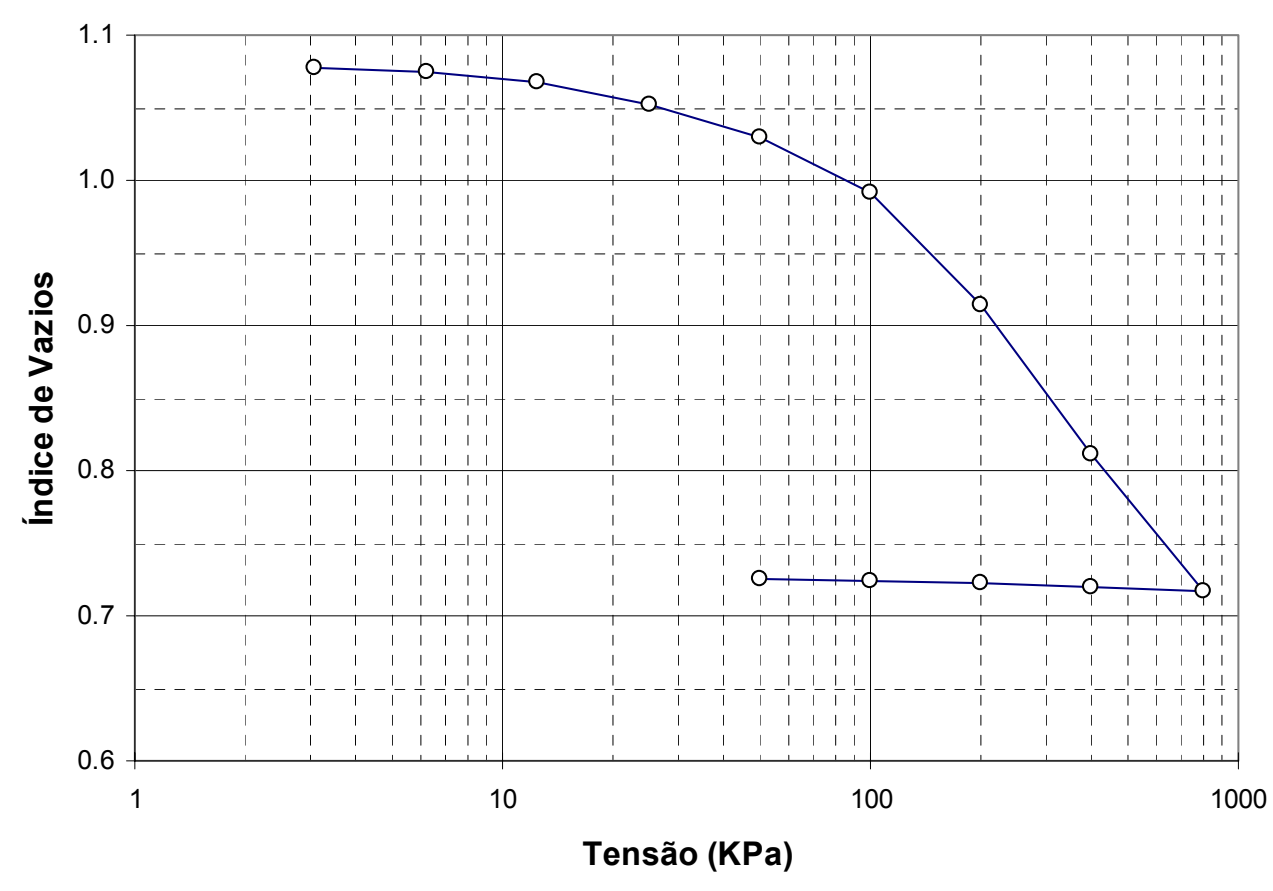

Figura 3.13. Curva de compressão edométrica obtida para o entorno do aterro de resíduos sólidos de Bauru.

\subsubsection{Resultados dos Ensaios Previamente Realizados para o EIA/RIMA}

A Tabela 3.11 apresenta os resultados dos ensaios de laboratório realizados com amostras coletadas no local antes da implantação do aterro. Estas informações foram diretamente obtidas a partir do EIA/RIMA (1992), que apresenta os resultados dos ensaios de Proctor na energia normal, de limites de consistência, de peso específico dos sólidos, de metodologia MCT e de permeabilidade com carga variável em corpos de prova de dimensões reduzidas segundo a metodologia MCT.

Também foram realizados ensaios de granulometria conjunta para algumas amostras coletadas durante as sondagens SPT, realizadas em dezembro de $1991 \mathrm{e}$ janeiro de 1992 (Figura 3.14). Estes ensaios confirmam a característica de areia argilosa do solo local, já observada anteriormente. 


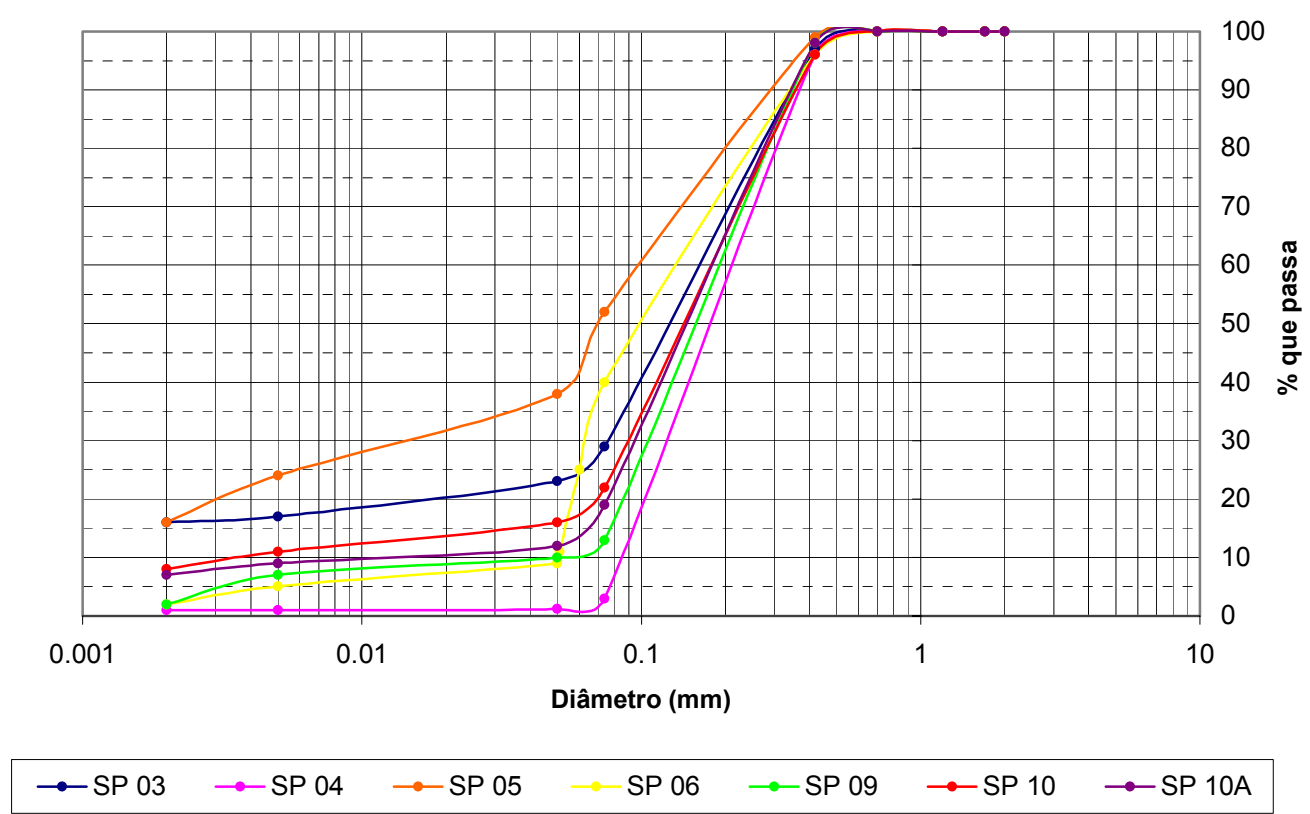

Figura 3.14. Curvas granulométricas obtidas para amostras coletadas quando da elaboração do EIA/RIMA (1992).

\subsubsection{Perfil Típico que Ocorre no Local}

A fim de se obter um perfil representativo do local onde tem-se a provável pluma de contaminação, selecionaram-se resultados das sondagens SPT realizadas na região a oeste do aterro, como mostra a Figura 3.15. Nas Figuras 3.16 e 3.17 tem-se representado o perfil típico interpretado que ocorre no local.

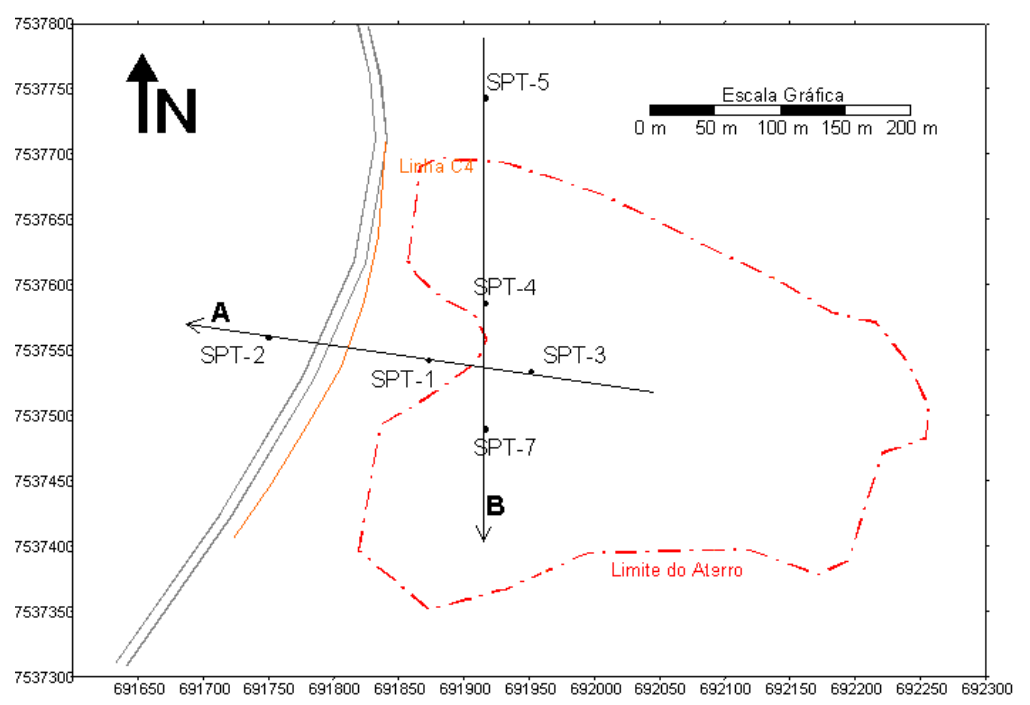

Figura 3.15. Localização dos perfis A e B no aterro de resíduos sólidos de Bauru. 
Tabela 3.11. Resultados dos ensaios de caracterização realizados quando da elaboração do EIA/RIMA (1992).

\begin{tabular}{|c|c|c|c|c|c|c|c|c|c|c|c|c|c|c|c|c|c|c|c|}
\hline \multirow[t]{2}{*}{ Amostra } & \multirow[t]{2}{*}{$\begin{array}{c}\gamma_{\mathrm{s}} \\
\left(\mathrm{KN} / \mathrm{m}^{3}\right)\end{array}$} & \multicolumn{5}{|c|}{$\begin{array}{c}\text { Composição Granulométrica (NBR } \\
6502 / 95)\end{array}$} & \multicolumn{3}{|c|}{$\begin{array}{c}\text { Limites de } \\
\text { Consistência }\end{array}$} & \multicolumn{5}{|c|}{ Metodologia MCT } & \multicolumn{2}{|c|}{$\begin{array}{l}\text { Parâmetros de } \\
\text { Compactação }\end{array}$} & \multicolumn{3}{|c|}{ Ensaio de Permeabilidade } \\
\hline & & $\begin{array}{c}\text { Areia } \\
\text { Média } \\
(\%)\end{array}$ & $\begin{array}{c}\text { Areia } \\
\text { Fina } \\
(\%)\end{array}$ & $\begin{array}{l}\text { Silte } \\
(\%)\end{array}$ & $\begin{array}{c}\text { Argila } \\
(\%)\end{array}$ & Textura & $\begin{array}{l}L L \\
(\%)\end{array}$ & $\begin{array}{l}\mathbf{L P} \\
(\%)\end{array}$ & $\begin{array}{l}\text { IP } \\
(\%)\end{array}$ & $\mathbf{c}^{\prime}$ & $\begin{array}{l}\mathbf{P i} \\
(\%)\end{array}$ & $d^{\prime}$ & $\mathbf{e}^{\prime}$ & Grupo & $\begin{array}{c}\rho_{\mathrm{d}} \\
\left(\mathrm{g} / \mathrm{cm}^{3}\right)\end{array}$ & $\begin{array}{l}\mathbf{w}_{\text {ot }} \\
(\%)\end{array}$ & $\begin{array}{c}\rho_{d} \\
\left(g / \mathrm{cm}^{3}\right)\end{array}$ & $\begin{array}{l}\mathrm{w}_{\text {ot }} \\
(\%)\end{array}$ & $\mathbf{K}(\mathbf{m} / \mathbf{s})$ \\
\hline \multirow[t]{5}{*}{1} & \multirow[t]{5}{*}{26.85} & \multirow[t]{5}{*}{27.0} & \multirow[t]{5}{*}{53.5} & \multirow[t]{5}{*}{5.5} & \multirow[t]{5}{*}{14.0} & \multirow{5}{*}{$\begin{array}{c}\text { Areia } \\
\text { Fina } \\
\text { Argilosa }\end{array}$} & \multirow[t]{5}{*}{ - } & \multirow[t]{5}{*}{-} & \multirow[t]{5}{*}{-} & \multirow[t]{5}{*}{0.77} & \multirow[t]{5}{*}{24} & \multirow[t]{5}{*}{86} & \multirow[t]{5}{*}{0.78} & \multirow[t]{5}{*}{$\mathrm{LA}^{\prime}$} & \multirow[t]{5}{*}{1.858} & \multirow[t]{5}{*}{12.4} & 1.831 & 10.0 & $2.6 \times 10^{-7}$ \\
\hline & & & & & & & & & & & & & & & & & 1.906 & 10.8 & $5.0 \times 10^{-8}$ \\
\hline & & & & & & & & & & & & & & & & & 1.945 & 11.9 & $1.5 \times 10^{-8}$ \\
\hline & & & & & & & & & & & & & & & & & 1.939 & 12.8 & $2.0 \times 10^{-9}$ \\
\hline & & & & & & & & & & & & & & & & & 1.909 & 13.8 & $1.2 \times 10^{-9}$ \\
\hline \multirow[t]{4}{*}{2} & \multirow[t]{4}{*}{28.24} & \multirow[t]{4}{*}{20.0} & \multirow[t]{4}{*}{36.0} & \multirow[t]{4}{*}{13.0} & \multirow[t]{4}{*}{31.0} & \multirow{4}{*}{$\begin{array}{c}\text { Areia } \\
\text { Fina } \\
\text { Argilosa }\end{array}$} & \multirow[t]{4}{*}{28.4} & \multirow[t]{4}{*}{21.0} & \multirow[t]{4}{*}{7.4} & - & - & - & - & - & 1.828 & 16.0 & - & 13.7 & $1.4 \times 10^{-8}$ \\
\hline & & & & & & & & & & & & & & & & & - & 14.6 & $1.0 \times 10^{-9}$ \\
\hline & & & & & & & & & & & & & & & & & - & 15.3 & $1.0 \times 10^{-9}$ \\
\hline & & & & & & & & & & & & & & & & & - & 17.3 & $3.2 \times 10^{-11}$ \\
\hline
\end{tabular}




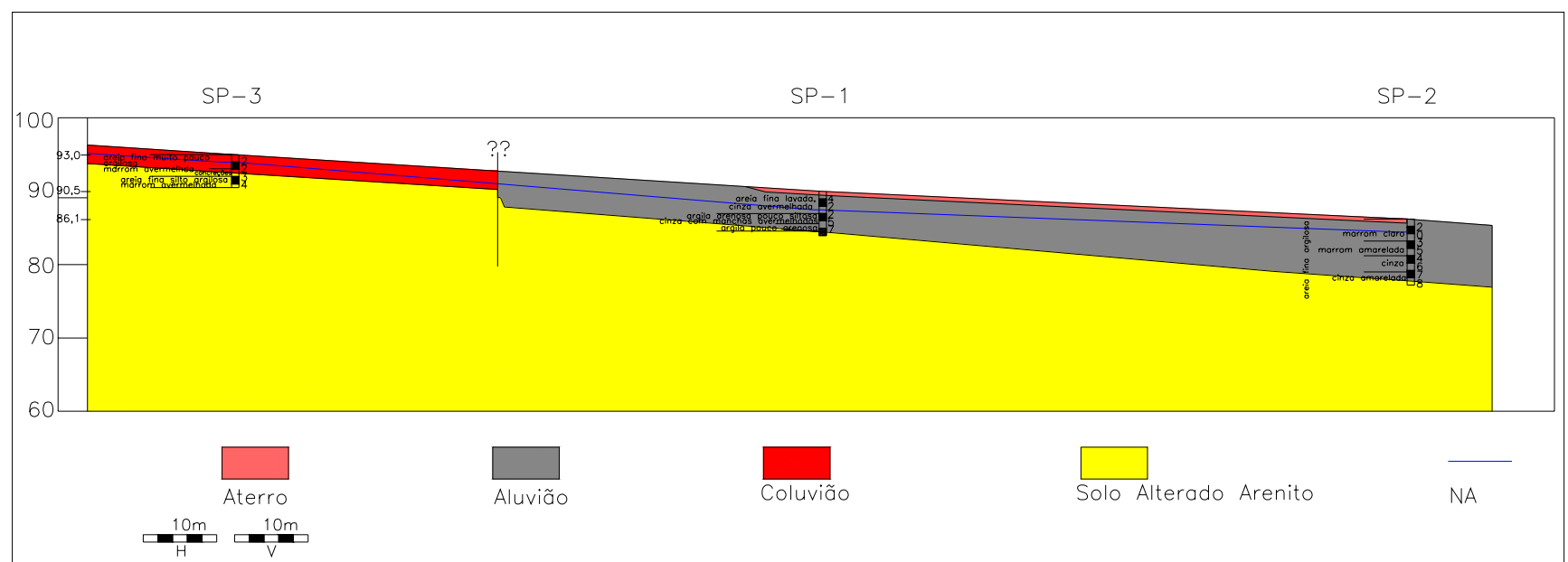

Figura 3.16. Perfil A representativo da região do aterro na direção leste-oeste, transversal à estrada.

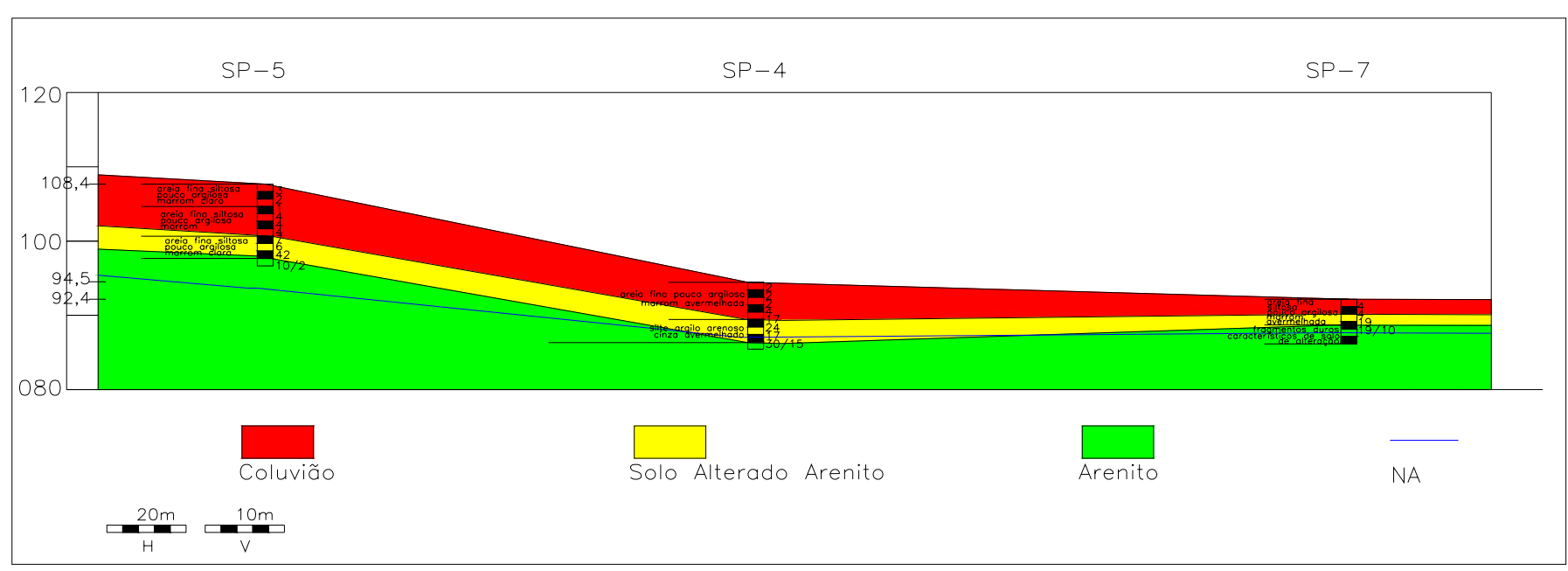

Figura 3.17. Perfil B representativo da região do aterro na direção norte-sul, paralelo à estrada. 


\subsection{Os Ensaios Realizados e Equipamentos Utilizados}

\subsubsection{Sondagens de Eletrorresitividade de Superfície}

Para uma avaliação preliminar da presença de contaminantes no subsolo, foram realizadas sondagens elétricas de superfície, conforme ilustrado nas Fotos 3.8 e 3.9. O equipamento utilizado na área do aterro de resíduos sólidos urbanos de Bauru foi o eletrorresistivímetro do Instituto de Astronomia, Geofísica e Ciências Atmosféricas (IAG), da USP. A descrição detalhada do equipamento utilizado e da técnica empregada pode ser obtida em LAGO (2004).

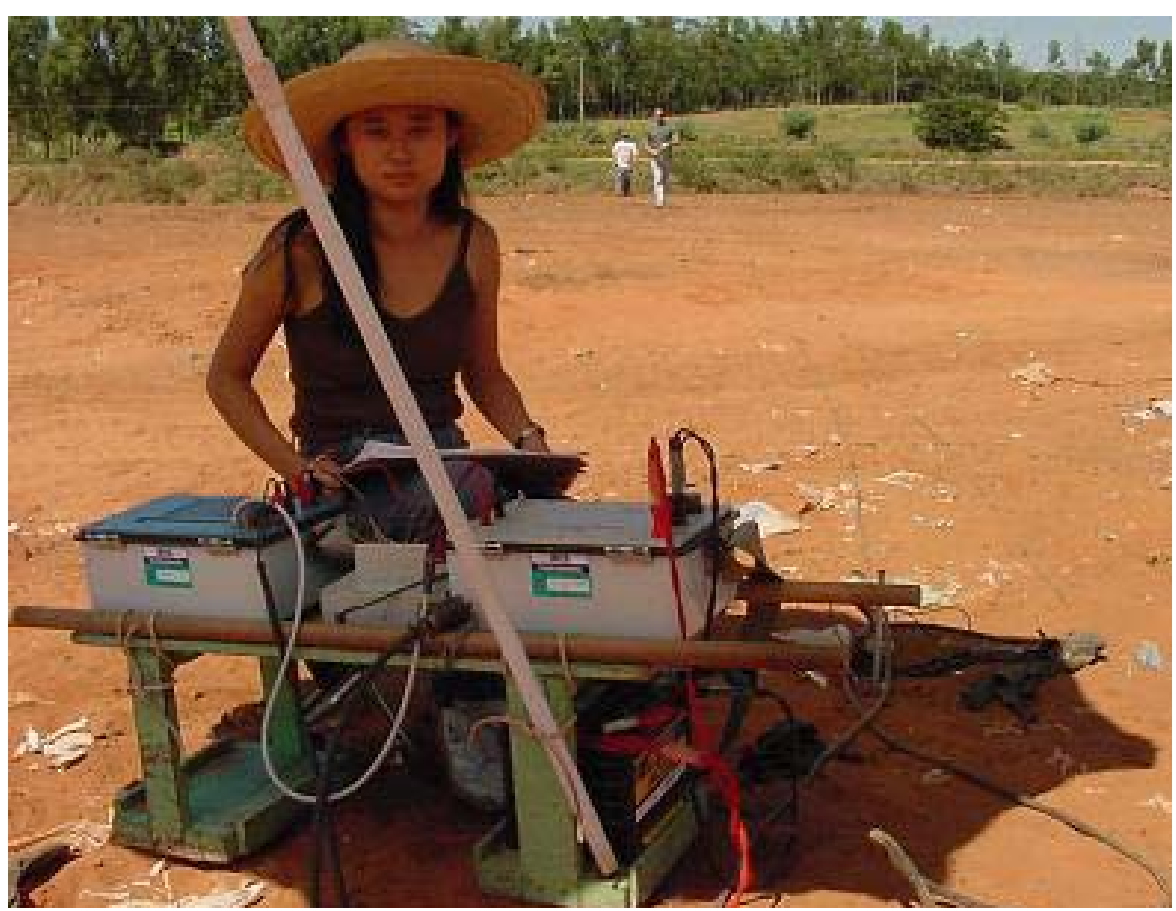

Foto 3.8. Caminhamento elétrico sendo executado no aterro de resíduos sólidos de Bauru. 


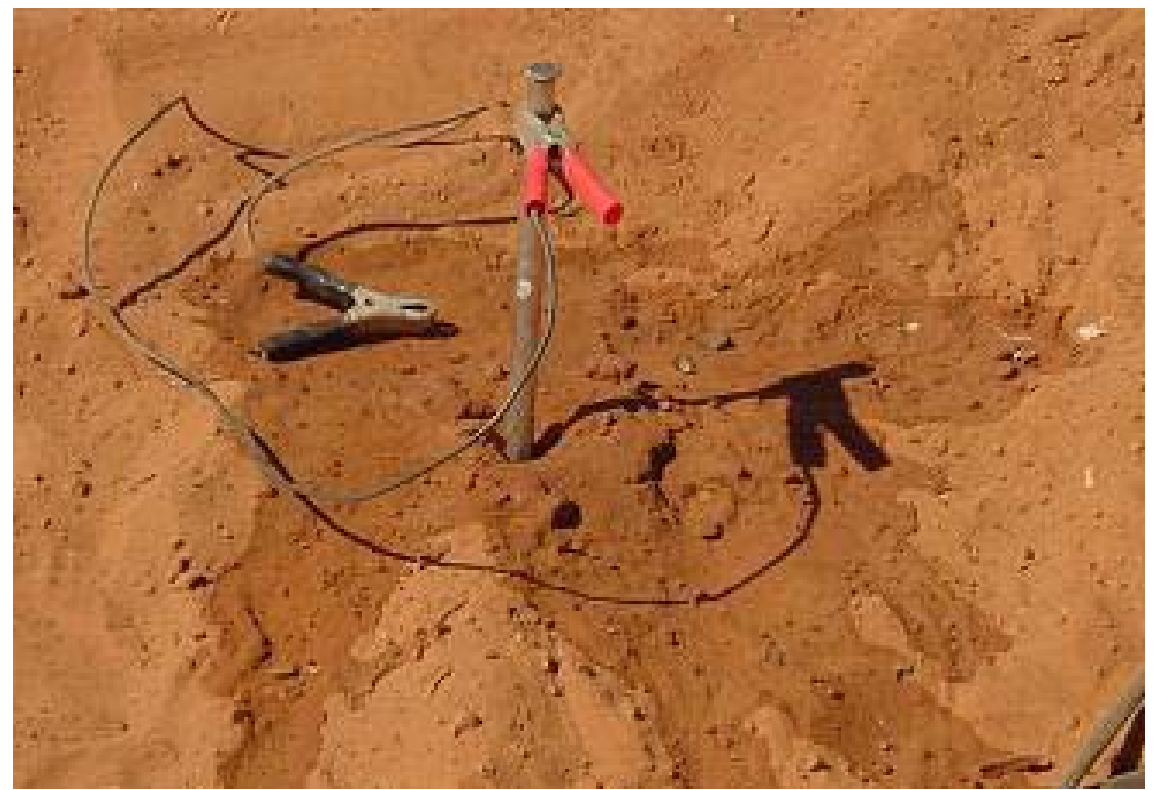

Foto 3.9. Eletrodo cravado no solo do aterro de resíduos sólidos de Bauru.

\subsubsection{Ensaios com o Piezocone (CPTU)}

\subsubsection{Descrição do Piezocone}

O piezocone utilizado nesse trabalho transmite os sinais através de ondas sonoras de fabricação da Geotech $A B \mathbb{B}$. O aparelho possui um inclinômetro incorporado que é útil para monitorar a verticalidade do furo. Ele também possui um transdutor de pressão na posição padrão $\left(\mathrm{U}_{2}\right)$ que, além de permitir o uso de um filtro convencional saturado com água ou glicerina, possibilita ainda o emprego do filtro de cavidade saturado com graxa, recurso que foi empregado no aterro de resíduos sólidos de Bauru e no lixão de Ribeirão Preto. A Foto 3.10 mostra o piezocone utilizado, com pilhas usadas para geração dos sinais sonoros e filtro de cavidade.

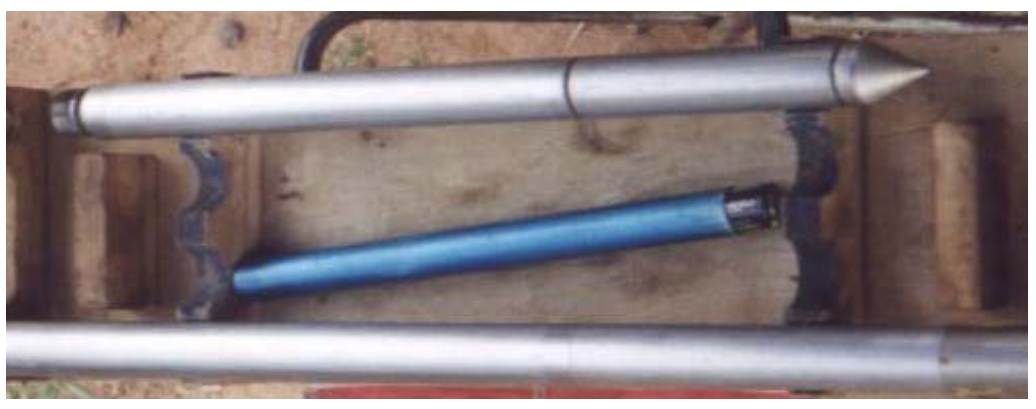

Foto 3.10. Piezocone sem fio com filtro de cavidade, utilizado nas sondagens CPTU. 


\subsubsection{Sistema de Reação}

O equipamento utilizado para penetração do cone foi um penetrômetro multifunção, que possui um sistema hidráulico modelo TG 73 200, com capacidade de 200 $\mathrm{kN}$ em função da possibilidade de ancorar-se ao solo através de um sistema de hastes helicoidais dispostas em sua base. A Foto 3.11 apresenta o penetrômetro multifunção, utilizado.

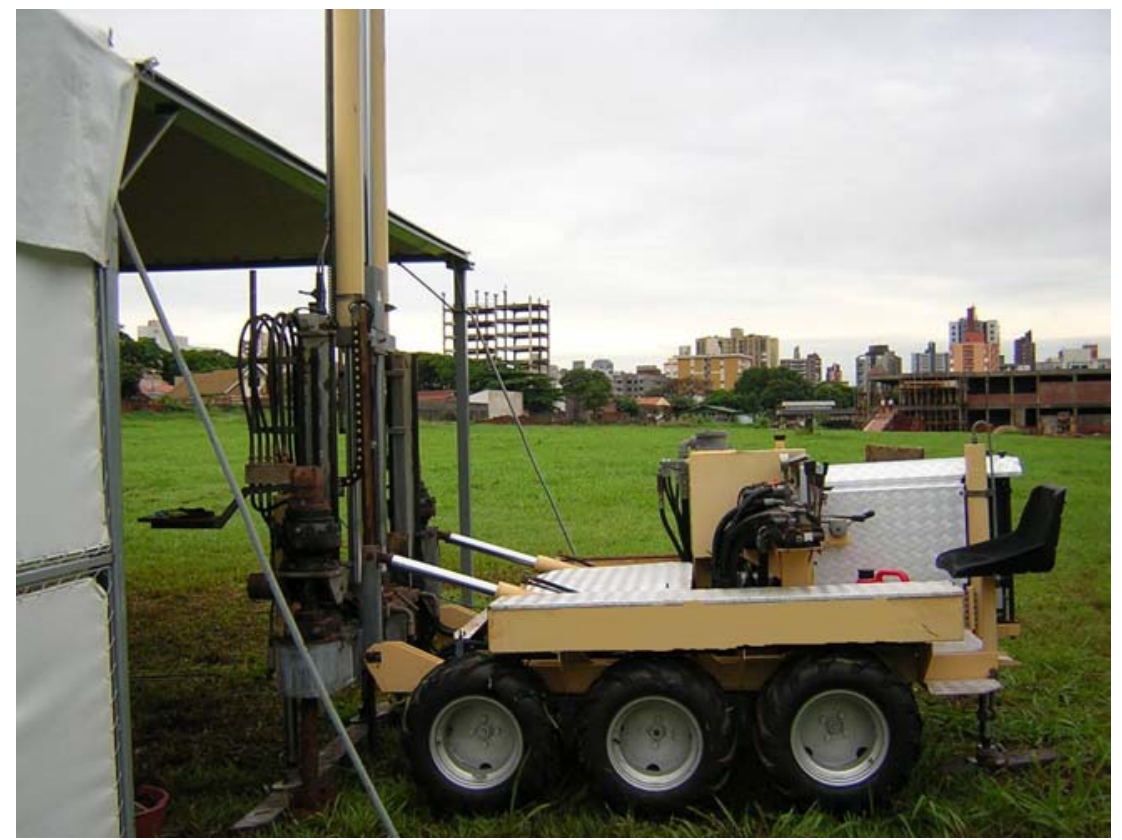

Foto 3.11. Penetrômetro multi-função utilizado nos ensaios com piezocone.

\subsubsection{Saturação do Piezocone}

Nos ensaios realizados no aterro de resíduos sólidos urbanos de Bauru e no lixão de Ribeirão Preto, em todas as sondagens realizadas com o piezocone utilizouse um filtro de cavidade preenchido com graxa ("slot filter") para permitir o registro do excesso de poro-pressão, como descrito por LARSSON (1995). Apenas no ensaio RCPTU 05, em Bauru, foi utilizado o procedimento convencional da pedra porosa saturada com glicerina.

O emprego do filtro de cavidade preenchido com graxa automotiva é mais prático que o uso do filtro poroso saturado com glicerina, pois sua preparação consta apenas em inserir o bico de um tubo de graxa na ponteira cônica, pressionando-o até preencher todas as cavidades da ponteira. O piezocone é virado de cabeça para baixo 
e a cavidade mais interna do transdutor de poro-pressão é preenchido com água deaerada e então a ponteira é parafusada a ele fazendo com que a graxa espirre para fora. $\mathrm{O}$ cone então pode ter fácil manuseio, sem arranjos extras para manter a saturação devido à dureza da graxa que impede que a própria graxa e a água de dentro do transdutor escapem (SGI, 1995).

Já a prática para saturação do filtro poroso consiste em submergi-lo em glicerina aquecida num banho à alto vácuo. Depois de ficar vibrando por algumas horas a glicerina aumenta sua temperatura, o que reduz sua viscosidade e melhora a saturação.

Optou-se pelo emprego da técnica do filtro de cavidade preenchido com graxa automotiva em quase a totalidade dos ensaios realizados com o piezocone, uma vez que grande parte dessas sondagens atravessava grandes pacotes de solo não saturado antes de atingir o nível d'água, o que torna difícil manter a saturação do piezocone quando se utiliza o procedimento convencional da pedra porosa saturada com glicerina.

\subsubsection{Execução do Ensaio}

Os ensaios CPTU foram realizados nas áreas estudas até cerca de $20 \mathrm{~m}$ de profundidade, determinando-se a resistência de ponta, atrito lateral e poro-pressão na posição $\mathrm{u}_{2}$, a intervalos regulares de $25 \mathrm{~mm}$. Monitorava-se sempre a inclinação do furo através de inclinômetro incorporado ao piezocone para garantir a qualidade do resultado e especialmente para não comprometer o aparelho utilizado.

\subsubsection{Ensaio de Dissipação de Poro-Pressão}

No aterro de resíduos sólidos de Bauru, foram possíveis a realização de 5 dissipações, nas sondagens RCPTU 1, 4, 5, 6 e 8.

\subsubsection{Tratamento de Dados e Interpretação dos Resultados}

Os dados obtidos foram transferidos para planilhas eletrônicas, tratados e apresentados em forma gráfica para permitir a interpretação do perfil geotécnico. 


\subsubsection{Piezocone de Resistividade}

Foram realizados ensaios RCPTU em diversos locais do aterro de resíduos de Bauru. Para garantir a qualidade dos dados obtidos com o piezocone de resistividade, desenvolveu-se um sistema para checagem e calibração do dispositivo para medida da resistividade no Laboratório de Geotecnia de Solos Tropicais da Unesp de Bauru.

\subsubsection{Sistema para Calibração e Checagem do Dispositivo para Medida da Resistividade}

Também para as sondagens RCPTU, a calibração e a checagem são fundamentais para a garantia da qualidade dos dados de resistividade obtidos nesse ensaio. Desta forma, desenvolveu-se um sistema para calibração e checagem, o qual será descrito detalhadamente a seguir.

O sistema desenvolvido é constituído basicamente de um reservatório com diâmetro tal que não houvesse influência da borda nas leituras, permitindo que o sensor fosse colocado na posição vertical, e cujo material fosse inerte, não causando a contaminação da água a ser ensaiada. A Foto 3.12 apresenta o sistema de calibração utilizado.

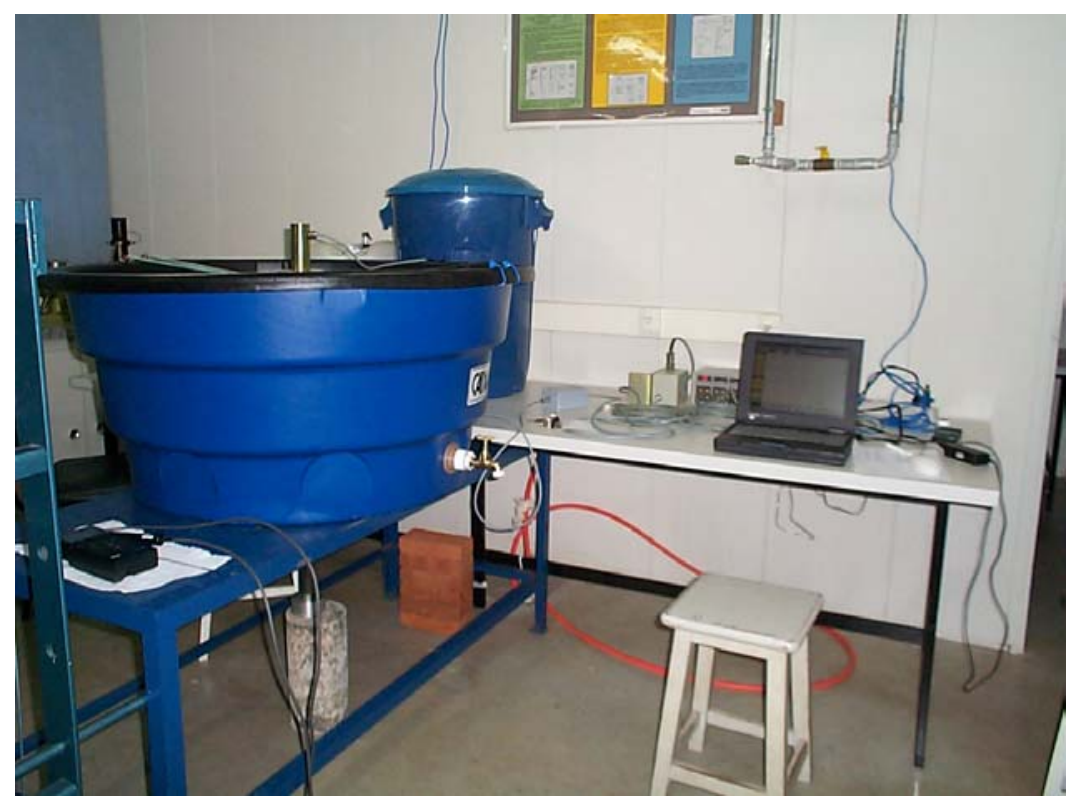

Foto 3.12. Sistema de calibração do sensor de condutividade do piezocone de resistividade. 
Inicialmente, foram realizadas várias calibrações, as quais serviram de aperfeiçoamento do sistema de calibração. O ensaio considerado como calibração e/ou avaliação do sistema de condutividade foi iniciado com água destilada e depois disso foi aumentando-se a concentração de sal, variando desde 0 até $33000 \mathrm{mg} / \mathrm{L}$, que corresponde a uma concentração aproximada da água do mar.

O programa utilizado durante a calibração foi o CPT Data Acquision Software da Geotech $A B \mathbb{B}$. Através desse software é possível tanto a aquisição dos dados durante a cravação ou calibração do cone, como a apresentação dos dados (Figura 3.18).

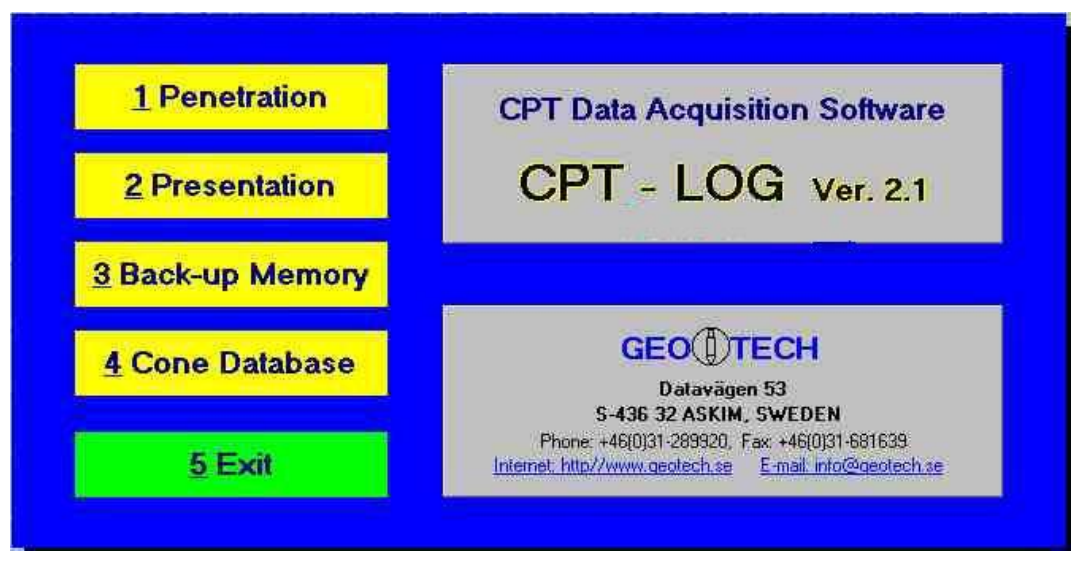

Figura 3.18. Tela de entrada do programa de aquisição de dados do piezocone de resistividade utilizado.

O piezocone foi instalado verticalmente no reservatório (Foto 3.13), sendo então preenchido com água destilada. As calibrações consistiram em obter os valores de condutividade da água a diferentes salinidades, tanto através de um condutivímetro (Foto 3.14), como através do piezocone de resistividade (Foto 3.15). 

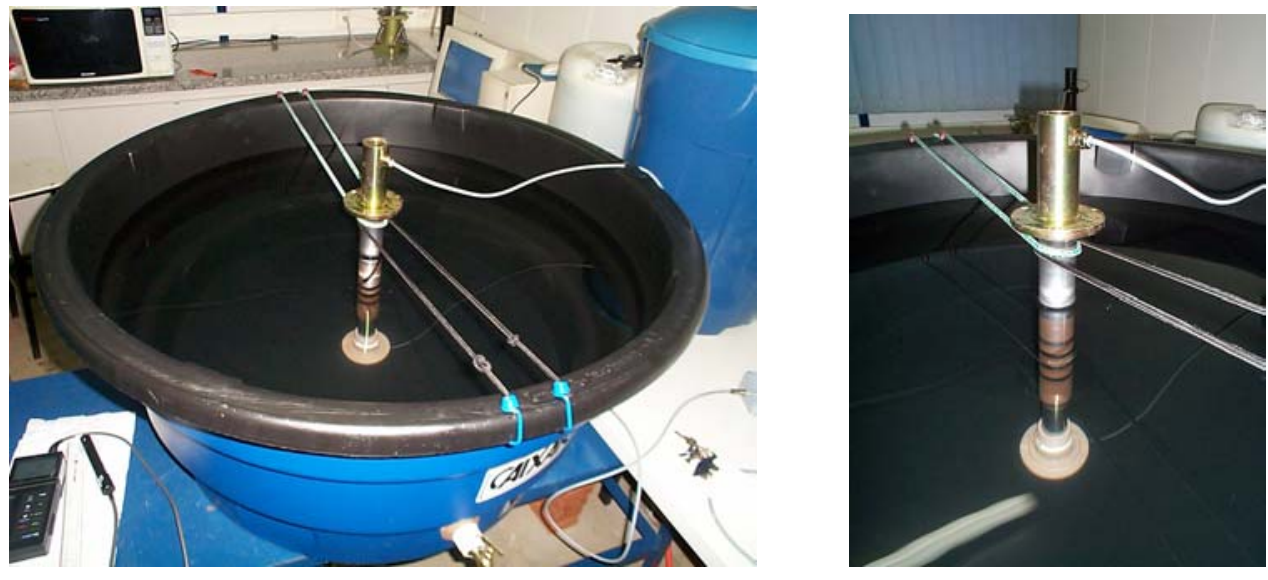

Foto 3.13. Instalação do piezocone de resistividade no reservatório.

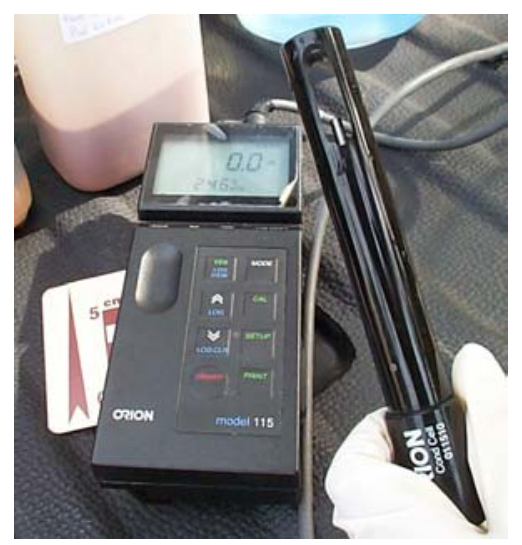

Foto 3.14. Condutivímetro utilizado no Laboratório de Geotecnia de Solos Tropicais da Unesp de Bauru.

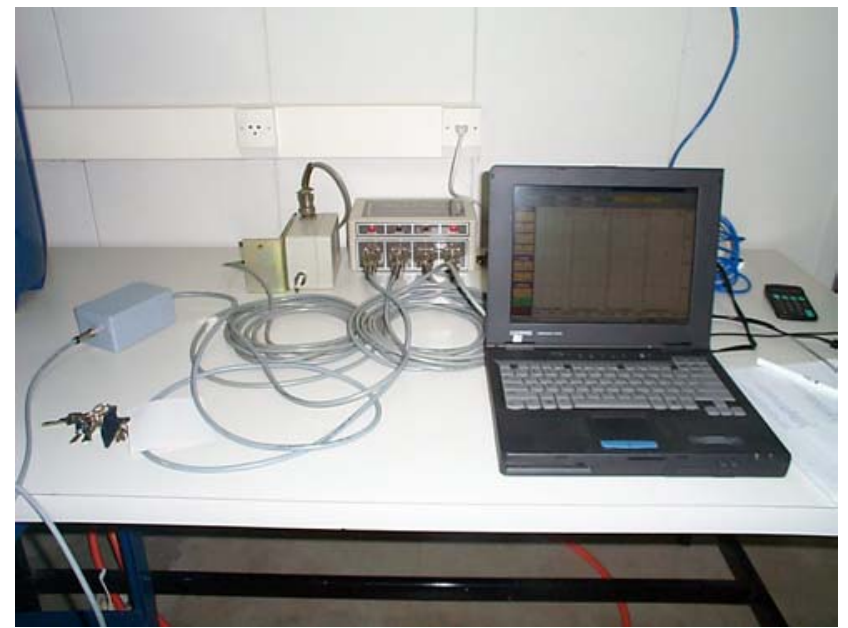

Foto 3.15. Sistema de aquisição de dados utilizados. 


\subsubsection{Dispositivo para Medida da Resistividade}

\section{a) Descrição do Dispositivo Utilizado}

O dispositivo para medida da resistividade utilizado nos ensaios de piezocone também transmite os sinais através de ondas sonoras e também foi fabricado pela Geotech $A B \otimes$. A Foto 3.16 mostra o piezocone de resistividade utilizado e a Foto 3.17 mostra o aparelho sendo cravado no terreno. O arranjo Werner é a configuração do piezocone de resistividade utilizado. A medida da resistividade aparente para esse arranjo é calculada através de:

$$
\rho=2 \mathrm{a} \times \frac{\Delta \mathrm{V}}{\mathrm{I}}
$$

onde:

$\rho$ : resistividade aparente (ohm.m);

a: distância entre os eletrodos (m);

$\Delta \mathrm{V}$ : diferença de potencial entre $\mathrm{M}$ e $\mathrm{N}(\mathrm{mV})$;

I: intensidade de corrente (mA).

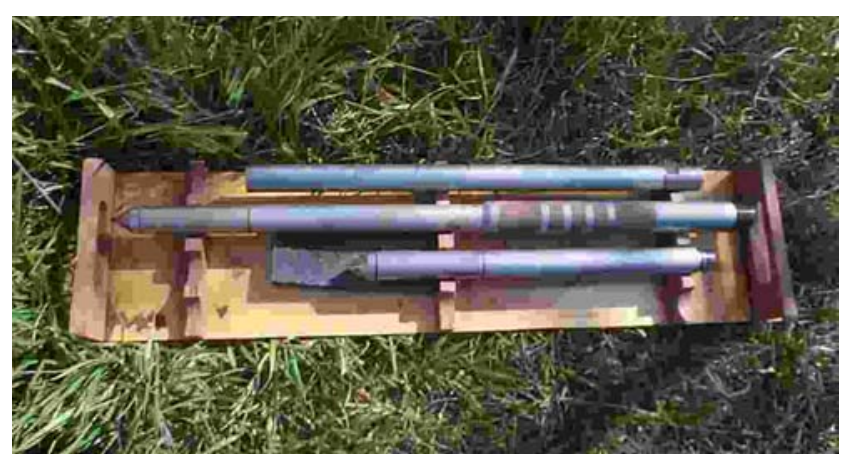

Foto 3.16. Piezocone de resistividade (RCPTU) utilizado no aterro de resíduos sólidos de Bauru. 


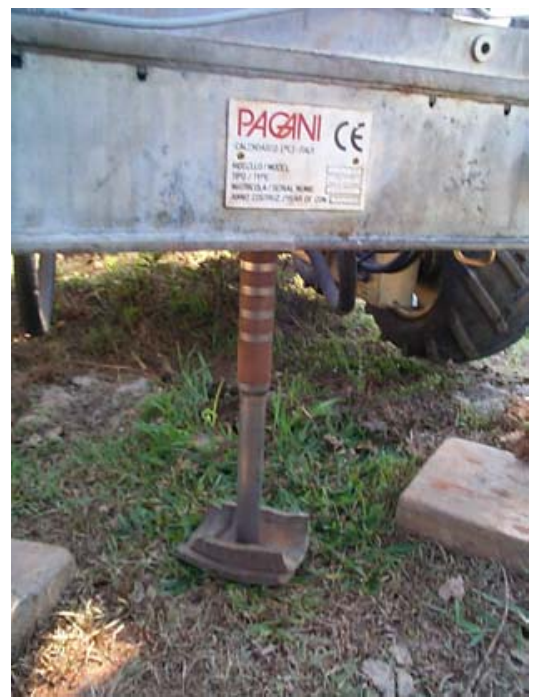

Foto 3.17. Sondagem com piezocone de resistividade sendo realizada na área do aterro de resíduos sólidos de Bauru.

\section{b) Sistema de Reação}

O dispositivo para medida da resistividade sempre é cravado no terreno em conjunto com o piezocone. Sendo assim, utilizou-se o piezocone e o penetrômetro já descritos anteriormente. Nas Fotos 3.18 e 3.19, observa-se o equipamento sendo utilizado no aterro de resíduos sólidos de Bauru e no lixão de Ribeirão Preto, respectivamente.

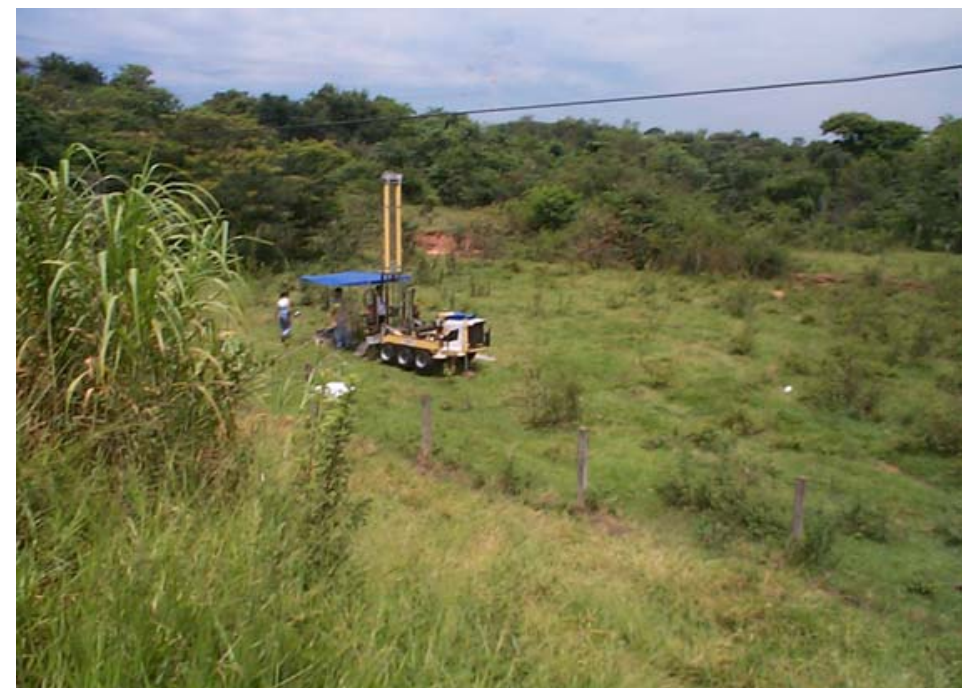

Foto 3.18. Sondagem com piezocone sendo realizada na área do aterro de resíduos sólidos de Bauru. 


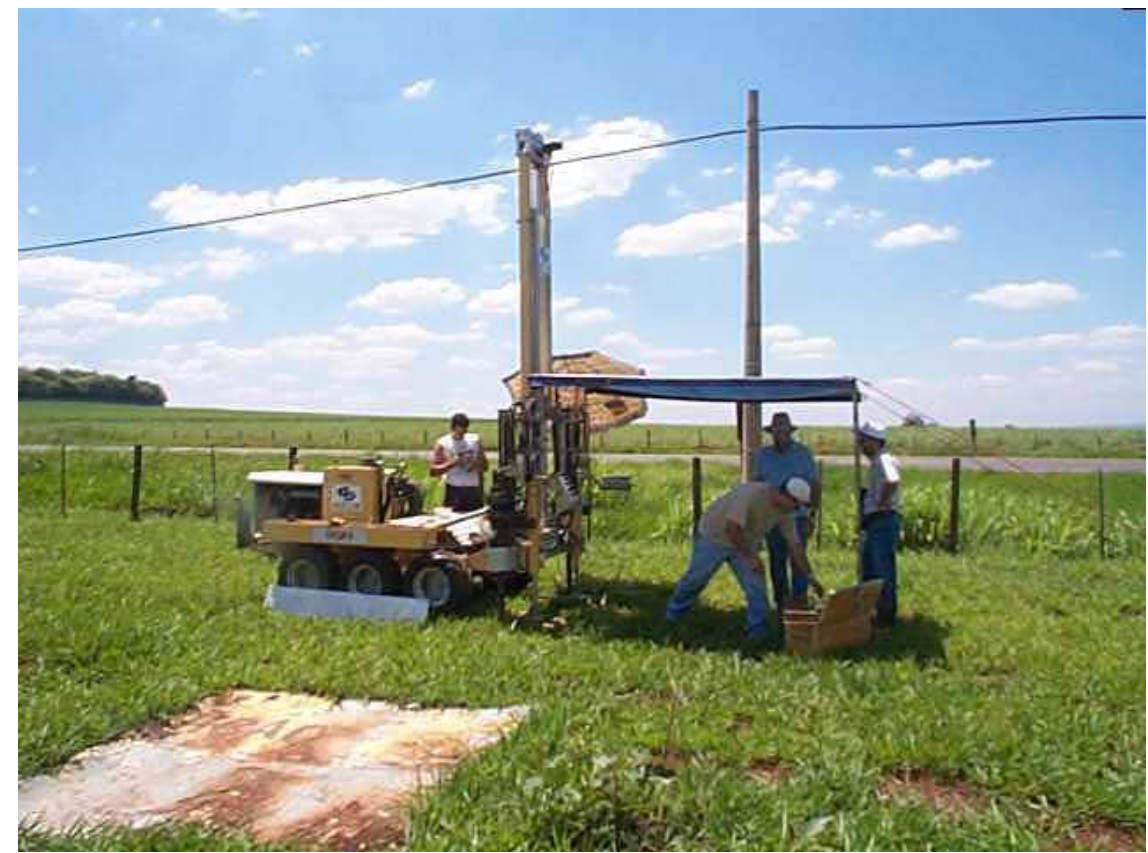

Foto 3.19. Sondagem com piezocone sendo realizada na área do lixão de Ribeirão Preto.

\subsubsection{Amostragem de Água e Solo}

Nos dois locais estudados também foram realizadas coletas de solo e água, utilizando o sistema Geoprobe $®$ para amostragem de água (Foto 3.20) e solo (Foto 3.21) orientados a partir das sondagens CPT ou RCPTU que já haviam sido realizadas. Em poços de monitoramento temporários abertos, foi realizada a coleta de água utilizando o penetrômetro multi-função (Foto 3.22) e o amostrador apresentado na Foto 3.23 


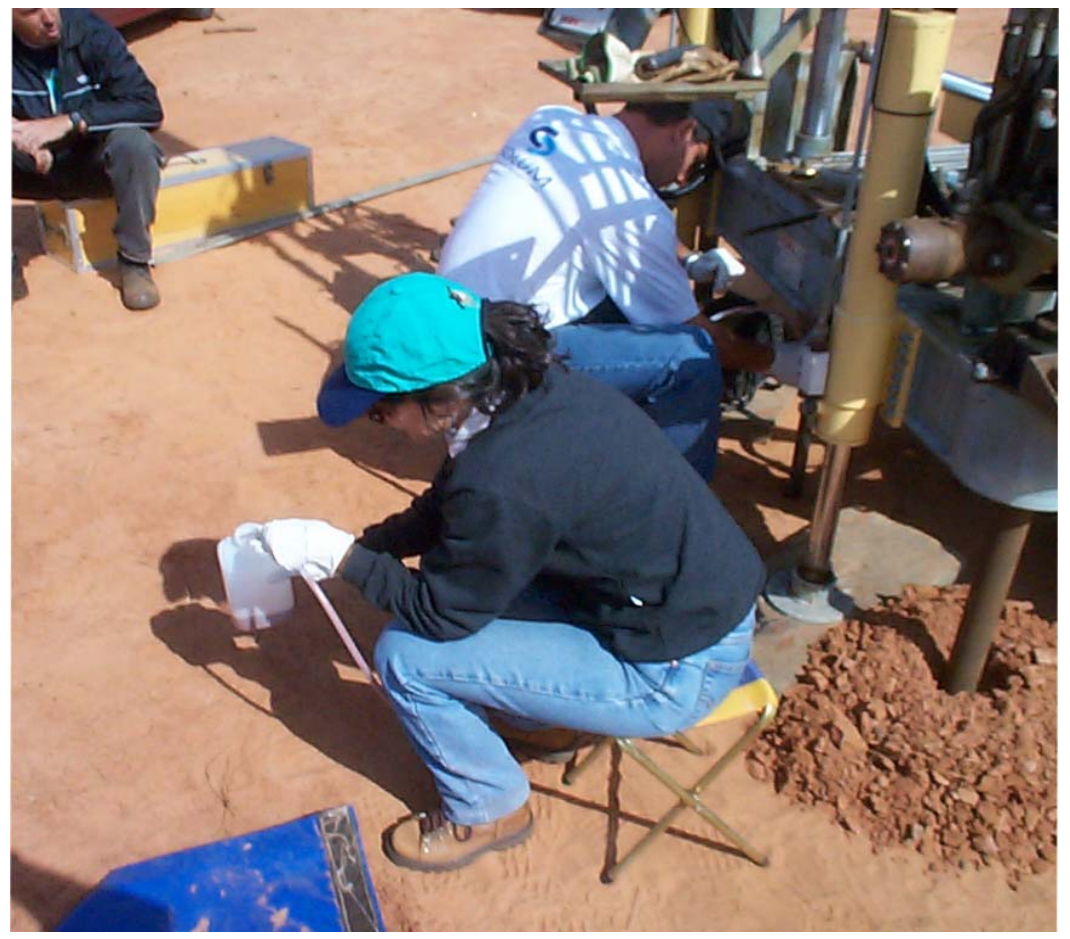

Foto 3.20. Amostragem de água no aterro de resíduos sólidos de Bauru utilizando o Geoprobe $\mathbb{R}$.

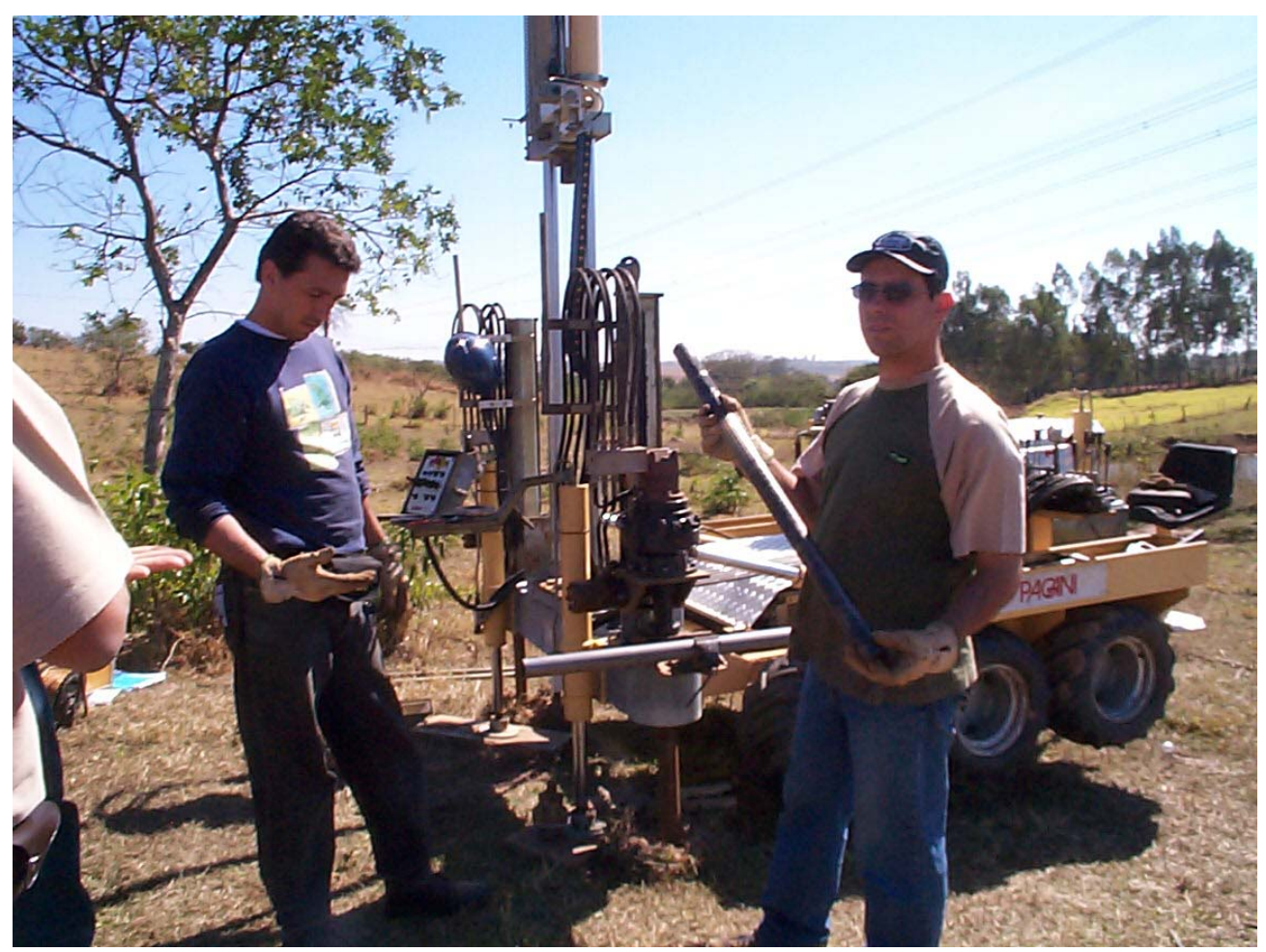

Foto 3.21. Amostragem de solo no aterro de resíduos sólidos de Bauru utilizando o Geoprobe $\mathbb{R}$. 

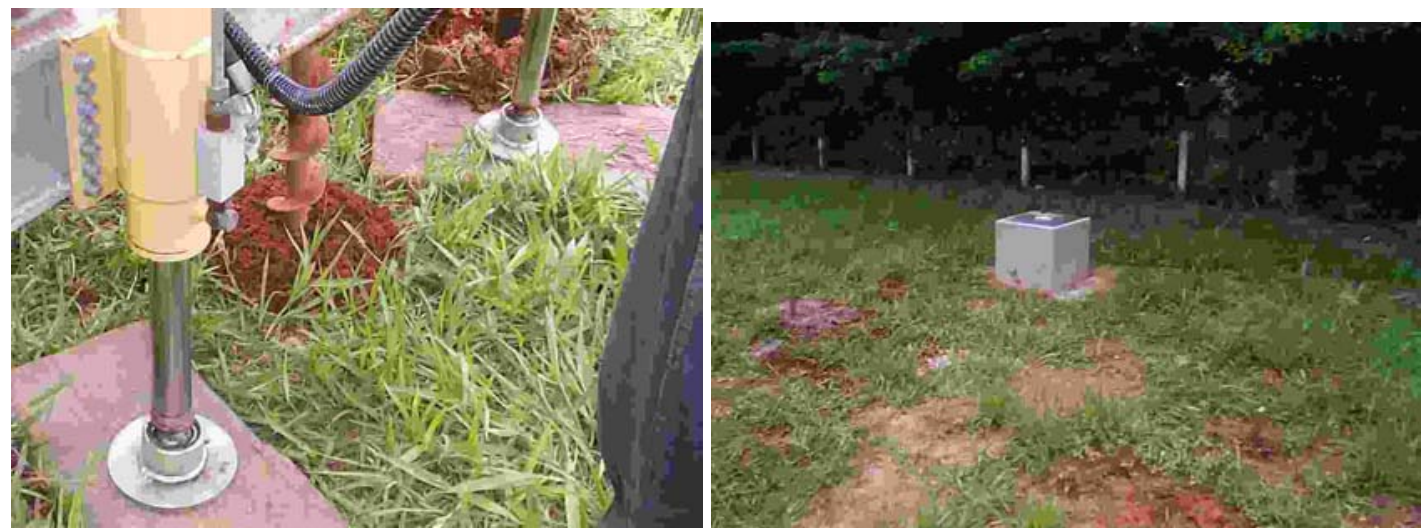

Foto 3.22. Amostragem de água no aterro de resíduos sólidos de Bauru utilizando poço temporário de monitoramento.
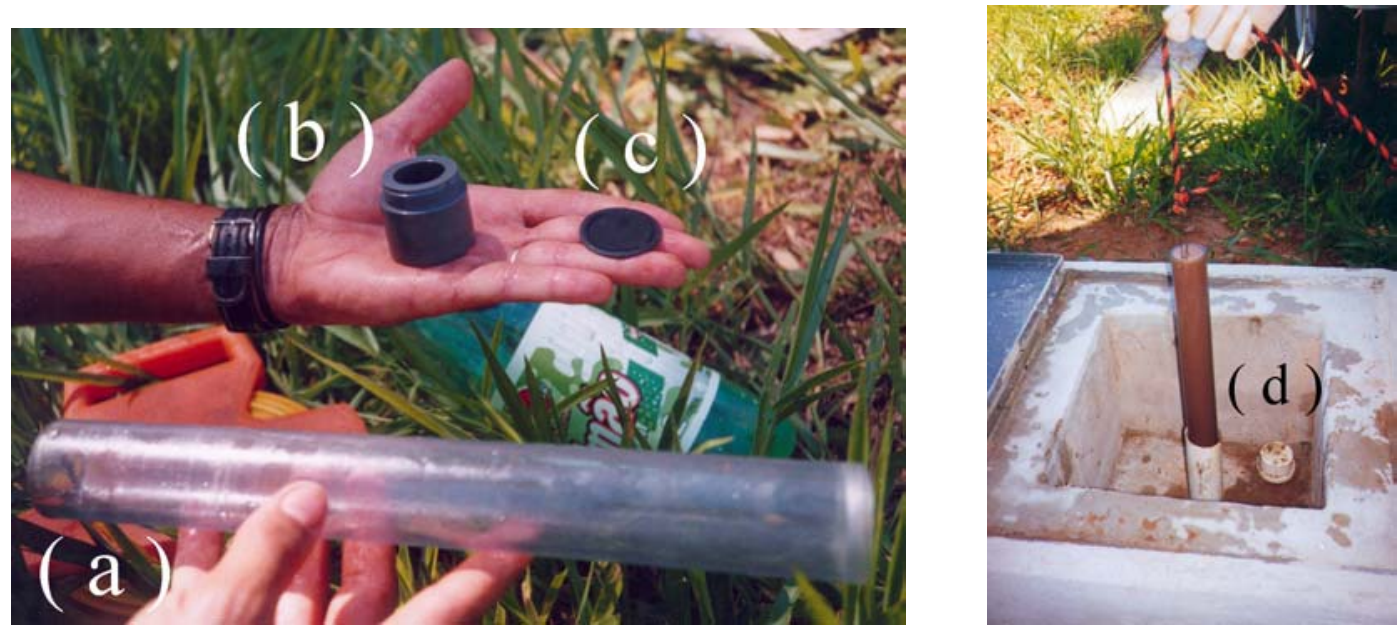

Foto 3.23. Amostrador de água utilizado nos poços de monitoramento temporários.

A Tabela 3.12 apresenta um quadro resumo das amostras de solo coletadas no aterro de resíduos sólidos de Bauru. As profundidades de coleta foram determinadas a partir da interpretação os resultados das sondagens com o piezocone. Já a Tabela 3.13 apresenta o quadro resumo das coletas de amostras de água realizadas em julho de 2002. 
Tabela 3.12. Quadro resumo das de amostras de solo coletadas com o amostrador

Geoprobe ${ }^{\circledR}$.

\begin{tabular}{|c|c|c|c|c|c|c|}
\hline Sondagem & $\begin{array}{c}\mathbf{N}^{\mathbf{0}} \text { da } \\
\text { amostra }\end{array}$ & Data & $\begin{array}{c}\text { Prof. inicial } \\
(\mathbf{m})\end{array}$ & $\begin{array}{c}\text { Prof. final } \\
(\mathbf{m})\end{array}$ & $\begin{array}{c}\text { Diâmetro } \\
(\mathbf{m})\end{array}$ & $\begin{array}{c}\mathbf{w} \\
\mathbf{( \% )}\end{array}$ \\
\hline CPTU 01 & 1 & Dez/2001 & 6.0 & 7.0 & 0.20 & 11.7 \\
\cline { 2 - 7 } & 2 & Dez/2001 & 9.5 & 10.5 & 0.20 & 6.8 \\
\hline CPTU 02 & 1 & Dez/2001 & 2.0 & 3.0 & 0.20 & - \\
\hline \multirow{3}{*}{ CPTU 03 } & 1 & Dez/2001 & 5.0 & 6.0 & 0.20 & 21.5 \\
\cline { 2 - 7 } & 2 & Dez/2001 & 6.0 & 7.0 & 0.20 & 17.6 \\
\cline { 2 - 7 } & 3 & Dez/2001 & 7.0 & 8.0 & 0.20 & 18.6 \\
\hline \multirow{3}{*}{ CPTU 04 } & 1 & Dez/2001 & 5.0 & 6.0 & 0.20 & 21.5 \\
\cline { 2 - 7 } & 2 & Dez/2001 & 6.0 & 7.0 & 0.20 & 16.6 \\
\cline { 2 - 7 } & 3 & Dez/2001 & 7.0 & 8.0 & 0.20 & 21.5 \\
\hline \multirow{3}{*}{ RCPTU 13 } & 1 & $\mathrm{Jul} / 2002$ & 1.5 & 2.5 & 0.20 & 2.5 \\
\cline { 2 - 7 } & 2 & $\mathrm{Jul} / 2002$ & 3.5 & 4.5 & 0.20 & 18.6 \\
\cline { 2 - 7 } & 3 & $\mathrm{Jul} / 2002$ & 7.5 & 8.5 & 0.20 & - \\
\cline { 2 - 8 } & 1 & $\mathrm{Jul} / 2002$ & 2.0 & 3.0 & 0.20 & 5.1 \\
\cline { 2 - 7 } & 2 & $\mathrm{Jul} / 2002$ & 5.0 & 6.0 & 0.20 & 18.1 \\
\cline { 2 - 7 } & 3 & $\mathrm{Jul} / 2002$ & 6.0 & 7.0 & 0.20 & 18.1 \\
\hline
\end{tabular}

Tabela 3.13. Quadro resumo das amostras de água coletadas com amostrador

Geoprobe $\mathbb{R}$.

\begin{tabular}{|c|c|c|c|c|}
\hline Sondagem & $\begin{array}{c}\mathbf{N}^{\mathbf{0}} \text { da } \\
\text { amostra }\end{array}$ & Data & $\begin{array}{c}\text { Prof. inicial } \\
(\mathbf{m})\end{array}$ & $\begin{array}{c}\text { Cota final } \\
(\mathbf{m})\end{array}$ \\
\hline RCPTU 13 & 1 & $\mathrm{Jul} / 2002$ & 3.5 & 4.5 \\
\hline RCPTU 14 & 1 & $\mathrm{Jul} / 2002$ & 7.3 & 8.3 \\
\hline \multirow{2}{*}{ RCPTU 15 } & 1 & $\mathrm{Jul} / 2002$ & 6.0 & 7.0 \\
\cline { 2 - 5 } & 2 & $\mathrm{Jul} / 2002$ & 8.0 & 9.0 \\
\hline
\end{tabular}

\subsubsection{Instalação de Poços de Monitoramento Permanentes}

No aterro de resíduos sólidos de Bauru foram construídos 9 poços de monitoramento definitivos. A localização desses poços (Figura 3.4) foi projetada com base nos resultados das campanhas de ensaios geofísicos e RCPTU realizados. Os poços foram executados entre os dias 16 e 26/09/2002, contratados e pagos pela EMDURB, órgão municipal responsável pela operação do aterro. 
Os poços PP-1, PP-2 e PP-3 foram executados à jusante e próximos ao aterro onde, pela geofísica, encontra-se a pluma de contaminação, praticamente não atenuada pelo solo. Os demais poços também foram executados em locais definidos pela geofísica. Estes poços receberam a colocação de um selo de cimento acima do nível d'água, onde poderia haver um caminho preferencial de água entre a superfície e as águas subterrâneas, o que ocasionaria a obtenção de amostras comprometidas. Para evitar que o selo de cimento preenchesse os vazios da areia do pré-filtro, foi colocada, também, entre o pré-filtro e o selo de cimento, uma camada de solo local (com espessura entre $0.5 \mathrm{~m}$ e $1.0 \mathrm{~m}$ ). Importante também salientar que esse solo foi propositalmente colocado a cerca de $2.0 \mathrm{~m}$ do filtro de PVC para prevenir futuras variações do nível d'água, visto que estes foram executados em um período de seca. Os poços PP-8 e PP-9 foram executados próximos, a 3.0 m de distância entre eles, em local onde o nível d'água se localiza a pouco mais de $6.0 \mathrm{~m}$ de profundidade. No dia da perfuração, o poço PP-8 atingiu a profundidade de $30 \mathrm{~m}$ e o PP-9 de $14 \mathrm{~m}$. A diferença de profundidade foi intencional para que fosse possível a obtenção de amostras praticamente no mesmo local, a profundidades diferentes (Tabela 3.14).

Um desenho esquemático de um poço de monitoramento instalado no aterro de resíduos sólidos de Bauru é apresentado na Figura 3.19. Na Foto 3.24 tem-se o equipamento de sondagem utilizado para instalação desse tipo de poço. 
Tabela 3.14. Características dos poços de monitoramento permanentes instalados no aterro de resíduos sólidos de Bauru.

\begin{tabular}{|c|c|c|c|c|c|c|c|}
\hline \multirow[b]{2}{*}{ Poço } & \multirow{2}{*}{$\begin{array}{l}\text { Prof. } \\
\text { (m) }\end{array}$} & \multirow[b]{2}{*}{$\Phi$} & \multicolumn{2}{|c|}{ Revestimentos } & \multirow{2}{*}{$\begin{array}{l}\text { Pré- } \\
\text { Filtro }\end{array}$} & \multirow{2}{*}{$\begin{array}{c}\text { Nível } \\
\text { Estático } \\
\text { (m) }\end{array}$} & \multirow[b]{2}{*}{ Geologia } \\
\hline & & & $\begin{array}{c}\text { Filtro } \\
\text { Geomecânico } \\
\text { Prof. (m) } \\
\end{array}$ & $\begin{array}{c}\text { Tubo Liso } \\
\text { Geomecânico } \\
\text { Prof. (m) } \\
\end{array}$ & & & \\
\hline 01 & 12.0 & $9 "$ & 08 a 12 & 0 a 08 & $\begin{array}{c}\text { seixos } \\
1 \mathrm{a} 3 \\
\mathrm{~mm} \\
\end{array}$ & 7.75 & $\begin{array}{c}\text { Formação } \\
\text { Bauru / } \\
\text { Marília } \\
\end{array}$ \\
\hline 02 & 12.0 & 9" & 08 a 12 & 0 a 08 & $\begin{array}{c}\text { seixos } \\
1 \mathrm{a} 2 \\
\mathrm{~mm} \\
\end{array}$ & 6.95 & $\begin{array}{c}\text { Formação } \\
\text { Bauru / } \\
\text { Marília } \\
\end{array}$ \\
\hline 03 & 14.0 & 9" & 10 a 14 & 0 a 10 & $\begin{array}{c}\text { seixos } \\
1 \mathrm{a} 2 \\
\mathrm{~mm}\end{array}$ & 9.42 & $\begin{array}{c}\text { Formação } \\
\text { Marília }\end{array}$ \\
\hline 04 & 37.4 & 9" & 33.4 a 37.4 & 0 a 33.4 & $\begin{array}{c}\text { seixos } \\
1 \mathrm{a} 2 \\
\mathrm{~mm}\end{array}$ & 30.23 & $\begin{array}{c}\text { Formação } \\
\text { Bauru / } \\
\text { Marília }\end{array}$ \\
\hline 05 & 8.0 & 9" & 04 a 08 & 0 a 4 & $\begin{array}{c}\text { seixos } \\
1 \mathrm{a} 2 \\
\mathrm{~mm} \\
\end{array}$ & 5.78 & $\begin{array}{c}\text { Formação } \\
\text { Bauru }\end{array}$ \\
\hline 06 & 6.0 & 9" & 2 a 6 & 0 a 2 & $\begin{array}{c}\text { seixos } \\
1 \mathrm{a} 2 \\
\mathrm{~mm}\end{array}$ & 2.90 & $\begin{array}{c}\text { Formação } \\
\text { Bauru }\end{array}$ \\
\hline 07 & 12.0 & 9" & 8 a 12 & 0 a 8 & $\begin{array}{c}\text { seixos } \\
1 \mathrm{a} 2 \\
\mathrm{~mm} \\
\end{array}$ & 7.00 & $\begin{array}{c}\text { Formação } \\
\text { Bauru / } \\
\text { Marília }\end{array}$ \\
\hline 08 & 30.0 & 9" & 26 a 30 & 0 a 26 & $\begin{array}{c}\text { seixos } \\
1 \mathrm{a} 2 \\
\mathrm{~mm}\end{array}$ & 6.30 & $\begin{array}{c}\text { Formação } \\
\text { Bauru / } \\
\text { Marília }\end{array}$ \\
\hline 09 & 14.0 & 9" & 10 a 14 & 0 a 10 & $\begin{array}{c}\text { seixos } \\
1 \mathrm{a} 2 \\
\mathrm{~mm} \\
\end{array}$ & 6.22 & $\begin{array}{c}\text { Formação } \\
\text { Bauru }\end{array}$ \\
\hline
\end{tabular}




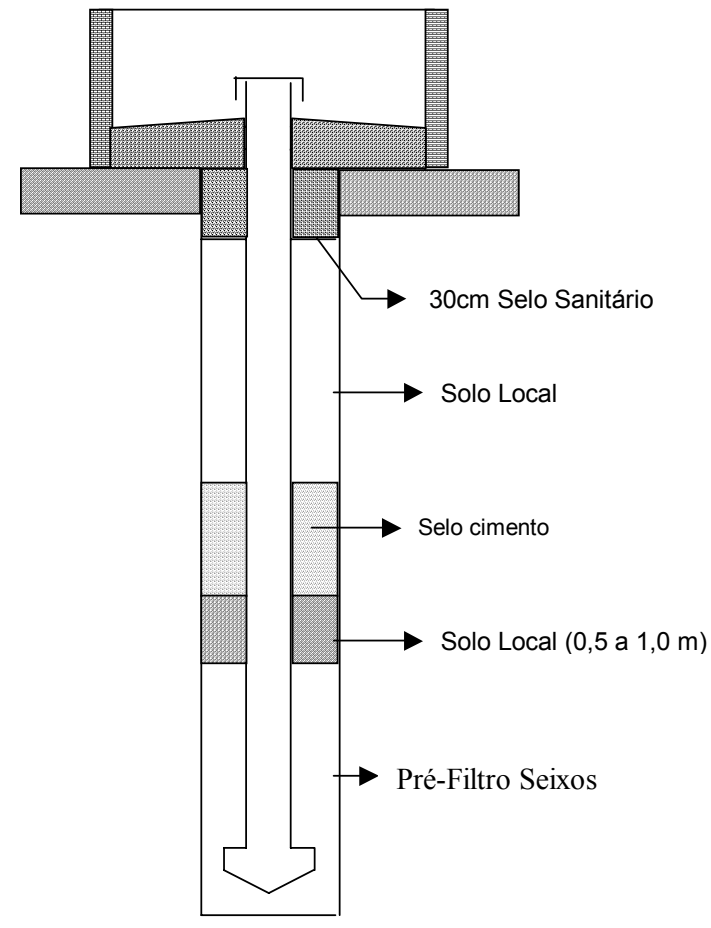

Figura 3.19. Croqui de um dos poços instalados no aterro de resíduos sólidos de Bauru.

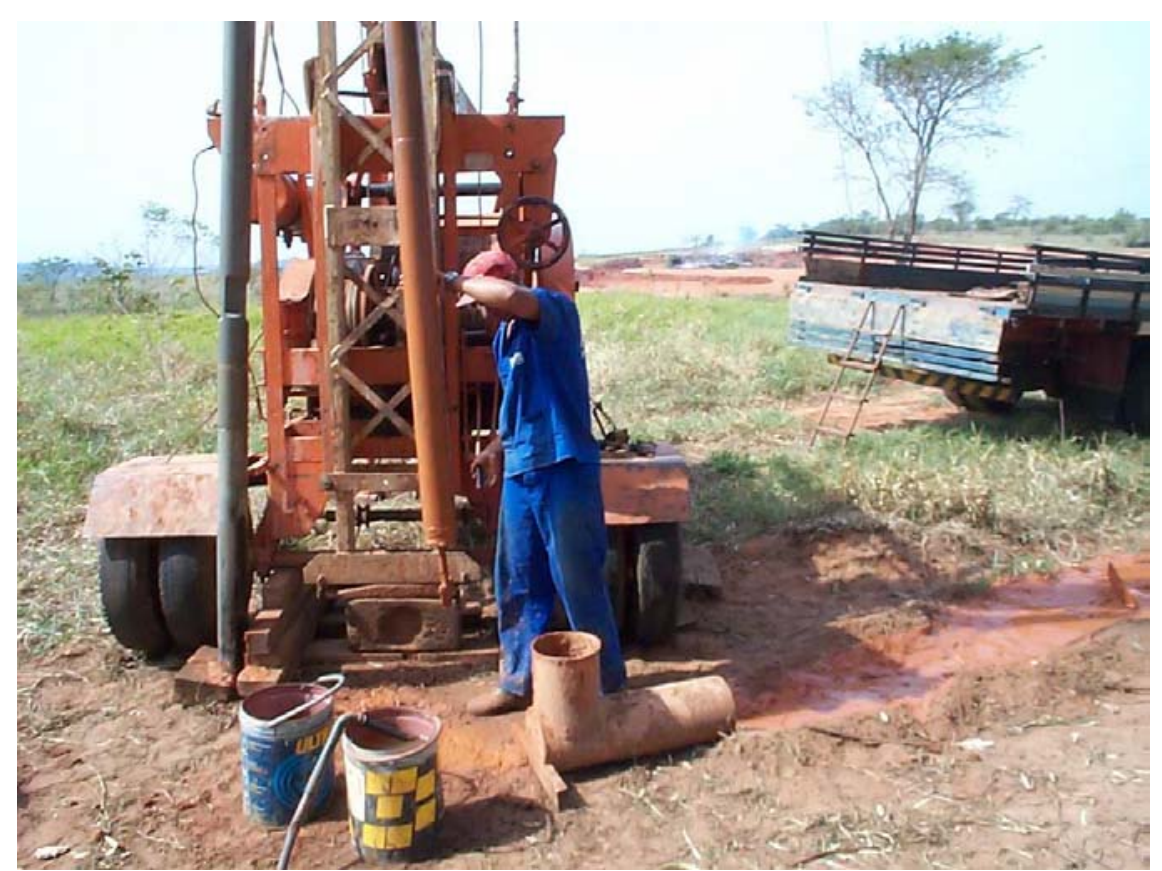

Foto 3.24. Instalação de poço de monitoramento no aterro de resíduos sólidos de Bauru. 
Um resumo das etapas de execução desses poços é apresentado a seguir:

- Perfuração à percussão de furos com 9" de diâmetro;

- Realização de furo até encontrar o nível d'água;

- Aprofundamento do furo até 4 a 5 m abaixo do nível d'água;

- Colocação do filtro geomecânico rígido de PVC, com 4" de diâmetro e ranhuras de $0.75 \mathrm{~mm}$. Foram colocados 2 tubos de $2.0 \mathrm{~m}$, totalizando $4.0 \mathrm{~m}$ de filtro a partir da base do furo executado;

- Colocação do tubo geomecânico de PVC de 4" standard, até ultrapassar a cota do terreno;

- Colocação de pré-filtro, constituído de areia grossa com diâmetro entre 1 mm e 3 $\mathrm{mm}$, da base do furo até $6.0 \mathrm{~m}$ desta;

- Colocação do solo local, com espessura variando entre $0.5 \mathrm{~m}$ e $1.0 \mathrm{~m}$;

- Colocação do selo de cimento, sendo usados em média 40 litros de água por saco de cimento $(50 \mathrm{~kg})$;

- Colocação do solo local até $-0.30 \mathrm{~m}$ da cota do terreno;

- Execução de selo sanitário com traço igual ao selo de cimento;

- Execução de laje de proteção e caixa de alvenaria com tampa metálica e cadeado.

\subsubsection{Avaliação Preliminar da Contaminação e da Atenuação do Solo do Aterro de Resíduos Sólidos de Bauru}

Como os valores de resistividade obtidos a partir dos ensaios RCPTU podem ser afetados por uma série de características dos solos, possibilitando apenas um detalhamento do caminhamento da pluma de contaminação para jusante do aterro, apresenta-se aqui uma campanha de coleta de amostras de água realizada em locais específicos do aterro, selecionados a partir do programa de investigação geoambiental realizado. Os poços de monitoramento temporários, apresentados na Figura 3.4, foram considerados pontos críticos, pois interceptam a pluma de contaminação e, portanto foram aqueles utilizados para verificar a contaminação. Para a comparação com os pontos considerados não afetados pelos resíduos, foram escolhidos três pontos ao sul do aterro, onde existe uma nascente. Esses pontos, 
apresentados na Figura 3.4, foram considerados como pontos para obtenção de valores de "background" e foram identificados como Nascente, Açude 1 e Açude 2. A qualidade da água das Erosões 1 e 2 também foi analisada. Todas as amostras coletadas foram analisadas nos laboratórios da Unesp de Bauru, pois este estudo fez parte de um outro programa de pesquisa desta universidade.

As coletas foram feitas praticamente no mesmo horário, entre 9 e 11 horas da manhã, para que se pudesse assim ter algum controle da influência das águas de chuva na amostragem. Para essa análise preliminar das águas superficiais e subsuperficiais, foram determinados os parâmetros $\mathrm{pH}$, cloretos, alcalinidade total, $\mathrm{DBO}_{5}$ (Demanda Bioquímica de Oxigênio), DQO (Demanda Química de Oxigênio), condutividade elétrica, nitrogênio amoniacal e nitrogênios nitrato e nitrito. Para as amostras da última campanha de coleta também foi realizada uma análise dos metais chumbo e ferro.

\subsubsection{Ensaios de Laboratório para a Avaliação da Retenção de Poluentes pelo Solo do Aterro de Resíduos Sólidos de Bauru}

Devido às diversas variáveis que afetam os resultados dos ensaios de campo para avaliação do caminhamento da pluma de contaminação, procurou-se estudar com maior detalhe como se dá a contaminação e a atenuação de contaminantes no aterro de resíduos sólidos de Bauru, iniciando-se assim um programa de ensaios geoambientais no Laboratório de Mecânica dos Solos da Escola Politécnica da USP (LMS-EPUSP).

Várias foram as dificuldades encontradas para a realização dos ensaios que envolveram solo e solução/poluente, uma vez que a idéia inicial era trabalhar com o chorume original do aterro como solução percoladora, para a avaliação da retenção de metais pesados pelo solo em seu estado indeformado. Estas seriam as condições que mais se aproximariam das condições reais de campo, adicionadas à boa capacidade de controle que os equipamentos do LMS-EPUSP permitem.

Como nestas condições seriam ensaios pioneiros, alguns problemas ocorreram, como, por exemplo, a perda de um ensaio de adsorção em lote, todo 
realizado com chorume coletado do aterro e amostra deformada de solo retirada a 3.0 $\mathrm{m}$ de profundidade do talude descrito no item 3.2.1.

Descobriu-se, a partir de uma análise química de varredura realizada pelo Laboratório de Espectrometria de Emissão e Absorção Atômica do Instituto de Química da USP, que o chorume não tem concentração de metais suficiente para uma obtenção precisa dos parâmetros de transporte de poluentes requeridos pelos ensaios de coluna e de adsorção em lote, com valores da ordem de $1 \mathrm{mg} / \mathrm{L}$, como mostra a Tabela 3.15 .

Tabela 3.15. Análise química realizada para o chorume do aterro de resíduos sólidos de Bauru.

\begin{tabular}{|c|c|}
\hline Elemento & Concentração (mg/L) - Chorume (06/06/2003) \\
\hline $\mathrm{Al}$ & 5.923 \\
\hline $\mathrm{As}$ & 32.002 \\
\hline $\mathrm{Ba}$ & 20.242 \\
\hline $\mathrm{Ca}$ & 85.542 \\
\hline $\mathrm{Cd}$ & 0.070 \\
\hline $\mathrm{Co}$ & 0.069 \\
\hline $\mathrm{Cr}$ & 0.559 \\
\hline $\mathrm{Cu}$ & 0.241 \\
\hline $\mathrm{Fe}$ & 12.980 \\
\hline $\mathrm{K}$ & 1206.000 \\
\hline $\mathrm{Mg}$ & 79.290 \\
\hline $\mathrm{Mn}$ & 0.778 \\
\hline $\mathrm{Mo}$ & 1.420 \\
\hline $\mathrm{Na}$ & 1206.000 \\
\hline $\mathrm{Ni}$ & 0.448 \\
\hline $\mathrm{P}$ & 7.110 \\
\hline $\mathrm{Pb}$ & 0.705 \\
\hline $\mathrm{Ru}$ & 0.735 \\
\hline $\mathrm{S}$ & 18.800 \\
\hline $\mathrm{Se}$ & 86.700 \\
\hline $\mathrm{Sn}$ & 0.422 \\
\hline $\mathrm{Ti}$ & 1.430 \\
\hline $\mathrm{V}$ & 0.704 \\
\hline $\mathrm{Zn}$ & 5.120 \\
\hline & 0.290 \\
\hline
\end{tabular}


Comparando-se os valores apresentados nesta tabela com valores típicos de chorume de aterros sanitários domésticos publicados por VANGULCK \& ROWE (2002) e pelo IPT/CEMPRE (2000), tem-se que estes são valores aceitáveis para um aterro que possui um pouco mais 10 anos, estando portanto em fase metanogênica, com exceção dos elevadas concentrações de $\mathrm{Na}$ e K.

O chorume utilizado nos ensaios foi coletado de uma caixa de armazenamento e recirculação, como mostram as Fotos 3.25 e 3.26, pois ele é tratado sendo recirculado novamente para o aterro. Ele foi então transportado para São Paulo em recipiente adequado e guardado em geladeira, para a manutenção de suas características físico-químicas.

Para que as amostras de chorume fossem submetidas à análise química, adicionou-se ácido nítrico até que seu $\mathrm{pH}$ atingisse valor menor ou igual a 2 , conforme preconiza a AMERICAN PUBLIC HEALH ASSOCIATION, a AMERICAN WATER WORKS ASSOCIATION e a WATER ENVIRONMENTAL FEDERATION (1995), para que as amostras preservassem as concentrações de metais pesados. Como o chorume também contém muitos sólidos suspensos, as amostras foram centrifugadas durante 20 minutos a $3000 \mathrm{rpm}$ para evitar o entupimento do espectrômetro. A centrífuga EXCELSA 3 plus, Modelo 280 utilizada é pertencente ao LMS-EPUSP (Foto 3.27).

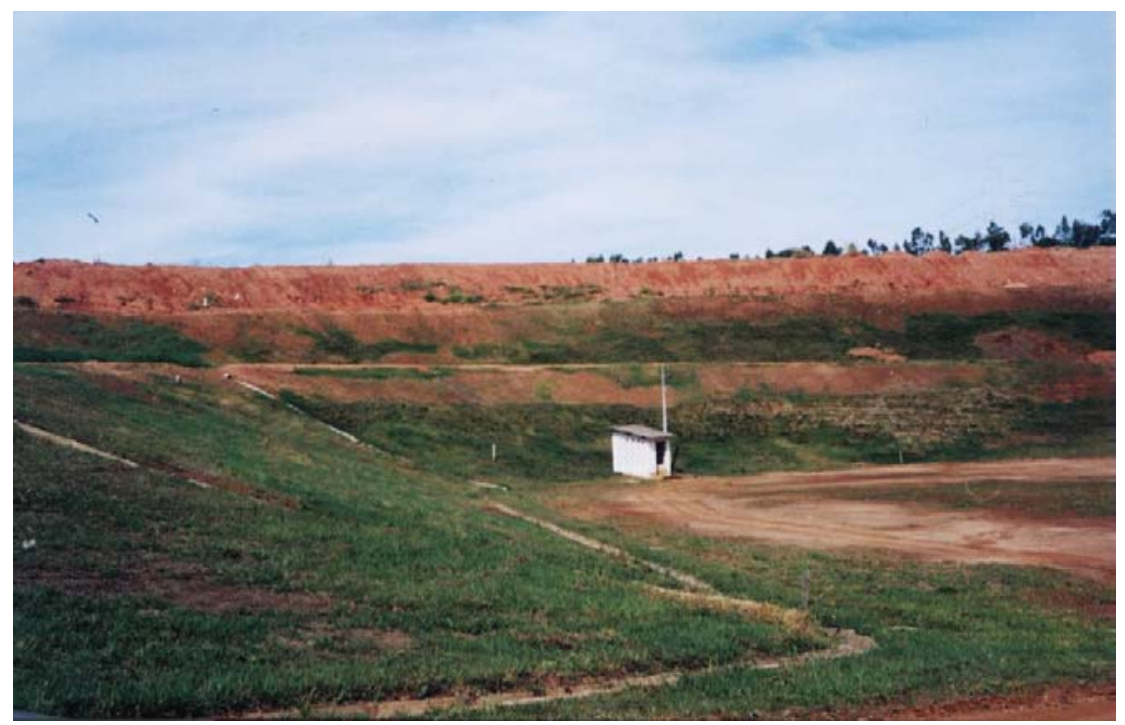

Foto 3.25. Localização da caixa de armazenamento e recirculação do chorume, à jusante do aterro de resíduos sólidos de Bauru. 


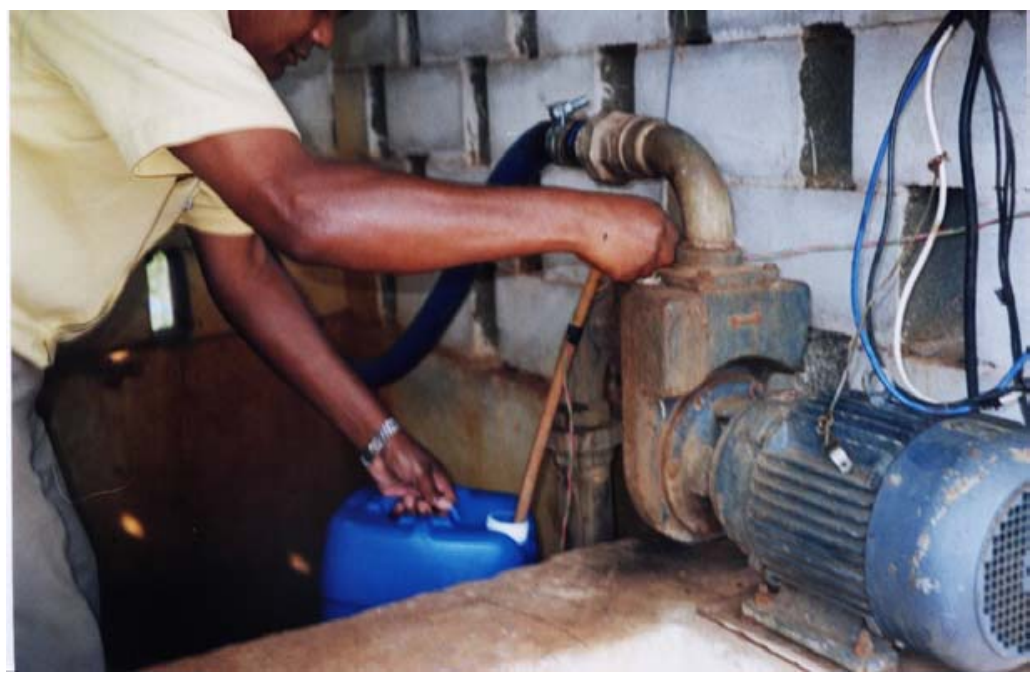

Foto 3.26. Detalhe do momento da coleta do chorume na caixa de armazenamento e recirculação.

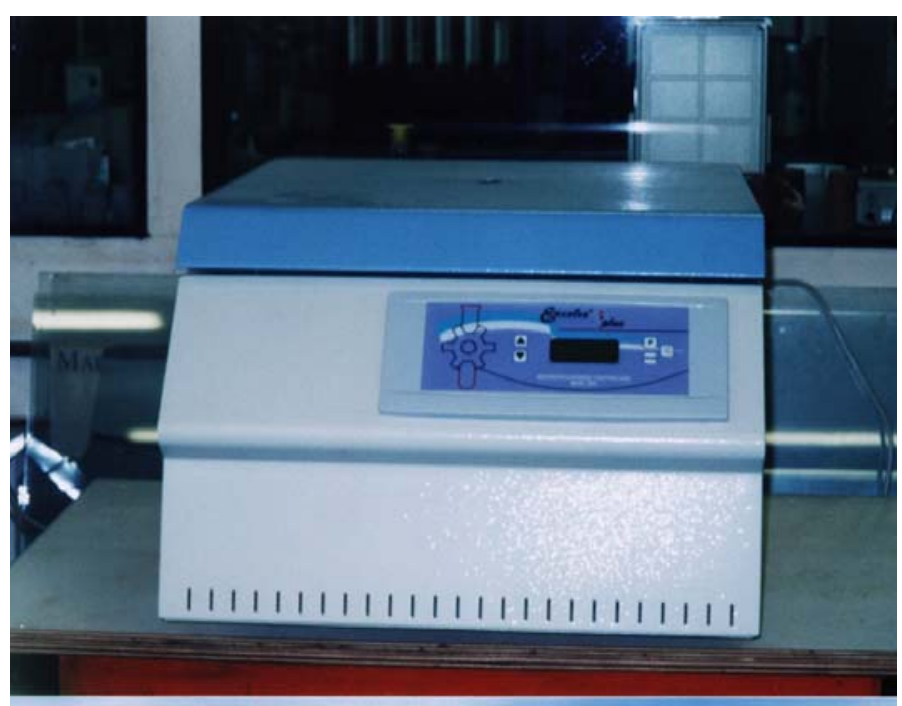

Foto 3.27. Centrífuga utilizada no LMS-EPUSP para preparação das amostras de chorume a serem submetidas à análise química.

Ensaios de coluna com percolação de água, solução salina $(\mathrm{NaCl})$ e poluentes foram realizados, utilizando um sistema de permâmetros Tri-Flex 2. Optou-se por utilizar uma solução salina de $100 \mathrm{mg} / \mathrm{L}$ e dois tipos de solução de poluentes: uma constituída por um "coquetel" de metais pesados, formada por aproximadamente 10 $\mathrm{mg} / \mathrm{L}$ de $\mathrm{Cd}, \mathrm{Ni}, \mathrm{Zn}$ e $\mathrm{Pb}$, e outra constituída pelo próprio chorume do aterro, acrescido de uma certa quantidade destes metais, de modo que ficasse com 
aproximadamente $10 \mathrm{mg} / \mathrm{L}$ de cada um deles. $\mathrm{O} \mathrm{pH}$ da solução de metais foi corrigido para o valor do $\mathrm{pH}$ do chorume ensaiado $(\cong 8.3)$, acrescentando-se hidróxido de sódio a ela. Também foi realizado o ensaio de adsorção em lote para estas duas situações, das quais pretende-se observar se existe grande diferença entre se trabalhar com soluções a base de água, de onde se deriva a maioria dos trabalhos publicados sobre esse assunto, e entre se trabalhar com o próprio chorume do aterro.

\subsubsection{Ensaios de Permeabilidade}

Antes de iniciar os ensaios de coluna com percolação de poluentes, optou-se por realizar três ensaios de permeabilidade com percolação de água, variando-se a tensão confinante a um gradiente constante. As tensões confinantes utilizadas foram de 30,90 e $180 \mathrm{kPa}$, enquanto o gradiente hidráulico utilizado foi igual a 11. Estes valores foram definidos a partir das condições de campo e dos limites mínimos e máximos do aparelho de aplicação das pressões no laboratório. Para a aplicação da tensão confinante igual a $180 \mathrm{kPa}$ supôs-se que a amostra estivesse na base e no centro do aterro, enquanto a aplicação da tensão confinante igual a $30 \mathrm{kPa}$ representa a situação crítica de maior interesse desta pesquisa, em que a amostra de solo estaria localizada à jusante do aterro, com baixa profundidade e nível d'água elevado. A aplicação da tensão confinante igual a $90 \mathrm{kPa}$ seria uma condição intermediária às outras duas, e foi utilizada para verificar como a permeabilidade varia com o aumento da tensão confinante. O gradiente hidráulico igual a 11 foi o menor conseguido pelo aparelho, que perde precisão no caso de aplicação de tensão menor que $14 \mathrm{kPa}$. Além disso, a máxima altura de moldagem do corpo de prova conseguida foi de cerca de $12.5 \mathrm{~cm}$. O corpo de prova utilizado foi moldado de uma amostra indeformada, retirada a $3.0 \mathrm{~m}$ de profundidade de um talude localizado ao norte do aterro, como já apresentado no item 3.2.

A Foto 3.28 mostra o corpo de prova sendo talhado com $7 \mathrm{~cm}$ de diâmetro e $12.5 \mathrm{~cm}$ de altura, enquanto a Foto 3.29 mostra um detalhe do corpo de prova já envolto por uma membrana de borracha dentro da célula de ensaio. A Foto 3.30 apresenta uma vista geral do ensaio, mostrando o painel de controle de pressões, que foi utilizado com a aplicação de carga (14 a $15 \mathrm{kPa}$ ) pela base do corpo de prova (fluxo ascendente). A saturação do corpo de prova foi realizada com percolação de 
água a gradientes da ordem de 5 e o adensamento com tensão confinante igual a 30 $\mathrm{kPa}$. Após o término do ensaio de permeabilidade, quando havia passado dois ou mais volumes de vazios de água pelo corpo de prova, este era adensado novamente, só que agora com confinante igual a $90 \mathrm{kPa}$, seguindo-se o mesmo procedimento até adensá-lo novamente com $180 \mathrm{kPa}$.

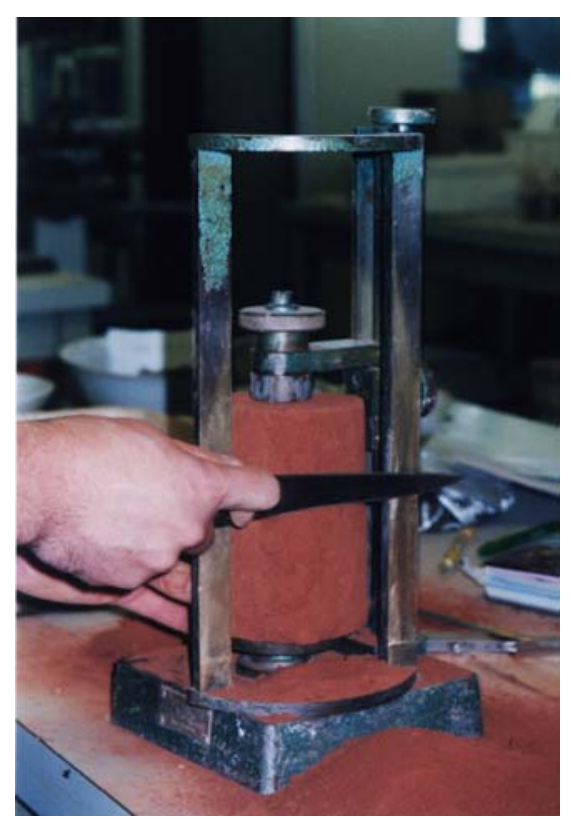

Foto 3.28. Amostra de solo do aterro de resíduos sólidos de Bauru sendo preparada para a realização do ensaio de permeabilidade.

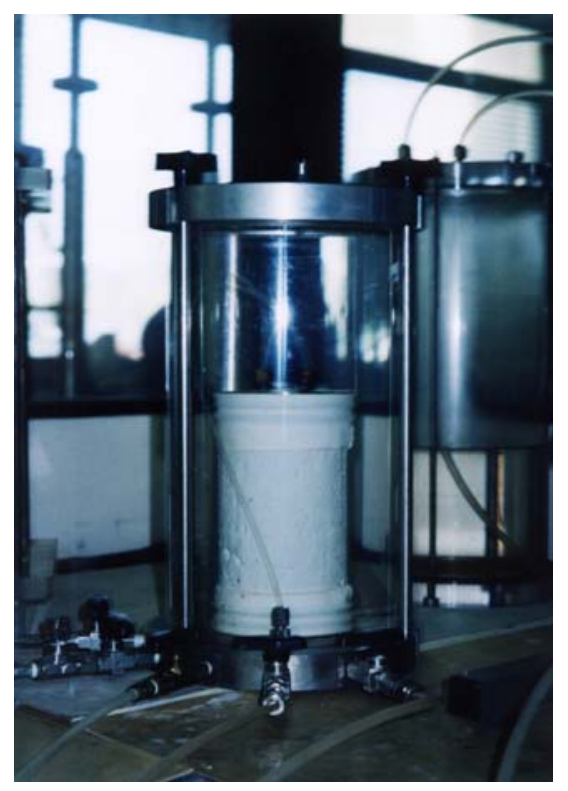

Foto 3.29. Corpo de prova já moldado dentro da célula de ensaio. 


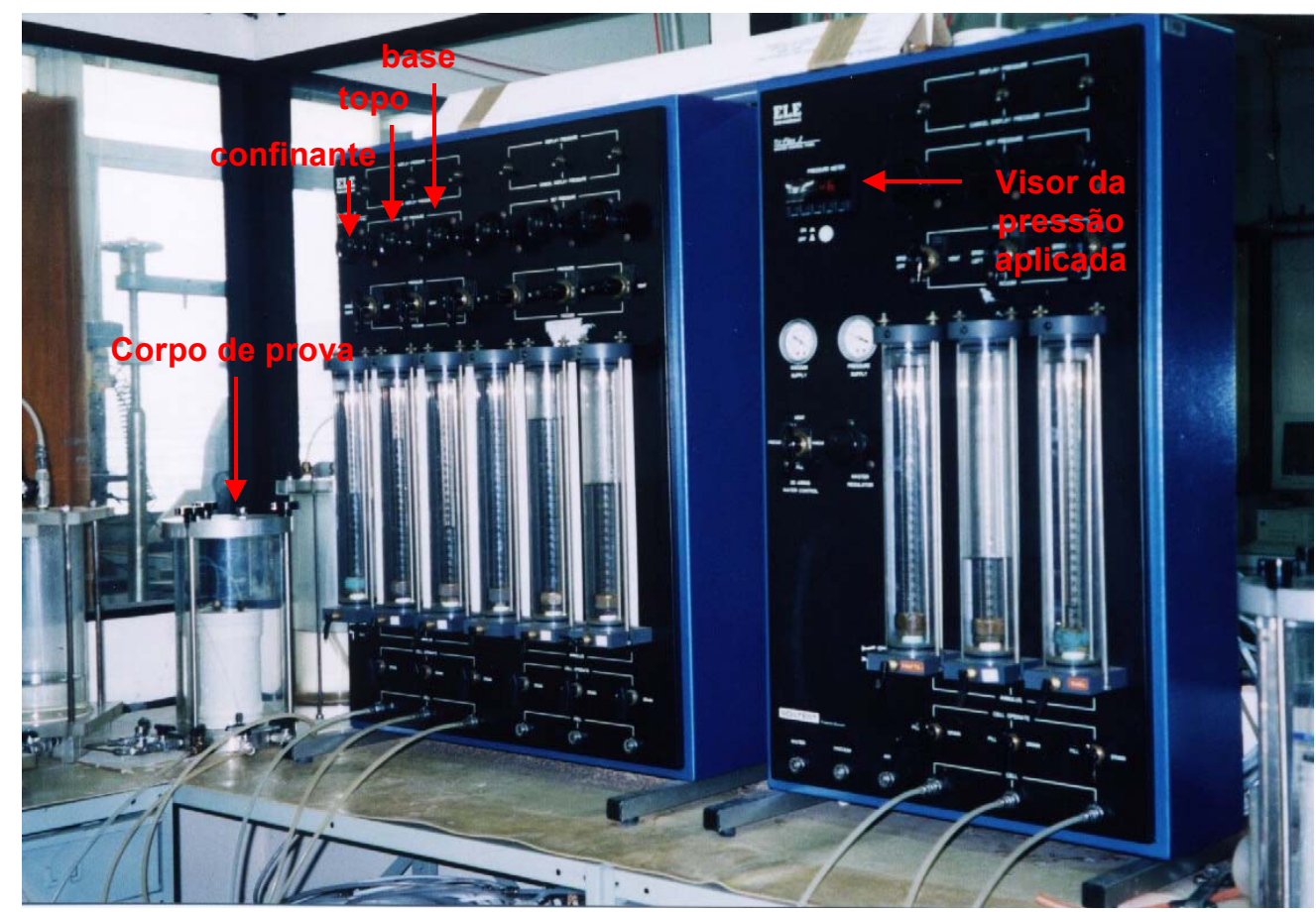

Foto 3.30. Detalhe do painel de controle utilizado no LMS-EPUSP para a aplicação de gradientes e confinantes durante a realização dos ensaios de permeabilidade e de coluna.

\subsubsection{Ensaio de Coluna com Percolação de Solução Salina}

Para que a resposta físico-química do solo submetido a um fluido de alta condutividade fosse observada, um ensaio de coluna com percolação de solução salina $(\mathrm{NaCl})$ foi realizado. O teor de cloreto de sódio aplicado foi de $100 \mathrm{mg} / \mathrm{L}$, definido conforme os resultados obtidos através das análises químicas das amostras de água coletadas com o amostrador Geoprobe ${ }^{\circledR}$ a partir de algumas sondagens RCPTU e dos valores de cloretos apresentados pelos poços de monitoramento permanentes.

As condições de ensaio foram as mesmas descritas anteriormente para a percolação com água, procurando-se trabalhar agora apenas com a tensão confinante igual a $30 \mathrm{kPa}$, que indica a condição mais crítica. Porém, para confirmação dos resultados obtidos, optou-se por realizar um novo ensaio, agora com tensão confinante igual $90 \mathrm{kPa}$. Antes do início da percolação com sal foram realizadas as etapas de saturação, adensamento e percolação de dois volumes de vazios com água 
pelo corpo de prova. Terminada esta fase, a solução salina foi colocada num reservatório (Foto 3.31), o qual foi ligado a uma interface que fazia contato com a pressão de água da base que era aplicada pelo painel de controle (Foto 3.32). O efluente era recolhido pelo topo do corpo de prova a cada $20 \mathrm{ml}$ acumulados, quando era obtida a condutividade elétrica por meio de um condutivímetro (Foto 3.33) e o $\mathrm{pH}$ através de um medidor de $\mathrm{pH}$ (Foto 3.34). As concentrações foram calculadas através de uma curva de calibração, função da condutividade, realizada no laboratório (Figura 3.20). A Foto 3.35 mostra uma vista geral do ensaio.

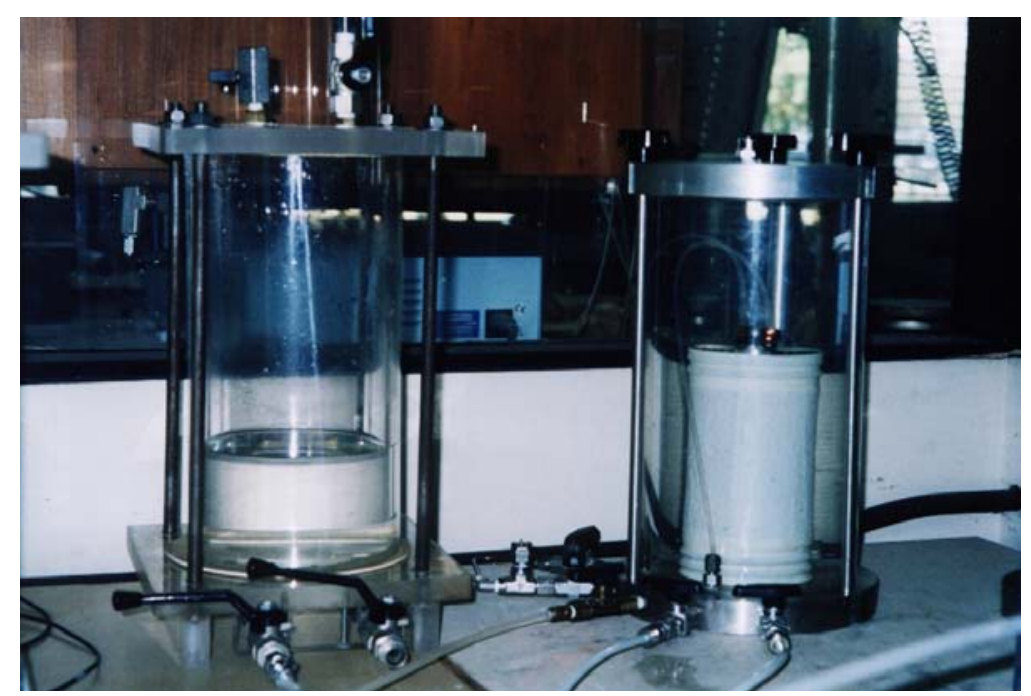

Foto 3.31. Reservatório utilizado para armazenamento de poluentes durante os ensaios de coluna (esquerda) ao lado do corpo de prova (direita).

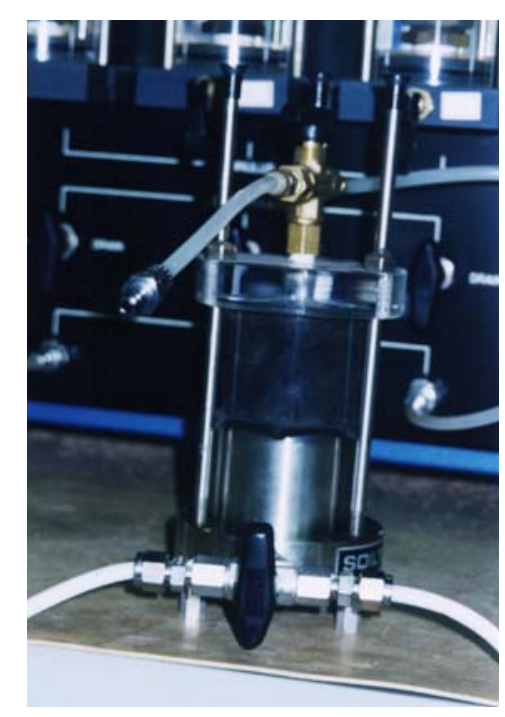

Foto 3.32. Interface água/poluente utilizada durante os ensaios de coluna. 


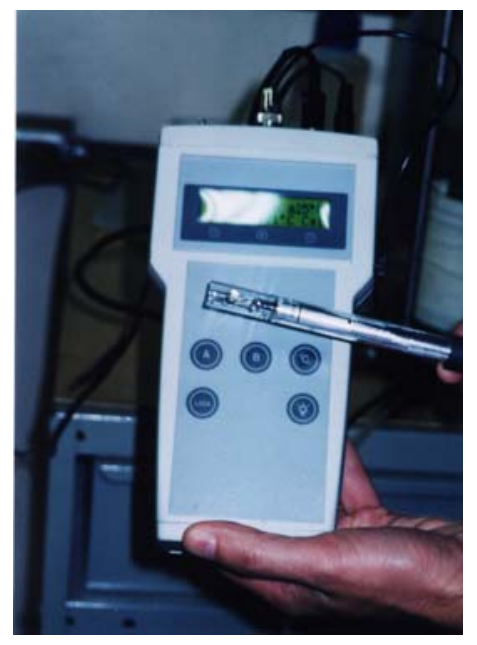

Foto 3.33. Condutivímetro utilizado para medir a condutividade elétrica da solução efluente dos ensaios de coluna no LMS-EPUSP.

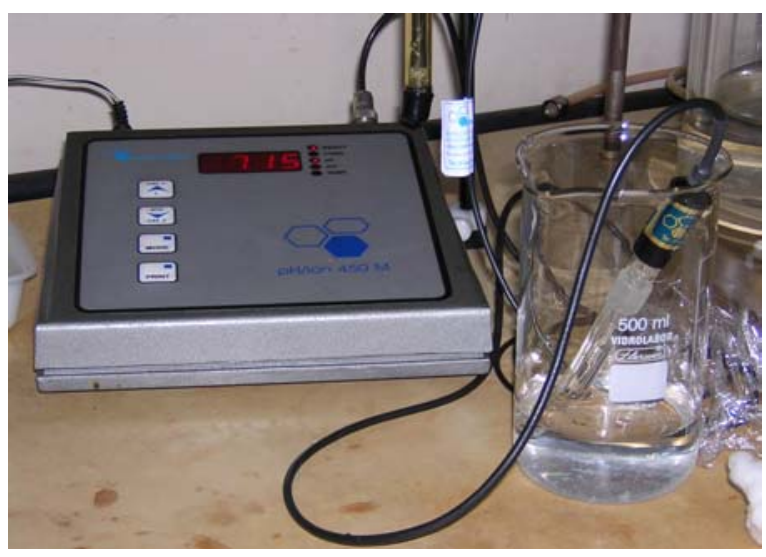

Foto 3.34. Aparelho utilizado para medir o pH da solução efluente durante os ensaios de coluna no LMS-EPUSP.

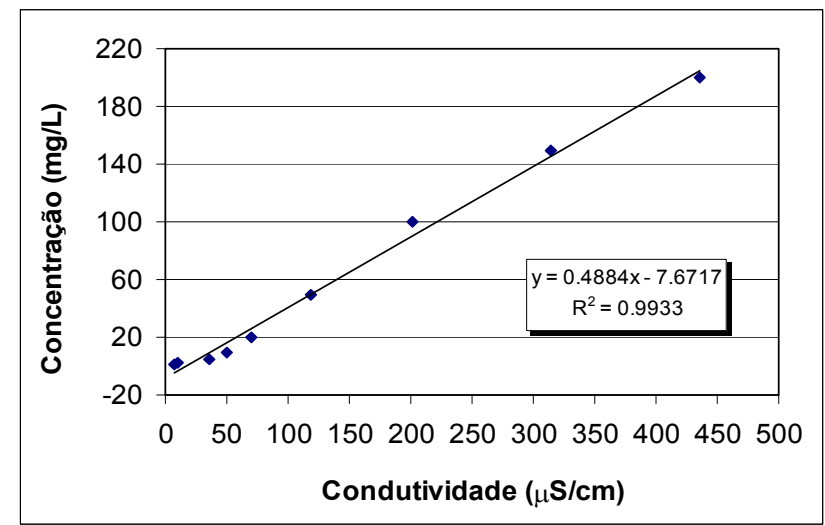

Figura 3.20. Curva de calibração entre condutividade elétrica e concentração de solução de $\mathrm{NaCl}$. 


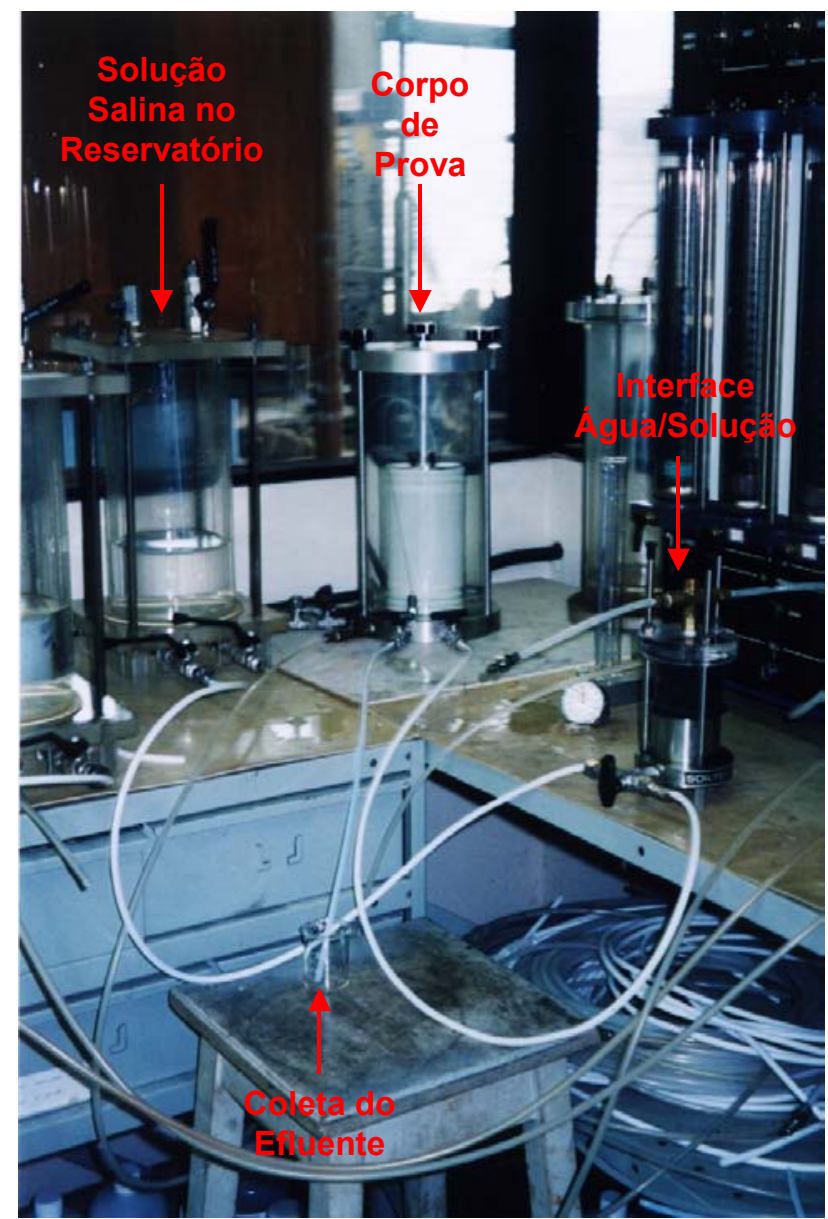

Foto 3.35. Vista geral do ensaio de coluna com percolação de solução salina.

\subsubsection{Ensaio de Coluna com Percolação de Solução de Metais}

O ensaio de coluna com percolação da solução de metais foi realizado segundo o procedimento descrito para a solução salina e com a tensão confinante igual $30 \mathrm{kPa}$. Às soluções efluentes foi adicionado ácido nítrico até o pH atingir valor menor que 2 , sendo então armazenadas em geladeira a $5.5^{\circ} \mathrm{C}$. Como já citado, isto foi feito para preservação das concentrações dos metais pesados, até que estas amostras pudessem ser levadas ao laboratório para análise.

\subsubsection{Ensaio de Coluna com Percolação de Chorume mais Metais}

O ensaio de coluna com percolação do chorume acrescido dos metais $\mathrm{Cd}, \mathrm{Ni}$, $\mathrm{Zn}$ e $\mathrm{Pb}$ também foi realizado segundo o mesmo procedimento descrito para a 
solução salina e para a solução de metais, sob tensão confinante igual a $30 \mathrm{kPa}$. As soluções efluentes foram tratadas com aplicação de ácido nítrico até que o pH atingisse valor menor que 2 e depois eram centrifugadas e filtradas em papel filtro faixa azul antes de serem levadas ao laboratório. Um cuidado especial foi tomado para encher o reservatório com o chorume, como mostra a Foto 3.36.

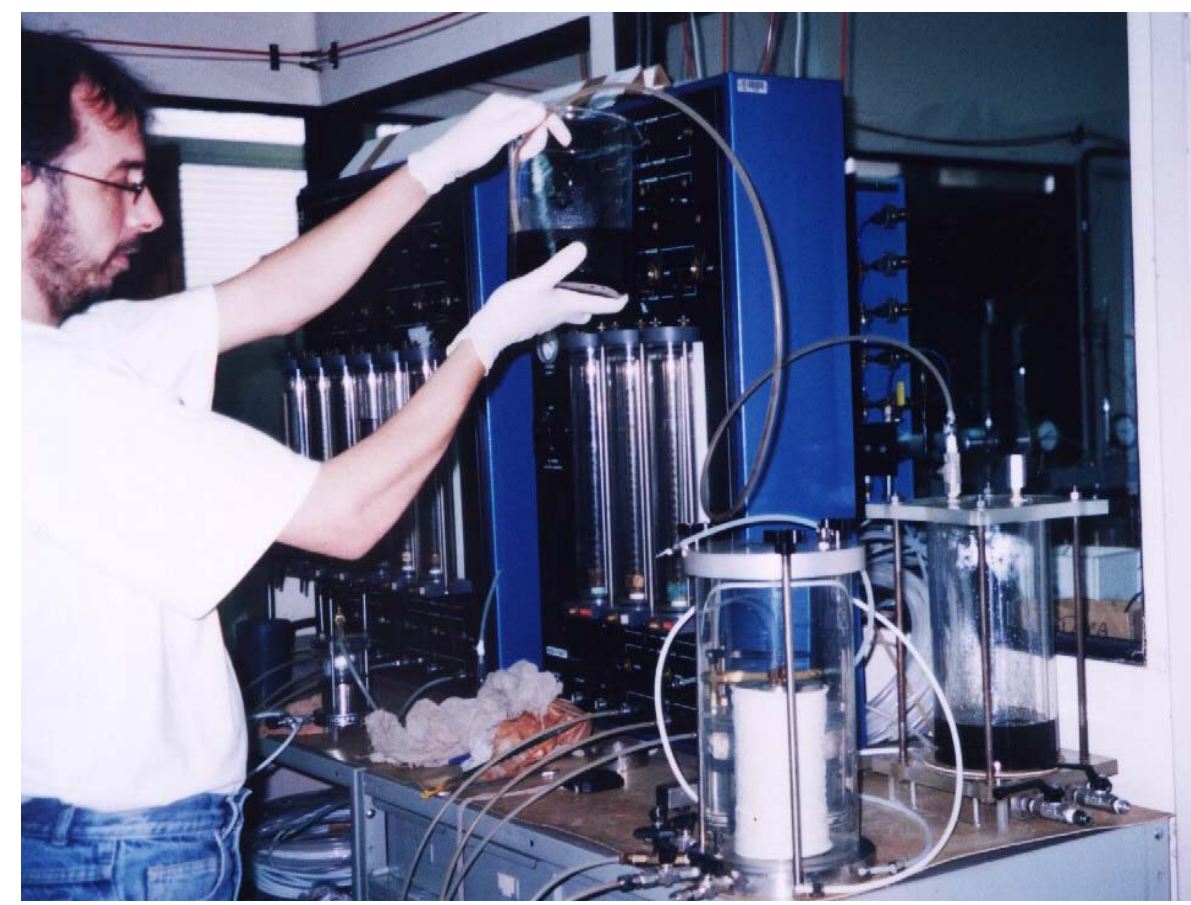

Foto 3.36. Preenchimento do reservatório com o chorume.

\subsubsection{Ensaio de Adsorção em Lote ("Batch Test")}

Como descrito anteriormente, foram realizados ensaios de adsorção em lote com a solução de metais e com o chorume acrescido de metais, nas mesmas condições utilizadas nos ensaios de coluna.

Primeiramente, procurou-se determinar a Razão Solo-Solução (RSS) para cada uma destas situações, que define a quantidade em massa de solo seco, em gramas, dividida pelo volume da solução utilizada, em ml. Segundo LEITE (2001), a RSS deve ser escolhida de forma a permitir que uma quantidade suficiente e estatisticamente relevante de soluto seja adsorvida. ROY et al. (1992) recomendam como critério valores da porcentagem de adsorção (A) situados entre 10 e 30\% para a 
mais alta concentração de soluto. Eles afirmam que valores situados dentro desse intervalo promovem uma diminuição discernível na concentração de soluto, que é estatisticamente aceitável com respeito à concentração inicial. Desta maneira, foi realizado o teste prévio de RSS, que dura $24 \mathrm{~h}$, variando-se as quantidades de solo e mantendo-se constante o volume da solução e do chorume. Foram testadas RSSs de 1:4, 1:10, 1:20, 1:50, 1:100, 1:200 e 1:500, como mostram os resultados no Anexo V. A RSS de 1:100 apresentou porcentagens de adsorção entre 10 e $30 \%$ para todos os frascos com solução de metais, com exceção do chumbo. E para os frascos com chorume, observou-se que cada metal apresenta valores de A diferentes para uma mesma RSS. Como o objetivo é a realização destes ensaios sempre nas mesmas condições para o chorume e para a solução, decidiu-se trabalhar com a RSS de 1:4, que foi a que apresentou os maiores valores de A e que, conseqüentemente, apresentaria o maior tempo de equilíbrio.

Após esta etapa, o tempo de equilíbrio foi então determinado para o chorume e para a solução de metais como sendo de uma semana (168 h). A velocidade de rotação utilizada foi de $60 \mathrm{rpm}$, que era a mínima que o aparelho Stuart Scientific, modelo Orbital Shaker SO1, oferecia (Foto 3.37), estando portanto acima da velocidade que ROY et al. (1992) apud LEITE (2001) propõem (29 rpm). Foram obtidas amostras após 2, 4, 24, 48, 72 e 168 h de rotação, quando os frascos contendo solução eram filtrados e acrescidos de ácido nítrico e os frascos contendo chorume eram filtrados, acrescidos de ácido nítrico, centrifugados e, finalmente, filtrados novamente. Todos estes frascos ficaram armazenados em geladeira, a $5.5^{\circ} \mathrm{C}$, até serem levados à análise química. O tempo de equilíbrio foi determinado através da estabilização da curva de concentração $(\mathrm{C})$ versus o tempo (t), para cada metal estudado. 


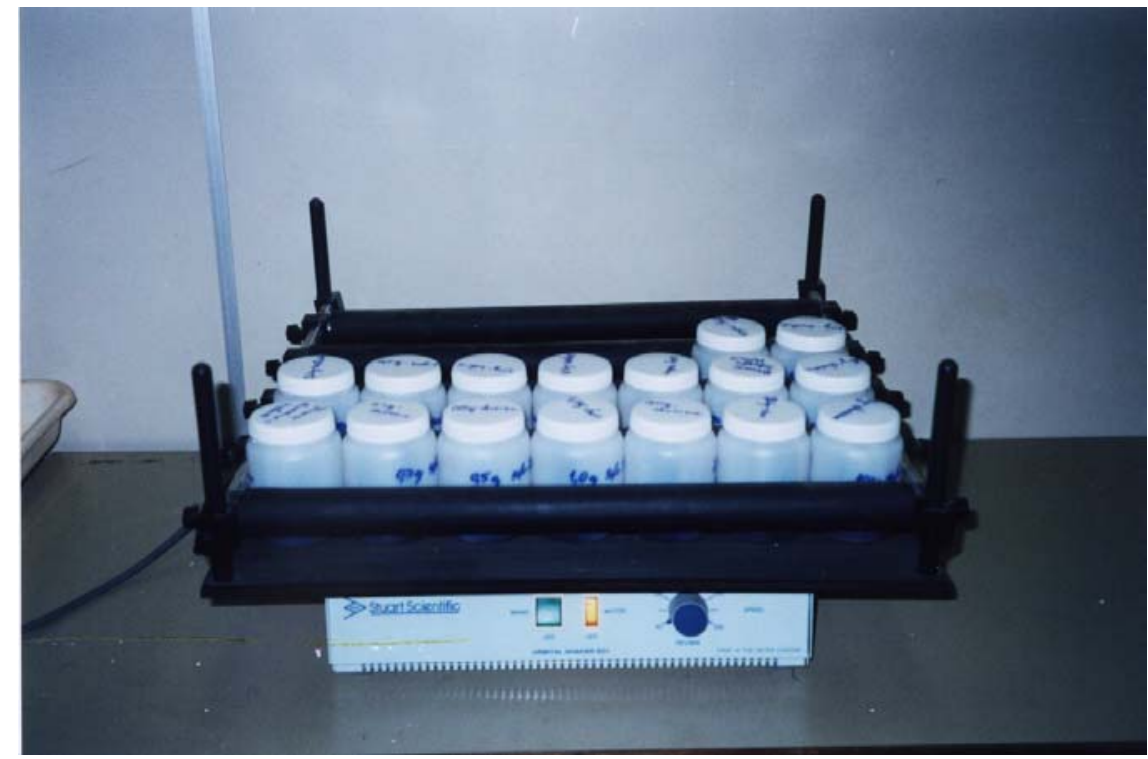

Foto 3.37. Equipamento de rotação utilizado durante os ensaios de adsorção em lote.

As isotermas foram construídas variando-se a RSS para os mesmos valores descritos acima, uma vez que as concentrações dos metais no chorume não podem ser alterados. Estas isotermas são conhecidas como ambientalmente conservativas ou ECL (Environmentally Conservative Isotherms RSS). O grau de adsorção (S) foi calculado como sendo:

$$
\mathrm{S}=\frac{\left(c_{0}-c_{e}\right) \cdot V}{M}
$$

onde:

$\mathrm{c}_{0}=$ concentração inicial da solução ("branco");

$\mathrm{c}_{\mathrm{e}}=$ concentração no tempo de equilíbrio;

$\mathrm{V}=$ volume da solução no frasco;

$\mathrm{M}=$ massa de solo seco. 


\section{RESULTADOS E DISCUSSÕES}

\subsection{Lixão de Ribeirão Preto}

\subsubsection{Sondagens Elétricas de Superfície}

Esta área de estudo foi investigada detalhadamente por ELIS (1999) e (2003b), sendo apresentados aqui apenas os resultados que possam contribuir e dar suporte à interpretação das sondagens CPTU e à amostragem de solos, que foram realizadas durante o desenvolvimento desta pesquisa.

As sondagens elétricas verticais (SEVs) puderam ser divididas em dois conjuntos: um representado pelos ensaios realizados dentro das cavas preenchidas com resíduos e outro pelas sondagens executadas fora das cavas. Essas sondagens permitiram definir, além da relação entre os resíduos e o meio geológico, algumas características da variação das camadas de solo e, principalmente, a posição da zona saturada. As Figuras 4.1 e 4.2 apresentam os resultados das SEVs 5 (à montante da cava de resíduos) e 6 (dentro da cava de resíduos) interpretadas pelo software RESIXIP (INTERPEX, 1993 apud ELIS, 2003b), respectivamente. 


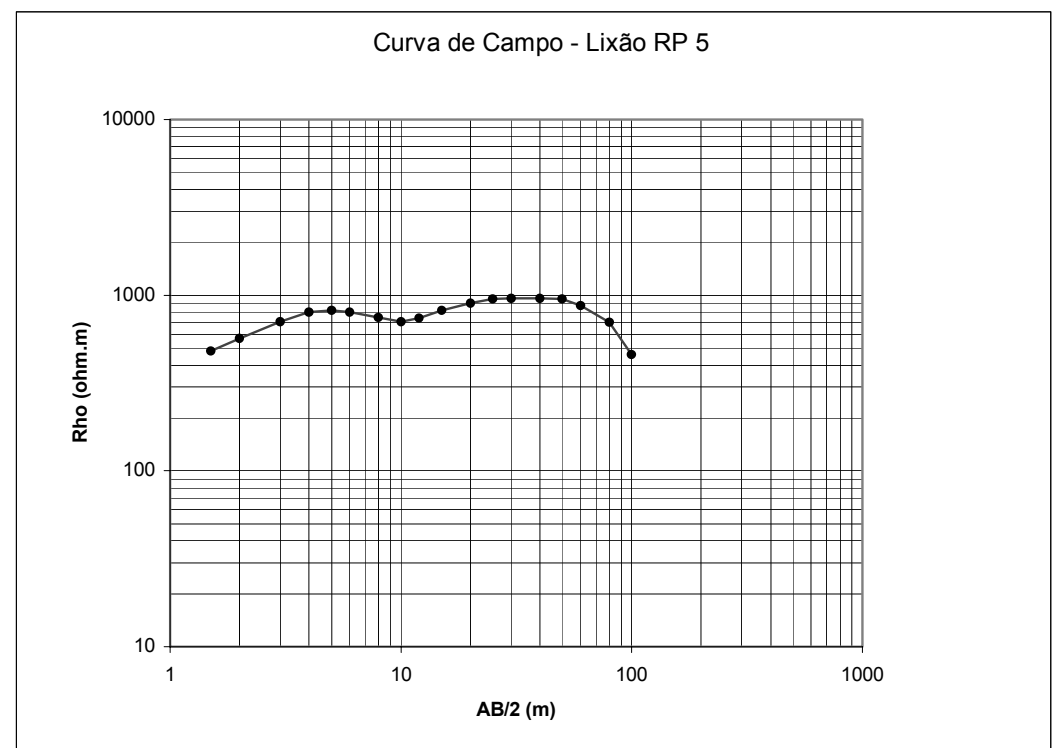

\begin{tabular}{|c|c|c|c|}
\hline & MODELO & GEOELÉTRICO & INTERPRETADO \\
\hline Camada & Espessura & Resistividade & Interpretação \\
\hline 1 & $0,7 \mathrm{~m}$ & 314 ohm.m & \multirow[b]{2}{*}{ Solo superficial } \\
\hline 2 & $1,7 \mathrm{~m}$ & 1724 ohm.m & \\
\hline 3 & $2,6 \mathrm{~m}$ & 224 ohm.m & \multirow{2}{*}{ Solo Não-Saturado } \\
\hline 4 & $16,9 \mathrm{~m}$ & 2328 ohm.m & \\
\hline 5 & $1,2 \mathrm{~m}$ & 908 ohm.m & $\begin{array}{c}\text { Zona de } \\
\text { capilaridade }\end{array}$ \\
\hline 6 & & 88 ohm.m & $\begin{array}{c}\text { Zona saturada } \\
\text { (solo/saprolito/arenito) }\end{array}$ \\
\hline
\end{tabular}

Erro $=3,5 \%$

Figura 4.1. Interpretação da SEV 5, localizada à montante da cava de resíduos no lixão de Ribeirão Preto (ELIS, 2003b). 


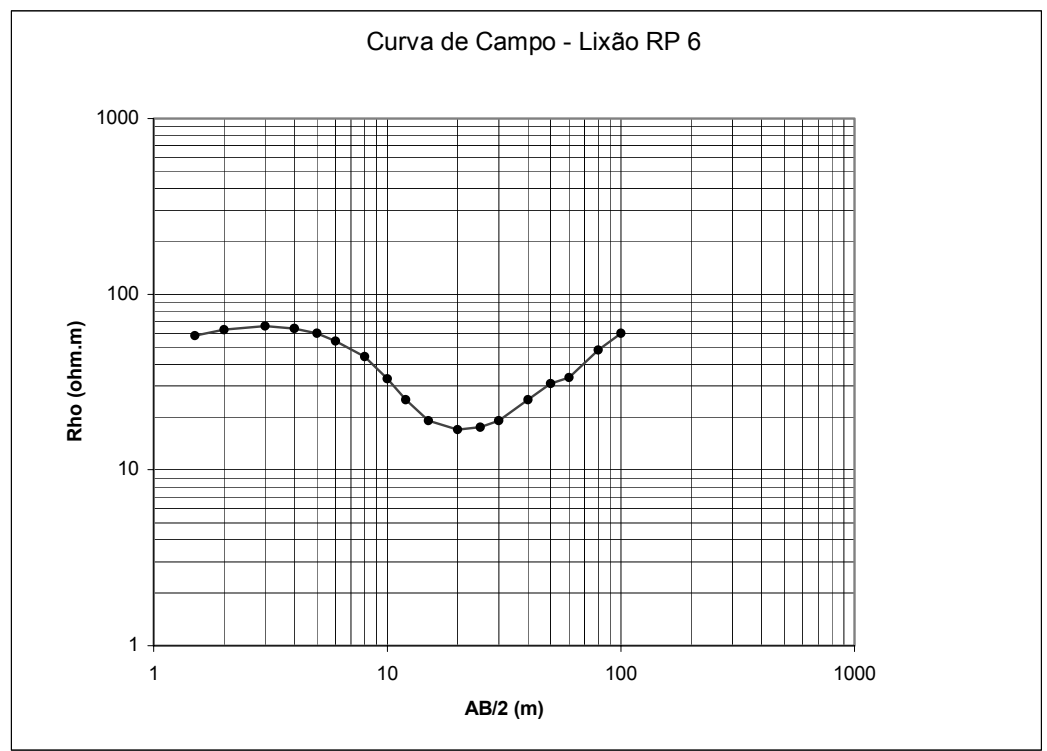

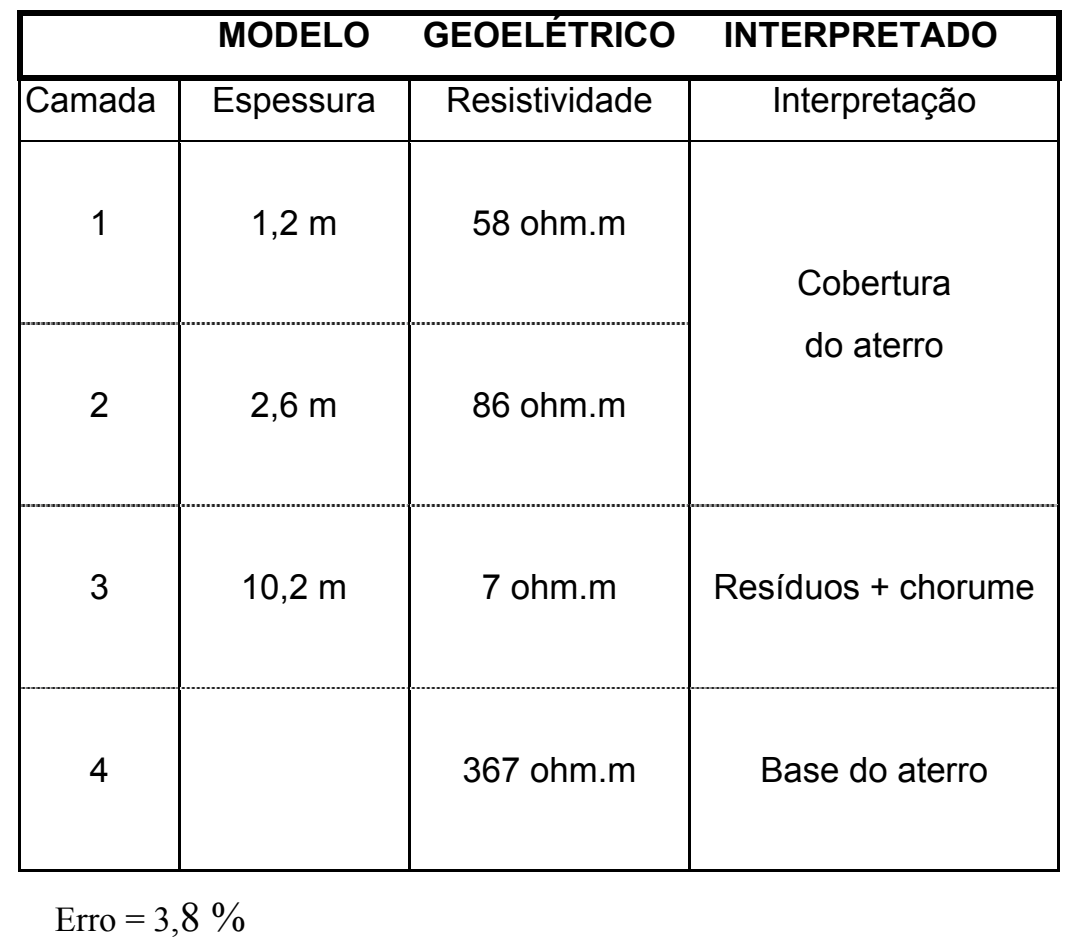

Figura 4.2. Interpretação da SEV 6, localizada dentro da cava de resíduos no lixão de Ribeirão Preto (ELIS, 2003b).

Estas SEVs permitiram identificar alguns valores típicos de resistividade para cada tipo de material que ocorre no terreno. Por exemplo, a camada que contém resíduos foi muito bem identificada na SEV 6, com um valor de resistividade muito 
baixo, da ordem de 7ohm.m. Na SEV 5, ficou nítida a transição entre as camadas de solo não-saturado (2328 ohm.m) e de solo acima da zona saturada (908 ohm.m), diminuindo para 88 ohm.m na a zona saturada.

A partir dos resultados obtidos para a zona saturada foi construído, tomandose as cotas do nível d'água em cada sondagem, o mapa de fluxo subterrâneo, apresentado na Figura 4.3, que mostra que o principal sentido do fluxo local é predominantemente para nordeste.

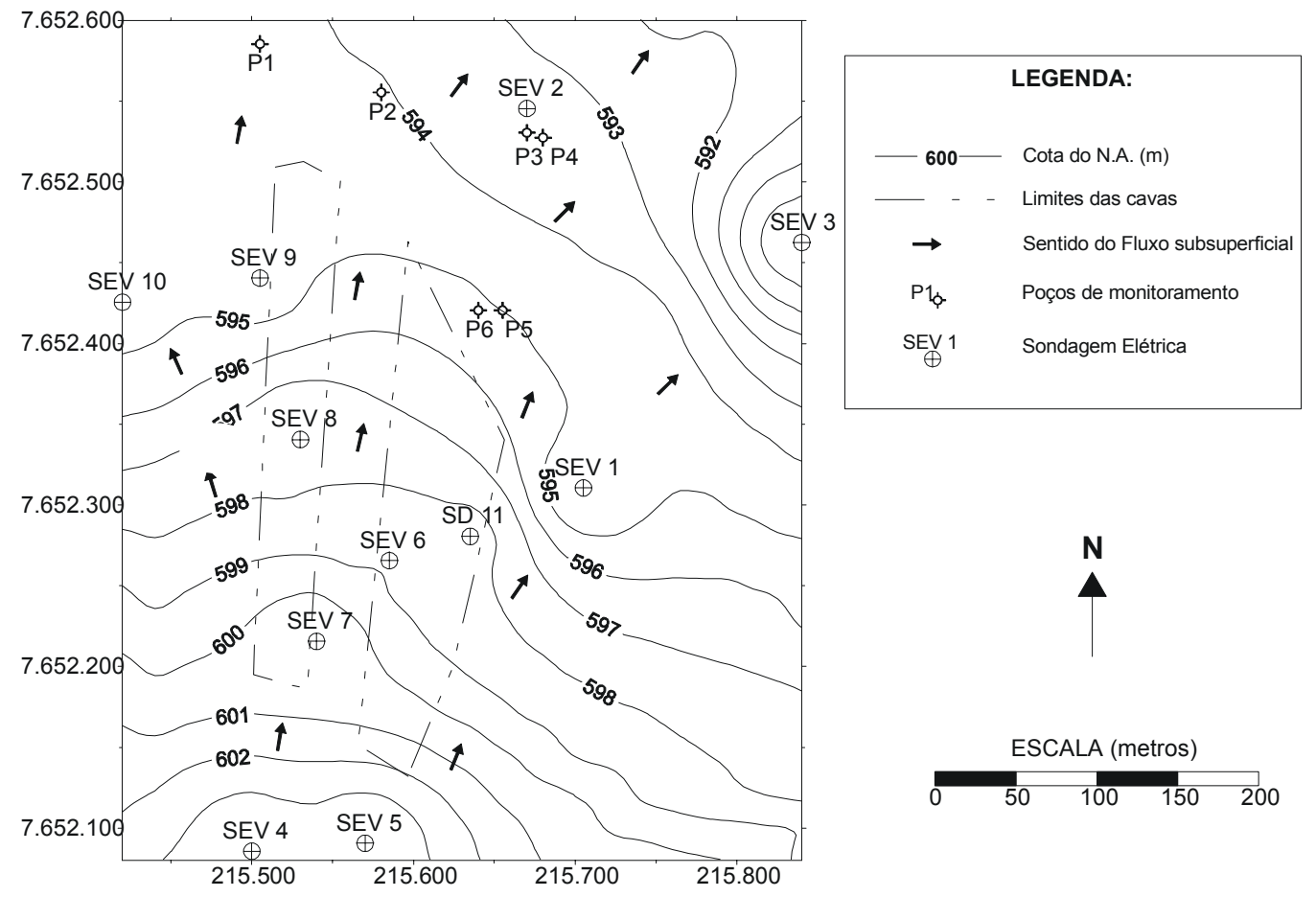

Figura 4.3. Mapa de fluxo subterrâneo definido através das SEVs e dos poços existentes (ELIS, 2003b).

As Figuras 4.4 e 4.5, a seguir, apresentam as seções das Linhas C1 (à jusante do lixão) e C4 (transversal às duas cavas de resíduos) interpretadas por ELIS (2003b) a partir do software de modelagem RES2Dinv, seguidas de suas respectivas seções estimadas para o lixão.

Estas seções de resistividade real obtidas nos ensaios de caminhamento elétrico mostraram um forte contraste entre as zonas preenchidas com resíduos (valores de resistividade inferiores a $20 \mathrm{ohm} . \mathrm{m}$ ), zonas afetadas pela contaminação 
(valores entre 20 e 200 ohm.m) e o terreno natural (em geral, valores superiores a $200 \mathrm{ohm} . \mathrm{m})$, permitindo assim identificar os locais mais alterados.

\section{Linha C1 - Fase 1}

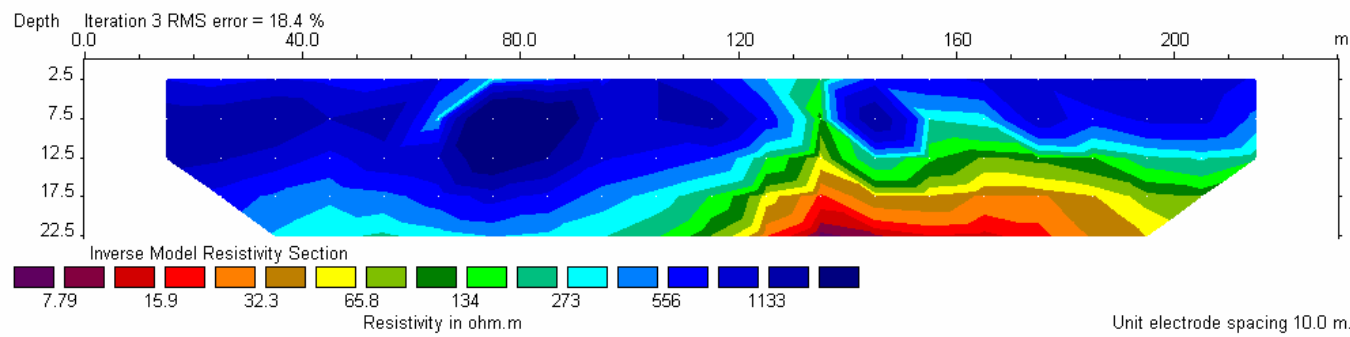

\section{Linha C1 - Fase 2}
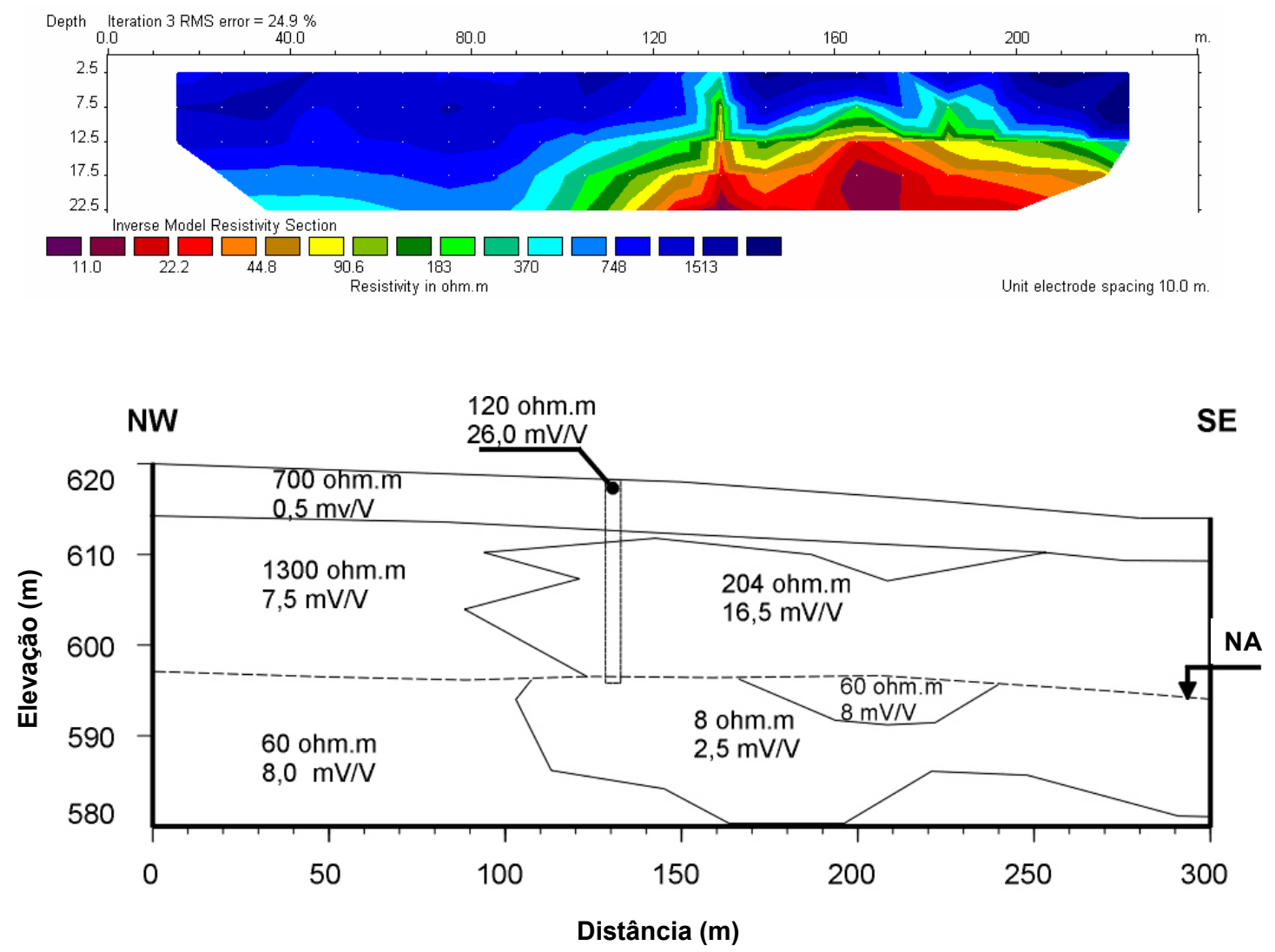

Figura 4.4. Seções de resistividade modeladas para as Fases 1 e 2 da Linha C1

(ELIS, 2003b; 2004). 


\section{Linha C4 - Fase 1}

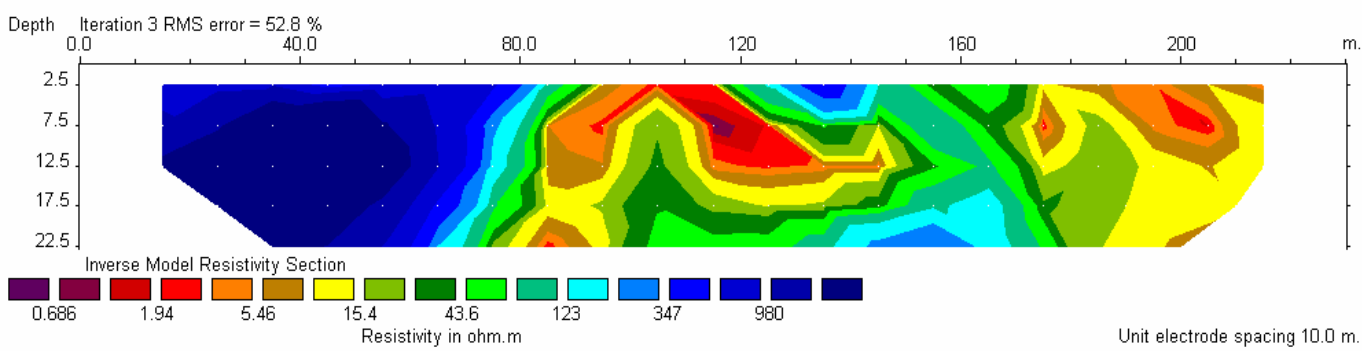

\section{Linha C4 - Fase 2}
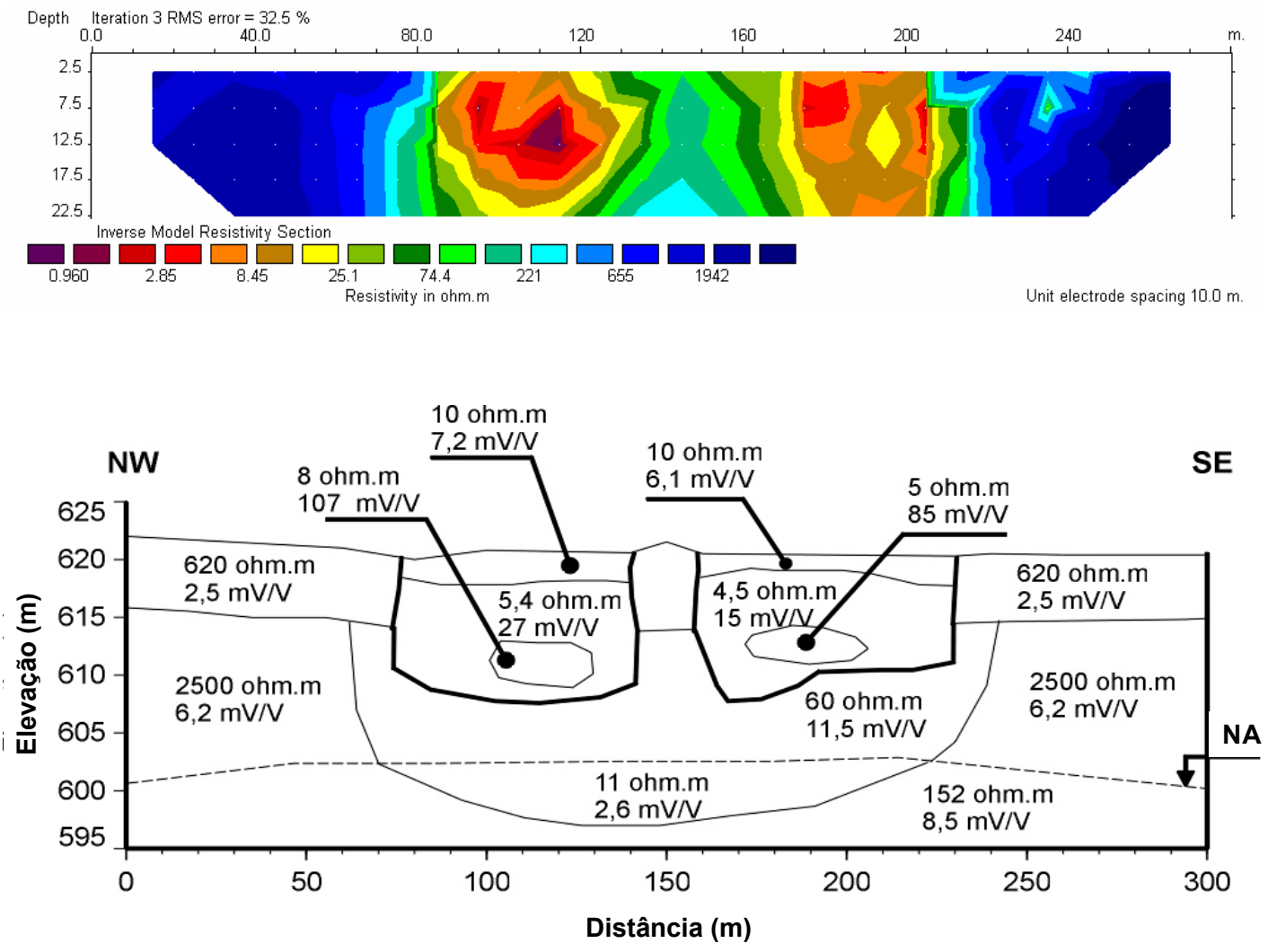

Figura 4.5. Seções de resistividade modeladas para as Fases 1 e 2 da Linha C4 (ELIS, 2003b; 2004).

Na seção da Linha C1, apresentada na Figura 4.4, observa-se que em sua maior parte os valores de resistividade são altos, normalmente acima de 500 ohm.m. No espaço a partir da distância 110 metros até o final do perfil ocorre, em profundidades teóricas abaixo de $15 \mathrm{~m}$, uma zona de baixa resistividade, com valores inferiores a 20 ohm.m, que caracteriza a pluma de contaminação chegando na zona saturada. 
Na seção da Linha C4, apresentada na Figura 4.5, as duas cavas estão bem representadas. Os locais ocupados pelos resíduos mostram valores de resistividade inferiores a $200 \mathrm{ohm} . \mathrm{m}$, enquanto que os valores inferiores a $8 \mathrm{ohm} . \mathrm{m}$ caracterizam a presença de chorume.

O conjunto de dados de resistividade obtido pelos ensaios de caminhamento elétrico foi utilizado para a elaboração de mapas de resistividade aparente de alguns níveis teóricos, os quais possibilitaram uma análise do comportamento da contaminação no sentido horizontal. O mapa do nível teórico $30 \mathrm{~m}$, apresentado na Figura 4.6 para a Fase 2, caracteriza a zona saturada e possibilita a visualização de uma frente de contaminação (valores de resistividade aparente inferiores a 200 ohm.m) se desenvolvendo a partir dos resíduos, no sentido do fluxo subterrâneo local (norte-nordeste). Um fator importante a ressaltar nesta figura, conforme observado por ELIS (1999), é que as posições dos poços de monitoramento, construídos anteriormente à realização desses ensaios, com exceção dos poços P3 e P4, estão fora da faixa mais afetada pela contaminação.

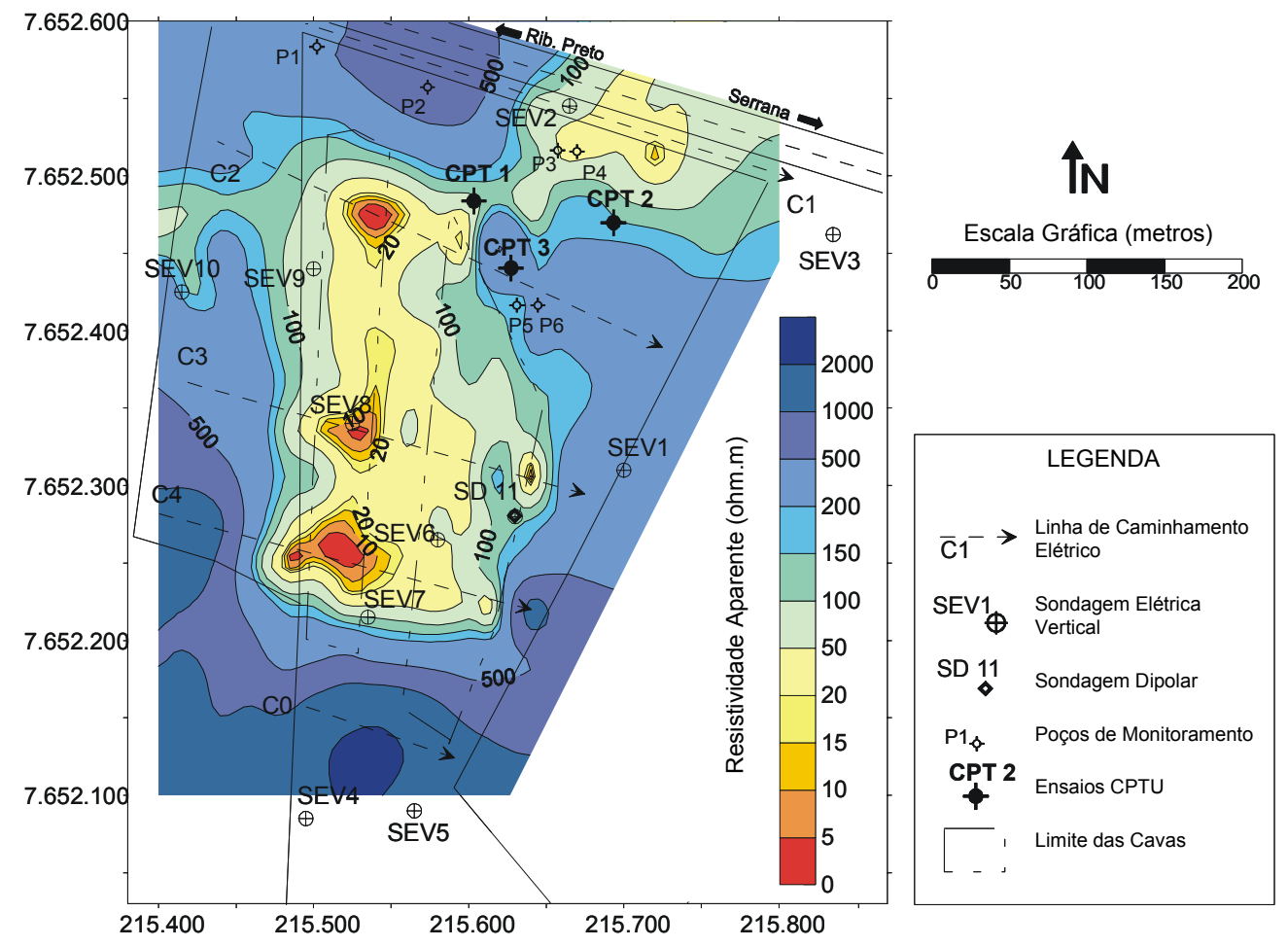

Figura 4.6. Mapa de resistividade aparente do nível $30 \mathrm{~m}$ mostrando a pluma se desenvolvendo no sentido do fluxo subterrâneo, à nordeste (ELIS, 2003b). 


\subsubsection{Poços de Monitoramento}

PEJON \& ZUQUETTE (1991) realizaram análises químicas de amostras de água coletadas nos poços de monitoramento existentes no local. Estes poços foram instalados no ano de 1991, 18 anos após a instalação do lixão e 1 ano após sua desativação. As análises realizadas em águas coletadas naquela época nos poços de monitoramento existentes e localizados a norte e a noroeste (poços P1 e P2) e a nordeste (poços P3 e P4) das cavas preenchidas com lixo não apresentaram variações nos parâmetros medidos que caracterizassem seguramente uma contaminação. Esses poços têm $20 \mathrm{~m}$ de profundidade, suficiente para atingir a parte mais superior do nível d'água. Somente o poço P2 apresentou valores anômalos em relação aos demais (inclusive ao poço P5, com medidas anteriores à instalação do lixão) quanto às concentrações dos íons $\mathrm{Na}^{+}, \mathrm{Cu}^{++}$e $\mathrm{Mn}^{++}$e valor mais alto de condutividade, seguido do poço P3 (Tabela 4.1).

Tabela 4.1. Dados da análise físico-química das águas dos poços do lixão de Ribeirão Preto (PEJON \& ZUQUETTE, 1991).

\begin{tabular}{|c|c|c|c|c|c|}
\hline Parâmetros & Poço P1 & Poço P2 & Poço P3 & Poço P4 & Poço P5 \\
\hline Temperatura $\left({ }^{\circ} \mathrm{C}\right)$ & 22.0 & 22.5 & 24.0 & 20.0 & 22.0 \\
\hline Condutividade $(\mu \mathrm{S} / \mathrm{cm})$ & 33.0 & 690 & 150 & 72.0 & 33.0 \\
\hline pH & 5.87 & 5.14 & 6.87 & 6.44 & 7.05 \\
\hline $\mathrm{Ca}^{++}(\mathrm{mg} / \mathrm{L})$ & 1.66 & 3.49 & 5.76 & 1.48 & 2.88 \\
\hline $\mathrm{Mg}^{++}(\mathrm{mg} / \mathrm{L})$ & 1.10 & 5.56 & 6.06 & 1.78 & 1.26 \\
\hline $\mathrm{Na}^{+}(\mathrm{mg} / \mathrm{L})$ & 2.00 & 70.00 & 3.00 & 5.00 & 1.00 \\
\hline $\mathbf{K}^{+}(\mathrm{mg} / \mathrm{L})$ & 1.40 & 2.75 & 2.50 & 1.50 & 2.75 \\
\hline $\mathrm{Zn}^{2+}(\mathrm{mg} / \mathrm{L})$ & 0.00 & 0.00 & 0.00 & 0.00 & 0.00 \\
\hline $\mathrm{Cu}^{++}(\mathrm{mg} / \mathrm{L})$ & 0.00 & 0.586 & 0.00 & 0.00 & 0.00 \\
\hline $\mathrm{Cd}^{++}(\mathrm{mg} / \mathrm{L})$ & 0.00 & 0.00 & 0.00 & 0.00 & 0.00 \\
\hline $\mathrm{Mn}^{++}(\mathrm{mg} / \mathrm{L})$ & 0.48 & 12.50 & 0.00 & 0.40 & 0.01 \\
\hline $\mathbf{P b}^{++}(\mathrm{mg} / \mathrm{L})$ & 0.00 & 0.00 & 0.00 & 0.00 & 0.00 \\
\hline $\mathrm{Cr}^{+6}(\mathrm{mg} / \mathrm{L})$ & 0.00 & 0.00 & 0.00 & 0.00 & 0.00 \\
\hline
\end{tabular}




\subsubsection{Ensaios com o Piezocone (CPTU)}

Três sondagens CPTU foram realizadas na área do antigo lixão de Ribeirão Preto, sendo duas delas localizadas na região em que a geofísica de superfície indicou contaminação (Figura 4.6), e a outra numa área onde a geofísica não apresentou indícios da presença da pluma de contaminação (CPTU 3). Os ensaios com o piezocone não atingiram o nível d'água, uma vez que este era mais profundo que o impenetrável do cone. Sendo assim, não foi possível coletar água para análise e avaliação da contaminação. Foram então coletadas amostras de solo utilizando o amostrador Geoprobe ${ }^{\circledR}$, próximo ao ensaio CPTU 1. As profundidades de coleta de amostras de solo foram definidas com base nas alterações nos valores de $q_{c}$ e $R_{f}$ observadas nos perfis de sondagem obtidos. A partir dessas amostras, foram realizados ensaios de granulometria conjunta e determinação da condutividade elétrica e pH na água lixiviada pelo solo. Os perfis obtidos pelo piezocone foram interpretados utilizando o ábaco de ROBERTSON et al. (1986), para a classificação do tipo de solo existente no local. Estes resultados são apresentados no Anexo I, na Tabela 4.2 e na Figura 4.7.

Tabela 4.2. Resultados dos ensaios realizados nas amostras de solo coletadas com o amostrador Geoprobe ${ }^{\circledR}$, sendo a granulometria obtida a partir da NBR 6502/95, e pH e a condutividade $(\mathrm{C})$ obtidos a partir da água lixiviada pelo solo.

\begin{tabular}{|ccc|c|c|c|c|c|c|}
\hline $\begin{array}{c}\text { Profundidade } \\
(\mathbf{m})\end{array}$ & $\mathbf{p H}$ & $\begin{array}{c}\mathbf{C} \\
(\mu \mathbf{S} / \mathbf{c m})\end{array}$ & $\begin{array}{c}\mathbf{R} \\
(\mathbf{o h m} . \mathbf{m})\end{array}$ & $\begin{array}{c}\text { Areia } \\
(\mathbf{\%})\end{array}$ & $\begin{array}{c}\text { Silte } \\
(\mathbf{\%})\end{array}$ & $\begin{array}{c}\text { Argila } \\
(\mathbf{\%})\end{array}$ \\
\hline $\mathbf{1 . 5}$ & $\mathbf{a}$ & $\mathbf{2 . 5}$ & 5.43 & 35.6 & 280.9 & 42 & 32 & 26 \\
\hline $\mathbf{4 . 5}$ & $\mathbf{a}$ & $\mathbf{5 . 5}$ & 5,60 & 26.4 & 378.8 & 37 & 32 & 31 \\
\hline $\mathbf{7 . 0}$ & a & $\mathbf{8 . 0}$ & 5.56 & 31.7 & 315.5 & 32 & 34 & 34 \\
\hline $\mathbf{8 . 2}$ & a & $\mathbf{9 . 0}$ & 5.61 & 43.1 & 232.0 & 23 & 40 & 37 \\
\hline $\mathbf{1 1 . 5}$ & a & $\mathbf{1 2 . 0}$ & 5.72 & 51.6 & 193.8 & 38 & 32 & 30 \\
\hline $\mathbf{1 3 . 0}$ & a & $\mathbf{1 3 . 8}$ & 5.84 & 58.3 & 171.5 & 44 & 40 & 16 \\
\hline $\mathbf{1 3 . 8}$ & a & $\mathbf{1 4 . 0}$ & 5.69 & 56.4 & 177.3 & - & - & - \\
\hline
\end{tabular}




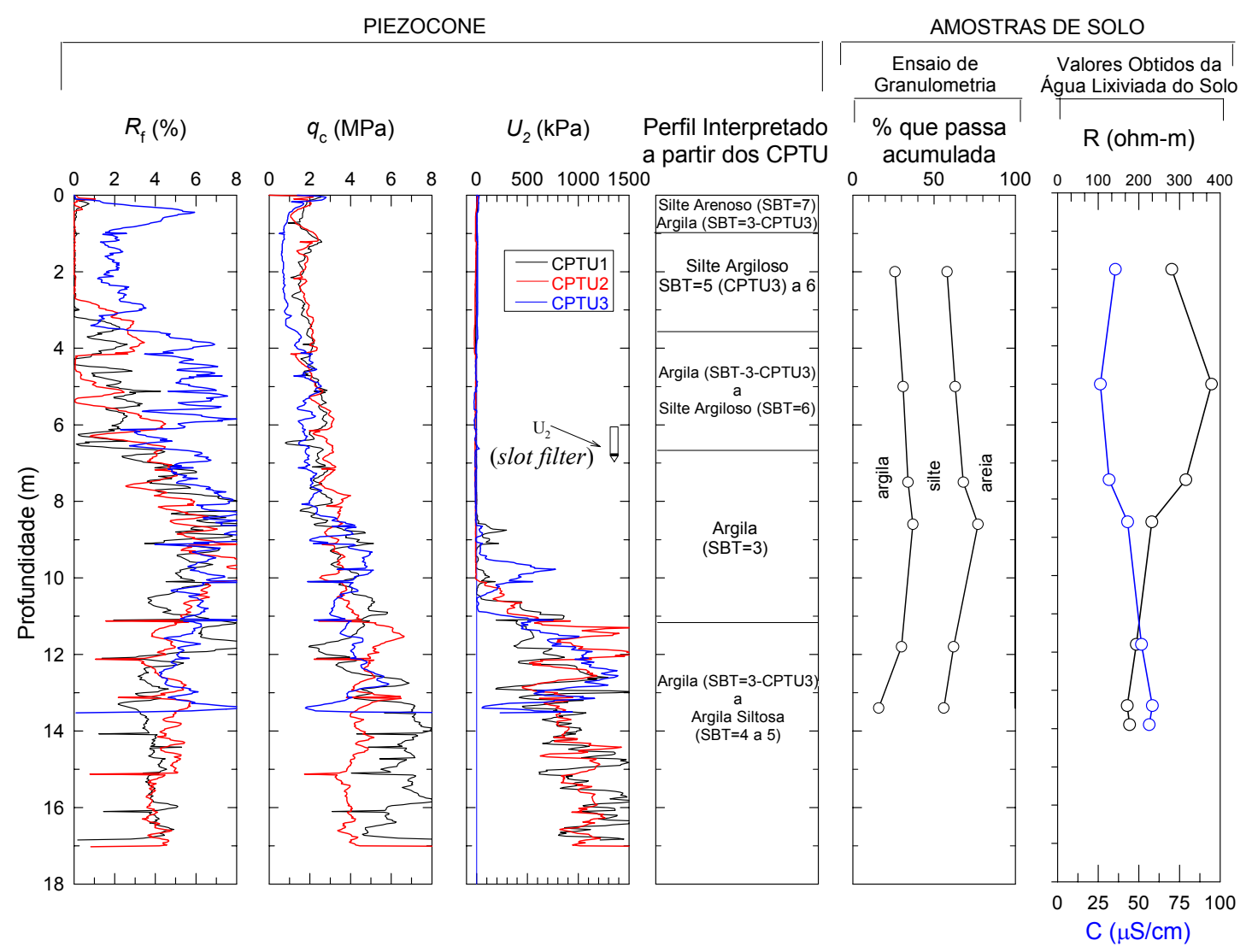

Figura 4.7. Resultados das sondagens CPTU e das amostragens de solo realizadas na área do lixão de Ribeirão Preto.

Comparando-se o perfil geotécnico interpretado a partir da classificação de ROBERTSON et al. (1986) com aquele determinado a partir da amostragem de solo, observa-se a limitação desta proposta quanto à definição da textura para este tipo de solo, uma vez que na classificação granulométrica apresentada pela Tabela 4.2 a porcentagem de areia é sempre maior do que a de silte e de argila, com exceção da camada entre 7 e $9 \mathrm{~m}$. Porém, é justamente nesta camada que o perfil interpretado indica a presença de material argiloso, o que mostra a sensibilidade desta ferramenta para identificar camadas de diferentes comportamentos. Esta conclusão está de acordo com o trabalho de MARQUES (2002), que constatou que o ábaco de classificação de ROBERTSON et al. (1986) apresenta limitação para solos tropicais, apesar dos valores de $\mathrm{q}_{\mathrm{c}}$ e $\mathrm{R}_{\mathrm{f}}$ serem sensíveis à mudança de comportamento do solo, onde o autor recomenda que seja feita amostragem de solo. 
Outro aspecto importante na investigação geoambiental é a estimativa de parâmetros geotécnicos das camadas que compõem o perfil. De especial interesse é a estimativa do coeficiente de permebilidade do solo e a avaliação de um possível gradiente hidráulico. Para as três sondagens CPTU realizadas não foi possível fazer o ensaio de dissipação do excesso de poro-pressão gerado, o qual permitiria a estimativa da permeabilidade, devido ao fato de não ter sido possível atingir o nível d'água por limitação da cravação do equipamento. Este foi o grande problema para aplicação dessa técnica de investigação, uma vez que a presença do nível d'água abaixo do impenetrável do cone impossibilita a definição da posição desse nível d'água, a estimativa da permeabilidade do solo e a coleta de amostras de água para avaliação da presença de algum contaminante nessa água.

O nível d'água profundo, comum em perfis de solos tropicais, faz com que o emprego do filtro de cavidade preenchido com graxa automotiva (LARSSON, 1995) seja um recurso interessante para que se possa obter registro de poro-pressões e portanto, foi utilizado nesta área. Os valores de $U_{2}$ utilizando este recurso foram maiores que zero a partir de $10 \mathrm{~m}$ de profundidade, muito acima do nível d'água. Acredita-se que isto se deve ao alto teor de umidade existente numa zona de capilaridade em solos argilosos, resultando assim em geração de excesso de poropressão quando se emprega o filtro de cavidade com graxa, conforme tem sido observado por DE MIO (2003) em outras sondagens CPTU realizadas em situações semelhantes a esta.

\subsubsection{Avaliação da Contaminação da Área}

As análises físico-químicas das águas dos poços de monitoramento realizadas por PEJON \& ZUQUETTE (1991) indicaram o poço P2 como o mais contaminado, apesar deste também não estar no ponto mais crítico da pluma de contaminação determinada em duas épocas distintas por ELIS (1999 e 2003b). Sugere-se que novas coletas sejam realizadas nestes poços, principalmente para a confirmação de que os poços P3 e P4 apresentem maior contaminação, conforme indica a pluma de contaminação da Figura 4.6. A Tabela 4.3, a seguir, mostra que naquela época os 
poços praticamente não tiveram seus valores excedidos pelos limites de potabilidade divulgados pela CETESB (2001) e pela Portaria n ${ }^{\circ} 1.469$ do Ministério da Saúde.

Tabela 4.3. Poços cujas amostras ultrapassaram os limites estabelecidos pela CETESB (2001) e pela Portaria n ${ }^{0} 1.469$ do Ministério da Saúde.

\begin{tabular}{|c|c|c|}
\hline Elemento & $\begin{array}{c}\text { Valores de } \\
\text { Intervenção (mg/L) }\end{array}$ & Poço \\
\hline $\mathrm{Cr}$ & 0.050 & - \\
\hline $\mathrm{Cd}$ & 0.005 & - \\
\hline $\mathrm{Cu}$ & 2.000 & - \\
\hline $\mathrm{Mn}$ & 0.100 & $\mathrm{P} 1, \mathrm{P} 2$ e P4 \\
\hline $\mathrm{Na}$ & 200.0 & - \\
\hline $\mathrm{Pb}$ & 0.010 & - \\
\hline $\mathrm{Zn}$ & 5.000 & - \\
\hline
\end{tabular}

Com relação à aplicação da tecnologia do piezocone, o grande problema foi atingir o impenetrável antes de chegar ao nível d'água. Isto impossibilitou a identificação da posição desse nível d'água, a estimativa da permeabilidade do solo e a coleta de amostras de água, impossibilitando uma análise da concentração de contaminantes presentes na água a partir de resultados da resistividade determinada numa sondagem RCPTU, que um dos objetivos deste trabalho. Por isso, ensaios para determinação da condutividade elétrica e $\mathrm{pH}$ foram realizados na água lixiviada pelas amostras de solo coletadas com o amostrador Geoprobe ${ }^{\circledR}$ (Tabela 4.2). Esses resultados indicaram que o $\mathrm{pH}$ ficou praticamente constante com a profundidade (da ordem de 5.6). Observou-se, entretanto, que a resistividade elétrica, derivada da condutividade da água percolada pelo solo, diminuiu a partir dos $7 \mathrm{~m}$ de profundidade, onde iniciava-se uma camada de solo argiloso (Figura 4.7). Contudo, quando a granulometria indicou novamente a presença de material um pouco mais grosso a partir dos $11 \mathrm{~m}$ de profundidade, os valores de resisitividade continuaram diminuindo, o que é um indicativo de uma possível contaminação na zona não saturada desse solo. Isto pode ser confirmado na pseudo-seção da Linha C1 interpretada (Figura 4.4), onde existe uma gradual diminuição da resisitividade com a profundidade na parte leste da seção, apresentando valores menores que $200 \mathrm{ohm} . \mathrm{m}$ 
antes de atingir o nível d'água contaminado, caracterizado por resistividades menores que 20 ohm.m.

Infelizmente, não foi possível coletar amostras de solo a partir dos $13.8 \mathrm{~m}$ de profundidade, uma vez que não foi possível cravar o amostrador de solo, devido à limitação do sistema de reação utilizado. Esta limitação poderá restringir muito o emprego desta técnica de investigação em perfis de solos residuais, os quais são freqüentes em regiões de clima tropical. Isto se torna ainda mais crítico quando o interesse é coletar amostras de água subterrânea ou estimar o coeficiente de permeabilidade a partir do ensaio de dissipação de poro-pressão, já que muitas vezes, em solos residuais, o nível d'água estará abaixo do impenetrável, como foi o caso descrito aqui.

\subsection{Aterro de Resíduos Sólidos Urbanos de Bauru}

\subsubsection{Sondagens Elétricas de Superfície}

No aterro de resíduos sólidos de Bauru foram realizados, entre outubro de 2001 e maio de 2003, uma série de ensaios geofísicos com os métodos da eletrorresistividade, polarização induzida e potencial espontâneo. Estes ensaios foram interpretados por LAGO (2004), e serão descritos a seguir:

- 9 sondagens elétricas verticais de resistividade e polarização induzida, arranjo Schlumberger, com espaçamento AB máximo de 150 metros;

- 5 linhas de caminhamento elétrico dipolo-dipolo de resistividade e polarização induzida, com espaçamento dos eletrodos de 10 metros (C1 a C5);

- Repetição, em períodos diferentes, dos ensaios nas Linhas C1, C2 e C4;

- 5 linhas de potencial espontâneo (método de potenciais), com espaçamento dos eletrodos de 20 metros.

A localização desses ensaios na área em estudo é apresentada na Figura 4.8, dos quais a maioria foi concentrada em duas fases. A Fase 1 foi realizada em outubro de 2001, antes do período das chuvas e a Fase 2 em abril de 2002, logo após o período chuvoso. 
As sondagens elétricas verticais (SEVs) podem ser divididas em dois grupos: um representado pelos ensaios realizados fora da cava preenchida com resíduos (SEVs 1 a 7) e outro pelas sondagens executadas dentro da cava (SEVs 8 e 9). As Figuras 4.9 e 4.10 apresentam os resultados das SEVs 3 (à jusante da cava de resíduos) e 8 (dentro da cava de resíduos) respectivamente, interpretadas pelo software IPI por LAGO (2004).

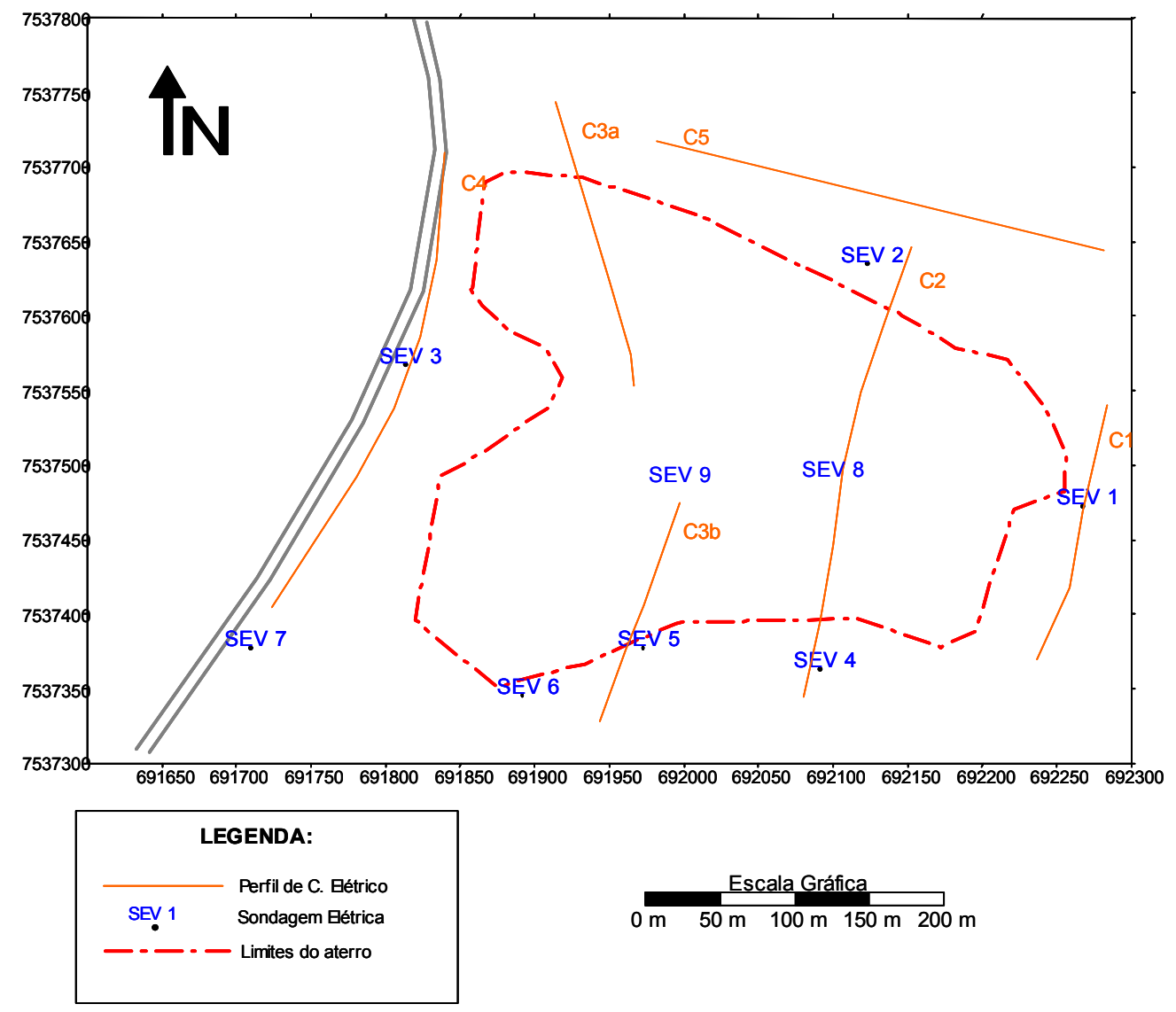

Figura 4.8. Mapa de localização dos ensaios geofísicos realizados no aterro de resíduos sólidos urbanos de Bauru (LAGO, 2004). 


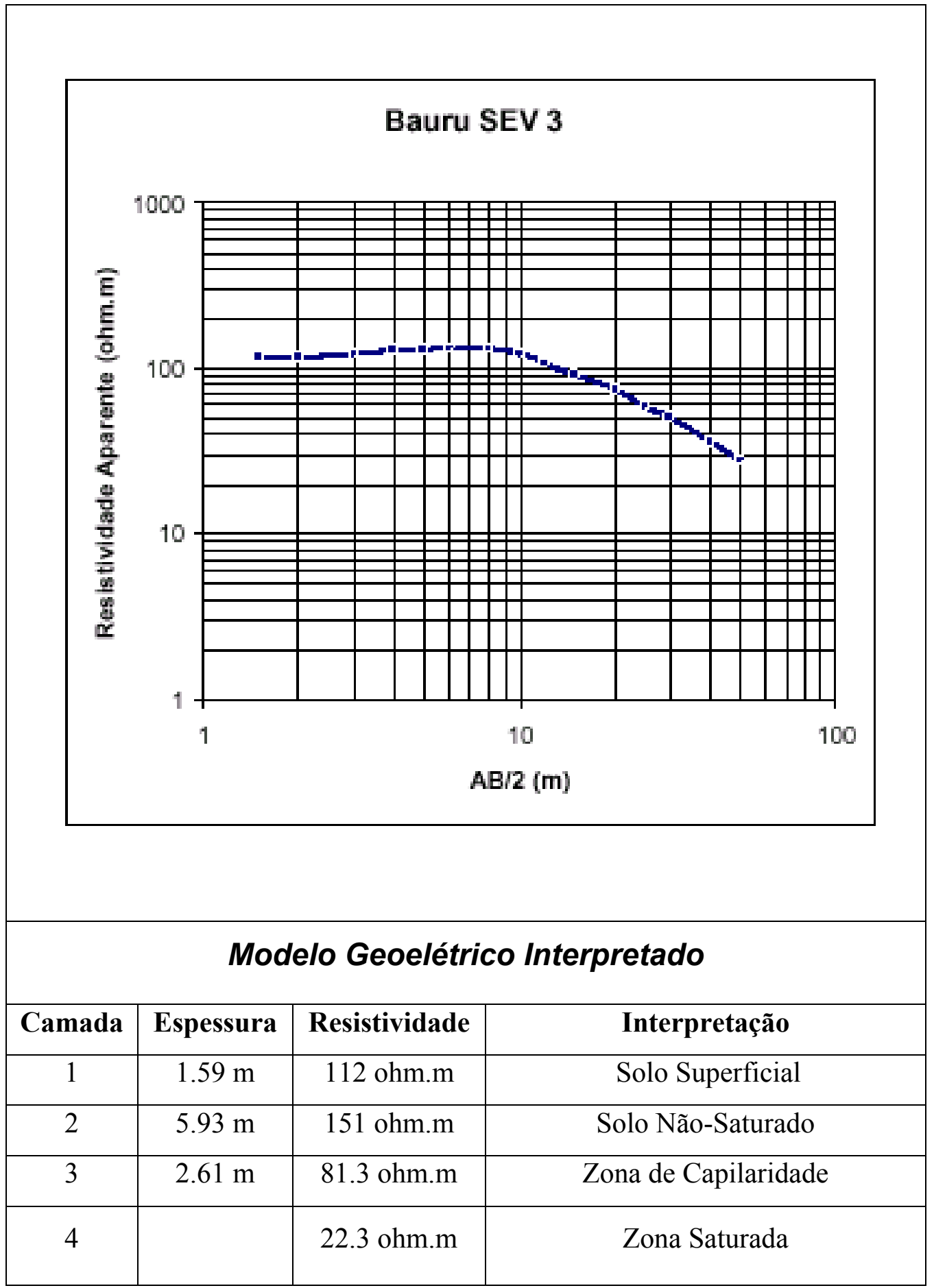

Figura 4.9. Interpretação da SEV 3, localizada à jusante da cava de resíduos no aterro de resíduos sólidos de Bauru (LAGO, 2004). 


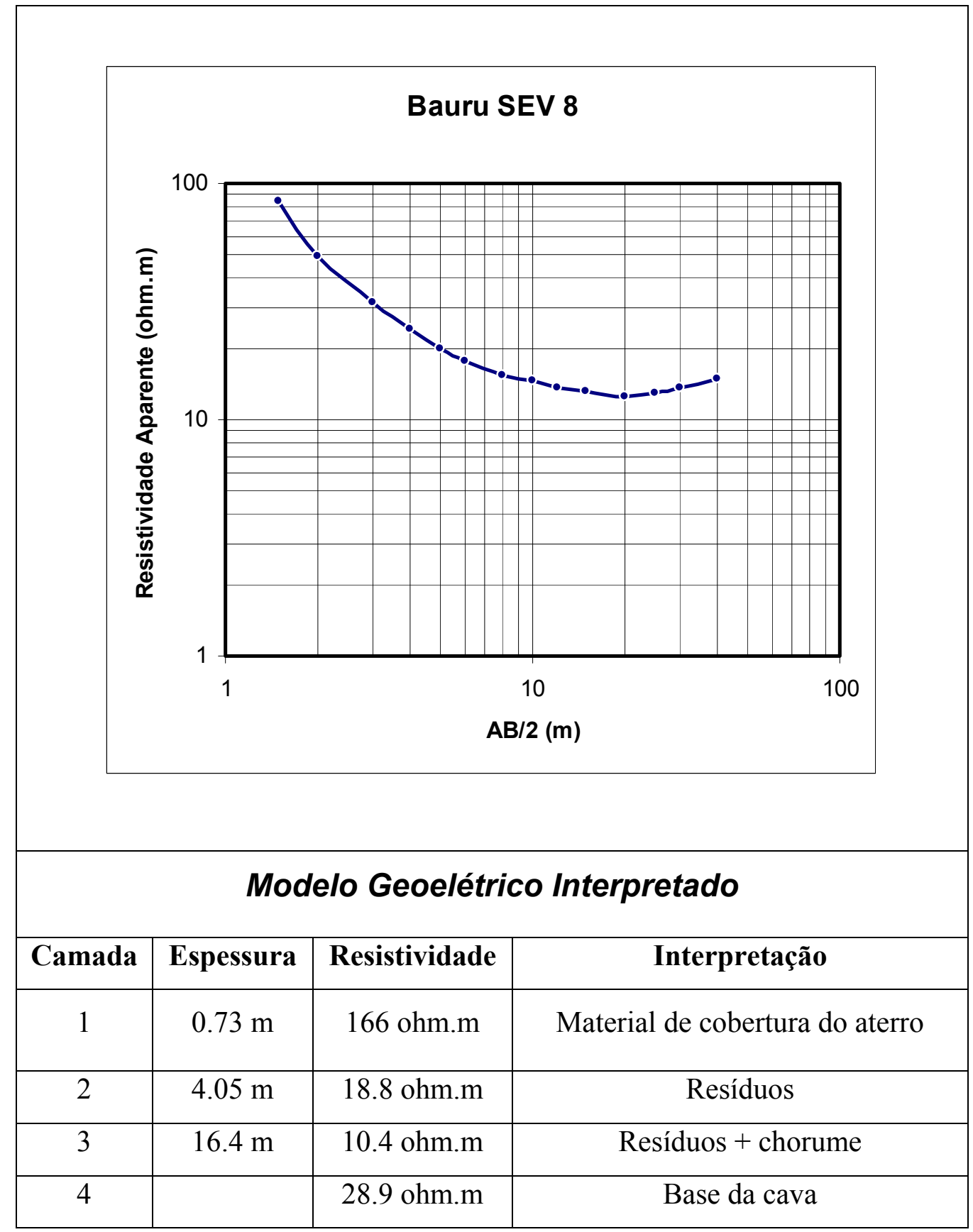

Figura 4.10. Interpretação da SEV 8, localizada dentro da cava de resíduos no aterro de resíduos sólidos de Bauru (LAGO, 2004).

Segundo LAGO (2004), as sondagens executadas fora da cava de resíduos, como a SEV 3, por exemplo, forneceram dados a respeito da posição do nível d'água e do posicionamento dos diversos materiais em subsuperfície (resíduos e materiais 
naturais). Os resultados desses ensaios possibilitaram também a elaboração do mapa de fluxo subterrâneo. Os resultados dessas sondagens mostraram uma grande heterogeneidade para os modelos interpretados, sobretudo em relação às camadas mais superficiais. Essa heterogeneidade elétrica reflete a mistura de materiais que caracterizam o solo superficial na área, ora por uma camada de areia fina, siltoargilosa, seguida de solo coluvionar, ora pelo próprio colúvio composto por areia argilosa.

Já, as sondagens executadas dentro da cava de resíduos, como a SEV 8, por exemplo, possibilitaram a definição da espessura da camada de resíduos, com valores de resistividade baixos (10.2 a 18.8 ohm.m), e conseqüentemente a base da cava, definida por valores de resistividade um pouco mais elevados (28.9 a $29.9 \mathrm{ohm} . \mathrm{m})$.

O mapa de fluxo subterrâneo, apresentado na Figura 4.11, mostra que o principal sentido do fluxo local é predominantemente para oeste-noroeste.

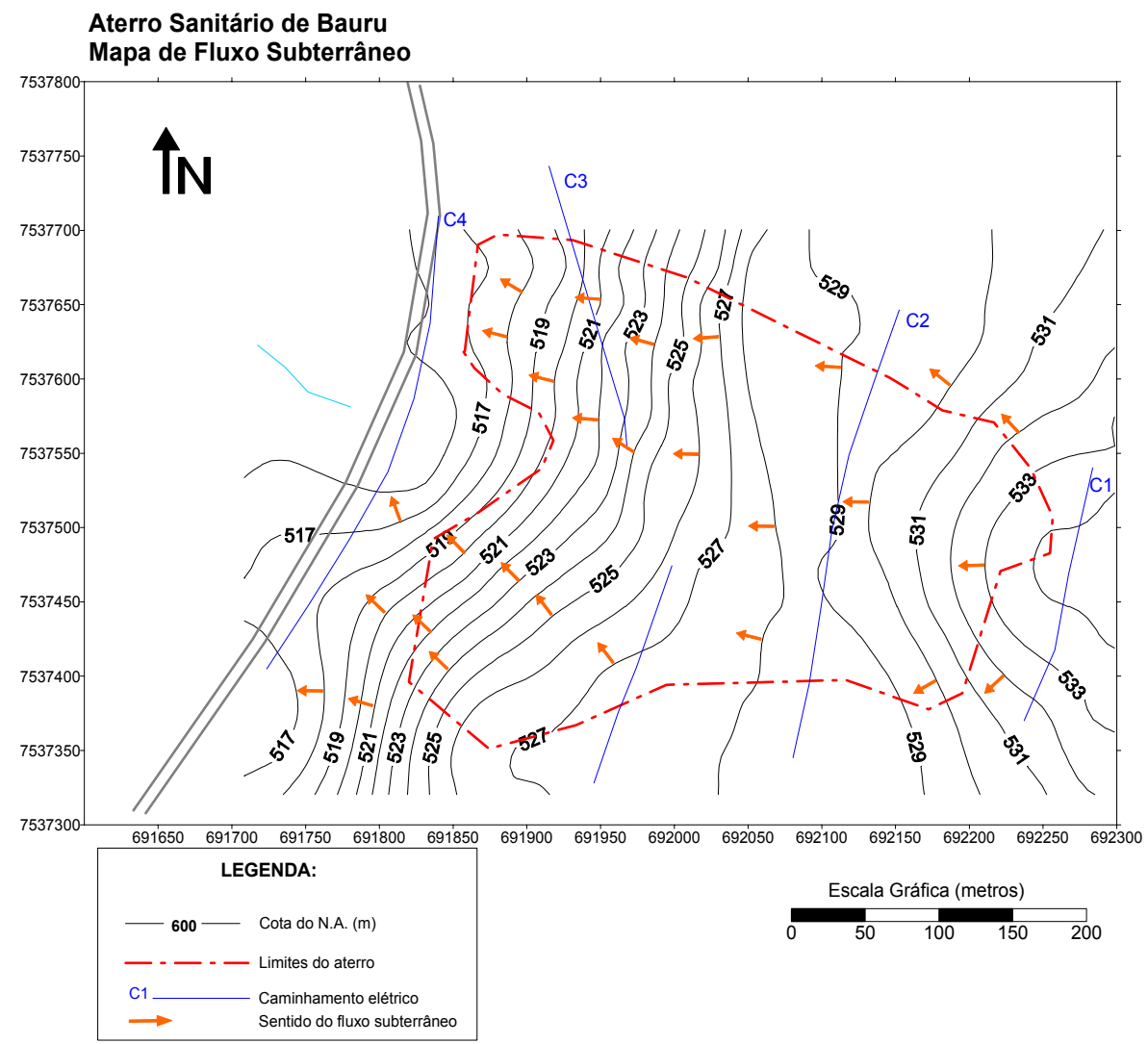

Figura 4.11. Mapa de fluxo subterrâneo definido através das SEVs (LAGO, 2004). 
As Figuras 4.12 e 4.13, a seguir, apresentam as seções das Linhas C2 (dentro da cava de resíduos) e C4 (à jusante do aterro) interpretadas por LAGO (2004) a partir do software de modelagem RES2Dinv.

\section{Linha C2 - Fase 1}

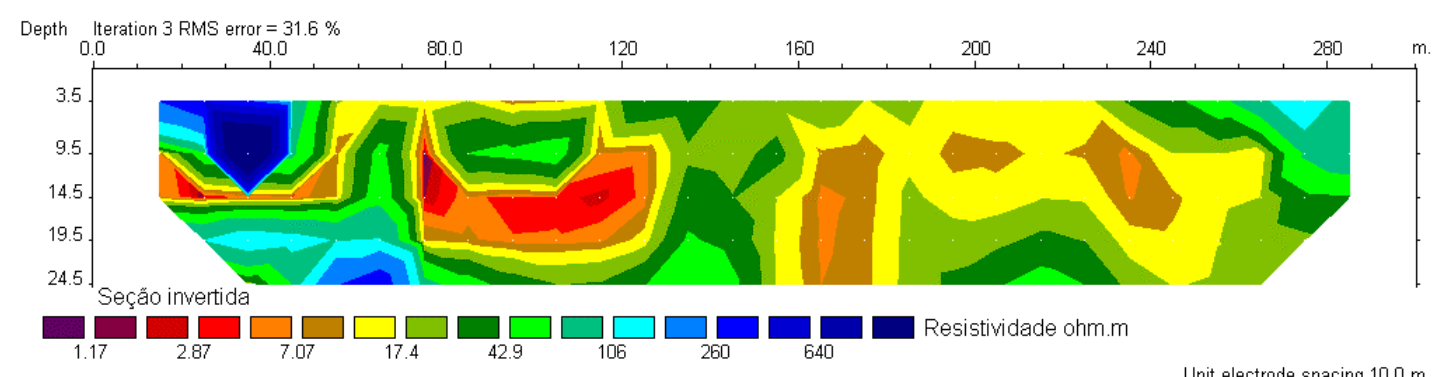

\section{Linha C2 - Fase 2}
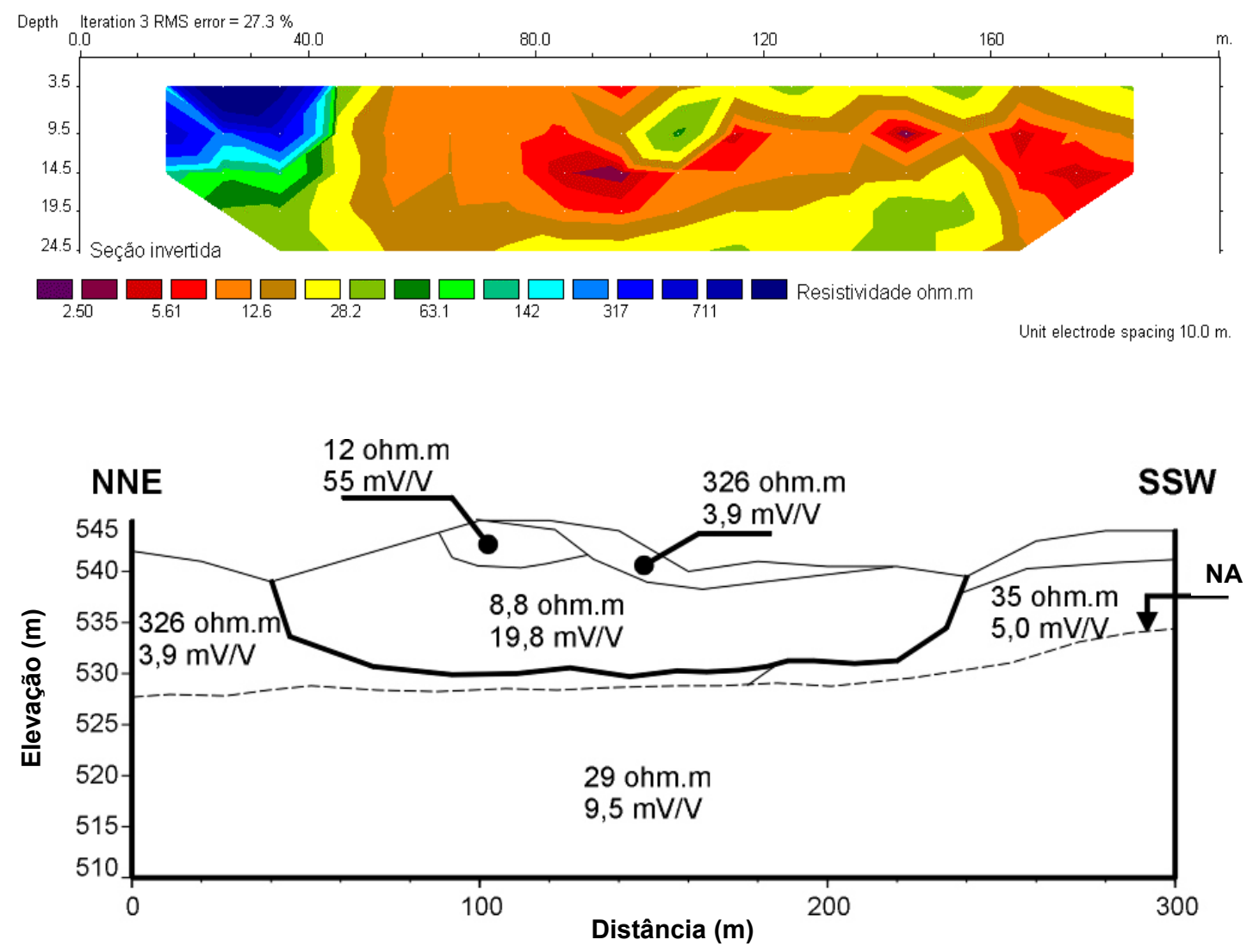

Figura 4.12. Seções de resistividade modeladas para as Fases 1 e 2 da Linha C2 (ELIS, 2004). 


\section{Linha C4 - Fase 1}

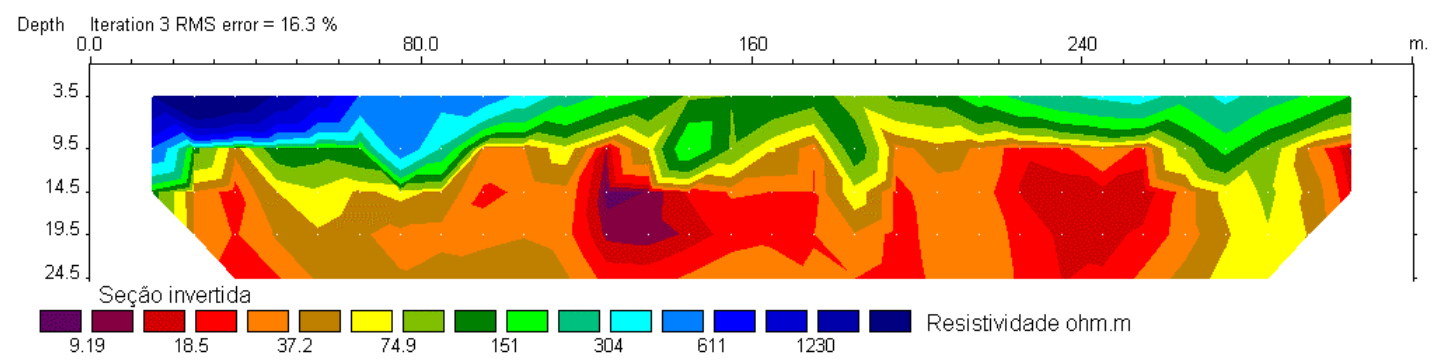

Linha C4 - Fase 2

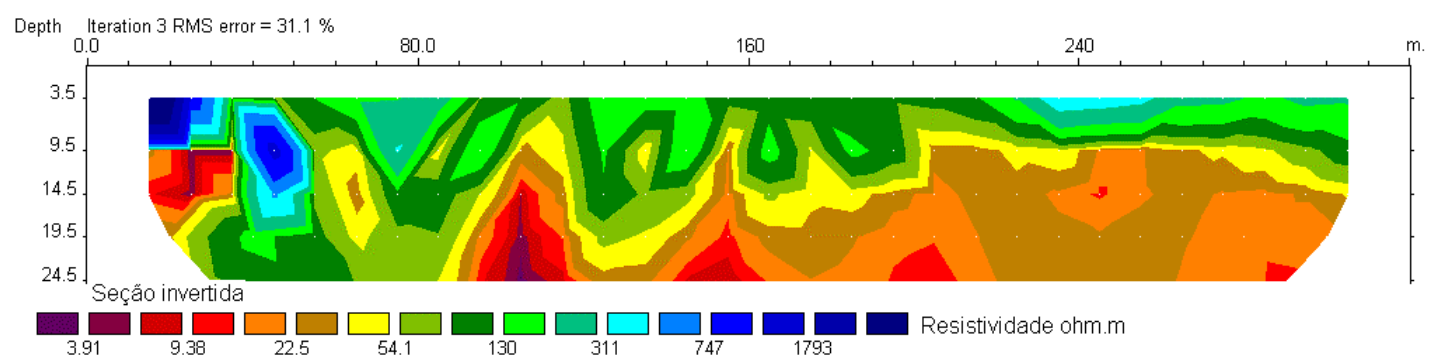

Unit electrode spacing $10.0 \mathrm{~m}$.

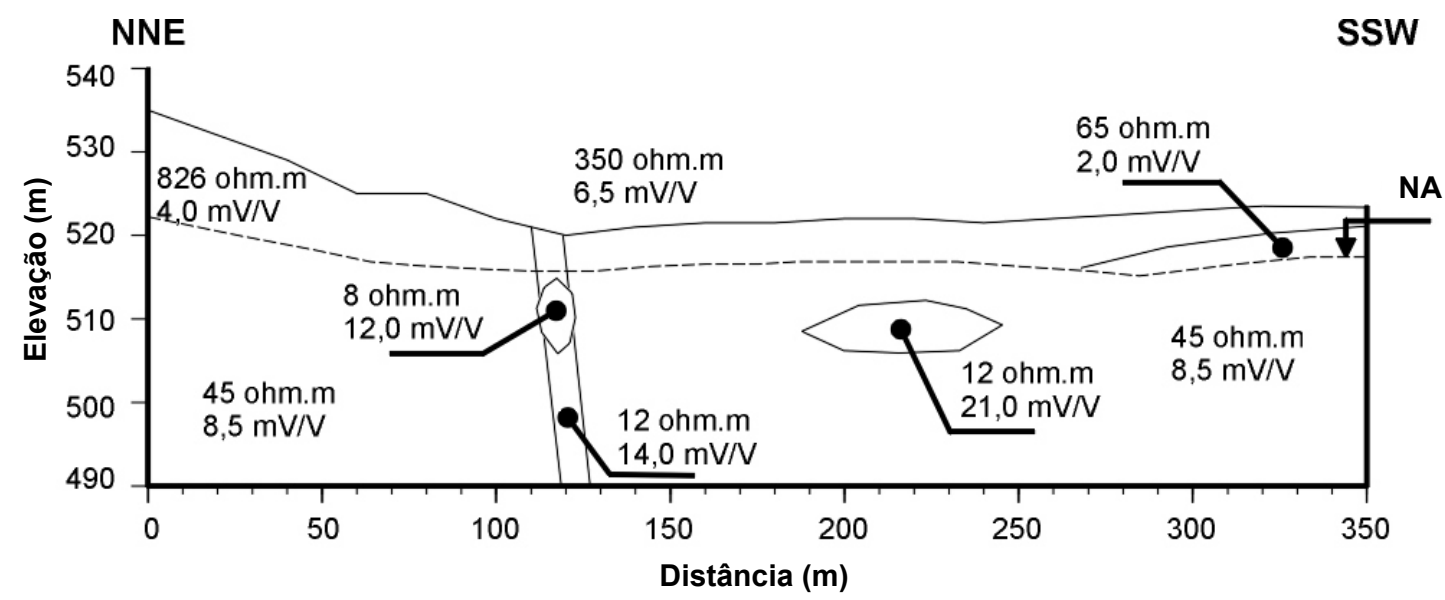

Figura 4.13. Seções de resistividade modeladas para as Fases 1 e 2 da Linha C4 (ELIS, 2004).

As seções de resistividade da Linha C2 (Figura 4.12) mostraram que os valores de resistividade superiores a $40 \mathrm{ohm}$.m são interpretados como sendo relativo as zonas de material natural. Observa-se a zona mais condutora entre as distâncias 50 e 250 metros que caracterizaram a cava preenchida com resíduos. Os ensaios de 
eletrorresistividade executados em períodos diferentes apresentaram diferenças significativas dentro do corpo de resíduos. No ensaio da segunda fase é possível observar uma diminuição dos valores de resistividade dentro da cava preenchida com resíduos, o que reflete o aumento de líquidos dentro dos resíduos devido ao período de chuva.

Nas seções de resistividade da Linha C4 (Figura 4.13) pode-se observar a presença dos materiais não saturados e a presença da zona saturada. As seções mostraram que os materiais não saturados (solos superficiais) são caracterizados por valores de resistividade superiores a 100 ohm.m. Observam-se dentro da zona saturada menores resistividades nas posições entre 120 e 140 m e 200 e 250 m, o que sugere uma provável contaminação da água subterrânea.

O conjunto de dados de resistividade obtido pelos ensaios de caminhamento elétrico foi utilizado para a elaboração de mapas de resistividade aparente de alguns níveis teóricos, os quais possibilitaram uma análise do caminhamento da contaminação no sentido horizontal. Na Figura 4.14 é apresentado o mapa do nível teórico $15 \mathrm{~m}$, onde pode ser observada a anomalia de baixa resistividade na área ocupada pelos resíduos e pelos materiais naturais, de maior resistividade. O mapa do nível teórico $30 \mathrm{~m}$ (Figura 4.15) caracteriza os materiais abaixo da zona saturada e permite observar o sentido preferencial de fluxo do local. Ele mostra as zonas de menor resistividade desenvolvendo-se principalmente no sentido oeste-noroeste e quando comprado ao mapa do nível teórico $15 \mathrm{~m}$, observa-se uma tendência de aumento da área de menor resistividade no sentido sudoeste.

A partir dos resultados obtidos pelos caminhamentos elétricos realizados nas duas fases de investigação geofísica, recomendou-se que as sondagens RCPTU, a instalação dos poços de monitoramento permanentes e as amostragens de solo e água fossem realizados principalmente em algumas posições específicas da Linha $\mathrm{C} 4$, logo à jusante do aterro, e também à noroeste do aterro, na direção do fluxo subterrâneo, uma vez que nesses locais identificaram-se baixos valores de resistividade dentro da zona saturada, sugerindo assim a presença de contaminantes. Portanto, as investigações diretas foram realizadas em regiões previamente selecionadas com base na interpretação qualitativa e quantitativa dos ensaios geofísicos realizados nesta área. 


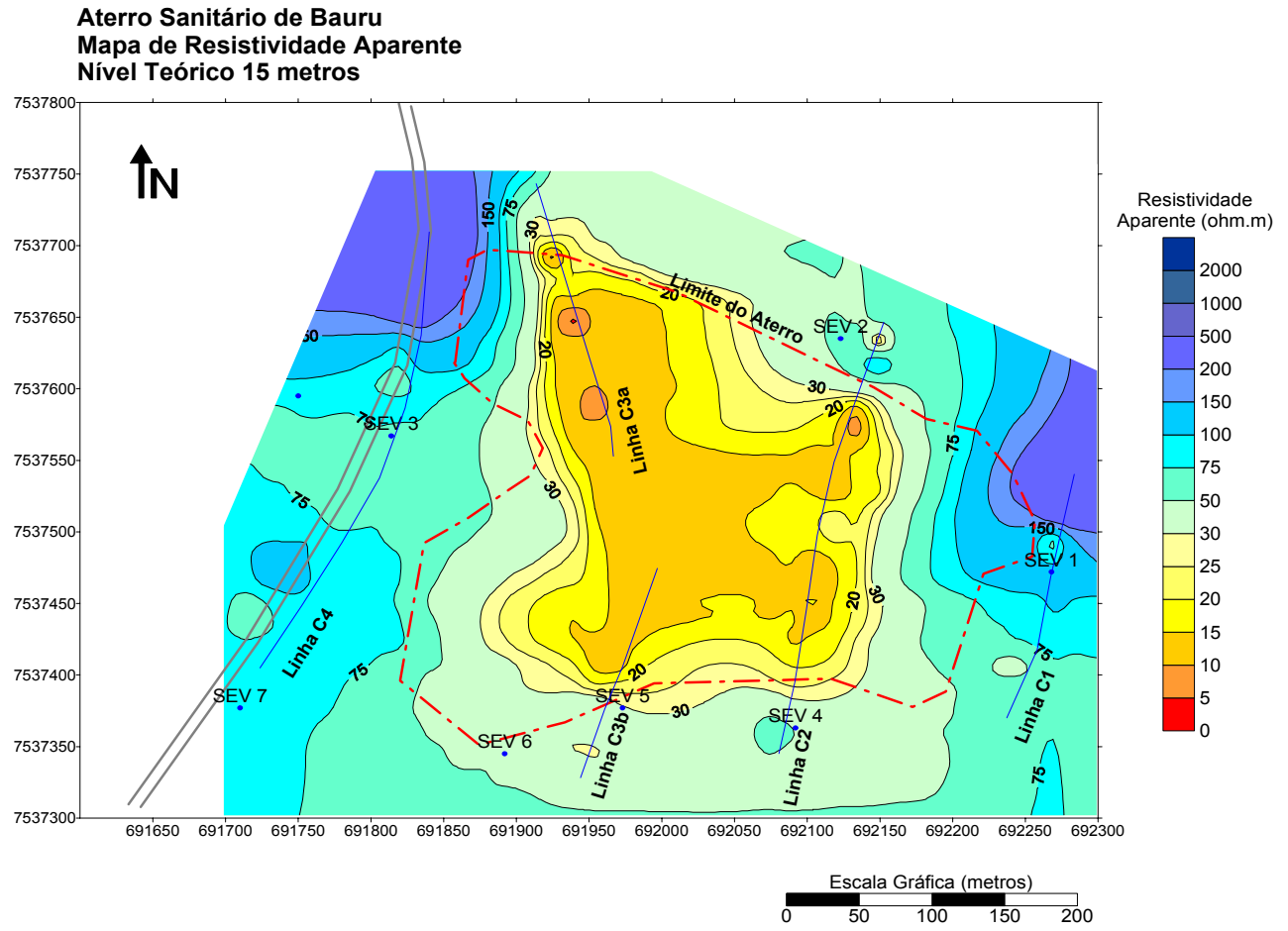

Figura 4.14. Mapa de resistividade aparente do nível teórico 15 m, Fase 1 (LAGO, 2004).

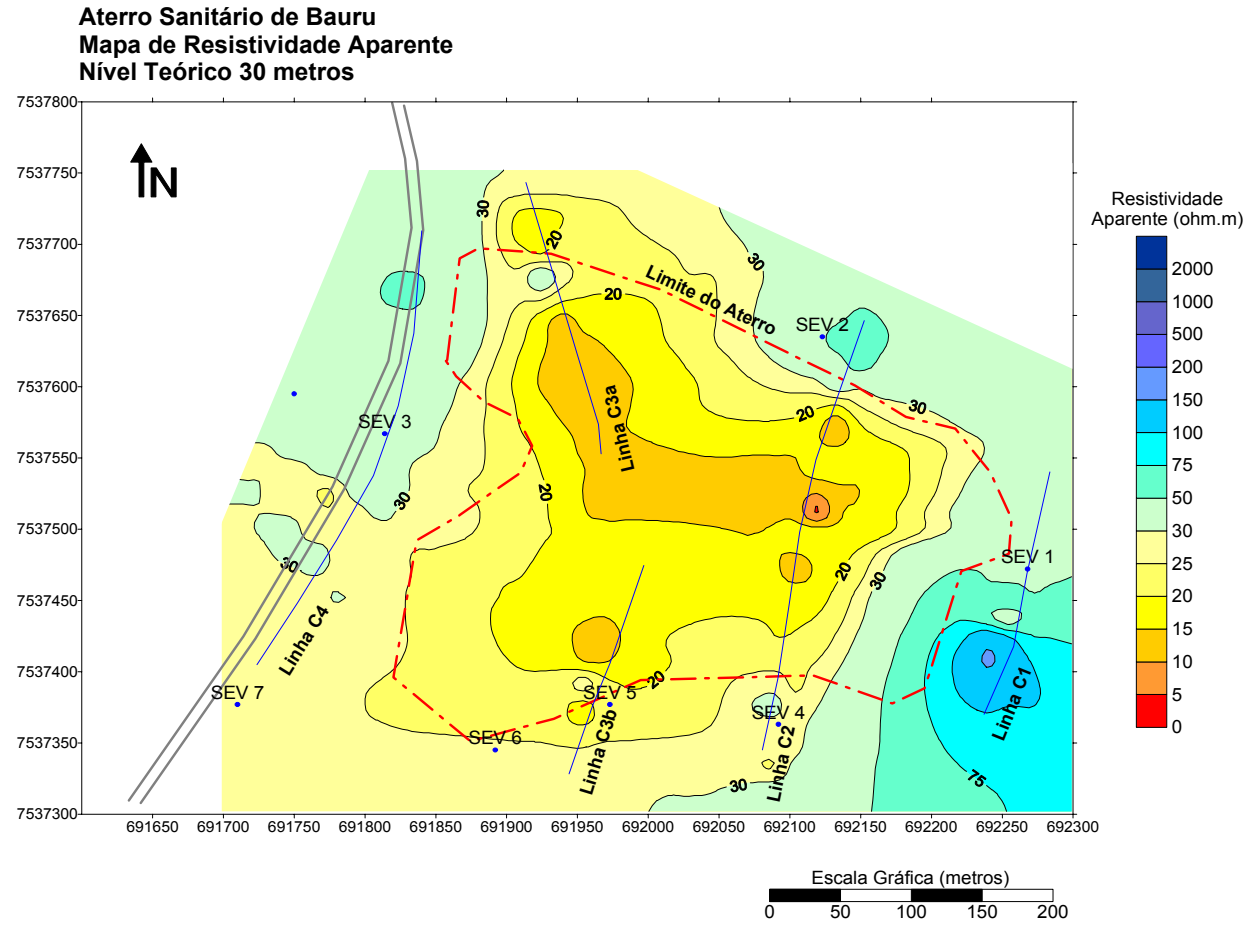

Figura 4.15. Mapa de resistividade aparente do nível teórico 30 m, Fase 1 (LAGO, 2004). 
Um outro aspecto interessante a observar a partir dos resultados das sondagens de eletrorresistividade de superfície encontra-se na Figura 4.16. Nela, tem-se tanto a planta do aterro de resíduos de Bauru como as linhas de isorresistividade determinadas a partir da campanha de eletrorresistividade de superfície. É possível identificar, nesta figura, que os menores valores de resistividade ocorrem abaixo das lagoas de chorume e se desenvolvem a partir daí, o que indica que deve haver vazamento desse percolado através dessa lagoa. Isto mostra que a opção de impermeabilização do fundo do aterro realizada com CM-30 diluído (Foto 3.5) não foi eficiente para impedir a percolação, especialmente na região onde se dispõe o chorume para promover a recirculação.

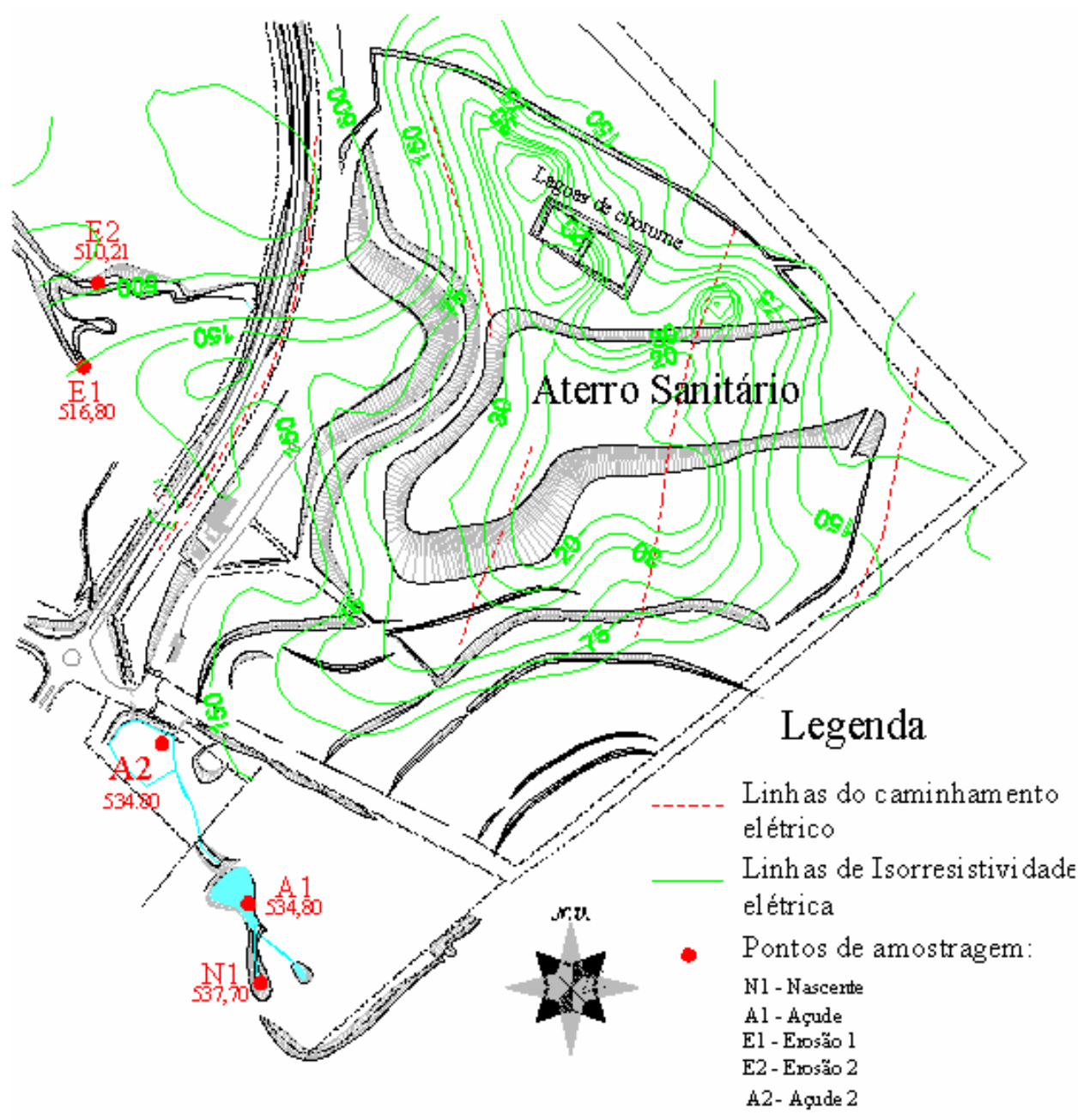

Figura 4.16. Conjunto com planta do aterro de resíduos sólidos de Bauru, linhas de isorresistividade e pontos de coleta de amostras de água para avaliação preliminar da contaminação. 


\subsubsection{Ensaios com o Piezocone (CPTU e RCPTU)}

\subsubsection{Calibração do Piezocone}

Para a execução de uma sondagem utilizando o piezocone, é necessária a checagem dos dispositivos de medida de todo o equipamento antes de utilizá-lo nos ensaios. Para tanto, deve-se realizar uma calibração em laboratório para cada um dos sensores existentes no piezocone, comparando-se os valores gerados pelo piezocone com os valores de referência medidos por células de carga ou transdutores de pressão. Detalhes sobre a realização da calibração do piezocone podem ser encontrados em MARQUES (2002).

Nas Figuras 4.17, 4.18 e 4.19 tem-se exemplos de resultados obtidos a partir da calibração dos sensores de resistência de ponta $\left(\mathrm{q}_{\mathrm{c}}\right)$, de atrito lateral $\left(\mathrm{f}_{\mathrm{s}}\right)$ e de poropressão $\left(\mathrm{U}_{2}\right)$, respectivamente. Estes resultados mostram que bons ajustes puderam ser obtidos, possibilitando assim a correção dos dados dos ensaios pelos coeficientes de calibração obtidos para cada sensor.

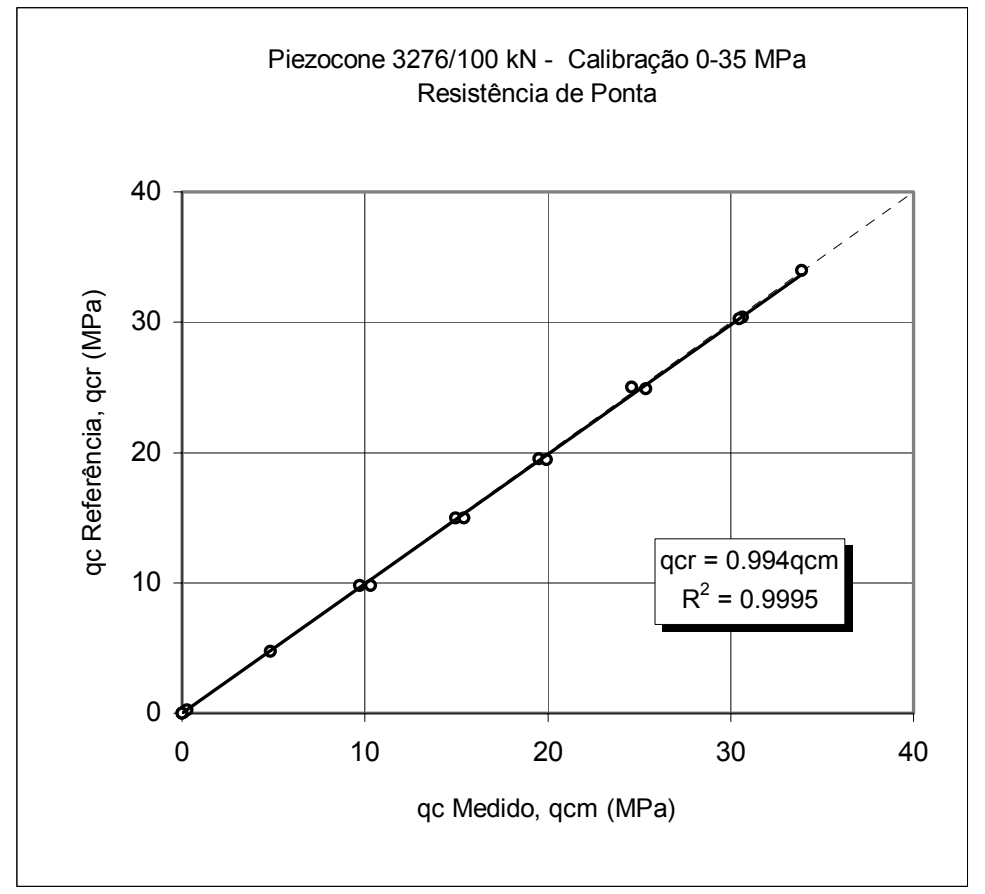

Figura 4.17. Calibração da célula de carga da resistência de ponta, no intervalo de 0 $35 \mathrm{MPa}$. 


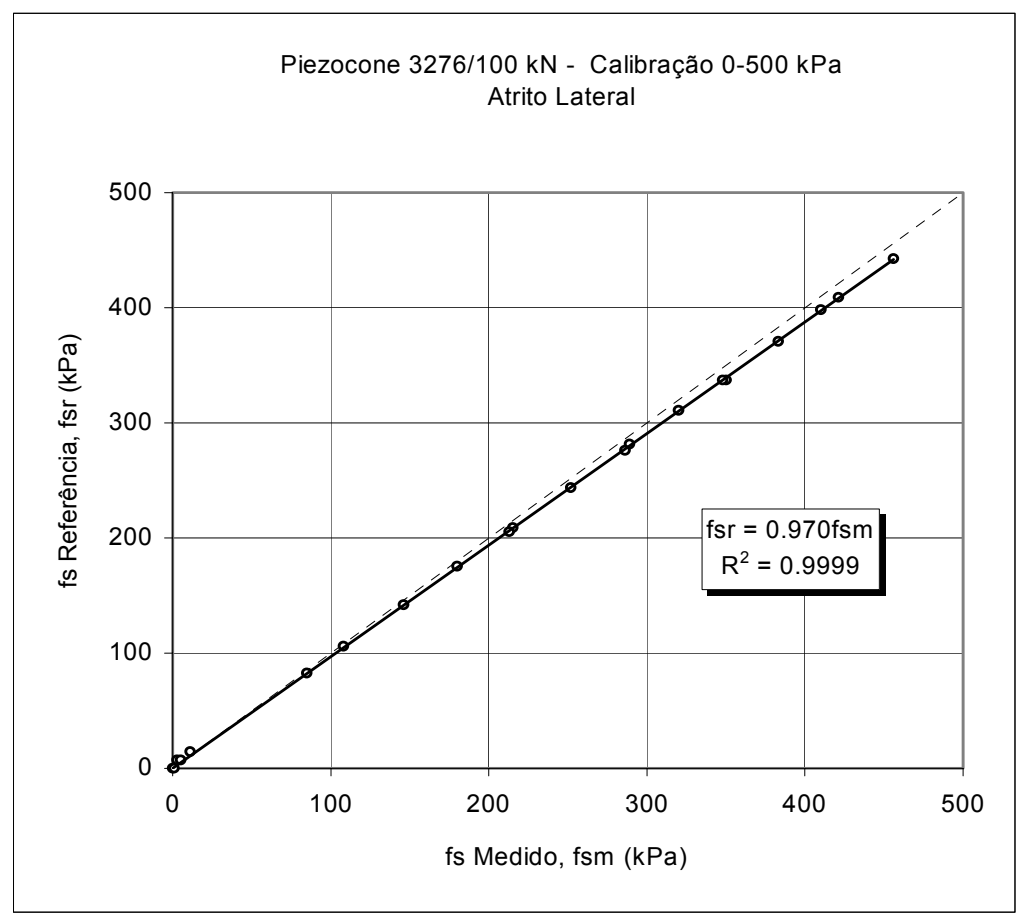

Figura 4.18. Calibração da célula de carga do atrito lateral, no intervalo de $0-0.5$ MPa.

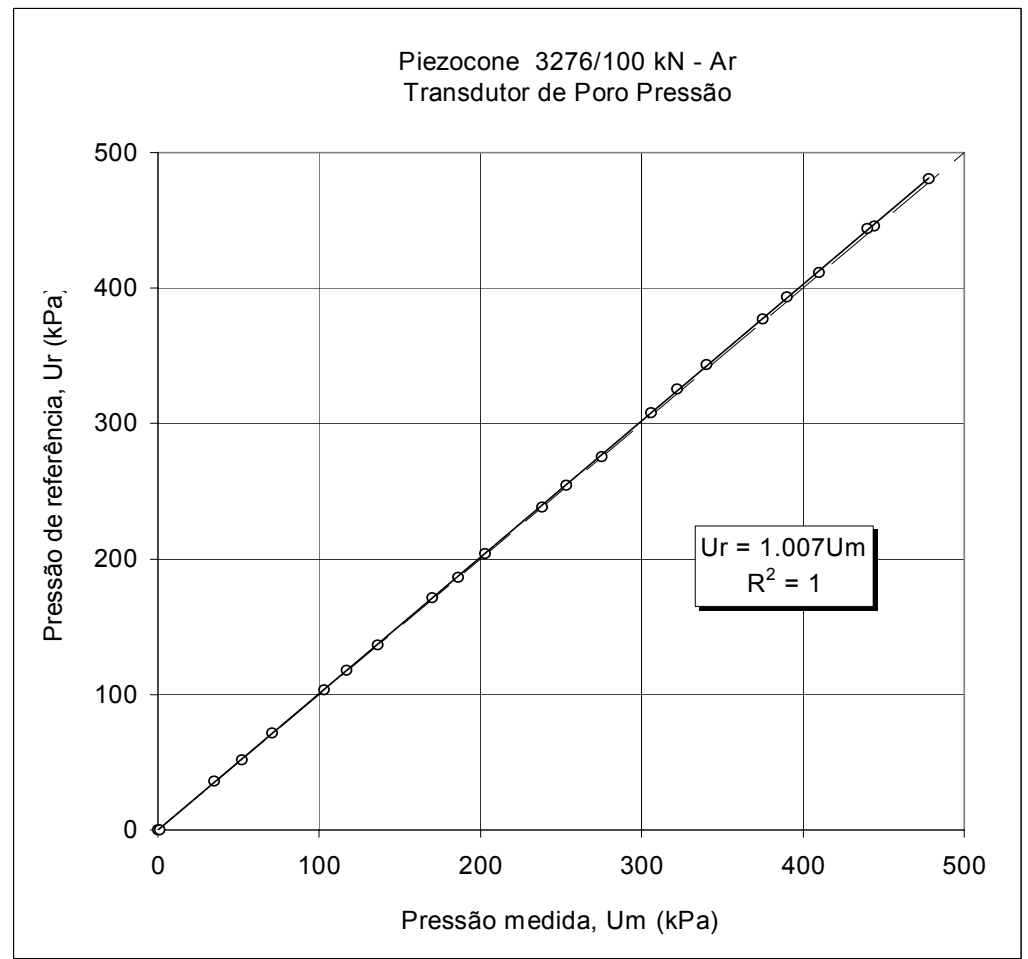

Figura 4.19. Calibração do transdutor de poro-pressão. 


\subsubsection{Calibração do Dispositivo de Medida de Resistividade do Piezocone}

Nas Figuras 4.20 e 4.21 são apresentados os resultados da calibração do dispositivo de medida de resistividade aclopado ao piezocone, realizada conforme descrito no item 3.3.3.1. A primeira mostra os valores de resistividade variando de 2 a $5000 \mathrm{ohm} . \mathrm{m}$ e a segunda de 2 a 257 ohm.m. Observa-se que as funções de ajuste obtidas estão de acordo com as recomendações do fabricante até a faixa de 5000 $\mu \mathrm{S} / \mathrm{cm}$, acima da qual (ou abaixo de $2 \mathrm{ohm} . \mathrm{m}$ ) a função deixa de ser linear, como mostra a Figura 4.22.

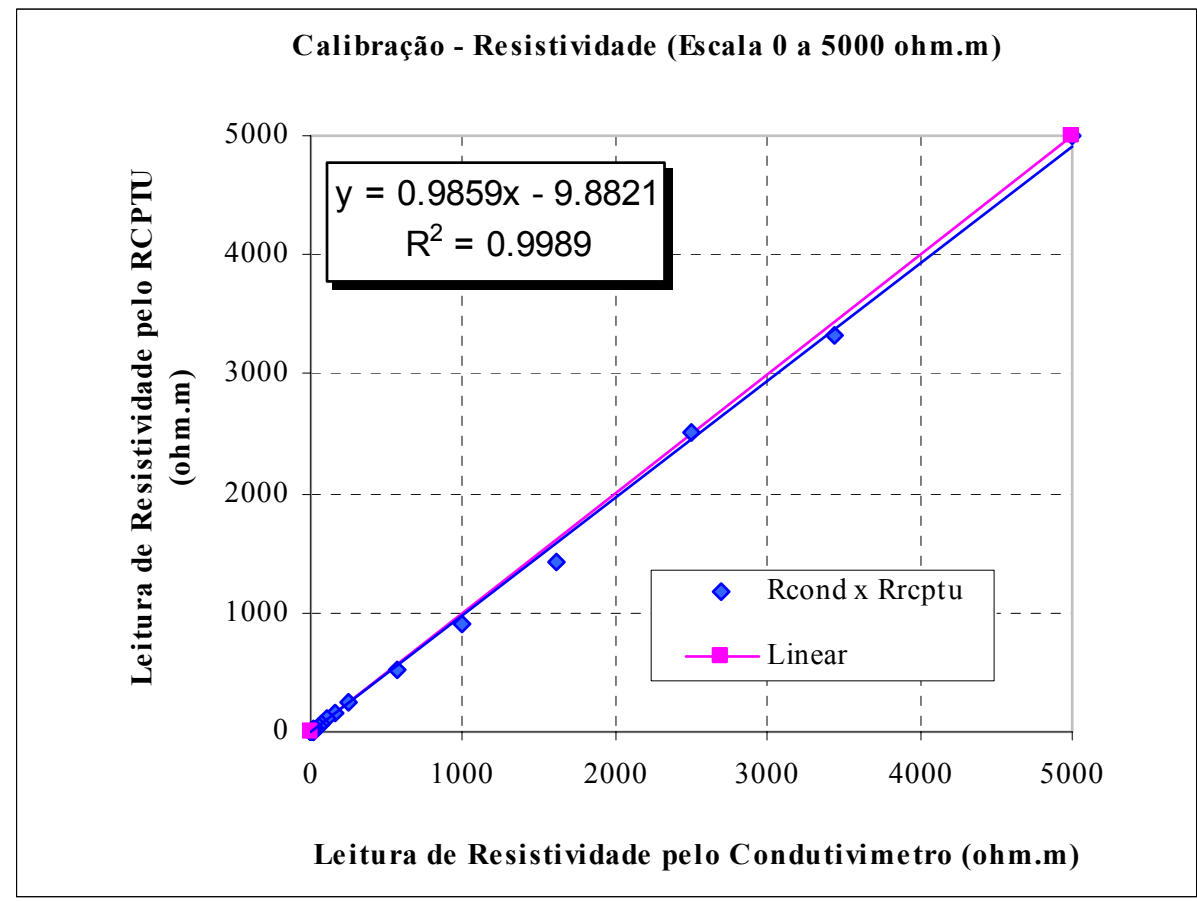

Figura 4.20. Calibração do sensor de resistividade - Faixa de valores 0 a 5000 ohm.m. 


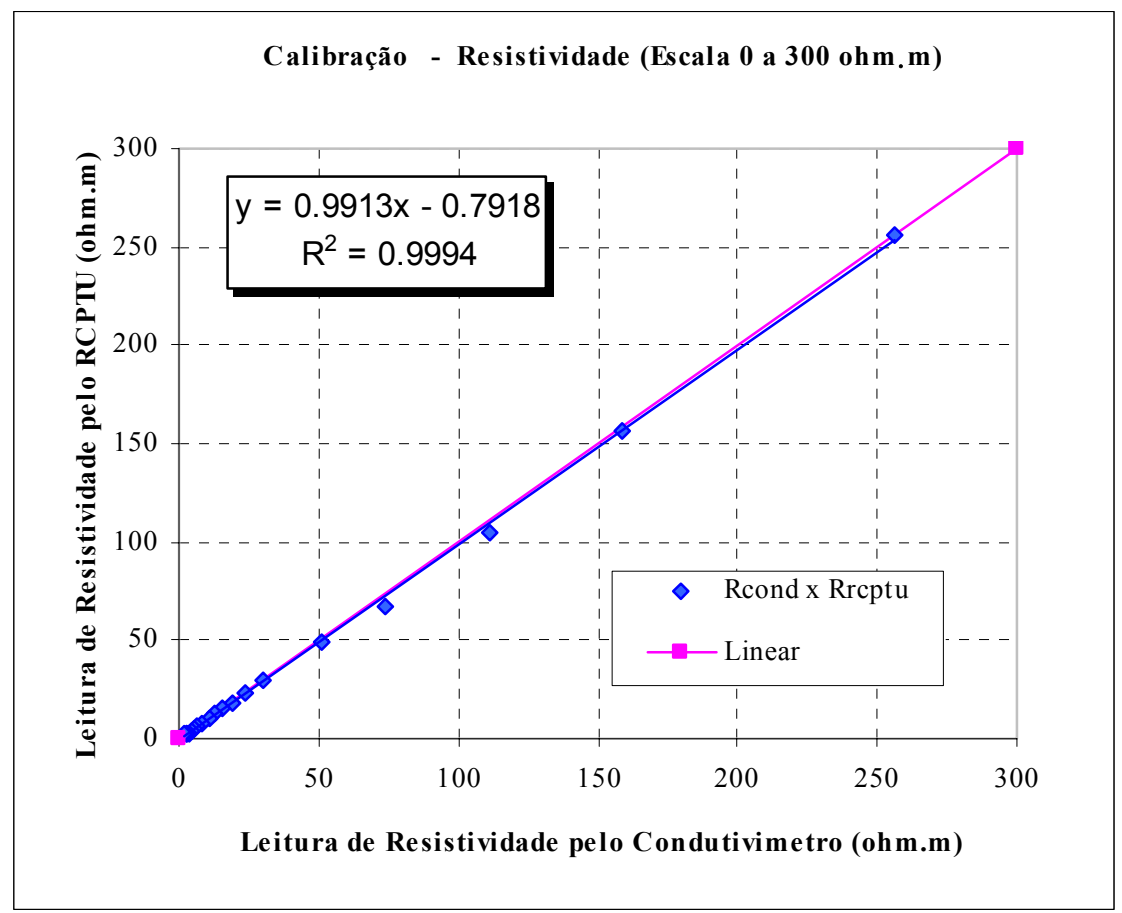

Figura 4.21. Calibração do sensor de resistividade - Faixa de valores 0 a 300 ohm.m.

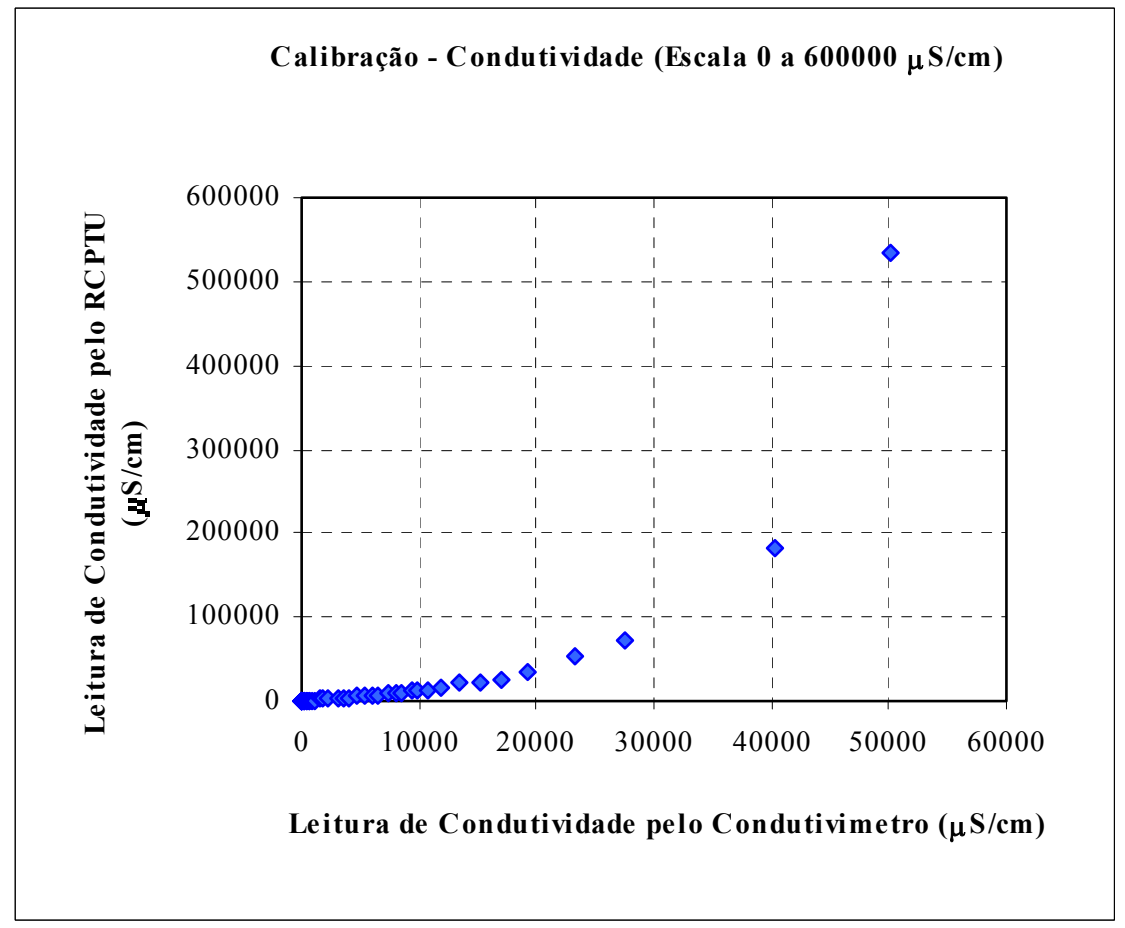

Figura 4.22. Calibração do sensor de resistividade - Faixa de valores 0 a 5000 ohm.m. 
Estas curvas de calibração permitiram avaliar as capacidades máxima e mínima do equipamento. Para o valor de condutividade entre $2 \mu \mathrm{S} / \mathrm{cm}$ (ou resistividade $5000 \mathrm{ohm} . \mathrm{m}$ ) e $5000 \mu \mathrm{S} / \mathrm{cm}$ (ou resistividade $2 \mathrm{ohm} . \mathrm{m}$ ), os coeficientes de variação são menores que $5 \%$ e os erros relativos menores que $10 \%$. Para valores acima de $5000 \mu \mathrm{S} / \mathrm{cm}$ (ou menores que $2 \mathrm{ohm} . \mathrm{m}$ ) as leituras obtidas através do piezocone de resistividade durante esta calibração não foram confiáveis, embora o fabricante recomende que o sensor tenha capacidade de medir valores de condutividade de até $30000 \mu \mathrm{S} / \mathrm{cm}$ (ou $0.3 \mathrm{ohm} . \mathrm{m}$ ). Ressalta-se que os valores obtidos em campo estão dentro da faixa de utilização do piezocone, o que não prejudicou o uso desse aparelho.

\subsubsection{Resultados dos Ensaios com o Piezocone (CPTU e RCPTU)}

Foram realizadas quatro campanhas de ensaios com o piezocone, totalizando quatro sondagens CPTUs e dezesseis sondagens RCPTUs.

$\mathrm{Na}$ primeira campanha, em dezembro de 2001, foram realizados os quatro ensaios CPTU, visando uma caracterização geotécnica preliminar do local. Nessa mesma época, foi realizada a primeira campanha de ensaios geofísicos, cujos resultados foram úteis para a locação dos ensaios das próximas campanhas. Também foram coletadas amostras de solo através da técnica direct-push nas quatro sondagens realizadas na área.

Em fevereiro de 2002, durante a estação das chuvas, foram realizados os primeiros ensaios com o piezocone de resistividade. Três ensaios no entorno do CPTU 03 (RCPTUs 04, 05 e 06), outros três próximos ao CPTU 04 (RCPTUs 01, 02 e 03), um próximo a uma erosão à jusante do aterro (RCPTU 07) e, por último, uma sondagem um pouco mais próxima à cava de resíduos, mas também à jusante (RCPTU 08).

Em abril de 2002, foram realizadas mais seis sondagens:

- O RCPTU 09, próxima ao ensaio CPTU 04;

- O RCPTU 10, também na área da erosão à jusante do aterro;

- O RCPTU 11, próxima ao ensaio CPTU 03;

- O RCPTU 12, em uma área fora do aterro, ao sul; 
- O RCPTU 13, em uma área ao sul do aterro, em uma várzea onde ocorre solo mole;

- O RCPTU 14, próxima à cava de resíduos, à jusante do aterro.

Nesta época, não foi possível realizar a coleta de solo e água devido a problemas operacionais da empresa que operava o penetrômetro multifunção utilizado.

Em julho de 2002, foram realizadas mais duas sondagens: RCPTU 15, também próxima à cava de resíduos e à jusante desta, e RCPTU 16, na área de várzea. Nesta fase, foram coletadas amostras de solo e água próximo aos ensaios RCPTU 13, 14 e 15.

Todos os resultados desses ensaios, interpretados a partir da carta de classificação de ROBERTSON et al. (1986), são apresentados no Anexo II. A fim de facilitar a análise dos resultados desses ensaios, eles são aqui apresentados ao lado da granulometria obtida a partir das amostras de solo coletadas com o amostrador (Tabela 4.6) e foram agrupados da seguinte maneira:

- Na Figura 4.23, os resultados do ensaio CPTU 01 (à montante do aterro);

- Na Figura 4.24, os resultados dos ensaios CPTU 02 e RCPTU 12 (ao sul do aterro);

- Na Figura 4.25, os resultados dos ensaios CPTU 03, RCPTU 04, 05, 06 e 11 (à jusante do aterro e no entorno do poço de monitoramento temporário PT-1);

- Na Figura 4.26, os resultados dos ensaios CPTU 04, RCPTU 01, 02, 03 e 09 (à jusante do aterro e no entorno do poço de monitoramento temporário PT-2);

- Na Figura 4.27, os resultados do ensaio RCPTU 08 (à jusante e próximo ao aterro);

- Na Figura 4.28, os resultados dos ensaios RCPTU 14 e 15 (à jusante e próximos ao aterro);

- Na Figura 4.29, os resultados do ensaio RCPTU 07 (à jusante e próximo à erosão);

- Na Figura 4.30, os resultados do ensaio RCPTU 10 (à jusante e próximo à erosão);

- Na Figura 4.31, os resultados dos ensaios RCPTU 13 e 16 (na área de várzea, externa ao aterro). 


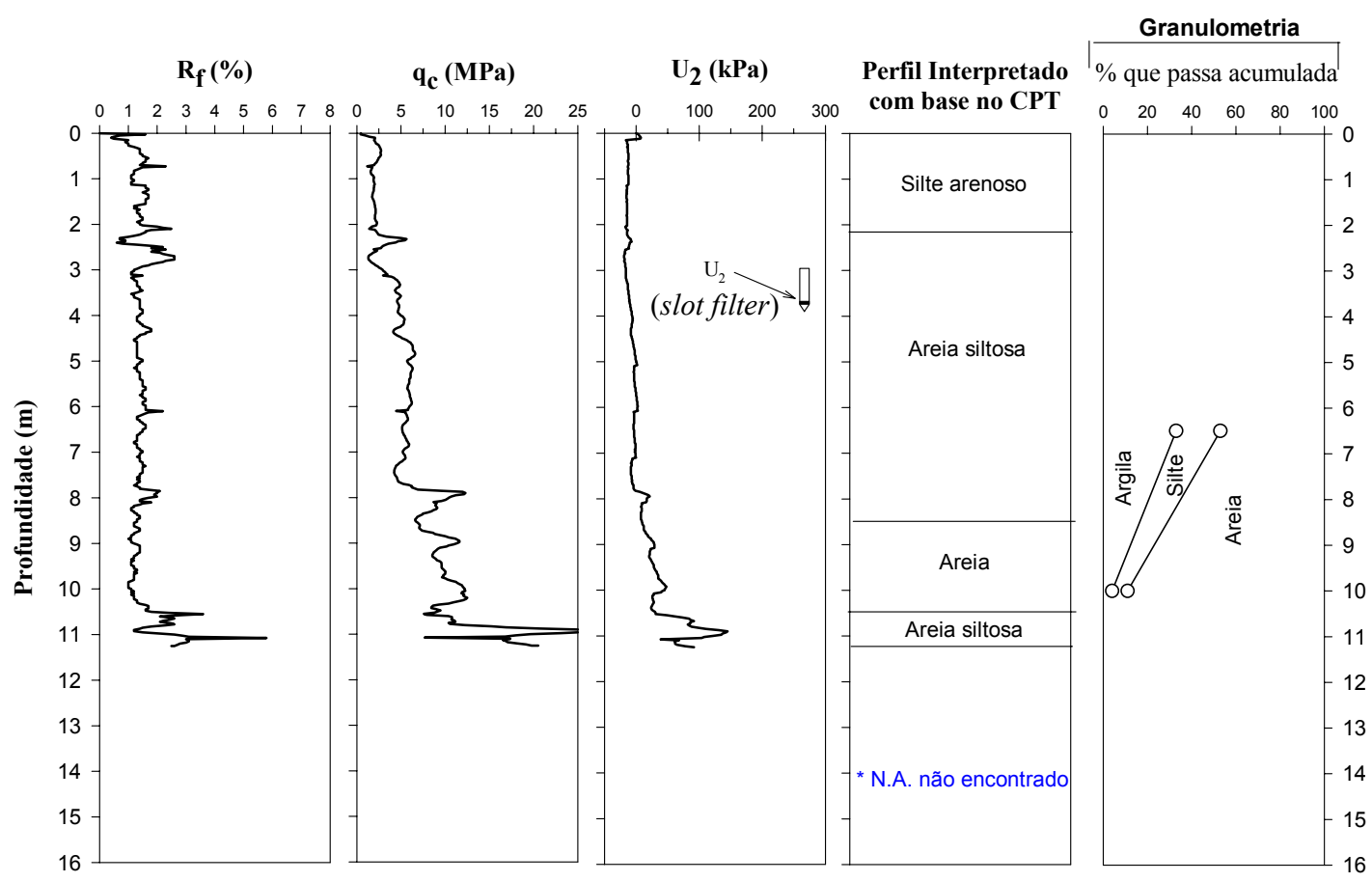

Figura 4.23. Resultados do ensaio de piezocone CPTU 01 realizado à montante do aterro.

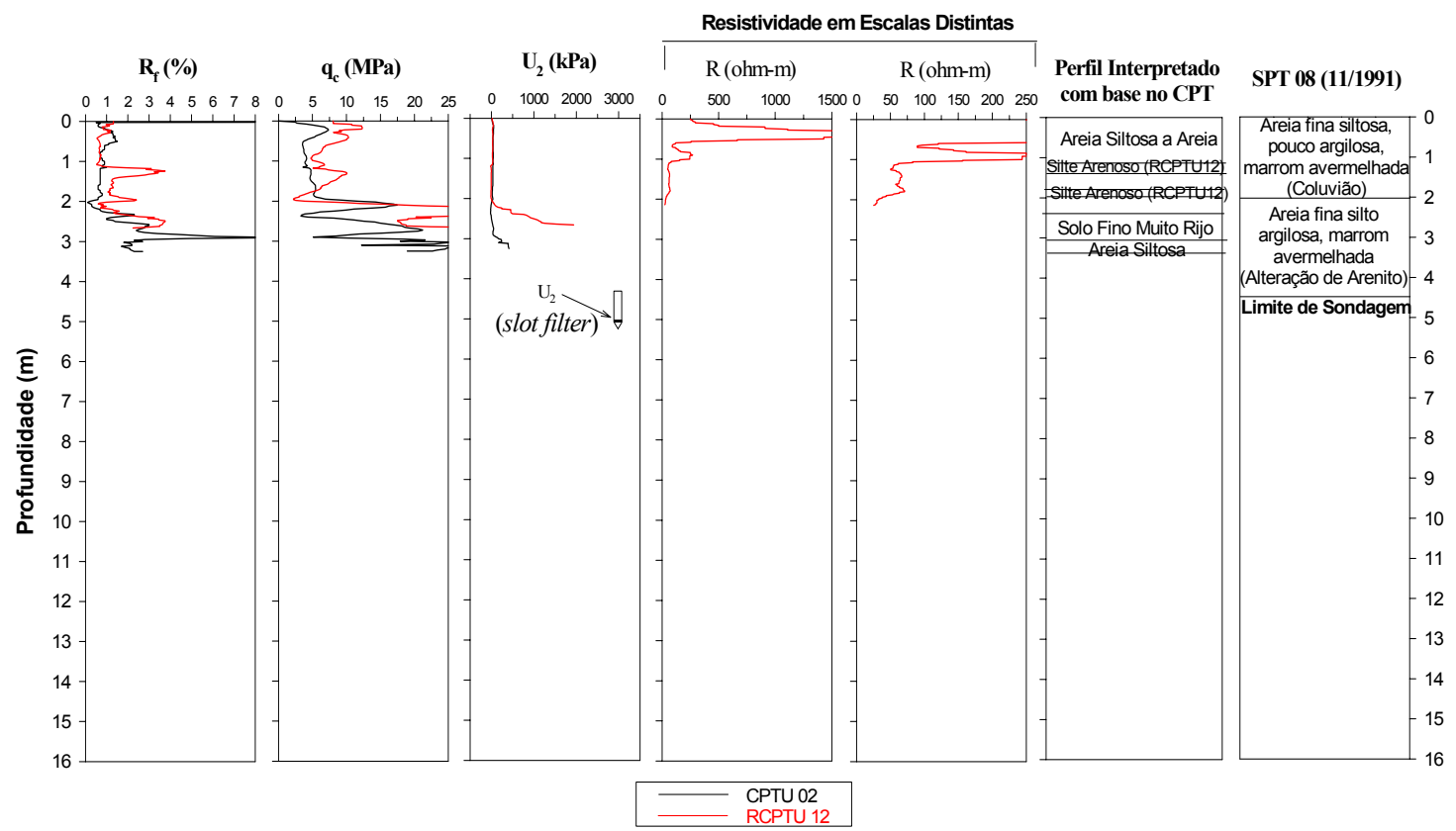

Figura 4.24. Resultados dos ensaios de piezocone CPTU 02 e RCPTU 12 realizados ao sul, fora do aterro, próximos à sondagem SPT 08. 


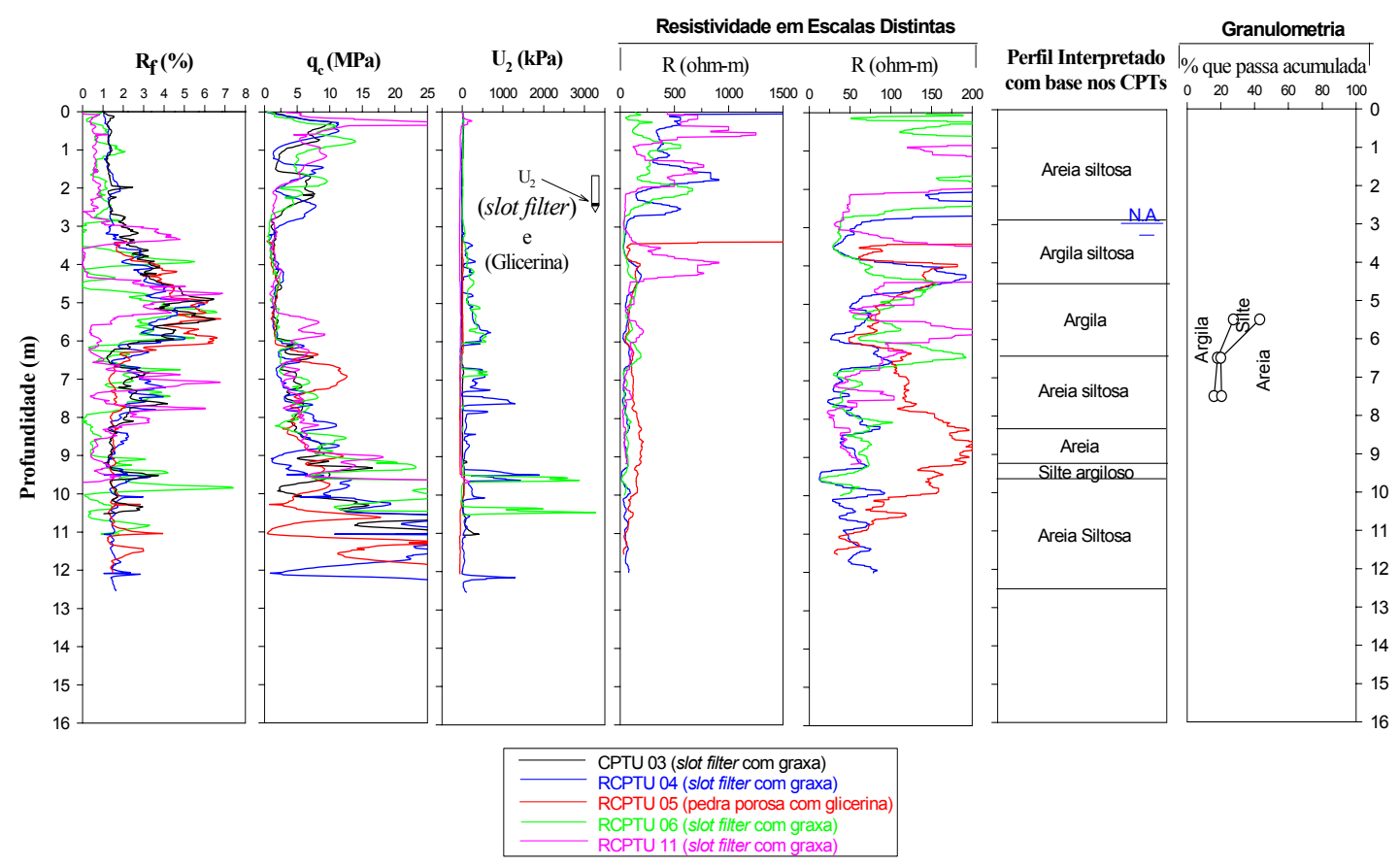

Figura 4.25. Resultados dos ensaios de piezocone CPTU 03, RCPTU 04, 05, 06 e 11 realizados à jusante do aterro e no entorno do poço de monitoramento temporário PT-1.

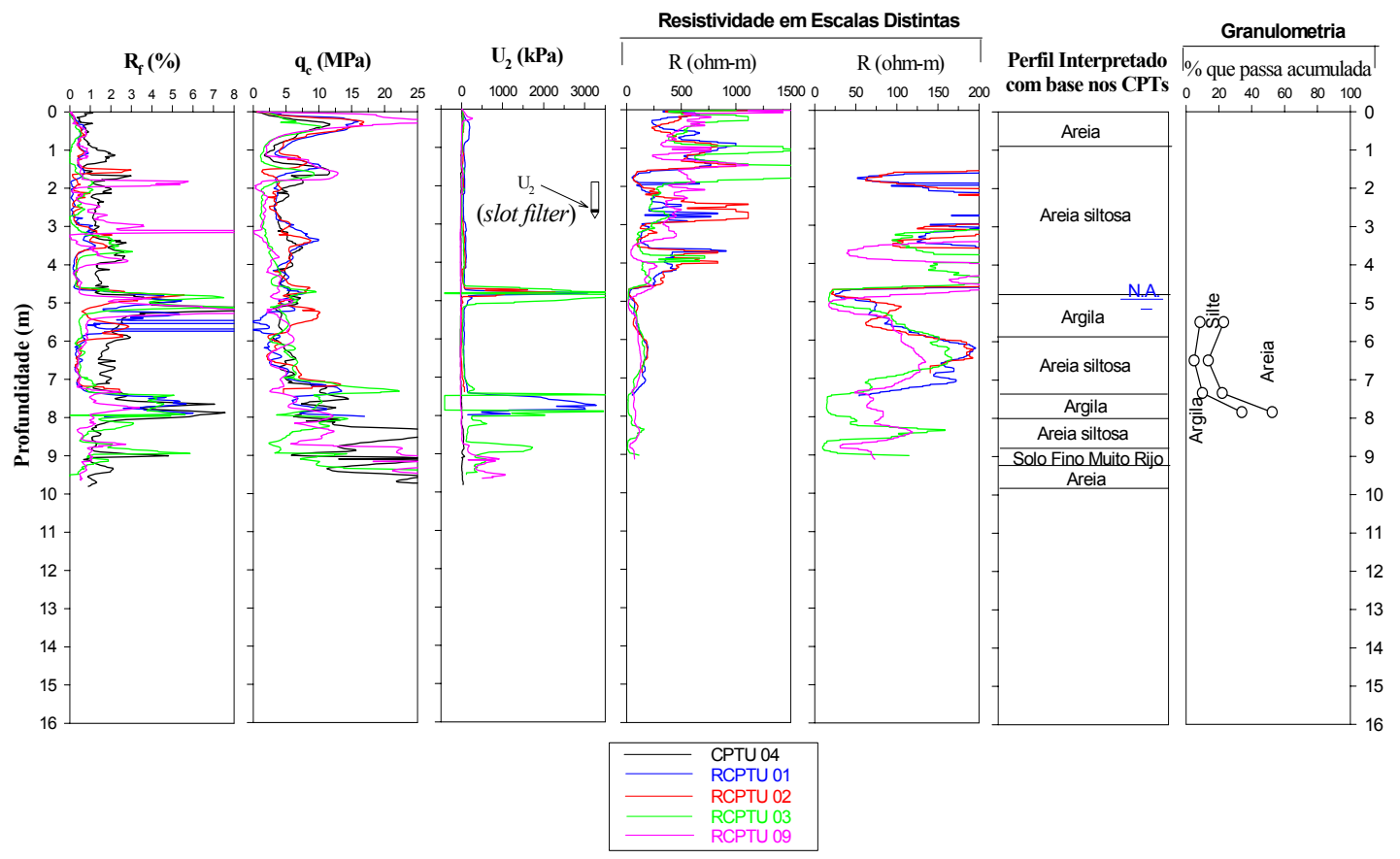

Figura 4.26. Resultados dos ensaios de piezocone CPTU 04, RCPTU 01, 02, 03 e 09 realizados à jusante do aterro e no entorno do poço de monitoramento temporário PT-2. 


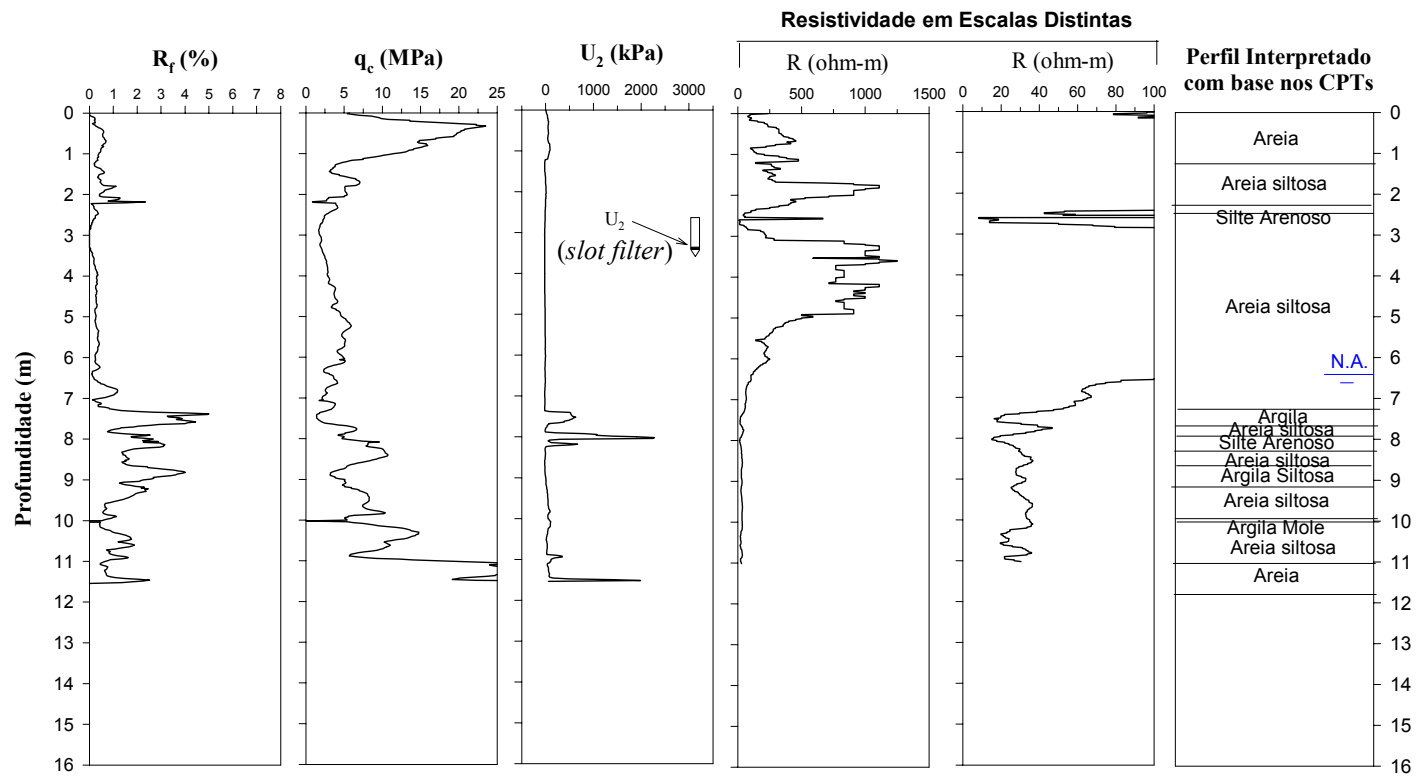

Figura 4.27. Resultados do ensaio de piezocone RCPTU 08 realizado à jusante e próximo ao aterro.

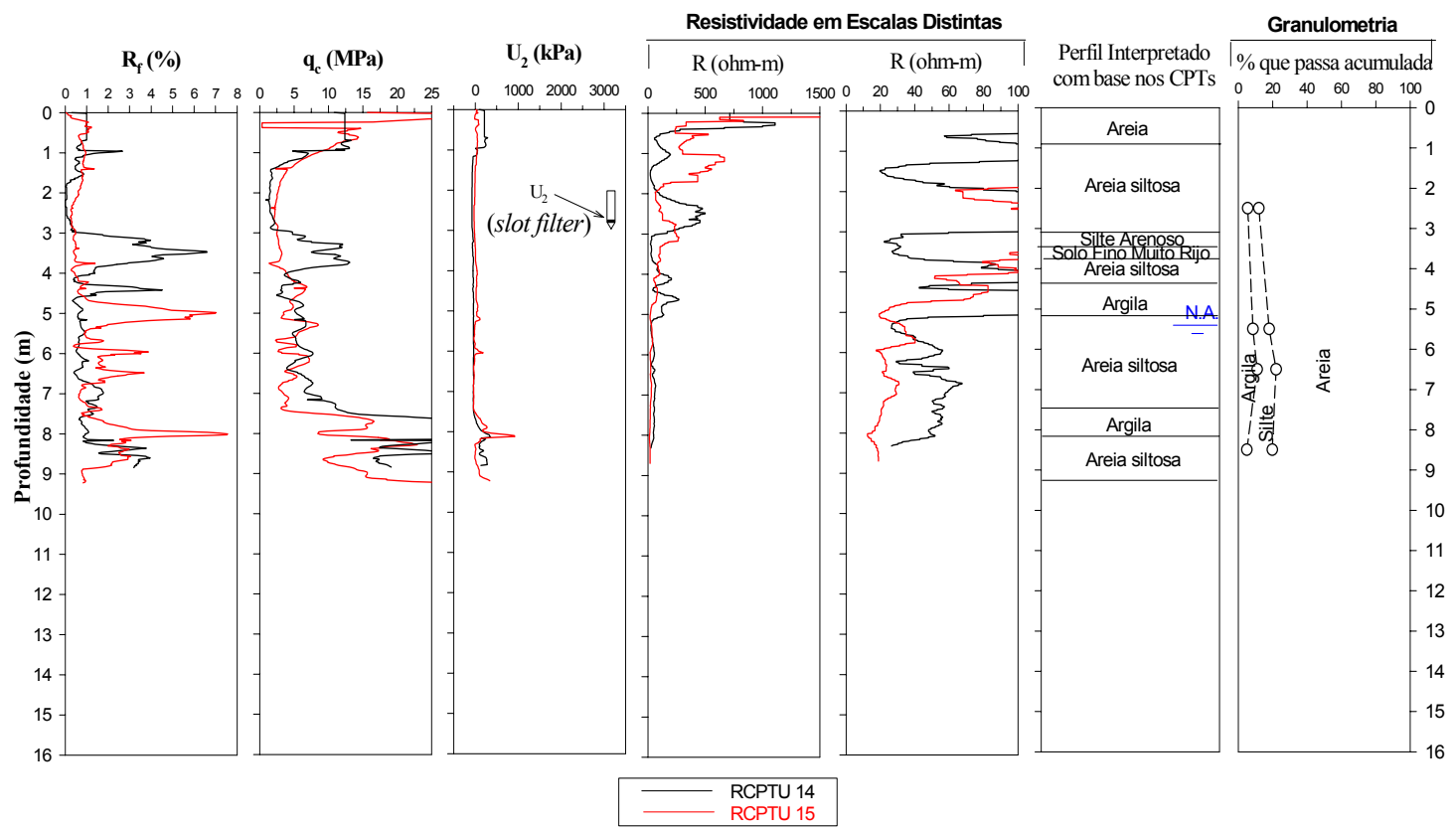

Figura 4.28. Resultados dos ensaios de piezocone RCPTU 14 e 15 realizados à jusante e próximos ao aterro. 


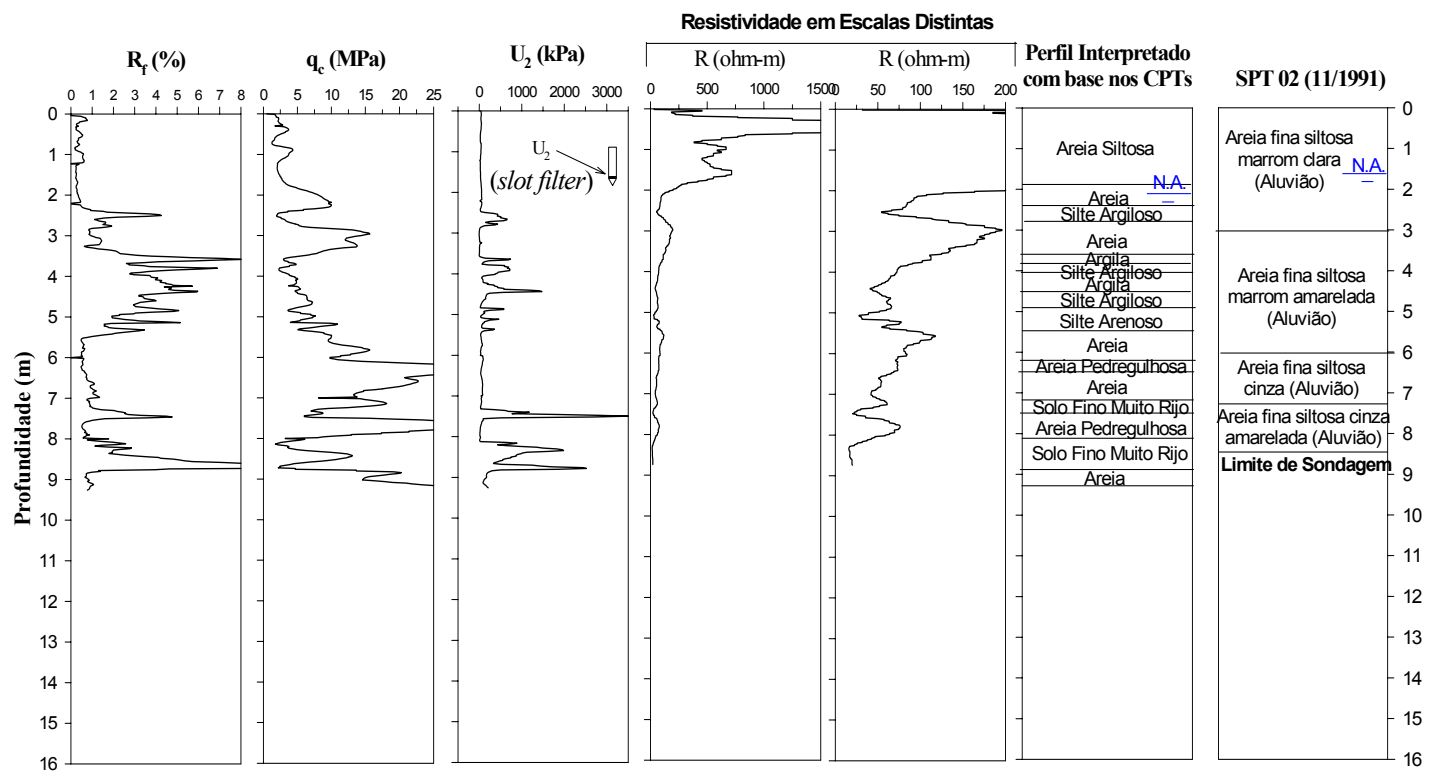

Figura 4.29. Resultados do ensaio de piezocone RCPTU 07 realizado à jusante do aterro e próximo à erosão, onde se tem sondagem SPT 02.

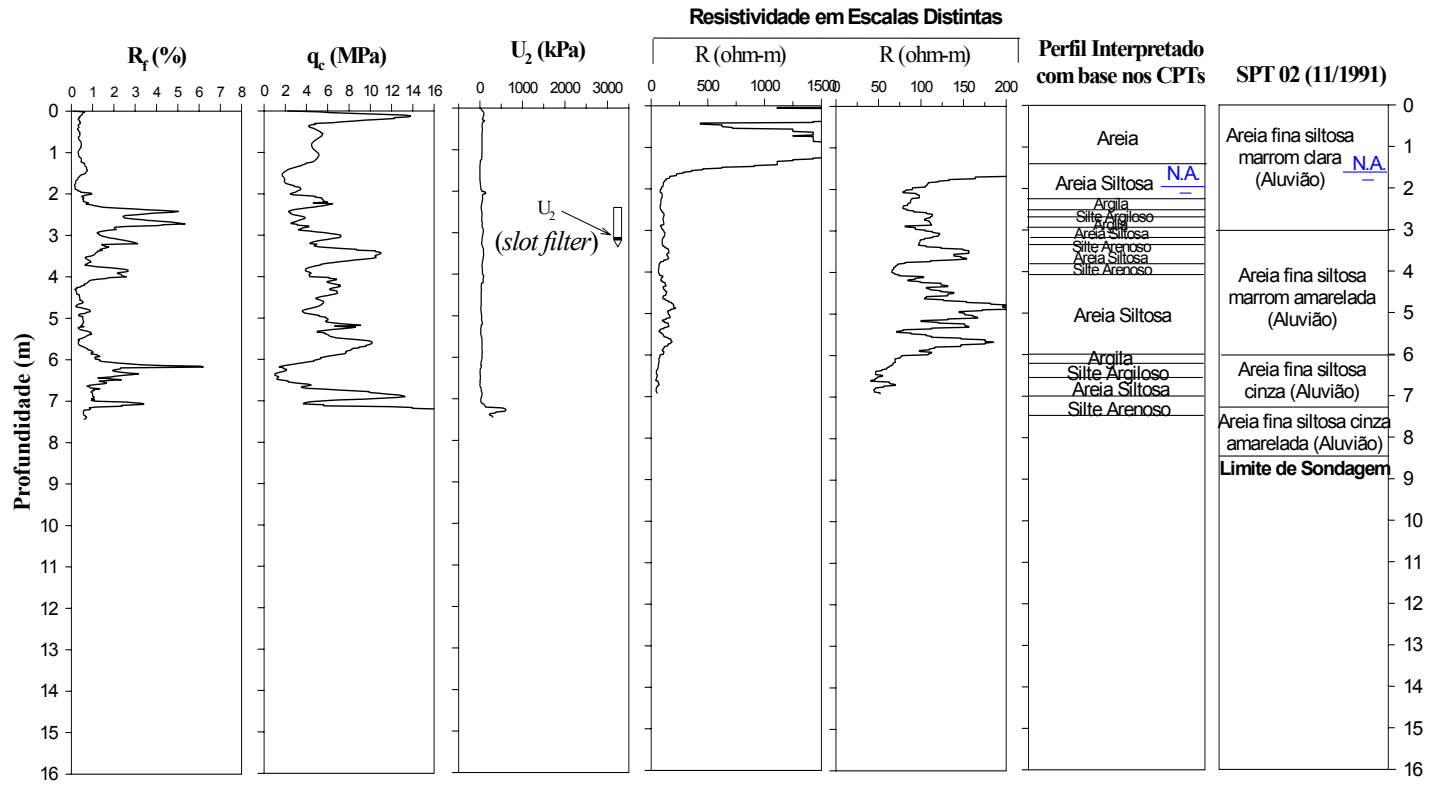

Figura 4.30. Resultados do ensaio de piezocone RCPTU 10 realizado à jusante do aterro e próximo à erosão, onde se tem a sondagem SPT 02. 


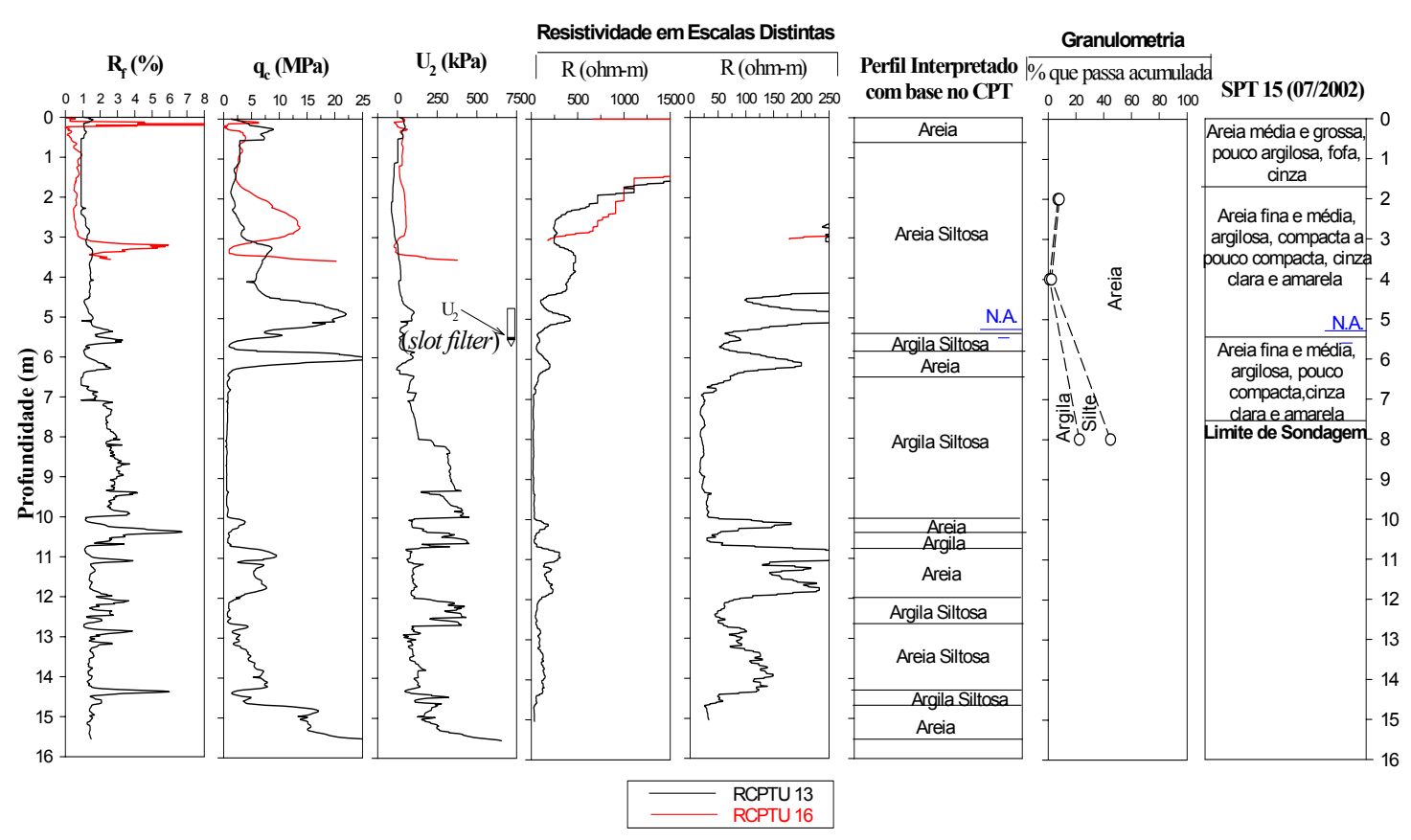

Figura 4.31. Resultados dos ensaios de piezocone RCPTU 13 e 16 realizados na região de várzea, ao sul do aterro, próximos à sondagem SPT 15.

\subsubsection{Identificação do Perfil Geotécnico}

Uma das finalidades da sondagem com o piezocone é a identificação detalhada do perfil geotécnico, conforme descrito por LUNNE et al. (1997), ROBERTSON \& CAMPANELLA (1986), entre outros.

Os resultados das sondagens CPTU e RCPTU realizadas no local serão interpretadas com o objetivo de avaliar a metodologia tradicional de interpretação de sondagens com o piezocone, utilizando a proposta de ROBERTSON et al. (1986).

As Figuras 3.16 e 3.17 mostram perfis representativos do local, na região à jusante do aterro, e foram elaborados a partir dos resultados das sondagens SPT realizadas antes da implantação do aterro. Observa-se que à medida que se caminha de montante para jusante do aterro, a camada de solo coluvionar dá espaço ao solo aluvionar. O coluvião cobre praticamente toda a base do aterro e, os resultados das sondagens SPT indicam que o solo que ocorre na área tem as mesmas características do solo da região de Bauru, residual do Grupo Bauru, classificado como areia argilosa vermelha. Na região onde ocorre o aluvião, próxima ao córrego e às erosões, 
tem-se uma camada de argila cinza próxima à superfície, seguida de uma camada de areia fina quartzosa.

Nas Figuras 4.23 a 4.31 e no Anexo II são apresentados os perfis geotécnicos interpretados a partir de sondagens CPTU e RCPTU realizadas no local, estando alguns acompanhados dos perfis interpretados com base nos resultados das sondagens SPT e outros acompanhados da granulometria obtida a partir das amostras de solo coletadas com o amostrador. De maneira geral, observa-se uma certa coerência entre os perfis interpretados utilizando o piezocone e a granulometria, uma vez que a porcentagem de argila e de silte diminuem quando o piezocone registra aumento na resistência de ponta $\left(\mathrm{q}_{\mathrm{c}}\right)$ e redução na razão de atrito $\left(\mathrm{R}_{\mathrm{f}}\right)$.

Como descrito anteriormente, a área de implantação do aterro é formada por solos e rochas de diferentes litologias e por isso os ensaios CPTU e RCPTU foram divididos de forma que se pudesse ter uma classificação mais detalhada de cada região. À jusante, por exemplo, concentrou-se a maioria das sondagens, pois é nela que os ensaios geofísicos indicaram a ocorrência da pluma de contaminação. As Figuras 4.25 e 4.26 mostram que esta região é composta uma camada de areia siltosa avermelhada até cerca de 3 a $4.5 \mathrm{~m}$ de profundidade, seguida de uma camada de argila, até cerca de $6 \mathrm{~m}$. A partir daí, existem camadas muito finas intercaladas entre si identificadas como areia siltosa e argila (ou silte argiloso) até aproximadamente $9.5 \mathrm{~m}$, surgindo então uma camada de areia siltosa (ou argilosa), residual de arenito até o impenetrável do cone. Estas intercalações são mais freqüentes nos RCPTUs 7 e 10 (Figuras 4.29 e 4.30), que estão próximos às erosões, e vão desaparecendo conforme se caminha para montante do aterro, como pode ser observado já no perfil do RCPTU 8 (Figura 4.27), onde estas intercalações aparecem mais profundas e nos perfis dos RCPTUs 14 e 15 (Figura 4.28), onde elas praticamente já desapareceram.

Existe ainda uma área de várzea (Figura 4.31), ao sul do aterro, onde ocorre uma areia amarela acinzentada até aproximadamente $6 \mathrm{~m}$, seguida de uma camada de argila cinza até $10 \mathrm{~m}$ de profundidade. A partir daí camadas de areia e argila se intercalam, como também mostraram os outros perfis já citados, à oeste do aterro. A Foto 4.1, a seguir, mostra um pouco desta estratigrafia, de característica aluvionar, localizada na Erosão 1, à jusante do aterro. 


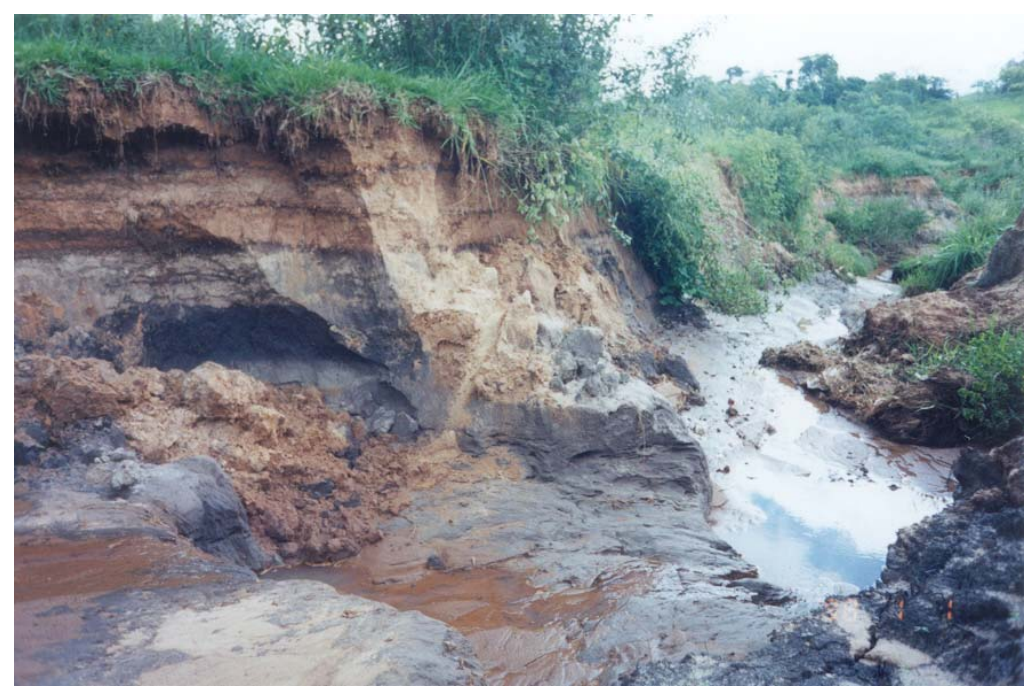

Foto 4.1. Erosão localizada à jusante do aterro de resíduos sólidos de Bauru, onde é possível observar a heterogeneidade do solo que ocorre no local.

Os ensaios realizados lado a lado, mostrados nas Figuras 4.25 e 4.26, apresentaram resultados repetitivos, com exceção daqueles que foram feitos em épocas diferentes, como o CPTU 04 e o RCPTU 11, onde se observa um comportamento um pouco diferente da maioria. Isto pode ter ocorrido devido a algumas diferenças de cota e à alta sensibilidade que o cone tem de identificar camadas muito finas, que podem estar presentes em alguns pontos específicos ensaiados.

Os resultados dessa pesquisa mostram que a identificação do perfil geotécnico a partir de sondagens CPTU, baseado no ábaco de classificação de ROBERTSON et al. (1986), apresenta limitações para essa área, uma vez que o mesmo não possibilita a classificação textural do solo. Entretanto, a análise conjunta de $\mathrm{q}_{\mathrm{c}}$ e $\mathrm{f}_{\mathrm{s}}$ permite identificar solos de comportamentos distintos. Estes resultados estão de acordo com as conclusões de MARQUES (2002), que interpretou resultados de diversos ensaios com o piezocone em solos tropicais de três campos experimentais que ocorrem no interior de São Paulo. Nas camadas onde o cone apresenta resposta diferente, se recomenda a amostragem de solo utilizando, por exemplo, amostradores do sistema direct-push, conforme recomenda GIACHETI (2001), para apropriada classificação textural do solo. Esse foi o procedimento utilizado nessa pesquisa para possibilitar uma adequada representação do perfil geotécnico dos solos investigados. 


\subsubsection{Definição da Posição do Nível D’Água}

A definição da posição do nível d'água é uma informação importante na investigação geoambiental. O registro da poro-pressão é um recurso interessante que pode auxiliar na definição dessa posição, quando se tem a cravação do piezocone em uma camada saturada que não gera excesso de poro-pressão, conforme mostra CAMPANELLA et al. (1995), ou quando se realiza um ensaio de dissipação do excesso de poro-pressão.

O nível d'água relativamente profundo da maioria dos ensaios realizados também nesta área fez com que se optasse pela utilização do filtro de cavidade preenchido com graxa automotiva. A interpretação dos resultados desses ensaios pelo procedimento convencional não possibilitou a identificação precisa da posição do nível d'água.

Contudo, na área do aterro de resíduos sólidos de Bauru, foi possível utilizar o piezocone de resistividade em várias das sondagens realizadas. Os resultados destas sondagens, como por exemplo aquelas apresentadas nas Figuras 4.25 a 4.31, indicam que o emprego do sensor de resistividade acoplado ao piezocone é uma ferramenta eficiente para definição da posição do nível d'água, aspecto que não foi possível utilizando-se apenas o registro das poro-pressões. Observou-se que a queda brusca na resistividade, para valores inferiores a $200 \mathrm{ohm} . \mathrm{m}$, indicava a presença do nível d'água, conforme os resultados dos ensaios geofísicos já haviam mostrado.

\subsubsection{Coeficiente de Permeabilidade}

A estimativa de parâmetros geotécnicos a partir dos resultados do piezocone, como aquela realizada por MONDELLI et al. (2002) para o solo que ocorre no Campo Experimental da Unesp de Bauru, não foi realizada neste trabalho. $O$ parâmetro de maior interesse neste caso foi o coeficiente de permeabilidade, estimado a partir dos ensaios de dissipação de poro-pressão, uma vez que o interesse desta investigação é o entendimento do fluxo de contaminantes na região onde se encontra o aterro de resíduos sólidos de Bauru.

Um resumo dos resultados obtidos através da realização da dissipação do excesso de poro-pressão durante alguns ensaios RCPTU realizados no aterro de resíduos sólidos de Bauru é apresentado na Tabela 4.4. O valor de $\alpha$ para estimativa 
do módulo confinado $(\mathrm{M})$ a partir da resistência de ponta $\left(\mathrm{q}_{\mathrm{c}}\right)$ foi assumido igual a 2.5, conforme recomendado por CAMPANELLA et al. (1995), considerando a ocorrência de um solo areno-argiloso em todas as sondagens e por ser um valor intermediário entre 1.5 e 4.0. O fator de correção de anisotropia utilizado para estimar o coeficiente de adensamento vertical $\left(c_{v}\right)$ foi de $k_{h} / k_{v}=1.2$, pois admitiu-se que o solo que ocorre no local tem baixo grau de anisotropia.

As Figuras 4.32 e 4.33 apresentam as curvas de dissipação obtidas para as sondagens RCPTU 05 (onde se utilizou glicerina) e RCPTU 08 (onde se utilizou graxa). As curvas de dissipação obtidas para estas e para as demais sondagens encontram-se no Anexo III.

Tabela 4.4. Resumo dos resultados obtidos a partir dos ensaios de dissipação do excesso de poro-pressão gerada durante alguns ensaios RCPTU.

\begin{tabular}{|c|c|c|c|c|c|}
\hline RCPTU & 1 & 4 & 5 & 6 & 8 \\
\hline Prof. (m) & 7.46 & 9.50 & 9.46 & 5.15 & 8.06 \\
\hline Posição N.A. (m) & 4.70 & 2.80 & 3.00 & 2.55 & 6.25 \\
\hline $\mathbf{t}_{50}(\mathrm{~s})$ & 1438 & 298 & $659^{(*)}$ & 116 & 51 \\
\hline$c_{h}\left(m^{2} / s\right)$ & $5.4 \times 10^{-7}$ & $2.6 \times 10^{-6}$ & $3.8 \times 10^{-7}$ & $6.7 \times 10^{-6}$ & $1.5 \times 10^{-5}$ \\
\hline$c_{v}\left(m^{2} / s\right)$ & $4.5 \times 10^{-7}$ & $2.2 \times 10^{-6}$ & $3.1 \times 10^{-7}$ & $5.6 \times 10^{-6}$ & $1.3 \times 10^{-5}$ \\
\hline$\alpha$ & 2.5 & 2.5 & 2.5 & 2.5 & 2.5 \\
\hline$q_{c}$ (bar) & 61.6 & 90.9 & 84.9 & 22.4 & 74.0 \\
\hline$R_{f}(\%)$ & 4.7 & 2.8 & 0.8 & 4.3 & 2.9 \\
\hline M (bar) & 154 & 227 & 212 & 56 & 185 \\
\hline $\mathbf{k}_{\mathrm{v}}(\mathrm{m} / \mathrm{s})$ & $3 \times 10^{-8}$ & $9 \times 10^{-8}$ & $1 \times 10^{-8}$ & $1 \times 10^{-6}$ & $7 \times 10^{-7}$ \\
\hline $\begin{array}{c}\text { Saturação do } \\
\text { Piezo-elemento }\end{array}$ & $\begin{array}{c}\text { Slot filter } \\
\text { (graxa) }\end{array}$ & $\begin{array}{c}\text { Slot filter } \\
\text { (graxa) }\end{array}$ & $\begin{array}{c}\text { Pedra porosa } \\
\text { (glicerina) }\end{array}$ & $\begin{array}{l}\text { Slot filter } \\
\text { (graxa) }\end{array}$ & $\begin{array}{l}\text { Slot filter } \\
\text { (graxa) }\end{array}$ \\
\hline $\begin{array}{c}\text { Camada de } \\
\text { dissipação com } \\
\text { interpretação } \\
\text { RCPTU } \\
\end{array}$ & $\begin{array}{l}\text { Solo Fino } \\
\text { Muito Rijo } \\
(\mathrm{SBT}=11)\end{array}$ & $\begin{array}{c}\text { Silte } \\
\text { Arenoso a } \\
\text { Argiloso } \\
(\mathrm{SBT}=6)\end{array}$ & $\begin{array}{c}\text { Areia Siltosa } \\
\quad(\mathrm{SBT}=8)\end{array}$ & $\begin{array}{c}\text { Argila } \\
(\mathrm{SBT}=3)\end{array}$ & $\begin{array}{c}\text { Silte } \\
\text { Arenoso a } \\
\text { Argiloso } \\
(\mathrm{SBT}=6)\end{array}$ \\
\hline
\end{tabular}

(*) $\mathrm{t}_{30}$, ou seja, tempo igual a $30 \%$ de dissipação, onde $\mathrm{T}^{*}{ }_{30}=0.078$, uma vez que a dissipação não atingiu $50 \%$. 


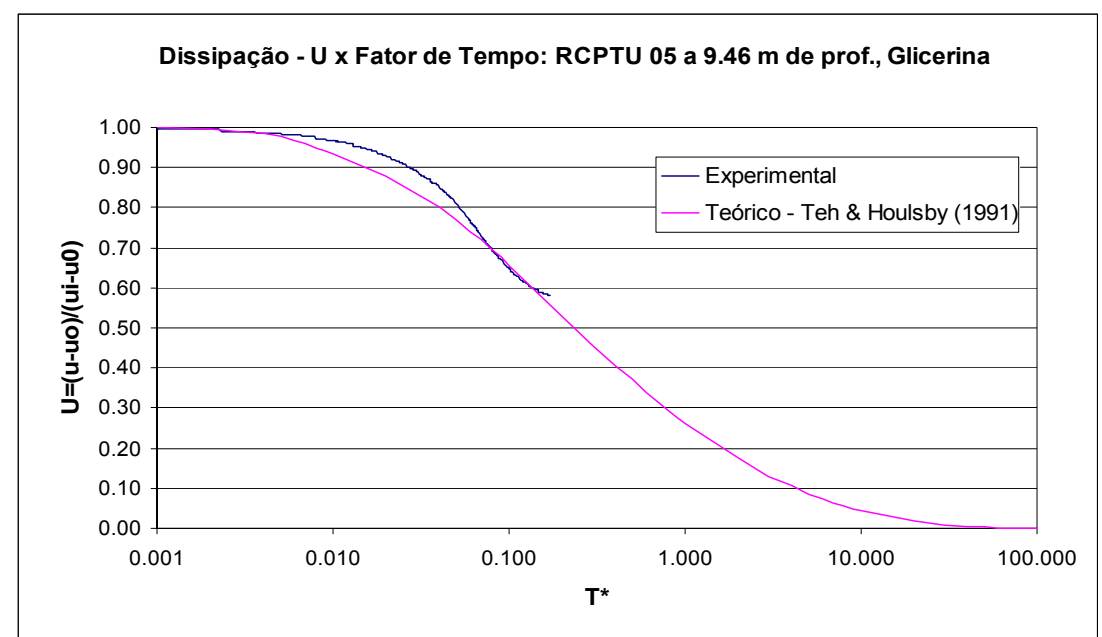

Figura 4.32. Curva de dissipação do excesso de poro-pressão obtida durante o ensaio RCPTU 05, saturado com glicerina, a $9.6 \mathrm{~m}$ de profundidade.

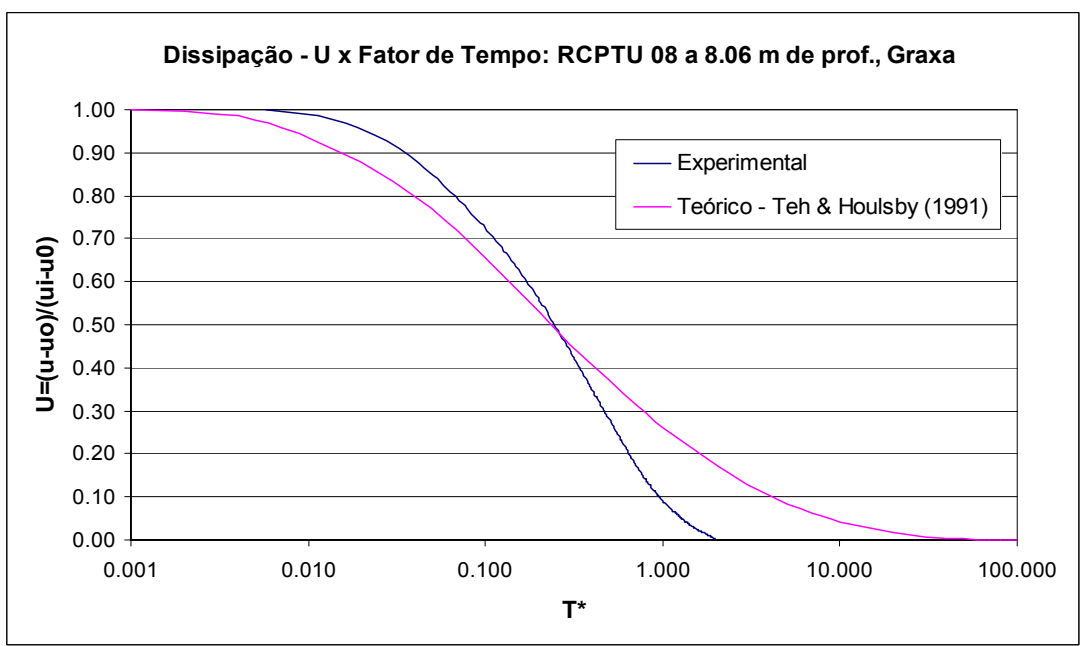

Figura 4.33. Curva de dissipação do excesso de poro-pressão obtida durante o ensaio RCPTU 08, saturado com graxa, a $8.06 \mathrm{~m}$ de profundidade.

Observa-se, na Figura 4.32, que a dissipação do excesso de poro-pressão foi muito lenta, atingindo apenas $40 \%$ do total de excesso gerado. Este fato prejudicou a estimativa do coeficiente de permeabilidade $(\mathrm{K})$ na profundidade em que foi realizado o ensaio, pois o valor de $\mathrm{K}$ igual a $1 \times 10^{-8} \mathrm{~m} / \mathrm{s}$, obtido para a camada de solo classificada como areia siltosa pelo ábaco de ROBERTSON et al. (1986), é considerado baixo. Entretanto, nota-se um mesmo comportamento para o ensaio RCPTU 01 (Anexo III), realizado com piezo-elemento preenchido com graxa, onde a dissipação também foi lenta e o solo da camada ensaiada foi classificado como solo 
fino muito rijo. O coeficiente de permeabilidade estimado para este ensaio também foi baixo, $3 \times 10^{-8} \mathrm{~m} / \mathrm{s}$, muito próximo do valor encontrado para o ensaio realizado com glicerina.

A Figura 4.33 apresenta uma curva com 100 \% de dissipação, obtida para o ensaio RCPTU 08, realizado com o piezo-elemento preenchido com graxa. Quando comparada com as curvas obtidas pelos ensaios de dissipação realizados durante as sondagens RCPTU 04 e 06, esta foi a curva que mais se aproximou da curva teórica obtida por TEH \& HOULSBY (1991). O valor de K estimado para a camada ensaiada do RCPTU 08, identificada como silte arenoso a argiloso, foi de $7 \times 10^{-7} \mathrm{~m} / \mathrm{s}$. Já, para a mesma camada identificada para o RCPTU 04, não se teve um bom ajuste entre a curva experimental e a teórica, o valor de $\mathrm{K}$ obtido foi de $9 \times 10^{-8} \mathrm{~m} / \mathrm{s}$. O ensaio de dissipação realizado durante o ensaio RCPTU 06 resultou em uma estimativa de $\mathrm{K}$ igual a $1 \times 10^{-6} \mathrm{~m} / \mathrm{s}$, próximo àquele obtido pelo ensaio RCPTU 08 , porém, em um solo classificado como argiloso.

Apesar das restrições do uso do slot filter, principalmente num ensaio de dissipação de poro-pressão em que não existe uma base teórica para sua interpretação, pois não há garantia de saturação, os valores determinados são compatíveis com aqueles obtidos pelos ensaios de permeabilidade realizados em laboratório com o solo do entorno do aterro de resíduos sólidos de Bauru, $\mathrm{K}$ da ordem de $10^{-7}$ a $10^{-6} \mathrm{~m} / \mathrm{s}$. Observou-se também não existe coerência entre a classificação do solo obtida a partir do ábaco de ROBERTSON et al. (1986) e o valor de $\mathrm{K}$ determinado.

Sugere-se que novos ensaios de dissipação sejam realizados na área, tanto com o piezo-elemento saturado com glicerina como com o filtro de cavidade preenchido com graxa. Isto possibilitará um melhor entendimento da resposta do slot filter para estimativa do coeficiente de permeabilidade in situ.

\subsubsection{Resistividade (RCPTU)}

\section{a) Considerações Gerais}

A dificuldade encontrada até o momento para análise dos resultados das sondagens RCPTU foi a falta de valores de referência para a resistividade 
determinada em solos com as mesmas características dos solos tropicais, uma vez que diversos fatores afetam esse parâmetro, especialmente nesse tipo de solo. Uma possível solução seria fazer uma interpretação por contraste, como sugere CAMPANELLA et al. (1993). Assim, seria necessário executar essa sondagem RCPTU antes da implantação do aterro ou então em uma área com as mesmas características daquela que se quer avaliar e onde se tivesse certeza de que não houve contaminação. Para o desenvolvimento deste estudo a primeira opção não foi possível, pois todos os ensaios foram feitos depois da implantação do aterro. A tentativa de se adotar a segunda opção também não foi possível, pois os perfis de solo não contaminado à montante (CPTU 01) e ao sul do aterro (CPTU 02 e RCPTU 12) apresentaram uma resistência à penetração do cone maior que a capacidade do penetrômetro, antes de atingir o nível d'água, e os ensaios de caracterização da várzea indicaram a presença de um tipo de solo diferente daquele onde está situado o aterro.

Optou-se então por comparar os perfis de resistividade gerados a partir das diversas sondagens RCPTU, na zona saturada, pois sabe-se, pela Lei de Archie, que o grau de saturação tem grande influencia nos valores de resistividade, especialmente para baixos graus de saturação. Este aspecto foi discutido por DANIEL et al. (2002), que mostram, na Figura 4.34, resultados de duas sondagens RCPTU lado a lado na zona não saturada de um perfil de solo arenoso do Canadá.

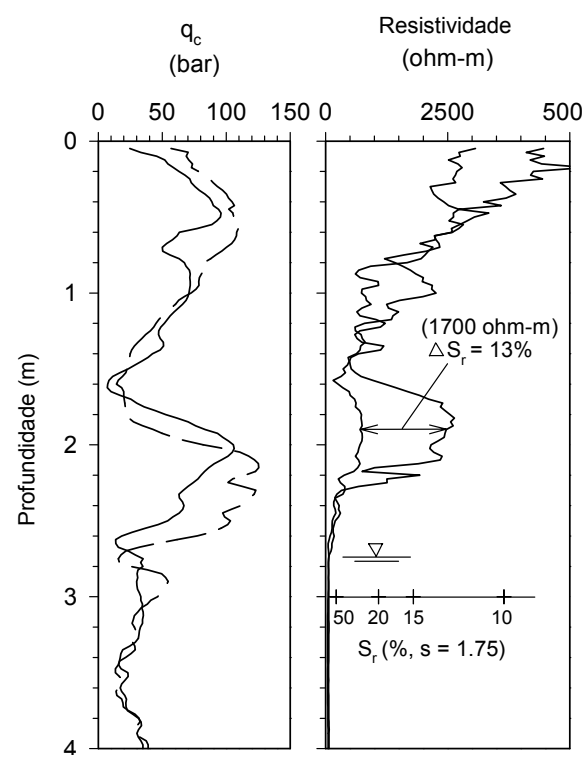

Figura 4.34. Efeito da variação do grau de saturação na resistividade (DANIEL et al., 2002). 
Observa-se, nesta figura, que para as duas sondagens RCPTU realizadas muito próximas uma da outra, a variabilidade entre seus resultados em termos de resistência de ponta $\left(\mathrm{q}_{\mathrm{c}}\right)$ é muito pequena. Porém, nota-se que os perfis de resistividade determinados nas duas sondagens seguem a mesma tendência, mas apresenta valores muito discrepantes em certas profundidades (por exemplo, de 1.6 a $2.2 \mathrm{~m}$ ). Apenas para fins de comparação, foi plotada, nesta figura, uma escala para o grau de saturação, assumindo-se um fator $s$ da Lei de Archie igual a 1.75. Esta escala mostra que a diferença de $1700 \mathrm{ohm} . \mathrm{m}$ entre as duas sondagens na profundidade de $1.9 \mathrm{~m}$ deve-se, provavelmente, a uma pequena variação do grau de saturação $(\approx 13$ $\%)$.

A conclusão de DANIEL et al. (2002) é que uma pequena variação no grau de saturação em perfis de solos não saturados pode representar uma grande variação nos valores de resistividade, dificultando assim a interpretação dos resultados de sondagens RCPTU em perfis de solos não saturados.

\section{b) Valores Típicos de Resistividade para as Camadas de Solo Saturadas}

$\mathrm{Na}$ região da várzea (Figura 4.31), a sondagem RCPTU 13 atingiu $15.5 \mathrm{~m}$ de profundidade e possibilitou que se observasse uma perfeita sincronia entre a variação dos valores de resistividade e a estratigrafia interpretada, a partir da zona saturada. Nas camadas argilosas, os valores de resistividade variaram entre 25 e 50 ohm.m, enquanto nas camadas arenosas esses valores variaram entre 150 e 200 ohm.m. Destaca-se que estas faixas de valores são características de solos argilosos e arenosos, conforme pode ser observado nas Tabelas 2.4 e 2.5 .

Na região próxima às erosões (RCPTUs 07 e 10), observa-se que os valores de resistividade das camadas argilosas também ficaram em torno de 25 e $50 \mathrm{ohm} . \mathrm{m}$ no RCPTU 07 e aumentaram um pouco na sondagem RCPTU 10, assumindo valores em torno de 50 e 80 ohm.m. Já, nas camadas arenosas observou-se uma maior variação nos valores de resistividade, entre 75 e 200 ohm.m para as duas sondagens realizadas. Destaca-se, de maneira geral, que a sondagem RCPTU 07 apresentou valores de resistividade menores que a sondagem RCPTU 10, o que está de acordo com o que se observa na Figura 4.35, uma vez que a sondagem RCPTU 07 está 
localizada numa região de resistividade menor do que aquela onde está localizada a sondagem RCPTU 10.

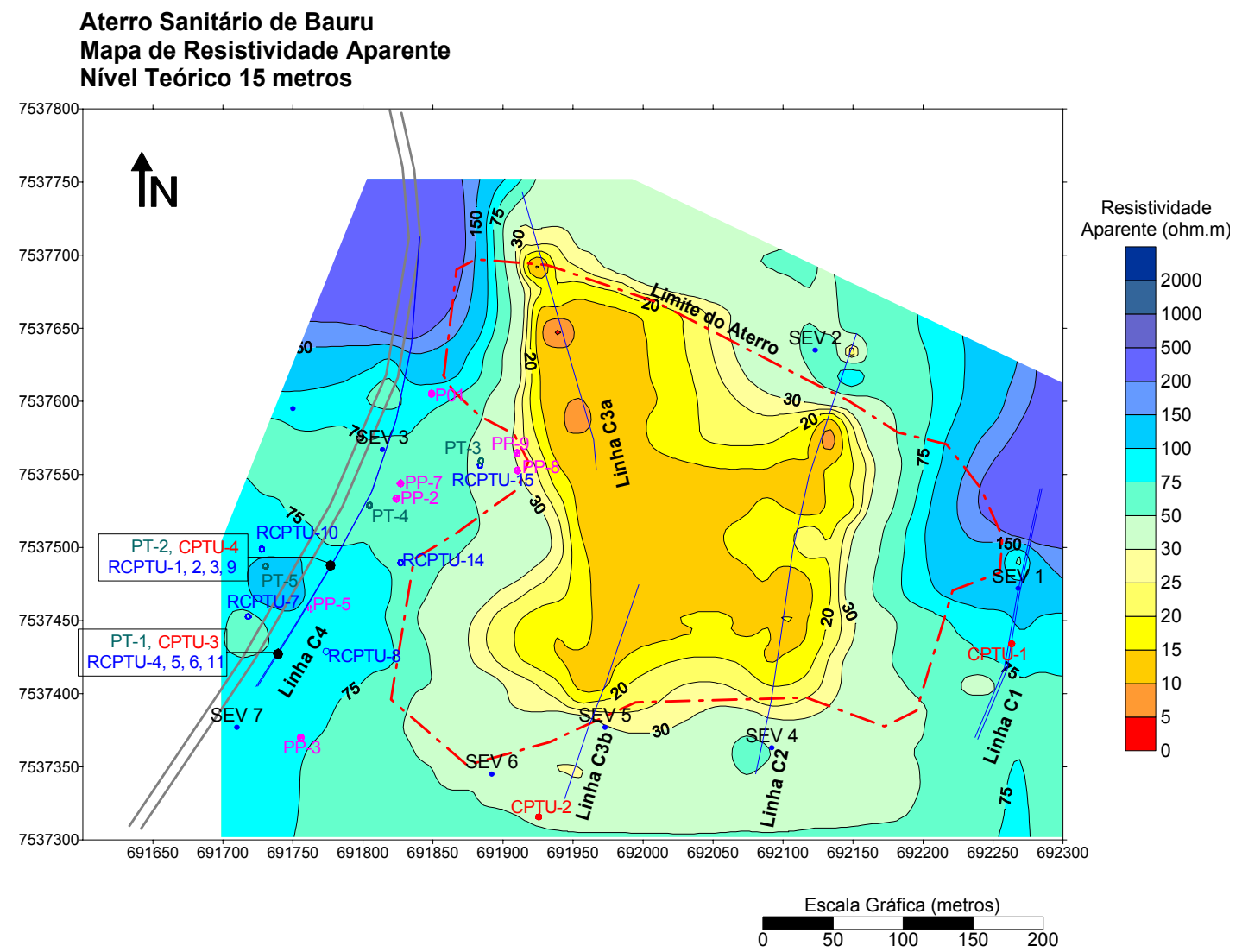

Figura 4.35. Mapa de resistividade do nível teórico $15 \mathrm{~m}$ do aterro de resíduos sólidos de Bauru. As regiões com valores de resistividade menores que 75 ohm.m indicam a contaminação da zona saturada.

Os resultados dos conjuntos de ensaios apresentados nas Figuras 4.25 e 4.26, realizados à jusante do aterro, podem ser interpretados considerando as informações que constam na seção de resistividade da Figura 4.13, obtida a partir do caminhamento elétrico da linha $\mathrm{C} 4$, uma vez que estes ensaios foram realizados sobre esta linha. Observa-se que os valores de resistividade medidos com o RCPTU na região não saturada variam de 250 a 1000 ohm.m, o que condiz com os valores desta mesma região obtidos através da geofísica de superfície. 
A Figura 4.26 mostra, na zona saturada, que a variação da resistividade com a profundidade é coerente com a variação da estratigrafia, com valores de resistividade variando de 20 a 75 ohm.m para as camadas argilosas e de 125 a $190 \mathrm{ohm} . \mathrm{m}$ para as camadas arenosas.

$\mathrm{Na}$ Figura 4.25, observa-se, na zona saturada, uma resposta um pouco diferente na sondagem RCPTU 05 do que a observada nas demais. A sondagem RCPTU 05 utilizou saturação do piezo-elemento com glicerina e, apesar das variações nos valores de $q_{c}$ e $R_{f}$ estarem acompanhando a estratigrafia, apresentou valores de resistividade um pouco maiores nas camadas arenosas de 6 a $9 \mathrm{~m}$ de profundidade, variando de 120 a 200 ohm.m. Apesar desta diferença, estes valores são compatíveis aqueles observados em outras sondagens realizadas na área. Já os demais ensaios apresentados na Figura 4.25 registraram resistividades muito baixas para as camadas arenosas (de 6.7 a $12 \mathrm{~m}$ ), com valores variando entre 25 e 75 ohm.m, além de valores abaixo de 20 ohm.m $(9.5 \mathrm{~m})$ para as camadas argilosas. Estes valores são menores do que os outros ensaios vinham apresentando, podendo estar indicando alguma influência do percolado nesta região do aterro, como já havia mostrado uma pequena mancha de contaminação na Figura 4.35.

Os resultados das sondagens realizadas mais próximas à cava resíduos, identificaram uma contaminação ainda maior. Entre 7.4 e $8.2 \mathrm{~m}$ de profundidade, o RCPTU 08 registrou uma resistividade de $40 \mathrm{ohm}$.m para a camada arenosa e de cerca de 20 ohm.m para as camadas argilosas. A partir desta profundidade, a variação da resistividade com a estratigrafia não foi tão nítida, permanecendo em torno de 30 ohm.m. O mesmo aconteceu com as sondagens RCPTU 14 e 15, com valores em torno de $50 \mathrm{ohm} . \mathrm{m}$ para a primeira e em torno de $20 \mathrm{ohm} . \mathrm{m}$ para a segunda. Isto indica a presença de contaminantes migrando nas camadas mais arenosas logo a frente do aterro, conforme mostraram os resultados da geofísica de superfície.

\section{c) Efeito da Saturação nos Valores de Resistividade}

Como as sondagens RCPTU foram realizadas em diferentes épocas do ano e mesmo na zona não saturada do perfil de solo existente no local foram determinados valores de resistividade dentro da faixa confiável de leituras do equipamento, 
procurou estudar a variação desses resultados em função da precipitação, uma vez que ela afeta o grau de saturação na zona não saturada.

Como a cidade de Bauru está situada na Bacia do Tietê (Figura 4.36), foram coletados dados junto ao INPE da variação da quantidade de chuvas ocorridas no intervalo em que foram realizadas as sondagens RCPTU (Figura 4.37). Na Figura 4.38 estão apresentadas as chuvas acumuladas nos meses em que foram realizados os ensaios.

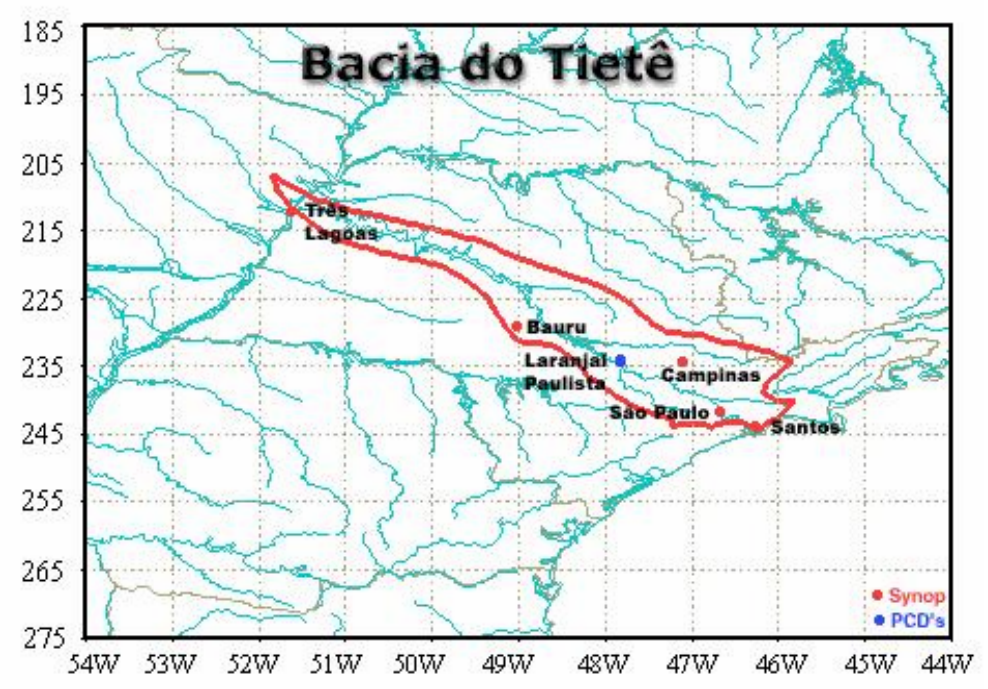

Figura 4.36. Localização de Bauru na Bacia do Rio Tietê (INPE, 2002).

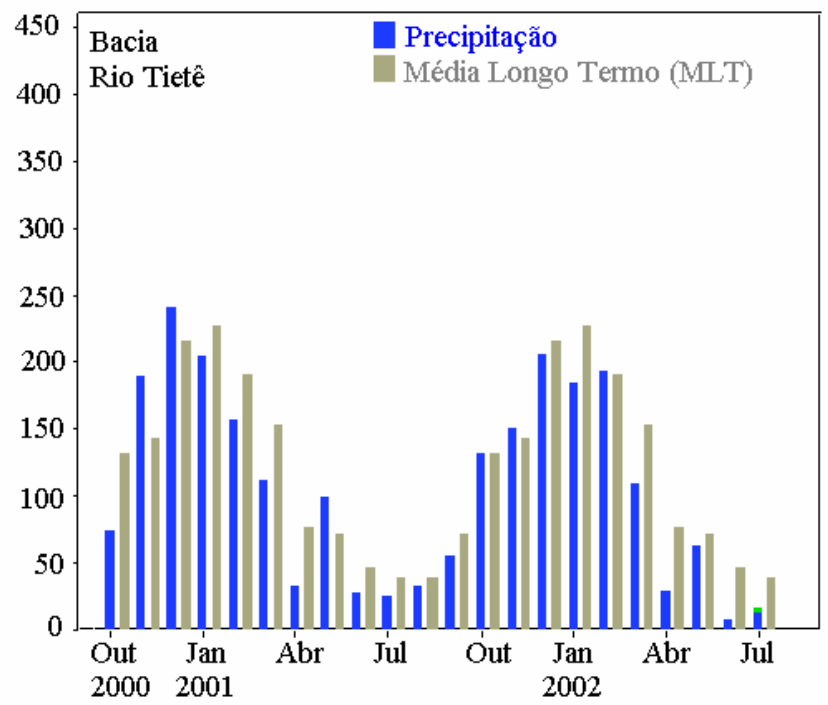

Figura 4.37. Precipitação ocorrida entre outubro de 2000 e julho de 2002 (INPE, 2002). 

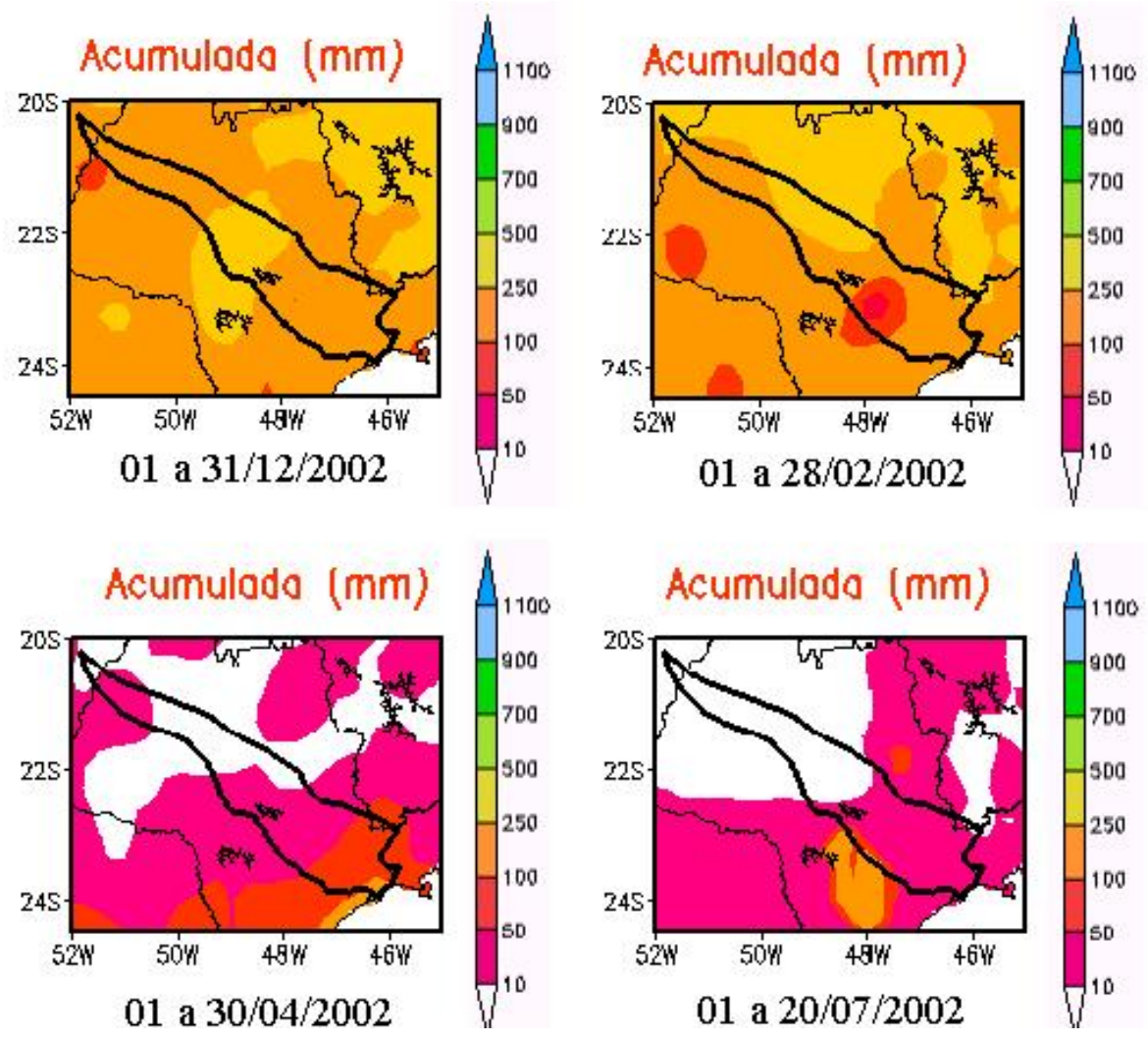

Figura 4.38. Precipitação acumulada mês a mês (INPE, 2002).

Analisando-se os resultados das sondagens RCPTU apresentadas na Figura 4.26, nota-se uma diferença nos valores de resistividade correspondentes aos meses de fevereiro (maior precipitação), RCPTUs 01, 02 e 03, e de abril (menor precipitação), RCPTU 09. Entre 1.5 e $2.0 \mathrm{~m}$ de profundidade tem-se uma grande diferença entre os valores de resistividade das sondagens RCPTU 01, 02 e 03 e a sondagem RCPTU 09. Se assumirmos que o único fator que possa ter contribuído para essa variação é o grau de saturação, a única explicação plausível para esse fato é que possa ter havido concentrações de umidade em regiões diferentes do maciço nas diferentes épocas. Já, a menor resistividade observada no RCPTU 09 entre as profundidades 3.0 e $4.5 \mathrm{~m}$, pode ser decorrência da camada de silte identificada nesta posição, enquanto os outros ensaios identificaram uma camada mais arenosa. Este fato pode estar ilustrando um aumento da variabilidade do solo local entre ensaios realizados em épocas diferentes. 
Já, os resultados da sondagem RCPTU 11 (Figura 4.25) mostraram uma diminuição nos valores de resistividade, na camada de areia, entre as profundidades de 2.0 e $3.0 \mathrm{~m}$. Esta redução pode ser um indício de presença de contaminantes, conforme indica os resultados das sondagens geofísicas realizadas nesta área. Além disso, essa sondagem foi executada em abril, mês com baixa precipitação acumulada, como indica a Figura 4.38, de modo que um menor grau de saturação do solo deveria resultar em maiores valores de resistividade, fato que não ocorreu nessa região do maciço e poderia explicar os elevados valores de resistividade entre 3.5 e $4.5 \mathrm{~m}$ de profundidade.

\section{d) Lei de Archie}

A fim de avaliar a influencia de diversos fatores nos valores de resistividade obtidos a partir das sondagens RCPTU, procurou-se aplicar a Lei de Archie, descrita pela Equação 2.45, para auxiliar na interpretação dos resultados das sondagens RCPTU realizadas. Para que isto fosse possível, trabalhou-se apenas com as sondagens que tinham amostras de solo e água coletadas através do Geoprobe ${ }^{\circledR}$, as quais serão apresentadas adiante no item 4.2.3.

A Tabela 4.5 apresenta a tentativa da aplicação desta lei para os solos tropicais que ocorrem no aterro de resíduos sólidos urbanos de Bauru. O fator de escala $a$ foi considerado igual a 1.0 para todas as sondagens, conforme sugere WEEMEES (1990) para solos normalmente adensados. Também segundo recomendações de JACKSON et al. (1978) apud WEEMEES (1990), a constante $m$ foi considerada igual a 1.5 para os solos classificados como arenosos, e igual a 2.0 para a camada de solo classificada como argilosa da sondagem RCPTU 13, entre 8.0 e $9.0 \mathrm{~m}$. A única camada de solo não saturado é aquela entre 3.5 e $4.5 \mathrm{~m}$ de profundidade do ensaio RCPTU 13, para a qual adotou-se $s$ igual a 2.0, conforme sugere Archie, segundo DANIEL (1997). 
Tabela 4.5. Aplicação da Lei de Archie para estimativa da resistividade do solo nos locais onde foram coletadas amostras de solo e água através do Geoprobe ${ }^{\circledR}$.

\begin{tabular}{|c|c|c|c|c|c|}
\hline SONDAGEM & RCPTU 13 & RCPTU 13 & RCPTU 14 & RCPTU 15 & RCPTU 15 \\
\hline Profundidade (m) & 3.5 a 4.5 & 8.0 a 9.0 & 7.3 a 8.3 & 6.0 a 7.0 & 8.0 a 9.0 \\
\hline$\%$ Areia & 97.5 & 55.0 & - & 78.0 & 80.2 \\
\hline \% Silte & 1.5 & 22.5 & - & 11.0 & 14.8 \\
\hline$\%$ Argila & 1.0 & 22.5 & - & 11.0 & 5.0 \\
\hline Descrição Táctil-Visual & $\begin{array}{c}\text { Areia Pura Amarela- } \\
\text { Acizentada }\end{array}$ & Argila Cinza & - & $\begin{array}{c}\text { Areia Argilosa } \\
\text { Vermelha } \\
\end{array}$ & $\begin{array}{c}\text { Areia Argilosa } \\
\text { Vermelha }\end{array}$ \\
\hline Interpretação do Piezocone & $\begin{array}{c}\text { Areia a Areia Siltosa } \\
(\mathrm{SBT}=8)\end{array}$ & $\begin{array}{l}\text { Argila Siltosa a } \\
\text { Argila }(\mathrm{SBT}=4)\end{array}$ & Areia $(\mathrm{SBT}=9)$ & $\begin{array}{c}\text { Areia Siltosa } \\
(\mathrm{SBT}=7)\end{array}$ & $\begin{array}{c}\text { Areia Siltosa } \\
(\mathrm{SBT}=7)\end{array}$ \\
\hline$\rho_{\mathrm{s}}(\mathrm{g} / \mathrm{cm} 3)$ & 2.63 & 2.52 & \begin{tabular}{|l|}
2.70 \\
\end{tabular} & 2.70 & 2.75 \\
\hline$\rho_{\mathrm{n}}(\mathrm{g} / \mathrm{cm} 3)$ & 1.7 & 1.7 & 1.7 & 1.7 & 1.7 \\
\hline CTC (meq/100g) & 0.18 & 7.9 & - & 6.81 & 9.41 \\
\hline $\mathrm{w}(\%)$ & 18.6 & 40 & 18.0 & 18.1 & 20.1 \\
\hline e & 0.83 & 1.08 & 0.87 & 0.88 & 0.94 \\
\hline Sr $(\%)$ & 58.6 & 100.0 & 100.0 & 100.0 & 100.0 \\
\hline n (\%) & 45.0 & 52.0 & 47.0 & 47.0 & 49.0 \\
\hline Condutividade - RCPTU $(\mu \mathrm{S} / \mathrm{cm})$ & 29 & 484 & 208 & 409 & 609 \\
\hline Resistividade - RCPTU (ohm.m) & 385 & 21 & $\mathbf{5 0}$ & 25 & 17 \\
\hline a (WEEMEES, 1990) & 1.0 & 1.0 & 1.0 & 1.0 & 1.0 \\
\hline m (WEEMEES, 1990) & 1.5 & 2.0 & 1.5 & 1.5 & 1.5 \\
\hline s (ARCHIE, 1942) & 2.0 & - & - & - & - \\
\hline Condutividade do fluido $(\mu \mathrm{S} / \mathrm{cm})$ & 100 & 85 & 51 & 40 & 203 \\
\hline Resistividade do fluido ( $\rho$ f) (ohm.m) & 100 & 118 & 196 & 250 & 49 \\
\hline pH do fluido & 6.1 & 5.7 & 5.3 & 5.9 & 5.8 \\
\hline Resistividade - Lei de Archie (ohm.m) & 949 & 438 & 616 & 784 & 146 \\
\hline
\end{tabular}


A partir destes resultados, elaborou-se um gráfico dos valores de resistividade obtidos a partir dos ensaios com o piezocone de resistividade (RCPTU) em função dos valores de resistividade calculados a partir da Lei de Archie, como mostra a Figura 4.39.

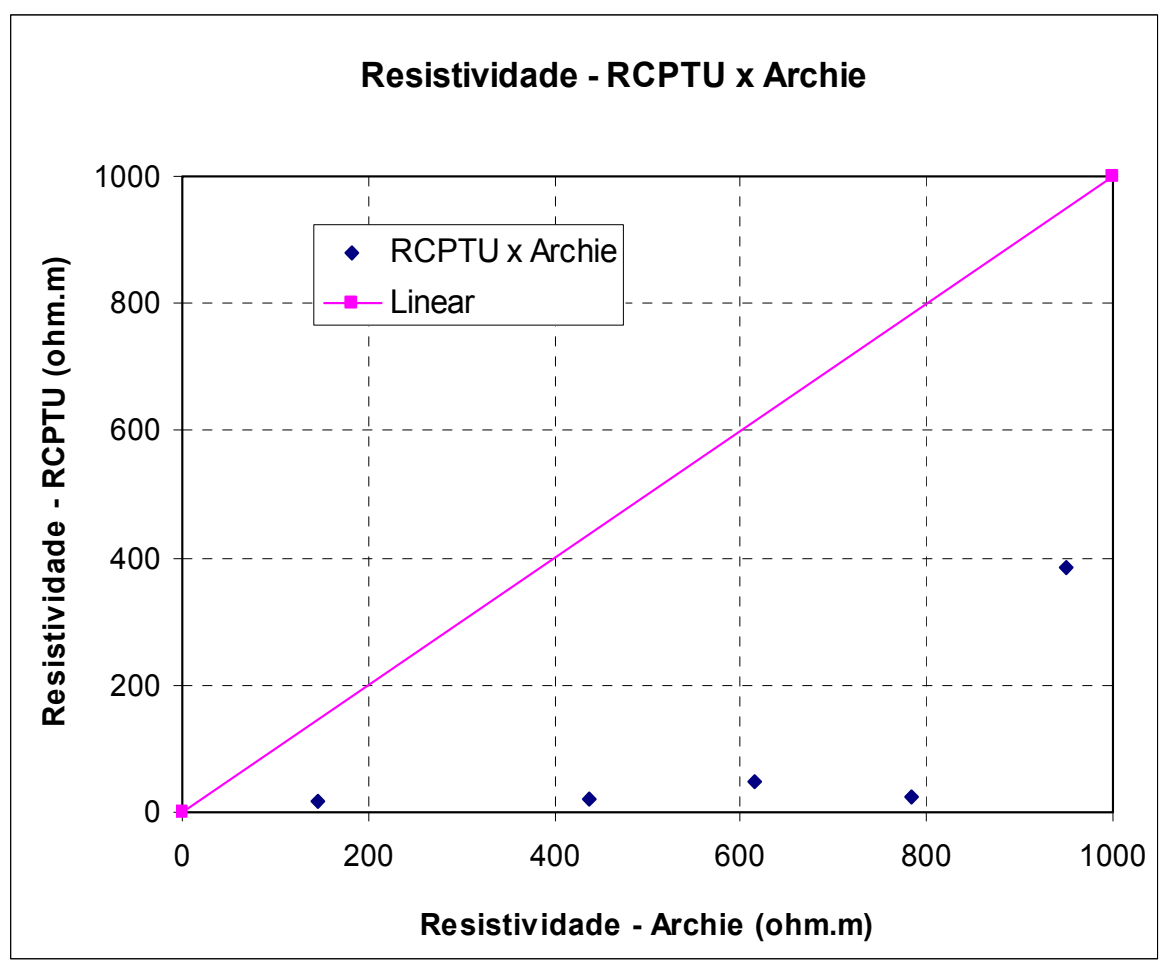

Figura 4.39. Valores de resistividade obtidos a partir dos ensaios RCPTU versus os valores de resistividade calculados a partir da Lei de Archie.

Observa-se, na Figura 4.39, que a aplicação da Lei de Archie superestima os valores de resistividade quando comparados com aqueles obtidos pelo piezocone. Possivelmente, isto se deve aos valores de $a, m$ e $s$ que foram recomendados para solos diferentes daqueles utilizados neste estudo. A determinação de novos valores destes parâmetros para solos tropicais poderia resultar numa melhor estimativa da resistividade do solo a partir da Lei de Archie. Um estudo deste tipo foi realizado por DANIEL (1997), que obteve estes parâmetros em laboratório para solos compactados de uma barragem de rejeitos do Canadá, o qual também poderia ser feito para solos tropicais. 


\subsubsection{Ensaios de Caracterização Geotécnica e Geoambiental}

\subsubsection{Amostras de Solo Coletadas com o Geoprobe $\mathbb{B}$}

Os resultados dos ensaios de caracterização das amostras de solo obtidas com

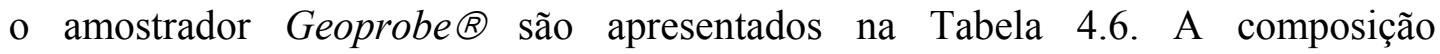
granulométrica das amostras foi obtida utilizando a escala definida pela NBR $6502 / 1995$.

Tabela 4.6. Resultados dos ensaios de caracterização geotécnica.

\begin{tabular}{|c|c|c|c|c|c|c|c|c|c|c|}
\hline \multirow[b]{2}{*}{ Furo } & \multirow[b]{2}{*}{$\begin{array}{l}\text { Prof. } \\
\text { (m) }\end{array}$} & \multirow[b]{2}{*}{$\begin{array}{c}\rho_{\mathrm{s}} \\
\left(\mathrm{g} / \mathrm{cm}^{3}\right)\end{array}$} & \multicolumn{4}{|c|}{ Granulometria (\%) } & \multirow[b]{2}{*}{$\begin{array}{l}\text { LL } \\
(\%)\end{array}$} & \multirow[b]{2}{*}{$\begin{array}{l}\text { IP } \\
(\%)\end{array}$} & \multirow[b]{2}{*}{$\begin{array}{c}\text { CTC } \\
(\mathrm{meq} / \mathbf{1 0 0 g})\end{array}$} & \multirow[b]{2}{*}{$\begin{array}{c}\text { VB } \\
(\mathrm{g} / \mathbf{1 0 0 g})\end{array}$} \\
\hline & & & $\begin{array}{l}\text { Areia } \\
\text { Média }\end{array}$ & $\begin{array}{l}\text { Areia } \\
\text { Fina }\end{array}$ & Silte & Argila & & & & \\
\hline \multirow[t]{2}{*}{ CPTU 1} & 6.0 a 7.0 & 2.636 & 18.0 & 29.0 & 20.0 & 33.0 & \multicolumn{2}{|c|}{ ND } & 3.36 & 1.08 \\
\hline & 9.5 a 10.5 & 2.644 & 50.0 & 39.0 & 7.0 & 4.0 & \multicolumn{2}{|c|}{ ND } & 5.03 & 1.61 \\
\hline CPTU 2 & 2.0 a 3.0 & 2.654 & 52.5 & 36.5 & 6.0 & 5.0 & \multicolumn{2}{|c|}{ ND } & 2.55 & 0.82 \\
\hline \multirow{3}{*}{ CPTU 3} & 5.0 a 6.0 & 2.663 & 26.0 & 31.0 & 15.5 & 27.5 & 32 & 12 & 6.00 & 1.92 \\
\hline & 6.0 a 7.0 & 2.642 & 46.0 & 34.0 & 2.0 & 18.0 & \multicolumn{2}{|c|}{ ND } & 2.88 & 0.92 \\
\hline & 7.0 a 8.0 & 2.651 & 44.0 & 35.5 & 4.5 & 16.0 & \multicolumn{2}{|c|}{ ND } & 2.74 & 0.88 \\
\hline \multirow{4}{*}{ CPTU 4} & 5.0 a 6.0 & 2.707 & 30.0 & 47.0 & 14.5 & 8.5 & \multicolumn{2}{|c|}{ ND } & 5.36 & 1.72 \\
\hline & 6.0 a 7.0 & 2.630 & 41.0 & 45.5 & 8.5 & 5.0 & \multicolumn{2}{|c|}{ ND } & 2.56 & 0.82 \\
\hline & 7.0 a 7.7 & 2.676 & 37.0 & 41.0 & 12.0 & 10.0 & \multicolumn{2}{|c|}{ ND } & 6.96 & 2.23 \\
\hline & 7.7 a 8.0 & 2.665 & 18.0 & 29.5 & 18.5 & 34.0 & 45 & 20 & 12.09 & 3.87 \\
\hline \multirow{3}{*}{$\begin{array}{c}\text { RCPTU } \\
13\end{array}$} & 1.5 a 2.5 & 2.663 & 52.0 & 40.0 & 1.0 & 7.0 & \multicolumn{2}{|c|}{ ND } & 1.97 & 0.63 \\
\hline & 3.5 a 4.5 & 2.627 & 57.5 & 40.0 & 1.5 & 1.0 & \multicolumn{2}{|c|}{ ND } & 0.18 & 0.06 \\
\hline & 7.5 a 8.5 & 2.517 & 22.0 & 33.0 & 22.5 & 22.5 & 37 & 11 & 7.90 & 2.55 \\
\hline \multirow{4}{*}{$\begin{array}{c}\text { RCPTU } \\
15\end{array}$} & 2.0 a 3.0 & 2.666 & 42.0 & 46.0 & 6.5 & 5.5 & \multicolumn{2}{|c|}{ ND } & 1.83 & 0.58 \\
\hline & 5.0 a 6.0 & 2.730 & 42.0 & 40.0 & 9.5 & 8.5 & \multicolumn{2}{|c|}{ ND } & 6.88 & 2.20 \\
\hline & 6.0 a 7.0 & 2.699 & 35.0 & 43.0 & 11.0 & 11.0 & \multicolumn{2}{|c|}{ ND } & 6.81 & 2.18 \\
\hline & 8.0 a 9.0 & 2.753 & 27.7 & 52.5 & 14.8 & 5.0 & \multicolumn{2}{|c|}{ ND } & 9.41 & 3.01 \\
\hline
\end{tabular}

* ND = Não Determinado.

Os resultados destes ensaios confirmam uma concordância razoável entre os perfis obtidos através dos ensaios CPTU e RCPTU e as mudanças de textura das 
camadas obtidas através de ensaios de granulometria, como já comentado no item 4.2.2.4. Destaca-se que é importante que uma interpretação correta das sondagens CPTU e RCPTU para definição do perfil geotécnico seja feita utilizando-se amostradores de solos apropriados, pelas limitações das cartas de classificação de solos a partir de resultados de sondagens CPTU, como aquela sugerida por ROBERTSON et al. (1986).

Para analisar a atividade da fração argilosa, foram realizados ensaios de adsorção de azul de metileno, através dos quais foi possível determinar o valor de azul (VB), a capacidade de troca cationica (CTC) e a quantidade de azul de metileno adsorvido por 100 gramas de argila (Acb) para cada amostra. A interpretação destes ensaios foi feita segundo a proposta de LAUTRIN (1989) apud PEJON (1992) e os resultados são apresentados na Tabela 4.7. Verifica-se, nesta tabela, que nos primeiros metros existe uma tendência dos argilo-minerais serem da família das caulinitas e, a profundidades maiores, serem da família das montmorilonitas, o que está de acordo com o que se encontra em perfís de evolução de solos tropicais.

Tabela 4.7. Interpretação dos resultados dos ensaios de adsorção de azul de metileno a partir da proposta de LAUTRIN (1989) apud PEJON (1992).

\begin{tabular}{|c|c|c|c|c|c|c|c|}
\hline Furo & $\begin{array}{l}\text { Prof. } \\
\text { (m) }\end{array}$ & CTC & VB & $\begin{array}{c}(\%) \\
\text { argila }\end{array}$ & $\begin{array}{c}\text { Acb } \\
(\mathrm{g} / \mathbf{1 0 0 g})\end{array}$ & \multicolumn{2}{|c|}{$\begin{array}{c}\text { Interpretação segundo } \\
\text { LAUTRIN (1989) }\end{array}$} \\
\hline \multirow[t]{2}{*}{ CPTU 1} & 6.0 a 7.0 & 3.36 & 1.08 & 33.0 & 3.27 & pouco ativa & caulinita \\
\hline & 9.5 a 10.5 & 5.03 & 1.61 & 4.0 & 40.25 & nociva & montmorilonita \\
\hline CPTU 2 & 2.0 a 3.0 & 2.55 & 0.82 & 5.0 & 16.40 & muito ativa & IIIta \\
\hline \multirow{3}{*}{ CPTU 3} & 5.0 a 6.0 & 6.00 & 1.92 & 27.5 & 6.98 & normal & caulinita \\
\hline & 6.0 a 7.0 & 2.88 & 0.92 & 18.0 & 5.11 & normal & caulinita \\
\hline & 7.0 a 8.0 & 2.74 & 0.88 & 16.0 & 5.50 & nor & \\
\hline \multirow{4}{*}{ CPTU 4} & 5.0 a 6.0 & 5.36 & 1.72 & 8.0 & 20.24 & nociva & montmorilonita \\
\hline & 6.0 a 7.0 & 2.56 & 0.82 & 5.0 & 16.40 & muito ativa & ilita \\
\hline & 7.0 a 7.7 & 6.96 & 2.23 & 10.0 & 22.30 & muito ativa & montmorilonita \\
\hline & 7.7 a 8.0 & 12.09 & 3.87 & 34.0 & 11.38 & ativa & montmorilonita \\
\hline \multirow{3}{*}{$\begin{array}{c}\text { RCPTU } \\
13\end{array}$} & 1.5 a 2.5 & 1.97 & 0.63 & 7.0 & 9.00 & & \\
\hline & 3.5 a 4.5 & 0.18 & 0.06 & 1.0 & 6.00 & normal & caulinita \\
\hline & 7.5 a 8.5 & 7.90 & 2.55 & 22.5 & 11.33 & ativa & \\
\hline \multirow{4}{*}{$\begin{array}{c}\text { RCPTU } \\
15\end{array}$} & 2.0 a 3.0 & 1.83 & 0.58 & 5.5 & 10.55 & ativa & caulinita \\
\hline & 5.0 a 6.0 & 6.88 & 2.20 & 8.5 & 25.88 & nociva & montmorilonita \\
\hline & 6.0 a 7.0 & 6.81 & 2.18 & 11.0 & 19.82 & nociva & montmorilonita \\
\hline & 8.0 a 9.0 & 9.41 & 3.01 & 5.0 & 60.20 & nociva & montmorilonita \\
\hline
\end{tabular}




\subsubsection{Amostras de Água Coletadas com o Geoprobe $\AA$}

$\mathrm{Na}$ Tabela 4.8 são apresentados os valores de $\mathrm{pH}$, temperatura e condutividade, determinados no momento da coleta das amostras de água.

A Tabela 4.9 mostra os resultados das análises químicas realizadas com as amostras de água no Laboratório de Resíduos Sólidos da Unesp de Bauru. Já a Tabela 4.10 mostra os resultados das determinações de concentrações de metais pesados, executados pelo Laboratório de Análises Químicas e Controle Industrial de Lins-SP, pelo método da espectrometria de absorção atômica.

Tabela 4.8. Resultados das determinações realizadas no campo para as amostras de água.

\begin{tabular}{|l|c|c|c|c|c|c|c|}
\hline Sondagem & $\begin{array}{c}\text { No. da } \\
\text { amostra }\end{array}$ & Data & $\begin{array}{c}\text { Prof. inicial } \\
(\mathbf{m})\end{array}$ & $\begin{array}{c}\text { Prof. final } \\
(\mathbf{m})\end{array}$ & $\begin{array}{c}\mathbf{p H} \\
(\mathbf{2 5})\end{array}$ & $\begin{array}{c}\text { Condut. } \\
(\boldsymbol{\mu S} / \mathbf{c m})\end{array}$ & $\begin{array}{c}\text { Temp. } \\
\left({ }^{\circ} \mathbf{C}\right)\end{array}$ \\
\hline \multirow{2}{*}{ RCPTU 13 } & 1 & $\mathrm{Jul} / 2002$ & 3.50 & 4.50 & 6.1 & 100 & 26.7 \\
\cline { 2 - 8 } & 2 & $\mathrm{Jul} / 2002$ & 8.0 & 9.0 & 5.7 & 85 & 23.4 \\
\hline RCPTU 14 & 1 & $\mathrm{Jul} / 2002$ & 7.3 & 8.30 & 5.3 & 51 & 24.4 \\
\hline \multirow{2}{*}{ RCPTU 15 } & 1 & $\mathrm{Jul} / 2002$ & 6.0 & 7.0 & 5.9 & 40 & 27.7 \\
\cline { 2 - 8 } & 2 & $\mathrm{Jul} / 2002$ & 8.0 & 9.0 & 5.8 & 203 & 26.4 \\
\hline
\end{tabular}

Tabela 4.9. Resultados das análises químicas realizadas nas amostras de água.

\begin{tabular}{|c|c|c|c|c|c|c|c|c|c|c|}
\hline \multirow[t]{2}{*}{ Furo } & \multirow{2}{*}{$\begin{array}{c}\text { Prof. } \\
\text { inicial } \\
\text { (m) }\end{array}$} & \multirow{2}{*}{$\begin{array}{c}\text { Prof. } \\
\text { final } \\
\text { (m) }\end{array}$} & \multirow{2}{*}{$\begin{array}{c}\text { pH } \\
25^{\circ} \mathrm{C} \\
\text { lab. }\end{array}$} & \multirow{2}{*}{$\begin{array}{l}\text { Alcal. } \\
\text { Total } \\
(\mathrm{mg} / \mathrm{L})\end{array}$} & \multirow[t]{2}{*}{$\begin{array}{c}\text { Cloretos } \\
(\mathrm{mg} / \mathrm{L})\end{array}$} & \multirow[t]{2}{*}{$\begin{array}{c}\text { DQO } \\
(\mathrm{mg} / \mathrm{L})\end{array}$} & \multicolumn{2}{|c|}{$\begin{array}{l}\text { Nitrogênio } \\
\text { Amoniacal }\end{array}$} & \multicolumn{2}{|c|}{ Nitratos } \\
\hline & & & & & & & $\mathbf{N}$ & $\mathbf{N H}_{3}$ & $\mathrm{NO}_{3}$ & $\mathrm{~N}-\mathrm{NO}_{3}$ \\
\hline \multirow{2}{*}{$\begin{array}{c}\text { RCPTU } \\
13\end{array}$} & 3.5 & 4.5 & 5.7 & 57.0 & - & N.D. & - & - & - & - \\
\hline & 8.0 & 9.0 & 5.0 & 44.0 & - & N.D. & - & - & - & - \\
\hline $\begin{array}{c}\text { RCPTU } \\
14\end{array}$ & 7.3 & 8.3 & 5.3 & 13.0 & 25.0 & 6.0 & N.D & 0.1 & 2.6 & 0.6 \\
\hline \multirow{2}{*}{$\begin{array}{c}\text { RCPTU } \\
15\end{array}$} & 6.0 & 7.0 & 6.2 & 73.0 & 73.0 & N.D. & 0.5 & 0.6 & N.D. & N.D. \\
\hline & 8.0 & 9.0 & 6.1 & 59.0 & 28.0 & 19.0 & 0.4 & 0.5 & N.D. & N.D. \\
\hline
\end{tabular}

- N.D. = não detectado. 
Tabela 4.10. Concentrações de metais pesados encontradas nas amostras de agua e chorume.

\begin{tabular}{|c|c|c|c|c|c|c|c|c|}
\cline { 2 - 9 } \multicolumn{1}{c|}{} & $\begin{array}{c}\text { Prof. } \\
\text { Inicial } \\
(\mathbf{m})\end{array}$ & $\begin{array}{c}\text { Prof. } \\
\text { Final } \\
\mathbf{( m )}\end{array}$ & $\begin{array}{c}\mathbf{C d} \\
\mathbf{( m g / L )}\end{array}$ & $\begin{array}{c}\mathbf{P b} \\
\mathbf{( m g / L )}\end{array}$ & $\begin{array}{c}\mathbf{C r} \\
\mathbf{t o t a l} \\
\mathbf{( m g / L )}\end{array}$ & $\begin{array}{c}\text { Fe total } \\
\mathbf{( m g / L )}\end{array}$ & $\begin{array}{c}\mathbf{H g} \\
(\mathbf{m g} / \mathbf{L})\end{array}$ & $\begin{array}{c}\mathbf{Z n} \\
\mathbf{( m g / L )}\end{array}$ \\
\hline RCPTU 13 & 3.50 & 4.50 & 0.011 & N.D. & 0.206 & 35.20 & N.D. & 0.483 \\
\hline RCPTU 14 & 7.3 & 8.30 & 0.014 & N.D. & N.D. & 0.457 & N.D. & 0.032 \\
\hline RCPTU 15 & 6.0 & 7.0 & 0.008 & N.D. & N.D. & 0.457 & N.D. & 0.035 \\
\cline { 2 - 9 } & 8.0 & 9.0 & 0.004 & N.D. & N.D. & 2.38 & N.D. & 0.131 \\
\hline $\begin{array}{c}\text { Chorume } \\
\text { fresco }\end{array}$ & - & - & 0.35 & 1.92 & 2.50 & 720.0 & $*$ & 40.0 \\
\hline $\begin{array}{c}\text { Chorume } \\
\text { em caixa de } \\
\text { acumulação }\end{array}$ & - & - & 0.10 & 0.62 & 0.80 & 140.0 & $*$ & 5.40 \\
\hline
\end{tabular}

- N.D. = não detectado;

- $\quad *$ = não determinado;

- Ensaios no chorume foram feitos pelos laboratórios da EESC/USP (FIPAI, 2001).

\subsubsection{Poços de Monitoramento e Águas Superficiais}

Os poços de monitoramento permanentes foram concluídos no início do mês de outubro de 2002 pela EMDURB, órgão municipal responsável pelo aterro. Duas campanhas de coletas de água desses poços foram realizadas durante esta pesquisa, nos dias 23/01/2003 e 12/08/2003 (Tabelas 4.11 e 4.12, respectivamente), no período da manhã. As análises químicas foram todas realizadas pelo Laboratório de Saneamento da EESC - USP. 
Tabela 4.11. Resultados da primeira campanha de análise das águas dos poços de monitoramento permanentes instalados no aterro de resíduos sólidos de Bauru.

\begin{tabular}{|c|c|c|c|c|c|c|c|c|c|}
\hline \multirow[b]{2}{*}{ PARÂMETROS } & \multicolumn{9}{|c|}{ POÇOS PERMANENTES DE MONITORAMENTO } \\
\hline & 1 & 2 & 3 & 4 & 5 & 6 & 7 & 8 & 9 \\
\hline Localização & $\begin{array}{l}\text { Jusante } \\
\text { (NW) }\end{array}$ & $\begin{array}{c}\text { Jusante } \\
\text { (W) }\end{array}$ & $\begin{array}{c}\text { Jusante } \\
\text { (SW) }\end{array}$ & $\begin{array}{l}\text { Mont. } \\
\text { (NW) }\end{array}$ & $\begin{array}{c}\text { Jusante } \\
\text { (W) }\end{array}$ & $\begin{array}{l}\text { Várzea } \\
(\mathrm{S})\end{array}$ & $\begin{array}{c}\text { Jusante } \\
\text { (W) }\end{array}$ & \begin{tabular}{|c|} 
Jusante \\
$(\mathrm{NW})$
\end{tabular} & $\begin{array}{c}\text { Jusante } \\
\text { (NW) }\end{array}$ \\
\hline Data da coleta & $23 / 1 / 03$ & $23 / 1 / 03$ & $23 / 1 / 03$ & $23 / 1 / 03$ & $23 / 1 / 03$ & $23 / 1 / 03$ & $23 / 1 / 03$ & $23 / 1 / 03$ & $23 / 1 / 03$ \\
\hline Chuvas 24 horas & Sim & $\operatorname{sim}$ & $\operatorname{sim}$ & $\operatorname{sim}$ & $\operatorname{sim}$ & $\operatorname{sim}$ & Sim & $\operatorname{sim}$ & Sim \\
\hline T Ar $\left({ }^{\circ} \mathrm{C}\right)$ & 23 & 23 & 23 & 23 & 23 & 23 & 23 & 23 & 23 \\
\hline $\mathrm{T}$ amostra $\left({ }^{\circ} \mathrm{C}\right)$ & 25.3 & 25.1 & 24.8 & 24.9 & 25.1 & 25.1 & 25.3 & 25.4 & 25.5 \\
\hline PH* & 4.64 & 5.41 & 6.22 & 5.88 & 7.9 & 4.84 & 5.36 & 5.78 & 5.89 \\
\hline $\begin{array}{l}\text { Alcalinidade* } \\
\text { (mg/L) }\end{array}$ & 5 & 13 & 122 & 118 & 72 & 6 & 37 & 56 & 73 \\
\hline Cloretos $(\mathrm{mg} / \mathrm{L})$ & 98 & 5 & 5.5 & 5 & 21 & 3.5 & 61.5 & 43.5 & 59 \\
\hline $\begin{array}{l}\text { Condutividade } \\
\text { (us/cm) }\end{array}$ & 465 & 47 & 183 & 174 & 360 & 55 & 257 & 161 & 286 \\
\hline OD $(\mathrm{mg} / \mathrm{L})$ & 3.08 & 4.59 & 4.01 & 3.65 & 2.34 & 2.44 & 3.78 & 3.69 & 3.79 \\
\hline DBO* (mg/L) & 18 & 8.9 & 6 & 3.5 & 9 & 10 & 3.2 & 11 & 2.9 \\
\hline DQO* (mg/L) & 39 & 18 & 8 & 4 & 16 & 13 & 3 & 16 & 3 \\
\hline $\begin{array}{l}\text { Carbono org.total } \\
(\mathrm{mg} \mathrm{C} / \mathrm{L})\end{array}$ & 1.433 & 0.585 & 0.731 & 0.948 & 3.034 & 3.28 & 1.361 & 1.187 & 1.583 \\
\hline Sulfatos (mg/L) & $<1$ & 1 & $<1$ & $<1$ & 65 & 9 & $<1$ & $<1$ & $<1$ \\
\hline Sulfetos (mg/L) & $<0.001$ & 0.001 & $<0.001$ & $<0.001$ & 0.003 & 0.007 & $<0.001$ & $<0.001$ & $<0.001$ \\
\hline $\begin{array}{l}\text { Nitrogênio } \\
\text { amoniacal (mg/L) }\end{array}$ & 0.15 & 0.05 & 0.02 & 0.05 & 0.91 & 0.08 & 0.11 & 0.04 & 0.32 \\
\hline $\begin{array}{l}\text { Nitrogênio nitrato } \\
(\mathrm{mg} / \mathrm{L})\end{array}$ & 1.08 & 0.27 & 0.54 & 0.66 & 14.85 & 0.49 & 0.24 & 0.53 & 0.77 \\
\hline $\begin{array}{l}\text { Nitrogênio nitrito } \\
(\mathrm{mg} / \mathrm{L})\end{array}$ & 0.001 & $<0.001$ & $<0.001$ & $<0.001$ & $<0.001$ & $<0.001$ & $<0.001$ & $<0.001$ & $<0.001$ \\
\hline $\begin{array}{l}\text { Nitrogênio total } \\
(\mathrm{mg} / \mathrm{L})\end{array}$ & 0.28 & 0.13 & 0.33 & 0.2 & 0.41 & 0.2 & 0.23 & 0.15 & 0.56 \\
\hline $\begin{array}{l}\text { Fosfato total } \\
(\mathrm{mg} / \mathrm{L})\end{array}$ & 0.04 & 0.03 & 0.06 & 0.04 & 0.07 & 0.04 & 0.04 & 0.03 & 0.04 \\
\hline $\begin{array}{l}\text { Coliformes totais } \\
\text { (UFC/100 mL) }\end{array}$ & 1060 & 600 & 900 & 18000 & 500 & 250 & 450 & 1200 & 20000 \\
\hline $\begin{array}{l}\text { E. COLI } \\
(\mathrm{UFC} / 100 \mathrm{~mL})\end{array}$ & 10 & 0 & 0 & 0 & 0 & 0 & 0 & 10 & 10 \\
\hline Zinco (mg/L) & 0.2 & 0.19 & 0.07 & 0.15 & 0.19 & 0.13 & 0.16 & 0.11 & 0.08 \\
\hline Cádmio (mg/L) & $<0.0006$ & $<0.0006$ & $<0.0006$ & 0.02 & 0.08 & $<0.0006$ & $<0.0006$ & $<0.0006$ & $<0.0006$ \\
\hline Níquel (mg/L) & 0.06 & $<0.008$ & $<0.008$ & 0.02 & 0.09 & $<0.008$ & 0.02 & $<0.008$ & $<0.008$ \\
\hline $\begin{array}{l}\text { Ferro total } \\
(\mathrm{mg} / \mathrm{L})\end{array}$ & 34.5 & 18.2 & 4.1 & 1.1 & 15.5 & 1.8 & 27.4 & 1 & 3.1 \\
\hline $\begin{array}{l}\text { Cromo Total } \\
(\mathrm{mg} / \mathrm{L})\end{array}$ & $<0.005$ & $<0.005$ & $<0.005$ & $<0.005$ & $<0.005$ & $<0.005$ & $<0.005$ & $<0.005$ & $<0.005$ \\
\hline
\end{tabular}

* Valores obtidos no Laboratório de Resíduos Sólidos da Unesp de Bauru. 
Tabela 4.12. Resultados da segunda campanha de análise das águas dos poços de monitoramento permanentes instalados no aterro de resíduos sólidos de Bauru.

\begin{tabular}{|c|c|c|c|c|c|c|c|c|c|}
\hline \multirow[b]{2}{*}{ PARÂMETROS } & \multicolumn{9}{|c|}{ POÇOS PERMANENTES DE MONITORAMENTO } \\
\hline & 1 & 2 & 3 & 4 & 5 & 6 & 7 & 8 & 9 \\
\hline Localização & $\begin{array}{l}\text { Jusante } \\
(\mathrm{NW})\end{array}$ & $\begin{array}{c}\text { Jusante } \\
\text { (W) }\end{array}$ & $\begin{array}{c}\text { Jusante } \\
(\mathrm{SW})\end{array}$ & $\begin{array}{l}\text { Mont. } \\
(\mathrm{NW})\end{array}$ & $\begin{array}{c}\text { Jusante } \\
\text { (W) }\end{array}$ & $\begin{array}{c}\text { Várzea } \\
(\mathrm{S})\end{array}$ & $\begin{array}{c}\text { Jusante } \\
\text { (W) }\end{array}$ & $\begin{array}{c}\text { Jusante } \\
\text { (NW) }\end{array}$ & $\begin{array}{c}\text { Jusante } \\
(\mathrm{NW})\end{array}$ \\
\hline Data da coleta & $12 / 8 / 03$ & $12 / 8 / 03$ & $12 / 8 / 03$ & $12 / 8 / 03$ & $12 / 8 / 03$ & $12 / 8 / 03$ & $12 / 8 / 03$ & $12 / 8 / 03$ & $12 / 8 / 03$ \\
\hline PH & 5.0 & 5.6 & 6.6 & 7.1 & 6.8 & 5.4 & 5.8 & 6.0 & 6.1 \\
\hline Cloretos $(\mathrm{mg} / \mathrm{L})$ & 131.0 & 3.1 & 2.3 & 1.8 & 19.4 & 3.7 & 53.5 & 21.6 & 54.5 \\
\hline $\begin{array}{l}\text { Condutividade } \\
\text { (us/cm) }\end{array}$ & 652.0 & 60.2 & 208.0 & 369.0 & 696.0 & 43.6 & 362.0 & 214.0 & 412.0 \\
\hline DBO (mg/L) & 17.0 & 7.0 & 4.0 & $<1.0$ & 7.0 & 7.0 & 3.0 & $<1.0$ & $<1.0$ \\
\hline DQO (mg/L) & 66.0 & 32.0 & 16.0 & 9.0 & 24.0 & 38.0 & 18.0 & 4.0 & 5.0 \\
\hline $\begin{array}{l}\text { Carbono orgânico } \\
\text { total (mg C/L) }\end{array}$ & 4.303 & 1.968 & 1.901 & 2.202 & 3.489 & 5.895 & 3.312 & 2.168 & 2.720 \\
\hline Sulfatos (mg/L) & 1 & 1 & $<1$ & $<1$ & 68 & 8 & $<1$ & $<1$ & $<1$ \\
\hline Sulfetos (mg/L) & $<0.001$ & 0.001 & $<0.001$ & $<0.001$ & $<0.001$ & $<0.001$ & $<0.001$ & $<0.001$ & $<0.001$ \\
\hline $\begin{array}{l}\text { Nitrogênio } \\
\text { amoniacal (mg/L) }\end{array}$ & 0.27 & 0.05 & 0.04 & 0.46 & 0.21 & 0.21 & 0.30 & 0.05 & 0.12 \\
\hline $\begin{array}{l}\text { Nitrogênio nitrato } \\
(\mathrm{mg} / \mathrm{L})\end{array}$ & 0.50 & 0.22 & 0.45 & 1.45 & 24.80 & 1.12 & 0.30 & 0.36 & 0.98 \\
\hline $\begin{array}{l}\text { Nitrogênio nitrito } \\
(\mathrm{mg} / \mathrm{L})\end{array}$ & 0.003 & $<0.001$ & $<0.001$ & 0.013 & 0.072 & 0.004 & $<0.001$ & $<0.001$ & 0.003 \\
\hline $\begin{array}{l}\text { Nitrogênio total } \\
(\mathrm{mg} / \mathrm{L})\end{array}$ & 2.7 & 1.0 & 1.0 & 1.4 & 2.4 & 2.6 & 0.4 & 0.8 & 1.7 \\
\hline $\begin{array}{l}\text { Fosfato total } \\
(\mathrm{mg} / \mathrm{L})\end{array}$ & 0.16 & 0.27 & 0.09 & 0.17 & 0.11 & 0.12 & 0.21 & 0.04 & 0.08 \\
\hline $\begin{array}{l}\text { Coliformes totais } \\
\text { (UFC/100 mL) }\end{array}$ & 200 & 9500 & 10000 & 100000 & 3000 & 84000 & 300 & 840 & 78000 \\
\hline $\begin{array}{l}\text { E. COLI } \\
(\mathrm{UFC} / 100 \mathrm{~mL})\end{array}$ & 42 & 500 & 25 & 140 & 47 & 10 & 25 & 30 & 3 \\
\hline Zinco (mg/L) & $<0.002$ & $<0.002$ & $<0.002$ & $<0.002$ & $<0.002$ & $<0.002$ & $<0.002$ & $<0.002$ & $<0.002$ \\
\hline Chumbo (mg/L) & 0.029 & 0.024 & 0.004 & 0.043 & 0.057 & 0.039 & 0.008 & 0.010 & 0.031 \\
\hline Cádmio (mg/L) & $<0.0006$ & $<0.0006$ & $<0.0006$ & $<0.0006$ & $<0.0006$ & $<0.0006$ & $<0.0006$ & 0.002 & 0.001 \\
\hline Níquel (mg/L) & 0.118 & 0.014 & $<0.001$ & $<0.001$ & 0.006 & 0.082 & 0.018 & 0.002 & 0.014 \\
\hline $\begin{array}{l}\text { Ferro total } \\
(\mathrm{mg} / \mathrm{L})\end{array}$ & 12.80 & 52.0 & 0.894 & 0.195 & 2.655 & 1.104 & 4.935 & 0.042 & 0.534 \\
\hline $\begin{array}{l}\text { Cromo Total } \\
(\mathrm{mg} / \mathrm{L})\end{array}$ & 0.228 & 0.256 & 0.105 & 0.078 & 0.117 & 0.132 & 0.140 & 0.113 & 0.089 \\
\hline
\end{tabular}


Os resultados das análises químicas realizadas nas amostras de água coletadas através de amostradores Geoprobe $\mathbb{B}$ e dos poços de monitoramento permanentes foram confrontados com os Valores de Intervenção para Águas Subterrâneas estabelecidos pela CETESB (2001) e mostrados na Tabela 2.1. A Tabela 4.13 apresenta as amostras e os poços que passaram dos limites propostos pela CETESB.

Tabela 4.13. Poços e amostras que ultrapassaram os limites estabelecidos pela CETESB (2001) e pela Portaria $n^{0} 1.469$ do Ministério da Saúde.

\begin{tabular}{|c|c|c|}
\hline Elemento & $\begin{array}{c}\text { Valor de } \\
\text { Intervenção }(\mathrm{mg} / \mathrm{L})\end{array}$ & Poço / Amostra \\
\hline $\mathrm{Cr}$ & 0.050 & $\begin{array}{c}\text { Todos os poços da } 2^{\text {a }} \text { campanha / Geoprobe } \mathbb{} \\
\text { próximo ao RCPTU } 13\end{array}$ \\
\hline $\mathrm{Cd}$ & 0.005 & $\begin{array}{c}\text { Poços PP-4 e PP-5 da } 1^{\text {a }} \text { campanha / Todas } \\
\text { amostras coletadas com o Geoprobe } \AA\end{array}$ \\
\hline Cloretos & 250.0 & - \\
\hline $\mathrm{Fe}$ & 0.300 & $\begin{array}{c}\text { Todos os poços da } 1^{\mathrm{a}} \text { campanha e Poços PP-1, } \\
\text { PP-2, PP-3, PP-5, PP-6, PP-7 e PP-9 da } 2^{\mathrm{a}} \\
\text { campanha / Todas amostras coletadas com o } \\
\text { Geoprobe } \AA\end{array}$ \\
\hline $\mathrm{Ni}$ & 0.050 & $\begin{array}{l}\text { Poços PP-1 e PP-5 da } 1^{\mathrm{a}} \text { campanha e Poços } \\
\text { PP-1 e PP-6 da } 2^{\mathrm{a}} \text { campanha }\end{array}$ \\
\hline $\begin{array}{l}\text { Nitrogênio } \\
\text { Amoniacal }\end{array}$ & 1.500 & - \\
\hline N. Nitrato & 10.00 & Poço PP-5 da $1^{\mathrm{a}}$ e $2^{\mathrm{a}}$ campanhas \\
\hline N. Nitrito & 1.000 & - \\
\hline $\mathrm{Pb}$ & 0.010 & $\begin{array}{l}\text { Poços PP-1, PP-2, PP-4, PP-5, PP-6 e PP-9 da } \\
2^{\text {a campanha }}\end{array}$ \\
\hline $\mathrm{Zn}$ & 5.000 & - \\
\hline
\end{tabular}

De maneira geral, pode-se dizer que o poço que mais está sofrendo a influência da pluma de contaminação é o PP-1, seguido do PP-5, com teores mais elevados de DBO, DQO, condutividade, cloretos, ferro, zinco e cromo, para as duas campanhas realizadas. O PP-5 foi o que apresentou os maiores valores de sulfatos, nitrogênio amoniacal e nitrogênio nitrato. Elevados teores de cloretos também foram obtidos para os poços PP-7, PP-8 e PP-9, apesar de não terem ultrapassado os limites estabelecidos pelo Ministério da Saúde. $\mathrm{O}$ pH permaneceu ácido para todas as coletas, com exceção do PP-5 para a $1^{\text {a }}$ campanha. 
A Tabela 4.13 mostra ainda que as amostras de água coletadas do poço PP-4 ultrapassa alguns limites de potabilidade de metais pesados, como o cádmio e chumbo, além de ter apresentado os mais elevados teores de coliformes totais para as duas campanhas (seguido pelo PP-9), os quais também foram elevados para todos os outros poços. Este fato indica uma possível influência de outras fontes de contaminação externas nas águas subterrâneas na região deste aterro, inclusive à montante, onde existe criação de gado.

Os elevados teores de ferro encontrados nas amostras de água coletadas em todos os poços e em todas as sondagens podem ser explicados pela grande quantidade de ferro encontrada nos solos tropicais, conforme pode ser observado em análises realizadas por AGNELLI (1997), em amostras de solos que ocorrem no Campo Experimental da Unesp de Bauru, que são típicas daquelas que ocorrem na cidade de Bauru e no aterro em estudo.

O resultados das análises químicas realizadas nas amostras de água coletadas nos poços de monitoramento temporários e em águas superficiais do entorno do aterro de resíduos sólidos de Bauru também foram avaliados, como descrito no item 3.3.6. Os gráficos das Figuras 4.40 e 4.41 mostram, respectivamente, os valores de DBO e de condutividade determinados para os diversos pontos de coleta em diferentes épocas do ano. Como foi difícil visualizar nestes gráficos a tendência de variação destes parâmetros, decidiu-se apresentar os valores médios destes parâmetros em cada ponto de coleta (Tabela 4.14). 
DBO

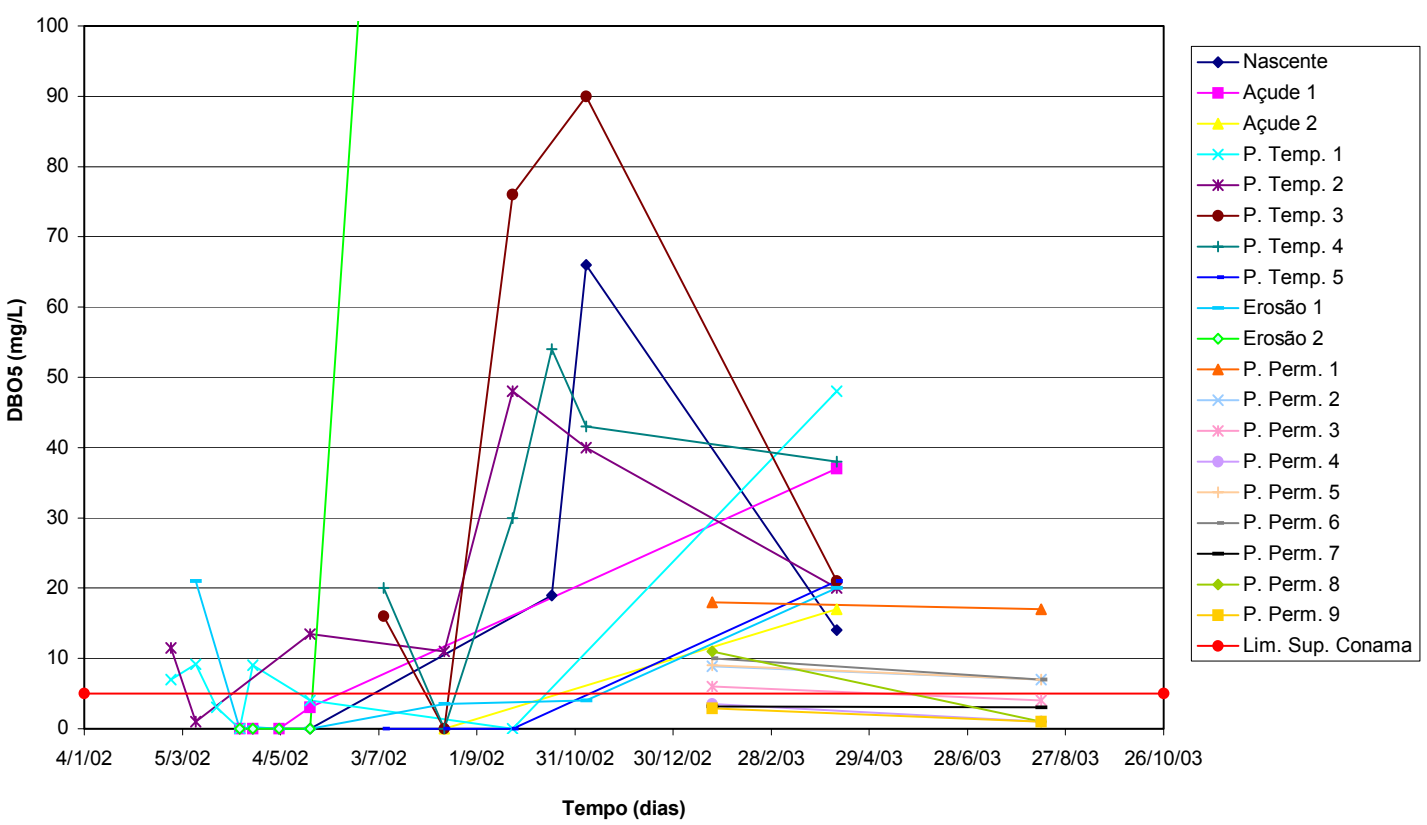

Figura 4.40. Variação da $\mathrm{DBO}_{5}$ nas amostras de água nos diversos pontos de amostragem.

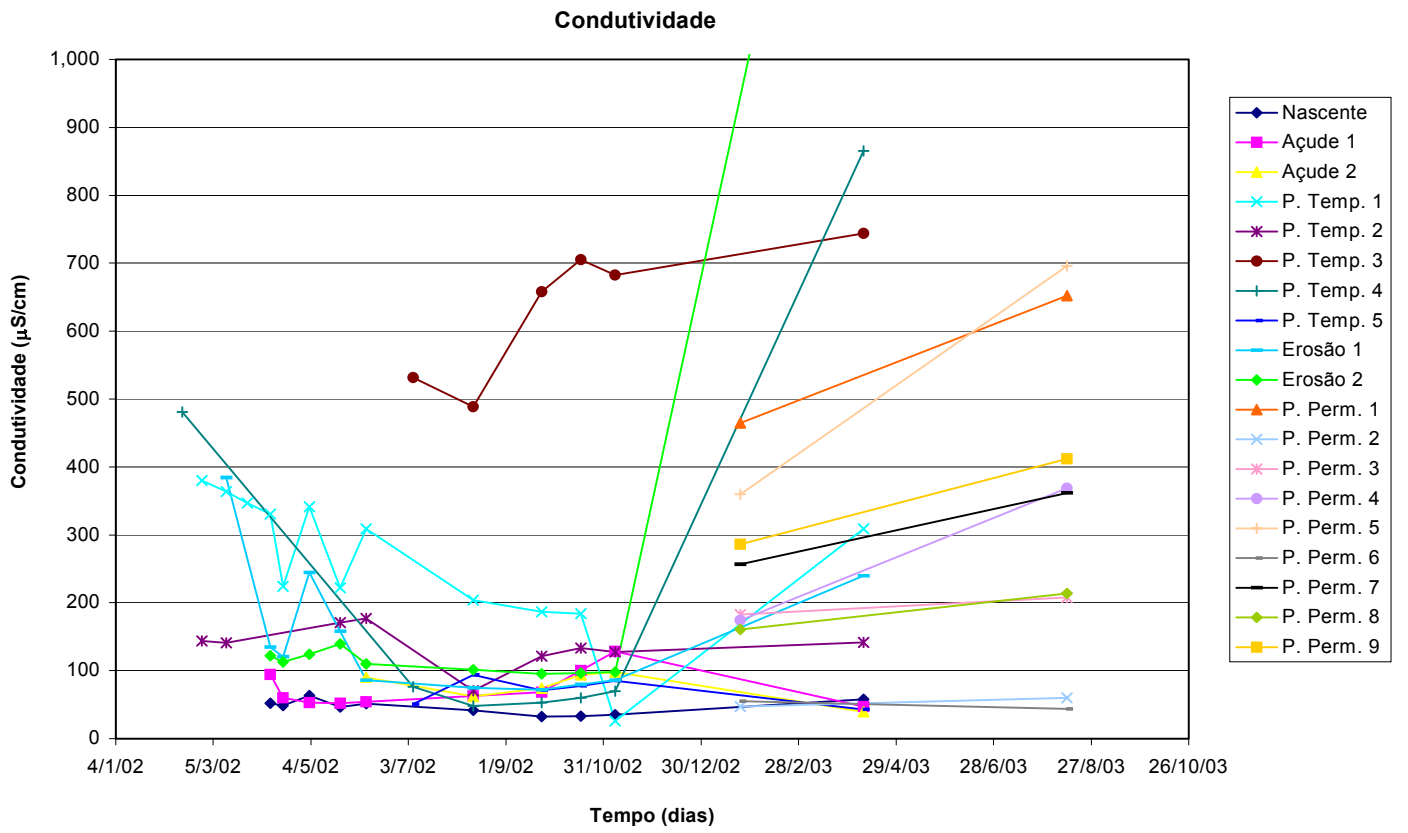

Figura 4.41. Variação da condutividade nas amostras de água nos diversos pontos de amostragem. 
Estes gráficos permitem comparar os resultados das duas campanhas de amostragem realizadas nos poços de monitoramento permanentes, mostrando que os valores de condutividade aumentaram para a maioria do poços na $2^{\mathrm{a}}$ campanha, e os valores de DBO permaneceram praticamente constantes, com exceção do poço PP-8, que diminuiu.

A Figura 4.40 mostra que quase todos os pontos de coleta superaram o limite tolerável pelo CONAMA para rios classe II, inclusive as águas superficiais, como a Nascente e o Açude 1 indicando, mais uma vez, a influência de atividades externas nas águas do entorno do aterro.

Um aumento muito significativo nos valores dos parâmetros determinados para a Erosão 2 pela última campanha de coletas de água (em 09/04/03) foi observado. Acredita-se que isto se deva ao intenso período de chuvas, que contribuiu para o aumento da quantidade de chorume produzido pelo aterro.

Os resultados da apresentados na Tabela 4.14, assim como aqueles que constam nas Figuras 4.40 e 4.41, indicam que o poço PT-3 é o mais contaminado, pois nele foram encontrados os mais altos teores de chumbo, ferro, DBO, DQO, cloretos e condutividade. Observa-se ainda a maior alcalinidade no poço PT-1, assim como elevados teores de chumbo, DQO, DBO e condutividade também para o poço PT-4. 
Tabela 4.14. Valores médios em diferentes épocas do ano para os parâmetros obtidos das amostras de águas superficiais e dos poços de monitoramento temporários.

\begin{tabular}{|c|c|c|c|c|c|c|c|c|c|c|c|c|}
\hline Parâmetro & Nascente & Açude 1 & Açude2 & PT 1 & PT 2 & PT 3 & PT 4 & PT 5 & Erosão 1 & Erosão 2 $^{\text {Chorume }}{ }^{(\mathbf{l}}$ & Limites $^{(2)}$ \\
\hline PH & 5.8 & 6.3 & 6.2 & 6.3 & 5.4 & 6.0 & 5.2 & 5.3 & 6.2 & 6.0 & 8.1 & $6.5-9.5$ \\
\hline Alcalinidade (mg/L) & 20.3 & 30.7 & 36.3 & 174.2 & 45.4 & 132.3 & 30.4 & 30.0 & 54.4 & 80.7 & 8630 & - \\
\hline Cloretos (mg/L) & 1.1 & 4.9 & 6.1 & 11.5 & 13.0 & 93.0 & 18.7 & 8.4 & 12.3 & 18.4 & 2640 & 250 \\
\hline DBO $_{5}(\mathrm{mg} / \mathrm{L})$ & 14.1 & 8.0 & 8.5 & 10.0 & 20.7 & 40.6 & 30.8 & 5.3 & 6.1 & 220.8 & 2065 & 5 \\
\hline DQO (mg/L) & 9.2 & 216.2 & 30.3 & 22.1 & 12.7 & 47.5 & 20.1 & 11.2 & 14.7 & 311.3 & 4925 & - \\
\hline Condutividade (mS/cm) & 46.3 & 72.0 & 76.4 & 263.7 & 136.3 & 635.2 & 236.0 & 70.3 & 152.8 & 278.0 & 7945 & - \\
\hline N. Amoniacal (mg/L) & 0.2 & 0.4 & 1.0 & 0.8 & 0.2 & 0.8 & 0.5 & 0.7 & 1.1 & 5.6 & 914 & 1.5 \\
\hline N. Nitrato (mg/L) & 0.6 & 1.0 & 1.9 & 0.9 & 5.7 & 0.6 & 1.3 & 0.8 & 4.3 & 3.3 & - & 10 \\
\hline N. Nitrito (mg/L) & 0.004 & 0.005 & 0.132 & 0.013 & 0.037 & 0.009 & 0.008 & 0.005 & 0.147 & 0.030 & - & 1 \\
\hline Chumbo (mg/L) & 0.12 & - & 0.024 & 0.162 & 0.08 & 0.53 & 0.105 & 0.146 & - & 0.78 & 0.705 & 0.01 \\
\hline Ferro (mg/L) & 2.488 & 1.685 & 0.129 & 11.1 & 0.033 & 62.2 & 0.07 & 5.553 & 2.278 & 13.5 & 12.98 & 0.3 \\
\hline
\end{tabular}

${ }^{(1)}$ Valores absolutos, determinados para diferentes campanhas de coleta do chorume. A cada campanha foi determinado um parâmetro diferente.

${ }^{(2)}$ Limites determinados pela Portaria 1.469, de 29/12/2000, do Ministério de Saúde

${ }^{(3)}$ Limite determinado para rios Classe II da Resolução do CONAMA. 


\subsubsection{Ensaios de Coluna}

\subsubsection{Ensaios de Permeabilidade}

Conforme descrito no item 3.3.7, optou-se por realizar uma campanha de ensaios de permeabilidade antes do início dos ensaios de coluna com percolação de poluentes, para determinação do coeficiente de permeabilidade a partir do sistema de permeâmetros Tri-Flex 2, disponível no Laboratório de Mecânica dos Solos da Escola Politécnica da USP (LMS-EPUSP).

O Anexo IV apresenta os resultados dos ensaios de permeabilidade com percolação de água realizados para avaliar o coeficiente de permeabilidade em função da tensão confinante aplicada. A Figura 4.42 mostra o resultado do ensaio para a amostra sob tensão confinante de $90 \mathrm{kPa}$. Observa-se, nesta figura, uma tendência de diminuição do coeficiente de permeabilidade com relação ao tempo. Este fato também foi verificado por NEVES (1987), em ensaios de permeabilidade realizados em corpos de prova do sedimento cenozóico que ocorre na cidade de São Carlos-SP, o qual tem características semelhantes ao solo que ocorre na região do aterro de resíduos sólidos de Bauru. A autora concluiu que isto se deve à destruição dos vínculos existentes entre as partículas do solo, fazendo com que os finos ou então as partículas mais grossas obturem os canalículos, ocorrendo com o tempo uma colmatação que dificulta a percolação da água através do corpo de prova.

ELBACHÁ (1989) apud NASCENTES (2003) atribui esta diminuição da permeabilidade à uma possível lixiviação de sais solúveis presentes no solo. Quando a água destilada é usada como fluido permeante em solo natural, os sais solúveis são lixiviados da amostra, fazendo com que a concentração eletrolítica do fluido nos poros do solo decresça, causando uma expansão da dupla camada difusa e uma tendência das partículas da argila a se dispersarem, resultando, usualmente, em uma redução da permeabilidade. 


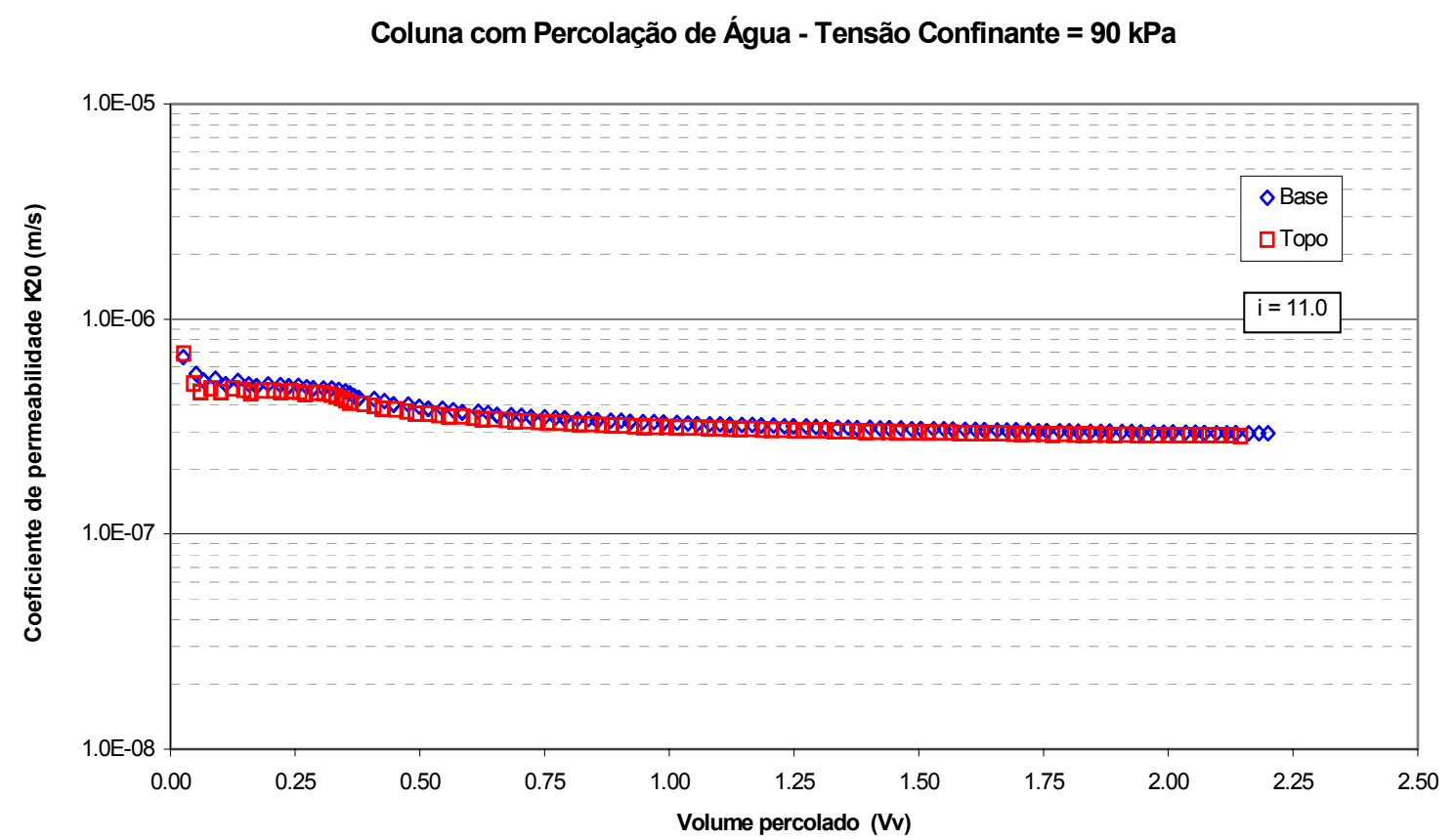

Figura 4.42. Variação do coeficiente de permeabilidade versus volume de água percolado para corpo de prova confinado a $90 \mathrm{kPa}$.

\subsubsection{Ensaio de Coluna com Percolação de Solução Salina}

A Figura 4.43 apresenta os coeficientes de permeabilidade determinados durante a fase de percolação com água e durante a fase de percolação com solução salina, para a tensão confinante igual a $30 \mathrm{kPa}$. Observa-se um aumento da permeabilidade quando o solo foi submetido à percolação com solução salina, fato que foi confirmado em outro ensaio, sob a tensão confinante de $90 \mathrm{kPa}$ (Anexo IV). Estes resultados não estão de acordo com aqueles apresentados por CORRÊA (2001), que realizou ensaios de coluna com percolação de solução salina a 1000 mg/L em solos silto-argilosos do Distrito Federal, uma vez que, para este caso, a autora observou uma redução de uma ordem de grandeza nos coeficientes de permeabilidade nos ensaios realizados com percolação de solução salina. 
Ensaio de Coluna com Percolação de Água e Sal - Tensão Confinante $=30 \mathrm{kPa}$

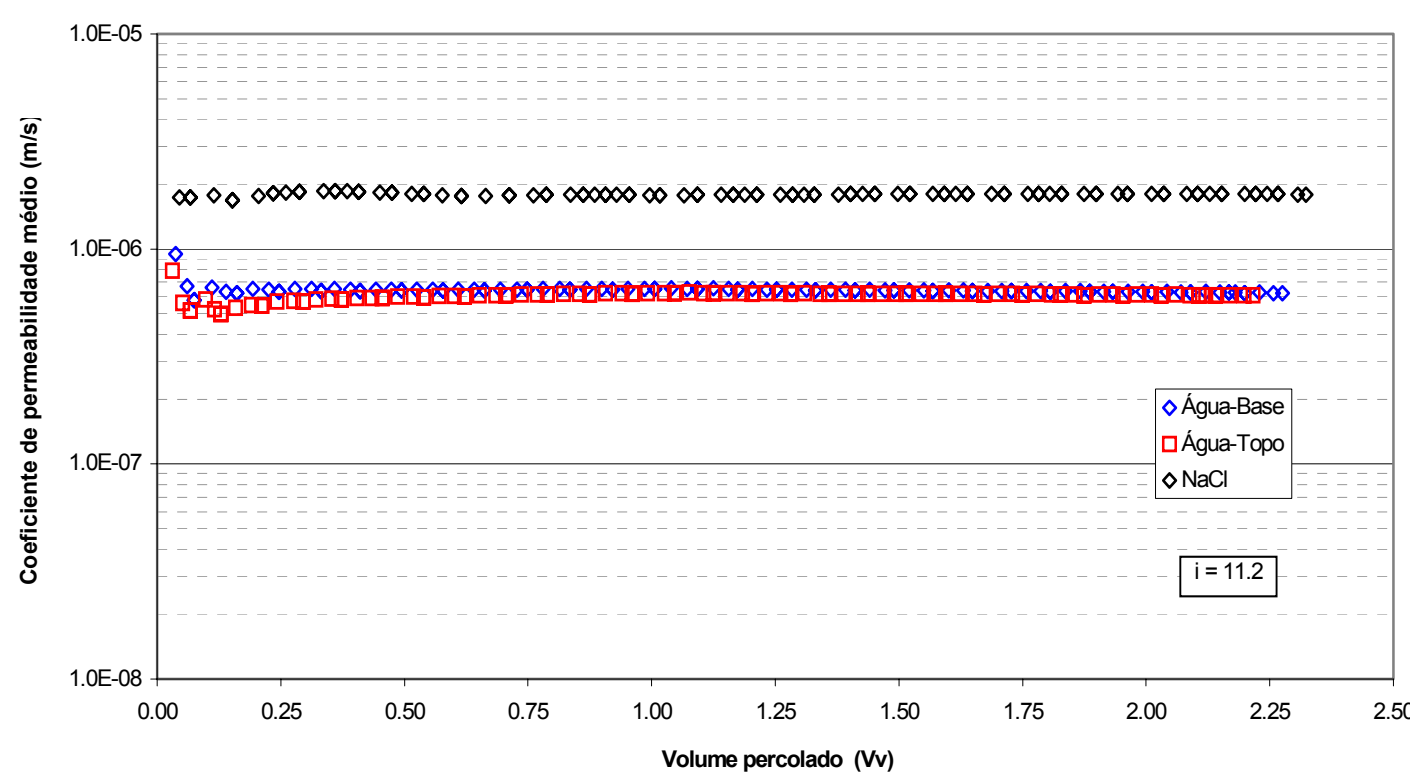

Figura 4.43. Variação do coeficiente de permeabilidade durante o ensaio de coluna com percolação de água e $\mathrm{NaCl}$.

A Figura 4.44 apresenta as curvas de monitoramento das concentrações de $\mathrm{NaCl}$ do efluente do topo do corpo de prova, uma vez que os ensaios foram realizados com fluxo ascendente. Nota-se que a estabilização ocorreu após percolados 2.25 volumes de vazios para o ensaio realizado com tensão confinante igual a $30 \mathrm{kPa}$ e após 4 volumes de vazios para o ensaio realizado com tensão confinante igual a $90 \mathrm{kPa}$. Verifica-se, na Figura 4.45, pouca variação do $\mathrm{pH}$ durante o ensaio, que apresentou um valor da ordem de 5.2, para a tensão confinante de 90 $\mathrm{kPa}$. Este resultado mostra que o $\mathrm{pH}$ da solução percoladora, que inicialmente era 7.0, sofreu influencia da acidez do solo. AGNELLI (1997) determinou o pH do solo com as mesmas características daquele que ocorre no aterro de resíduos sólidos de Bauru e obteve valores variando entre 4.0 e 5.0. 
Coluna com Percolação de Sal - Tensão Confinante $=30 \mathrm{kPa}$

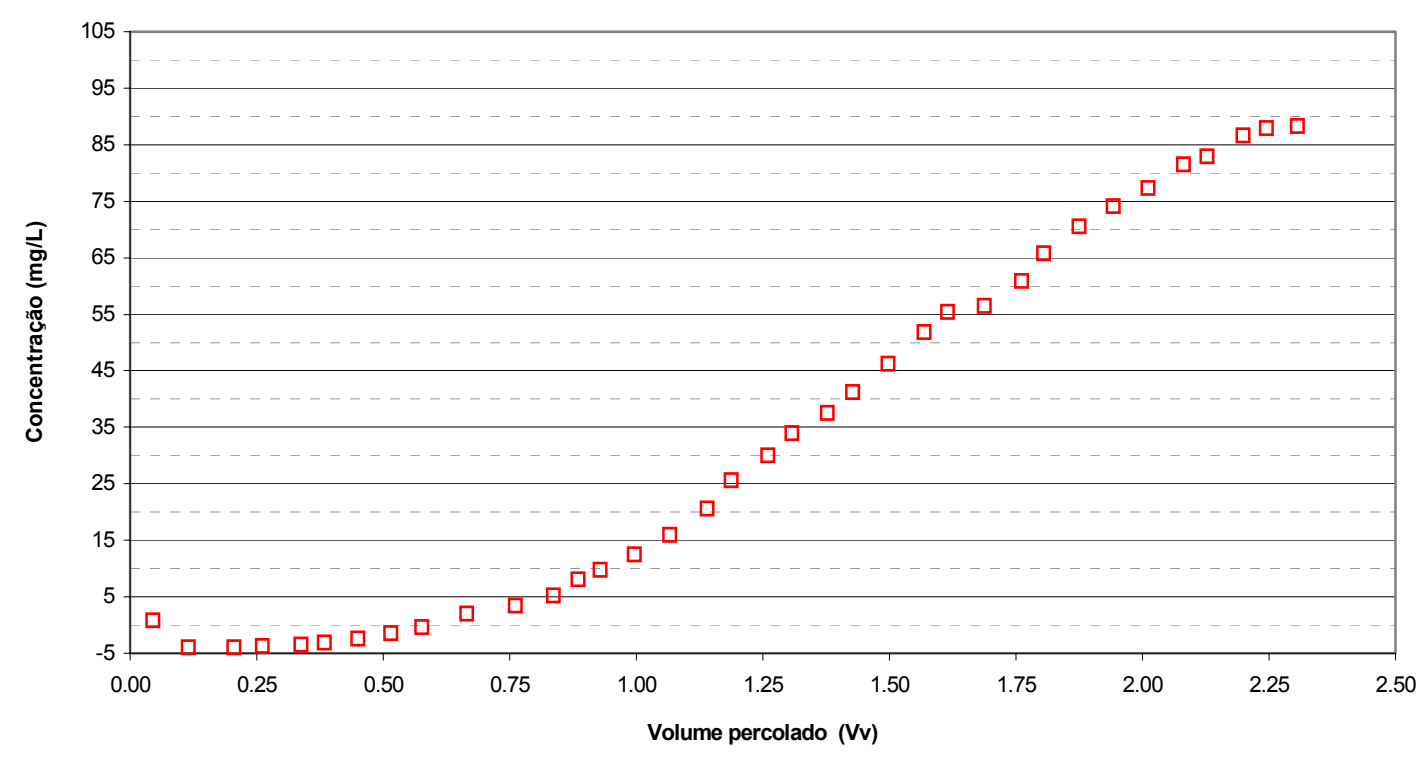

a) Ensaio realizado com tensão confinante igual a $30 \mathrm{kPa}$.

Coluna com Percolação de Sal - Tensão Confinante $=90 \mathrm{kPa}$

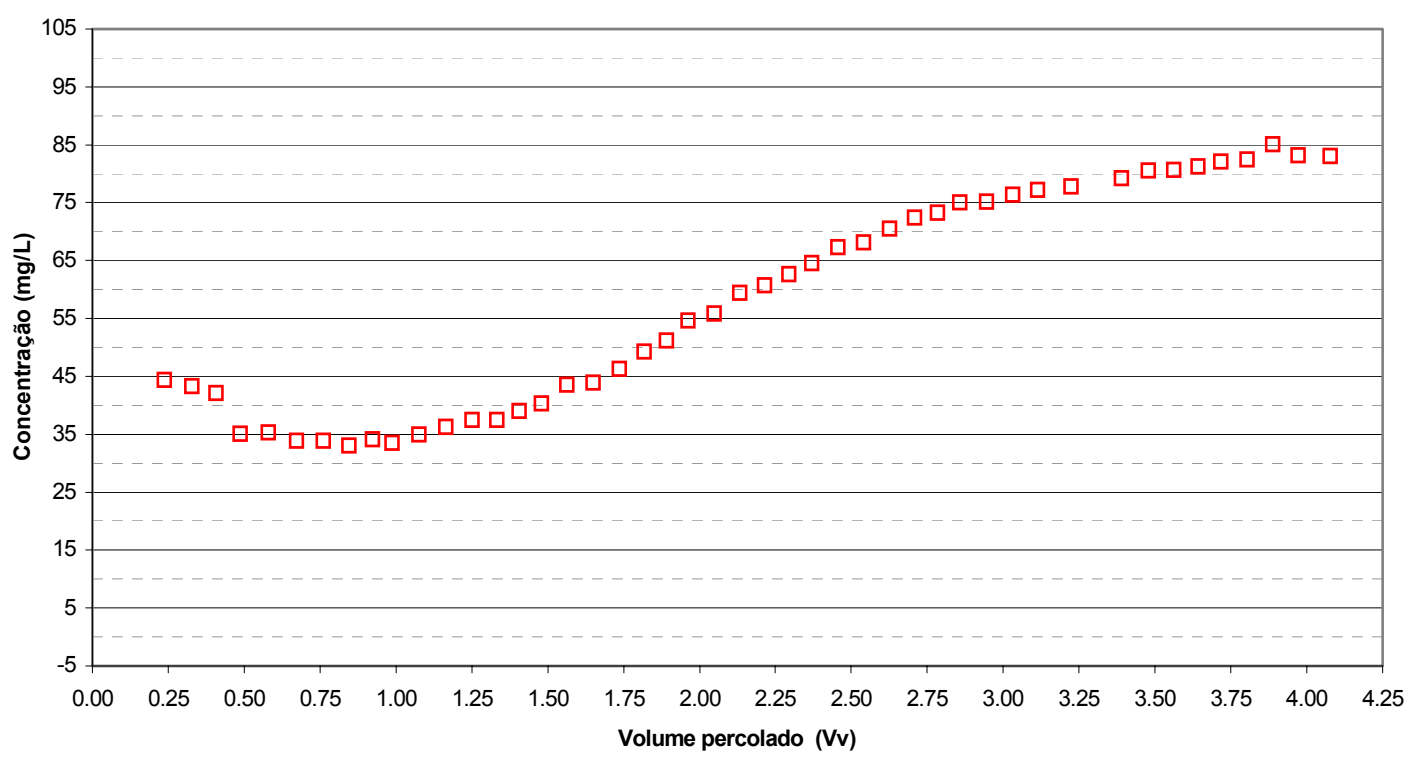

b) Ensaio realizado com tensão confinante igual a $90 \mathrm{kPa}$.

Figura 4.44. Monitoramento das concentrações de $\mathrm{NaCl}$ dos efluentes. 
Coluna com Percolação de Sal - Tensão Confinante $=90 \mathrm{kPa}$

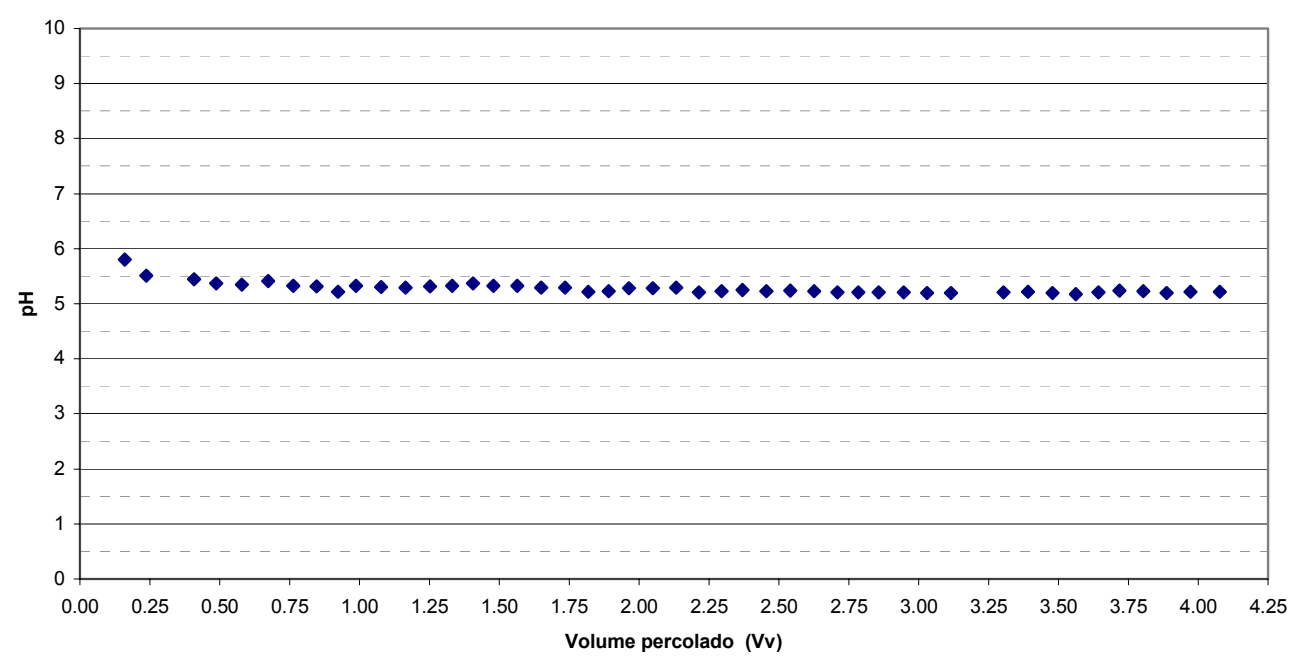

Figura 4.45. Monitoramento do $\mathrm{pH}$ dos efluentes da coluna com percolação de $\mathrm{NaCl}$.

A Figura 4.46 apresenta os valores dos coeficientes de permeabilidade determinados após a percolação de dois volumes de vazios em função da tensão confinante aplicada. Como já era esperado, a permeabilidade diminuiu com o aumento da tensão confinante.

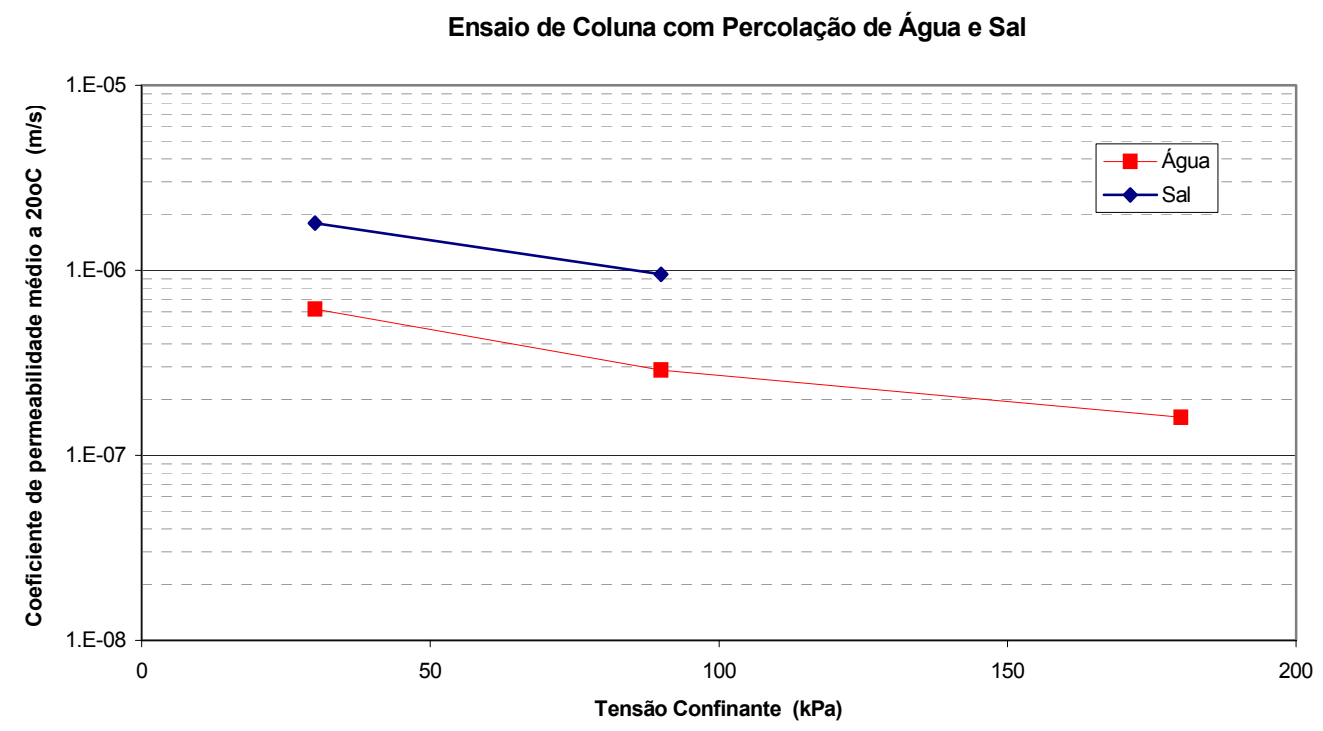

Figura 4.46. Variação do coeficiente de permeabilidade em função da tensão confinante aplicada ao corpo de prova. 
Assim, pode-se considerar que o coeficiente de permeabilidade da areia argilosa marrom-avermelhada que ocorre no aterro de resíduos sólidos de Bauru é da ordem de $10^{-7} \mathrm{~m} / \mathrm{s}$ ( ou $10^{-5} \mathrm{~cm} / \mathrm{s}$ ), uma vez que este foi o valor determinado a partir dos ensaios de coluna e de permeabilidade a carga variável (Tabela 3.9). Lembra-se que os ensaios de dissipação do excesso de poro-pressão realizados in situ também indicaram um coeficiente de permeabilidade desta mesma ordem de grandeza.

\subsubsection{Ensaio de Coluna com Percolação de Solução de Metais}

A Figura 4.47 apresenta a variação do coeficiente de permeabilidade durante as fases de percolação com água e com a solução de metais, para o corpo de prova sob uma tensão confinante de $30 \mathrm{kPa}$. Observa-se, nesta figura, um comportamento semelhante aquele observado para percolação com solução salina (Figura 4.43). Em ambos os casos o valor do coeficiente de permeabilidade após percolação de mais de dois volumes de vazios de água destilada foi da ordem de $10^{-6} \mathrm{~m} / \mathrm{s}$. A diferença é que a permeabilidade do solo quando percolado com solução de metais aumentou mais lentamente do que quando se percolou a solução salina.

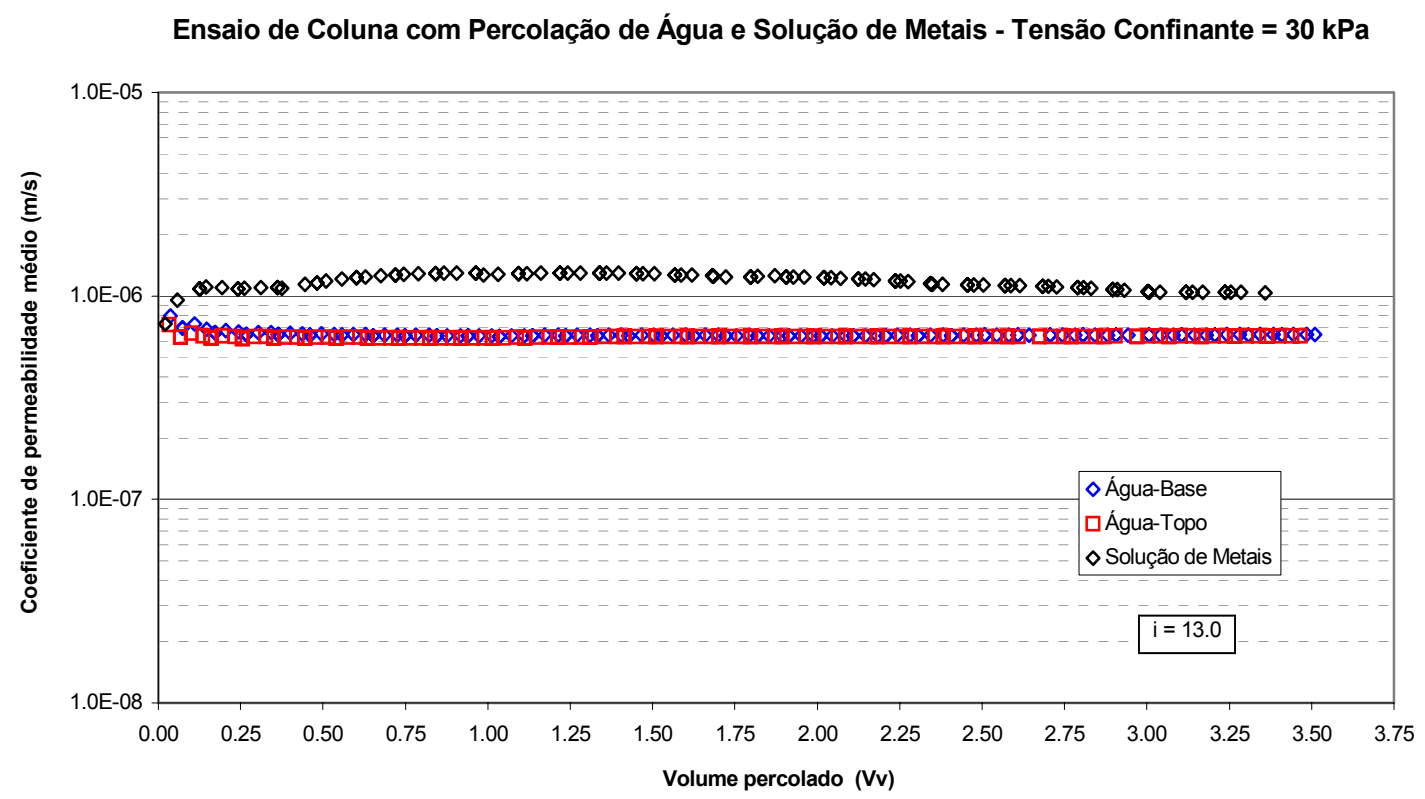

Figura 4.47. Variação do coeficiente de permeabilidade durante o ensaio de coluna com percolação de água e solução de metais. 
No Anexo IV tem-se a variação da condutividade elétrica, do $\mathrm{pH}$ e da concentração dos efluentes a medida que a solução percolava pelo corpo de prova. Observa-se, inicialmente, que o $\mathrm{pH}$ da solução de metais apresentou uma variação parecida com a da solução salina, ficando em torno de 5.5. Já, a condutividade, aumentou rapidamente até 0.25 volumes de vazios percolados, apresentando um comportamento bem diferente dos valores de condutividade obtidos para os efluentes da solução salina. Um dos motivos que pode explicar este fato é a baixa condutividade da solução inicial $(72.9 \mu \mathrm{S} / \mathrm{cm})$, além das mangueiras utilizadas durante o ensaio não terem sido adequadamente limpas. Após 0.25 volumes de vazios percolados, os valores de condutividade tenderam à estabilização, crescendo lentamente até atingir o valor da condutividade inicial da solução. Este fato, teoricamente, indica a chegada da frente de poluentes ao topo do corpo de prova, porém, observa-se que a concentração dos metais ainda era praticamente zero para quase 3.5 volumes de vazios percolados, como mostra Figura 4.48.

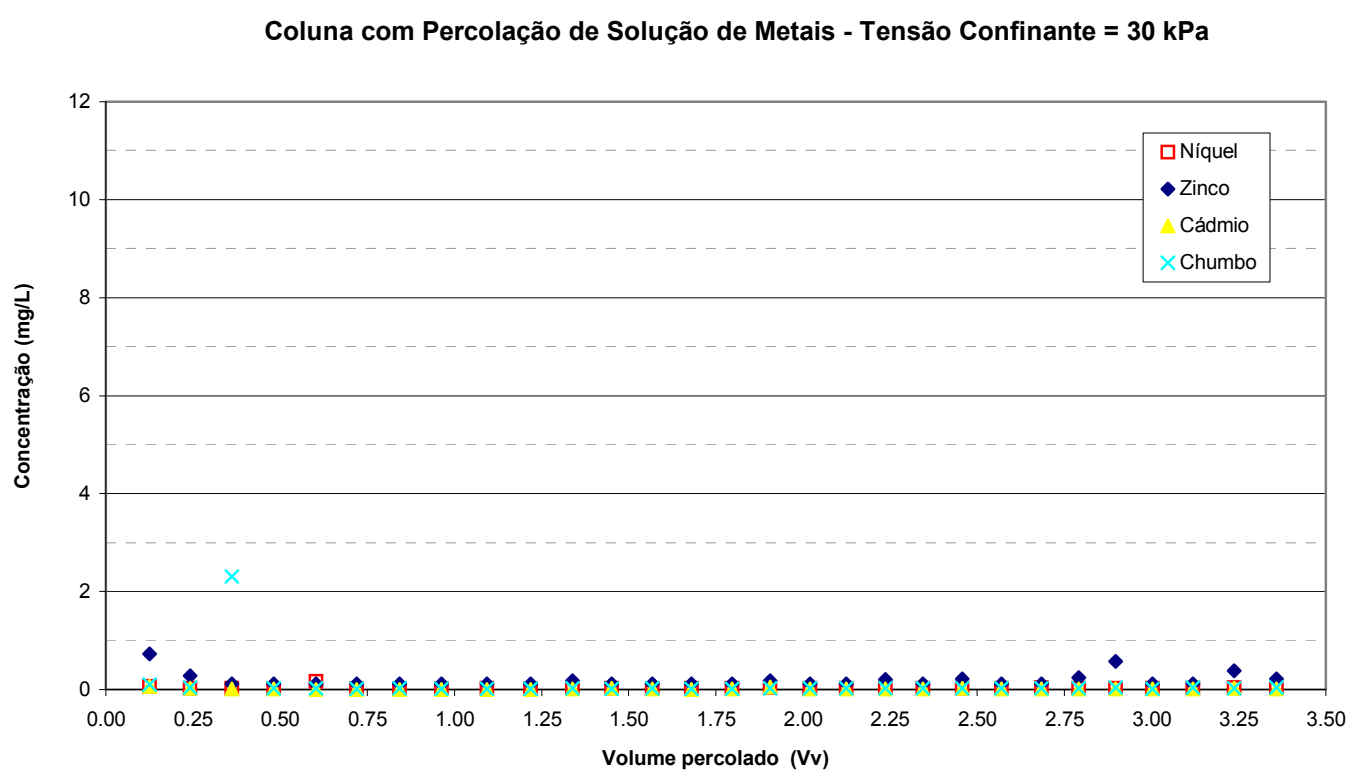

Figura 4.48. Monitoramento das concentrações de metais pesados durante o ensaio de coluna com percolação de solução de metais.

NASCENTES (2003) realizou ensaios de coluna com percolação de solução contaminante com gradientes hidráulicos entre 7 e 13 em solo de Visconde do Rio 
Branco - MG. Os resultados desses ensaios mostram que eles só terminavam após percolação de 150 volumes de vazios, enquanto a condutividade estabilizava após 20 volumes de vazios percolados. Um ensaio como este demanda cerca de 4 meses de duração, sem paralisação, e não é possível de ser realizado utilizando o sistema de permeâmetros Tri-Flex, como aquele existente no LMS da EPUSP. O sistema construído pelo Laboratório de Geotecnia do Departamento de Engenharia Civil da Universidade Federal de Viçosa é composto por frascos de Mariotte, onde é armazenada a solução percoladora, permitindo assim que o ensaio possa ser realizado sem paralisações e que o volume acumulado de efluente seja maior.

\subsubsection{Ensaio de Coluna com Percolação de Chorume mais Metais}

Conforme descrito no item 3.3.7, as concentrações dos metais pesados de interesse presentes no chorume do aterro de resíduos sólidos de Bauru são da ordem de $1 \mathrm{mg} / \mathrm{L}$, o que dificultaria a leitura das concentrações das soluções efluentes dos ensaios de coluna e de adsorção. Por isso, decidiu-se adicionar nitratos de Ni, Zn, Cd e $\mathrm{Pb}$ no chorume do aterro de resíduos sólidos de Bauru, até que ele ficasse com concentrações da ordem de $10 \mathrm{mg} / \mathrm{L}$.

A Figura 4.49 apresenta os coeficientes de permeabilidade determinados durante as fases de percolação com água e com o chorume acrescido de metais, com o corpo de prova sob tensão confinante de $30 \mathrm{kPa}$. Observa-se, nesta figura, que inicialmente a permeabilidade do solo quando percolou-se chorume é praticamente igual àquela determinada com a percolação de água, diminuindo a partir de 0.5 volumes de vazios percolados, quando foi verificada a saída de bolhas do corpo de prova. A partir de 1 volume de vazios percolado, a permeabilidade aumentou, assumindo valores praticamente idênticos aqueles determinados com a percolação de água. Estes resultados também não estão de acordo com aqueles obtidos por CORRÊA (2001), que determinou coeficientes de permeabilidade com a percolação de chorume 1.5 vezes menores que aqueles determinados com a percolação de água destilada, cujos valores variaram entre $10^{-9}$ a $10^{-11} \mathrm{~m} / \mathrm{s}$. Entretanto, a autora também obteve uma permeabilidade com percolação de chorume um pouco menor e relativamente próxima daquela determinada com a percolação da solução salina, o 
que está de acordo com os resultados apresentados neste trabalho (Figuras 4.43 e 4.49).

Ensaio de Coluna com Percolação de Água e Chorume + Metais - Tensão Confinante $=30 \mathrm{kPa}$

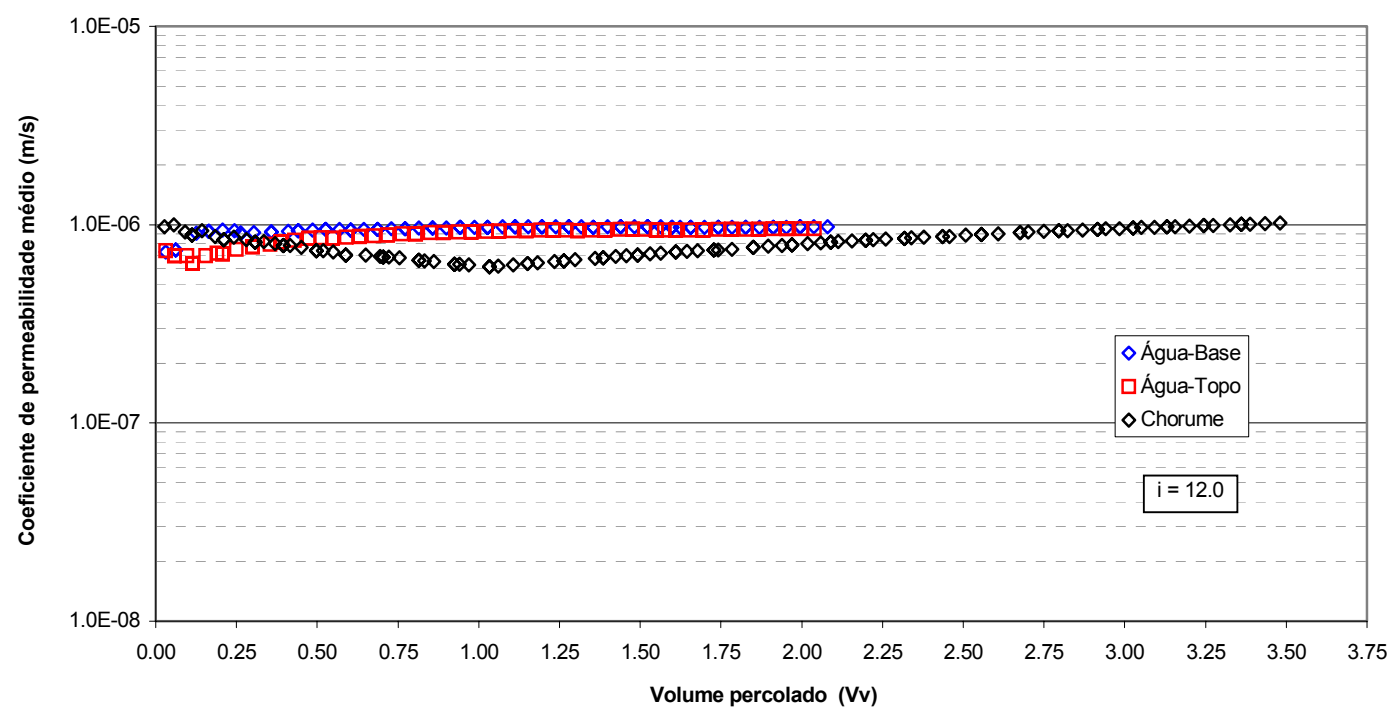

Figura 4.49. Variação do coeficiente de permeabilidade durante o ensaio de coluna com percolação de água e chorume.

No Anexo IV tem-se a variação da condutividade elétrica, do $\mathrm{pH}$ e da concentração dos efluentes a medida que o chorume percolava pelo corpo de prova. Observa-se que os resultados deste ensaio ficaram comprometidos, assim como aqueles do ensaio realizado com percolação da solução de metais, onde apenas a condutividade e o $\mathrm{pH}$ dos efluentes eram monitorados durante o ensaio. Nestes ensaios, a frente de condutividade chegou ao topo do corpo de prova, mas as curvas de eluição dos metais estavam apenas se iniciando, até cerca de 3.5 volumes de vazios percolados.

Com relação ao monitoramento do $\mathrm{pH}$, observa-se um comportamento diferente daquele observado para as soluções salina e de metais. No caso da percolação com o chorume, teve-se valores baixos no início do ensaio, em que 
prevalecia o efeito da acidez do solo, e aumentou a partir de 0.75 volumes de vazios percolados, quando começou a prevalecer o $\mathrm{pH}$ do chorume (Figura 4.50).

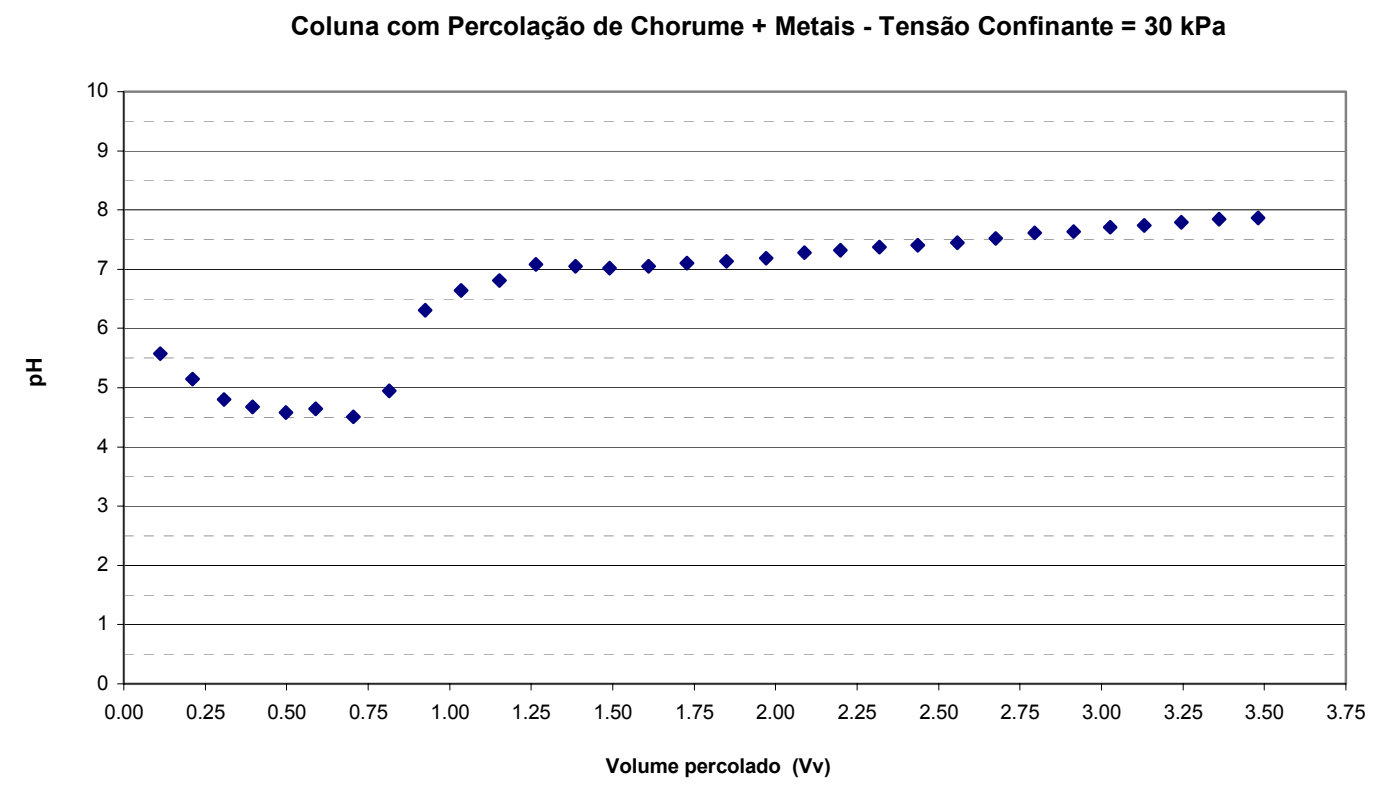

Figura 4.50. Monitoramento do $\mathrm{pH}$ dos efluentes da coluna com percolação de chorume acrescido de metais.

\subsubsection{Ensaios de Adsorção em Lote}

O Anexo $\mathrm{V}$ apresenta os resultados das três fases de ensaios de adsorção em lote realizados com o solo típico que ocorre na área de implantação do aterro de resíduos sólidos de Bauru.

A primeira fase do ensaio, determinação da Razão Solo-Solução, já foi discutida no capítulo anterior, quando decidiu-se usar $25 \mathrm{~g}$ de solo para $100 \mathrm{ml}$ de solução ou chorume (RSS = 1:4).

Com esta RSS, iniciou-se a segunda fase do ensaio: determinação do tempo de equilíbrio. Os gráficos e as tabelas do Anexo V mostram que a estabilização só ocorreu depois de 1 semana de ensaio (168 h), quando a diferença entre as duas últimas concentrações de cada metal estudado foi menor que $5 \%$. As Figuras $4.51 \mathrm{e}$ 
4.52 apresentam as curvas de concentração versus tempo, obtidas para o $\mathrm{Ni}$ com solução de metais e com chorume mais metais, respectivamente. Nota-se, para este e para os resultados obtidos para os demais metais apresentados no Anexo V ( $\mathrm{Zn}, \mathrm{Cd}$ e $\mathrm{Pb}$ ), uma tendência das concentrações obtidas com o chorume terem estabilizado um pouco mais rápido do que aquelas obtidas com a solução de metais. Além disso, os valores de adsorção obtidos com o chorume foram menores do que aqueles obtidos com a solução, com exceção do $\mathrm{Zn}$. Acredita-se que isto se deve à alta variedade de metais e sais existentes no chorume, além daqueles que foram adicionados. Já o Zn era o metal que apresentava maior concentração no chorume bruto $(\cong 5 \mathrm{mg} / \mathrm{L})$, como indica a Tabela 3.15, fato que pode explicar porque para os valores de adsorção para este metal foram maiores para o chorume do que para a solução.

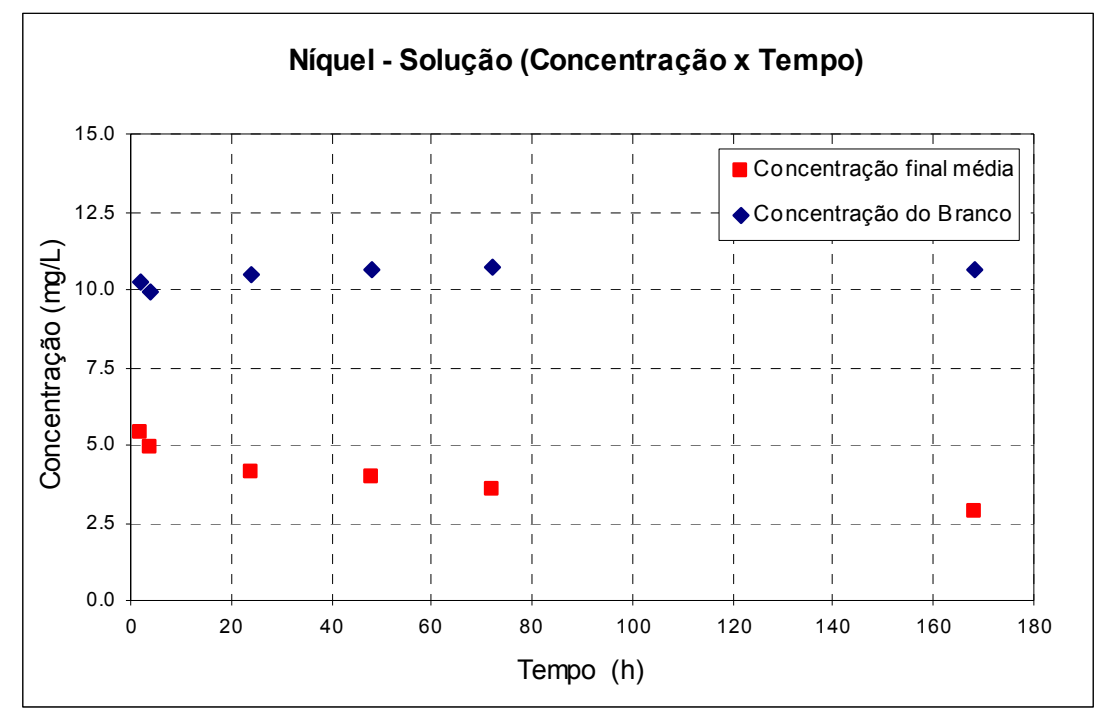

Figura 4.51. Determinação do tempo de equilíbrio para o Ni usando a solução de metais. 


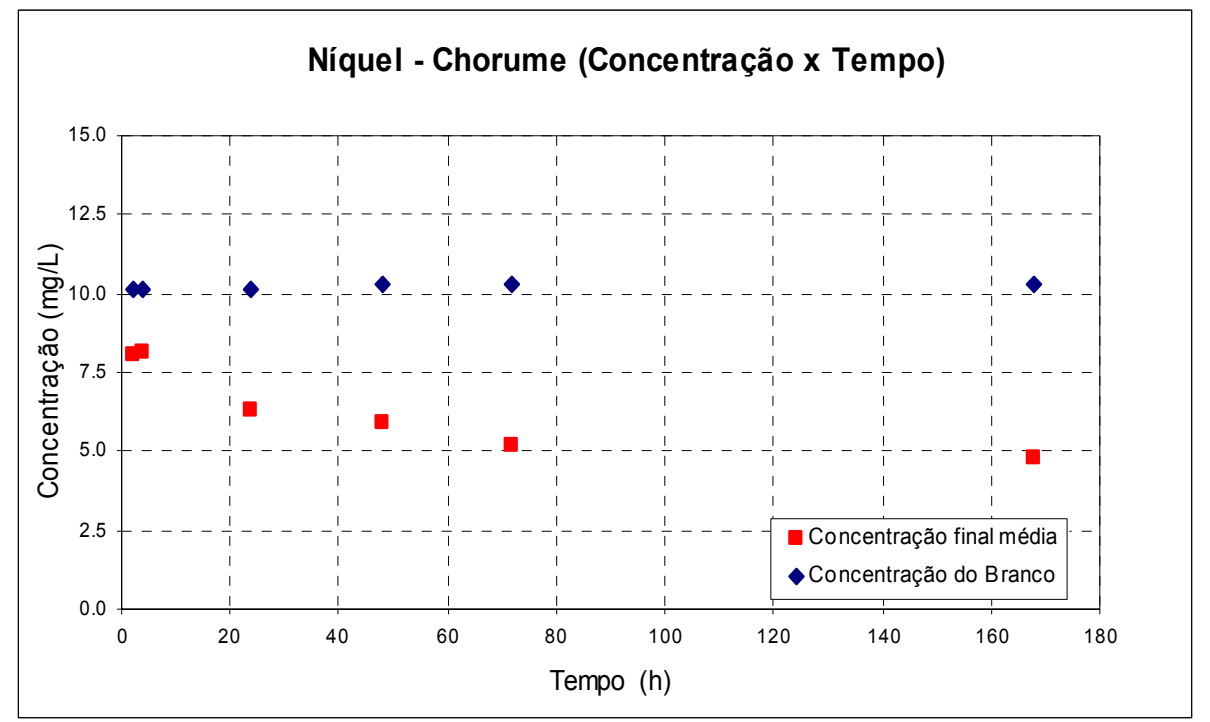

Figura 4.52. Determinação do tempo de equilíbrio para o Ni usando o chorume acrescido de metais.

Acredita-se que ocorreu precipitação do nitrato de $\mathrm{Pb}$ adicionado na solução de metais, uma vez que as concentrações de $\mathrm{Pb}$ dos "brancos" foram muito pequenas, variando entre valores de 0.2 a $1.0 \mathrm{mg} / \mathrm{L}$. Os baixos valores destas concentrações nos "brancos", assim como nas concentrações dos solutos não adsorvidos pelo solo, comprometeram os resultados do ensaio para este metal na solução de metais. Segundo OLIVEIRA (2003), a adição de hidróxido de sódio na solução pode ter causado esta precipitação.

Um outro fator importante que deve ser comentado é que durante esta segunda fase do ensaio de adsorção, o chorume foi preparado em três diferentes frascos, cada um de $1 \mathrm{~L}$, ao invés de ter sido preparado de uma só vez os $3 \mathrm{~L}$ que foi o volume total utilizado nesta etapa do ensaio. Este fato pode explicar a variação ocorrida nas concentrações de $\mathrm{Cd}$ e $\mathrm{Pb}$ dos frascos "brancos", quando são comparadas as leituras de 72 e $168 \mathrm{~h}$ com as demais. Afinal, estas duas partiram de um único frasco, enquanto as demais partiram de outros dois. Para a terceira fase do ensaio este problema ocorreu, uma vez que o chorume foi preparado num frasco com capacidade maior que $3 \mathrm{~L}$. 
Durante a fase de determinação do tempo de equilíbrio também foram monitorados o pH e a condutividade dos frascos, como mostram as Figuras 4.53 a 4.56 .

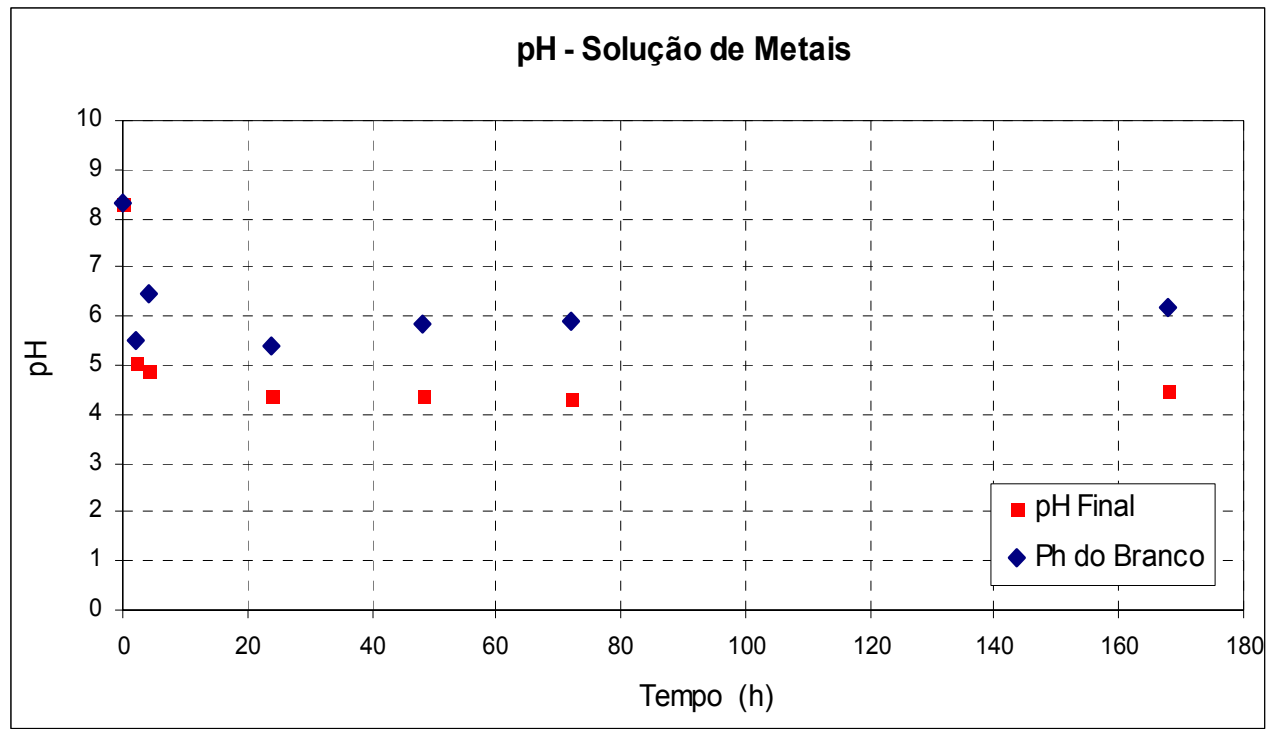

Figura 4.53. Monitoramento do pH durante o ensaio de adsorção realizado com a solução de metais.

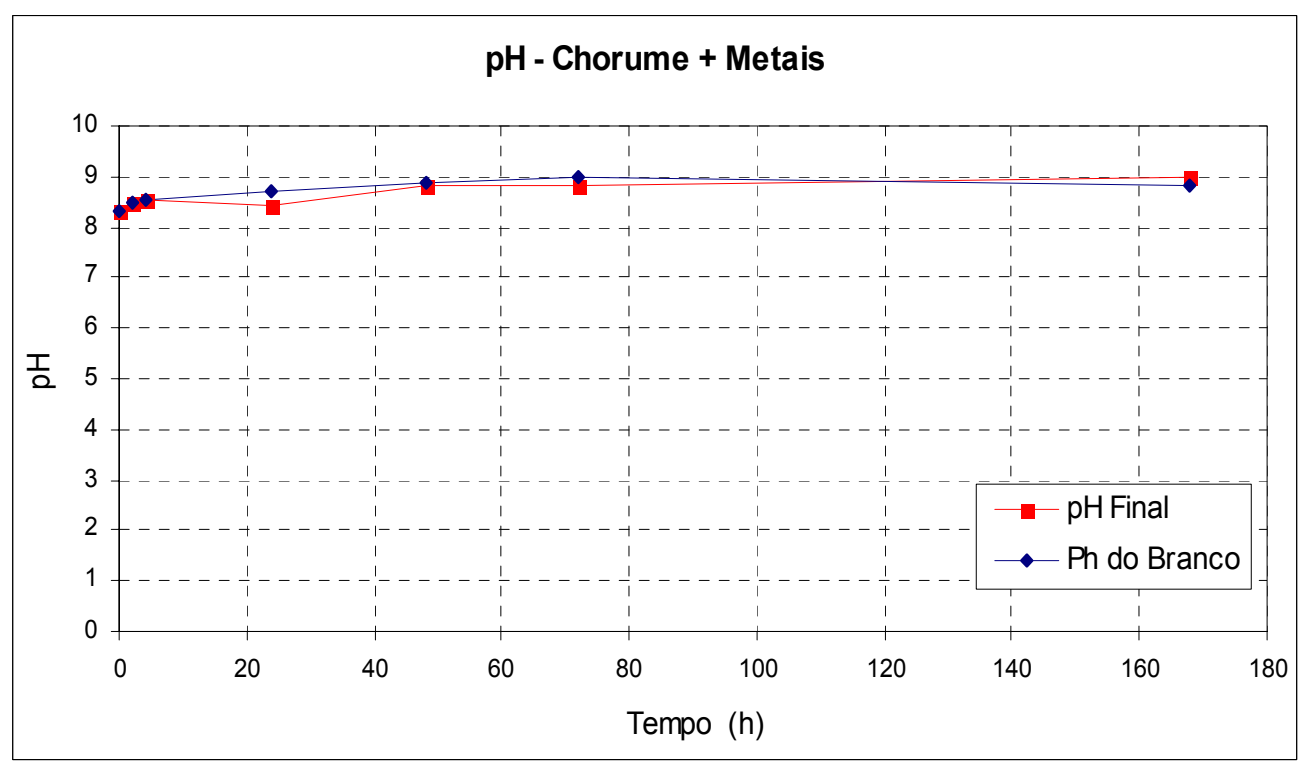

Figura 4.54. Monitoramento do pH durante o ensaio de adsorção realizado com o chorume acrescido de metais. 


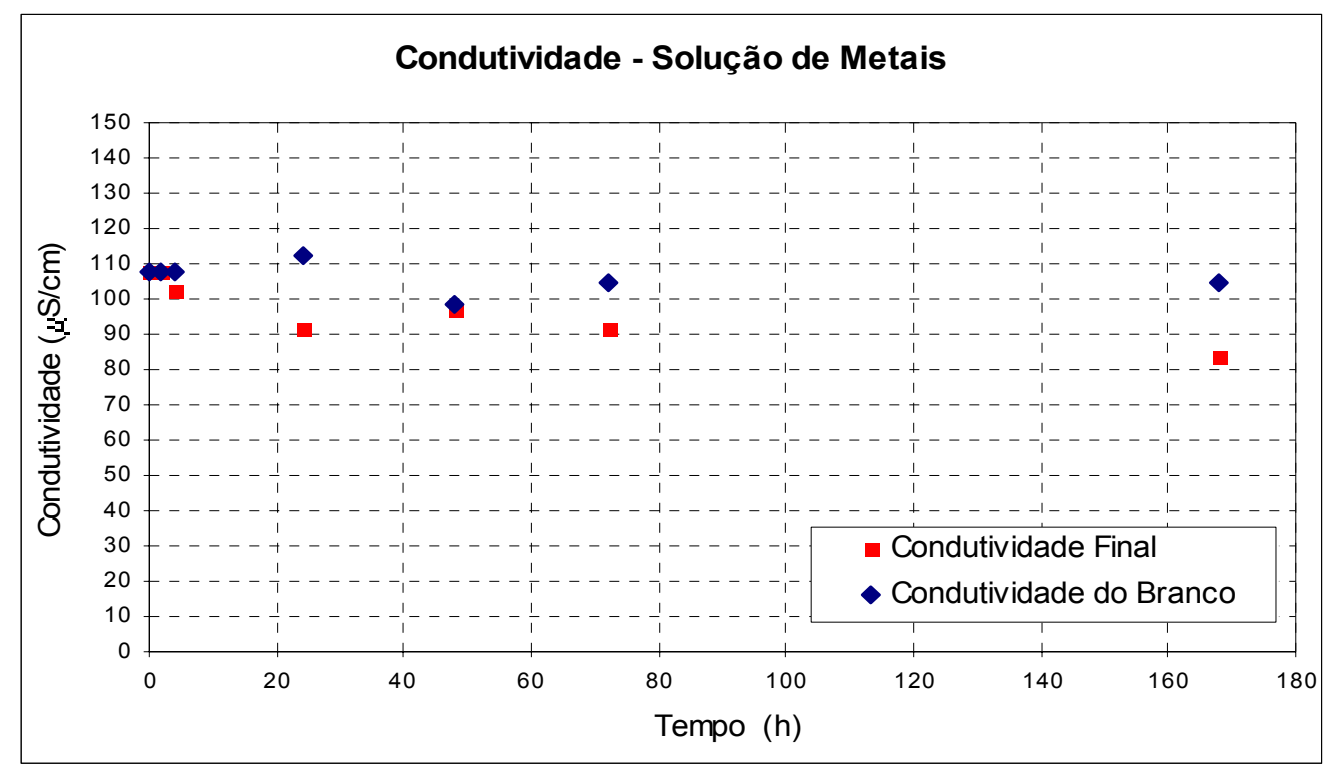

Figura 4.55. Monitoramento da condutividade durante o ensaio de adsorção realizado com a solução de metais.

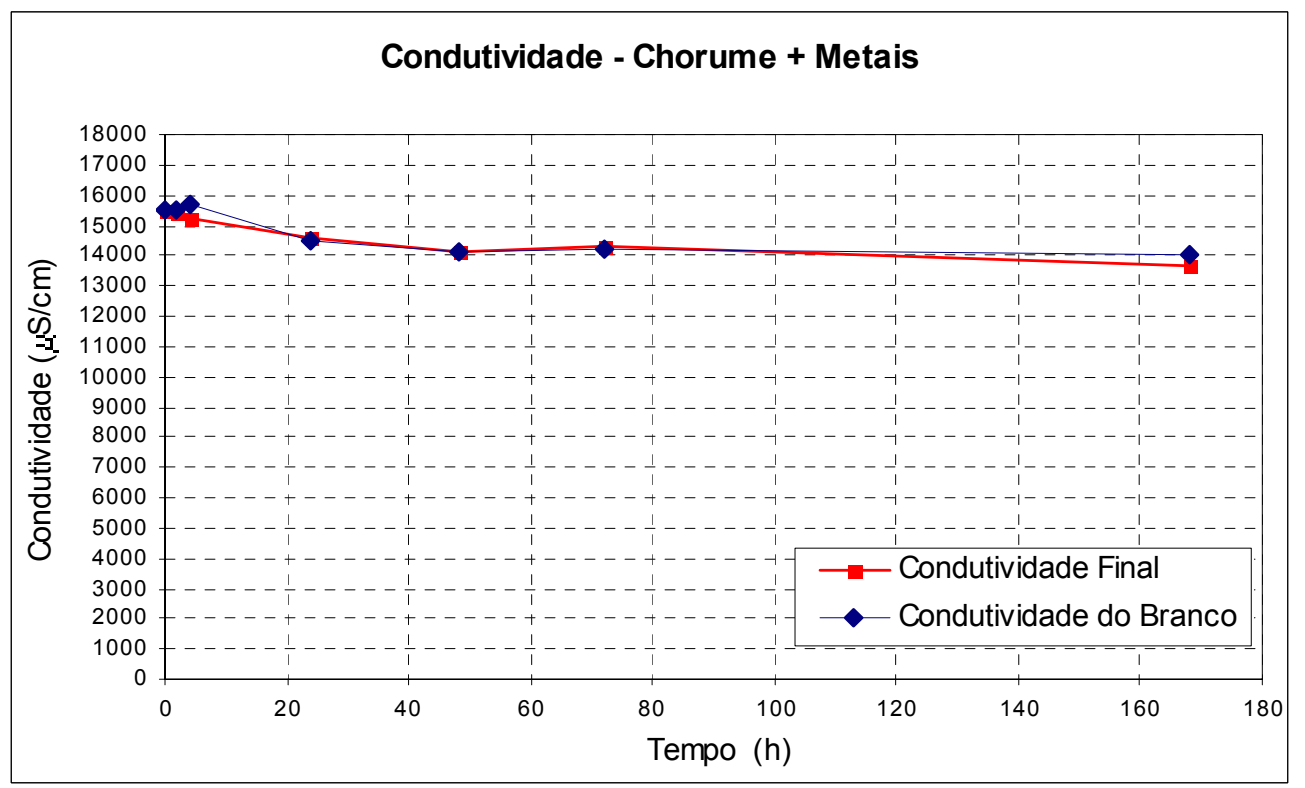

Figura 4.56. Monitoramento da condutividade durante o ensaio de adsorção realizado com o chorume acrescido de metais.

Observa-se, para o ensaio realizado com a solução de metais, que os valores de $\mathrm{pH}$ determinados para as soluções efluentes dos frascos que continham solo são menores que os valores de $\mathrm{pH}$ determinados para as soluções dos frascos "brancos", 
chegando a um valor 4.3 para as primeiras e se mantendo na ordem de 6.0 para as segundas. Deve-se destacar que o mesmo ocorreu com o ensaio de coluna com percolação da solução de metais, devido à acidez do solo. Já, o pH do chorume praticamente não sofreu alteração após o contato com o solo, tendo permanecido praticamente igual ao do "branco". Este comportamento já havia sido observado durante o ensaio de coluna com percolação de chorume.

Algo semelhante ocorreu com a condutividade, uma vez que para os ensaios realizados com solução de metais os valores de condutividade tenderam a permanecer menores para as soluções efluentes que tiveram contato com o solo do que os valores determinados para as soluções dos "brancos". E, para os ensaios realizados com o chorume acrescido de metais, as condutividades medidas para o chorume que tinha entrado em contato com o solo e para os "brancos" permaneceram praticamente iguais, porém, ambos tendendo a diminuir com o tempo. Esta redução pode ter sido causada por fatores como a variação da temperatura, a qual não foi controlada durante os ensaios de adsorção, ou pela variação do teor de matéria orgânica existente no chorume. Isto indica que, na solução, os íons adsorvidos pelo solo permitiram que a condutividade caísse em relação ao branco, enquanto que para o chorume os íons adsorvidos não foram suficientes para que diminuísse a sua condutividade, uma vez que ela é função dos outros constituintes do chorume. Talvez esta seja uma explicação para o fato da frente de condutividade ter chegado ao topo da coluna muito antes dos metais adicionados ao chorume.

A terceira e última fase do ensaio de adsorção foi a determinação das isotermas para cada metal estudado, como mostra o Anexo V. Primeiramente, cabe ressaltar que os pontos obtidos para as RSSs 1:200 e 1:500 foram retirados das isotermas, uma vez que o valor do Grau de Adsorção (S) é conseqüência do peso do solo colocado no frasco. Como o peso de solo para estas RSSs é muito pequeno, qualquer perda de alguns grãos de solo poderia influenciar no valor de $\mathrm{S}$, prejudicando a representação final da isoterma.

Sendo assim, observou-se que as isotermas obtidas com a solução de metais apresentavam uma curva convexa em relação ao eixo das abscissas, de forma que $\mathrm{S}$ crescia cada vez mais com o aumento da concentração de equilíbrio (Ce), não tendendo a permanecer constante (Figura 4.57). CHUI (1998) descreve este tipo de 
isoterma, e explica que a superfície do argilo-mineral muitas vezes pode se tornar eletrostaticamente maior. Ou seja, as moléculas adsorvidas mostram maior afinidade entre si do que afinidade pelo sólido adsorvente. Deste modo, optou-se por aplicar a isoterma linear para a estimativa do coeficiente de distribuição (Kd).

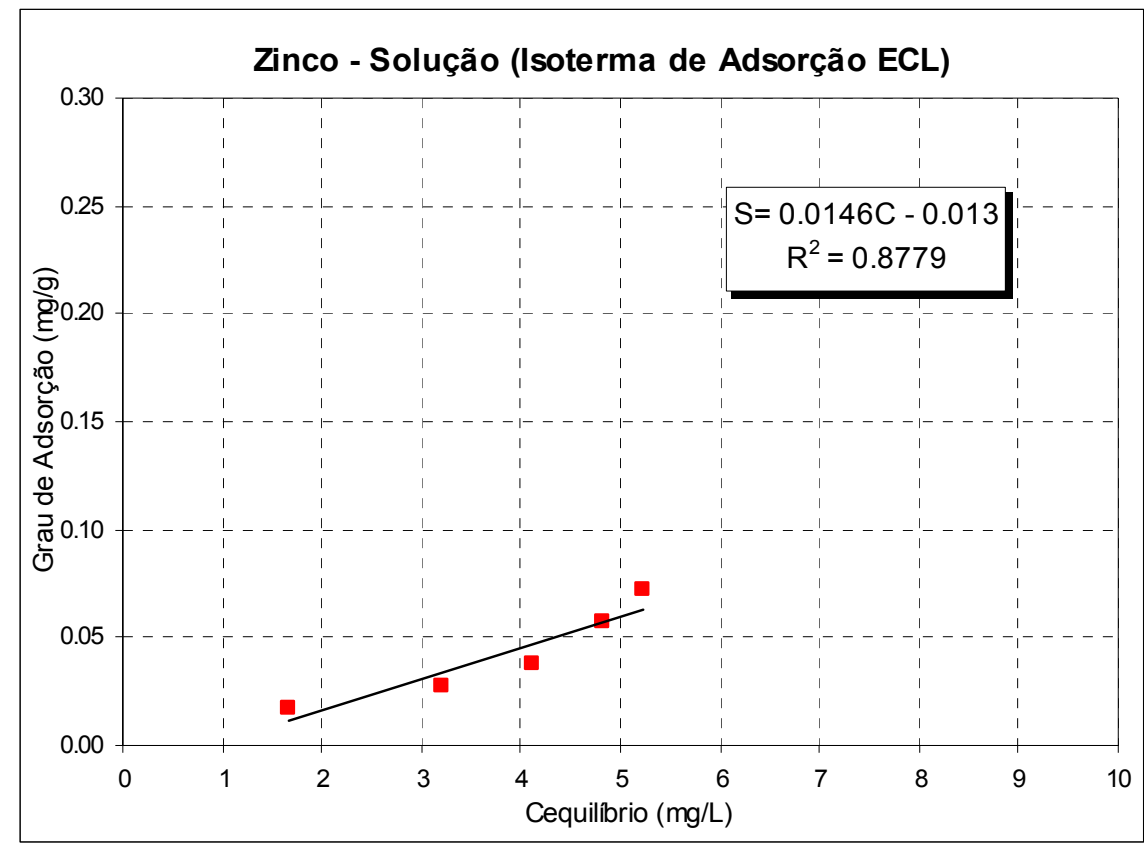

Figura 4.57. Isoterma de adsorção do Zn obtida para a solução de metais.

Os resultados obtidos para o $\mathrm{Pb}$ com a solução de metais mais uma vez foram comprometidos, como mostra o Anexo $\mathrm{V}$, podendo ter havido uma desadsorção de $\mathrm{Pb}$ do frasco utilizado durante o ensaio, do solo ou até mesmo da água destilada, uma vez que os valores de adsorção foram negativos e a concentração do "branco" muito baixa.

Já, as isotermas obtidas para o chorume mostraram uma forma levemente côncava em relação ao eixo das abscissas, também sem apresentar uma estabilização de $\mathrm{S}$ visível (Figura 4.58). Isto fez com que a aplicação da isoterma linear também fosse a melhor alternativa para a determinação do $\mathrm{Kd}$, inclusive apresentando melhores correlações em relação às isotermas determinadas para a solução de metais. 
Portanto, de acordo com as isotermas apresentadas no Anexo V, obteve-se os resultados apresentados na Tabela 4.15, lembrando que o fator de retardamento (Rd) foi calculado pela Equação 2.22.

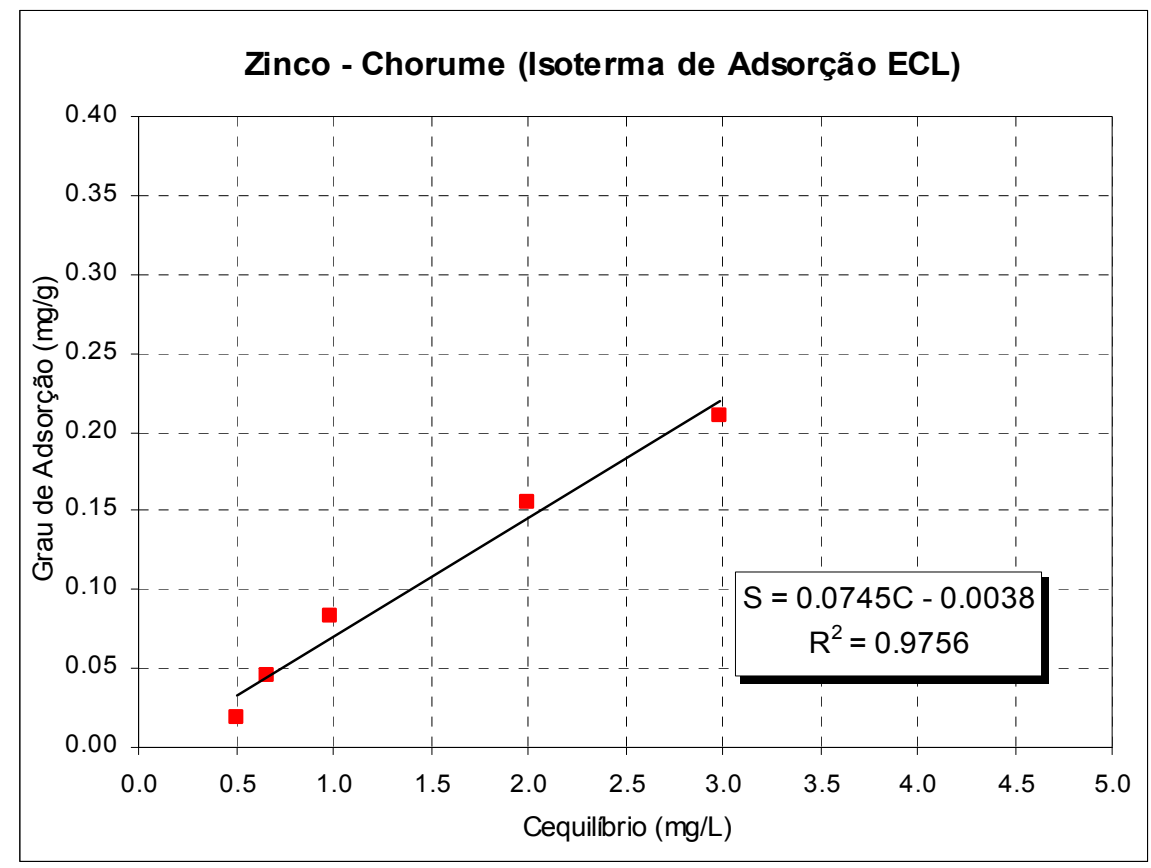

Figura 4.57. Isoterma de adsorção do Zn obtida para o chorume acrescido de metais.

Tabela 4.15. Determinação do coeficiente de distribuição $(\mathrm{Kd})$ e do fator de retardamento $(\mathrm{Rd})$ para os ensaios de adsorção em lote realizados com o solo do aterro de resíduos sólidos de Bauru.

\begin{tabular}{|c|c|c|c|c|c|c|c|}
\hline \multicolumn{2}{|c|}{} & $\rho_{\mathbf{d}}\left(\mathbf{g} / \mathbf{c m}^{\mathbf{3}}\right)$ & $\mathbf{n}(\%)$ & $\mathbf{C o}(\mathbf{m g} / \mathbf{L})$ & $\mathbf{K d}(\mathbf{m l} / \mathbf{g})$ & $\mathbf{R}^{2}$ & Rd \\
\hline \multirow{4}{*}{$\begin{array}{c}\text { Solução } \\
\text { de Metais }\end{array}$} & Níquel & 1.5 & 45.0 & 8.6 & 31.0 & 0.7802 & 104.3 \\
\cline { 2 - 8 } & Zinco & 1.5 & 45.0 & 6.0 & 14.6 & 0.8779 & 49.7 \\
\cline { 2 - 8 } & Cádmio & 1.5 & 45.0 & 8.4 & 21.6 & 0.8964 & 73.0 \\
\cline { 2 - 9 } & Chumbo & 1.5 & 45.0 & 0.1 & -76.4 & 0.6219 & -253.7 \\
\hline \multirow{4}{*}{$\begin{array}{c}\text { Chorume } \\
\text { mais Metais }\end{array}$} & Níquel & 1.5 & 45.0 & 8.8 & 7.2 & 0.7110 & 25.0 \\
\cline { 2 - 9 } & Zinco & 1.5 & 45.0 & 5.1 & 74.5 & 0.9756 & 249.3 \\
\cline { 2 - 9 } & Chumbo & 1.5 & 45.0 & 14.2 & 298.4 & 0.9934 & 995.7 \\
\hline
\end{tabular}


Quando os valores de $\mathrm{Kd}$ e Rd obtidos na tabela acima são comparados com valores obtidos na literatura, como aqueles apresentados nos trabalhos de CARVALHO (2001) e MATOS (1995), observa-se que são valores muito altos, indicando uma alta capacidade de retenção desse solo, uma vez que RITTER (1994) classifica o soluto como essencialmente imóvel quando o Kd é maior que 10.

Já, quando estes valores são comparados com aqueles obtidos por NASCENTES (2003), nota-se que Rd tem a mesma ordem de grandeza, quando se considera o intervalo de concentrações de equilíbrio usados neste trabalho. Por exemplo, para Ce variando entre 13.7 e $0.5 \mathrm{mg} / \mathrm{L}$, NASCENTES (2003) obteve Rd variando entre 24.6 e 218.3 para o $\mathrm{Zn}$ e entre 11.0 e 73.7 para o $\mathrm{Cd}$, aplicando-se a isoterma de Freundlich. Estes são resultados compatíveis, apesar da baixa correlação obtida pela isoterma linear, principalmente nos ensaios realizados com a solução de metais. AZEVEDO et al. (2003) lembra que os elevados valores de Rd obtidos no trabalho de NASCENTES (2003), que são compatíveis com os obtidos neste trabalho, podem ser conseqüência das baixas concentrações de metais utilizadas nas soluções contaminantes, uma vez que muitos trabalhos existentes na literatura usaram concentrações da ordem de $100 \mathrm{mg} / \mathrm{L}$, obtendo-se então Rds mais baixos.

Uma comparação entre os valores de $\mathrm{Rd}$ obtidos pelos ensaios de adsorção e de coluna seria interessante, porém não foi possível de ser realizada devido ao problema ocorrido com os ensaios de coluna. O coeficiente de dispersão hidrodinâmica $\left(\mathrm{D}_{\mathrm{hl}}\right)$, determinado a partir dos ensaios de coluna, também seria um parâmetro importante que poderia ser comparado com os que constam na literatura e que permitiria a realização de simulações numéricas para uma estimava da evolução da pluma de poluição com o tempo, como fez CARVALHO (2001) para o antigo lixão de Viçosa.

AZEVEDO et al. (2003) comentam que os ensaios de equilíbrio em lote podem ser utilizados para se obter uma estimativa inicial da capacidade de adsorção do solo para um dado soluto e não para estimativa do que ocorre no campo. Esta estimativa da capacidade de adsorção para o solo do aterro de resíduos sólidos de Bauru foi considerada elevada, provavelmente por causa da presença de óxidos de ferro e/ou alumínio, que são muito comuns em solos lateríticos, apesar dos minerais predominantes neste solo serem o quartzo e a caulinita. 
Observa-se ainda, com base nos resultados apresentados, que as seqüências de mobilidade determinadas pelos ensaios de equilíbrio em lote foram diferentes quando compara-se aquela obtida para o ensaio realizado com a solução de metais com aquela obtida para o ensaio realizado com o chorume acrescido de metais, sendo $\mathrm{Zn}>\mathrm{Cd}>\mathrm{Ni}$ para o primeiro e $\mathrm{Ni}>\mathrm{Cd}>\mathrm{Zn}>\mathrm{Pb}$ para o segundo.

\subsubsection{Avaliação da Contaminação no Aterro de Resíduos Sólidos Urbanos de Bauru}

As sondagens elétricas verticais (SEVs) realizadas fora da cava preenchida com resíduos forneceram informações da posição do nível d'água, que variou entre 12 (à montante) e $8 \mathrm{~m}$ (à jusante). Também possibilitaram a definição da espessura da camada de resíduos (cerca de $20 \mathrm{~m}$ ) e, conseqüentemente, a base da cava. Os resultados dessas sondagens indicaram uma grande heterogeneidade em relação às camadas de solo mais superficiais, confirmadas com os resultados dos ensaios de piezocone realizados mais à jusante do aterro.

A interpretação dos resultados dos ensaios de eletrorresistividade sugerem a possibilidade de fluxo de poluentes neste local no sentido do fluxo subterrâneo, para oeste-noroeste, aparecendo também regiões de baixa resistividade próximas à Linha C4. Sendo assim, estes ensaios foram fundamentais na locação dos poços de monitoramento e dos ensaios de piezocone.

Uma análise conjunta entre os resultados obtidos a partir dos ensaios geofísicos de superfície, da tecnologia do piezocone e dos poços de monitoramento realizados no aterro de resíduos sólidos de Bauru facilitou o entendimento da contaminação desta área, e os resultados dos ensaios geoambientais de laboratório serão úteis para orientar futuras medidas de remediação.

O mapa da Figura 4.35 e os resultados dos ensaios RCPTU apresentados nas Figuras 4.25 e 4.26 indicam coerência entre si para a zona saturada, uma vez que os ensaios RCPTUs 04, 05, 06 e 11 (Figura 4.25) registraram valores de resistividade mais baixos que os ensaios RCPTUs 01, 02, 03 e 09 (Figura 4.26). Destaca-se que os primeiros estão mais próximos de uma mancha de resistividade aparente menor que 
$75 \mathrm{ohm} . \mathrm{m}$ do que os últimos. Também observa-se que os valores de resistividade determinados a partir do piezocone foram coerentes com os contrastes de resistividade apresentados pelo mapa da Figura 4.35, onde pode-se notar que o ensaio RCPTU 15 é o que está mais próximo da cava preenchida com resíduos e o que apresentou menores valores de resistividade. Já, o ensaio RCPTU 14, que está localizado um pouco mais longe da cava, mas também numa região com indício de contaminação, apresentou valores de resistividade maiores que o ensaio RCPTU 15.

A contaminação próxima ao aterro, onde foi realizado o ensaio RCPTU 15, foi confirmada pela análise da amostra de água coletada entre 8 e $9 \mathrm{~m}$ de profundidade, obtendo-se uma condutividade de $203 \mu \mathrm{S} / \mathrm{cm}$. Os poços que apresentaram maiores valores de condutividade, cloretos, DBO, DQO e alguns metais pesados, como o PP-1 e o PT-3, também estão localizados nesta porção noroeste do aterro.

Os resultados das análises dos poços PP-5, PT-1 e PT-4 alertam para um possível espalhamento da pluma para oeste-sudoeste do aterro, como também mostraram os resultados dos ensaios RCPTUs 4, 5, 6 e 11 e o mapa de resistividade aparente do nível teórico $30 \mathrm{~m}$ (Figura 4.15).

A análise conjunta de todas as campanhas de ensaios realizados no aterro de resíduos sólidos de Bauru mostra que a pluma de contaminação já ultrapassa os limites do aterro para jusante, à oeste-noroeste.

O coeficiente de permeabilidade determinado a partir dos ensaios de coluna e com carga variável para o solo do entorno do aterro de resíduos sólidos de Bauru $\left(10^{-}\right.$ ${ }^{7} \mathrm{~m} / \mathrm{s}$ ) é considerado baixo para solos arenosos, porém este valor é considerado elevado quando estes solos são utilizados como fundação de aterros de resíduos.

Os resultados preliminares dos ensaios de adsorção em lote indicam que existe uma boa capacidade deste solo adsorver os metais $\mathrm{Ni}, \mathrm{Zn}, \mathrm{Cd}$ e $\mathrm{Pb}$. Porém, observou-se que o emprego de chorume, tanto nos ensaios de coluna como nos ensaios de adsorção, mostrou que os valores de $\mathrm{pH}$ e de condutividade não foram tão influenciados pelo solo, devido à presença de outros constituintes, como matéria orgânica e elevados teores de $\mathrm{Na}, \mathrm{K}, \mathrm{Ca}, \mathrm{Mg}$, entre outros. Este fato é um indicativo de que a poluição do entorno do aterro de resíduos sólidos de Bauru pode estar se dando de forma lenta, mas já mostra indícios de que uma medida de remediação 
deverá ser tomada, para proteção da região onde se encontram as erosões. Destaca-se assim, a importância da continuidade do monitoramento do aqǘfero local, a partir de campanhas periódicas de coleta de água dos poços de monitoramento, o que já vem sendo realizado pelo órgão municipal que gerencia o aterro. 


\section{CONCLUSÕES E SUGESTÕES PARA CONTINUIDADE}

\subsection{Lixão de Ribeirão Preto}

$\checkmark \mathrm{Na}$ área do antigo lixão de Ribeirão Preto, a detecção e a determinação do formato e extensão da pluma de contaminação foi identificada através da utilização do método da eletrorresistividade. Essa pluma se desenvolve a partir dos resíduos, no sentido do fluxo subterrâneo local (norte-nordeste).

$\checkmark$ Um aspecto importante a destacar é que a campanha de geofísica de superfície identificou que a maioria dos poços de monitoramento foram instalados em locais fora da região onde se identificou o caminhamento da pluma de contaminação. Assim, os resultados da campanha de ensaios de eletrorresistividade de superfície possibilitaram orientar a campanha de ensaios com o piezocone e a amostragem.

$\checkmark$ Quando se procurou aplicar a tecnologia do piezocone nesta área o impenetrável do cone foi atingido antes do nível d’água, impossibilitando assim, a identificação da posição desse nível d'água, a estimativa da permeabilidade do solo e a coleta de amostras de água. Essa limitação impossibilitou ainda que se tentasse avaliar a concentração de poluentes presentes na água a partir de resultados da resistividade determinada num ensaio de piezocone de resistividade (RCPTU).

$\checkmark$ A coleta de amostras de solo com o amostrador Geoprobe $®$ no centro de onde se identificou a pluma de contaminação possibilitou determinar a condutividade elétrica e o $\mathrm{pH}$ desse solo. Esses resultados indicaram um $\mathrm{pH}$ praticamente constante, com um valor médio da ordem de 5.6. Os valores crescentes com a profundidade da condutividade elétrica a partir de $7 \mathrm{~m}$ de profundidade indicam uma possível contaminação na zona não-saturada desse solo. Infelizmente não 
foi possível coletar amostras de solo a partir dos $13.8 \mathrm{~m}$ de profundidade uma vez que, o amostrador de solo da Geoprobe $\mathbb{B}$ também não pôde penetrar no solo devido à limitação do sistema de reação utilizado, como já discutido.

$\checkmark$ A identificação de perfil geotécnico a partir de dados de CPTU, baseado no ábaco de classificação de ROBERTSON et al. (1986), apresentou limitações para classificar o solo quanto à textura no lixão de Ribeirão Preto. Contudo, o cone identificou camadas que apresentam comportamentos distintos, sendo este o principal objetivo do sistema de classificação utilizado, conforme afirmam estes autores.

$\checkmark$ Devido a esta limitação, em perfis de solos tropicais, recomenda-se o emprego de amostradores de solos para identificar a textura e as características genéticas dos solos.

$\checkmark$ O amostrador da Geoprobe $\mathbb{R}$, que utiliza a tecnologia direct-push, tem como principal vantagem possibilitar a coleta de amostras protegidas por um liner e pode ser cravado utilizando o mesmo penetrômetro empregado no ensaio de piezocone. Este recurso reduz a exposição do operador ao solo amostrado, que é a sua principal vantagem sendo, portanto, apropriado para uma investigação geoambiental. A sua principal limitação é que, em solos residuais, como o caso do lixão de Ribeirão Preto, não foi possível obter amostras de água, uma vez que o penetrômetro não forneceu reação suficiente para garantir o esforço de cravação.

\subsection{Aterro de Resíduos Sólidos Urbanos de Bauru}

$\checkmark$ Os resultados das sondagens elétricas verticais (SEVs) possibilitaram identificar a posição do nível d'água, que variou entre 12 (à montante) e $8 \mathrm{~m}$ (à jusante). Também possibilitaram a definição da espessura da camada de resíduos (cerca de $20 \mathrm{~m}$ ) e, conseqüentemente, a base da cava. Os resultados dessas sondagens também indicaram uma grande heterogeneidade em relação às camadas de solo mais superficiais. 
$\checkmark$ Os resultados das sondagens de eletrorresistividade possibilitaram identificar que os menores valores de resistividade ocorrem abaixo das lagoas de chorume e se desenvolvem a partir daí, o que indica que deve haver vazamento desse percolado através dessa lagoa. A opção de impermeabilização do fundo do aterro com CM-30 diluído parece não ter sido eficiente, especialmente na região onde se dispõe o chorume para promover a recirculação.

$\checkmark$ A interpretação dos resultados dos ensaios de eletrorresistividade realizadas no aterro de resíduos sólidos de Bauru sugerem a possibilidade de fluxo de poluentes neste local no sentido do fluxo subterrâneo, para oeste-noroeste.

$\checkmark$ A partir dos resultados dos ensaios geofísicos, recomendou-se que as sondagens RCPTU, a instalação dos poços de monitoramento permanentes e as amostragens de solo e água fossem realizados em algumas posições específicas da Linha C4, logo à jusante do aterro, e também à noroeste do aterro, na direção do fluxo subterrâneo.

$\checkmark$ Assim, os ensaios intrusivos foram realizados em regiões previamente selecionadas com base na interpretação dos resultados dos ensaios geofísicos realizados na área do aterro de resíduos sólidos de Bauru. Entende-se que esta é a maneira mais racional de se conduzir um programa de investigação geoambiental.

$\checkmark$ Os ensaios com o piezocone também identificaram a presença de camadas heterogêneas à jusante do aterro e próximo às erosões, o que mostra a alta sensibilidade desta ferramenta em identificar camadas de comportamentos distintos.

$\checkmark$ As mesmas limitações apresentadas para o emprego da carta de classificação de ROBERTSON et al. (1986) para o solo da região do lixão de Ribeirão Preto ocorreram, em menor escala, para o solo da região do aterro de resíduos sólidos de Bauru, comprometendo assim a identificação de forma apropriada da textura do solo local. Por isso, o amostrador Geoprobe $\AA$ foi utilizado para coleta de amostras de solo nas camadas que indicaram comportamentos distintos a partir dos ensaios de piezocone. 
$\checkmark$ O emprego do sensor de resistividade acoplado ao piezocone é uma ferramenta eficiente para definição da posição do nível d'água, que não foi possível de ser identificado apenas pelo registro das poro-pressões nos ensaios com o piezocone.

$\checkmark$ Os coeficientes de permeabilidade estimados a partir dos ensaios de dissipação do excesso de poro-pressão utilizando o filtro de cavidade preenchido com graxa foram da mesma ordem de grandeza daqueles obtidos em laboratório para o solo do entorno do aterro de resíduos sólidos de Bauru. Entretanto, o número reduzido de ensaios e a falta de base teórica para sua interpretação não permite concluir que esse recurso possa ser utilizado para este fim.

$\checkmark$ A execução de uma sondagem RCPTU em uma área não contaminada e que tivesse as mesmas características do local para a determinação de valores de resistividade de referência não foi possível. Pois os perfis de solo à montante $\mathrm{e}$ ao sul do aterro apresentaram uma resistência à penetração maior que a capacidade do penetrômetro, antes de atingir o nível d'água.

$\checkmark$ Optou-se então por comparar os perfis de resistividade gerados a partir das diversas sondagens RCPTU, na zona saturada. Observou-se que os valores de resistividade são fortemente influenciados pelo tipo de solo presente no perfil, fato que auxiliou na interpretação de camadas mais ou menos resistivas, podendo indicar assim alguma contaminação.

$\checkmark$ Os valores de resistividade obtidos a partir dos ensaios RCPTUs 04, 05, 06, 11, 14 e 15 para a zona saturada confirmaram uma possível contaminação das regiões menos resistivas apresentadas no mapa de resistividade do nível teórico $15 \mathrm{~m}$ determinado a partir da geofísica de superfície.

$\checkmark$ A tentativa de avaliar os resultados de sondagens RCPTU em regiões não saturadas do maciço para fins de identificação de um aumento da contaminação não foi possível, uma vez que o grau de saturação tem grande influencia nos valores de resistividade. Em regiões não saturadas o efeito da condutividade dos grãos e da superfície especifica das partículas de argila se torna muito mais importante quando o grau de saturação diminui. 
$\checkmark$ Assim, a interpretação de sondagens RCPTU, especialmente em solos tropicais, deve ser feita com amostragem de solo e água, utilizando-se amostradores da tecnologia direct-push, que se adapta facilmente a tecnologia do piezocone, para que os fatores descritos acima possam ser avaliados, especialmente quando o interesse for a identificação da presença de um poluente no solo.

$\checkmark$ Esta amostragem ainda permite a aplicação da Lei de Archie para a estimativa da resistividade do solo, a qual apresentou limitações para a região estudada, superestimando os valores obtidos quando comparados com aqueles determinados pelas sondagens RCPTU, possivelmente por falta de parâmetros $a, m$ e $s$ apropriados para solos tropicais.

$\checkmark$ Os resultados das análises químicas realizadas para as amostras de água coletadas a partir dos poços de monitoramento e a partir do sistema direct-push indicaram os poços PP-1 e PT-3 e a sondagem RCPTU 15 como os mais contaminados, estando todos localizados à noroeste do aterro.

$\checkmark$ A partir das análises das águas superficiais do entorno do aterro e para o poço PP-4 localizado à montante, conclui-se que, além do aterro, existe influência de atividades externas nessas águas.

$\checkmark$ A análise conjunta de todas as campanhas de ensaios realizados no aterro de resíduos sólidos de Bauru mostra que a pluma de contaminação já ultrapassa os limites do aterro para jusante, à oeste-noroeste.

$\checkmark$ O coeficiente de permeabilidade do solo do entorno do aterro de Bauru determinado a partir dos ensaios de coluna e com carga variável foi de cerca de $10^{-7} \mathrm{~m} / \mathrm{s}$, que é um valor baixo para um solo arenoso. Entretanto, este valor é considerado elevado para solos utilizados como fundação de aterros de resíduos.

$\checkmark$ Os resultados preliminares dos ensaios de adsorção em lote mostram que existe uma boa capacidade deste solo adsorver os metais $\mathrm{Ni}, \mathrm{Zn}, \mathrm{Cd}$ e $\mathrm{Pb}$, apresentando elevados valores para o fator de retardamento ( $\mathrm{Rd})$. 
$\checkmark$ As seqüências de mobilidade obtidas para os ensaios de adsorção em lote realizados com a solução de metais e com o chorume foram de $\mathrm{Zn}>\mathrm{Cd}>\mathrm{Ni}$ e $\mathrm{Ni}>\mathrm{Cd}>\mathrm{Zn}>\mathrm{Pb}$, respectivamente.

$\checkmark$ O emprego de chorume em ensaios de laboratório é viável, desde que alguns cuidados especiais sejam tomados em seu manuseio e armazenamento. Os resultados obtidos com o chorume estão na mesma ordem de grandeza daqueles obtidos com a solução de metais em água destilada, apresentando alguma diferença de comportamento nas curvas de eluição.

$\checkmark$ Observa-se que para os ensaios realizados com o chorume os valores de $\mathrm{pH}$ e de condutividade não foram tão influenciados pelo solo, como para os ensaios realizados com a solução de metais.

$\checkmark$ Os resultados dos ensaios geoambientais de laboratório indicam que a poluição do entorno do aterro de resíduos sólidos de Bauru pode estar ocorrendo de forma lenta, destacando-se a importância da continuidade do monitoramento do aqüífero local a partir de campanhas periódicas de coleta de água dos poços de monitoramento.

\subsection{Sugestões para Continuidade}

$\checkmark$ A instalação de novos poços de monitoramento no lixão de Ribeirão Preto locados a partir dos resultados dos ensaios geofísicos, além do monitoramento contínuo destes poderia confirmar o sentido do caminhamento da pluma de contaminação para norte-nordeste do lixão e o agravamento desta pluma ao longo do tempo.

$\checkmark$ Em locais onde o impenetrável do cone é atingido antes do nível d'água, como ocorreu no lixão de Ribeirão Preto e à montante do aterro de resíduos sólidos de Bauru, técnicas para determinação dos valores de resistividade do solo em laboratório, como aquela realizada por DANIEL (1997), poderiam auxiliar na obtenção de valores de resistividade de referência e indicar parâmetros $a, m$ e $s$ da Lei de Archie mais apropriados para solos tropicais. 
$\checkmark$ Novos estudos para avaliar a aplicabilidade do filtro de cavidade preenchido com graxa deverão ser realizados, especialmente em perfis de solos tropicais, pelas vantagens de seu emprego em situações em que o nível d'água é profundo.

$\checkmark$ Coletas periódicas de água dos poços de monitoramento permanentes do aterro de resíduos sólidos de Bauru continuarão sendo realizadas pela EMDURB, órgão municipal responsável pela operação do aterro, para verificação de possível agravamento da pluma de contaminação.

$\checkmark$ Outras áreas devem ser investigadas utilizando-se o piezocone de resistividade segundo a proposta sugerida nesta pesquisa. Além disso, ensaios de laboratório também devem ser realizados para estudo de fatores que afetam a medida da resistividade em solos tropicais e que foram identificados a partir desta pesquisa.

$\checkmark$ A implantação de um sistema como aquele descrito por NASCENTES (2003) para realização de ensaios de coluna possibilitaria a realização de novos ensaios no solo do entorno do aterro de resíduos sólidos de Bauru, determinado-se assim os parâmetros necessários para a realização de simulações numéricas para uma estimativa da evolução da pluma de contaminação com o tempo. 


\section{REFERÊNCIAS BIBLIOGRÁFICAS}

ABGE (1998): Geologia de Engenharia. ABGE - Associação Brasileira de Geologia de Engenharia, 586p. ISBN 85-7270-002-1.

ABMS/ABEF (1998): Fundações - Teoria e Prática, $2^{\text {a }}$ edição, São Paulo: PINI, pp. $119-162$.

ABNT MB-3406 (1990): Solo - Ensaio de Penetração de Cone In Situ CPT, CB-O2,10 p.

ABNT / NBR 6457/86: Amostras de solo - Preparação para Ensaios de Compactação e Ensaios de Caracterização, $\mathrm{CB} 2: 9$ p.

ABNT / NBR - 6459/84: Solo- Determinação do Limite De Liquidez, CB2: 6 p.

ABNT / NBR - 6502/95: Rochas e Solos.

ABNT / NBR - 6508/84: Grãos de Solo que Passam na Peneira 4,8 mm Determinação da Massa Específica, CB2: 8 p.

ABNT / NBR - 7180/84: Solo- Determinação do Limite de Plasticidade, CB2: 3 p.

ABNT / NBR - 7181/84: Solo- Análise Granulométrica, CB2: 13 p.

ABNT / NBR - 7182/86: Compactação dos Solos, CB2.

ABNT / NBR - 10838/88: Solo - Determinação da Massa Específica Aparente de Amostras Indeformadas, com o Emprego da Balança Hidrostática.

ABNT / NBR - 13895/97: Construção de Poços de Monitoramento e Amostragem Procedimento.

AMERICAN PUBLIC HEALH ASSOCIATION, AMERICAN WATER WORKS ASSOCIATION, WATER ENVIRONMENTAL FEDERATION (1995): 
Standard Methods for the Examination of Water and Wastewater. Joint editorial board by Andrew D. Eaton, AWWA, Chair; Lenore S. Clesceri, WEF; Arnold E. Greenberg, APHA. Managing Editor Mary Ann H. Franson. $19^{\text {th }}$ Edition, pp. 3-1 $3-2$.

AOKI, N. \& VELLOSO, D.A. (1975): An approximate method to estimate the bearing capacity of piles. Proc.5th Panamerican Conference on Conference on Soil Mechanics and Foundation Engineering, Buenos Aires, pp. 367-376.

ARCHIE, G.E (1942): The Electrical Resistivity Log as an Aid in Determining Some Reservoir Characteristics. Trans. Am. Inst. Min. Eng., Vol. 146, pp. 54-62.

AZEVEDO, I.C.D, NASCENTES, C.R., AZEVEDO, R.F., MATOS, A.T. \& GUIMARÃES, L.M. (2003): Coeficiente de Dispersão Hidrodinâmica e Fator de Retardamento de Metais Pesados em Solo Residual Compactado. Revista "Solos e Rochas", Vol. 26, n 3, pp. 229-249.

ASTM D-3441 (1986): Standard Test Method for Deep Quasi-Static, Cone and Friction-Cone Penetration Tests of Soils, pp. 414-419.

BAGCHI, A. (1994): Design, Construction, and Monitoring of Landfills. John Wiley \& Sons, ISBN: 0471306819, $2^{\text {nd }}$ edition, 376p.

BOSCOV, M.E.G. (1997): Contribuição ao Projeto de Sistemas de Contenção de Resíduos Perigosos Utilizando Solos Lateríticos. Tese de Doutorado, Escola Politécnica da Universidade de São Paulo, São Paulo - SP.

BOSCOV, M.E.G. (2003): Notas de Aula da Disciplina "Transporte de Poluentes no Projeto de Aterros de Resíduos”. Escola Politécnica da Universidade de São Paulo, São Paulo - SP.

BOSCOV, M.E.G. \& ABREU, R.C. (2000): Aterros Sanitários. Previsão de Desempenho X Comportamento Real, editado por ABMS/NRSP, São Paulo, pp. 7 44. 
BRAGA, B., HESPANHOL, I., CONEJO, J.G.L., BARROS, M.T.L., SPENCER, M., PORTO, M., NUCCI, N., JULIANO, N., EIGER, S. (2002): Introdução à Engenharia Ambiental. Editora Prentice Hall, São Paulo-SP.

BRANDL, H. \& ROBERTSON, P.K. (1996): Geo-Environmental Site Investigation, Specification and Characterization. Proceedings of the International Congress on Environmental Geothecnics. Kyoto, Japão, Vol. 3, pp. 1345-1374.

BRATTON, W.L BRATTON, J.L \& SHINN, J.D. (1995): Direct penetrating technology for geotechnical and environmental site characterization, Geoenvironment 2000 - Caracterization, Containment, Remediation and Performance in Environmental Geotechnics, Vol. 1, pp. 105-121.

BURNS, S.E. \& MAYNE, P.W. (1998): Penetrometers for Soil Permeability and Chemical Detection. School of Civil and Environmental Engineering, Georgia Institute of Technology.

CALÇAS, D.A.N.Q.P. (2001): Atenuação da Carga Orgânica do Chorume de Aterro Sanitário em Solos Arenosos Compactados. Dissertação de Mestrado. Faculdade de Engenharia de Bauru, Universidade Estadual Paulista.

CAMPANELlA, R.C., ROBERTSON, P.K. GILLESPIE, D.G. \& GREIG, J. (1985):

Recent Developments in In-Situ Testing of Soils, Proceedings of XI ICSMFG, San Francisco, Vol.2, pp. 849-854.

CAMPANELlA, R.G. \& ROBERTSON, P.K. (1986): Factors Affecting the Pore Water Pressure and its Measurement around a Penetration Cone. $39^{\text {th }}$ Canadian Geotechnical Conference, Ottawa.

CAMPANELlA, R.G. \& ROBERTSON, P.K. (1988): Current Status of the Piezocone Test, Inv. lecture, ISOPT 1, Disney World, Balkema Publ., Vol. 1, pp. 93-117. 
CAMPANELlA, R.G. \& WEEMEES, I.A. (1990): Development and Use of an Electrical Resistivity Cone for Groundwater Contamination Studies, $42^{\text {th }}$ Canadian Geotechnical Conference, Winnipeg, pp. 1-11.

CAMPANELlA, R.G., DAVIES, M.P. \& BOYD, T.J. (1993): The Use of In-Situ Testing to Characterize Contaminated Soil and Groundwater Systems, $2^{\text {nd }}$ International Joint ASCE-CSCE Conference on Environmental Engineering, Publ. by Geotechnical Research Centre, McGill Univ., Montreal, Vol.2, pp. 1497-1505.

CAMPANELLA, R.G., STEWART, W.P., ROY, D. \& DAVIES, M.P. (1994): Low strain dynamic characteristics of soils with the downhole seismic piezocone penetrometer. ASTM Sym. on Dynamic Geotechnical Testing II, ASTM STP 1213, Jan., Reno, NV, pp. 73-87.

CAMPANELLA, R.G. \& RESEARCH STUDENTS (1995): Guidelines for Geotechnical Design Using the Cone Penetrometer Test and CPT with Pore Pressure Measurement. Fifth Edition, Civil Engineering Department, UBC, Vancouver/BC, Canada.

CARPENTER, P.J. KAUFMANN, R.S. \& PRICE, B. (1990): The Use of Resistivity Soundings to Determine Landfill Structure. Ground Water 28 (4), pp. 569-575.

CARValho, A.L. (2001): Contaminação de Águas Subsuperficiais em Área de Disposição de Resíduos Sólidos Urbanos - O Caso do Antigo Lixão de Viçosa (MG). Dissertação de Mestrado, Universidade Federal de Viçosa, 122p.

CETESB (1990): Compilação de Padrões Ambientais. São Paulo, 6p.

CETESB (1999): Manual de Gerenciamento de Áreas Contaminadas. Projeto CetesbGTZ. Cooperação Técnica Brasil-Alemanha. 1ªdição. São Paulo, 385p.

CETESB (2000): II Seminário Internacional Sobre Qualidade de Solos e Águas Subterrâneas: Propostas de Valores Orientativos para o Estado de São Paulo. Anais. São Paulo, 2000. 
CETESB (2001): Relatório de Estabelecimento de Valores Orientadores para Solos e Águas Subterâneas no Estado de São Paulo / Dorothy C.P. Casarini [el al]. São Paulo, 73p.

CHUI, Q.S.H. (1998): Contribuição ao Estudo da Vermiculita como Concentradora de Cátions. Tese de Doutorado, Instituto de Química da USP, São Paulo-SP.

CINTRA, F.H., HAMADA, J., IWAI, C.K. \& CASTILHO FILHO, G.S. (2002): Alterações na Qualidade das Águas do Entorno de um Aterro Controlado de Médio Porte para Resíduos Sólidos Urbanos. Simpósio Ítalo-Brasileiro de Engenharia Sanitária e Ambiental, Vitória-ES.

CONAMA (1986): Conselho Nacional do Meio Ambiente. Resolução $\boldsymbol{n}^{\boldsymbol{o}} 20$ de 20/07/86.

CORRÊA, A.C.S.S. (2001): Avaliação da Capacidade de Confinamento dos Solos Tropicais: Uma Contribuição à Escolha de Novas Areas para Distribuição de Resíduos Sólidos Urbanos. Tese de Doutorado em Geotecnia, Departamento de Engenharia Civil e Ambiental da Faculdade de Tecnologia da Universidade de Brasília.

DANIEL, D.E. (1984): Predicting Hidraulic Conductivy of Clay Liners. ASCE, Journal of Geotechnical Engineering, Vol. 110, n. 2, pp. 285-300.

DANIEL, C. (1997): An Investigation of the Factors Affecting Bulk Soil Electrical Resistivity. BASc, University of British Columbia, Department of Civil Engineering.

DANIEL, C.R., HOWIE, J.A., CAMPANELLA, R.G. \& GIACHETI, H.L. (2002): Specific Depth Cone Resistivity Measurements To Determine Soil Engineering Properties. Proceedings of Symposium on the Application of Geophysics to Engineering and Environmental Problems. 
DANZIGER, F.A.B. ALMEIDA, M.S.S. PAIVA, E.N. DE MELLO, L.G.F.S. \& DANZIGER, B.R. (1998): O piezocone como Ferranenta de Determinação da Estratigrafia e Classificação dos Solos, XI Congresso Brasileiro de Mecânica dos Solos e Engenharia Geotécnica, Brasilia/DF, Nov/98, pp. 917-926.

DAVIES, M.P. \& CAMPANELlA, R.G. (1995a): Piezocone Technology: Downhole Geophysics for the Geoenvironmental Characterization of Soil. Proceedings of Symposium on App. of Geophysics to Engineering and Environmental Problems, Environmental and Engineering Geophysics Society. Orlando, Florida, April, 11p.

DAVIES, M.P. \& CAMPANELLA, R.G. (1995b): Environmental Site Characterization Using In-Situ Testing Methods. $48^{\text {th }}$ Canadian Geotechnical Conference. Vancouver-BC, september.

DAVIS, J.L. \& ANANN, A.P. (1989): Ground Penetrating Radar for High Resolution Mapping Of Soil And Rock Stratigraphy. Geophysical Prospecting, 37 (5), pp. 531-552.

DE MIO, G. (2003): Comunicação Pessoal. Doutorando, Escola de Engenharia de São Carlos, Universidade de São Paulo, São Carlos-SP.

DE RUITER, J. (1971): Electronic Penetrometer for Site Investigations. Journal of the Soil Mechanics and Foundation Division, ASCE, Soil Mechanics Series, ${ }^{\circ}$. 2, vol. 97, pp. 457-472.

DOUGLAS, B.J. \& OLSEN, R.S. (1981): Soil Classification Using Electric Cone Penetrometer. Symposium on Cone Penetration Testing and Experience, St. Louis, pp. 209-227.

ELIS, V.R. (1993): A Aplicação da Geofísica para Análise do Meio Físico, Importância para Elaboração de Mapeamento Geotécnico. Dissertação de Mestrado, Rio Claro-SP, Instituto de Geociências e Ciências Exatas - UNESP, $120 \mathrm{p}$. 
ELIS, V.R. (1999): Avaliação da aplicabilidade de métodos elétricos de prospecção geofísica no estudo de áreas utilizadas para disposição de resíduos, Tese de Doutorado, Instituto de Geociências e Ciências Exatas, UNESP, Câmpus de Rio Claro - SP, 273p.

ELIS, V.R. (2001): Resultados Preliminares dos Ensaios Geofísicos na Área de um Aterro Sanitário. Relatório de pesquisa, 12p.

ELIS, V.R. (2003a): Geofísica Aplicada ao Estudo da Poluição de Solos e Águas Subterrâneas. V Escola de Verão de Geofísica, IAG - USP, São Paulo.

ELIS, V.R. (2003b): Aplicação Integrada de Métodos Geofísicos e Magneto Resistividade em Prospecção de Aquíferos Fissurais e Caracterização de Aterros Sanitários. Projeto FAPESP, Processo 99/12216-9.

ELIS, V.R. (2004): Comunicação Pessoal. Instituto de Astronomia, Geofísica e Ciências Atmosféricas da Universidade de São Paulo, São Paulo-SP.

ELIS, V.R. \& ZUQUETTE, L.V. (1996): Caminhamento Elétrico Dipolo-Dipolo Uma Técnica Eficiente na Caracterização de Depósitos de Resíduos, VIII Congresso Brasileiro de Geologia de Engenharia, Rio de Janeiro - RJ, Vol. 1, pp. $39-48$.

ELIS, V.R. \& ZUQUETTE, L.V. (1997): Determinação da Estrutura do Aterro Sanitário de Ribeirão Preto-SP através de métodos geoelétricos, V Congresso Internacional da Sociedade Brasileira de Geofísica, São Paulo - SP, Vol. 1, pp. 417-420.

EMDURB (2002): Comunicação Pessoal. Prefeitura Municipal de Bauru, Bauru-SP.

FIPAI (1992): Aterro Sanitário da Cidade de Bauru, Vol. 5, EIA-RIMA.

FIPAI (2001): Parecer Técnico das Análises de Líquidos Percolados Gerados no Aterro Sanitário Municipal de Bauru/SP, FIPAI/EESC/USP, Nov./2001, 7p. 
FREEZE, R.A. \& CHERRY, J.A. (1979): Groundwater. Editora Prentice Hall, Inc. Englewood Cliffs, New Jersey, USA.

FROHLICH, R.K. \& PARKE, C.D. (1989): The Electrical Resistivity of the Vadose Zone-Field Survey. Ground Water, Vol. 27, No. 4, pp. 524-530.

GEOPROBE SYSTEMS (1995): Geoprobe $®$ Screen Point 15 and Screen Point 16 Groundwater Samplers: Standard Operating Procedure. Technical Bulletin No 95-1500, revisado em abril de 2001.

GIACHETI, H.L. (1991): Estudo Experimental dos Parâmetros Dinâmicos de Alguns Solos Tropicais do Estado de São Paulo. Tese de Doutorado, EESC-USP, São Carlos/SP, 232p.

GIACHETI, H.L. (1995): Comparison of Field and Laboratory Shear Moduli for Tropical Soils, X Panamerican Conference on Conference on Soil Mechanics and Foundation Engineering, Guadalajara/Mexico, out-nov/95, Vol.1, pp. 176-188.

GIACHETI, H.L. (1998): Ensaios “In Situ” para Determinação de Parâmetros Geotécnicos do subsolo, Relatório de Pesquisa no Exterior, Fapesp, Proc. No. 970859-7, Vol.2, Inédito.

GIACHETI, H.L. (2001): Os Ensaios de Campo na Investigação do Subsolo: Estudos e Consideraçães quanto à Aplicação em Solos Tropicais. Tese de Livre Docência, FEB-Unesp, Bauru/SP, 299 p.

GIACHETI, H.L. \& CARVALHO, D. (1994): Estimativa do Módulo de Cisalhamento de Dois Solos Tropicais Típicos a partir de Resultados de Ensaios de Penetração, X Congresso Brasileiro de Mecânica dos Solos e Engenharia de Fundações, out/94, Foz do Iguaçu/PR, Vol.2, pp. 467-474.

GIACHETI, H.L. \& COELHO, V. (1996): Pavimentação Econômica com Solos Lateríticos. Notas de Aula, UNESP - Bauru. 
GIACHETI, H.L., ELIS, V.R., ZUQUETTE, L.V., ESQUIVEL, E.R. \& HAMADA, J. (1999): Perspectivas de Aplicação de Técnicas Combinadas para a Investigação e Caracterização Ambiental. In: IX Congresso Brasileiro de Geologia de Engenharia, São Pedro - SP. Anais do IX CBGE. São Paulo - SP: ABGE, 1999.

HAMADA, J., GIACHETI, H.L., ELIS, V.R. \& IWAI, C.K. (2002): Análise Crítica dos

Sistemas de Monitoramento de Efluentes Líquidos de Aterros para Resíduos

Sólidos. XXVIII Congresso Interamericano de Ingenieria Sanitaria y Ambiental, Cancún, México.

http://www.conetec.com/Pdf/cpt_ground.pdf $(J u l h o / 2002)$.

http://www.geoprobe.com/products/tools/gw_sampling/gw_sampling_tools_menu.htm $(02 / 2004)$.

http://www.vidagua.org.br/imagens/ImgBauru/mapa_d5.gif (02/2004).

IPT/CEMPRE (2000): Lixo Municipal: Manual de Gerenciamento Integrado. Coordenação: Maria Luiza Otero D’Almeida, André Vilhena - 2.ed. São Paulo.

KEYS, W.S. (1989): Borehole Geophysics Applied to Ground-Water Investigations. Published by National Water Well Association. Dublin, Ohio, 313 p.

LAGO, A.L. (2004): Aplicação Integrada de Métodos Geofísicos em Área de Disposição de Resíduos Sólidos Urbanos em Bauru - SP. Dissertação de Mestrado. Instituto de Astronomia, Geofísica e Ciências Atmosféricas da USP, São Paulo-SP.

LAGO, A.L., SILVA, E.M.A., ELIS, V.R. \& GIACHETI, H.L. (2003): Aplicação de Eletrorresistividade e Polarização Induzida em Área de Disposição de Resíduos Sólidos Urbanos em Bauru-SP. $8^{\text {th }}$ International Congress of the Brazilian Geophysical Society. Rio de Janeiro-RJ, Brazil.

LAGREGA, M.D., BUCKINGHAM, P.L., EVANS, J.C. (1994): Hazardous Waste Management. McGraw-Hill, Inc. 
LAMBE, T.W. \& WHITMAN, R.V. (1979): Soil Mechanics. SI version, John Wiley \& Sons, New York, EUA.

LARSSON, R. (1995): Use of a Thin Slot as Filter in Piezocone Tests. Swedish Geotechnical Institute, Linköping, Sweden.

LEITE, A.L. (2001): Migração de Contaminantes Inorgânicos em Alguns Solos Tropicais, com Ênfase na Sorção e Difusão Molecular. Tese de Doutorado, EESC-USP, São Carlos/SP, 254p.

LUNne, T. ROBERTSON, P.K. \& POWELL, J. (1997): Cone Penetration Test in Geotechnical Practice, Blackie Academic \& Professional, London, 311p.

MARQUES, M.E.M. (2002): Tecnologia do Piezocone para Investigação Geotécnica e Geoambiental de Solos Tropicais. Dissertação de Mestrado. Faculdade de Engenharia da Unesp, Bauru - SP.

MATOS, A.T. (1995): Fatores de Retardamento e Coeficientes de Dispersão-Difusão do Zinco, Cádmio, Cobre e Chumbo em Solos do Município de Viçosa-MG. Tese de Doutorado, Universidade Federal de Viçosa, 110p.

MAYNE, P.W. \& SCHNEIDER, J.A. (2001): Evaluating Axial Drilled Shaft Response by Seismic Cone. GSP 113, ASCE. Foundations \& Ground Improvement, pp. 655669.

MAYNE, P.W. (2001): Stress-Strain-Strenght-Flow Parameters from Enhanced InSitu Tests. International Conference on In-Situ Measurement of Soil Properties \& Case Histories, pp. 27-48.

MAYNE, P.W. BROWN, D. VINSON J. SCHNEIDER, J. A. \& FINKE, K.A. (2000): Site Characterization of Piedmont Residuals Soils at the the NGES, Opelika, Alabama. GSP 93. ASCE. National Geotechnical Experimentation Sites, pp. 160185. 
MCBEAN, E.A., ROVERS, F.A., FARQUHAR, G.J., (1995): Solid Waste Landfill Engineering and Design. Prentice Hall, Inc. 521 p., ISBN 0-13-079187-3.

MEIGH, A.C. (1987): Cone Penetration Testing: Methods And Interpretation. CIRIA ground engineering report: In-situ testing, Butterworths, London, England.

MITCHELL, J.K. (1993): Fundamentals of Soil Behavior. John Wiley \& Sons, New York, EUA.

MONDELLI, G., MARQUES, M.E.M. \& GIACHETI, H.L. (2002): Investigação do Subsolo Utilizando o CPT Elétrico: Aplicação em um Perfil de Solo Tropical Arenoso. XII COBRAMSEG, São Paulo - SP.

NASCENTES, C.R. (2003): Coeficiente de Dispersão Hidrodinâmica e Fator de Retardamento de Metais Pesados em Solo Residual Compactado. Dissertação de Mestrado, Universidade Federal de Viçosa, Viçosa-MG, 117 p.

NEVES, M. das (1987): Estudo da Permeabilidade do Solo Colapsível da Região de São Carlos. Dissertação de Mestrado, Escola de Engenharia de São Carlos, 139 p.

NOGAMI, J.S. \& VILLIBOR, D.F. (1995): Pavimentação de Baixo Custo com Solos Lateríticos. Editora Vilibor, São Paulo - SP, 240p.

ORTIGÃO, J.A.R.; CUNHA, R.P. E ALVES L.S. (1996): InSitu Tests in Brasília Porous Clay. Canadian Geotech. J. 33, (1), pp. 189-198.

PEJON, O.J. \& ZUQUETTE, L.V. (1991): Importance of Geological-Geotechnical Studies for Urban Waste Disposal, Proceedings of II Symposium of Tailings Dams and Urban Waste Disposal, (in portuguese), Rio de Janeiro/RJ/Brazil, pp. 367-377.

PEJON, O.J. (1992): Mapeamento Geotécnico da Folha de Piracicaba-SP (Escala 1:100.000): Estudo de Aspectos Metodológicos, de Caracterização e de Apresentação dos Atributos. Volume I. Tese de Doutorado, EESC-USP, São Carlos/SP, 213p. 
QASIM, S.R. \& CHIANG, W. (1994): Sanitary Landfill Leachate - Generation, Control and Treatment. Technomic Publishing Co., Inc. p. 323, ISBN 1-56676$129-8$.

OliveIRA, E. (2003): Comunicação Pessoal. Instituto de Química da Universidade de São Paulo, São Paulo-SP.

ROBERStSON, P.K. (1990): Soil Classification Using the Cone Penetration Test. Canadian Geotechnical Journal, vol. 27, $\mathrm{n}^{\circ}$. 1, pp. 151-158.

ROBERSTSON, P.K. (1998): Geo-Environmental Investigation, Characterization And Monitoring Using Penetration Techniques. Simpósio Brasileiro de Geotecnia Ambiental, São Paulo/SP, set/98.

ROBERTSON, P.K \& CAMPANELLA, R.G. (1986): Guidelines for Use, Interpretation and Application of the CPT And CPTU. Soil Mechanics Series $\mathrm{N}^{\circ}$ 105. Department of Civil Engineering, UBC, Vancouver, Canada.

ROBERTSON, P.K \& CAMPANELLA, R.G. (1988): Guidelines for Geotechnical Design Using CPT And CPTU Data. Report FHWA, 340p.

ROBERTSON, P.K. LUNNE, T. \& POWELL, J. (1996): Application of penetration tests for geo-emvironmental purposes. Advances in site investigation practice, Thomas Telford, London,. pp. 407-419.

ROBERTSON, P.K., CAMPANELLA, R.G., GILLESPIE, D.J. \& GRIEG, J. (1986): Use of Piezometer Cone Data, Proc. of In-Situ' 86, ASCE, Geotechnical Special Publication No. 6., pp. 1263-1280.

ROSE, C.M., ARMSTRONG, S.C., WALKER, J.L., YOUNG, G.N. \& BURTON, J.C. (1998): Collecting Real-Time Soil Moisture Profiles in the Vadose Zone. Geotechnical Site Characterization. Robertson and Mayne, Ed., Balkema, Rotterdam, 1998, pp. $589-594$. 
SCHMERTManN, J.H. (1978): Guidelines for Cone Penetration Test, Performance and Design. Federal Highway Administration, Report FHWA-TS-787-209, Washington.

SCHNAID, F., CONSOLI, N.C. \& AVERBECK, J.H. (1998): Aspects of Cone Penetration in Natural Weakly-Cemented Deposits. Geotechnical Site Characterization, Atlanta, 1988 Balkema, Rotterdam, Vol. 2, pp. 1159-1163.

SCHNEIDER, J.A. E MAYNE, P.W. (2000): Liquefaction Response of Soils In MidAmerica Evaluated by Seismic Cone Tests. Inovations and Applications in Geotechnical Site Characterization. Proceedings. In: Geo Denver 2000, pp. 1-16.

SCHNEIDER, J.A., HOYOS JR, LAUREANO, MAYNE, P.W., MACARI, E.J. \& RIX, G.J. (1999): Field and Laboratory Measurements of Dynamic Shear Modulus of Piedmont Residual Soils. GSP 92, ASCE. Behavioral Characteristics of residual Soils, pp. 12-25.

SGI - STATENS GEOTEKNISKA INSTITUT (1995): The CPT Test, Equipament Testing - Evaluation. Information 15 E, Linköping.

SHARMA, H.D. \& LEWIS, S.P. (1994): Waste Containment Systems, Waste Stabilization and Landfills: Design and Evaluation. John Wiley \& Sons, Inc. $1^{\text {st }}$ Edition.

TEH, C.I. \& HOUlSBY, G.T. (1991): An Analytical Study of the Cone Penetration Test in Clay. Geotechnique 41 (1), pp. 17-34.

TORSTENSSON, B.A. (1984): A New System for Groundwater Monitoring. Ground Water Monitoring Review, Fall 1984, pp. 131-138.

TORSTENSSON, B.A. \& PETSONK, A.M. (1988): A Hermetically Isolated Sampling Method for Ground-Water Investigations. Ground-Water Contamination: Field 
Methods, ASTM STP 963, A. G. Collins and A. I. Johnson, Eds., American Society for Testing and Materials, Philadelphia, pp. 274 - 289.

US EPA (1989): Seminar on Site Characterization for Subsurface Remediations. United States Environmental Protection Agency, Technology Transfer, Report CERI-89-224, 350p.

VANGULCK, J. \& ROWE, R.K. (2002): Experimental Results and Parameters Obtained from Leachate Column Clogging Studies. Proceedings of the Forth International Congress on Environmental Geothecnics ( $\left.4^{\text {th }} \mathrm{ICEG}\right)$, Rio de Janeiro RJ, Brazil, Vol. 1, pp. 33-38.

VOGELSANG, D. (1995): Environmental Geophysics. A practical Guide. Springer-Ve rlag, Berlim, 172p.

WEEMES, I. (1990): A Resistivity Cone Penetrometer for Ground-Water Studies. MASc, University of British Columbia, Department of Civil Engineering.

WILSON, D. \& CAMPANELLA, R.C. (1997): A Rapid In-Situ Hidraulic Conductivity Measurement in Sands Using a UBC Modified Bat Penetrometer. $50^{\text {th }}$ Canadian Geotechnical Conference, Ottawa, Oct 1997, pp. 34-41.

ZUQUETTE, L.V., GANDOLFI, N. \& PEJON, O.J. (1990): O Mapeamento Geotécnico na Previsão e Prevenção de Riscos Geológicos em Áreas Urbanas. I Simpósio Latino Americano sobre Risco Geológico Urbano, São Paulo-SP, pp. 305-315.

ZUQUETTE, L.V., PEJON, O.J., SINELLI, O. \& GANDOLFI, N. (1994): Methodology of Specific Engineering Geological Mapping for Selecting of Sites for Waste Disposal. $7^{\text {th }}$ International IAEG Congress, Lisboa, Portugal, pp. 2481-2489. 


\section{ANEXO I}

Ensaios CPTU Realizados no Antigo Lixão de Ribeirão Preto 


\section{Lixão de Ribeirão Preto - CPTU 1}

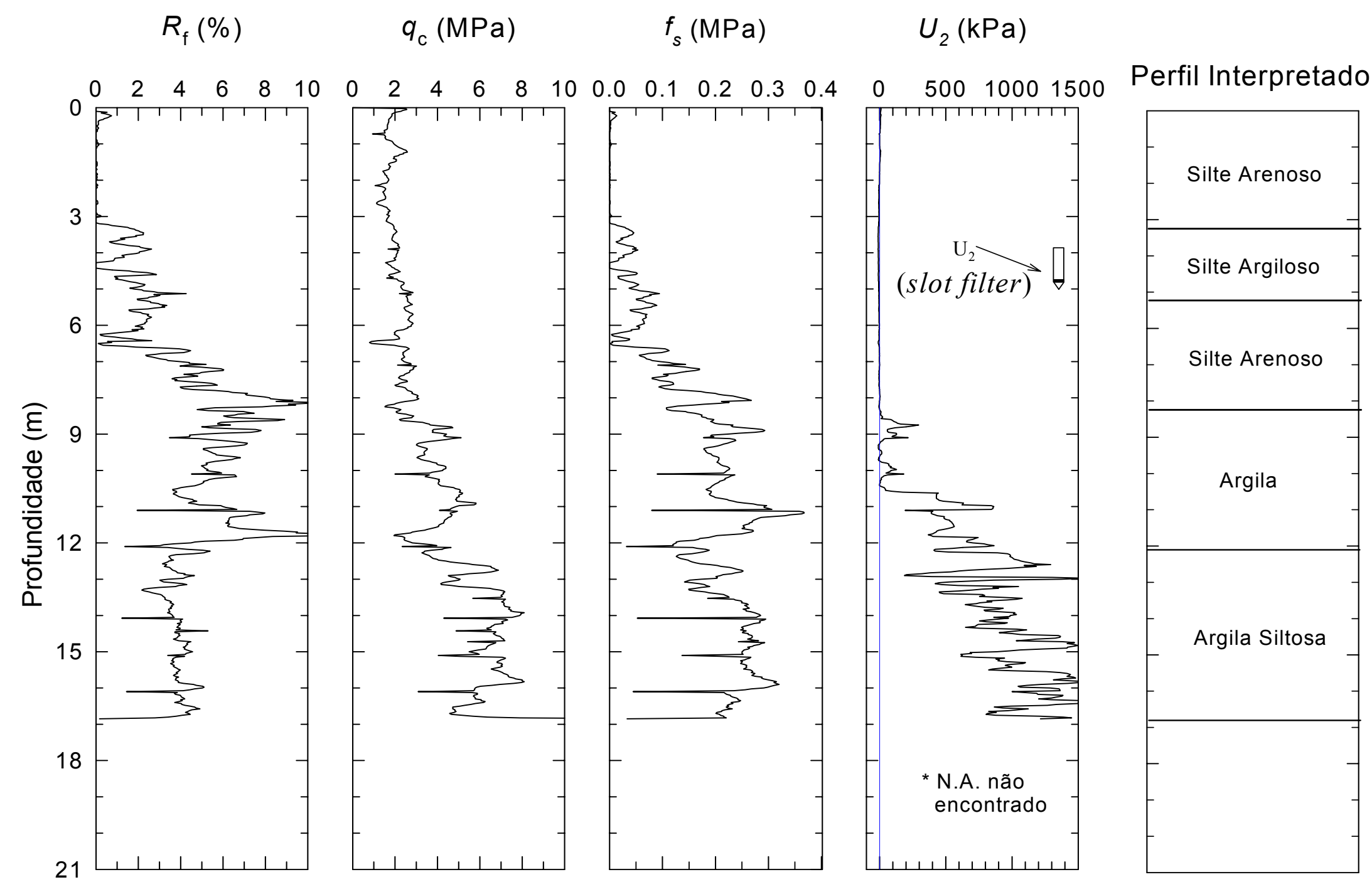




\section{Lixão de Ribeirão Preto - CPTU 2}

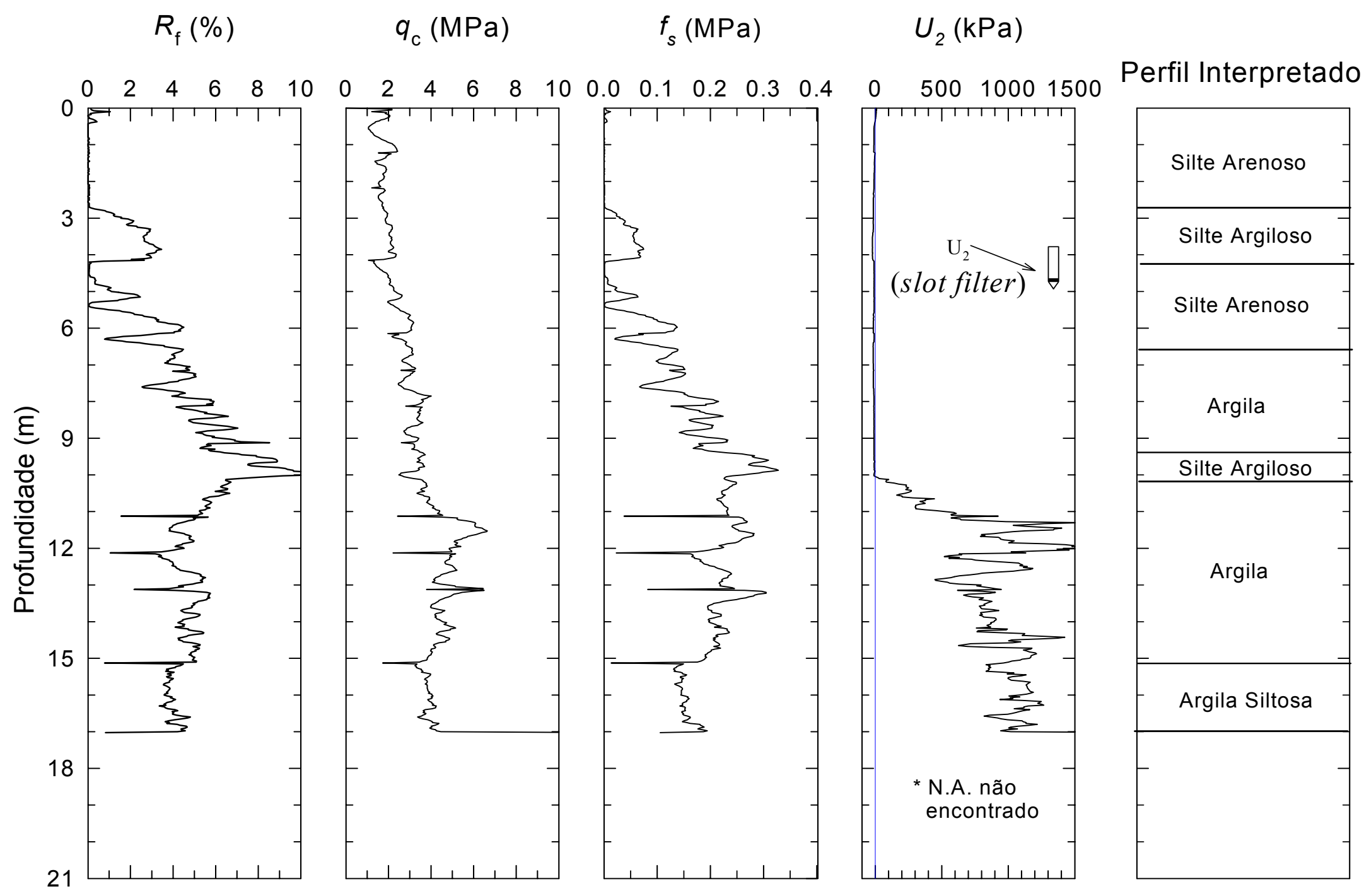




\section{Lixão de Ribeirão Preto - CPTU 3}

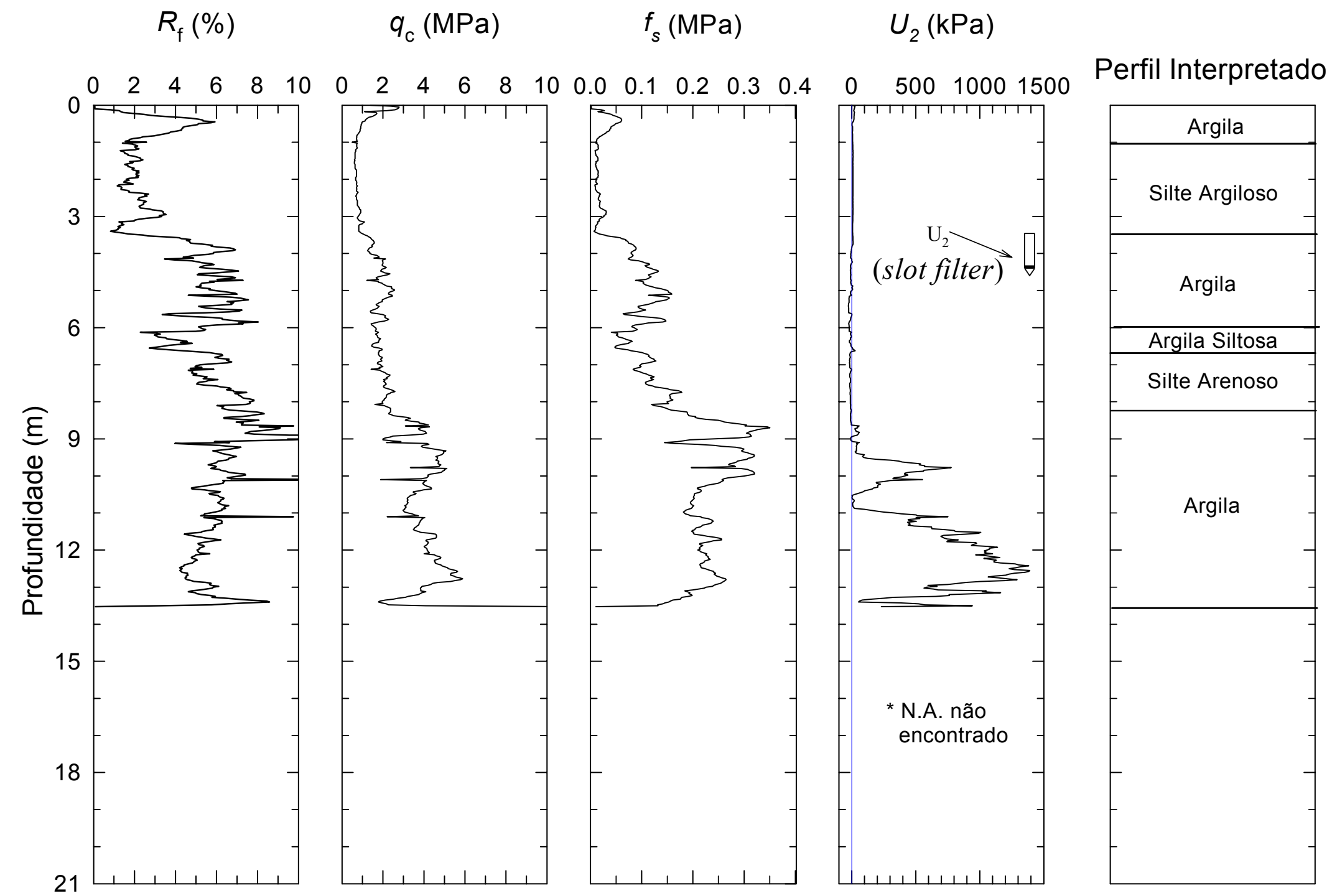




\section{ANEXO II}

Ensaios CPTU e RCPTU Realizados no Aterro de Resíduos Sólidos

Urbanos de Bauru 
Aterro de Resíduos Sólidos Urbanos de Bauru - CPTU 01 (Dez/2001)
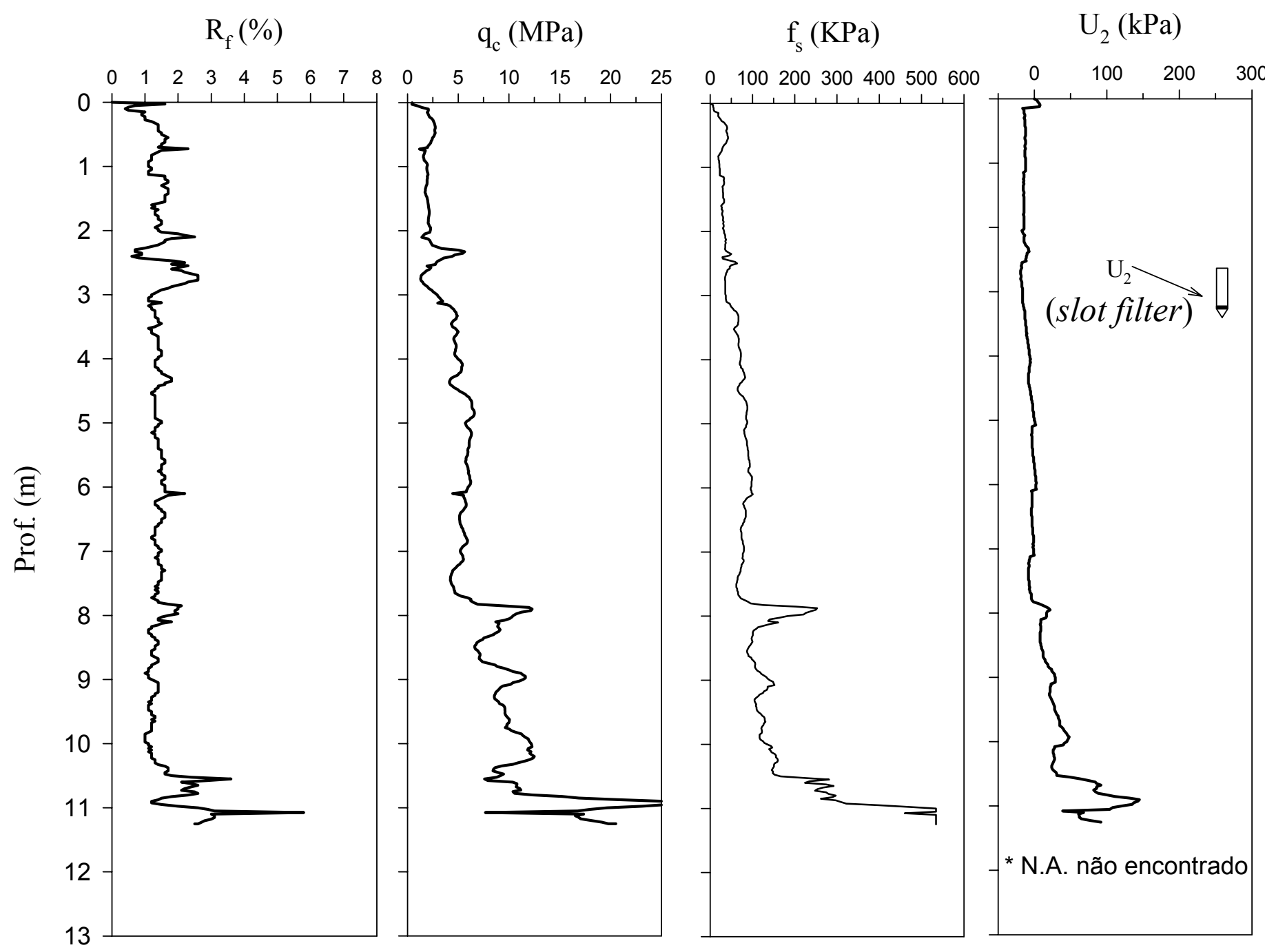

Perfil Interpretado

$\mathrm{q}_{\mathrm{c}}(\mathrm{MPa})$

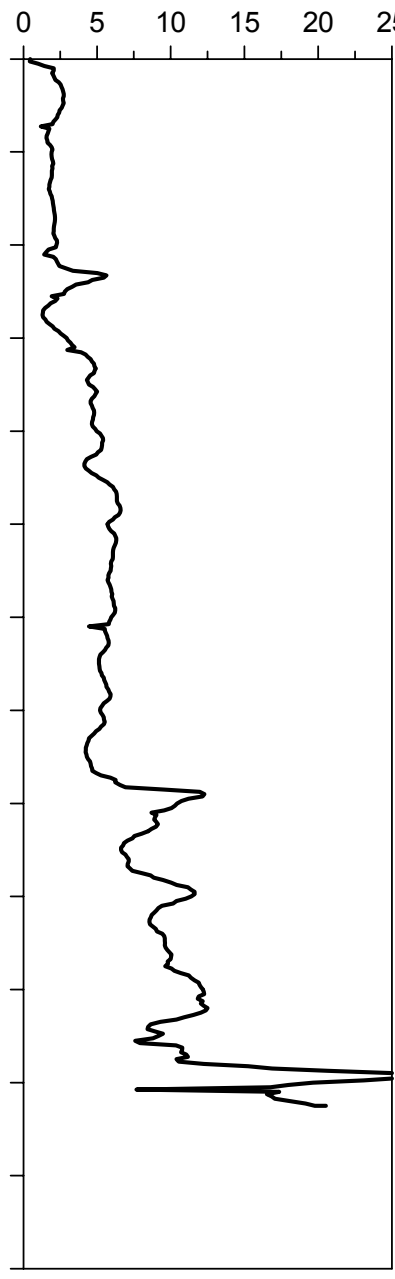

100200300400500600

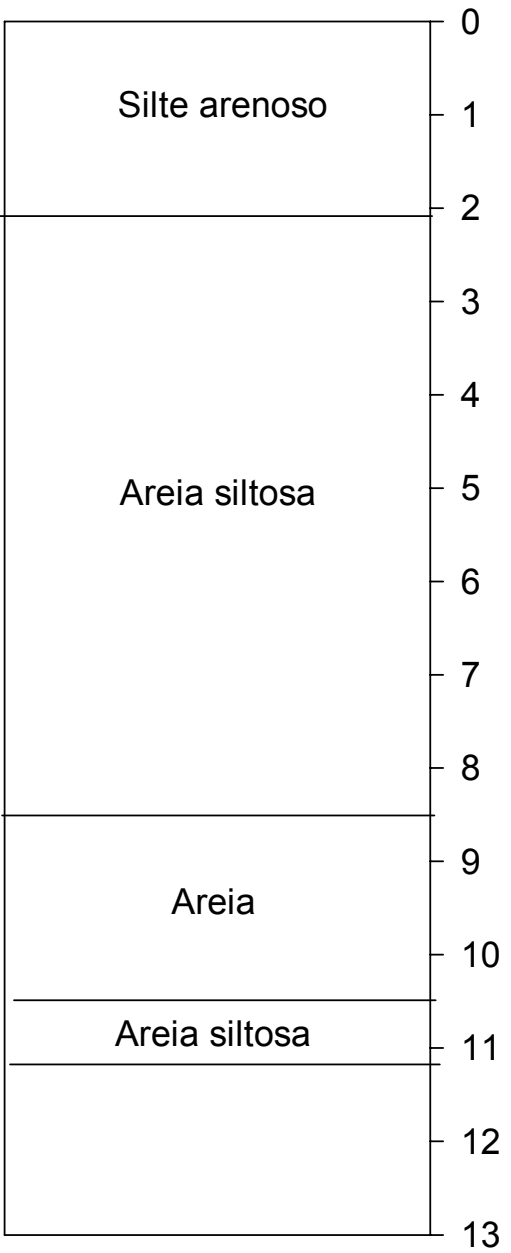


Aterro de Resíduos Sólidos Urbanos de Bauru - CPTU 02 (Dez/2001)

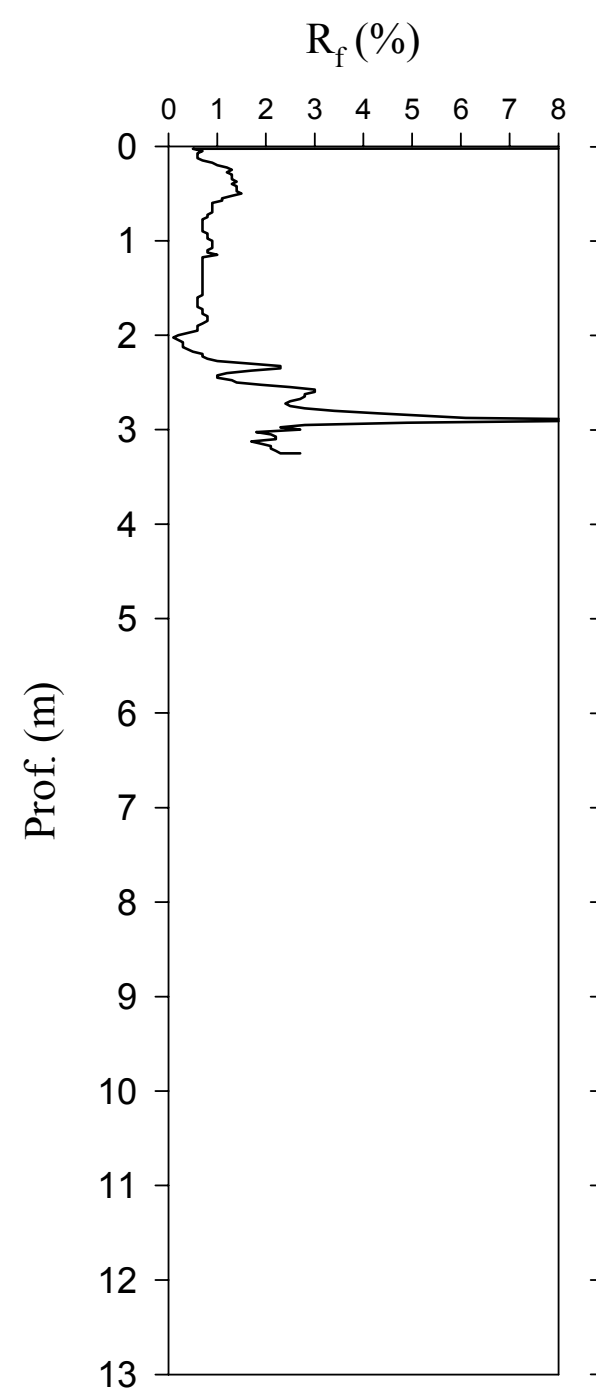

$\mathrm{q}_{\mathrm{c}}(\mathrm{MPa})$

$\mathrm{f}_{\mathrm{s}}(\mathrm{KPa})$

$\mathrm{U}_{2}(\mathrm{kPa})$

Perfil Interpretado
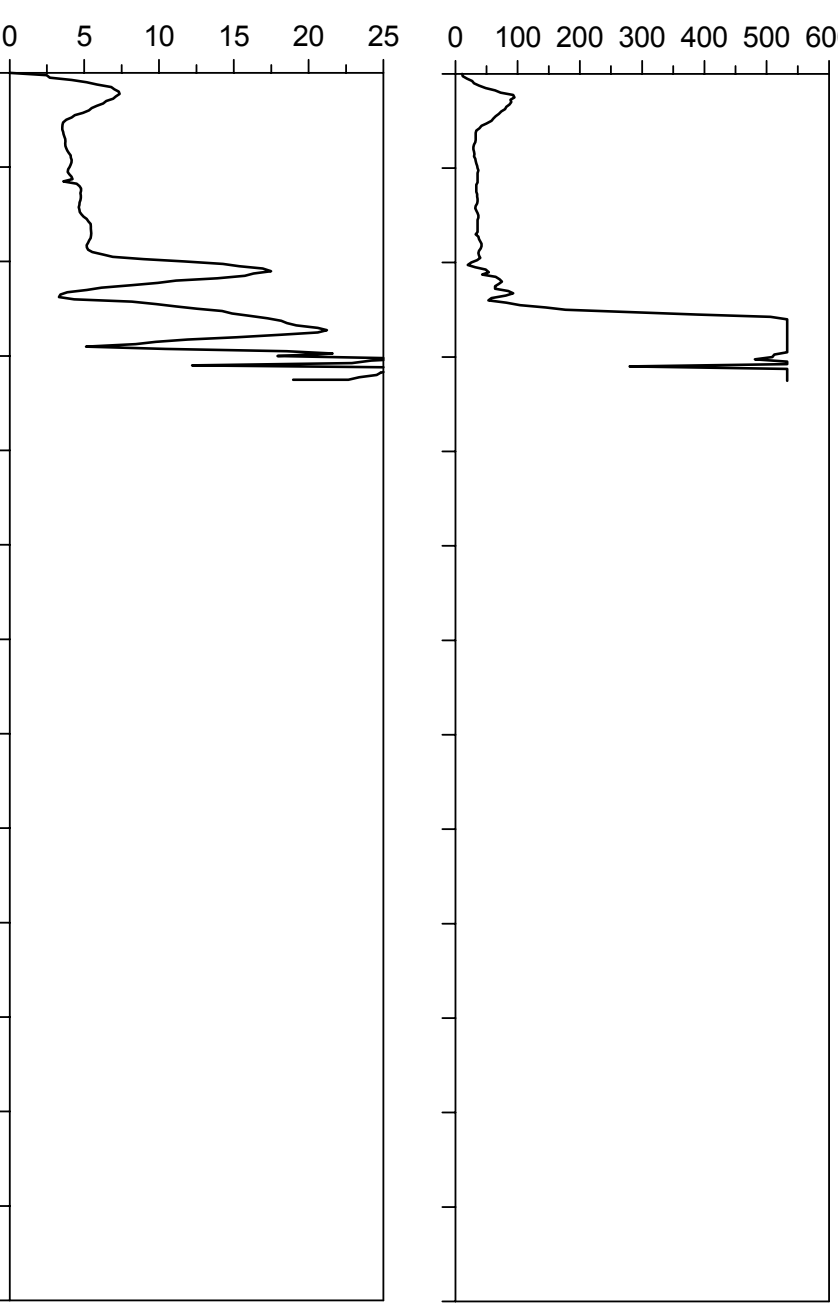

$0 \quad 100200300400500$
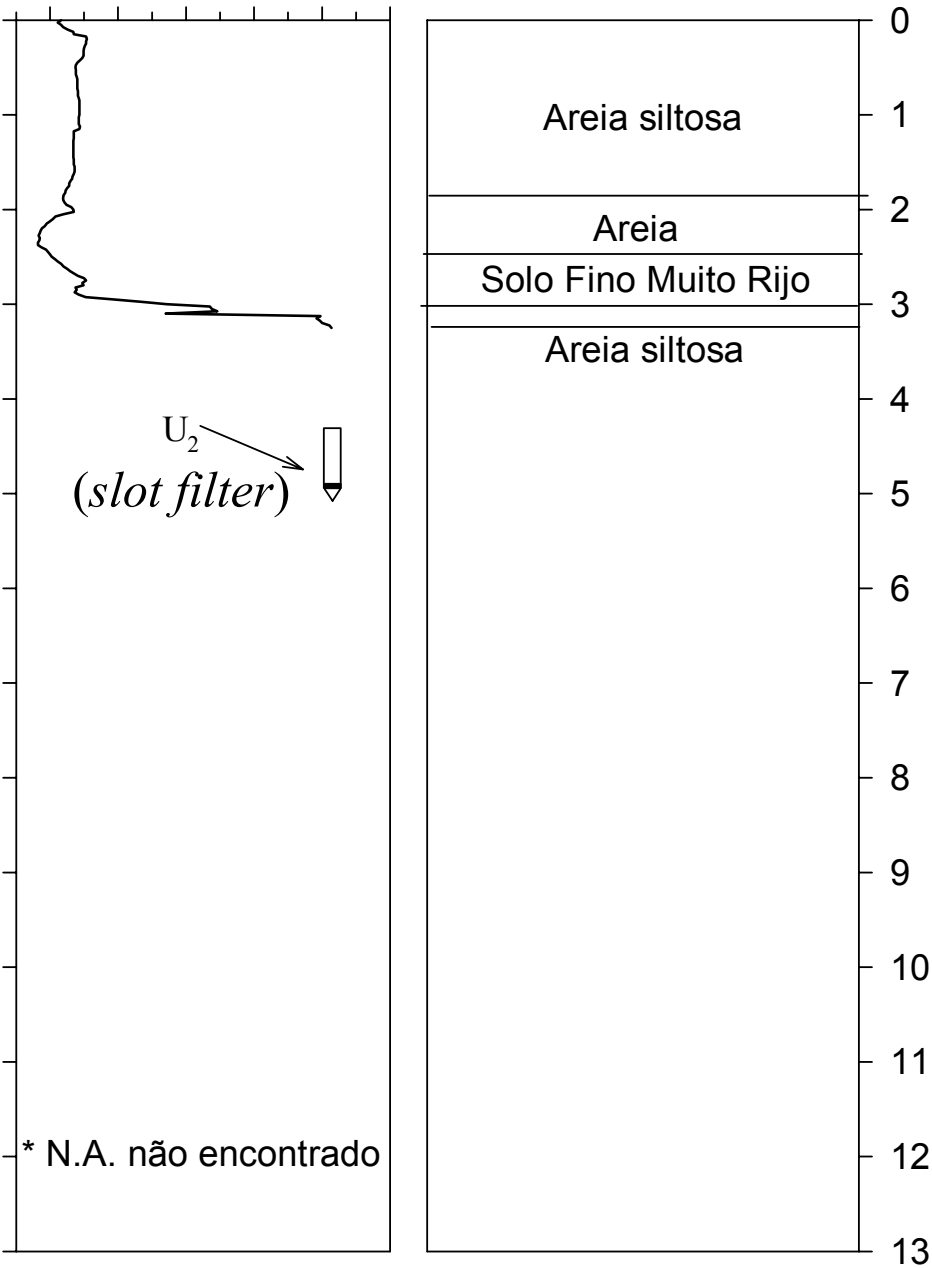

0

2


Aterro de Resíduos Sólidos Urbanos de Bauru - CPTU 03 (Dez/2001)

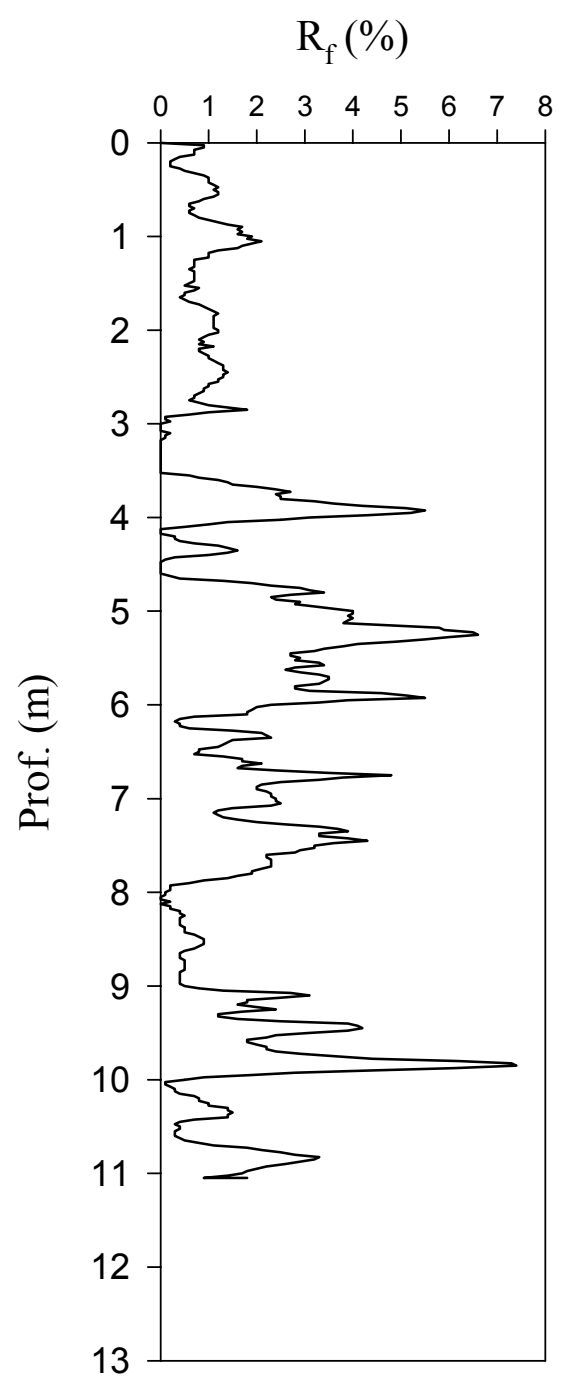

$\mathrm{q}_{\mathrm{c}}(\mathrm{MPa})$

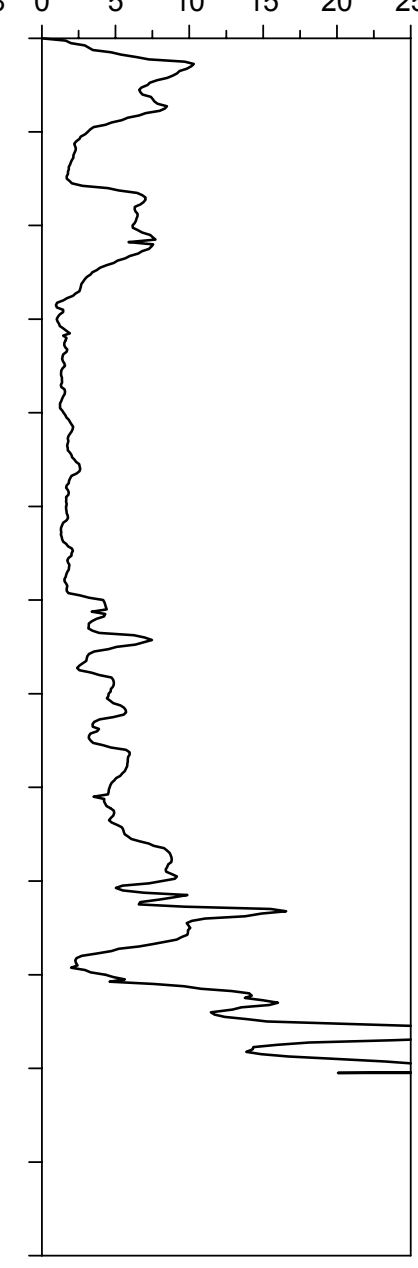

$\mathrm{f}_{\mathrm{s}}(\mathrm{KPa})$

o 100200300400500600

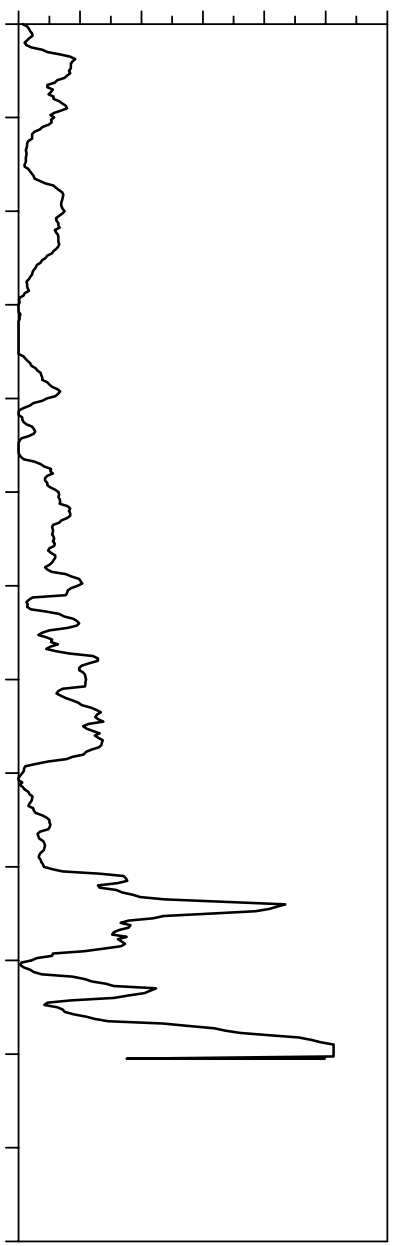

$\mathrm{U}_{2}(\mathrm{kPa})$

$\begin{array}{llllll}0 & 100 \quad 200 \quad 300 & 400 & 500\end{array}$

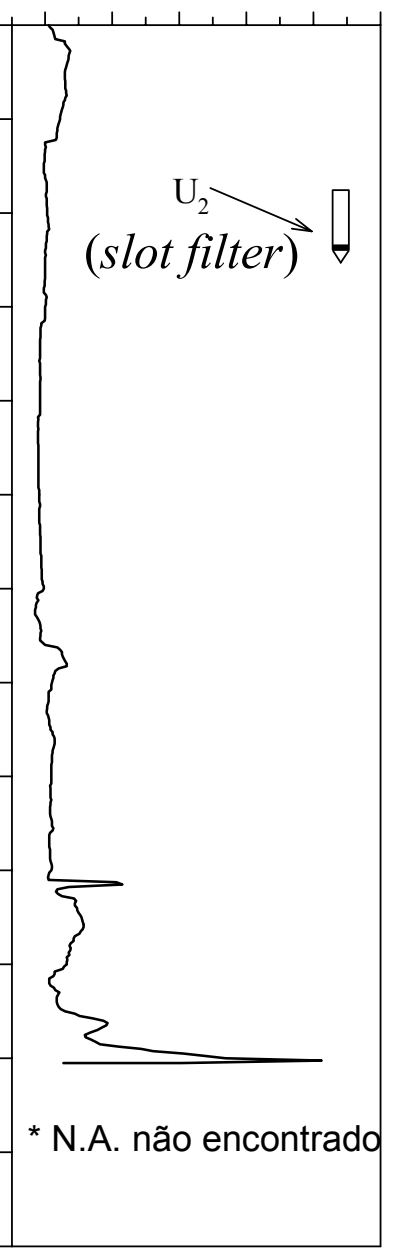

Perfil Interpretado

\begin{tabular}{|c|}
\hline Areia \\
\hline Areia siltosa \\
\hline Silte arenoso \\
\hline Argila siltosa \\
\hline Areia Siltosa \\
\hline Argila \\
\hline Areia siltosa \\
\hline Areia \\
\hline Silte argiloso \\
\hline Areia \\
\hline \\
\hline \\
\hline
\end{tabular}


Aterro de Resíduos Sólidos Urbanos de Bauru - CPTU 04 (Dez/2001)
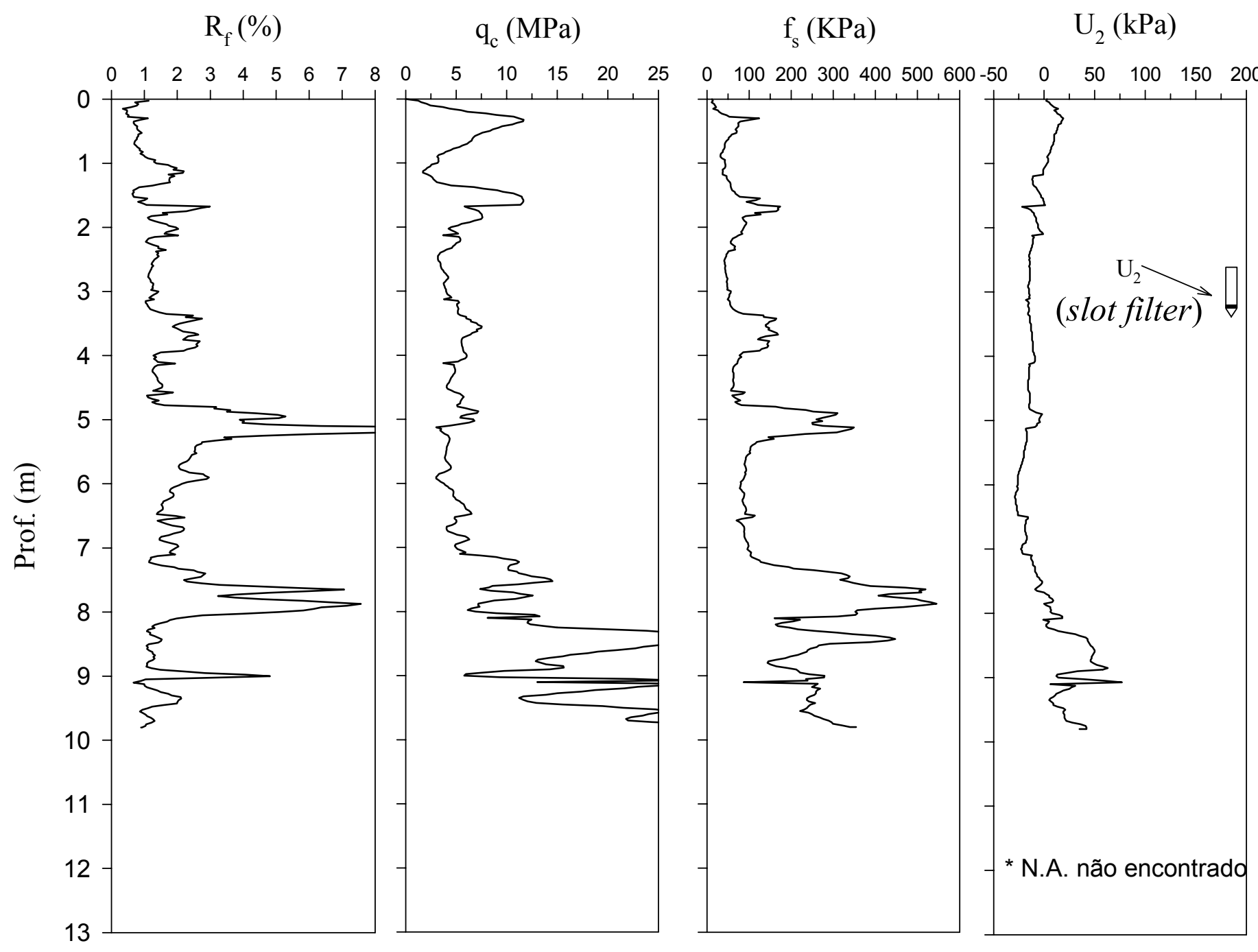

Perfil Interpretado

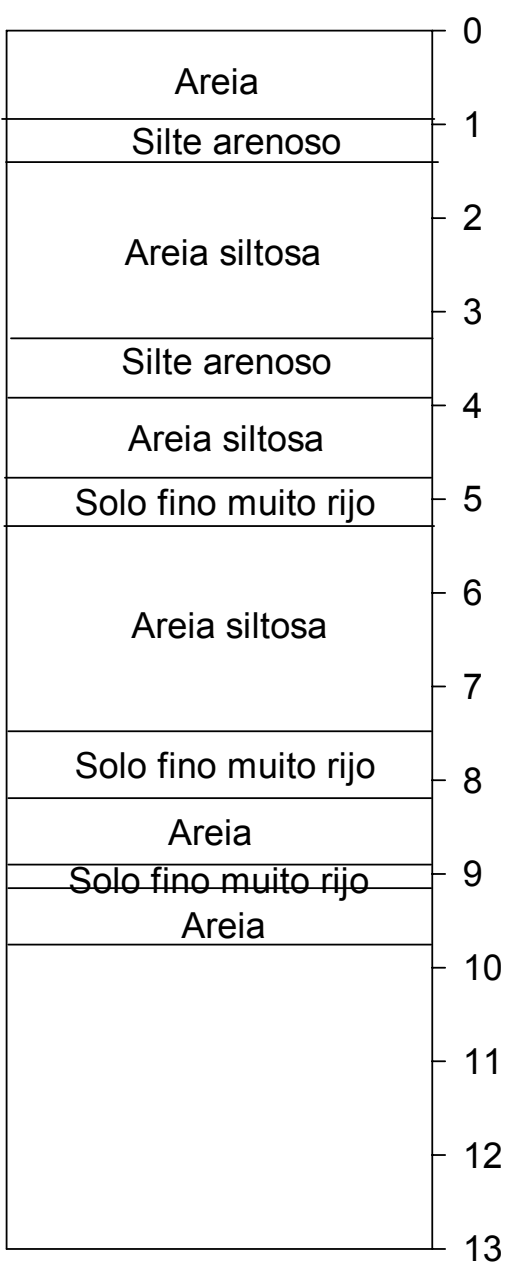




\section{Aterro de Resíduos Sólidos Urbanos de Bauru - RCPTU 01 (Fev/2002)}

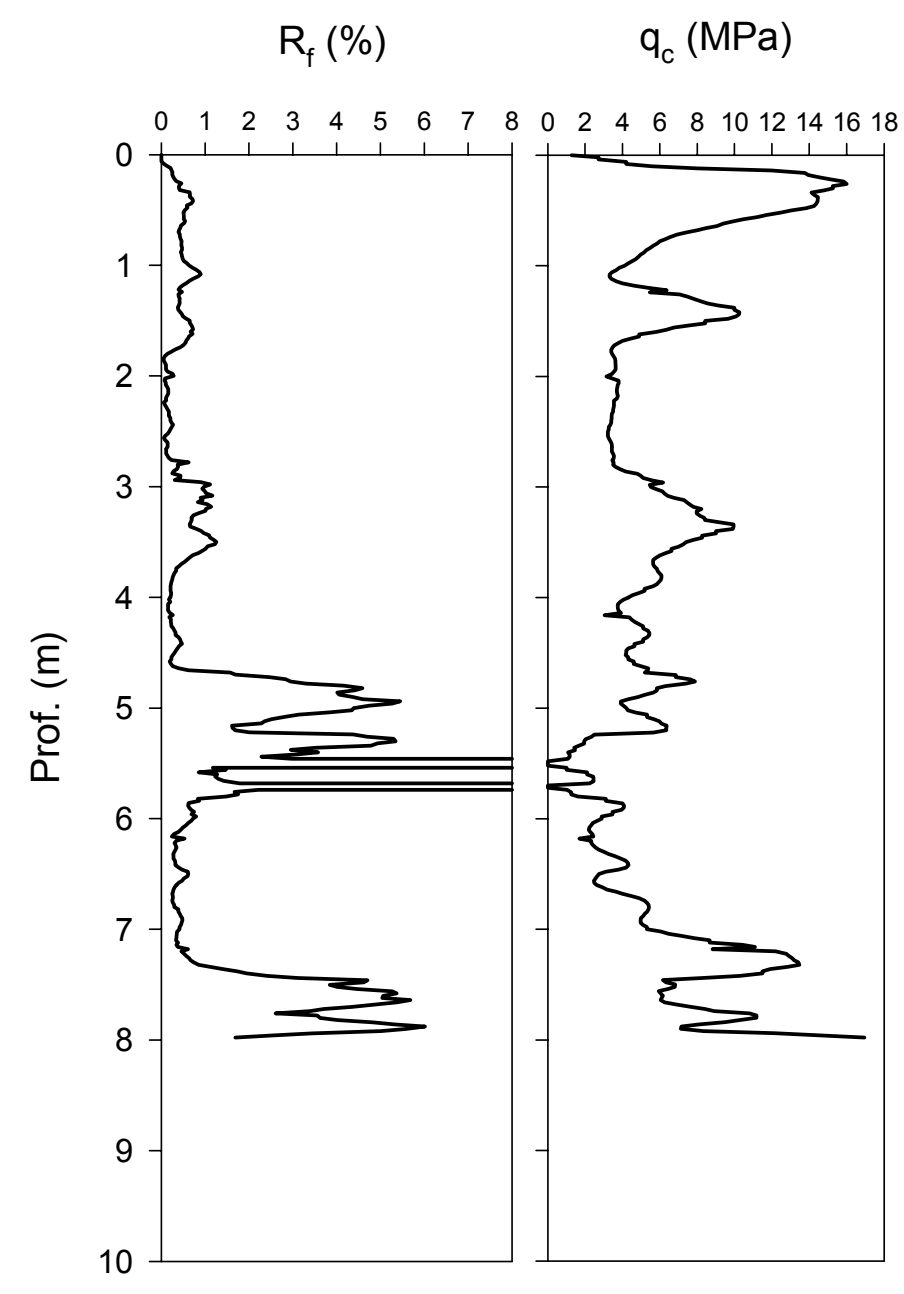

$\mathrm{f}_{\mathrm{s}}(\mathrm{KPa})$

$\mathrm{U}_{2}$ (MPa)

R (ohm-m)
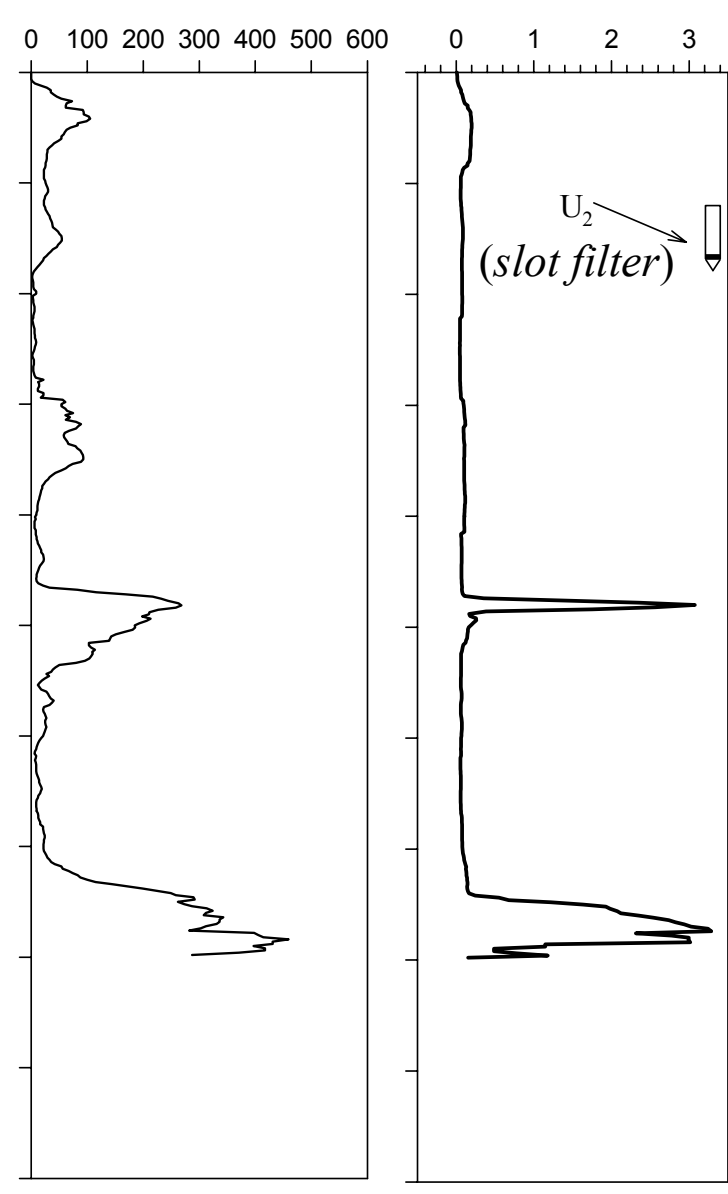

$0 \quad 30060090012001500$

Perfil Interpretado
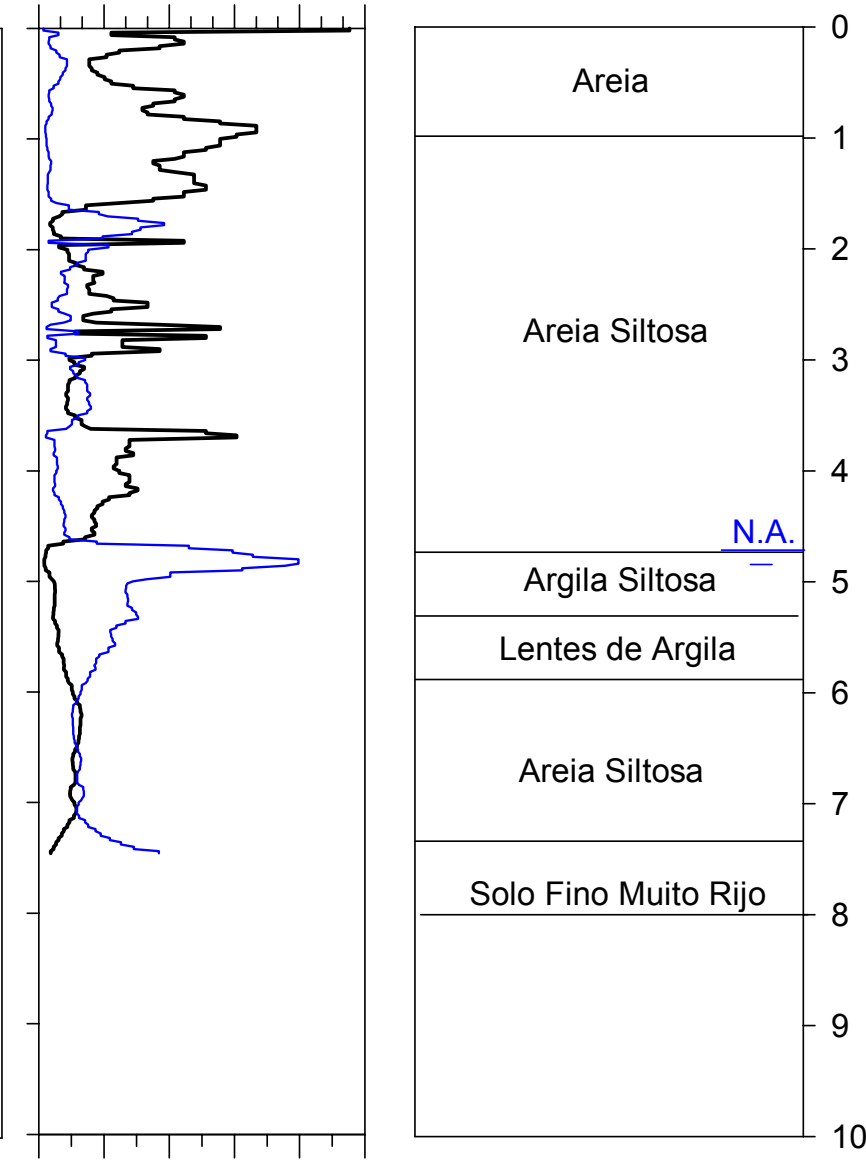

0100200300400500

C $(\mu \mathrm{S} / \mathrm{cm})$ 
Aterro de Resíduos Sólidos Urbanos de Bauru - RCPTU 02 (Fev/2002)

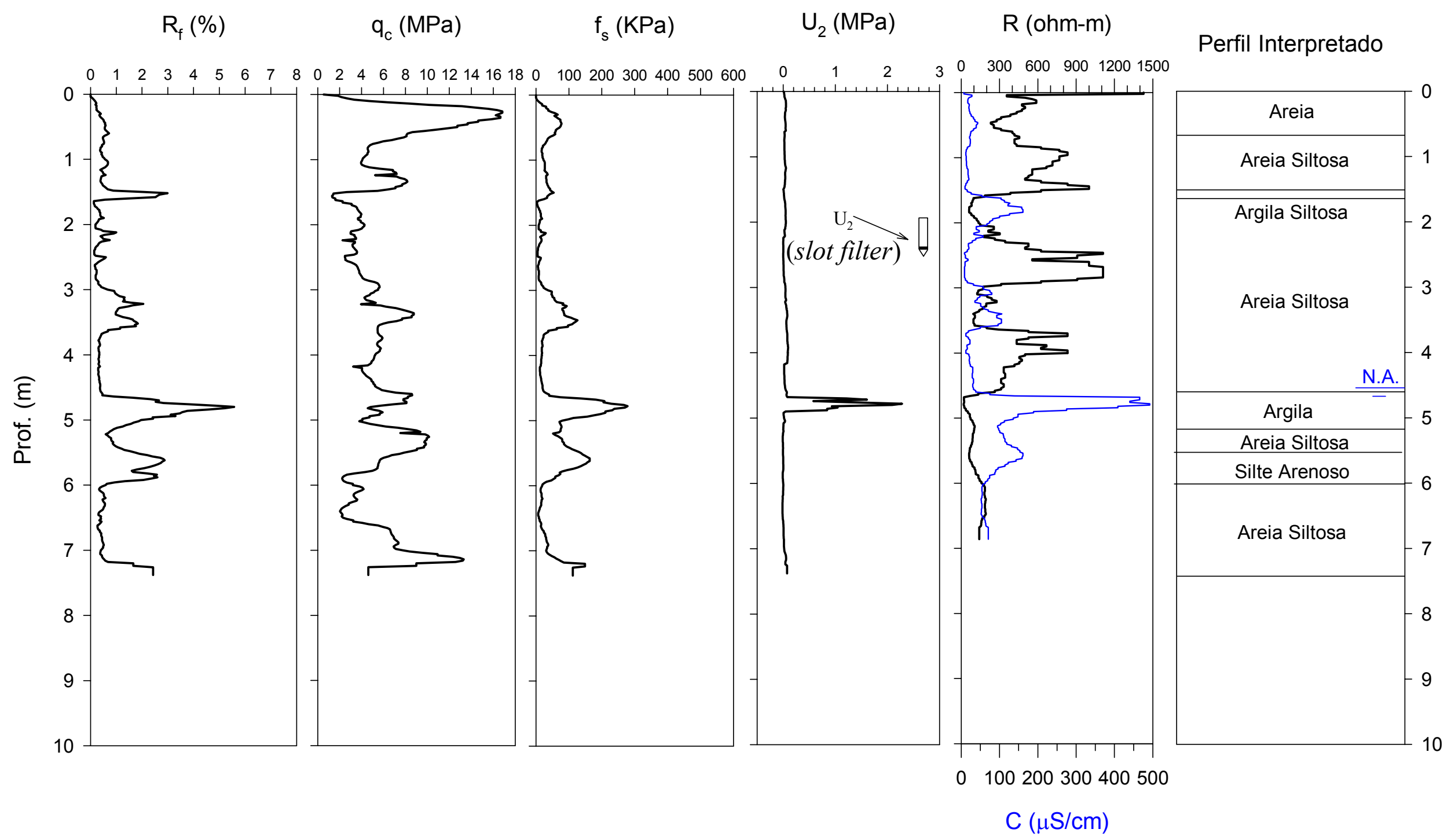


Aterro de Resíduos Sólidos Urbanos de Bauru - RCPTU 03 (Fev/2002)

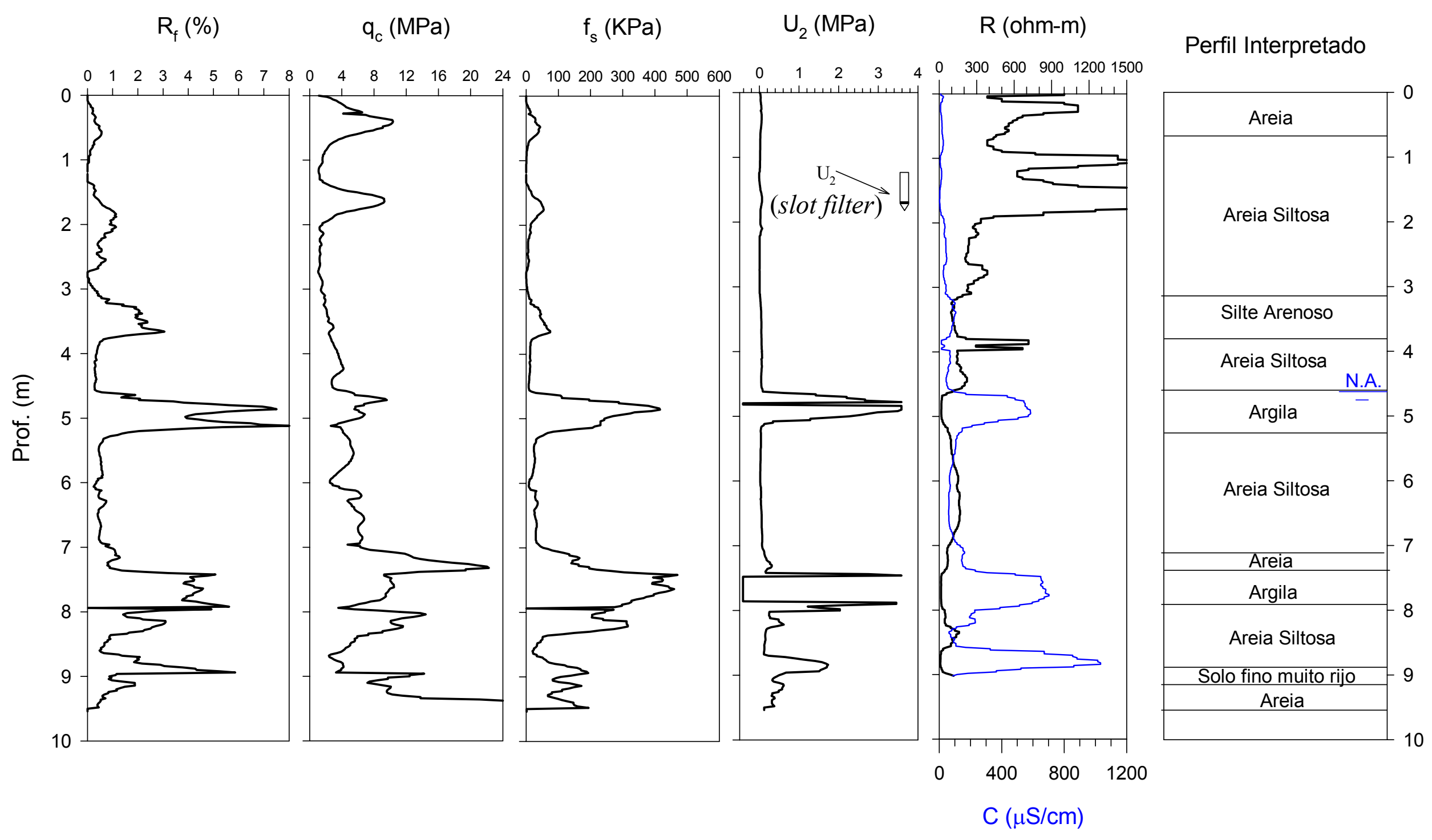




\section{Aterro de Resíduos Sólidos Urbanos de Bauru - RCPTU 04 (Fev/2002)}

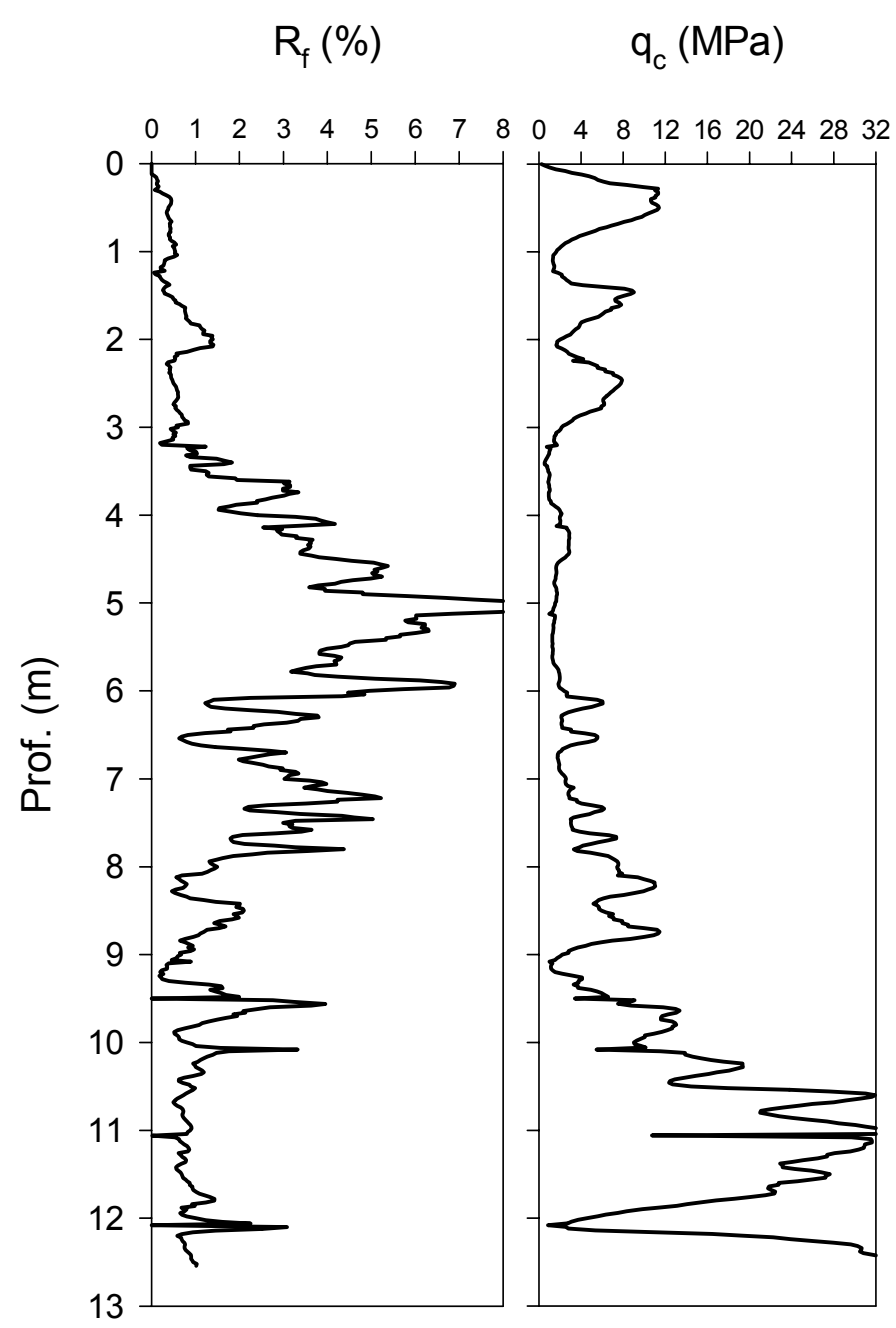

$f_{s}(K P a)$

$\mathrm{U}_{2}(\mathrm{MPa})$

$\mathrm{R}$ (ohm-m)
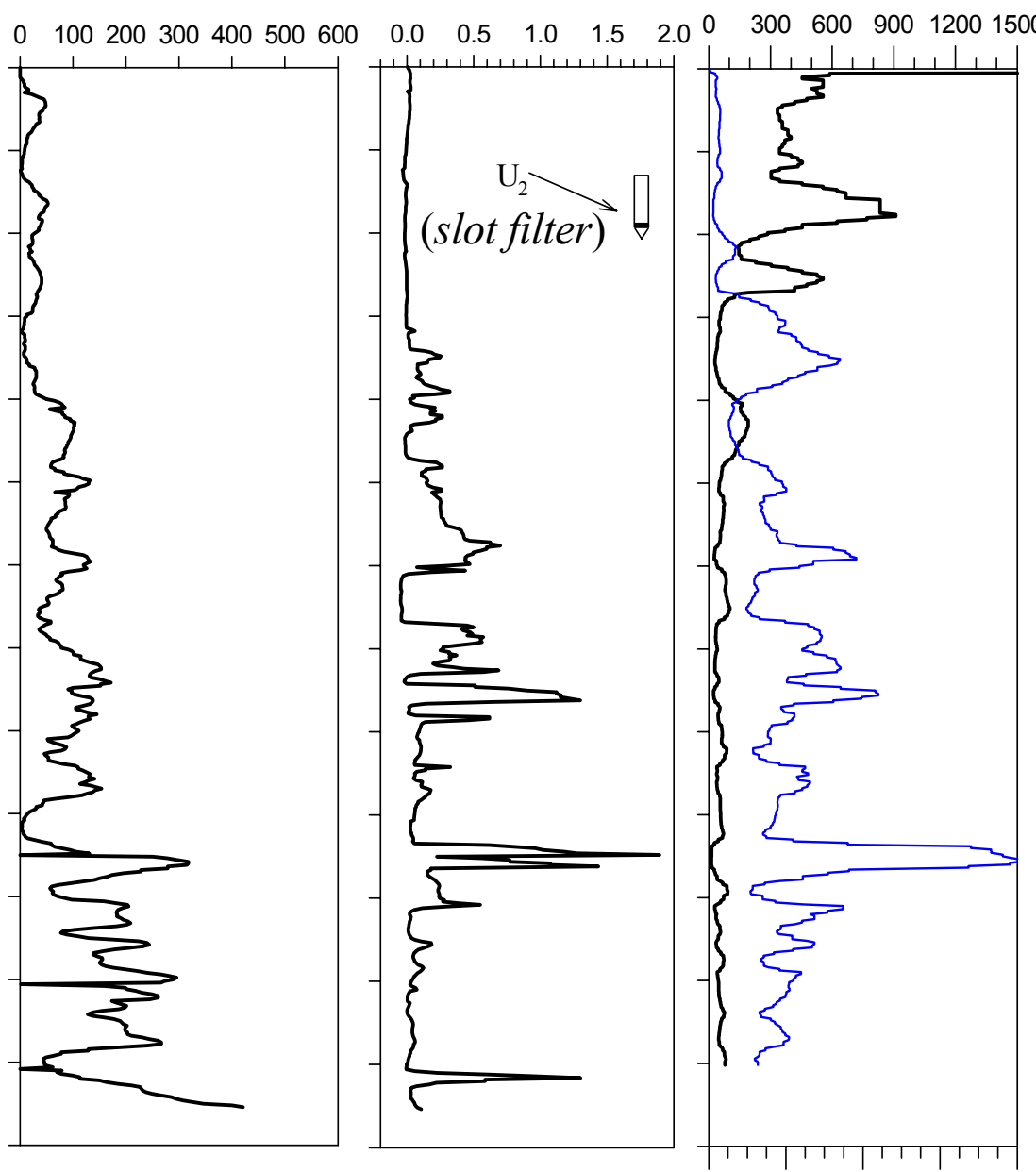

Perfil Interpretado

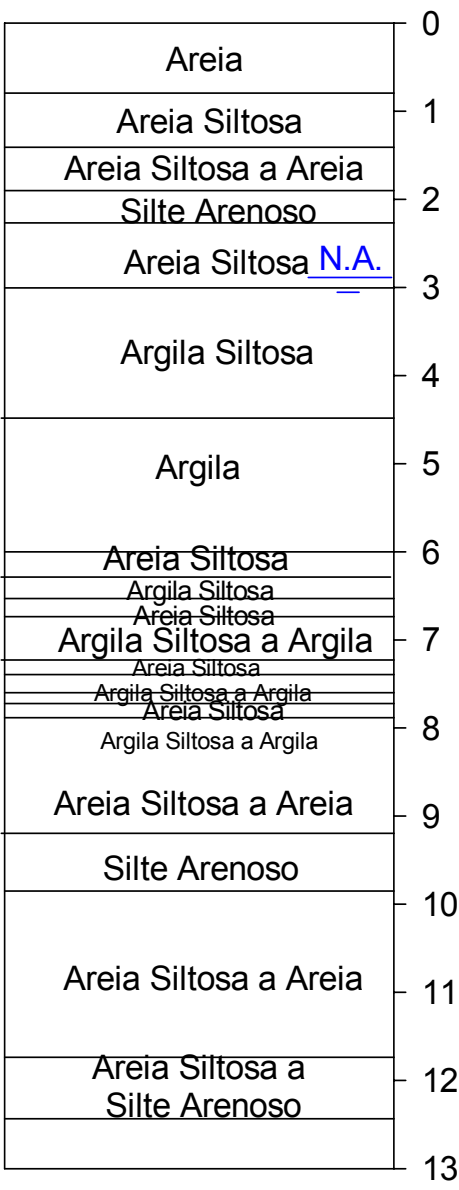

$0 \quad 200400 \quad 600 \quad 800$

$\mathrm{C}(\mu \mathrm{S} / \mathrm{cm})$ 
Aterro de Resíduos Sólidos Urbanos de Bauru - RCPTU 05 (Fev/2002)

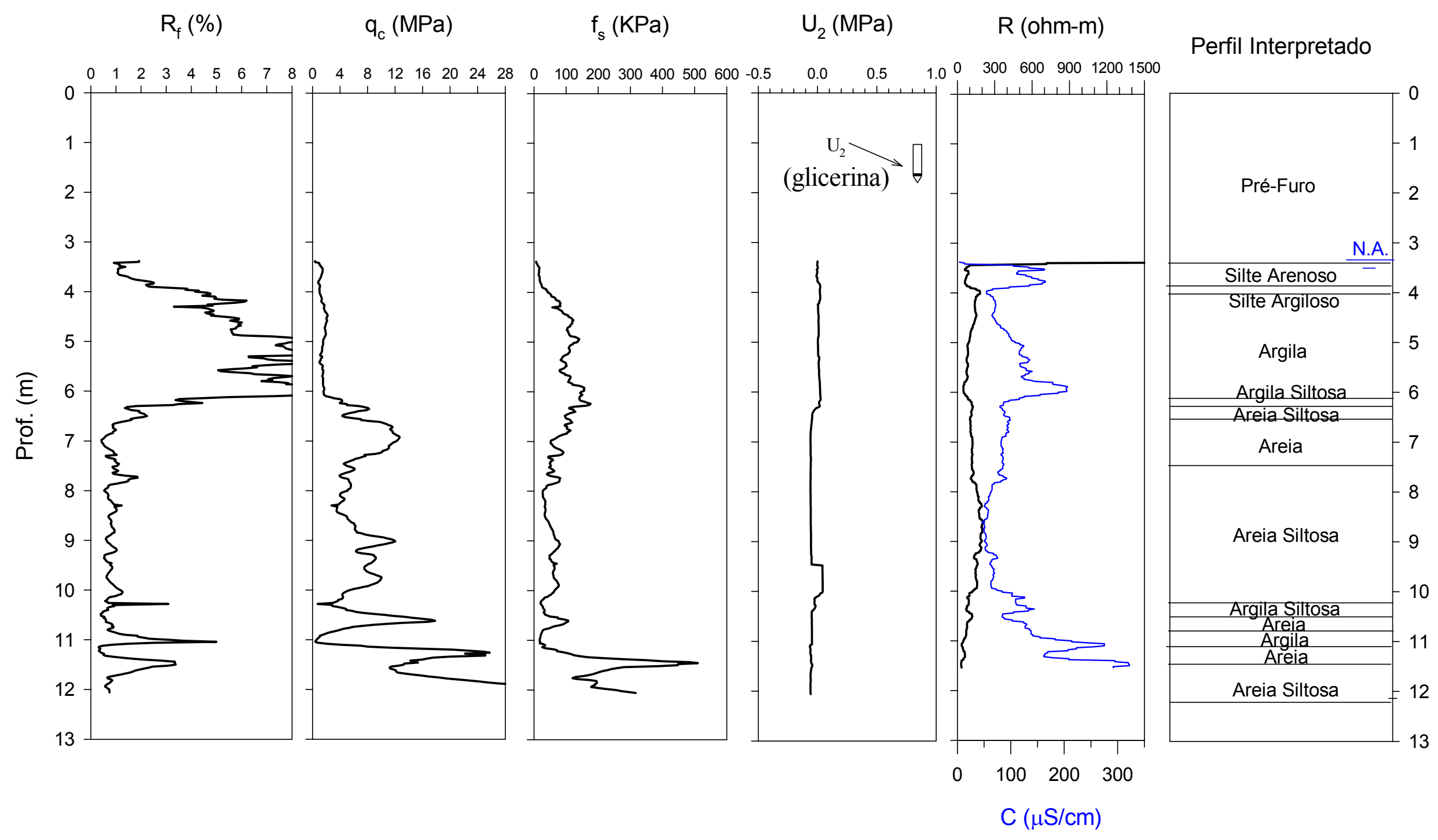


Aterro de Resíduos Sólidos Urbanos de Bauru - RCPTU 06 (Fev/2002)
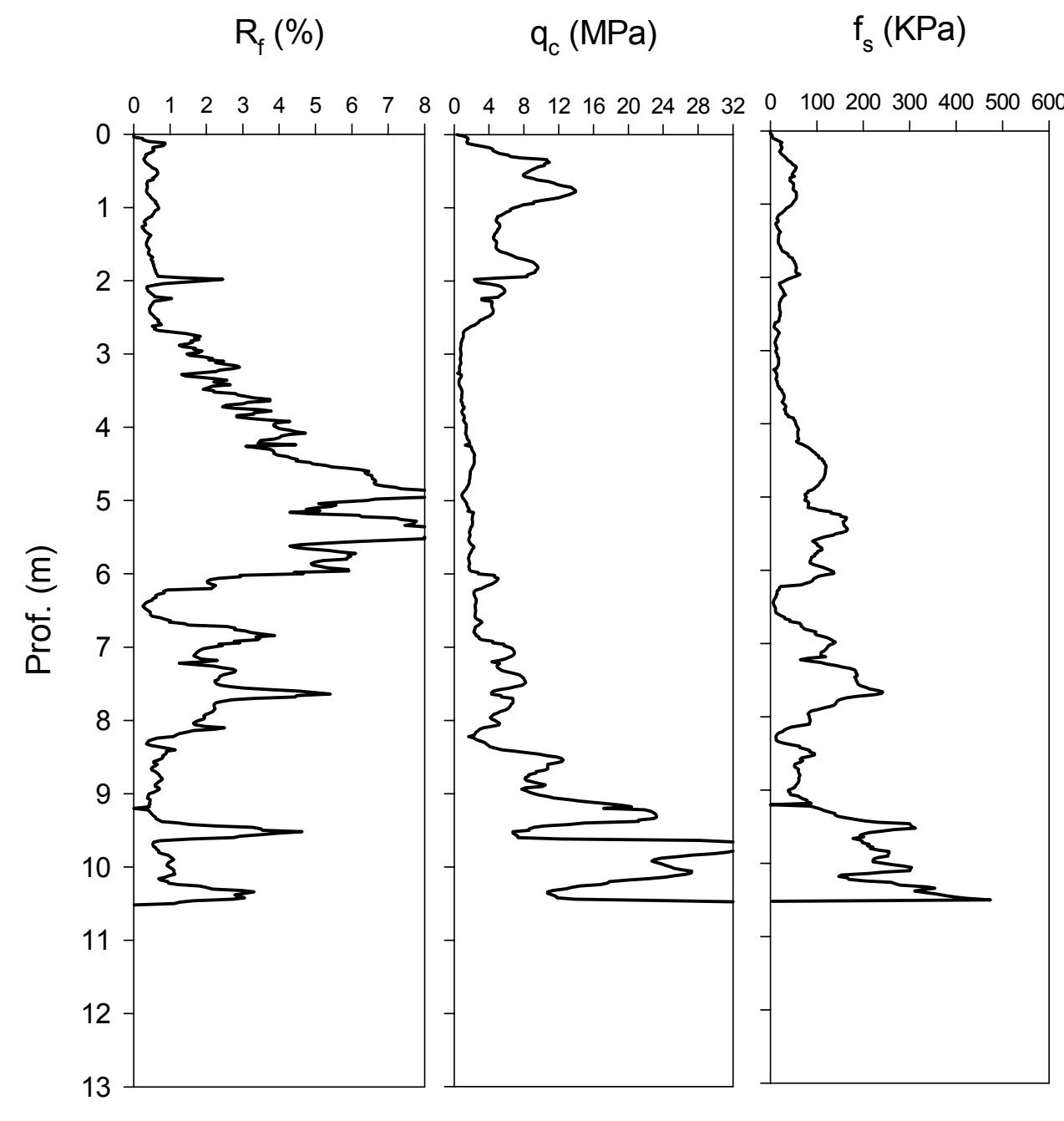

$$
\mathrm{U}_{2}(\mathrm{MPa})
$$

R (ohm-m)

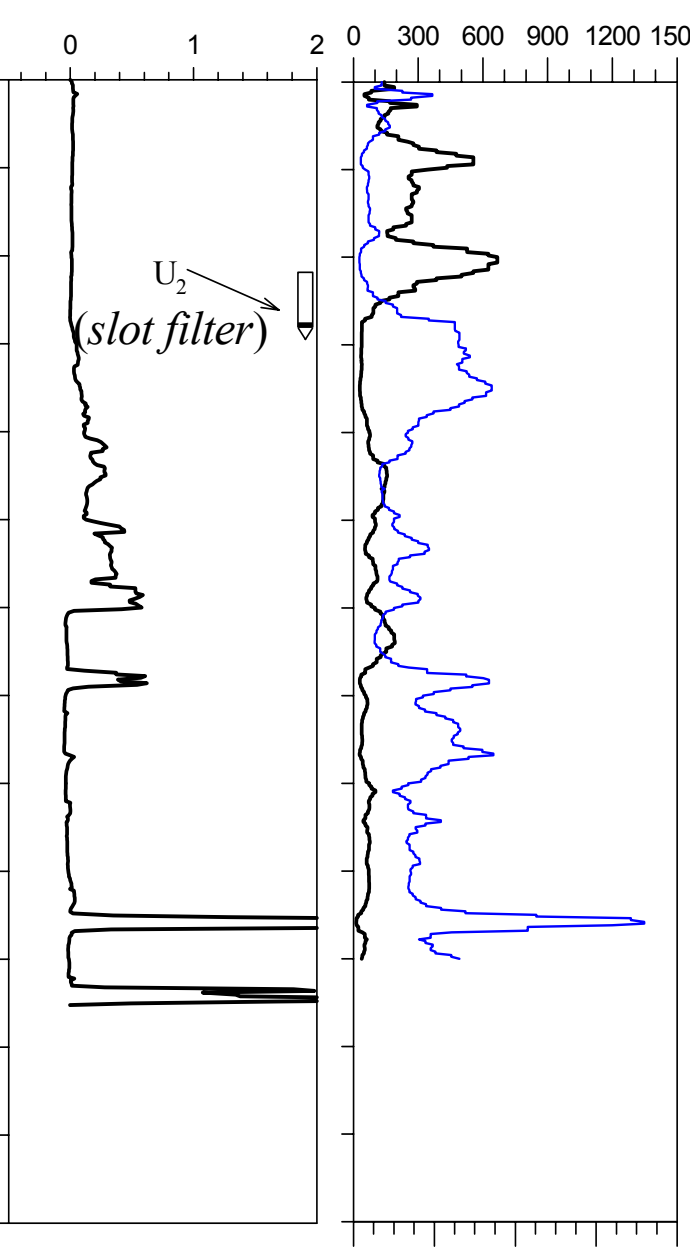

$\begin{array}{lllll}0 & 200 & 400 & 600 & 800\end{array}$

$\mathrm{C}(\mu \mathrm{S} / \mathrm{cm})$
Perfil Interpretado

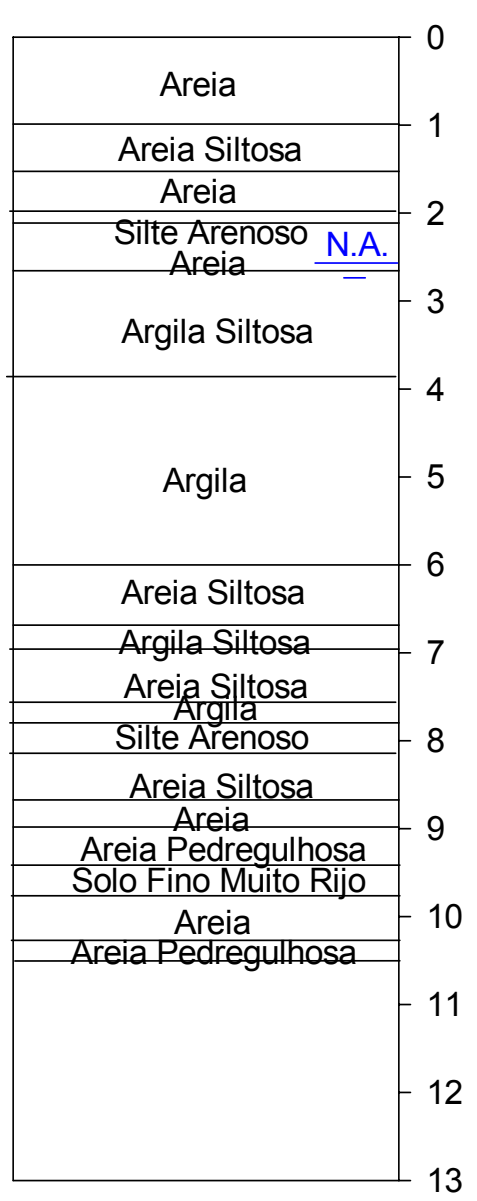

13 


\section{Aterro de Resíduos Sólidos Urbanos de Bauru - RCPTU 07 (Fev/2002)}

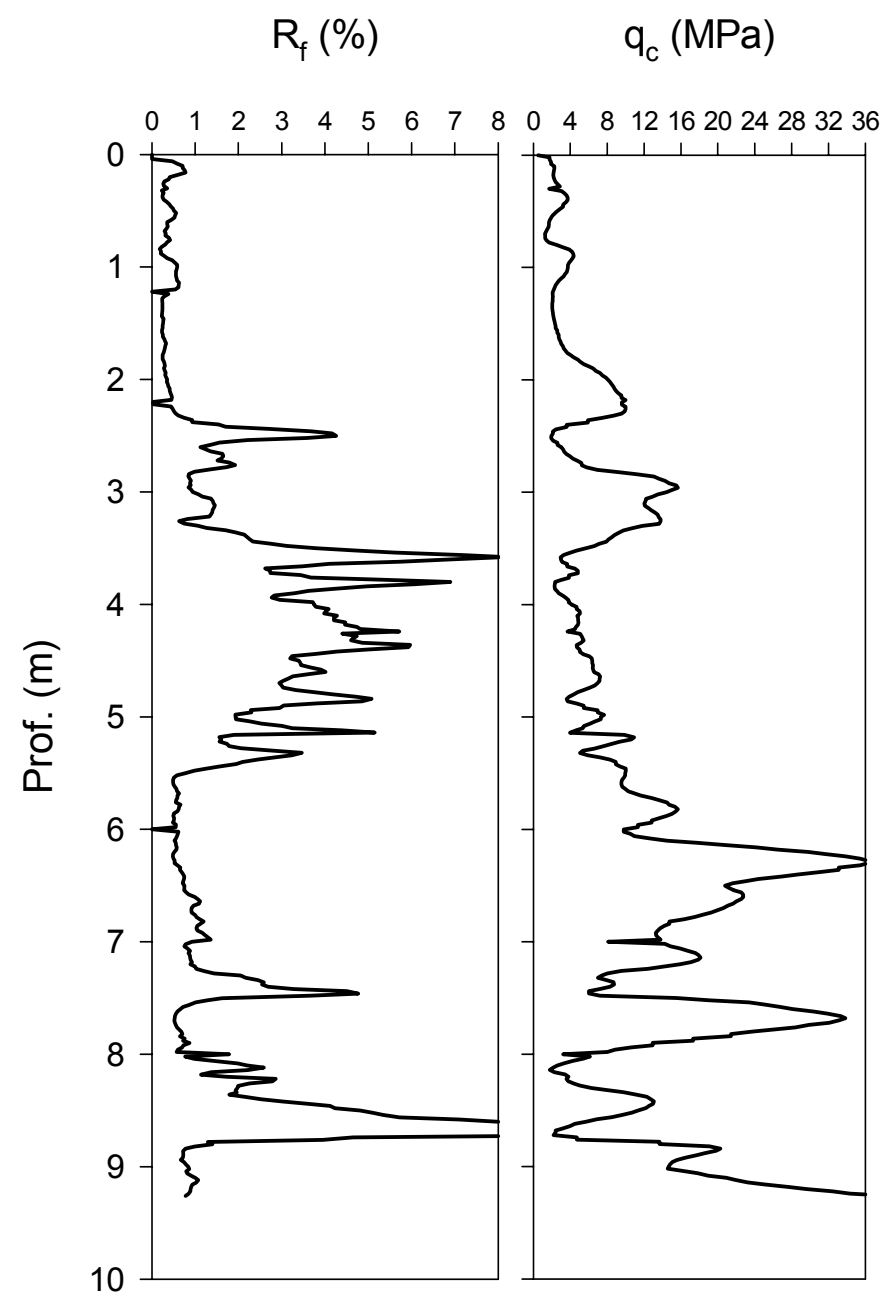

$\mathrm{f}_{\mathrm{s}}(\mathrm{KPa})$

$\mathrm{U}_{2}(\mathrm{MPa})$

R (ohm-m)
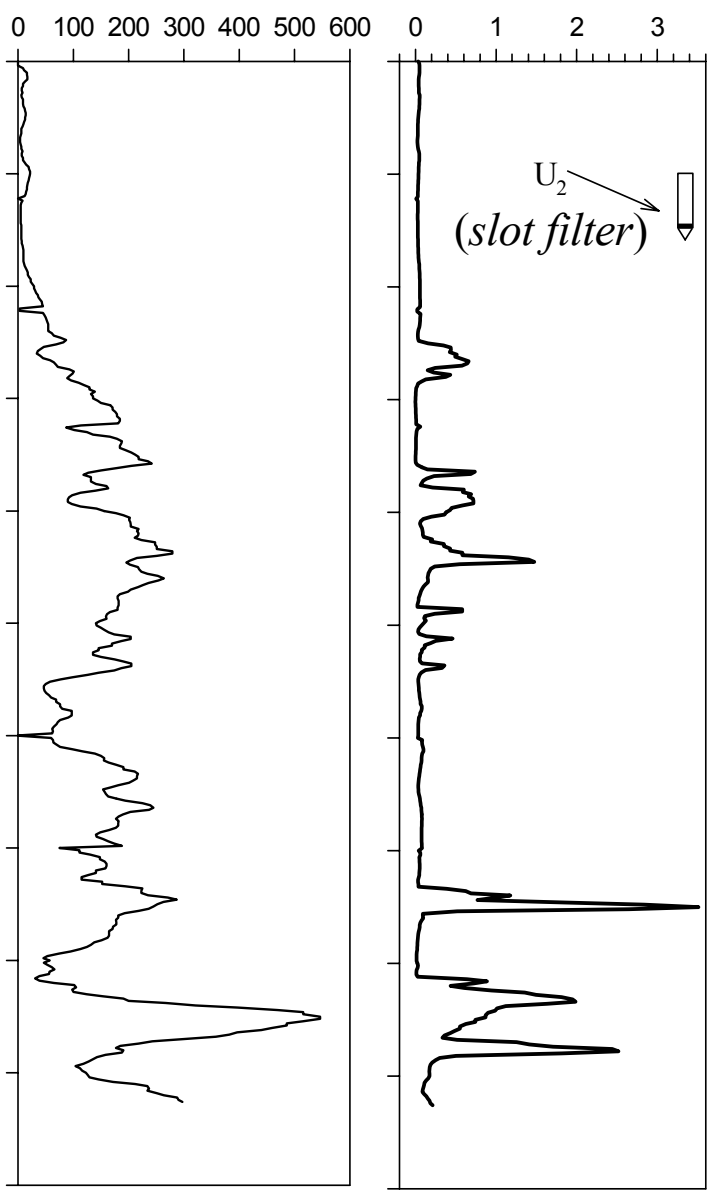

$0 \quad 30060090012001500$

Perfil Interpretado
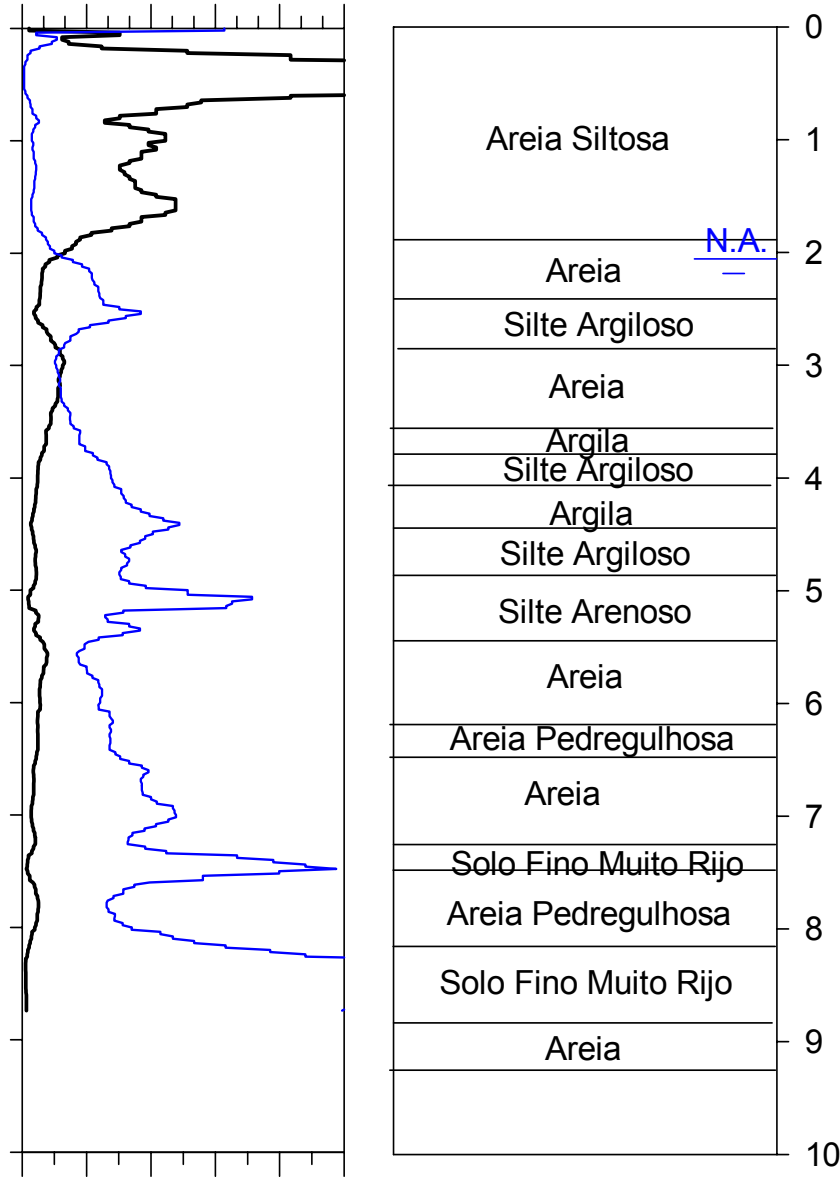

0100200300400500

$\mathrm{C}(\mu \mathrm{S} / \mathrm{cm})$ 
Aterro de Resíduos Sólidos Urbanos de Bauru - RCPTU 08 (Fev/2002)

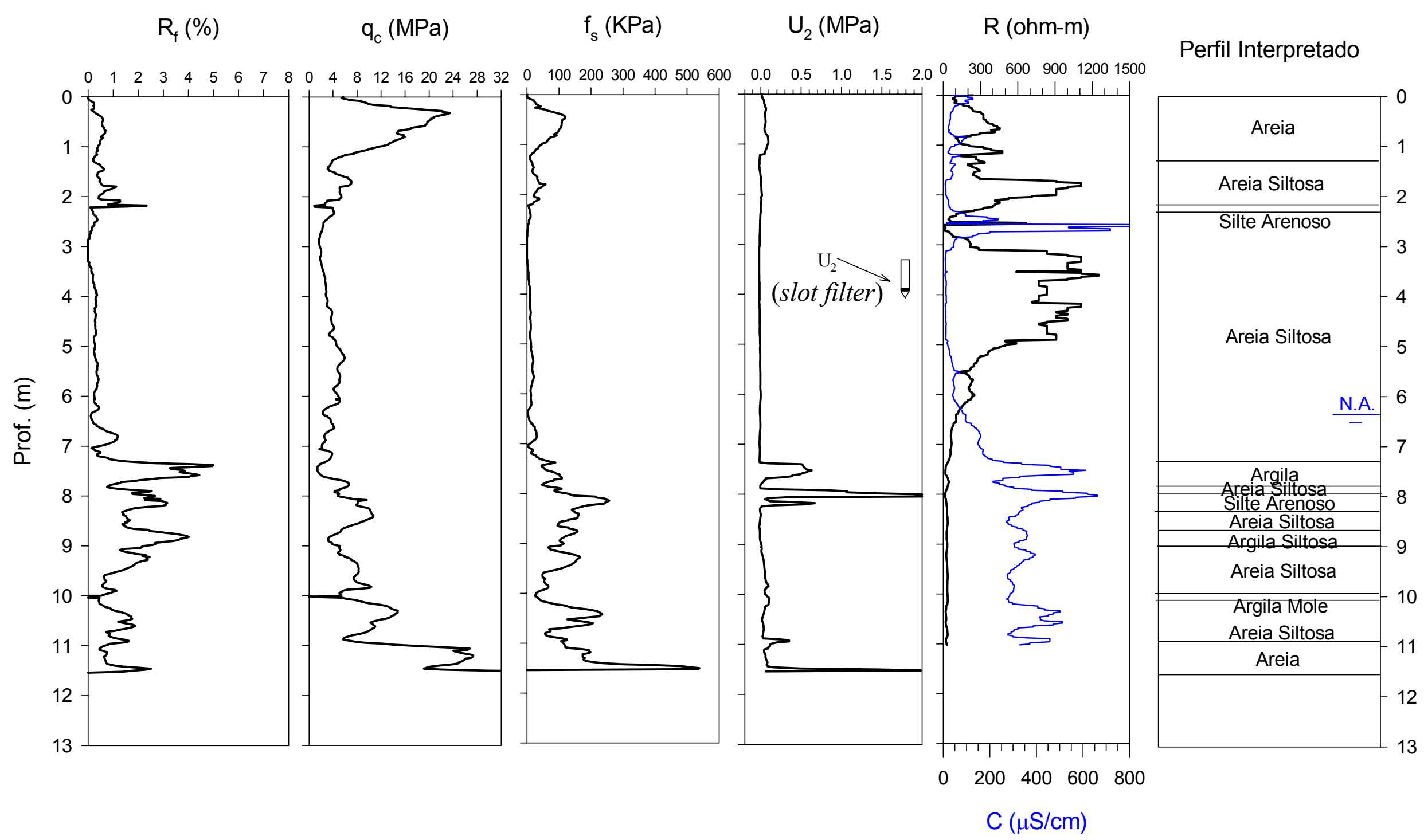


Aterro de Resíduos Sólidos Urbanos de Bauru - RCPTU 09 (Abr/2002)

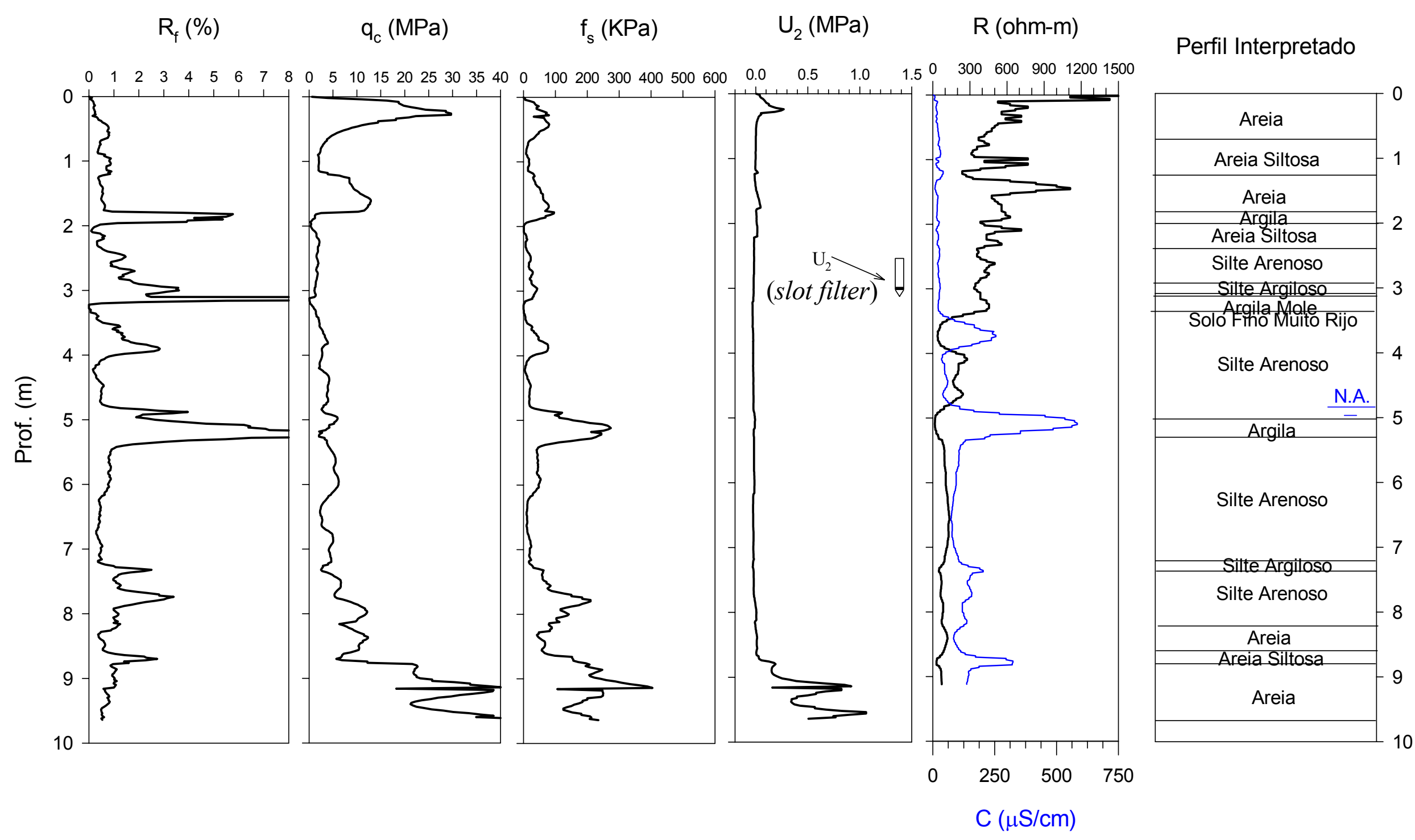


Aterro de Resíduos Sólidos Urbanos de Bauru - RCPTU 10 (Abr/2002)

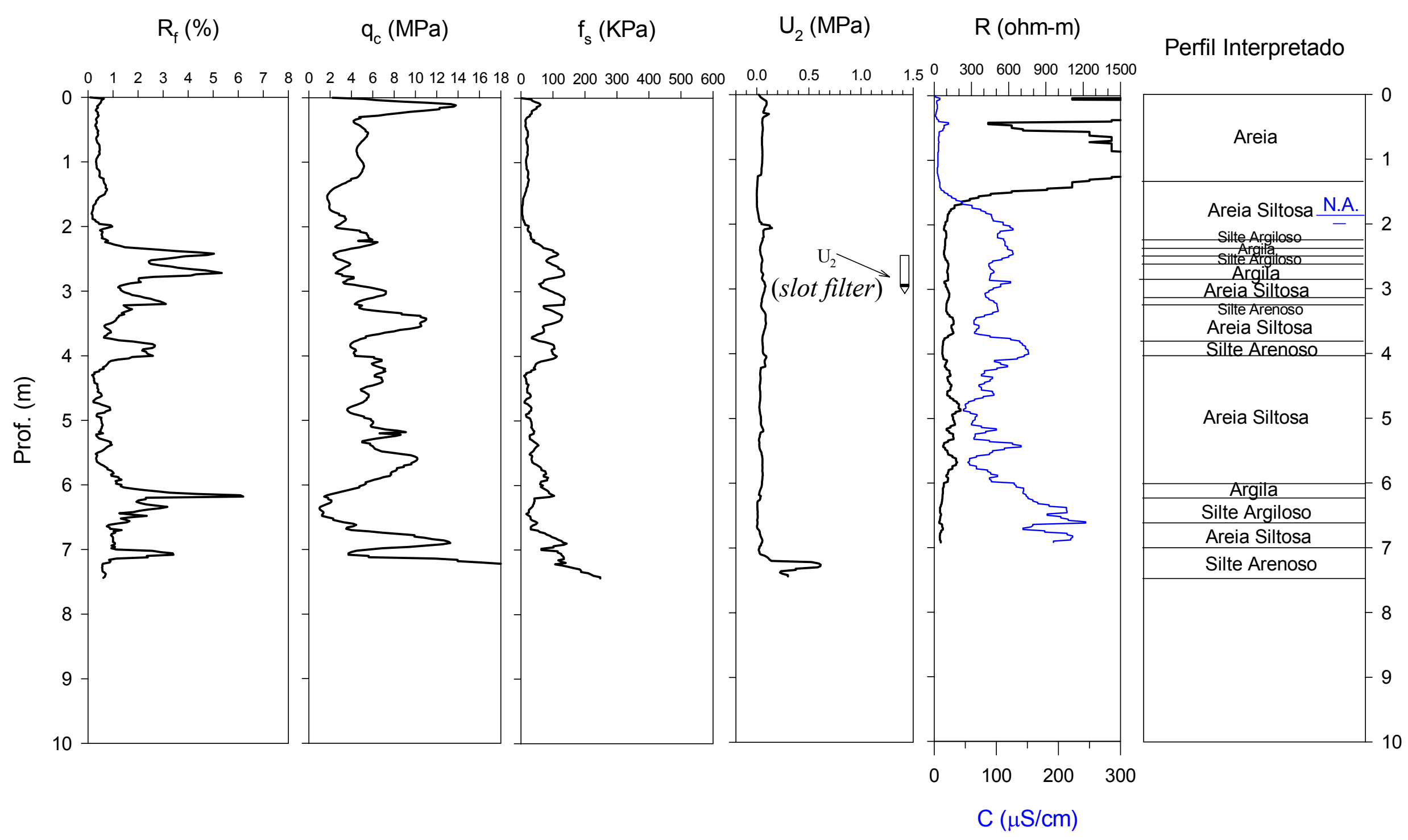


Aterro de Resíduos Sólidos Urbanos de Bauru - RCPTU 11 (Abr/2002)

$\mathrm{R}_{\mathrm{f}}(\%)$

$\mathrm{q}_{\mathrm{c}}(\mathrm{MPa})$

$\mathrm{f}_{\mathrm{s}}(\mathrm{KPa})$

$\mathrm{U}_{2}(\mathrm{MPa})$

R (ohm-m)
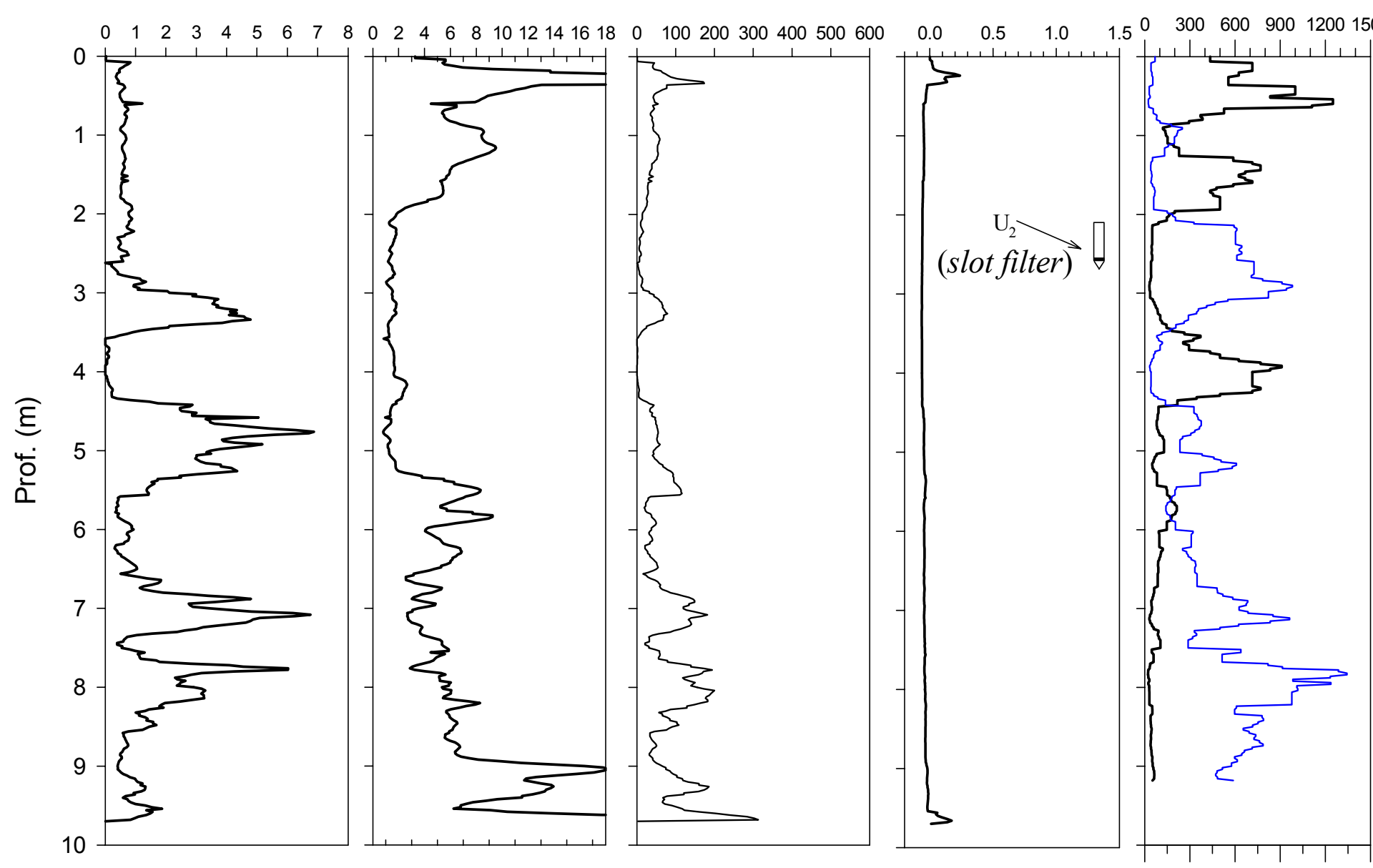

Perfil Interpretado

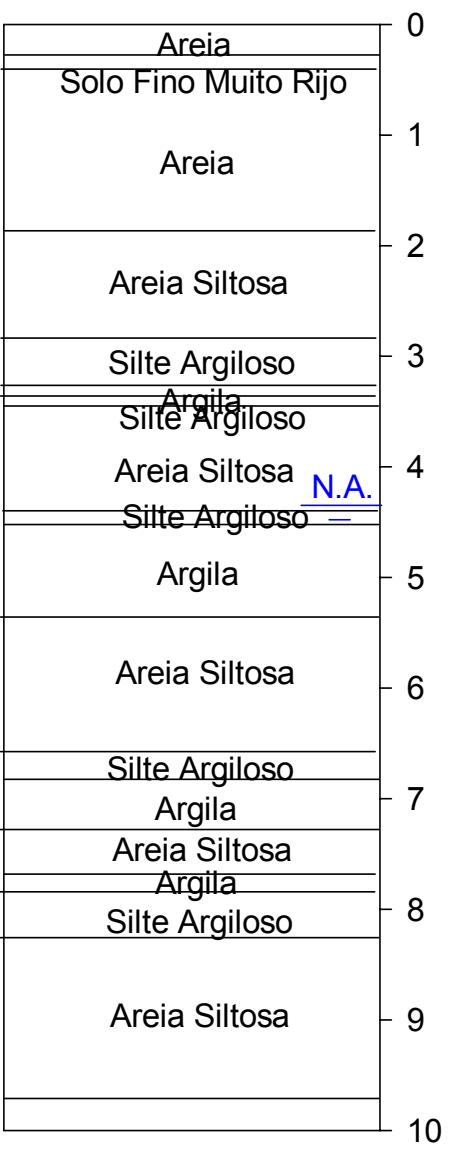

$0 \quad 100200300400500$

$\mathrm{C}(\mu \mathrm{S} / \mathrm{cm})$ 
Aterro de Resíduos Sólidos Urbanos de Bauru - RCPTU 12 (Abr/2002)

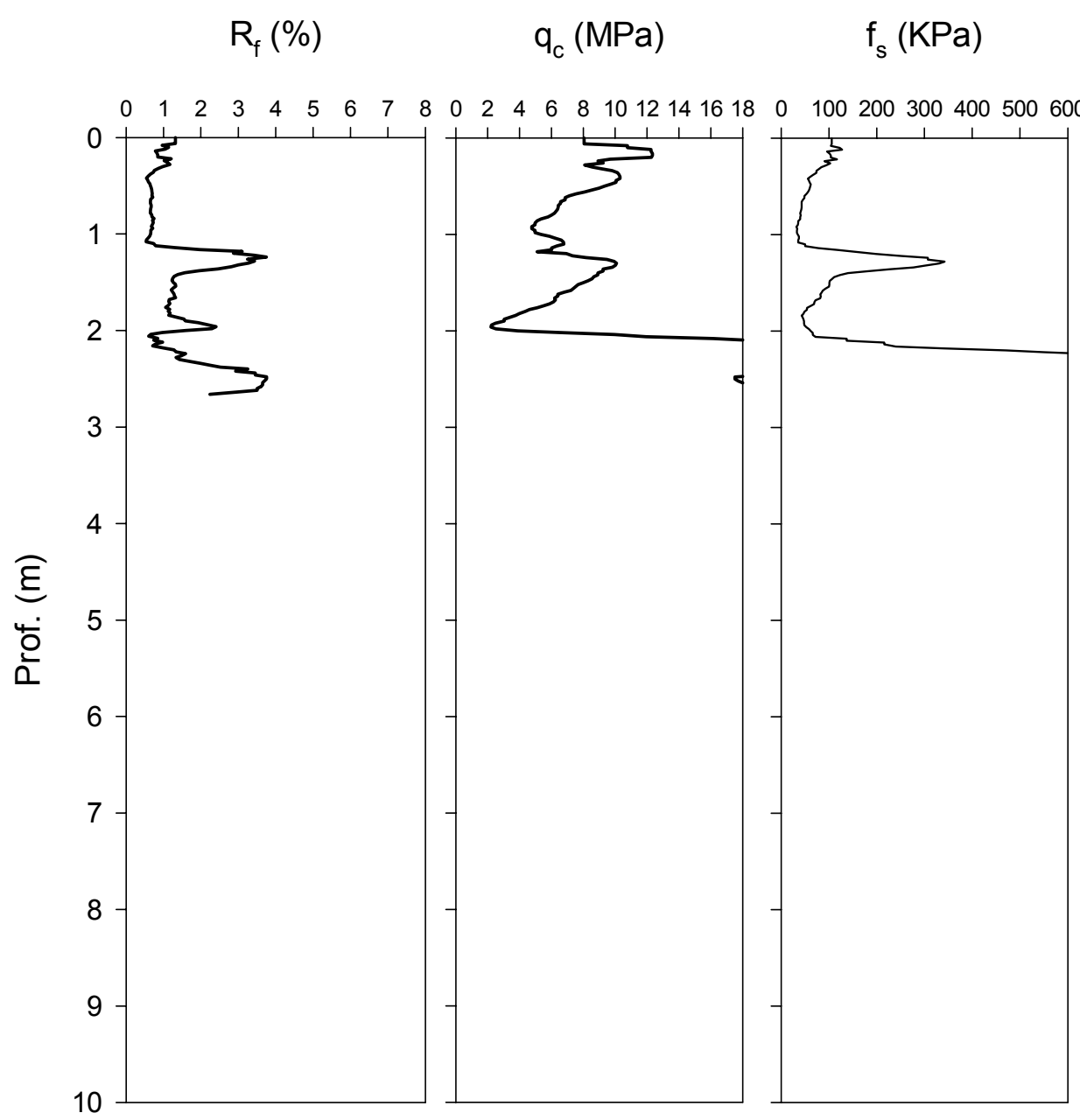

$\mathrm{f}_{\mathrm{s}}(\mathrm{KPa})$

$\mathrm{U}_{2}(\mathrm{MPa})$

$\mathrm{R}$ (ohm-m)

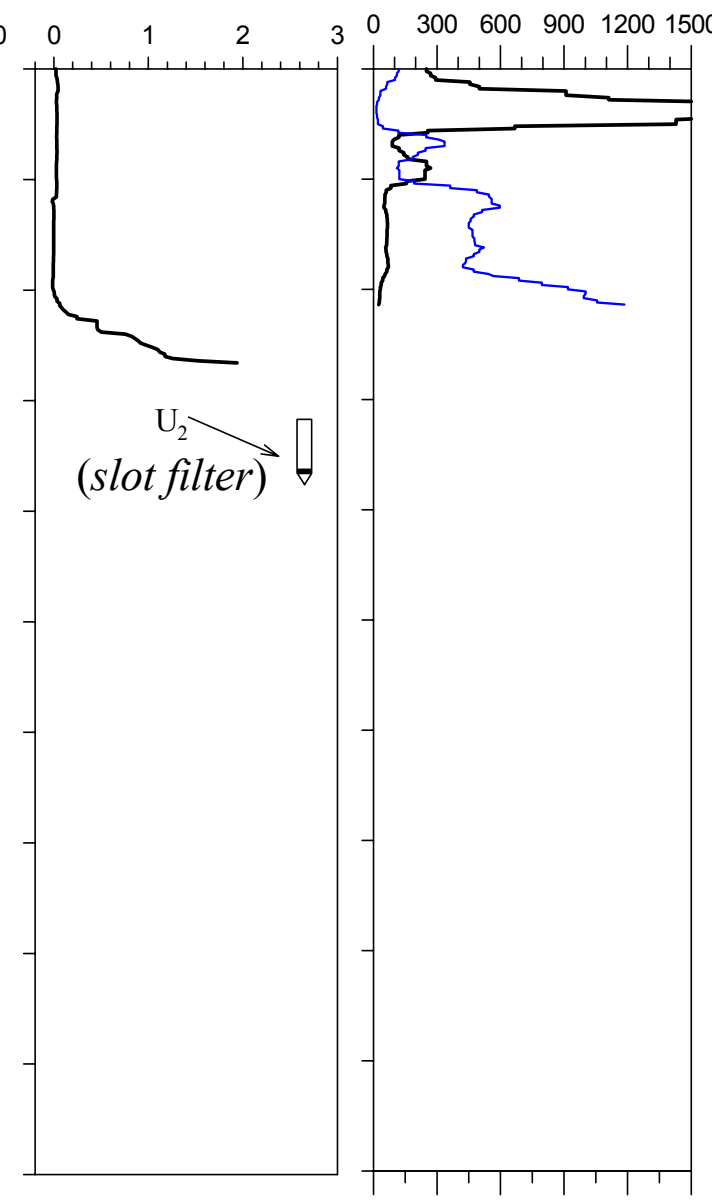

Perfil Interpretado

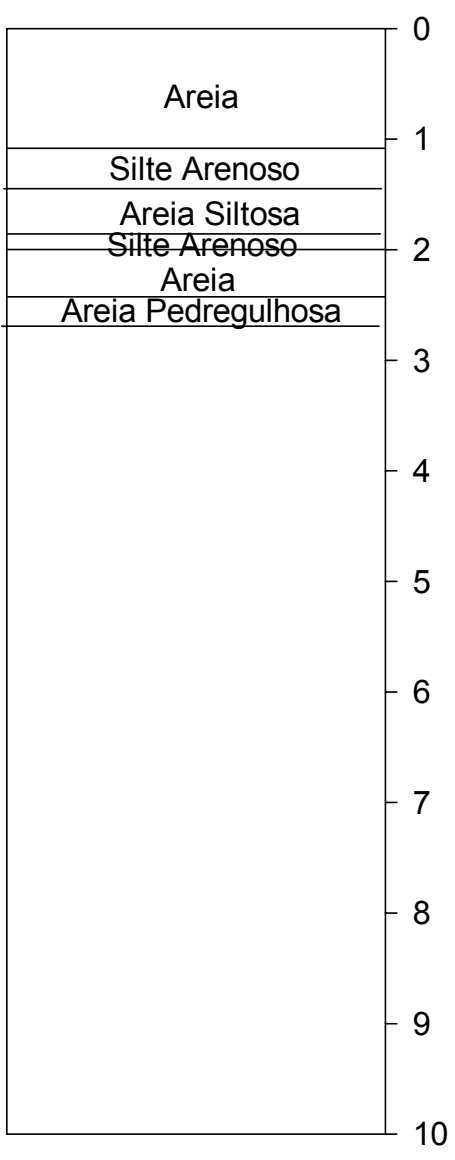

0100200300400500

$$
\mathrm{C}(\mu \mathrm{S} / \mathrm{cm})
$$


Aterro de Resíduos Sólidos Urbanos de Bauru - RCPTU 13 (Abr/2002)
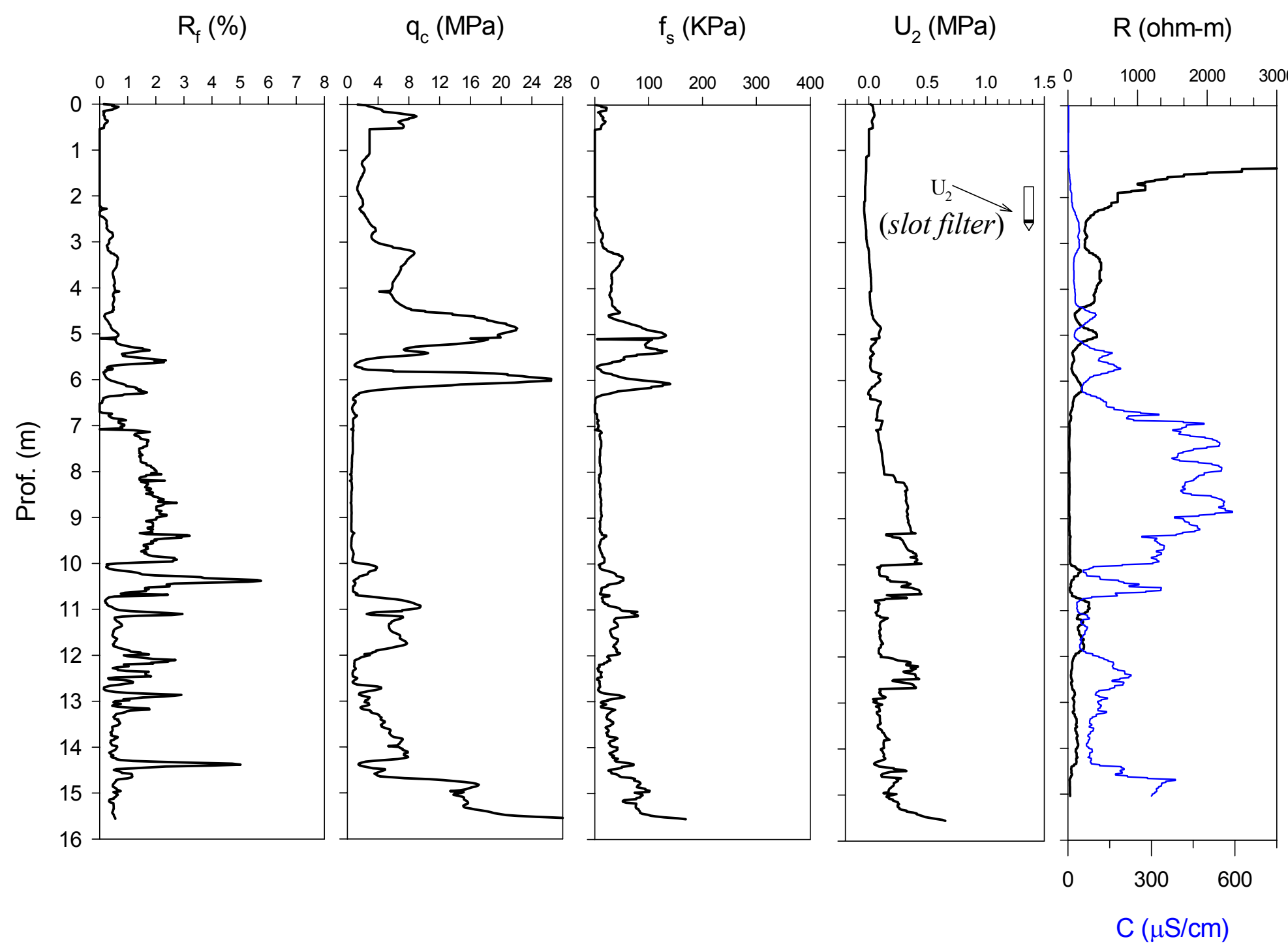

Perfil Interpretado

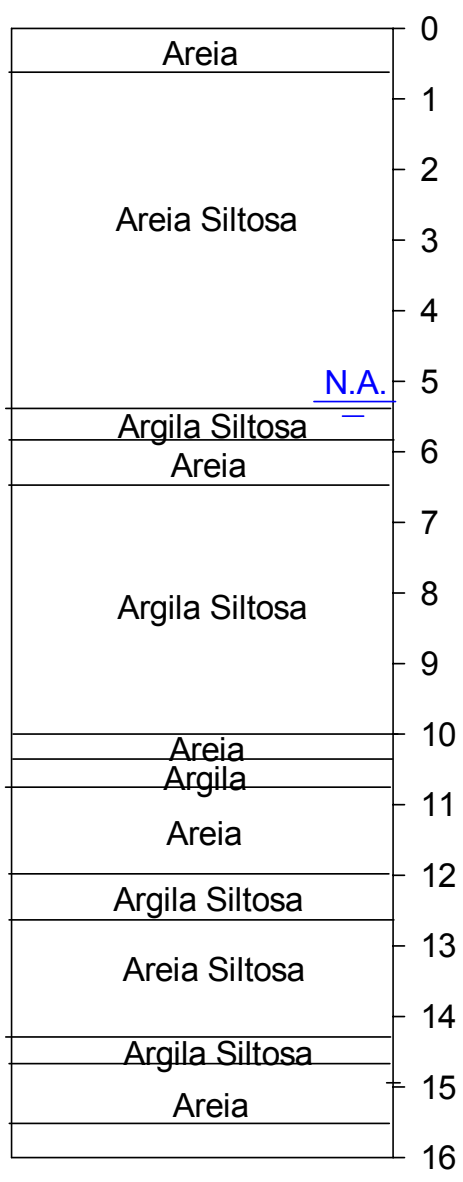


Aterro de Resíduos Sólidos Urbanos de Bauru - RCPTU 14 (Abr/2002)

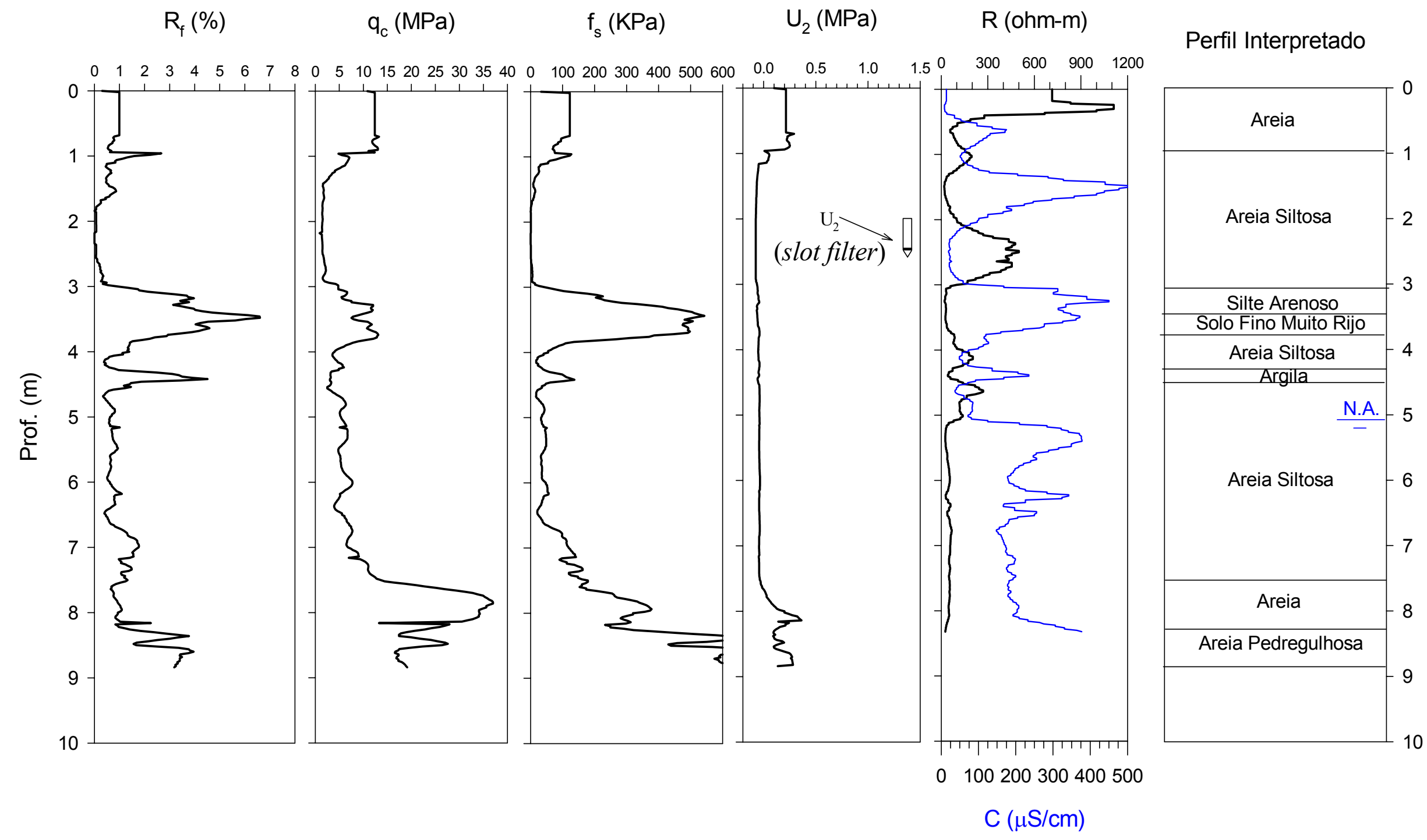


Aterro de Resíduos Sólidos Urbanos de Bauru - RCPTU 15 (Jul/2002)

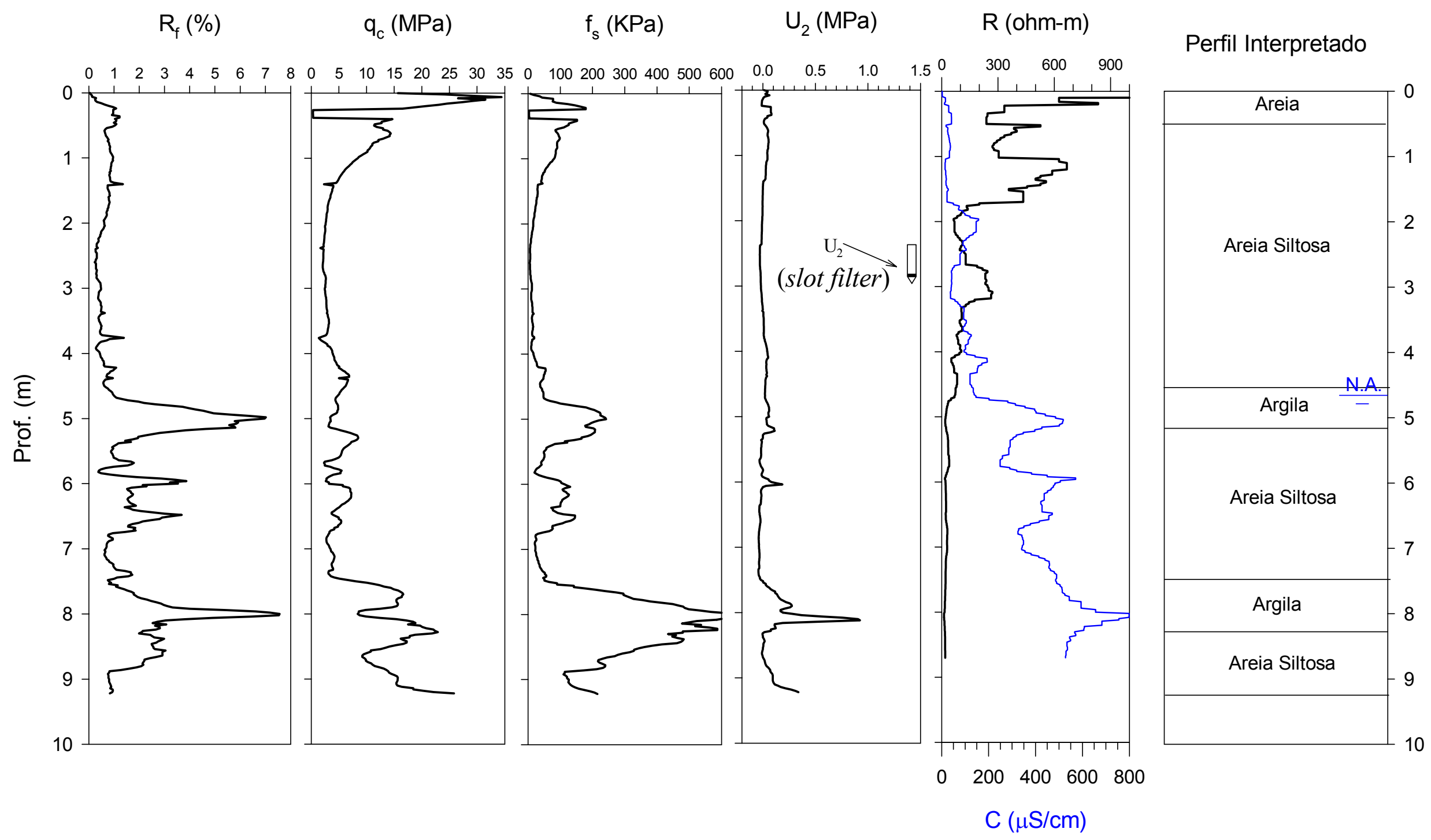




\section{Aterro de Resíduos Sólidos Urbanos de Bauru - RCPTU 16 (Jul/2002)}

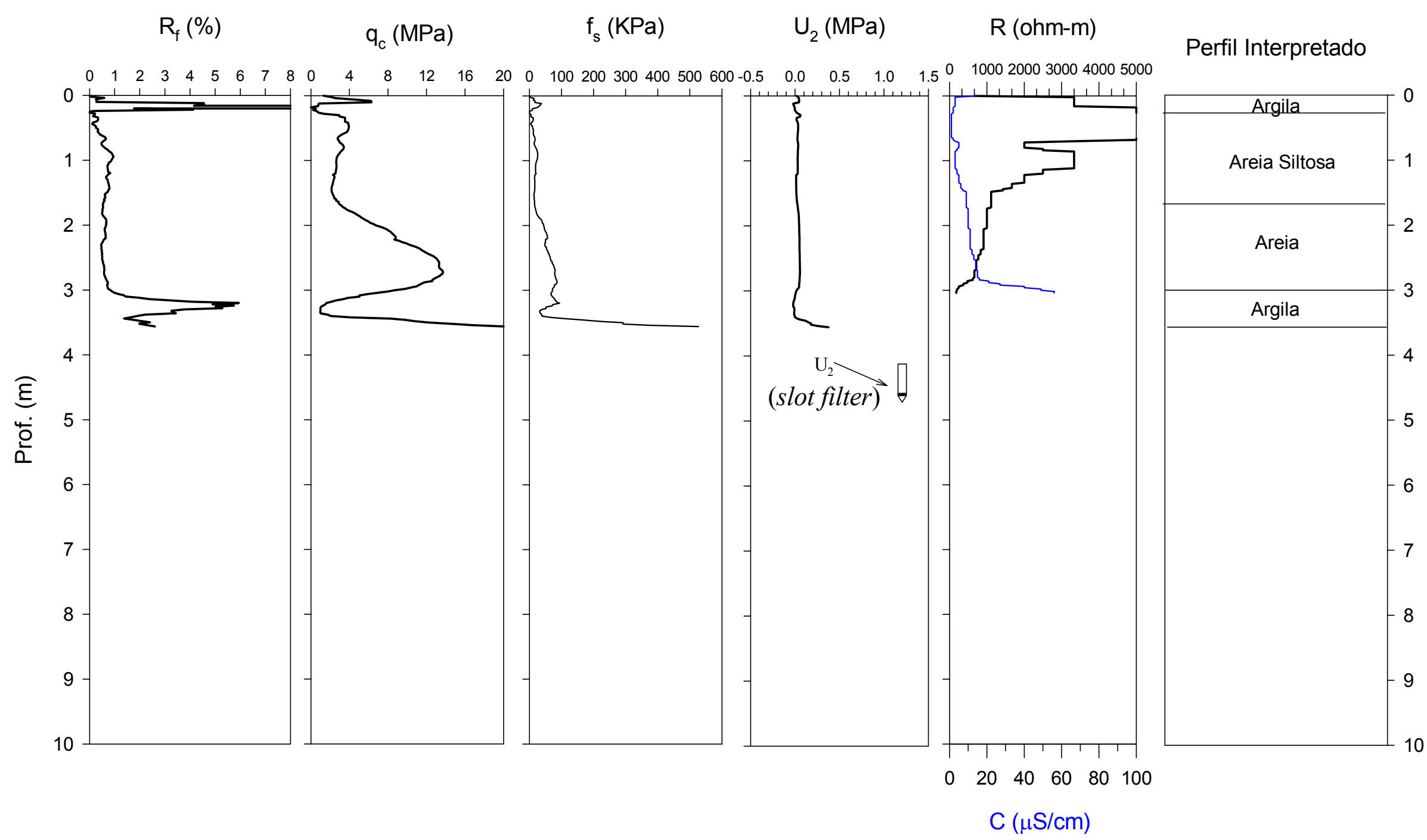




\section{ANEXO III}

Resultados das Dissipações do Excesso das Poro-pressões Realizadas em Algumas Sondagens RCPTU no Aterro de Resíduos Sólidos Urbanos de Bauru 


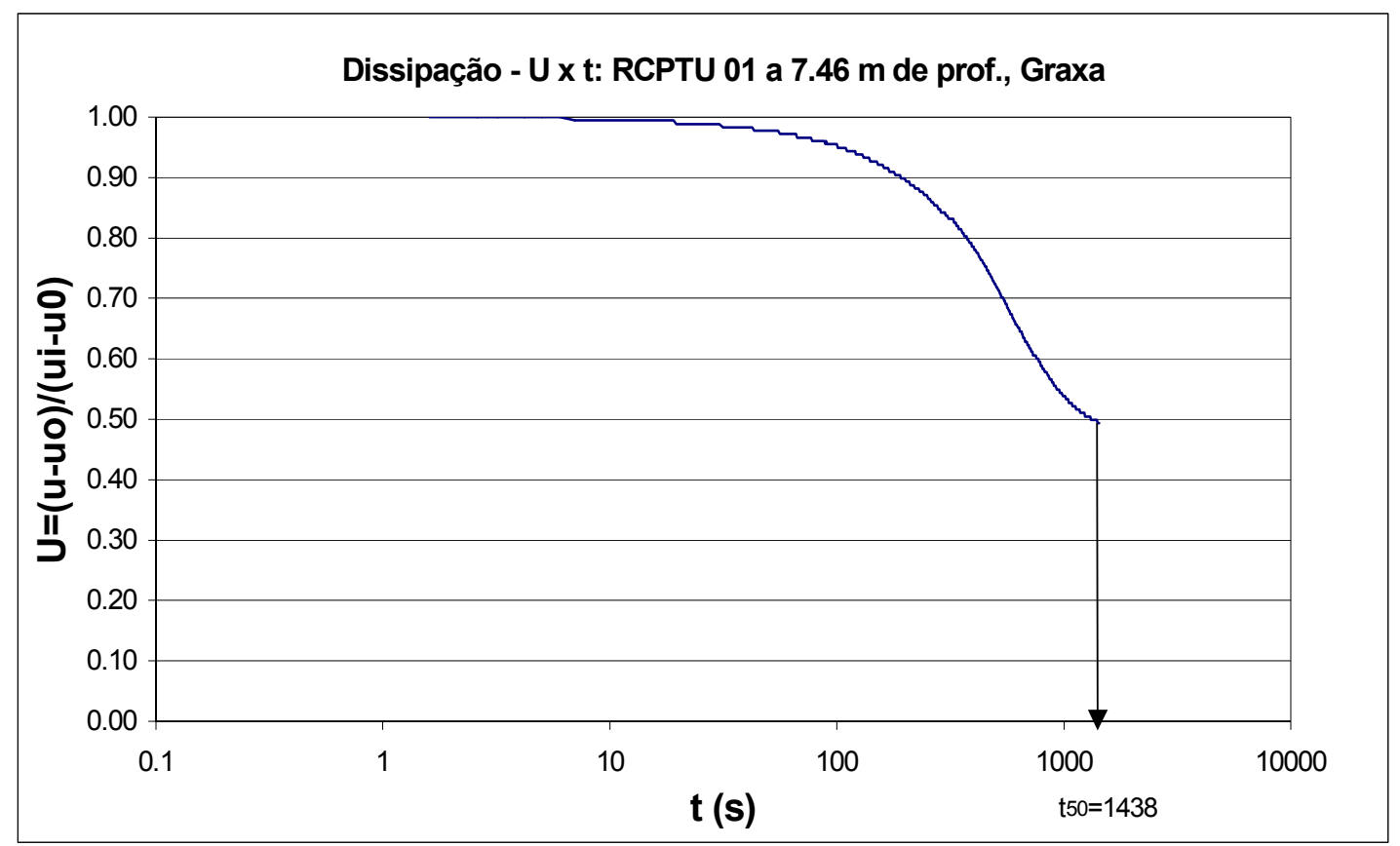

Curva de Dissipação do Excesso de Poro-pressão versus Tempo para o ensaio RCPTU 01

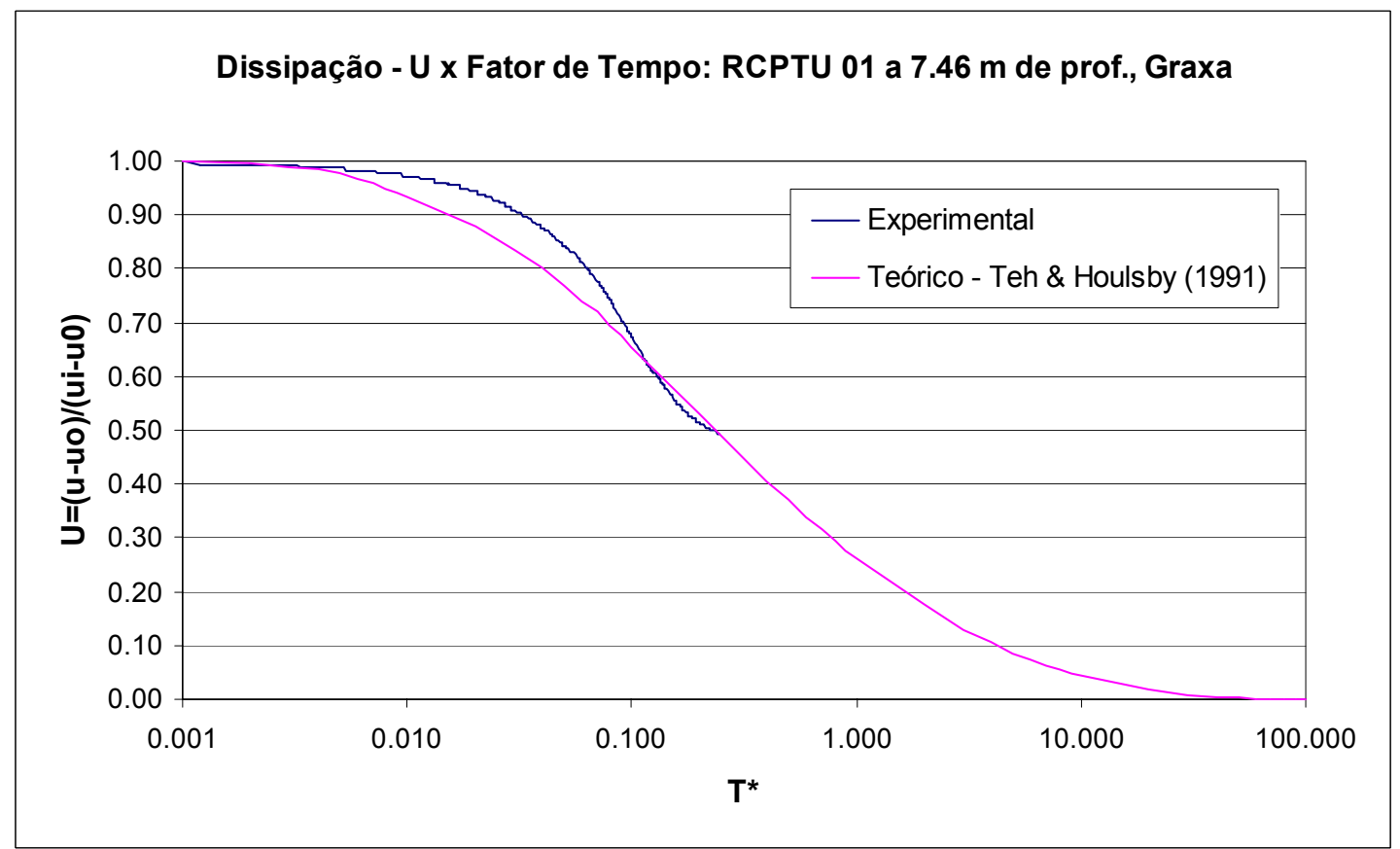

Curva de Dissipação do Excesso de Poro-pressão versus Fator Tempo para o ensaio RCPTU 01 


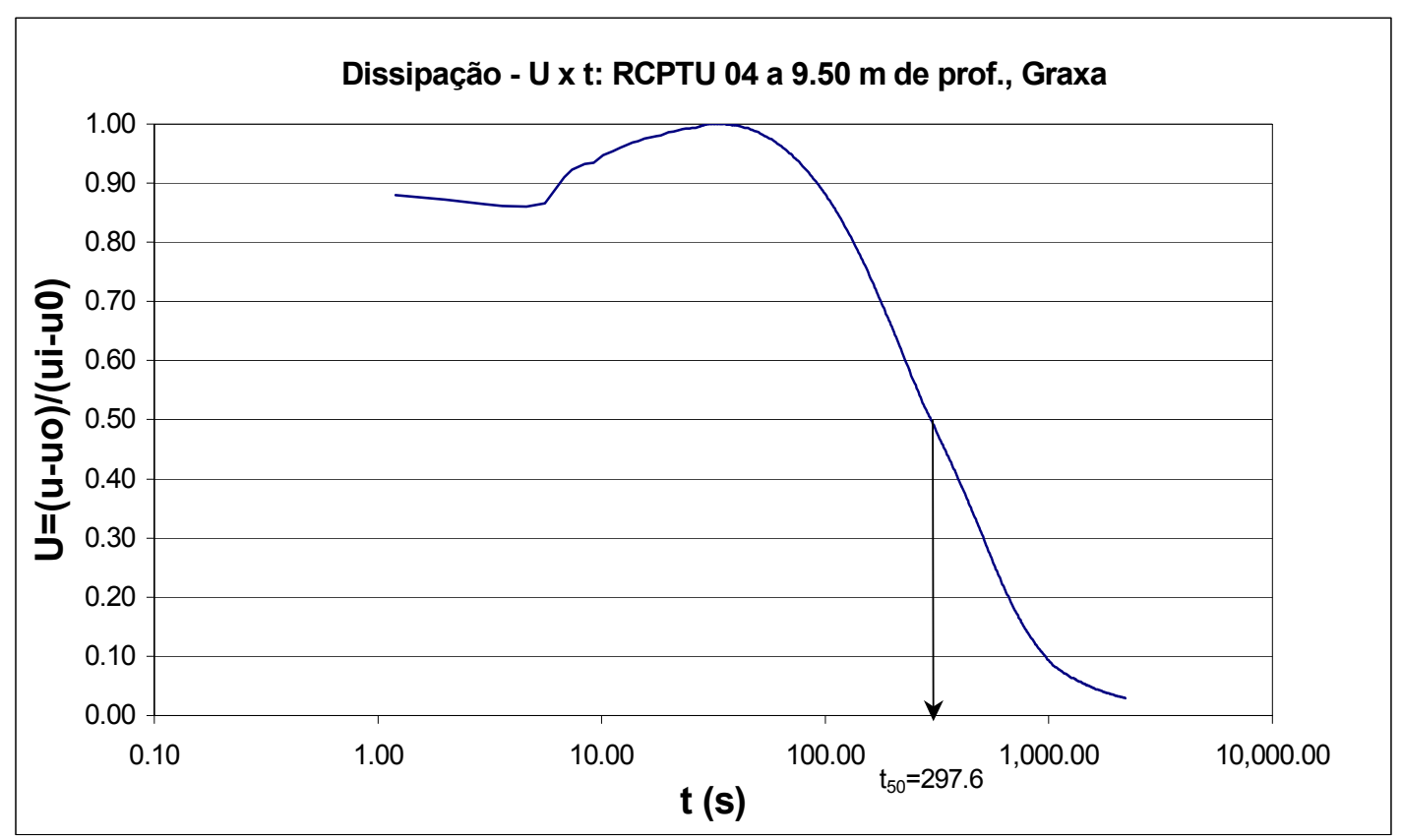

Curva de Dissipação do Excesso de Poro-pressão versus Tempo para o ensaio RCPTU 04

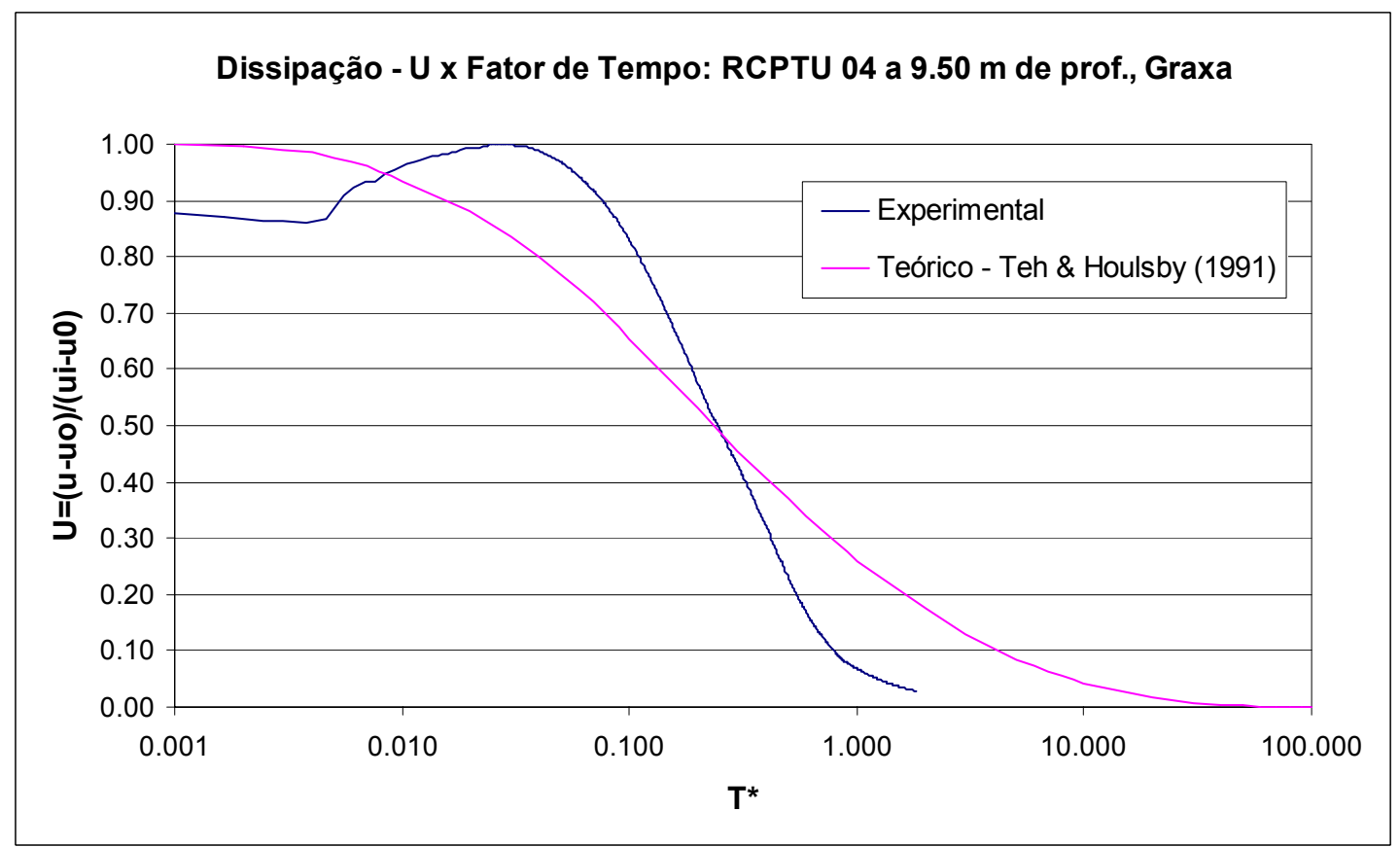

Curva de Dissipação do Excesso de Poro-pressão versus Fator Tempo para o ensaio RCPTU 04 


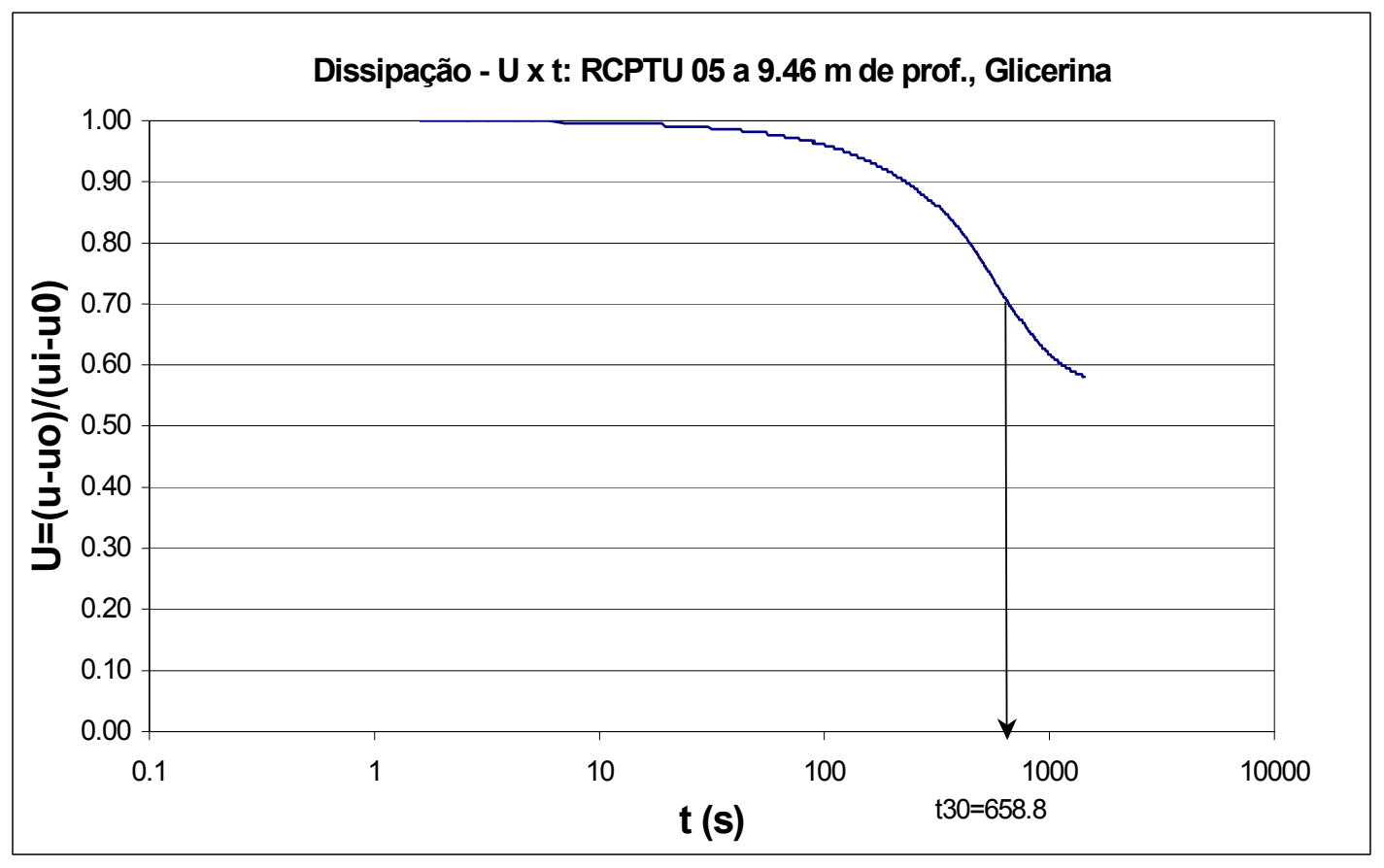

Curva de Dissipação do Excesso de Poro-pressão versus Tempo para o ensaio RCPTU 05

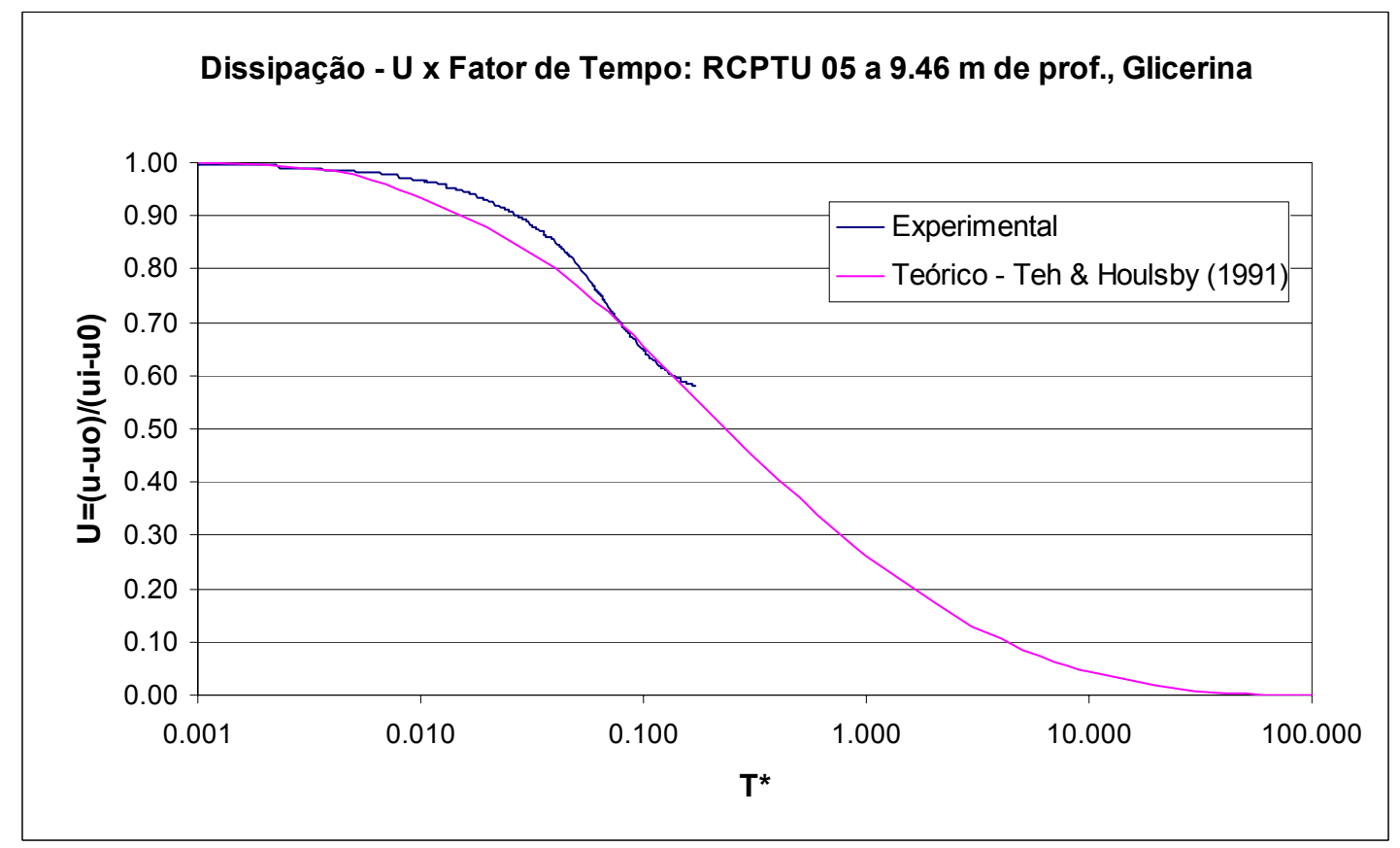

Curva de Dissipação do Excesso de Poro-pressão versus Fator Tempo para o ensaio RCPTU 05 


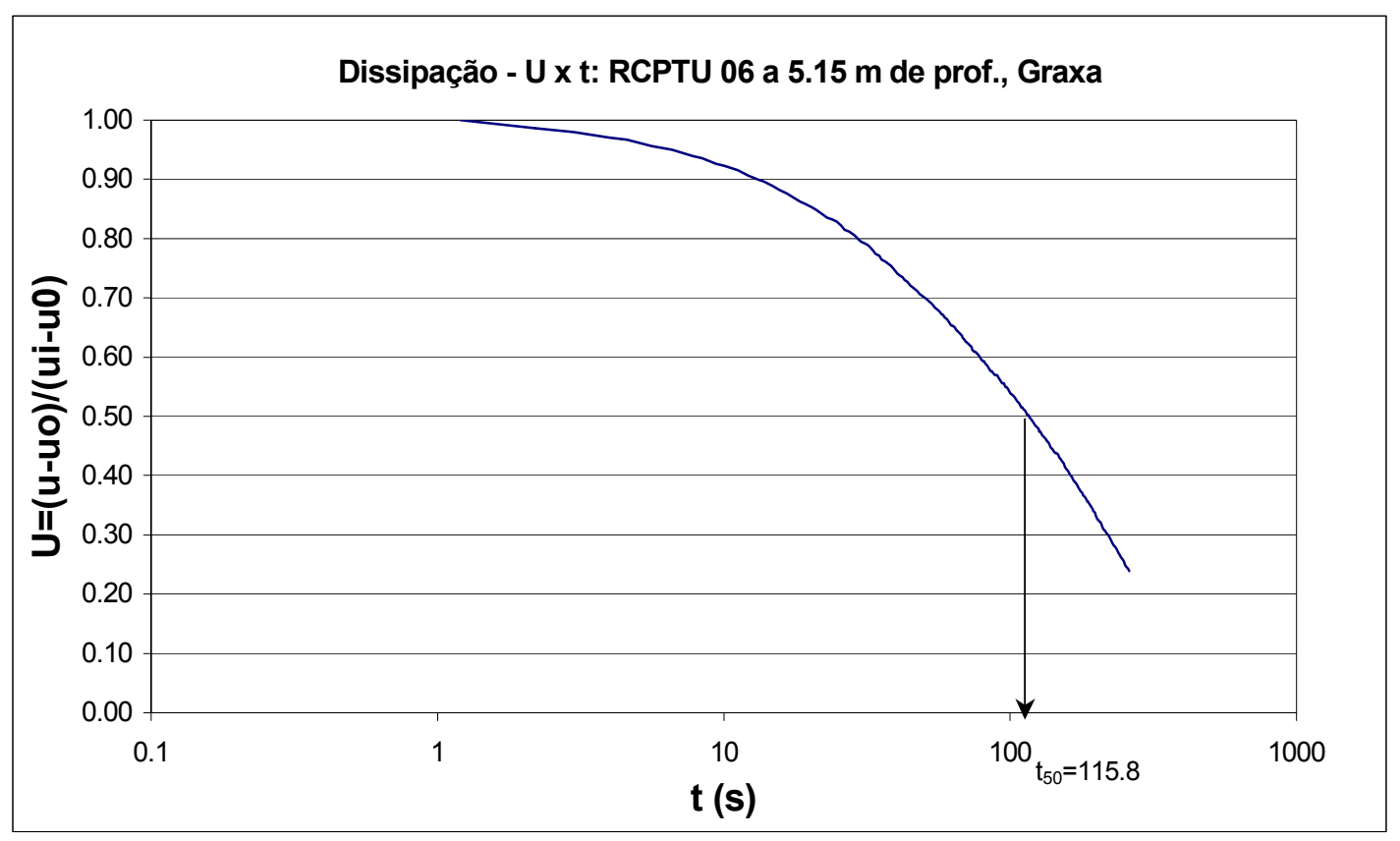

Curva de Dissipação do Excesso de Poro-pressão versus Tempo para o ensaio RCPTU 06

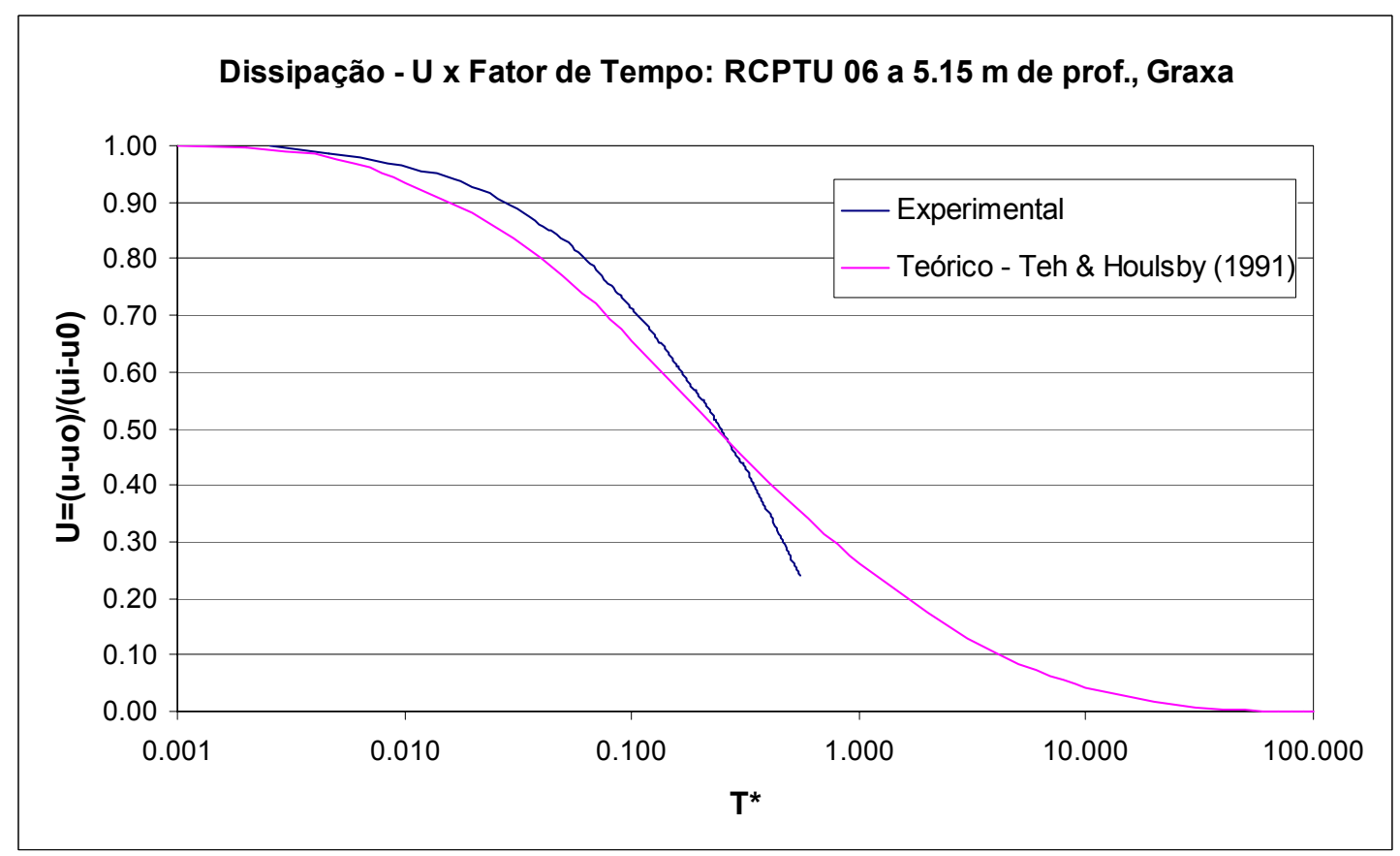

Curva de Dissipação do Excesso de Poro-pressão versus Fator Tempo para o ensaio RCPTU 06 


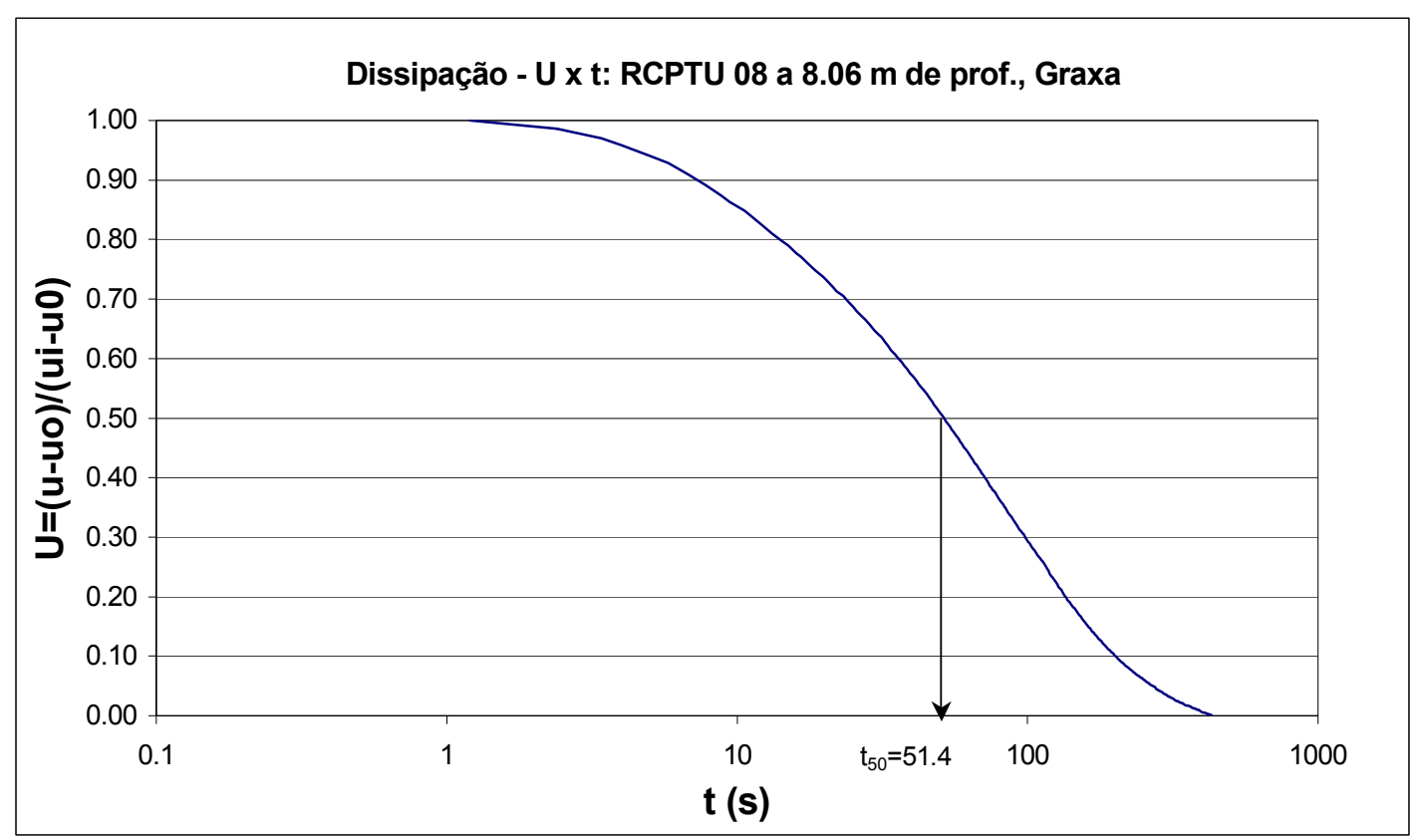

Curva de Dissipação do Excesso de Poro-pressão versus Tempo para o ensaio RCPTU 08

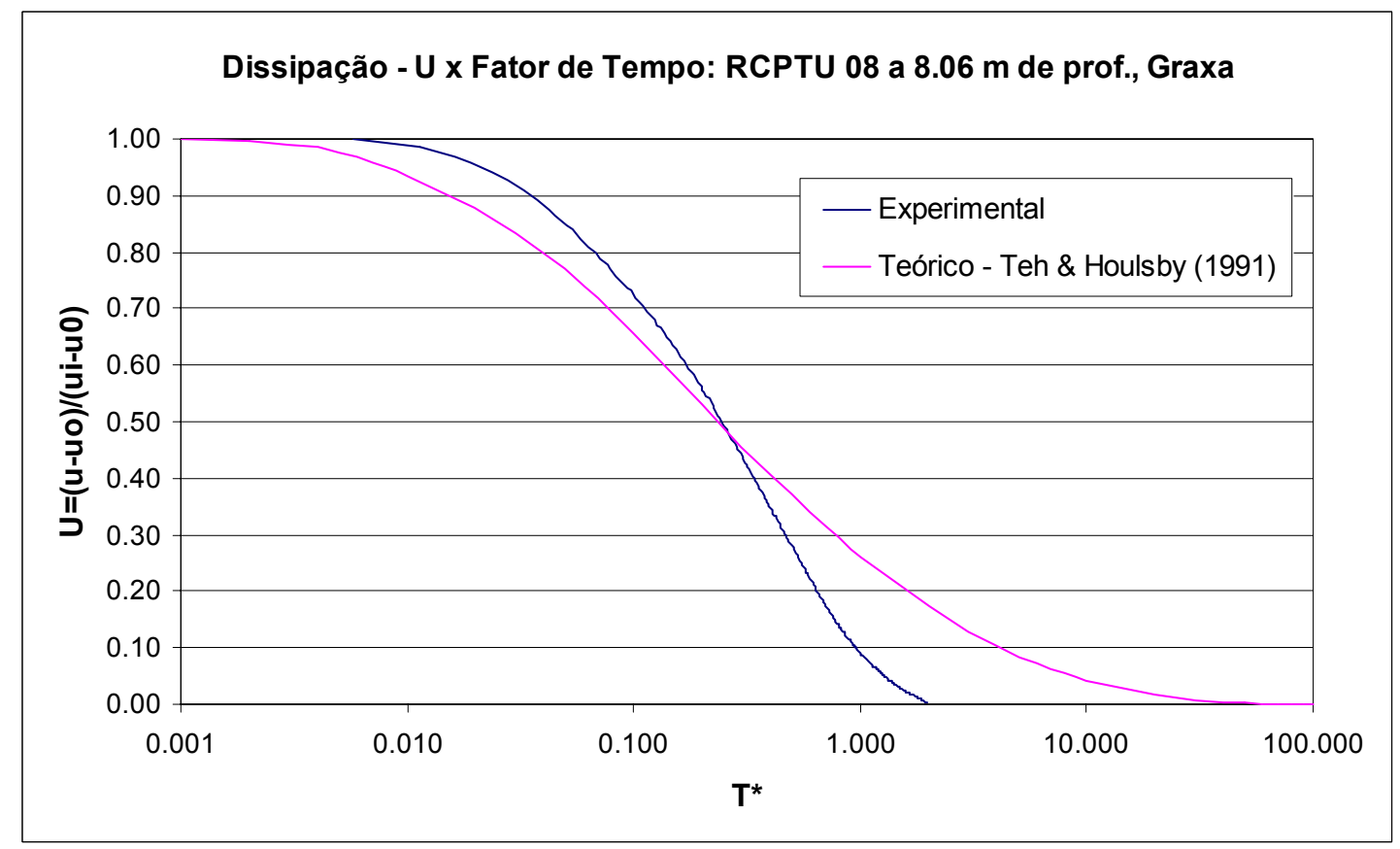

Curva de Dissipação do Excesso de Poro-pressão versus Fator Tempo para o ensaio RCPTU 08 


\section{ANEXO IV}

Resultados dos Ensaios de Permeabilidade e de Coluna Realizados com o Solo do Entorno do Aterro de Resíduos Sólidos Urbanos de Bauru 


\section{ENSAIOS DE PERMEABILIDADE COM PERCOLAÇÃO DE ÁGUA}

\section{Características Iniciais do Corpo de Prova:}

\begin{tabular}{|l|c|}
\hline Altura $(\mathrm{cm})$ & 12.71 \\
\hline Diâmetro $(\mathrm{cm})$ & 7.02 \\
\hline Área $\left(\mathrm{cm}^{2}\right)$ & 38.65 \\
\hline Volume $\left(\mathrm{cm}^{3}\right)$ & 491.24 \\
\hline Peso $(\mathrm{gf})$ & 771.65 \\
\hline$\rho_{\mathrm{n}}\left(\mathrm{gf} / \mathrm{cm}^{3}\right)$ & 1.571 \\
\hline $\mathrm{w}(\%)$ & 5.88 \\
\hline$\rho_{\mathrm{s}}\left(\mathrm{gf} / \mathrm{cm}^{3}\right)$ & 2.70 \\
\hline $\mathrm{e}$ & 0.82 \\
\hline $\mathrm{n}(\%)$ & 45.0 \\
\hline$\rho_{\mathrm{d}}\left(\mathrm{gf} / \mathrm{cm}^{3}\right)$ & 1.48 \\
\hline $\mathrm{S}(\%)$ & 19.4 \\
\hline $\mathrm{V}_{\mathrm{v}}$ inicial $\left(\mathrm{cm}^{3}\right)$ & 221.31 \\
\hline $\mathrm{V}_{\mathrm{s}}\left(\mathrm{cm}^{3}\right)$ & 269.92 \\
\hline
\end{tabular}

Estágio de Adensamento com Tensão Confinante Igual a $30 \mathrm{kPa}$ :

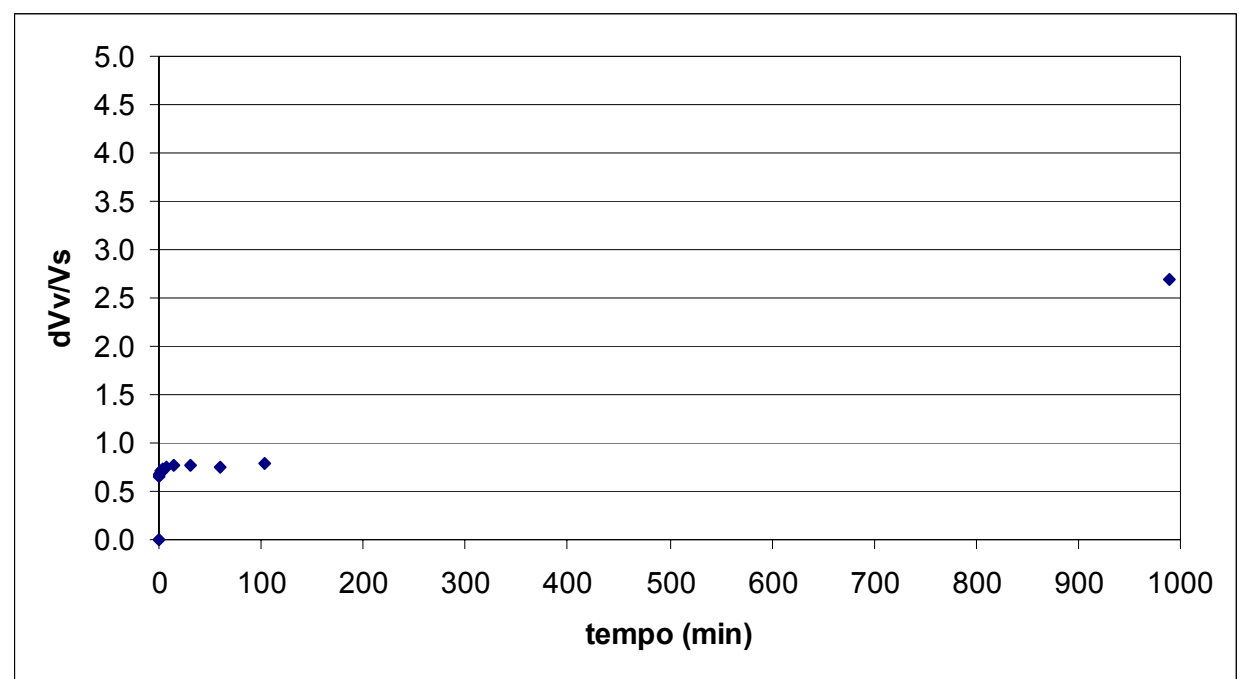


Características do corpo de prova após o adensamento:

$-\mathrm{Vv}=208.1 \mathrm{~cm}^{3}$

- e $=0.77$;

- Volume total do C.P. $=478.0 \mathrm{~cm}^{3}$.

Estágio de Percolação com Água e com Tensão Confinante Igual a 30 kPa:

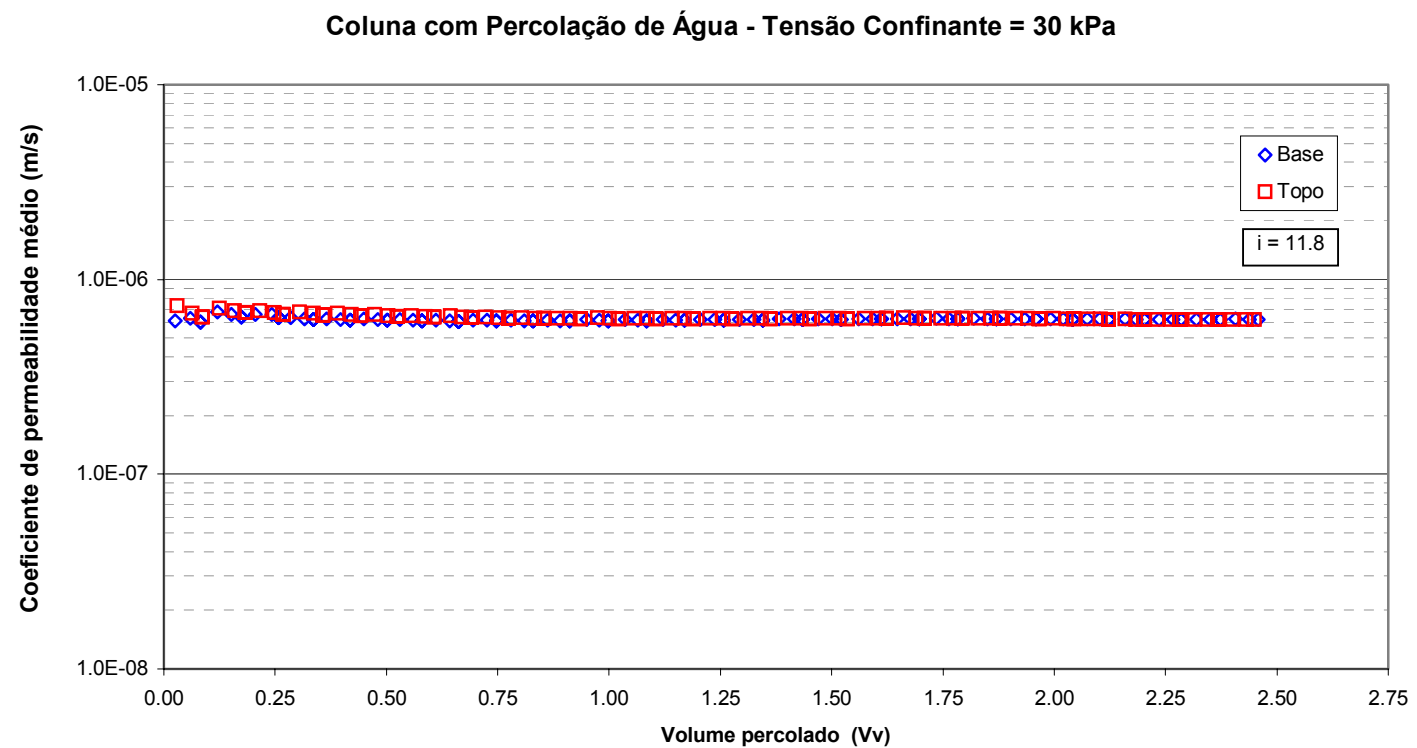

Coluna com Percolação de Água - Tensão Confinante $=30 \mathrm{kPa}$

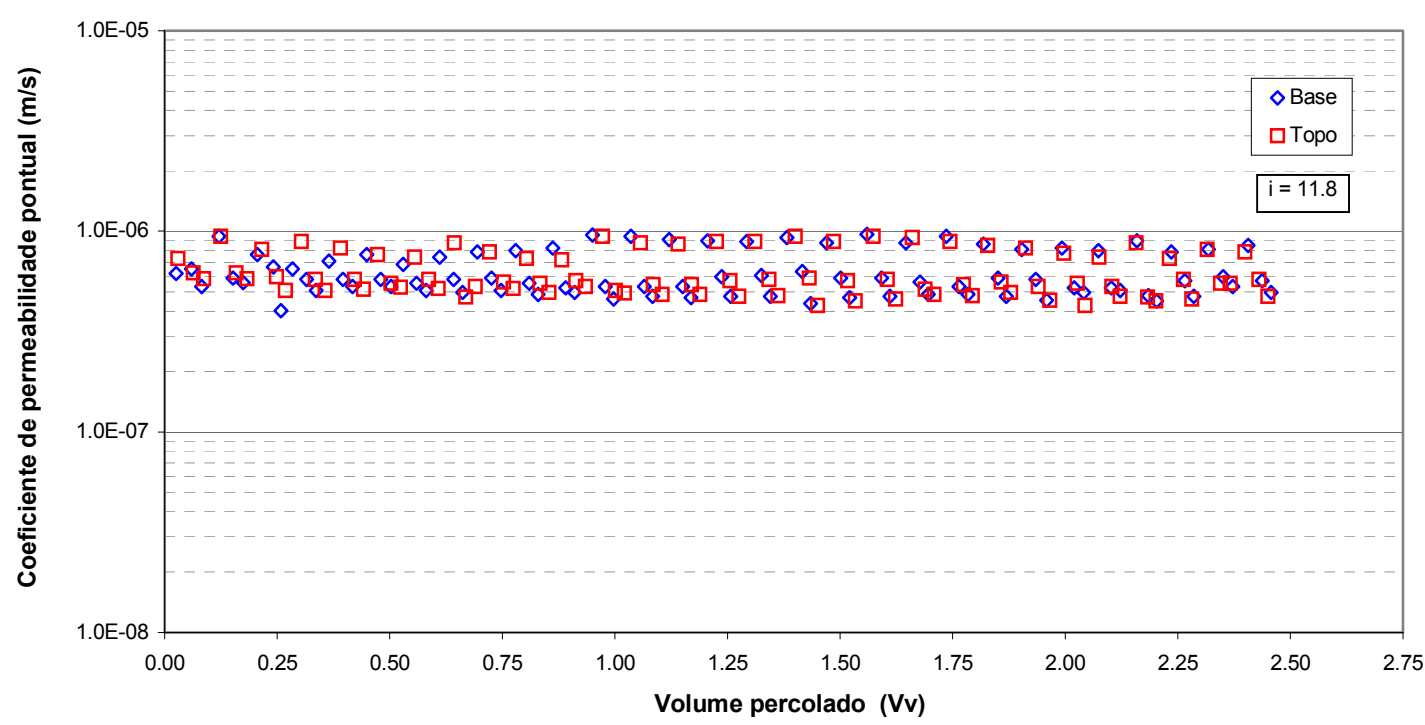


Estágio de Adensamento com Tensão Confinante Igual a 90 kPa:

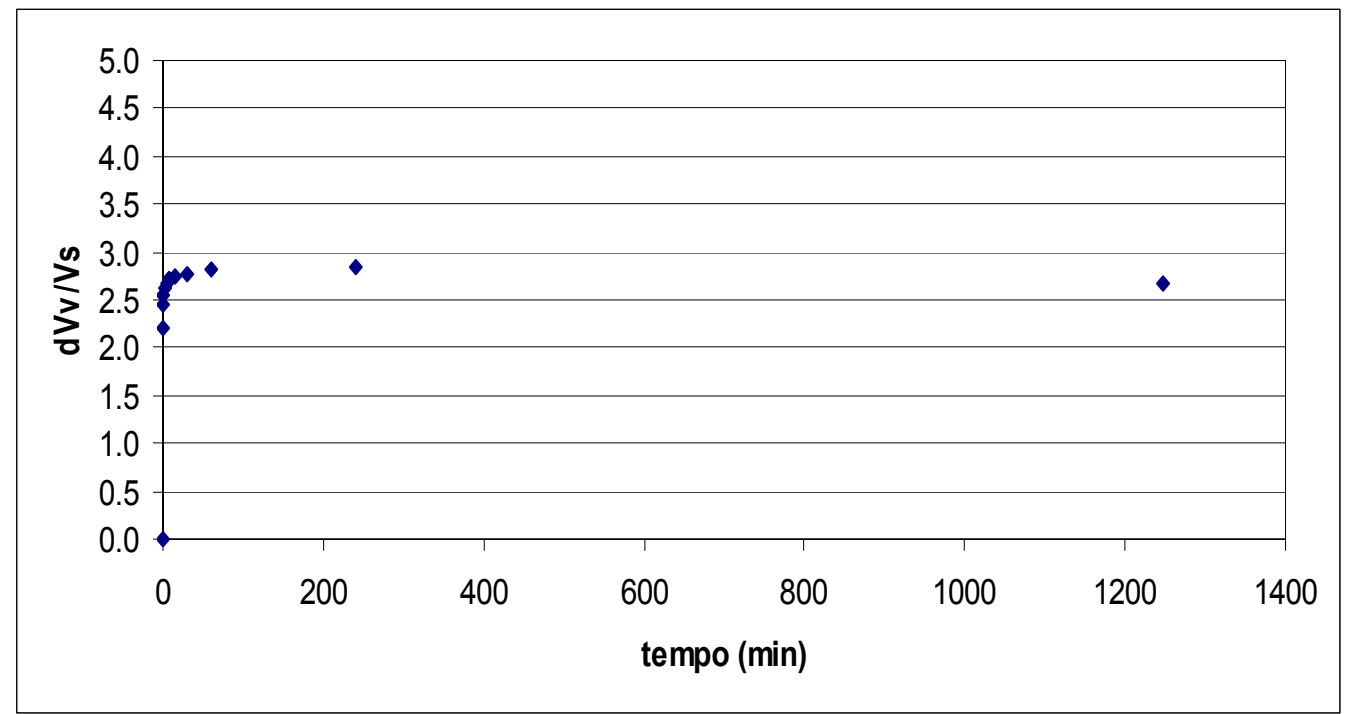

Características do corpo de prova após o adensamento:

- Vv $=195.4 \mathrm{~cm}^{3}$

- e $=0.72$;

- Volume total do C.P. $=465.3 \mathrm{~cm}^{3}$.

Estágio de Percolação com Água e com Tensão Confinante Igual a 90 kPa:

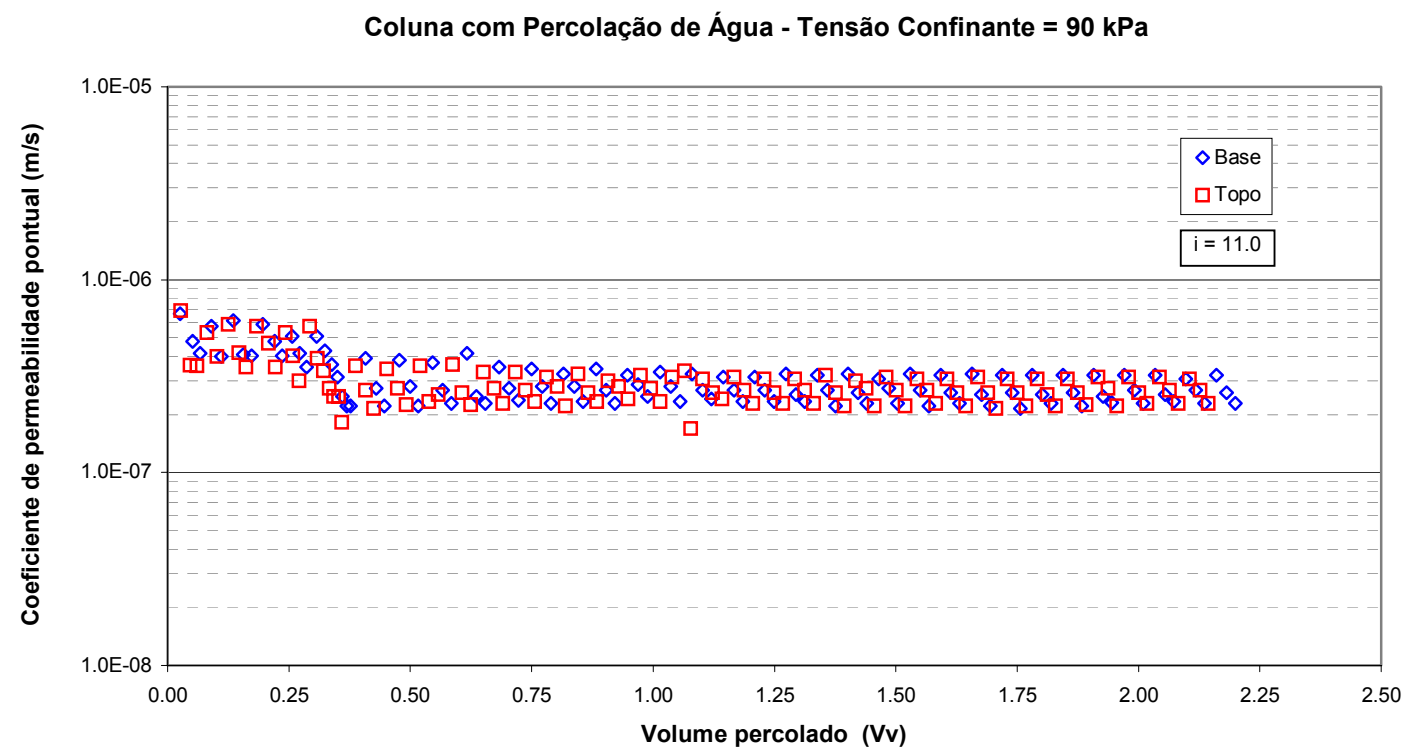


Coluna com Percolação de Água - Tensão Confinante $=90 \mathrm{kPa}$

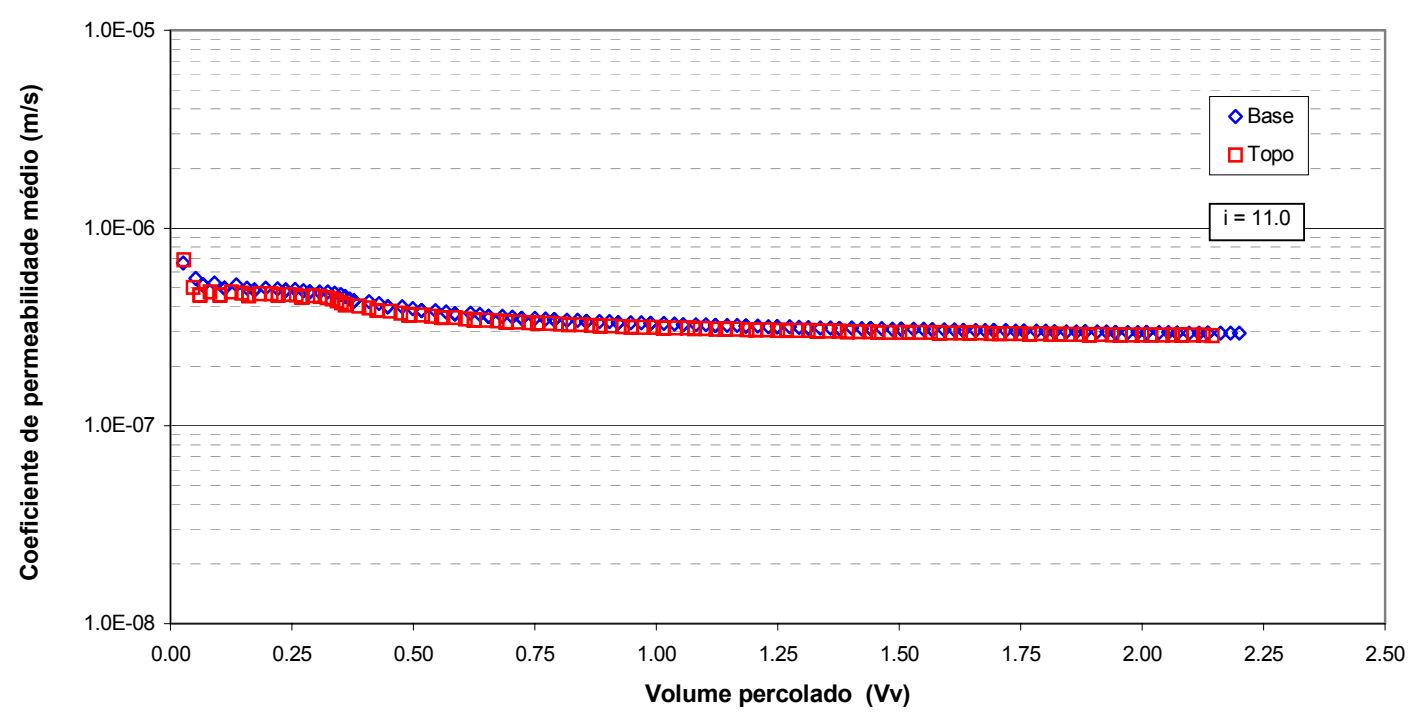

Estágio de Adensamento com Tensão Confinante Igual a 180 kPa:

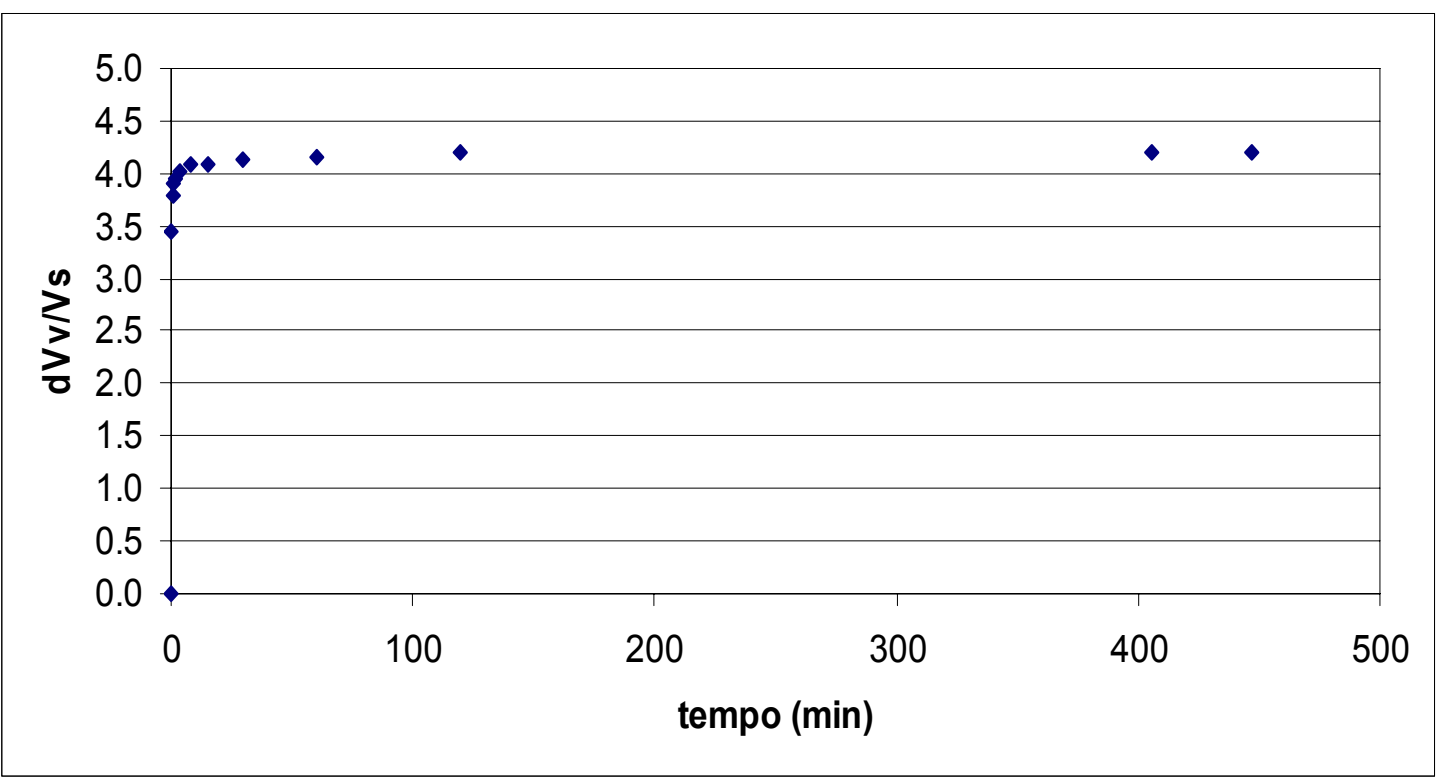

Características do corpo de prova após o adensamento:

$-\mathrm{Vv}=175.9 \mathrm{~cm}^{3}$;

- e $=0.65$;

- Volume total do C.P. $=445.8 \mathrm{~cm}^{3}$. 
Estágio de Percolação com Água e com Tensão Confinante Igual a 180 kPa:
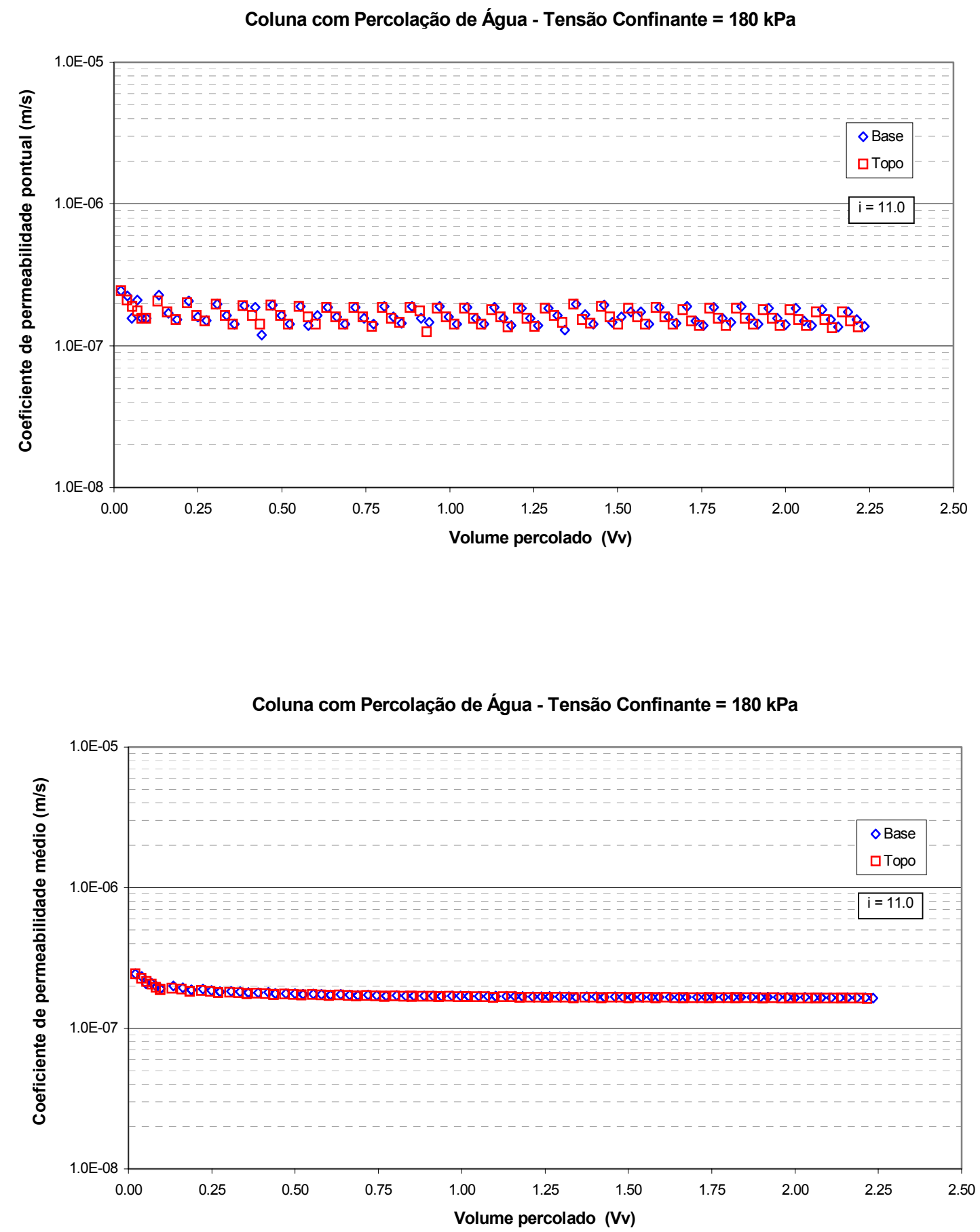
ENSAIO DE COLUNA COM PERCOLAÇÃO DE NaCI E CORPO DE PROVA SUBMETIDO A 30 KPA DE TENSÃO CONFINANTE

\section{Características Iniciais do Corpo de Prova:}

\begin{tabular}{|l|c|}
\hline Altura $(\mathrm{cm})$ & 12.55 \\
\hline Diâmetro $(\mathrm{cm})$ & 7.09 \\
\hline Área $\left(\mathrm{cm}^{2}\right)$ & 39.48 \\
\hline Volume $\left(\mathrm{cm}^{3}\right)$ & 495.48 \\
\hline Peso $(\mathrm{gf})$ & 798.18 \\
\hline$\rho_{\mathrm{n}}\left(\mathrm{gf} / \mathrm{cm}^{3}\right)$ & 1.611 \\
\hline $\mathrm{w}(\%)$ & 5.38 \\
\hline$\rho_{\mathrm{s}}\left(\mathrm{gf} / \mathrm{cm}^{3}\right)$ & 2.70 \\
\hline $\mathrm{e}$ & 0.77 \\
\hline $\mathrm{n}(\%)$ & 43.4 \\
\hline$\rho_{\mathrm{d}}\left(\mathrm{gf} / \mathrm{cm}^{3}\right)$ & 1.53 \\
\hline $\mathrm{S}(\%)$ & 19.0 \\
\hline $\mathrm{V}_{\mathrm{v}}$ inicial $\left(\mathrm{cm}^{3}\right)$ & 214.95 \\
\hline $\mathrm{V}_{\mathrm{s}}\left(\mathrm{cm}^{3}\right)$ & 280.53 \\
\hline
\end{tabular}

Estágio de Adensamento com Tensão Confinante Igual a $30 \mathrm{kPa}$ :

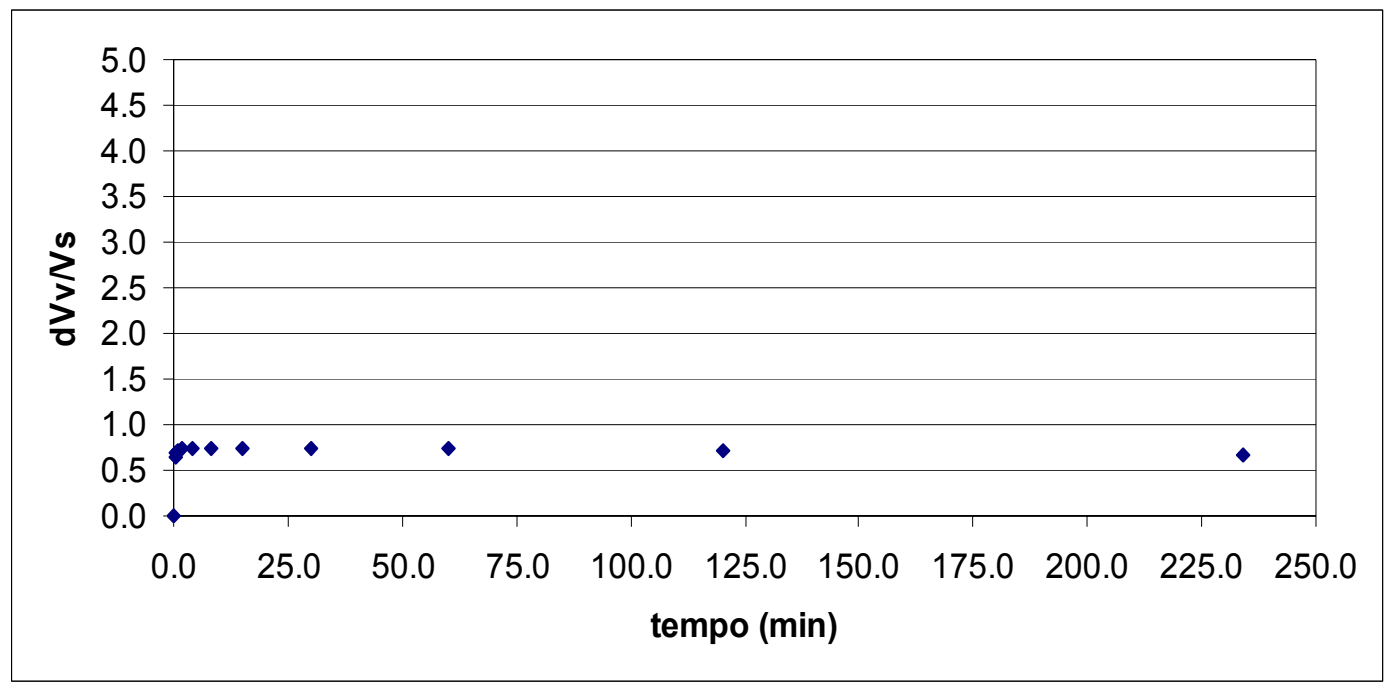


Características do corpo de prova após o adensamento:

$-\mathrm{Vv}=211.7 \mathrm{~cm}^{3}$

- e $=0.75$;

- Volume total do C.P. $=492.2 \mathrm{~cm}^{3}$.

\section{Coeficientes de Permeabilidade do Solo Submetido à Percolação com Água} Seguido de Percolação com NaCl:

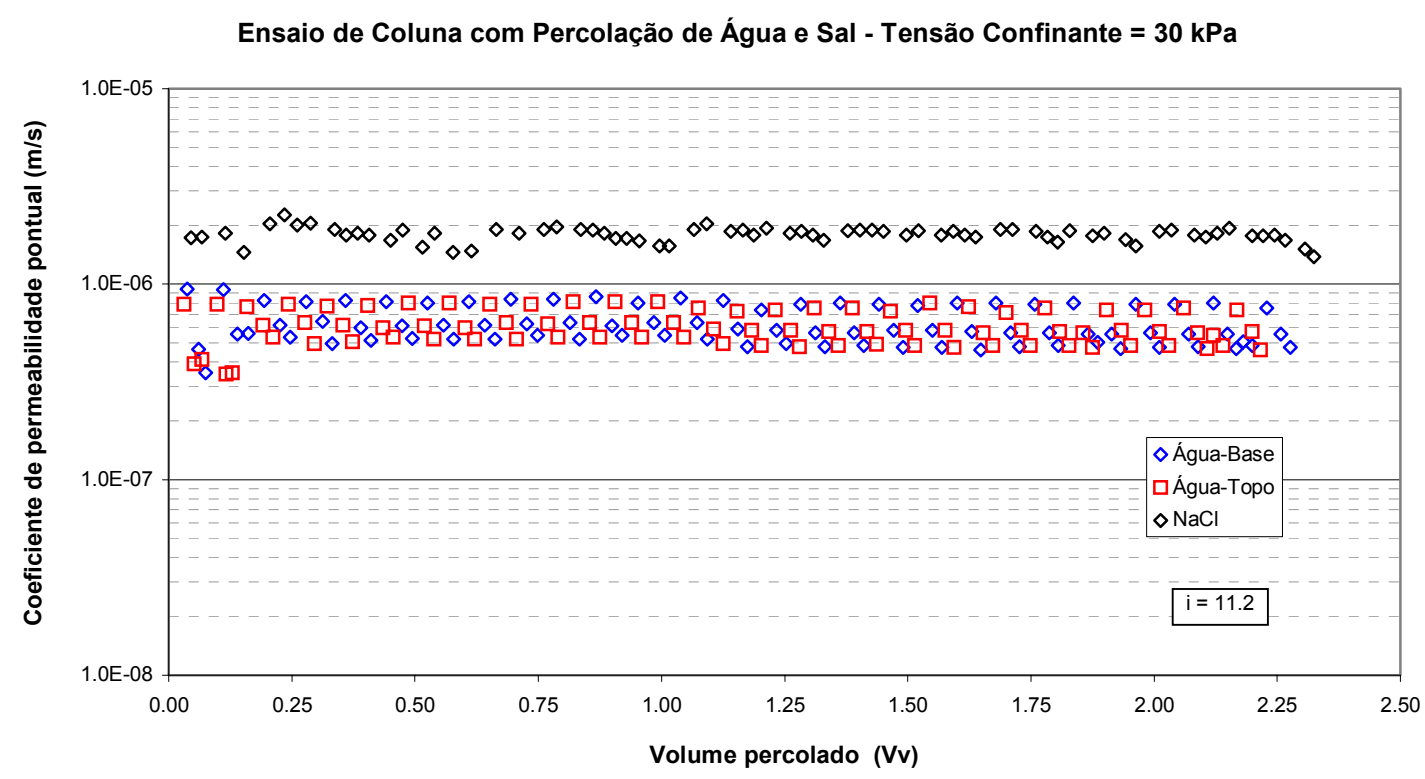

Ensaio de Coluna com Percolação de Água e Sal - Tensão Confinante $=30 \mathrm{kPa}$

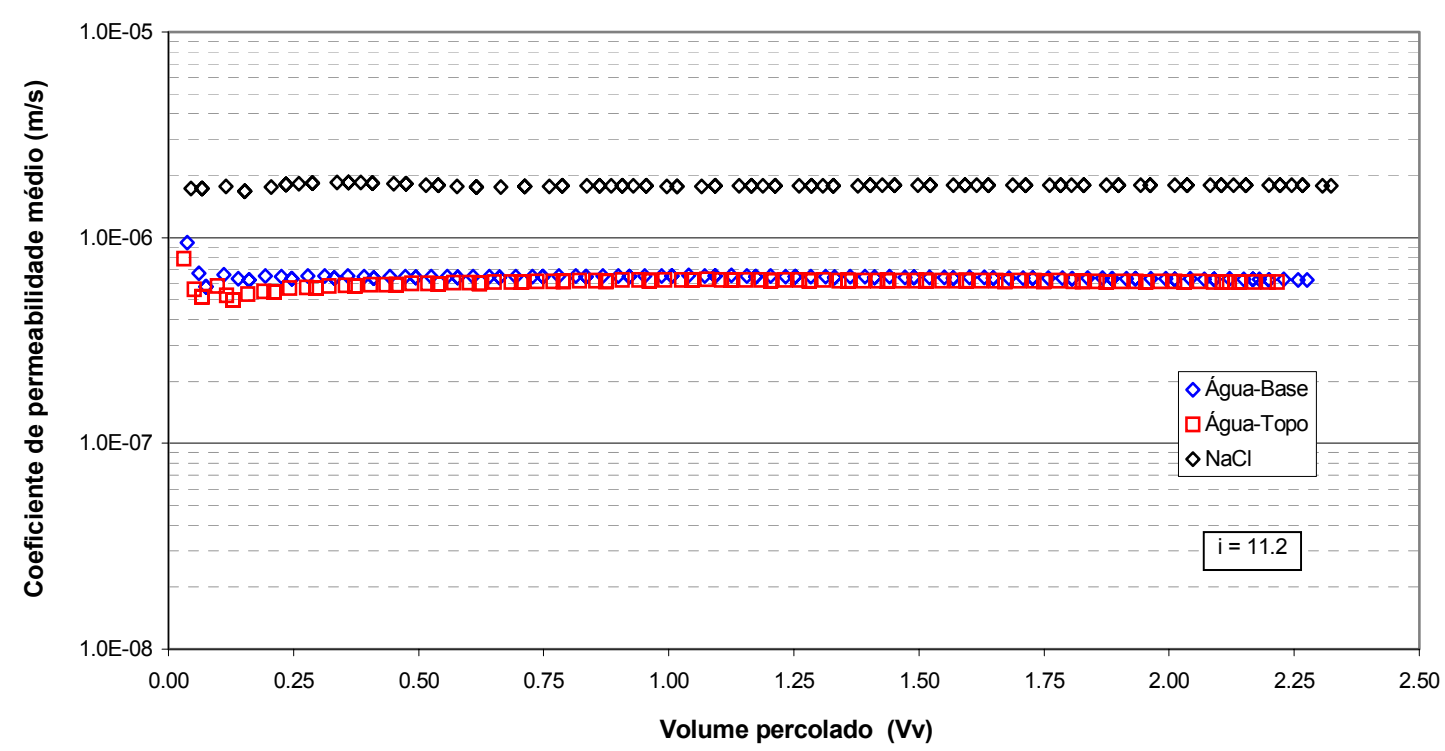




\section{Monitoramento dos Efluentes da Coluna de Solução Salina:}

Características iniciais da solução salina:

- Condutividade Inicial $=228.0 \mu \mathrm{S} / \mathrm{cm}$;

- Concentração Inicial $=103.7 \mathrm{mg} / \mathrm{L}$.

Coluna com Percolação de Sal - Tensão Confinante $=30 \mathrm{kPa}$

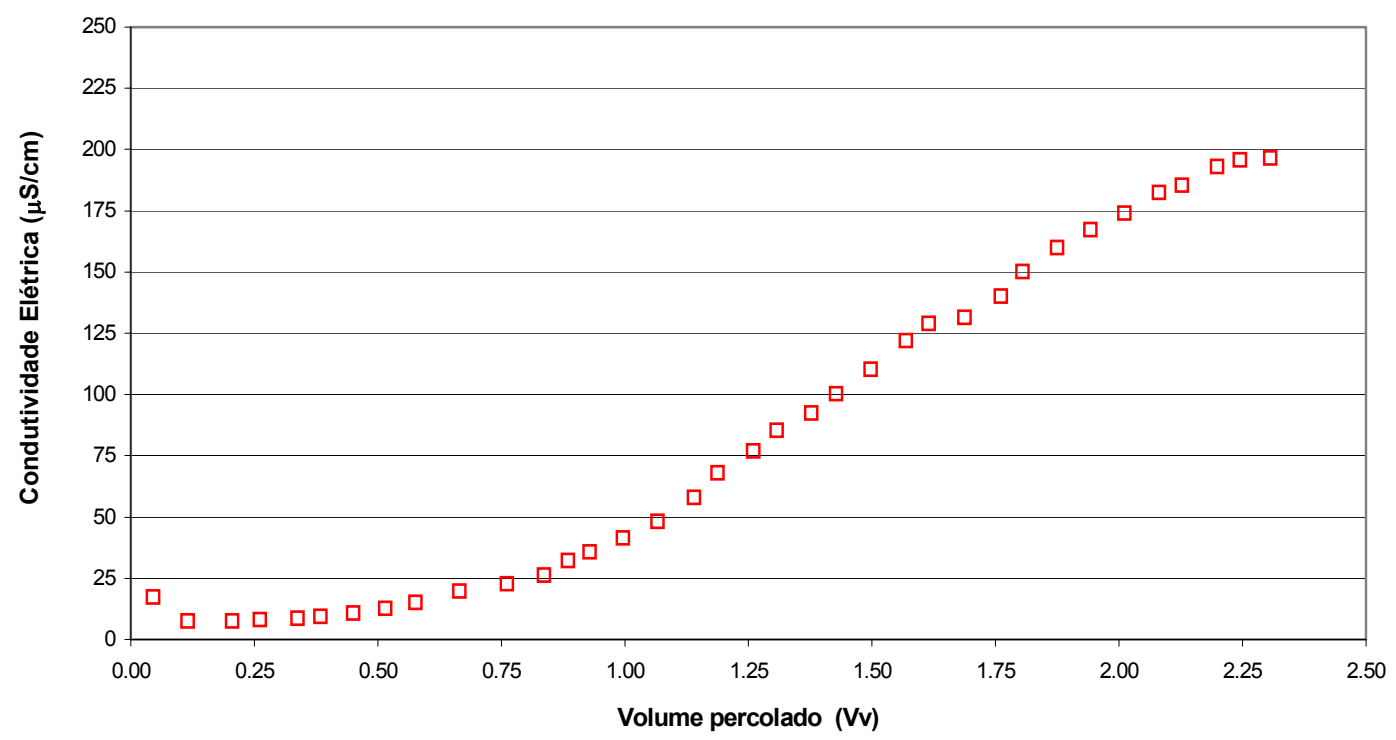

Coluna com Percolação de Sal - Tensão Confinante $=\mathbf{3 0} \mathrm{kPa}$

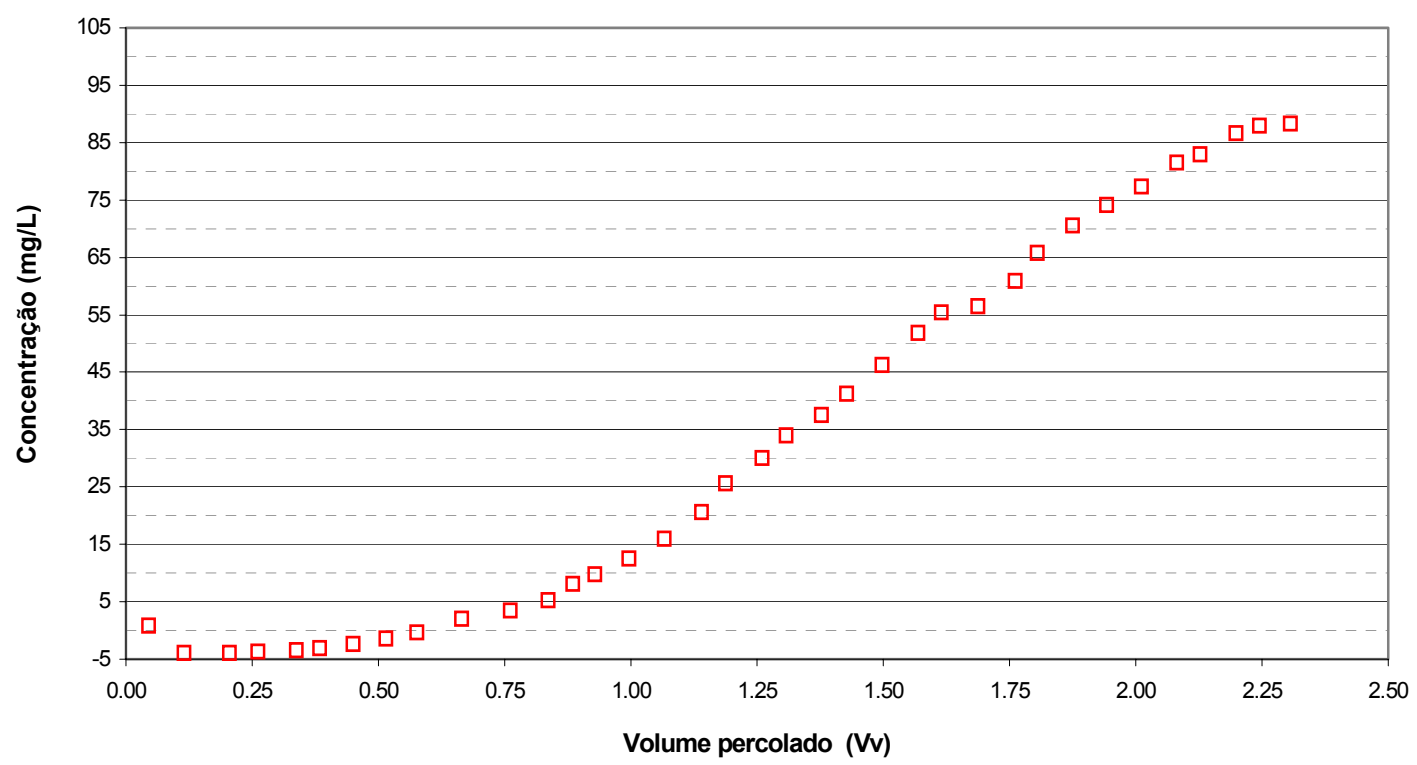


ENSAIO DE COLUNA COM PERCOLAÇÃO DE NaCI E CORPO DE PROVA SUBMETIDO A 90 KPA DE TENSÃO CONFINANTE

Características Iniciais do Corpo de Prova:

\begin{tabular}{|l|c|}
\hline Altura $(\mathrm{cm})$ & 12.91 \\
\hline Diâmetro $(\mathrm{cm})$ & 7.03 \\
\hline Área $\left(\mathrm{cm}^{2}\right)$ & 38.82 \\
\hline Volume $\left(\mathrm{cm}^{3}\right)$ & 501.10 \\
\hline Peso $(\mathrm{gf})$ & 798.18 \\
\hline$\rho_{\mathrm{n}}\left(\mathrm{gf} / \mathrm{cm}^{3}\right)$ & 1.593 \\
\hline $\mathrm{w}(\%)$ & 2.00 \\
\hline$\rho_{\mathrm{s}}\left(\mathrm{gf} / \mathrm{cm}^{3}\right)$ & 2.70 \\
\hline $\mathrm{e}$ & 0.73 \\
\hline $\mathrm{n}(\%)$ & 42.2 \\
\hline$\rho_{\mathrm{d}}\left(\mathrm{gf} / \mathrm{cm}^{3}\right)$ & 1.56 \\
\hline $\mathrm{S}(\%)$ & 7.4 \\
\hline $\mathrm{V}_{\mathrm{v}}$ inicial $\left(\mathrm{cm}^{3}\right)$ & 211.28 \\
\hline $\mathrm{V}_{\mathrm{S}}\left(\mathrm{cm}^{3}\right)$ & 289.83 \\
\hline
\end{tabular}

Estágio de Adensamento com Tensão Confinante Igual a 90 kPa:

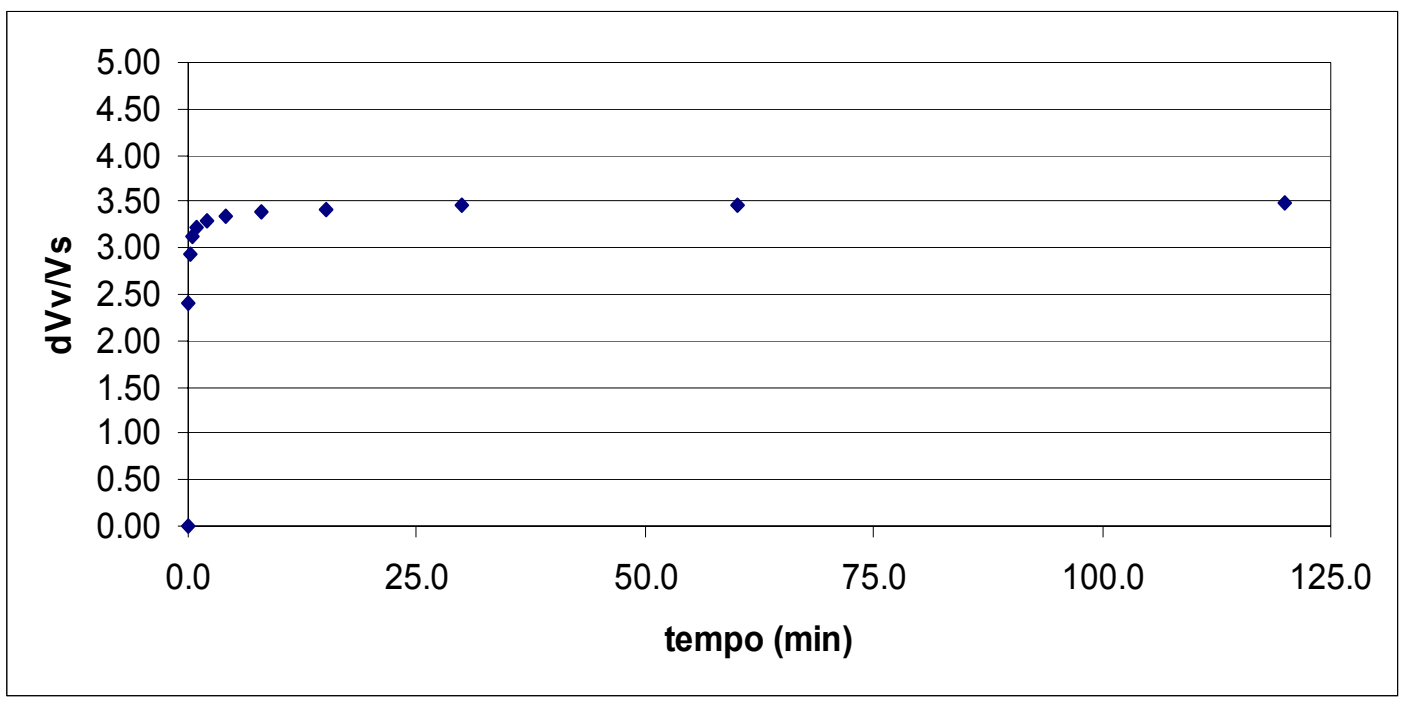


Características do corpo de prova após o adensamento:

$-\mathrm{Vv}=195.4 \mathrm{~cm}^{3}$

$-\mathrm{e}=0.72$;

- Volume total do C.P. $=465.3 \mathrm{~cm}^{3}$.

\section{Coeficientes de Permeabilidade do Solo Submetido à Percolação com Água Seguido de Percolação com NaCl:}

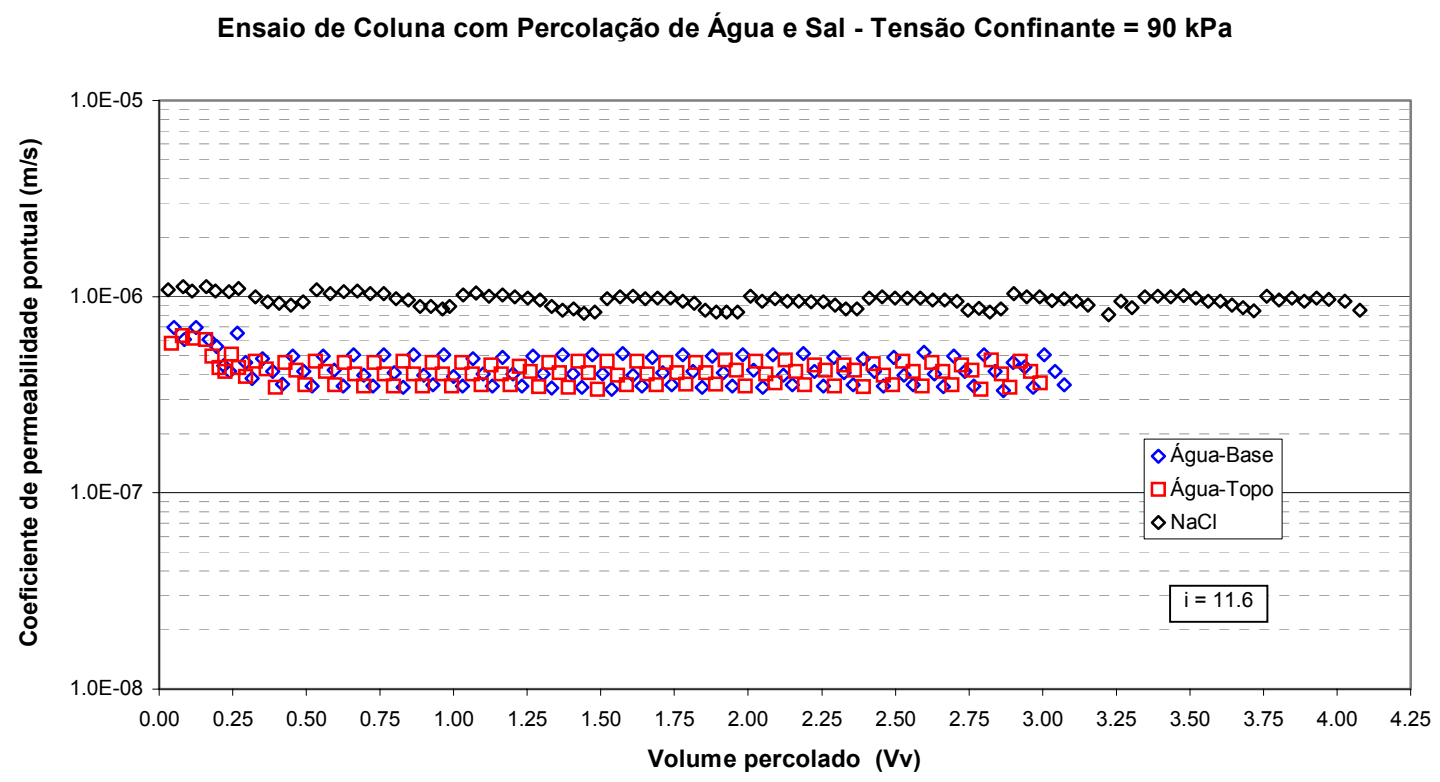

Ensaio de Coluna com Percolação de Água e Sal - Tensão Confinante $=90 \mathrm{kPa}$

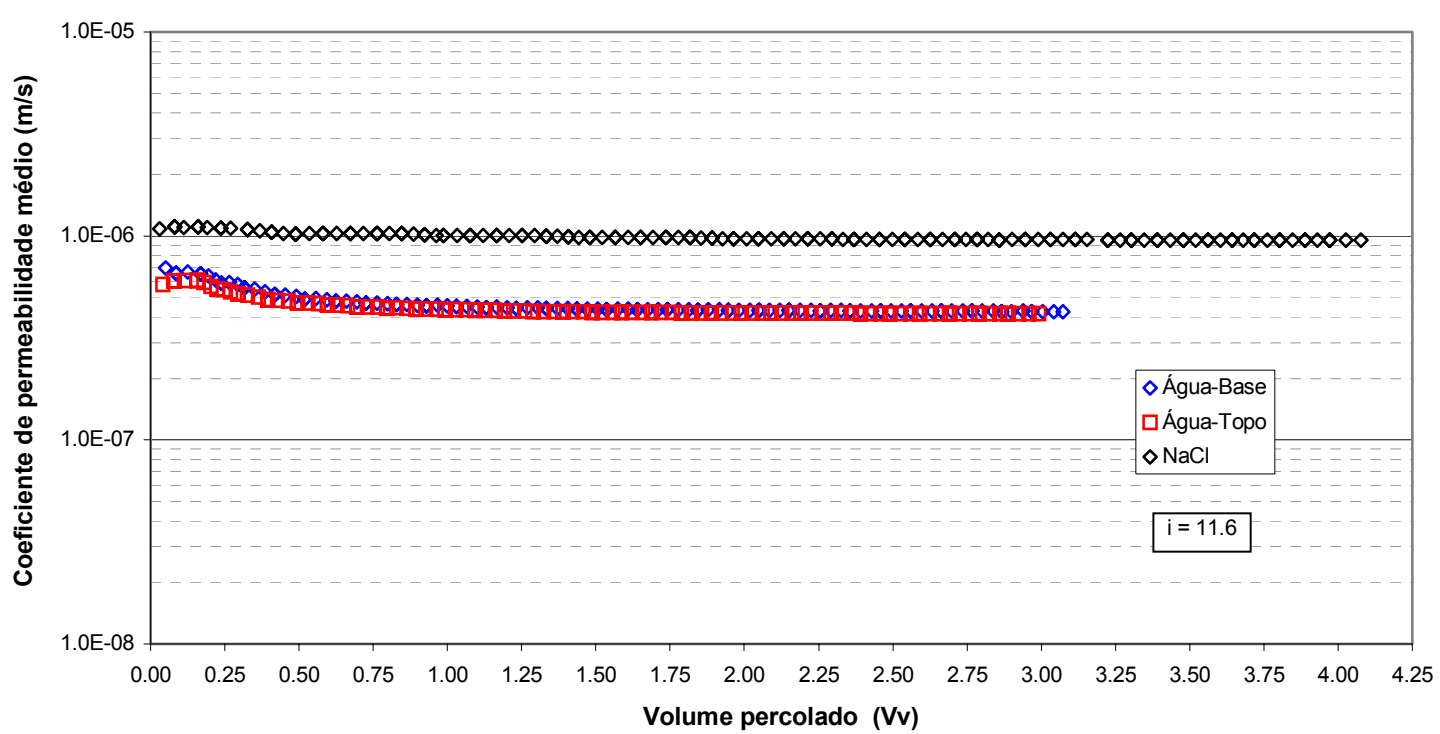




\section{Monitoramento dos Efluentes da Coluna de Solução Salina:}

Características iniciais da solução salina:

- Condutividade Inicial $=190.0 \mu \mathrm{S} / \mathrm{cm}$;

- Concentração Inicial = $85.1 \mathrm{mg} / \mathrm{L}$;

- $\mathrm{PH}$ inicial $=7.07$.

Coluna com Percolação de Sal - Tensão Confinante $=90 \mathrm{kPa}$

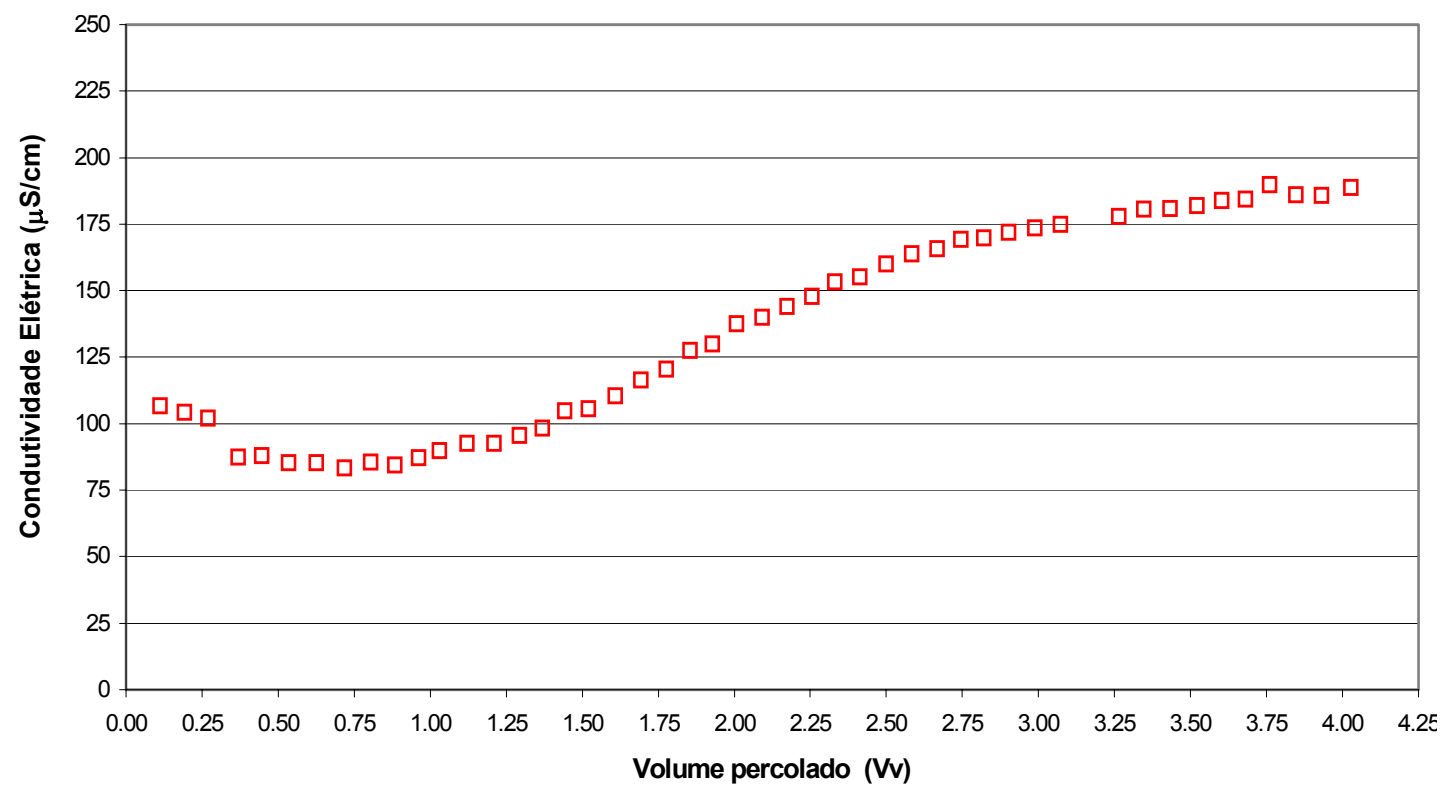

Coluna com Percolação de Sal - Tensão Confinante $=90 \mathrm{kPa}$

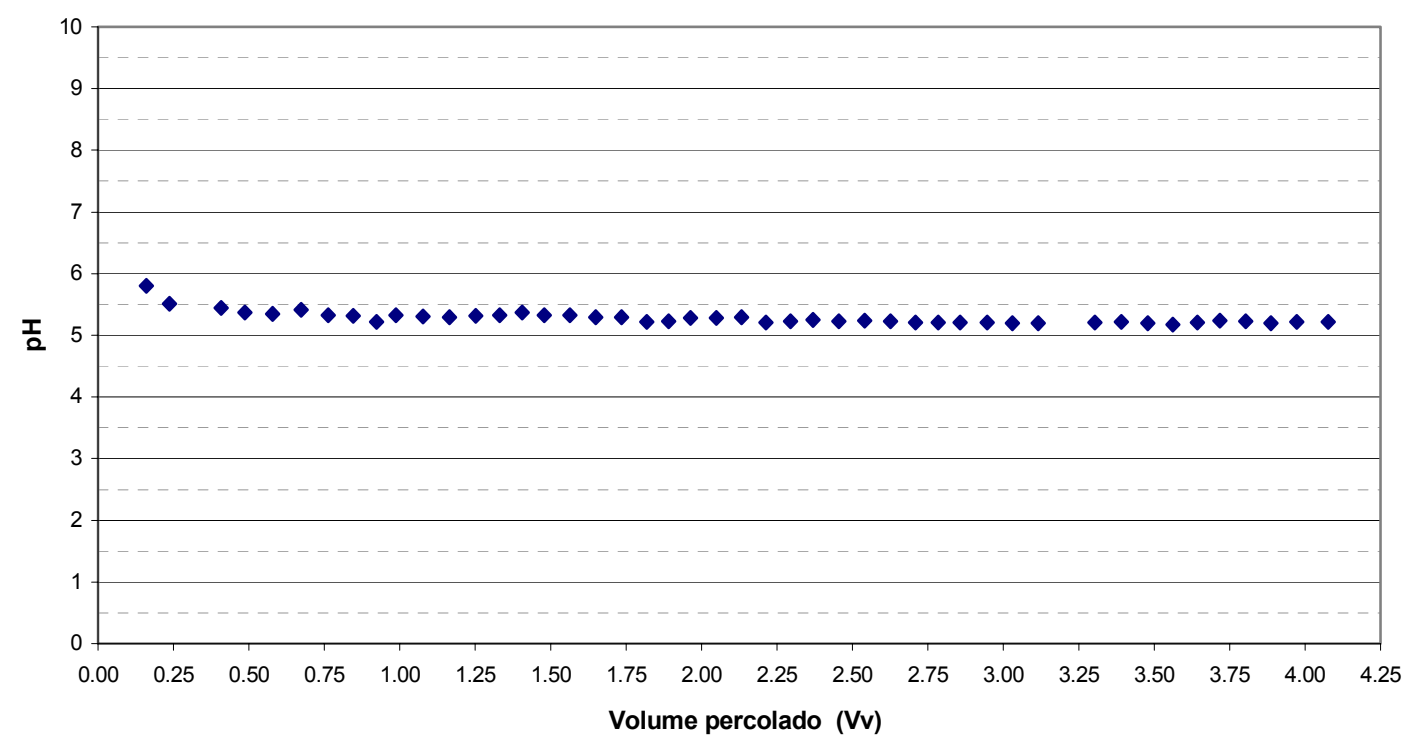


Coluna com Percolação de Sal - Tensão Confinante $=90$ kPa

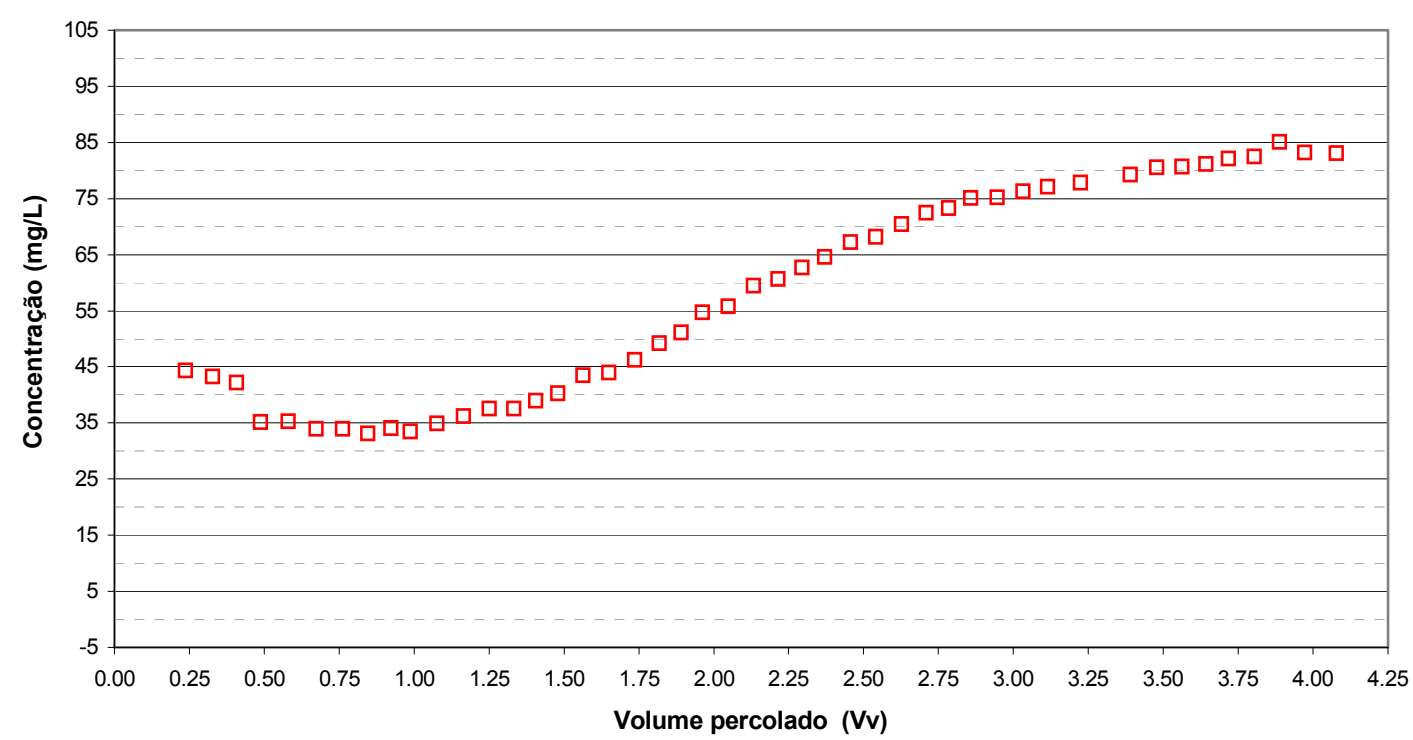

ENSAIO DE COLUNA COM PERCOLAÇÃO DE SOLUÇÃO DE METAIS E CORPO DE PROVA SUBMETIDO A 30 KPA DE TENSÃO CONFINANTE

Características Iniciais do Corpo de Prova:

\begin{tabular}{|l|c|}
\hline Altura $(\mathrm{cm})$ & 11.56 \\
\hline Diâmetro $(\mathrm{cm})$ & 7.12 \\
\hline Área $\left(\mathrm{cm}^{2}\right)$ & 39.82 \\
\hline Volume $\left(\mathrm{cm}^{3}\right)$ & 460.26 \\
\hline Peso $(\mathrm{gf})$ & 767.76 \\
\hline$\rho_{\mathrm{n}}\left(\mathrm{gf} / \mathrm{cm}^{3}\right)$ & 1.668 \\
\hline $\mathrm{w}(\%)$ & 8.37 \\
\hline$\rho_{\mathrm{s}}\left(\mathrm{gf} / \mathrm{cm}^{3}\right)$ & 2.70 \\
\hline $\mathrm{e}$ & 0.75 \\
\hline $\mathrm{n}(\%)$ & 43.0 \\
\hline$\rho_{\mathrm{d}}\left(\mathrm{gf} / \mathrm{cm}^{3}\right)$ & 1.54 \\
\hline $\mathrm{S}(\%)$ & 30.0 \\
\hline $\mathrm{V}_{\mathrm{v}}$ inicial $\left(\mathrm{cm}^{3}\right)$ & 197.87 \\
\hline $\mathrm{V}_{\mathrm{s}}\left(\mathrm{cm}^{3}\right)$ & 262.39 \\
\hline
\end{tabular}


Estágio de Adensamento com Tensão Confinante Igual a $30 \mathrm{kPa}$ :

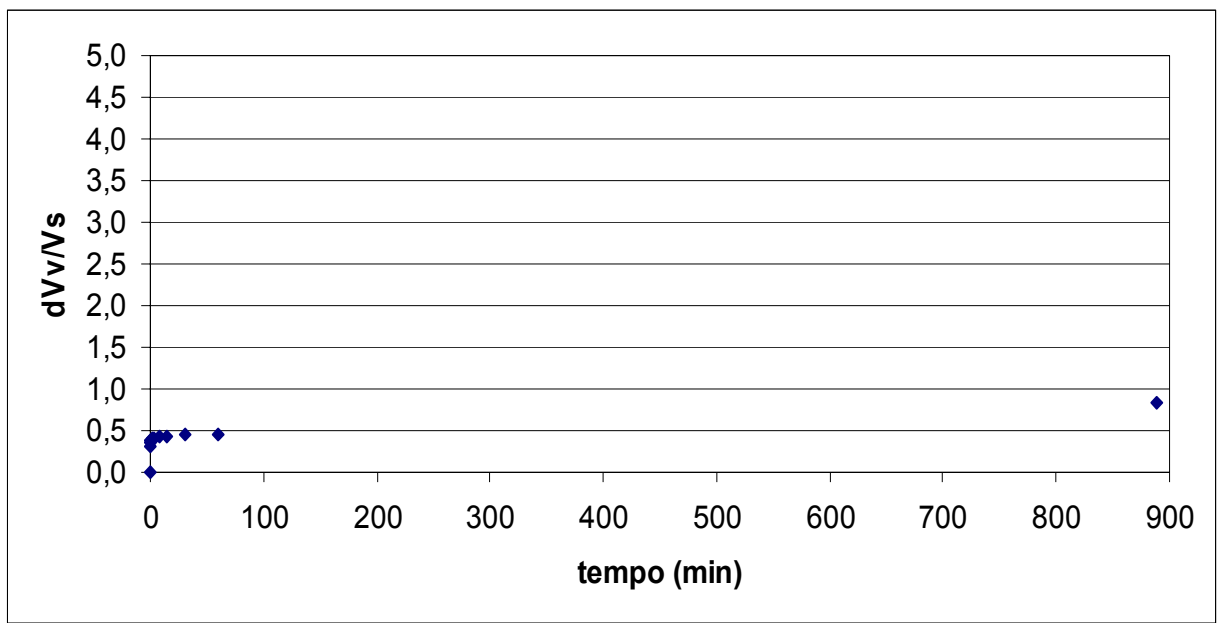

Características do corpo de prova após o adensamento:

$-\mathrm{Vv}=194.0 \mathrm{~cm}^{3}$;

- e $=0.74$

- Volume total do C.P. $=456.4 \mathrm{~cm}^{3}$.

Coeficientes de Permeabilidade do Solo Submetido à Percolação com Água Seguido de Percolação com Solução de Metais:

Ensaio de Coluna com Percolação de Água e Solução de Metais - Tensão Confinante $=\mathbf{3 0} \mathrm{kPa}$

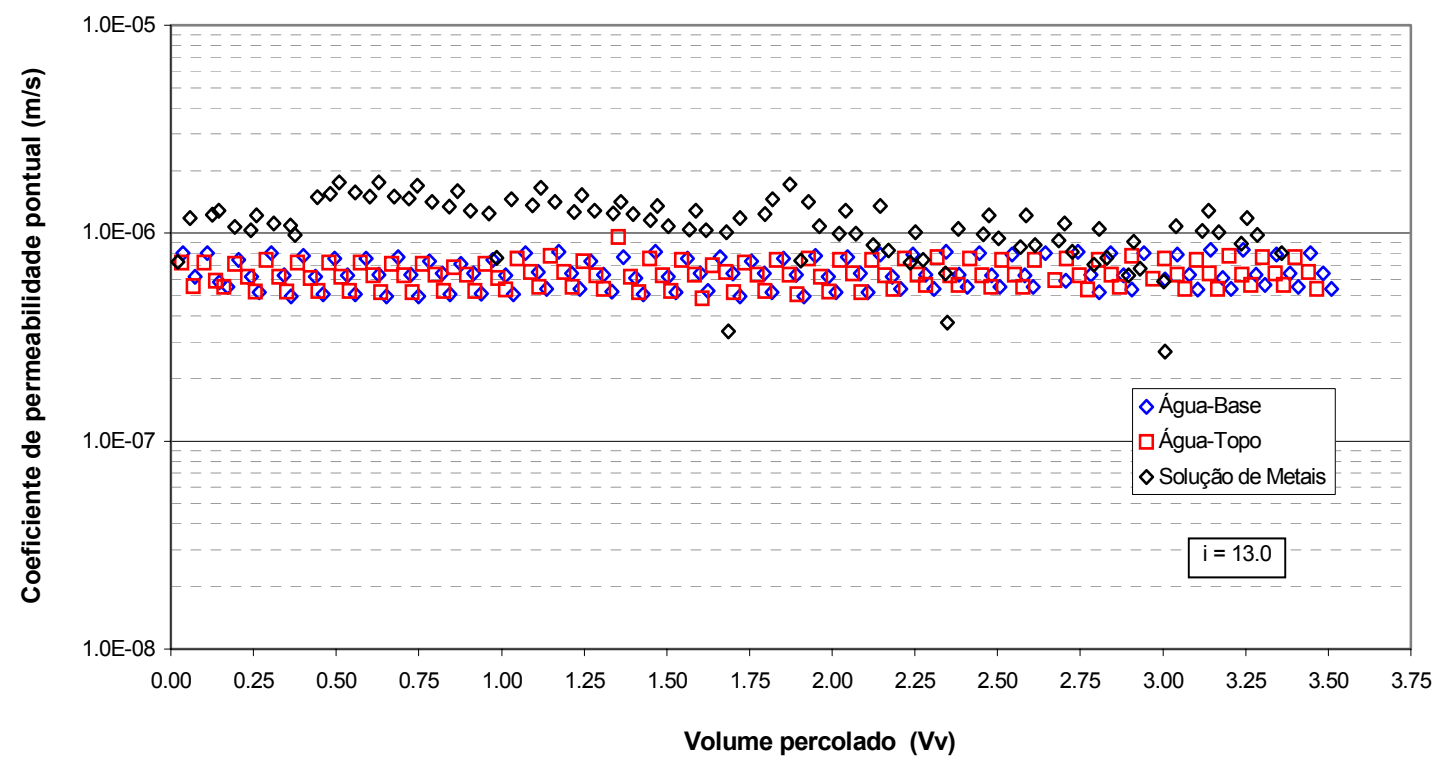


Ensaio de Coluna com Percolação de Água e Solução de Metais - Tensão Confinante $=30 \mathrm{kPa}$

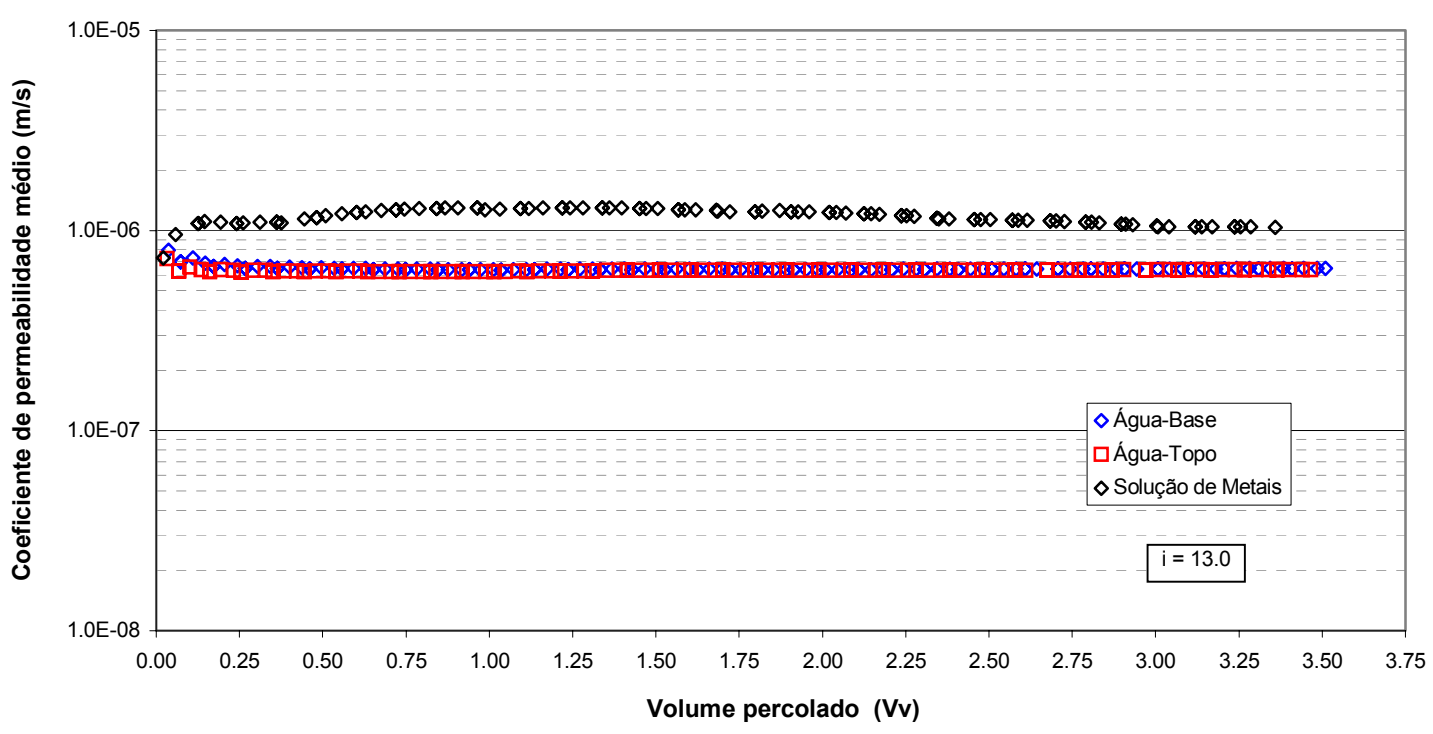

Monitoramento dos Efluentes da Coluna de Solução de Metais:

Características iniciais da solução de metais:

- Condutividade Inicial $=72.9 \mu \mathrm{S} / \mathrm{cm}$;

- $\mathrm{PH}$ inicial $=8.33$;

- Concentração Inicial de $\mathrm{Ni}=10.2 \mathrm{mg} / \mathrm{L}$;

- Concentração Inicial de $\mathrm{Zn}=4.9 \mathrm{mg} / \mathrm{L}$;

- Concentração Inicial de $\mathrm{Cd}=9.5 \mathrm{mg} / \mathrm{L}$;

- Concentração Inicial de $\mathrm{Pb}=8.1 \mathrm{mg} / \mathrm{L}$. 
Coluna com Percolação de Solução de Metais - Tensão Confinante $=30 \mathrm{kPa}$

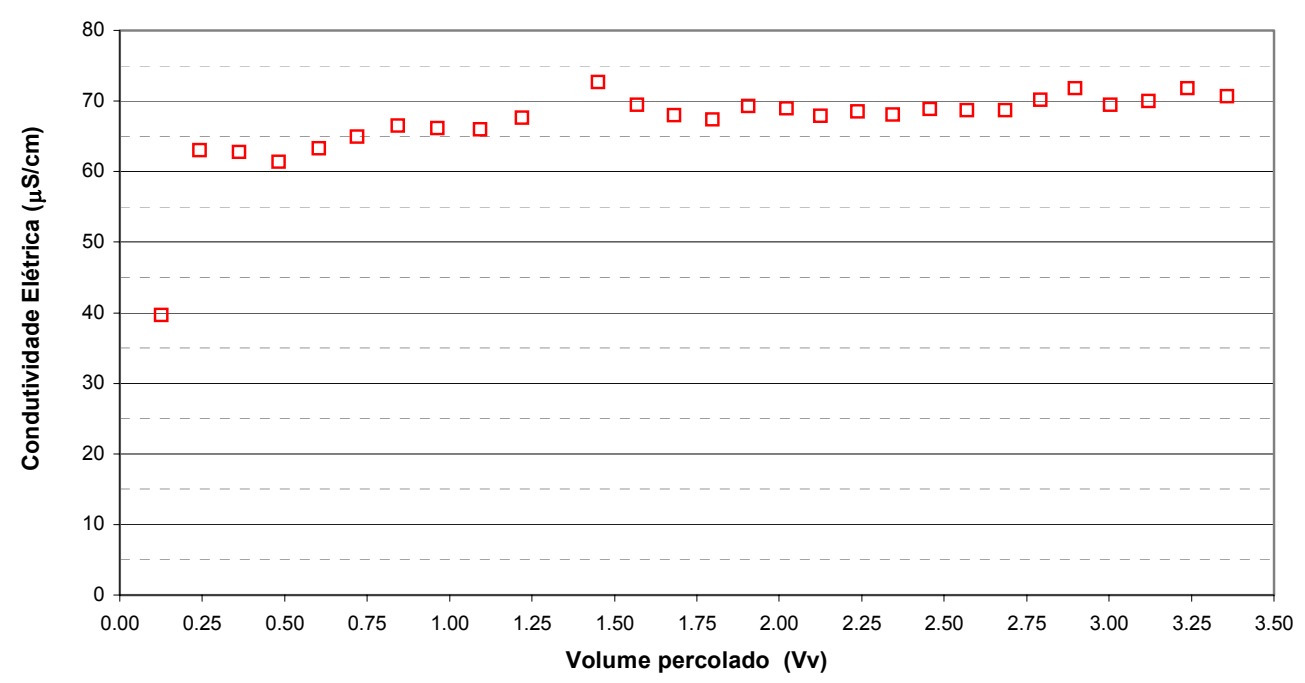

Coluna com Percolação de Solução de Metais - Tensão Confinante $=30 \mathrm{kPa}$

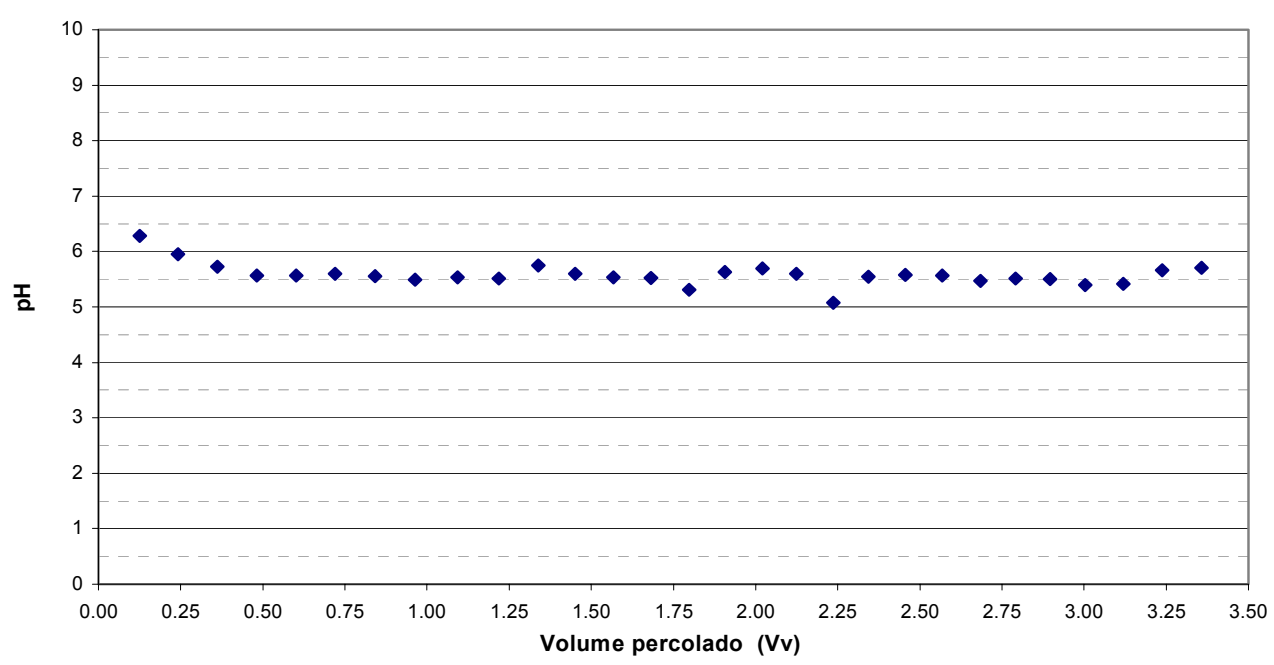

Coluna com Percolação de Solução de Metais - Tensão Confinante $=30 \mathrm{kPa}$

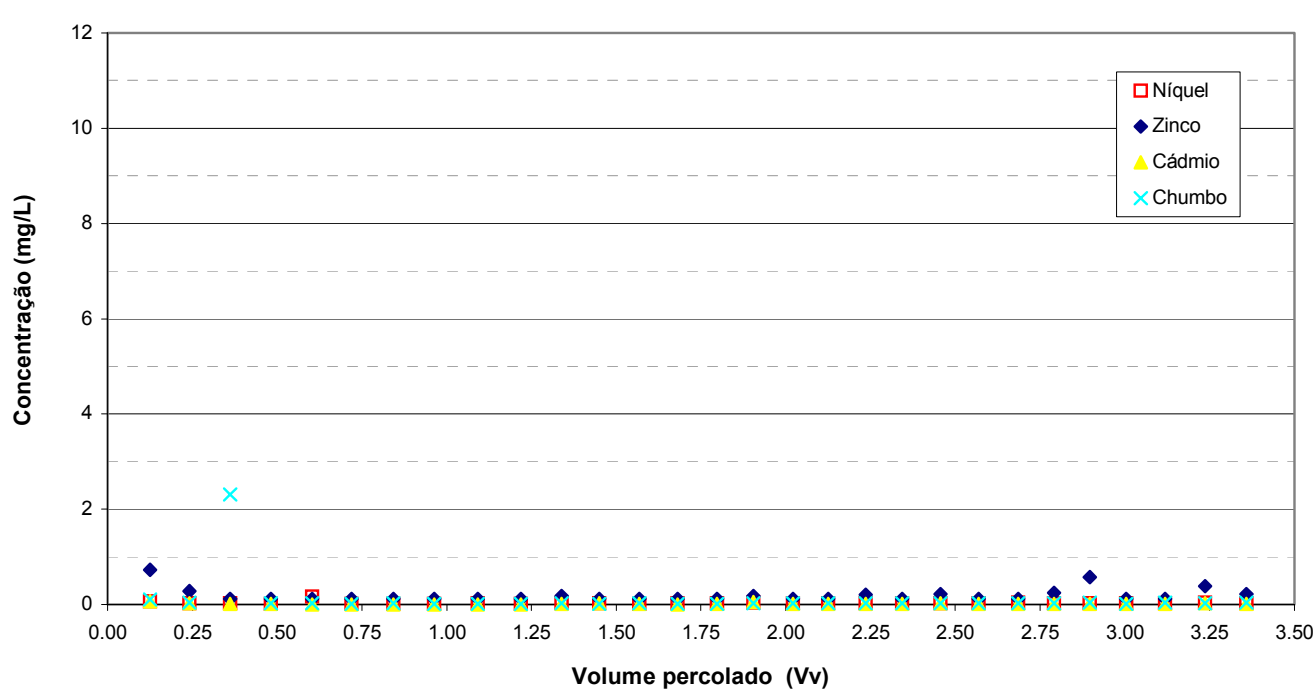


ENSAIO DE COLUNA COM PERCOLAÇÃO DE CHORUME MAIS METAIS E CORPO DE PROVA SUBMETIDO A 30 KPA DE TENSÃO CONFINANTE

Características Iniciais do Corpo de Prova:

\begin{tabular}{|l|c|}
\hline Altura $(\mathrm{cm})$ & 12.525 \\
\hline Diâmetro $(\mathrm{cm})$ & 7.00 \\
\hline Área $\left(\mathrm{cm}^{2}\right)$ & 38.48 \\
\hline Volume $\left(\mathrm{cm}^{3}\right)$ & 482.02 \\
\hline Peso $(\mathrm{gf})$ & 805.36 \\
\hline$\rho_{\mathrm{n}}\left(\mathrm{gf} / \mathrm{cm}^{3}\right)$ & 1.671 \\
\hline $\mathrm{w}(\%)$ & 8.62 \\
\hline$\rho_{\mathrm{s}}\left(\mathrm{gf} / \mathrm{cm}^{3}\right)$ & 2.70 \\
\hline $\mathrm{e}$ & 0.76 \\
\hline $\mathrm{n}(\%)$ & 43.0 \\
\hline$\rho_{\mathrm{d}}\left(\mathrm{gf} / \mathrm{cm}^{3}\right)$ & 1.54 \\
\hline $\mathrm{S}(\%)$ & 30.8 \\
\hline $\mathrm{V}_{\mathrm{v}}$ inicial $\left(\mathrm{cm}^{3}\right)$ & 207.41 \\
\hline $\mathrm{V}_{\mathrm{s}}\left(\mathrm{cm}^{3}\right)$ & 274.61 \\
\hline
\end{tabular}

Estágio de Adensamento com Tensão Confinante Igual a $30 \mathrm{kPa}$ :

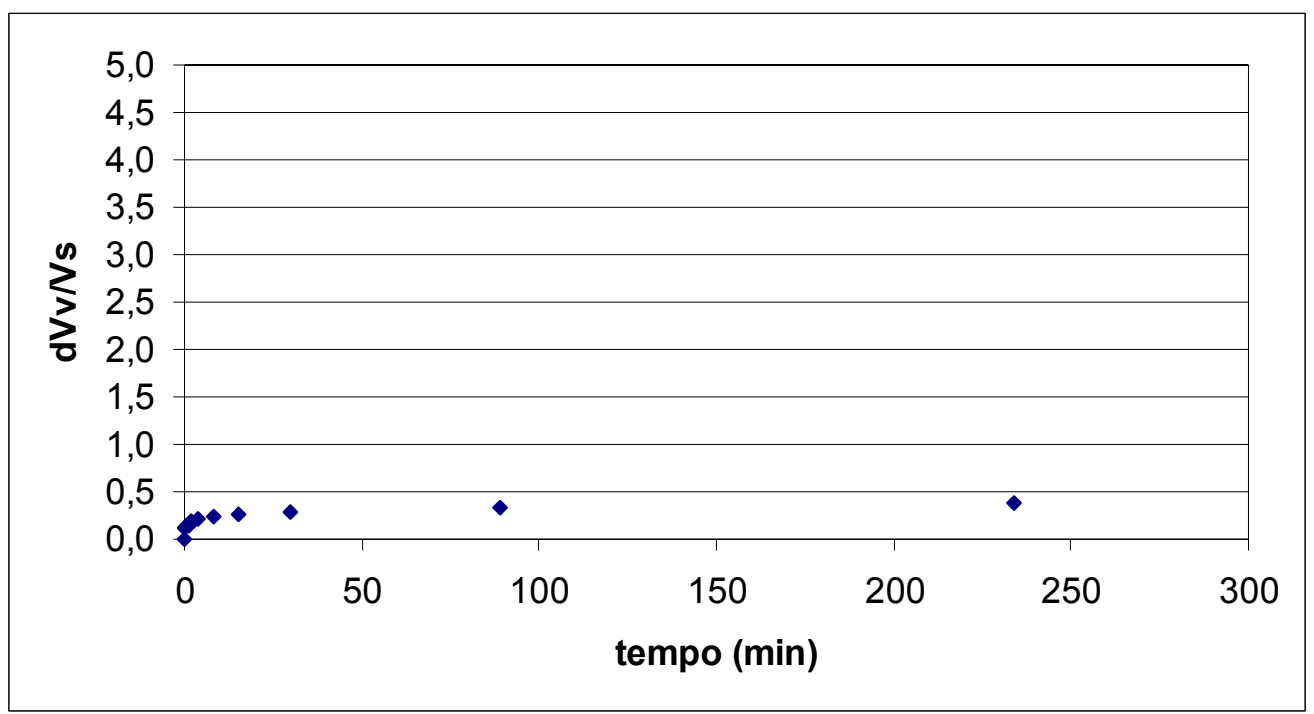


Características do corpo de prova após o adensamento:

$-\mathrm{Vv}=205.6 \mathrm{~cm}^{3}$

- e $=0.75$

- Volume total do C.P. $=480.2 \mathrm{~cm}^{3}$.

\section{Coeficientes de Permeabilidade do Solo Submetido à Percolação com Água Seguido de Percolação com Chorume mais Metais:}

Ensaio de Coluna com Percolação de Água e Chorume + Metais - Tensão Confinante $=30 \mathrm{kPa}$

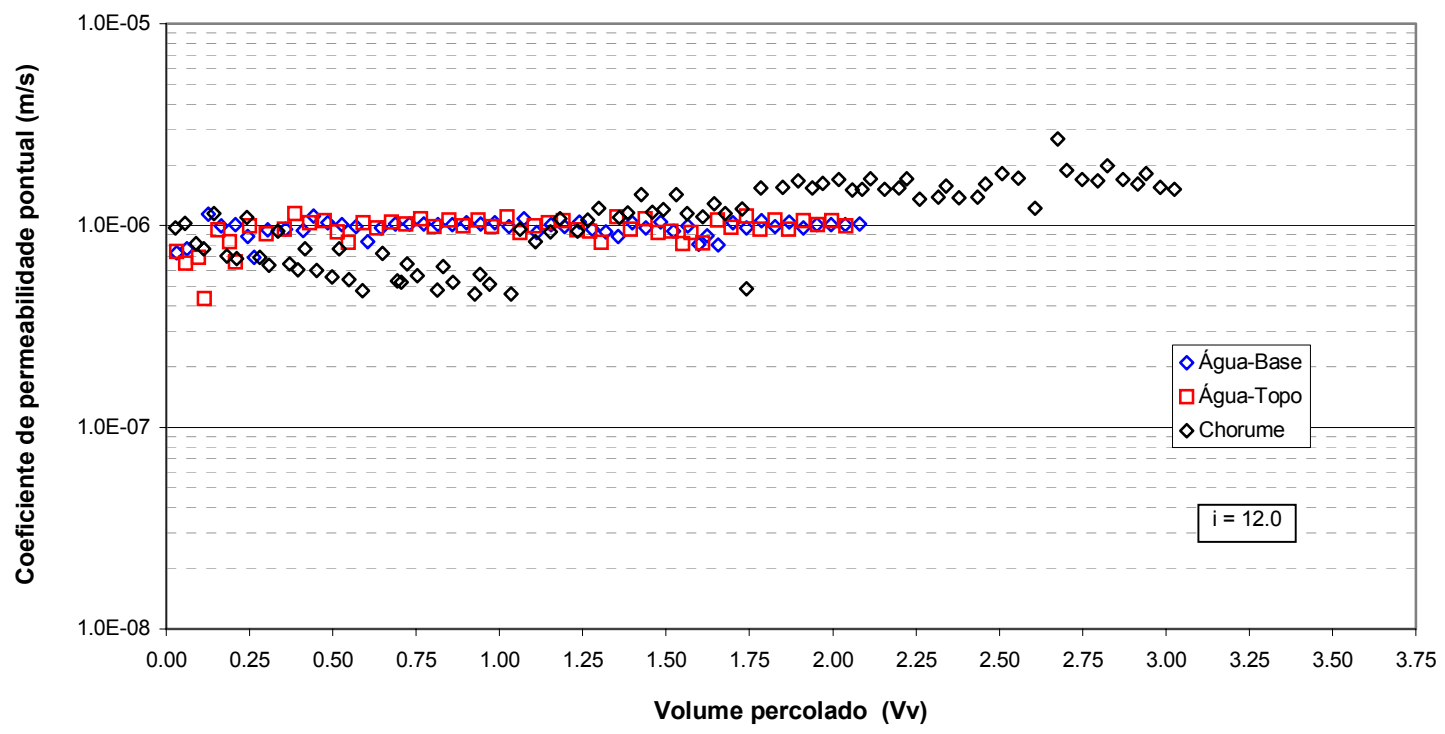

Ensaio de Coluna com Percolação de Água e Chorume + Metais - Tensão Confinante $=30 \mathrm{kPa}$

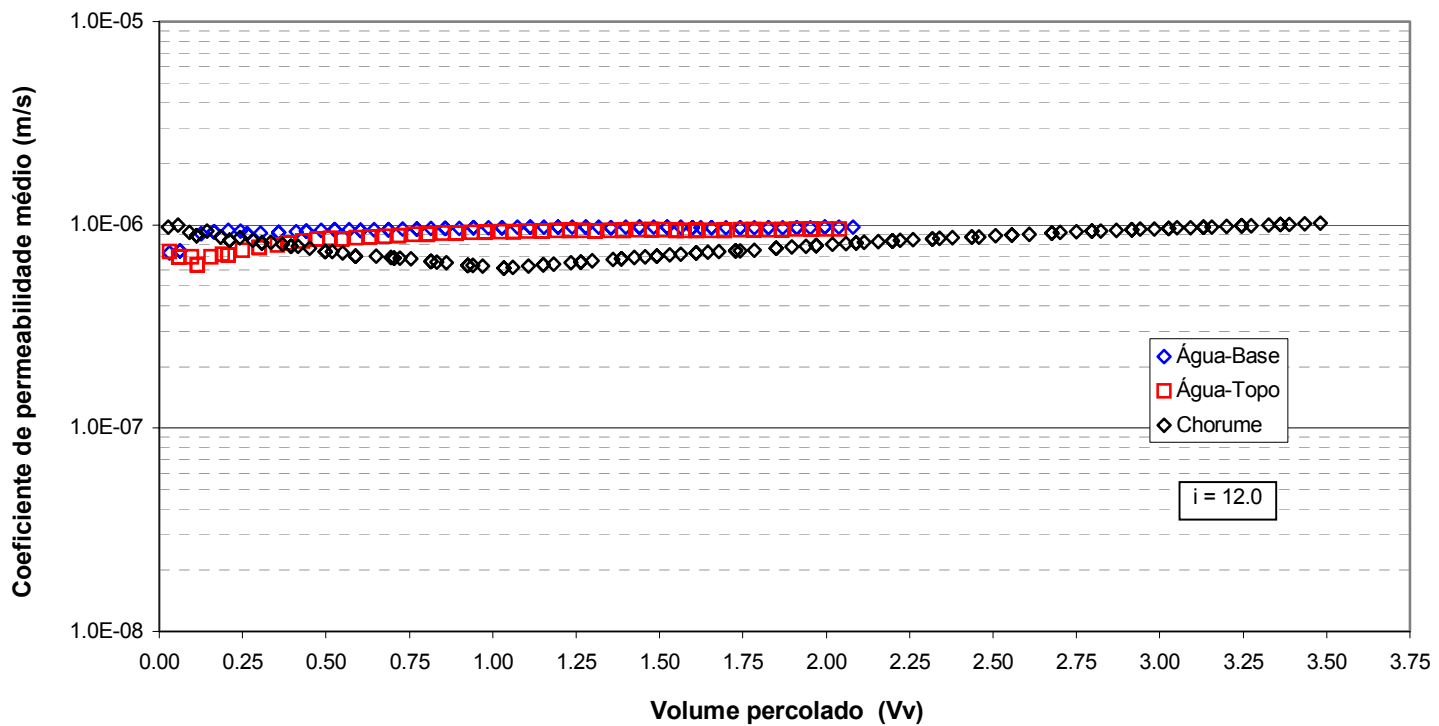




\section{Monitoramento dos Efluentes da Coluna de Chorume mais Metais:}

Características iniciais da solução de metais:

- Condutividade Inicial $=15140 \mu \mathrm{S} / \mathrm{cm}$;

- $\mathrm{PH}$ inicial $=8.19$;

- Concentração Inicial de $\mathrm{Ni}=11.2 \mathrm{mg} / \mathrm{L}$;

- Concentração Inicial de $\mathrm{Zn}=11.3 \mathrm{mg} / \mathrm{L}$;

- Concentração Inicial de $\mathrm{Cd}=6.3 \mathrm{mg} / \mathrm{L}$;

- Concentração Inicial de $\mathrm{Pb}=6.9 \mathrm{mg} / \mathrm{L}$;

Coluna com Percolação de Chorume + Metais - Tensão Confinante $=\mathbf{3 0} \mathbf{~} \mathrm{Pa}$

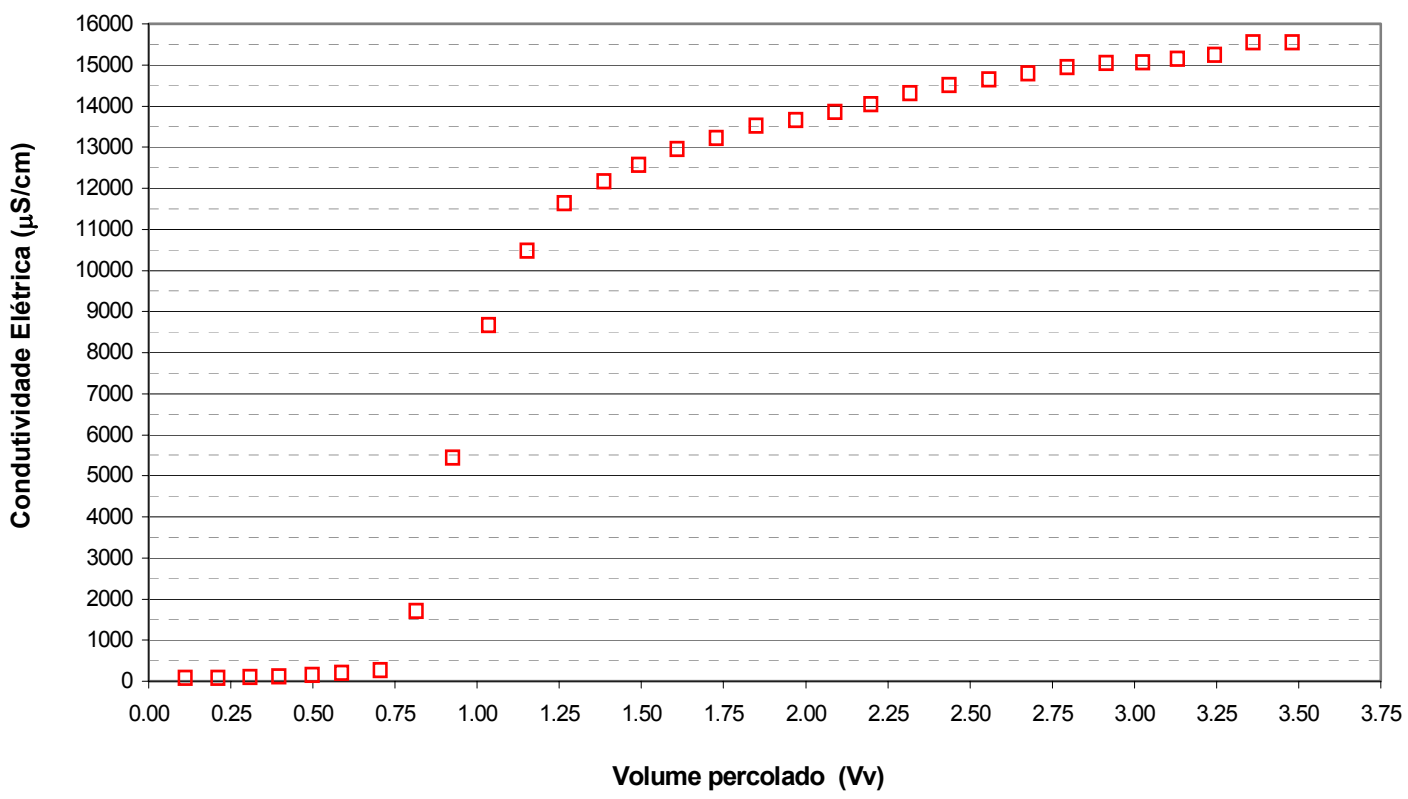


Coluna com Percolação de Chorume + Metais - Tensão Confinante $=30 \mathrm{kPa}$

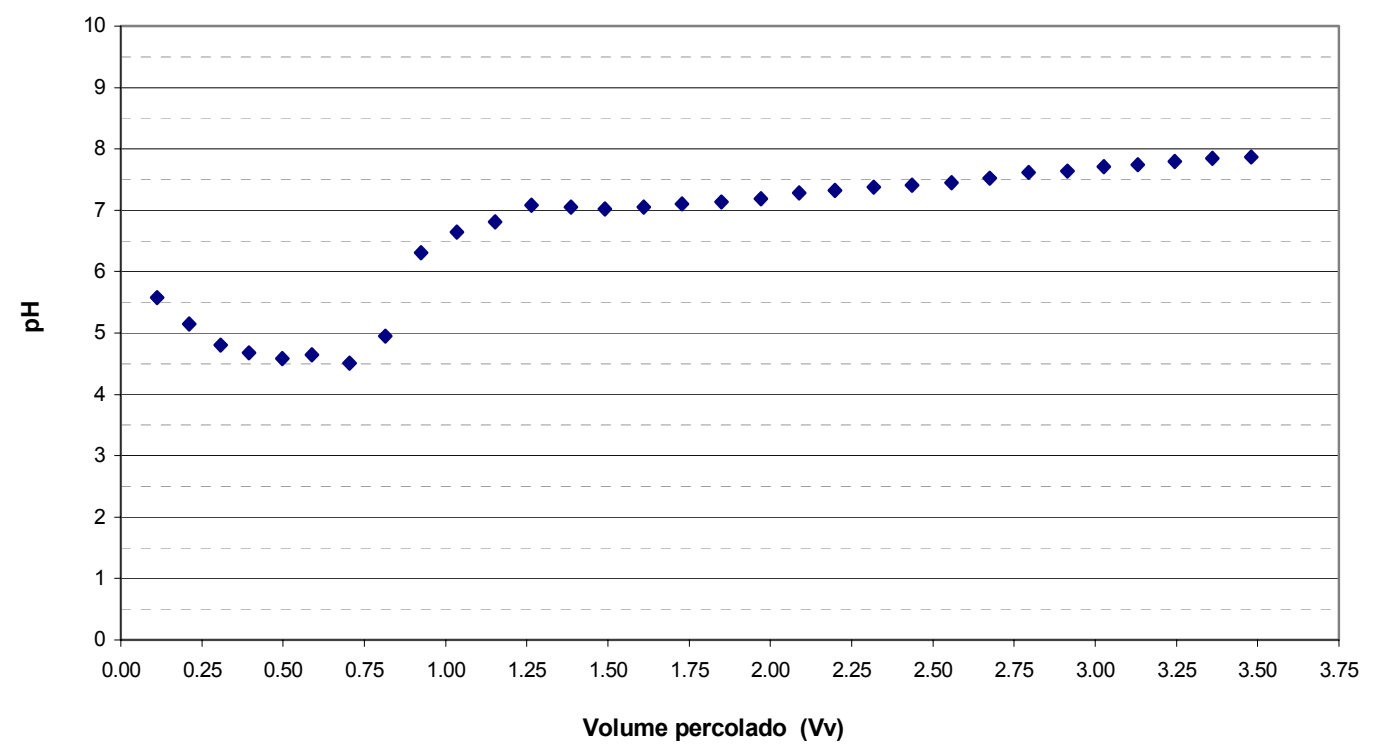

Coluna com Percolação de Chorume + Metais - Tensão Confinante $=30 \mathrm{kPa}$

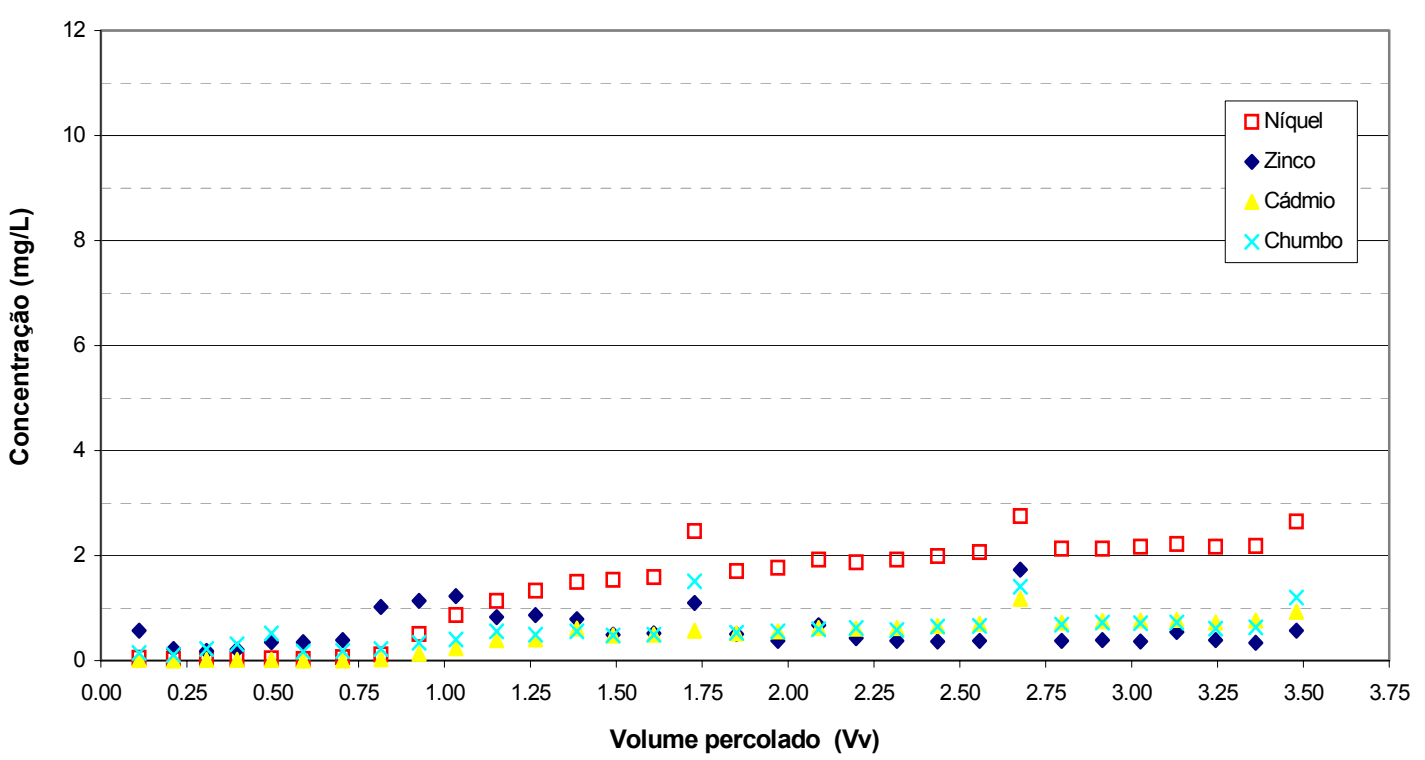




\section{ANEXO V}

Resultados dos Ensaios de Adsorção em Lote (Batch Tests) Realizados com o Solo do Entorno do Aterro de Resíduos de Bauru 


\section{DETERMINAÇÃO DA RAZÃO SOLO-SOLUÇÃO}

- Duração: 24 h

- Teor de umidade do solo seco ao ar e passado na peneira 40: $1.25 \%$

Níquel:

\begin{tabular}{|c|c|c|c|c|c|}
\hline \multirow{2}{*}{ Amostra } & Concentração & Psolo & $\mathbf{P}_{\text {sólido }}$ & $\mathbf{S}$ & $\mathbf{A}$ \\
\cline { 2 - 6 } & $\mathbf{( m g / L )}$ & $\mathbf{( g )}$ & $\mathbf{( g )}$ & $\mathbf{( m g / g )}$ & $\mathbf{( \% )}$ \\
\hline Solução 1:4 & 3.29 & 24.90 & 24.59 & 0.03 & 70.81 \\
\hline Solução 1:10 & 5.53 & 9.97 & 9.84 & 0.06 & 50.93 \\
\hline Solução 1:20 & 6.55 & 4.98 & 4.92 & 0.10 & 41.88 \\
\hline Solução 1:50 & 7.67 & 2.04 & 2.01 & 0.18 & 31.94 \\
\hline Solução 1:100 & 8.28 & 1.07 & 1.06 & 0.28 & 26.53 \\
\hline Solução 1:200 & 8.65 & 0.50 & 0.49 & 0.54 & 23.25 \\
\hline Solução 1:500 & 9.32 & 0.20 & 0.20 & 0.99 & 17.30 \\
\hline Solução - Branco & 11.27 & & & & \\
\hline Chorume 1:4 & 6.09 & 24.93 & 24.63 & 0.01 & 36.43 \\
\hline Chorume 1:10 & 7.22 & 10.08 & 9.96 & 0.02 & 24.63 \\
\hline Chorume 1:20 & 7.77 & 4.98 & 4.91 & 0.04 & 18.89 \\
\hline Chorume 1:50 & 8.92 & 2.03 & 2.00 & 0.03 & 6.89 \\
\hline Chorume 1:100 & 9.20 & 1.05 & 1.04 & 0.04 & 3.97 \\
\hline Chorume 1:200 & 9.39 & 0.50 & 0.49 & 0.04 & 1.98 \\
\hline Chorume 1:500 & 9.42 & 0.20 & 0.20 & 0.08 & 1.67 \\
\hline Chorume - Branco & 9.58 & & & & \\
\hline
\end{tabular}


$\underline{\text { Zinco: }}$

\begin{tabular}{|c|c|c|c|c|c|}
\hline \multirow{2}{*}{ Amostra } & Concentração & Psolo & $\mathbf{P}_{\text {sólido }}$ & $\mathbf{S}$ & $\mathbf{A}$ \\
\cline { 2 - 6 } & $\mathbf{( m g / L )}$ & $\mathbf{( g )}$ & $\mathbf{( g )}$ & $\mathbf{( m g / g )}$ & $\mathbf{( \% )}$ \\
\hline Solução 1:4 & 1.40 & 24.90 & 24.59 & 0.01 & 70.36 \\
\hline Solução 1:10 & 2.30 & 9.97 & 9.84 & 0.02 & 51.12 \\
\hline Solução 1:20 & 2.69 & 4.98 & 4.92 & 0.04 & 42.96 \\
\hline Solução 1:50 & 3.09 & 2.04 & 2.01 & 0.08 & 34.49 \\
\hline Solução 1:100 & 3.30 & 1.07 & 1.06 & 0.13 & 30.00 \\
\hline Solução 1:200 & 3.43 & 0.50 & 0.49 & 0.26 & 27.28 \\
\hline Solução 1:500 & 3.65 & 0.20 & 0.20 & 0.54 & 22.51 \\
\hline Solução - Branco & 4.71 & & & & \\
\hline Chorume 1:4 & 1.05 & 24.93 & 24.63 & 0.01 & 74.50 \\
\hline Chorume 1:10 & 1.26 & 10.08 & 9.96 & 0.03 & 69.24 \\
\hline Chorume 1:20 & 1.48 & 4.98 & 4.91 & 0.05 & 64.08 \\
\hline Chorume 1:50 & 2.11 & 2.03 & 2.00 & 0.10 & 48.73 \\
\hline Chorume 1:100 & 2.28 & 1.05 & 1.04 & 0.18 & 44.54 \\
\hline Chorume 1:200 & 2.72 & 0.50 & 0.49 & 0.28 & 33.83 \\
\hline Chorume 1:500 & 3.07 & 0.20 & 0.20 & 0.52 & 25.30 \\
\hline Chorume - Branco & 4.11 & & & & \\
\hline
\end{tabular}

Cádmio:

\begin{tabular}{|c|c|c|c|c|c|}
\hline \multirow{2}{*}{ Amostra } & Concentração & Psolo & $\mathbf{P}_{\text {sólido }}$ & $\mathbf{S}$ & $\mathbf{A}$ \\
\cline { 2 - 6 } & $\mathbf{( m g / \mathbf { L } )}$ & $\mathbf{( g )}$ & $\mathbf{( g )}$ & $\mathbf{( m g / g )}$ & $\mathbf{( \% )}$ \\
\hline Solução 1:4 & 3.36 & 24.90 & 24.59 & 0.03 & 69.89 \\
\hline Solução 1:10 & 5.58 & 9.97 & 9.84 & 0.06 & 50.00 \\
\hline Solução 1:20 & 6.68 & 4.98 & 4.92 & 0.09 & 40.14 \\
\hline Solução 1:50 & 7.70 & 2.04 & 2.01 & 0.17 & 31.00 \\
\hline Solução 1:100 & 8.26 & 1.07 & 1.06 & 0.27 & 25.99 \\
\hline Solução 1:200 & 8.72 & 0.50 & 0.49 & 0.50 & 21.86 \\
\hline Solução 1:500 & 9.47 & 0.20 & 0.20 & 0.86 & 15.14 \\
\hline Solução - Branco & 11.16 & & & & \\
\hline Chorume 1:4 & 0.40 & 24.93 & 24.63 & 0.00 & 57.81 \\
\hline Chorume 1:10 & 0.54 & 10.08 & 9.96 & 0.00 & 42.25 \\
\hline Chorume 1:20 & 1.05 & 4.98 & 4.91 & 0.00 & -11.36 \\
\hline Chorume 1:50 & 0.81 & 2.03 & 2.00 & 0.01 & 14.12 \\
\hline Chorume 1:100 & 0.78 & 1.05 & 1.04 & 0.02 & 17.41 \\
\hline Chorume 1:200 & 0.84 & 0.50 & 0.49 & 0.02 & 11.15 \\
\hline Chorume 1:500 & 0.88 & 0.20 & 0.20 & 0.03 & 6.26 \\
\hline Chorume - Branco & 0.94 & & & & \\
\hline
\end{tabular}


Chumbo:

\begin{tabular}{|c|c|c|c|c|c|}
\hline \multirow{2}{*}{ Amostra } & Concentração & Psolo & $\mathbf{P}_{\text {sólido }}$ & $\mathbf{S}$ & $\mathbf{A}$ \\
\cline { 2 - 6 } & $\mathbf{( m g / L )}$ & $\mathbf{( g )}$ & $\mathbf{( g )}$ & $\mathbf{( m g / g )}$ & $\mathbf{( \% )}$ \\
\hline Solução 1:4 & 1.18 & 24.90 & 24.59 & 0.03 & 87.58 \\
\hline Solução 1:10 & 1.24 & 9.97 & 9.84 & 0.08 & 86.95 \\
\hline Solução 1:20 & 2.22 & 4.98 & 4.92 & 0.15 & 76.68 \\
\hline Solução 1:50 & 2.35 & 2.04 & 2.01 & 0.36 & 75.29 \\
\hline Solução 1:100 & 3.90 & 1.07 & 1.06 & 0.53 & 59.04 \\
\hline Solução 1:200 & 2.87 & 0.50 & 0.49 & 1.36 & 69.85 \\
\hline Solução 1:500 & 2.90 & 0.20 & 0.20 & 3.37 & 69.59 \\
\hline Solução - Branco & 9.52 & & & & \\
\hline Chorume 1:4 & 0.69 & 24.93 & 24.63 & 0.01 & 76.81 \\
\hline Chorume 1:10 & 0.77 & 10.08 & 9.96 & 0.02 & 74.04 \\
\hline Chorume 1:20 & 3.14 & 4.98 & 4.91 & 0.00 & -5.84 \\
\hline Chorume 1:50 & 2.21 & 2.03 & 2.00 & 0.04 & 25.42 \\
\hline Chorume 1:100 & 3.34 & 1.05 & 1.04 & -0.04 & -12.80 \\
\hline Chorume 1:200 & 2.26 & 0.50 & 0.49 & 0.14 & 23.84 \\
\hline Chorume 1:500 & 2.20 & 0.20 & 0.20 & 0.38 & 25.59 \\
\hline Chorume - Branco & 2.96 & & & & \\
\hline
\end{tabular}

\section{DETERMINAÇÃO DO TEMPO DE EQUILÍBRIO}

\section{Solução de Metais:}

- Teor de umidade do solo seco ao ar e passado na peneira 40: $1.23 \%$

- RSS: $1: 4$

pH:

\begin{tabular}{|c|c|c|}
\hline Tempo (h) & $\mathrm{pH}$ final médio & $\mathrm{pH}$ Branco \\
\hline 0 & 8.29 & 8.29 \\
\hline 2 & 5.05 & 5.50 \\
\hline 4 & 4.86 & 6.46 \\
\hline 24 & 4.40 & 5.42 \\
\hline 48 & 4.38 & 5.86 \\
\hline 72 & 4.31 & 5.91 \\
\hline 168 & 4.52 & 6.19 \\
\hline
\end{tabular}




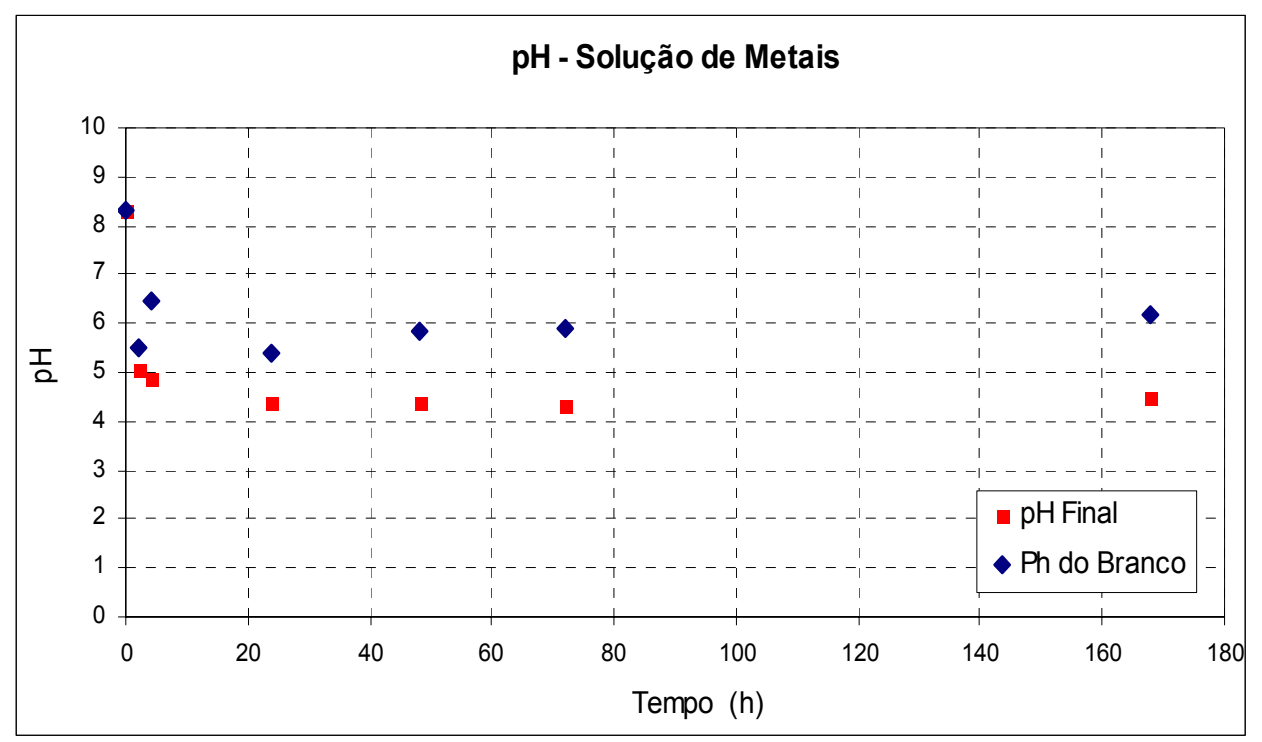

\section{Condutividade Elétrica:}

\begin{tabular}{|c|c|c|}
\hline Tempo $(\mathrm{h})$ & $\begin{array}{c}\text { Cond. final média } \\
(\mu \mathrm{S} / \mathrm{cm})\end{array}$ & $\begin{array}{c}\text { Cond. do Branco } \\
(\mu \mathrm{S} / \mathrm{cm})\end{array}$ \\
\hline 0 & 107.95 & 107.95 \\
\hline 2 & 107.60 & 107.95 \\
\hline 4 & 101.93 & 107.40 \\
\hline 24 & 91.77 & 112.40 \\
\hline 48 & 96.93 & 98.75 \\
\hline 72 & 91.17 & 104.50 \\
\hline 168 & 84.20 & 104.80 \\
\hline
\end{tabular}

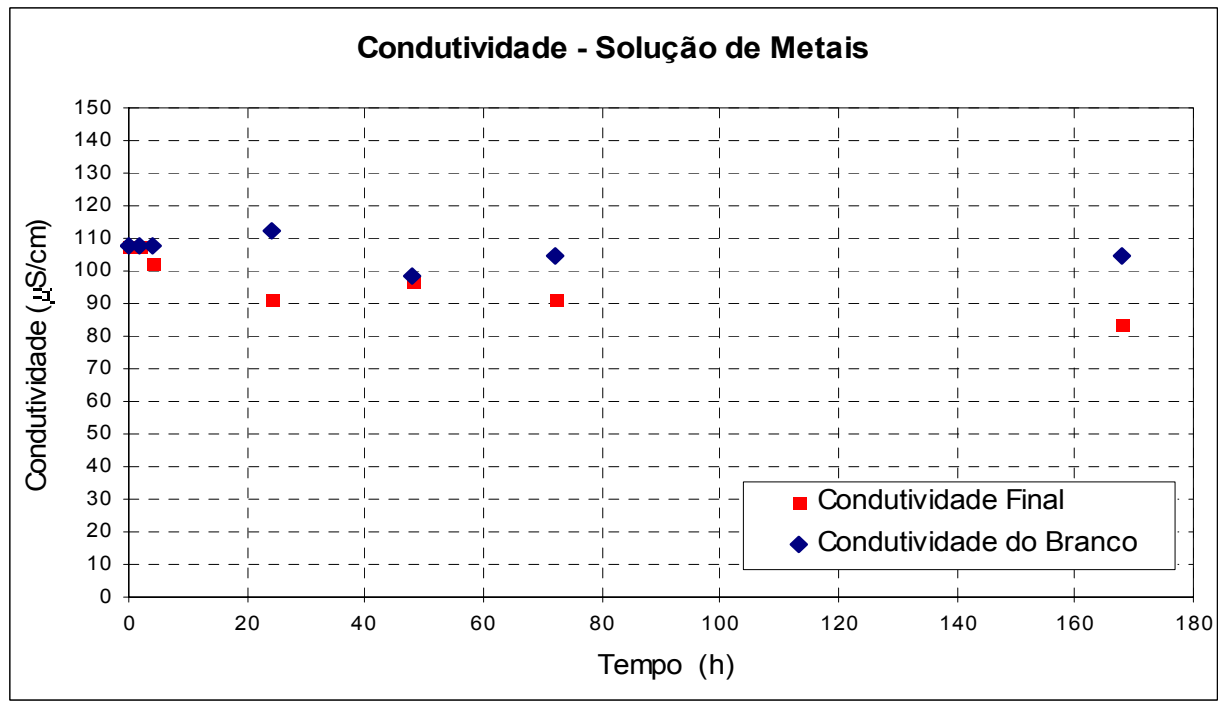


Níquel:

\begin{tabular}{|c|c|c|c|c|c|c|c|}
\hline \multirow{2}{*}{ Amostra } & \multirow[t]{2}{*}{ Tempo (h) } & \multicolumn{2}{|c|}{ Concentração Concentração } & \multirow{2}{*}{$\begin{array}{c}\text { Psolo } \\
\text { (g) }\end{array}$} & \multirow{2}{*}{\begin{tabular}{|c|} 
Psólido \\
(g)
\end{tabular}} & \multirow{2}{*}{\begin{tabular}{|c|} 
A \\
$(\%)$ \\
\end{tabular}} & \multirow{2}{*}{\begin{tabular}{|c|} 
A média \\
$(\%)$ \\
\end{tabular}} \\
\hline & & (mg/L) & média $(\mathrm{mg} / \mathrm{L})$ & & & & \\
\hline 2h B1 & \multirow{5}{*}{2} & 10.14 & \multirow{2}{*}{10.22} & & & & \\
\hline 2h B2 & & 10.29 & & & & & \\
\hline $2 \mathrm{~h} \mathrm{a}$ & & 5.04 & \multirow{3}{*}{5.41} & 25.02 & 24.71 & 50.66 & \\
\hline $2 \mathrm{~h} \mathrm{~b}$ & & 5.65 & & 24.99 & 24.69 & 44.69 & \\
\hline $2 \mathrm{~h} \mathrm{c}$ & & 5.54 & & 25.03 & 24.72 & 45.77 & 47.04 \\
\hline 4h B1 & \multirow{5}{*}{4} & 10.00 & \multirow{2}{*}{9.94} & & & & \\
\hline 4h B2 & & 9.87 & & & & & \\
\hline 4h a & & 5.11 & \multirow{3}{*}{4.92} & 25.02 & 24.72 & 48.57 & \\
\hline $4 \mathrm{~h} \mathrm{~b}$ & & 4.92 & & 25.04 & 24.73 & 50.46 & \\
\hline $4 h \mathrm{c}$ & & 4.74 & & 25.04 & 24.73 & 52.32 & 50.45 \\
\hline 24h B1 & \multirow{5}{*}{24} & 10.51 & \multirow{2}{*}{10.45} & & & & \\
\hline 24h B2 & & 10.39 & & & & & \\
\hline 24h a & & 4.32 & \multirow{3}{*}{4.16} & 25.01 & 24.71 & 58.70 & \\
\hline $24 h$ b & & 4.04 & & 25.03 & 24.73 & 61.37 & \\
\hline $24 \mathrm{~h} \mathrm{c}$ & & 4.11 & & 25.02 & 24.72 & 60.64 & 60.24 \\
\hline 48h B1 & \multirow{5}{*}{48} & 10.68 & \multirow{2}{*}{10.67} & & & & \\
\hline 48h B2 & & 10.66 & & & & & \\
\hline 48h a & & 4.32 & \multirow{3}{*}{3.93} & 25.03 & 24.72 & 59.56 & \\
\hline $48 \mathrm{~h} \mathrm{~b}$ & & 3.72 & & 24.99 & 24.69 & 65.10 & \\
\hline $48 \mathrm{~h} \mathrm{c}$ & & 3.76 & & 25.00 & 24.70 & 64.78 & 63.15 \\
\hline 72h B1 & \multirow{5}{*}{72} & 10.75 & \multirow{2}{*}{10.69} & & & & \\
\hline 72h B2 & & 10.63 & & & & & \\
\hline $72 \mathrm{~h}$ a & & 3.33 & \multirow{3}{*}{3.55} & 25.00 & 24.70 & 68.90 & \\
\hline $72 \mathrm{~h} \mathrm{~b}$ & & 3.72 & & 25.02 & 24.71 & 65.23 & \\
\hline $72 \mathrm{~h} \mathrm{c}$ & & 3.62 & & 24.99 & 24.69 & 66.16 & 66.76 \\
\hline $\begin{array}{c}1 \text { semana } \\
\text { B1 }\end{array}$ & \multirow{5}{*}{168} & 10.68 & \multirow{2}{*}{10.61} & & & & \\
\hline $\begin{array}{c}1 \text { semana } \\
\text { B2 }\end{array}$ & & 10.54 & & & & & \\
\hline 1 semana a & & 2.85 & \multirow{3}{*}{2.83} & 25.03 & 24.73 & 73.14 & \\
\hline 1 semana $b$ & & 2.70 & & 25.01 & 24.71 & 74.58 & \\
\hline 1 semana c & & 2.93 & & 25.00 & 24.70 & 72.37 & 73.36 \\
\hline
\end{tabular}



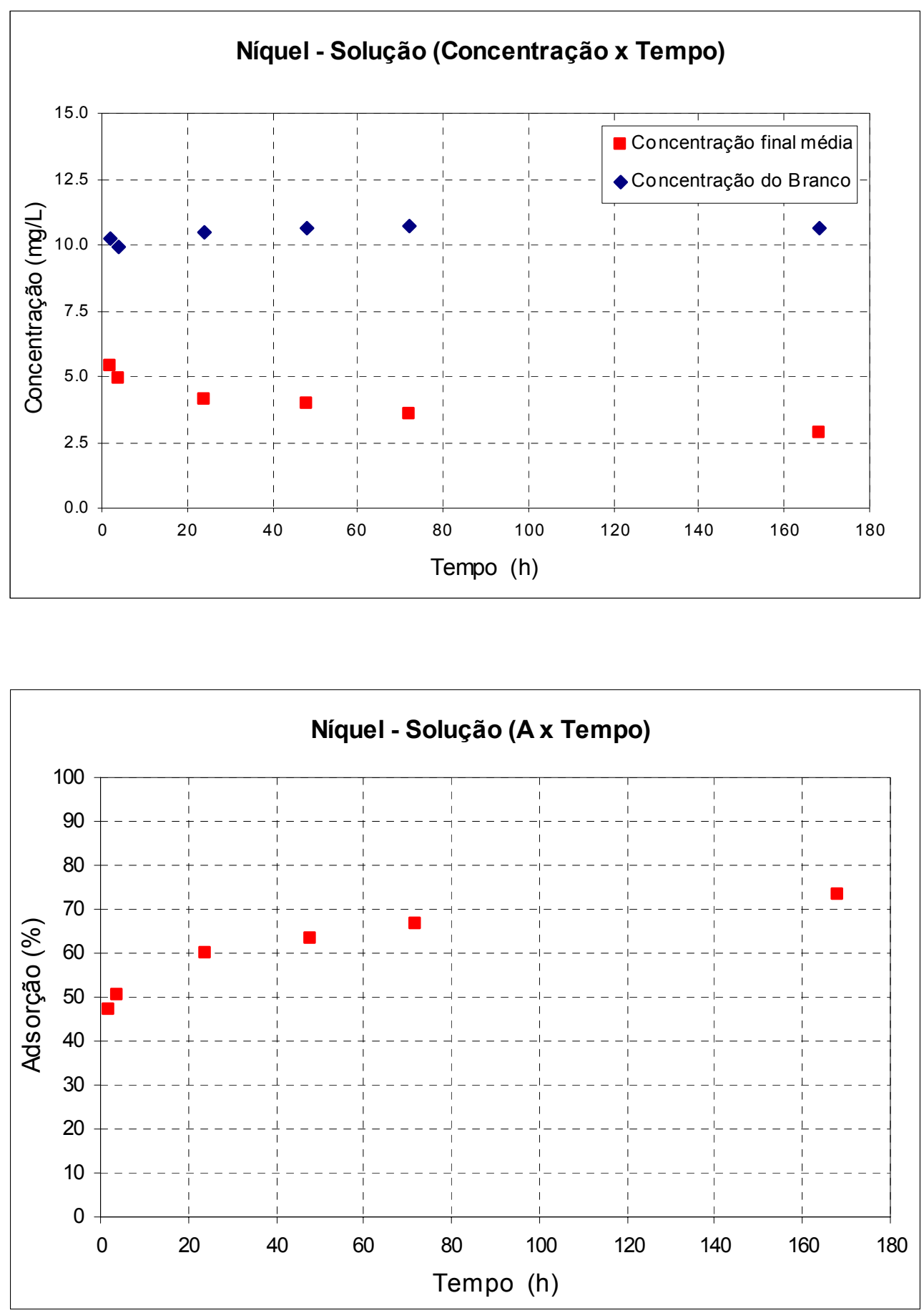
$\underline{\text { Zinco: }}$

\begin{tabular}{|c|c|c|c|c|c|c|c|}
\hline Amostra & Tempo (h) & $\begin{array}{c}\text { Concentraçã } \\
(\mathrm{mg} / \mathrm{L})\end{array}$ & $\begin{array}{l}\text { oConcentração } \\
\text { média }(\mathrm{mg} / \mathrm{L})\end{array}$ & $\begin{array}{c}\text { Psolo } \\
\text { (g) }\end{array}$ & \begin{tabular}{|c|} 
Psólido \\
(g)
\end{tabular} & \begin{tabular}{|c|} 
A \\
$(\%)$
\end{tabular} & \begin{tabular}{|c|} 
A média \\
$(\%)$ \\
\end{tabular} \\
\hline 2h B1 & \multirow{5}{*}{2} & 7.50 & \multirow{2}{*}{7.60} & & & & \\
\hline 2h B2 & & 7.69 & & & & & \\
\hline $2 \mathrm{~h}$ a & & 4.02 & \multirow{3}{*}{4.29} & 25.02 & 24.71 & 47.03 & \\
\hline $2 \mathrm{~h} \mathrm{~b}$ & & 4.46 & & 24.99 & 24.69 & 41.30 & \\
\hline $2 \mathrm{~h} \mathrm{c}$ & & 4.40 & & 25.03 & 24.72 & 42.08 & 43.47 \\
\hline 4h B1 & \multirow{5}{*}{4} & 7.31 & \multirow{2}{*}{7.24} & & & & \\
\hline 4h B2 & & 7.17 & & & & & \\
\hline $4 \mathrm{~h}$ a & & 3.93 & \multirow{3}{*}{3.82} & 25.02 & 24.72 & 45.79 & \\
\hline $4 \mathrm{~h} \mathrm{~b}$ & & 3.81 & & 25.04 & 24.73 & 47.32 & \\
\hline $4 \mathrm{~h} \mathrm{c}$ & & 3.72 & & 25.04 & 24.73 & 48.63 & 47.25 \\
\hline 24h B1 & \multirow{5}{*}{24} & 7.99 & \multirow{2}{*}{7.93} & & & & \\
\hline 24h B2 & & 7.86 & & & & & \\
\hline $24 \mathrm{~h}$ a & & 3.42 & \multirow{3}{*}{3.28} & 25.01 & 24.71 & 56.81 & \\
\hline $24 \mathrm{~h} \mathrm{~b}$ & & 3.17 & & 25.03 & 24.73 & 59.97 & \\
\hline $24 \mathrm{~h} \mathrm{c}$ & & 3.25 & & 25.02 & 24.72 & 59.03 & 58.60 \\
\hline 48h B1 & \multirow{5}{*}{48} & 8.06 & \multirow{2}{*}{8.14} & & & & \\
\hline 48h B2 & & 8.21 & & & & & \\
\hline $48 h$ a & & 3.43 & \multirow{3}{*}{3.10} & 25.03 & 24.72 & 57.85 & \\
\hline $48 \mathrm{~h} \mathrm{~b}$ & & 2.89 & & 24.99 & 24.69 & 64.45 & \\
\hline $48 \mathrm{~h} \mathrm{c}$ & & 2.99 & & 25.00 & 24.70 & 63.21 & 61.84 \\
\hline 72h B1 & \multirow{5}{*}{72} & 8.19 & \multirow{2}{*}{8.08} & & & & \\
\hline 72h B2 & & 7.97 & & & & & \\
\hline $72 \mathrm{~h}$ a & & 2.68 & \multirow{3}{*}{2.83} & 25.00 & 24.70 & 66.84 & \\
\hline $72 \mathrm{~h} \mathrm{~b}$ & & 2.93 & & 25.02 & 24.71 & 63.75 & \\
\hline $72 \mathrm{~h} \mathrm{c}$ & & 2.88 & & 24.99 & 24.69 & 64.34 & 64.98 \\
\hline $\begin{array}{c}1 \text { semana } \\
\text { B1 }\end{array}$ & \multirow{5}{*}{168} & 8.17 & \multirow{2}{*}{8.05} & & & & \\
\hline $\begin{array}{c}1 \text { semana } \\
\text { B2 }\end{array}$ & & 7.93 & & & & & \\
\hline 1 semana a & & 2.27 & \multirow{3}{*}{2.24} & 25.03 & 24.73 & 71.75 & \\
\hline 1 semana $b$ & & 2.11 & & 25.01 & 24.71 & 73.84 & \\
\hline 1 semana $\mathrm{c}$ & & 2.35 & & 25.00 & 24.70 & 70.82 & 72.14 \\
\hline
\end{tabular}



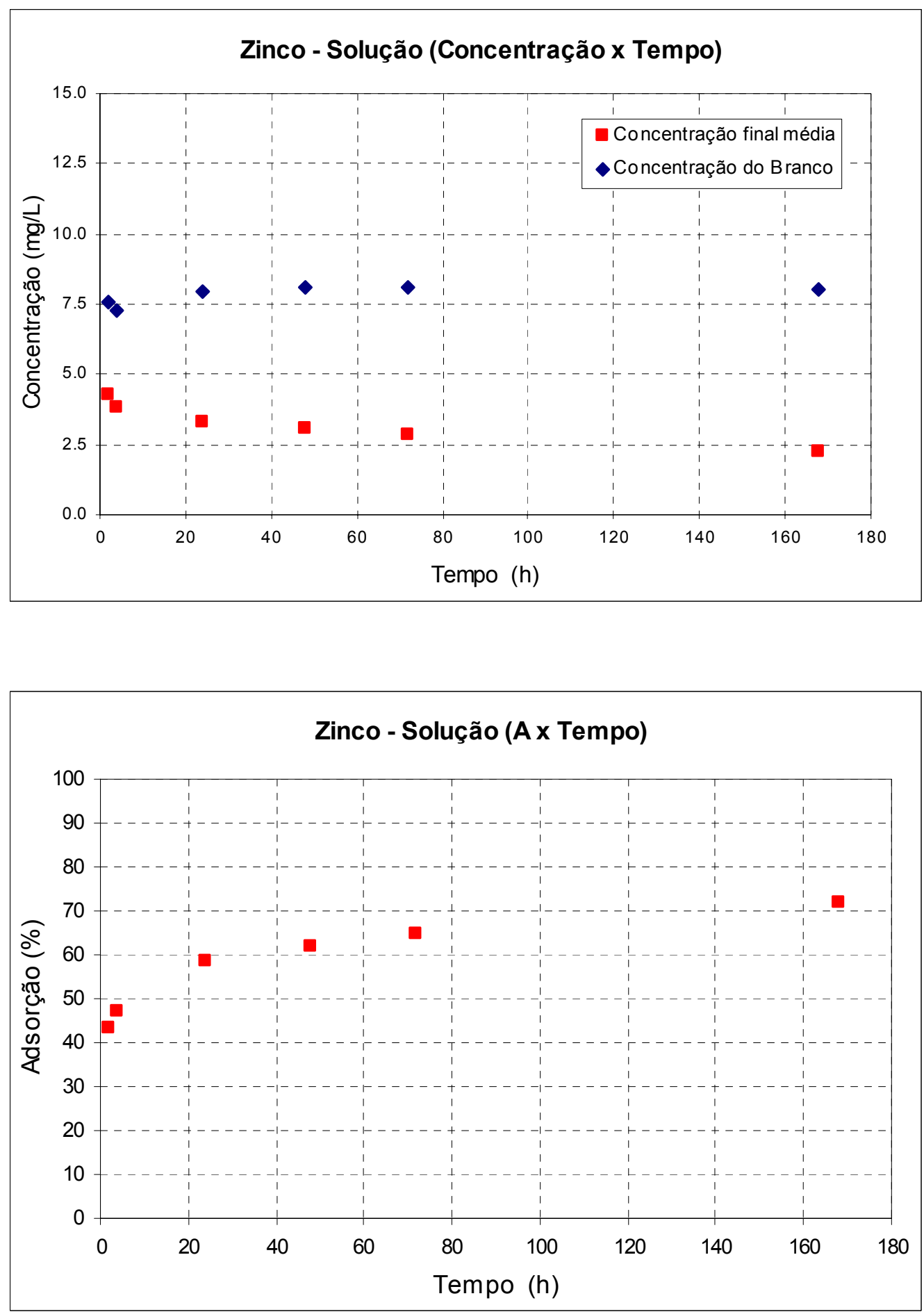
Cádmio:

\begin{tabular}{|c|c|c|c|c|c|c|c|}
\hline \multirow{2}{*}{ Amostra } & \multirow[t]{2}{*}{ Tempo (h) } & \multicolumn{2}{|c|}{ Concentração Concentração } & \multirow{2}{*}{$\begin{array}{c}\text { Psolo } \\
\text { (g) }\end{array}$} & \multirow{2}{*}{\begin{tabular}{|c|} 
Psólido \\
(g)
\end{tabular}} & \multirow{2}{*}{\begin{tabular}{|c|}
$A$ \\
$(\%)$ \\
\end{tabular}} & \multirow{2}{*}{\begin{tabular}{|c|} 
A média \\
$(\%)$
\end{tabular}} \\
\hline & & $(\mathrm{mg} / \mathrm{L})$ & média $(\mathrm{mg} / \mathrm{L})$ & & & & \\
\hline 2h B1 & \multirow{5}{*}{2} & 10.16 & \multirow{2}{*}{10.30} & & & & \\
\hline 2h B2 & & 10.43 & & & & & \\
\hline $2 \mathrm{~h} \mathrm{a}$ & & 5.35 & \multirow{3}{*}{5.73} & 25.02 & 24.71 & 48.03 & \\
\hline $2 \mathrm{~h} \mathrm{~b}$ & & 5.96 & & 24.99 & 24.69 & 42.11 & \\
\hline $2 \mathrm{~h} \mathrm{c}$ & & 5.87 & & 25.03 & 24.72 & 42.98 & 44.37 \\
\hline 4h B1 & \multirow{5}{*}{4} & 10.05 & \multirow{2}{*}{9.93} & & & & \\
\hline 4h B2 & & 9.81 & & & & & \\
\hline $4 \mathrm{~h} \mathrm{a}$ & & 5.39 & \multirow{3}{*}{5.16} & 25.02 & 24.72 & 45.72 & \\
\hline $4 \mathrm{~h} \mathrm{~b}$ & & 5.12 & & 25.04 & 24.73 & 48.44 & \\
\hline $4 \mathrm{~h} \mathrm{c}$ & & 4.98 & & 25.04 & 24.73 & 49.89 & 48.02 \\
\hline 24h B1 & \multirow{5}{*}{24} & 10.53 & \multirow{2}{*}{10.46} & & & & \\
\hline 24h B2 & & 10.38 & & & & & \\
\hline 24h a & & 4.61 & \multirow{3}{*}{4.44} & 25.01 & 24.71 & 55.88 & \\
\hline $24 h$ b & & 4.32 & & 25.03 & 24.73 & 58.65 & \\
\hline 24h c & & 4.39 & & 25.02 & 24.72 & 58.01 & 57.51 \\
\hline 48h B1 & \multirow{5}{*}{48} & 10.75 & \multirow{2}{*}{10.74} & & & & \\
\hline 48h B2 & & 10.73 & & & & & \\
\hline $48 \mathrm{~h} a$ & & 4.61 & \multirow{3}{*}{4.19} & 25.03 & 24.72 & 57.05 & \\
\hline $48 \mathrm{~h} \mathrm{~b}$ & & 3.93 & & 24.99 & 24.69 & 63.38 & \\
\hline $48 \mathrm{~h} \mathrm{c}$ & & 4.02 & & 25.00 & 24.70 & 62.58 & 61.00 \\
\hline 72h B1 & \multirow{5}{*}{72} & 10.82 & \multirow{2}{*}{10.79} & & & & \\
\hline $72 \mathrm{~h} \mathrm{B2}$ & & 10.76 & & & & & \\
\hline $72 \mathrm{~h} \mathrm{a}$ & & 3.55 & \multirow{3}{*}{3.78} & 25.00 & 24.70 & 67.06 & \\
\hline $72 \mathrm{~h} \mathrm{~b}$ & & 3.94 & & 25.02 & 24.71 & 63.46 & \\
\hline $72 \mathrm{~h} \mathrm{c}$ & & 3.83 & & 24.99 & 24.69 & 64.48 & 65.00 \\
\hline $\begin{array}{c}1 \text { semana } \\
\text { B1 }\end{array}$ & \multirow{5}{*}{168} & 10.61 & \multirow{2}{*}{10.55} & & & & \\
\hline $\begin{array}{c}1 \text { semana } \\
\text { B2 }\end{array}$ & & 10.48 & & & & & \\
\hline 1 semana a & & 3.04 & \multirow{3}{*}{3.04} & 25.03 & 24.73 & 71.19 & \\
\hline 1 semana $b$ & & 2.94 & & 25.01 & 24.71 & 72.17 & \\
\hline 1 semana c & & 3.16 & & 25.00 & 24.70 & 70.05 & 71.14 \\
\hline
\end{tabular}



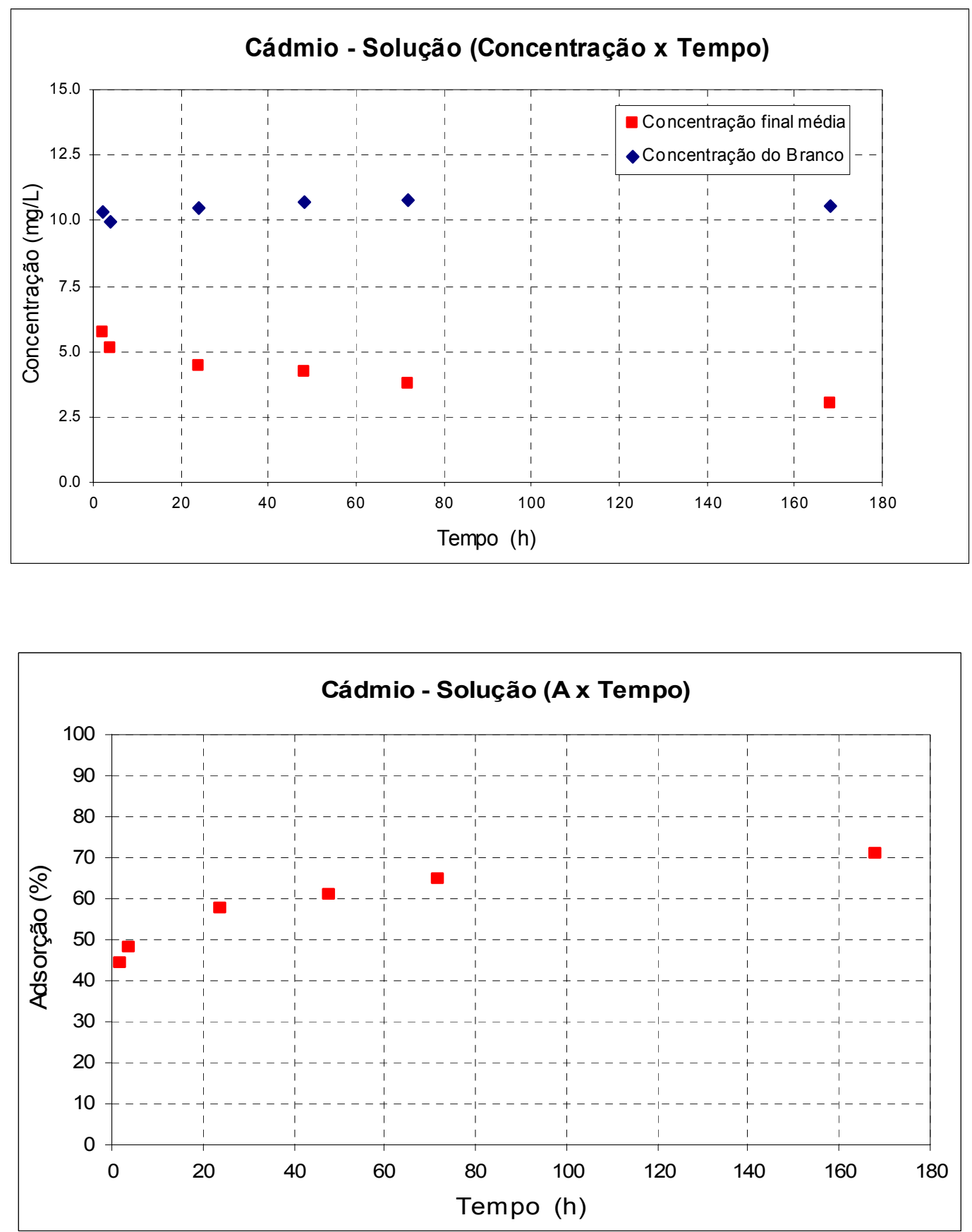
Chumbo:

\begin{tabular}{|c|c|c|c|c|c|c|c|}
\hline Amostra & Tempo (h) & \begin{tabular}{|c|} 
Concentração \\
$(\mathrm{mg} / \mathrm{L})$
\end{tabular} & $\begin{array}{l}\text { Concentração } \\
\text { média }(\mathrm{mg} / \mathrm{L})\end{array}$ & \begin{tabular}{|c|} 
Psolo \\
(g)
\end{tabular} & \begin{tabular}{|c|} 
Psólido \\
(g)
\end{tabular} & $\begin{array}{c}A \\
(\%)\end{array}$ & \begin{tabular}{|c|} 
A média \\
$(\%)$
\end{tabular} \\
\hline 2h B1 & \multirow{5}{*}{2} & 0.70 & \multirow{2}{*}{0.58} & & & & \\
\hline 2h B2 & & 0.47 & & & & & \\
\hline $2 \mathrm{~h}$ a & & 1.34 & \multirow{3}{*}{1.44} & 25.02 & 24.71 & -129.30 & \\
\hline $2 \mathrm{~h} \mathrm{~b}$ & & 1.49 & & 24.99 & 24.69 & -154.96 & \\
\hline $2 \mathrm{~h} \mathrm{c}$ & & 1.48 & & 25.03 & 24.72 & -152.40 & -145.55 \\
\hline 4h B1 & \multirow{5}{*}{4} & 0.15 & \multirow{2}{*}{0.14} & & & & \\
\hline 4h B2 & & 0.13 & & & & & \\
\hline $4 h$ a & & 1.04 & \multirow{3}{*}{1.06} & 25.02 & 24.72 & -639.38 & \\
\hline $4 \mathrm{~h} \mathrm{~b}$ & & 0.96 & & 25.04 & 24.73 & -577.05 & \\
\hline $4 \mathrm{~h} \mathrm{c}$ & & 1.18 & & 25.04 & 24.73 & -738.53 & -651.65 \\
\hline 24h B1 & \multirow{5}{*}{24} & 0.36 & \multirow{2}{*}{0.26} & & & & \\
\hline 24h B2 & & 0.17 & & & & & \\
\hline $24 h a$ & & 0.85 & \multirow{3}{*}{0.76} & 25.01 & 24.71 & -224.31 & \\
\hline $24 \mathrm{~h} \mathrm{~b}$ & & 0.68 & & 25.03 & 24.73 & -159.83 & \\
\hline $24 \mathrm{~h} \mathrm{c}$ & & 0.77 & & 25.02 & 24.72 & -195.14 & -193.10 \\
\hline 48h B1 & \multirow{5}{*}{48} & 0.32 & \multirow{2}{*}{0.25} & & & & \\
\hline 48h B2 & & 0.18 & & & & & \\
\hline $48 \mathrm{~h}$ a & & 0.87 & \multirow{3}{*}{0.69} & 25.03 & 24.72 & -245.06 & \\
\hline $48 \mathrm{~h} \mathrm{~b}$ & & 0.56 & & 24.99 & 24.69 & -123.41 & \\
\hline $48 \mathrm{~h} \mathrm{c}$ & & 0.65 & & 25.00 & 24.70 & -156.81 & -175.09 \\
\hline 72h B1 & \multirow{5}{*}{72} & 0.31 & \multirow{2}{*}{0.29} & & & & \\
\hline 72h B2 & & 0.26 & & & & & \\
\hline $72 \mathrm{~h} \mathrm{a}$ & & 0.49 & \multirow{3}{*}{0.57} & 25.00 & 24.70 & -69.61 & \\
\hline $72 \mathrm{~h} \mathrm{~b}$ & & 0.68 & & 25.02 & 24.71 & -136.50 & \\
\hline $72 \mathrm{~h} \mathrm{c}$ & & 0.54 & & 24.99 & 24.69 & -85.80 & -97.30 \\
\hline $\begin{array}{c}1 \text { semana } \\
\text { B1 }\end{array}$ & \multirow{5}{*}{168} & 0.16 & \multirow{2}{*}{0.17} & & & & \\
\hline $\begin{array}{c}1 \text { semana } \\
\text { B2 }\end{array}$ & & 0.19 & & & & & \\
\hline 1 semana a & & 0.33 & \multirow{3}{*}{0.31} & 25.03 & 24.73 & -90.44 & \\
\hline 1 semana $b$ & & 0.28 & & 25.01 & 24.71 & -62.92 & \\
\hline 1 semana c & & 0.33 & & 25.00 & 24.70 & -94.46 & -82.60 \\
\hline
\end{tabular}



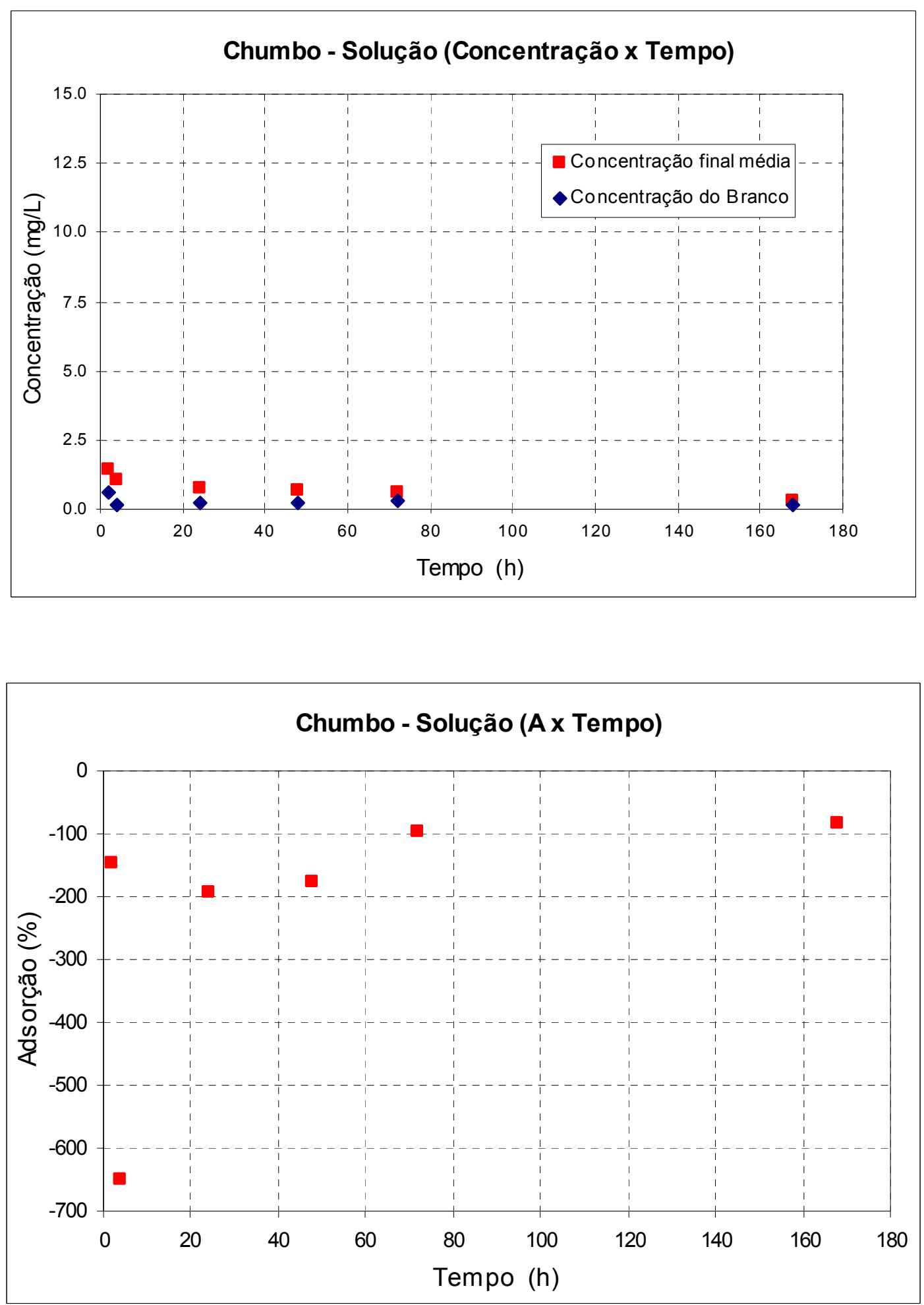


\section{Chorume mais Metais:}

- Teor de umidade do solo seco ao ar e passado na peneira 40: $1.23 \%$

- RSS: $1: 4$

pH:

\begin{tabular}{|c|c|c|}
\hline Tempo (h) & $\mathrm{pH}$ final médio & $\mathrm{pH}$ Branco \\
\hline 0 & 8.30 & 8.30 \\
\hline 2 & 8.50 & 8.51 \\
\hline 4 & 8.54 & 8.56 \\
\hline 24 & 8.42 & 8.71 \\
\hline 48 & 8.80 & 8.90 \\
\hline 72 & 8.80 & 8.98 \\
\hline 168 & 9.00 & 8.84 \\
\hline
\end{tabular}

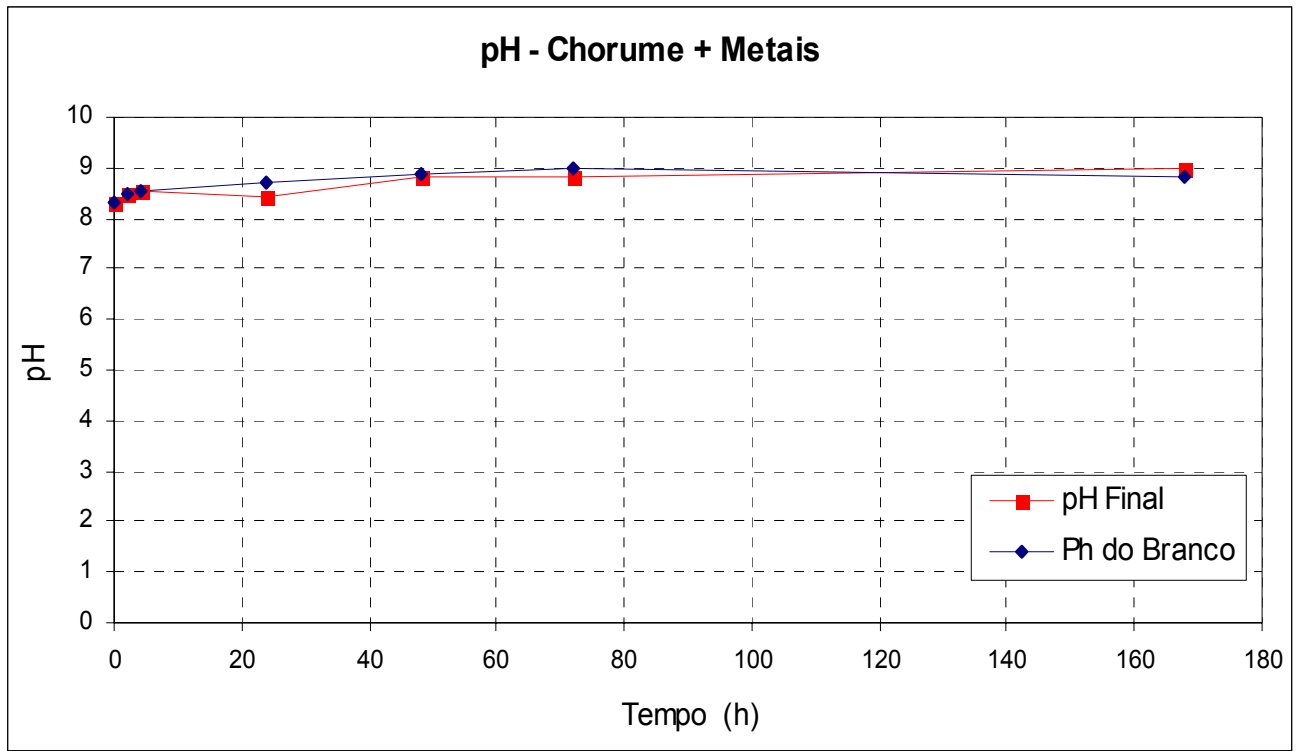




\section{Condutividade Elétrica:}

\begin{tabular}{|c|c|c|}
\hline Tempo $(\mathrm{h})$ & Cond. final média $(\mu \mathrm{S} / \mathrm{cm})$ & Cond. do Branco $(\mu \mathrm{S} / \mathrm{cm})$ \\
\hline 0 & 15505 & 15505 \\
\hline 2 & 15430 & 15505 \\
\hline 4 & 15227 & 15650 \\
\hline 24 & 14563 & 14460 \\
\hline 48 & 14087 & 14160 \\
\hline 72 & 14283 & 14200 \\
\hline 168 & 13700 & 14030 \\
\hline
\end{tabular}

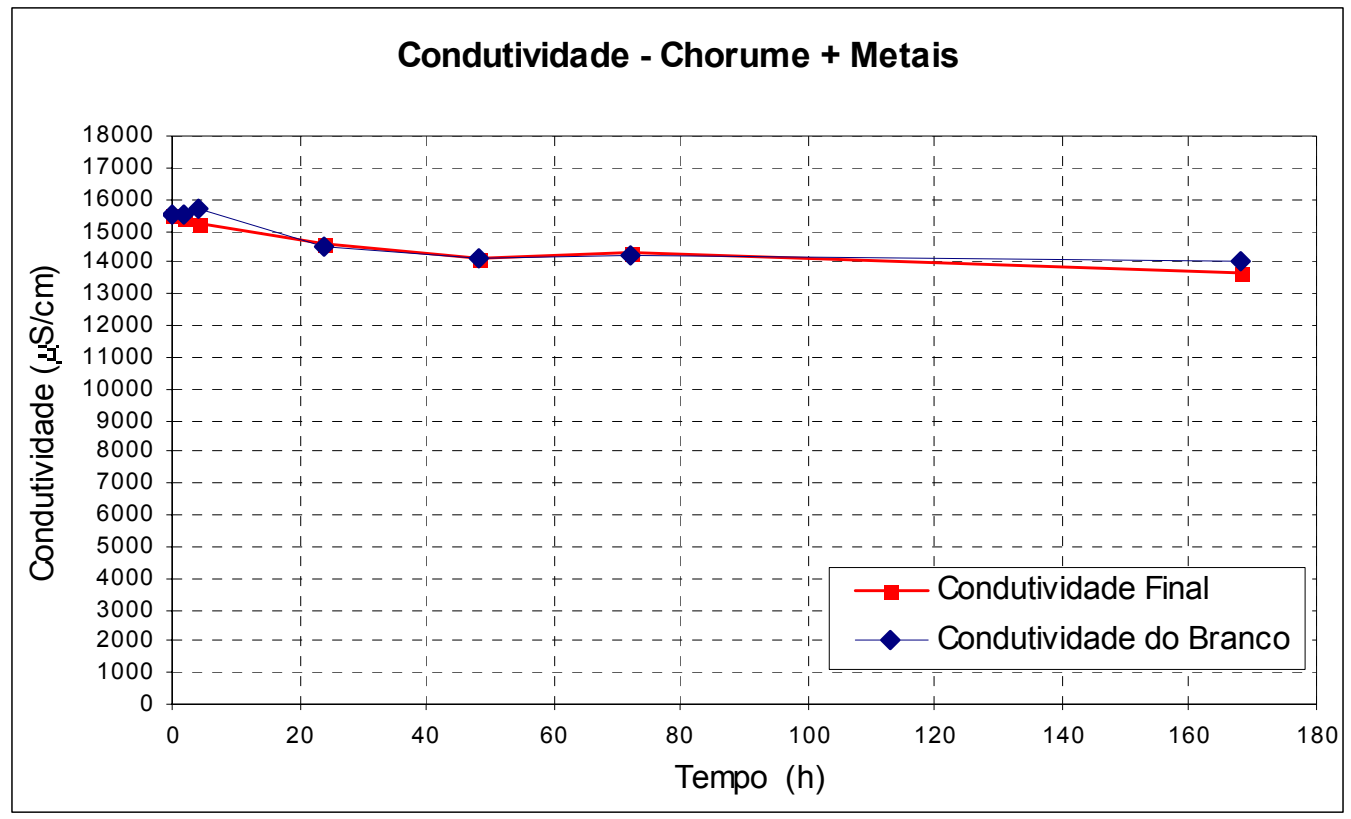


Níquel:

\begin{tabular}{|c|c|c|c|c|c|c|c|}
\hline \multirow{2}{*}{ Amostra } & \multirow[t]{2}{*}{ Tempo (h) } & \multicolumn{2}{|c|}{ Concentração Concentração } & \multirow{2}{*}{$\begin{array}{c}\text { Psolo } \\
\text { (g) }\end{array}$} & \multirow{2}{*}{\begin{tabular}{|c|} 
Psólido \\
(g)
\end{tabular}} & \multirow{2}{*}{$\begin{array}{c}A \\
(\%)\end{array}$} & \multirow{2}{*}{\begin{tabular}{|c|} 
A média \\
$(\%)$
\end{tabular}} \\
\hline & & (mg/L) & média $(\mathrm{mg} / \mathrm{L})$ & & & & \\
\hline 2h B1 & \multirow{5}{*}{2} & 10.19 & \multirow{2}{*}{10.15} & & & & \\
\hline 2h B2 & & 10.11 & & & & & \\
\hline 2h a & & 8.13 & \multirow{3}{*}{8.05} & 25.04 & 24.73 & 19.90 & \\
\hline $2 \mathrm{~h} \mathrm{~b}$ & & 7.83 & & 25.03 & 24.72 & 22.86 & \\
\hline $2 \mathrm{~h} \mathrm{c}$ & & 8.18 & & 25.01 & 24.71 & 19.41 & 20.72 \\
\hline 4h B1 & \multirow{5}{*}{4} & 10.13 & \multirow{2}{*}{10.17} & & & & \\
\hline 4h B2 & & 10.20 & & & & & \\
\hline 4h a & & 8.18 & \multirow{3}{*}{8.13} & 24.98 & 24.68 & 19.53 & \multirow[b]{3}{*}{20.02} \\
\hline $4 \mathrm{~h} \mathrm{~b}$ & & 8.10 & & 24.97 & 24.66 & 20.31 & \\
\hline $4 h \mathrm{c}$ & & 8.11 & & 24.99 & 24.69 & 20.22 & \\
\hline 24h B1 & \multirow{5}{*}{24} & 10.09 & \multirow{2}{*}{10.16} & & & & \\
\hline 24h B2 & & 10.22 & & & & & \\
\hline $24 \mathrm{~h} \mathrm{a}$ & & 6.11 & \multirow{3}{*}{6.27} & 25.00 & 24.69 & 39.83 & \multirow[b]{3}{*}{38.26} \\
\hline $24 \mathrm{~h} \mathrm{~b}$ & & 6.25 & & 25.02 & 24.72 & 38.45 & \\
\hline $24 \mathrm{~h} \mathrm{c}$ & & 6.45 & & 24.96 & 24.66 & 36.48 & \\
\hline 48h B1 & \multirow{5}{*}{48} & 10.44 & \multirow{2}{*}{10.31} & & & & \\
\hline 48h B2 & & 10.18 & & & & & \\
\hline $48 \mathrm{~h}$ a & & 5.58 & \multirow{3}{*}{5.88} & 25.00 & 24.69 & 45.88 & \multirow[b]{3}{*}{43.00} \\
\hline $48 \mathrm{~h} \mathrm{~b}$ & & 6.26 & & 25.04 & 24.73 & 39.28 & \\
\hline $48 \mathrm{~h} \mathrm{c}$ & & 5.79 & & 24.98 & 24.68 & 43.84 & \\
\hline 72h B1 & \multirow{5}{*}{72} & 10.34 & \multirow{2}{*}{10.29} & & & & \\
\hline 72h B2 & & 10.23 & & & & & \\
\hline $72 \mathrm{~h} \mathrm{a}$ & & 5.16 & \multirow{3}{*}{5.21} & 25.02 & 24.71 & 49.83 & \multirow[b]{3}{*}{49.38} \\
\hline $72 \mathrm{~h} \mathrm{~b}$ & & 5.47 & & 25.03 & 24.72 & 46.82 & \\
\hline $72 \mathrm{~h} \mathrm{c}$ & & 4.99 & & 25.04 & 24.74 & 51.49 & \\
\hline $\begin{array}{c}1 \text { semana } \\
\text { B1 }\end{array}$ & \multirow{5}{*}{168} & 10.23 & \multirow{2}{*}{10.26} & & & & \\
\hline $\begin{array}{c}1 \text { semana } \\
\text { B2 }\end{array}$ & & 10.29 & & & & & \\
\hline 1 semana a & & 5.01 & \multirow{3}{*}{4.81} & 25.04 & 24.74 & 51.17 & \\
\hline 1 semana $b$ & & 4.79 & & 25.03 & 24.73 & 53.34 & \\
\hline 1 semana c & & 4.62 & & 25.03 & 24.73 & 54.98 & 53.16 \\
\hline
\end{tabular}



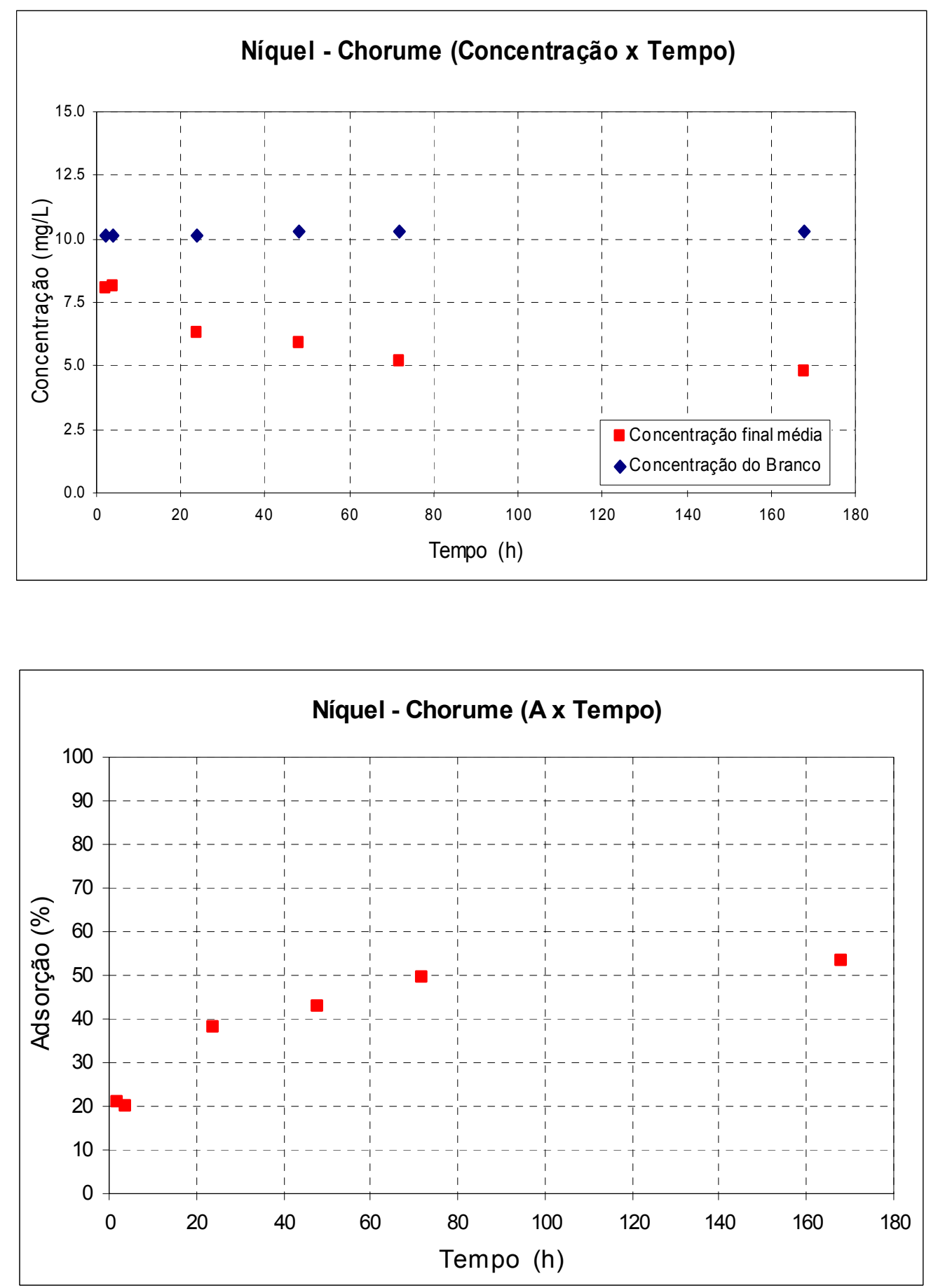
$\underline{\text { Zinco: }}$

\begin{tabular}{|c|c|c|c|c|c|c|c|}
\hline Amostra & Tempo (h) & \begin{tabular}{|c|} 
Concentração \\
$(\mathrm{mg} / \mathrm{L})$
\end{tabular} & $\begin{array}{l}\text { Concentração } \\
\text { média }(\mathrm{mg} / \mathrm{L})\end{array}$ & $\begin{array}{c}\text { Psolo } \\
\text { (g) }\end{array}$ & $\begin{array}{c}\text { Psólido } \\
\text { (g) }\end{array}$ & \begin{tabular}{|c|} 
A \\
$(\%)$ \\
\end{tabular} & \begin{tabular}{|c|} 
A média \\
$(\%)$ \\
\end{tabular} \\
\hline 2h B1 & \multirow{5}{*}{2} & 5.28 & \multirow{2}{*}{5.27} & & & & \\
\hline 2h B2 & & 5.25 & & & & & \\
\hline $2 \mathrm{~h} \mathrm{a}$ & & 1.60 & \multirow{3}{*}{1.53} & 25.04 & 24.73 & 69.57 & \\
\hline $2 \mathrm{~h} \mathrm{~b}$ & & 1.37 & & 25.03 & 24.72 & 73.90 & \\
\hline $2 \mathrm{~h} \mathrm{c}$ & & 1.61 & & 25.01 & 24.71 & 69.46 & 70.98 \\
\hline 4h B1 & \multirow{5}{*}{4} & 5.20 & \multirow{2}{*}{5.27} & & & & \\
\hline 4h B2 & & 5.33 & & & & & \\
\hline $4 h$ a & & 1.81 & \multirow{3}{*}{1.78} & 24.98 & 24.68 & 65.64 & \multirow[b]{3}{*}{66.13} \\
\hline $4 \mathrm{~h} \mathrm{~b}$ & & 1.76 & & 24.97 & 24.66 & 66.63 & \\
\hline 4h c & & 1.78 & & 24.99 & 24.69 & 66.13 & \\
\hline 24h B1 & \multirow{5}{*}{24} & 5.26 & \multirow{2}{*}{5.28} & & & & \\
\hline 24h B2 & & 5.30 & & & & & \\
\hline $24 \mathrm{~h}$ a & & 1.02 & \multirow{3}{*}{1.42} & 25.00 & 24.69 & 80.61 & \multirow[b]{3}{*}{73.14} \\
\hline $24 h$ b & & 1.11 & & 25.02 & 24.72 & 78.90 & \\
\hline $24 \mathrm{~h} \mathrm{c}$ & & 2.12 & & 24.96 & 24.66 & 59.92 & \\
\hline 48h B1 & \multirow{5}{*}{48} & 5.36 & \multirow{2}{*}{5.31} & & & & \\
\hline 48h B2 & & 5.25 & & & & & \\
\hline $48 h$ a & & 0.95 & \multirow{3}{*}{1.04} & 25.00 & 24.69 & 82.04 & \multirow[b]{3}{*}{80.49} \\
\hline $48 \mathrm{~h} \mathrm{~b}$ & & 1.18 & & 25.04 & 24.73 & 77.76 & \\
\hline $48 \mathrm{~h} \mathrm{c}$ & & 0.97 & & 24.98 & 24.68 & 81.68 & \\
\hline 72h B1 & \multirow{5}{*}{72} & 4.52 & \multirow{2}{*}{4.43} & & & & \\
\hline 72h B2 & & 4.35 & & & & & \\
\hline $72 \mathrm{~h}$ a & & 0.73 & \multirow{3}{*}{0.79} & 25.02 & 24.71 & 83.46 & \multirow[b]{3}{*}{82.13} \\
\hline $72 \mathrm{~h} \mathrm{~b}$ & & 0.87 & & 25.03 & 24.72 & 80.35 & \\
\hline $72 \mathrm{~h} \mathrm{c}$ & & 0.77 & & 25.04 & 24.74 & 82.58 & \\
\hline $\begin{array}{c}1 \text { semana } \\
\text { B1 }\end{array}$ & \multirow{5}{*}{168} & 4.03 & \multirow{2}{*}{4.25} & & & & \\
\hline $\begin{array}{c}1 \text { semana } \\
\text { B2 }\end{array}$ & & 4.47 & & & & & \\
\hline 1 semana a & & 0.79 & \multirow{3}{*}{0.75} & 25.04 & 24.74 & 81.44 & \multirow[b]{3}{*}{82.24} \\
\hline 1 semana $b$ & & 0.92 & & 25.03 & 24.73 & 78.45 & \\
\hline 1 semana $\mathrm{c}$ & & 0.56 & & 25.03 & 24.73 & 86.81 & \\
\hline
\end{tabular}



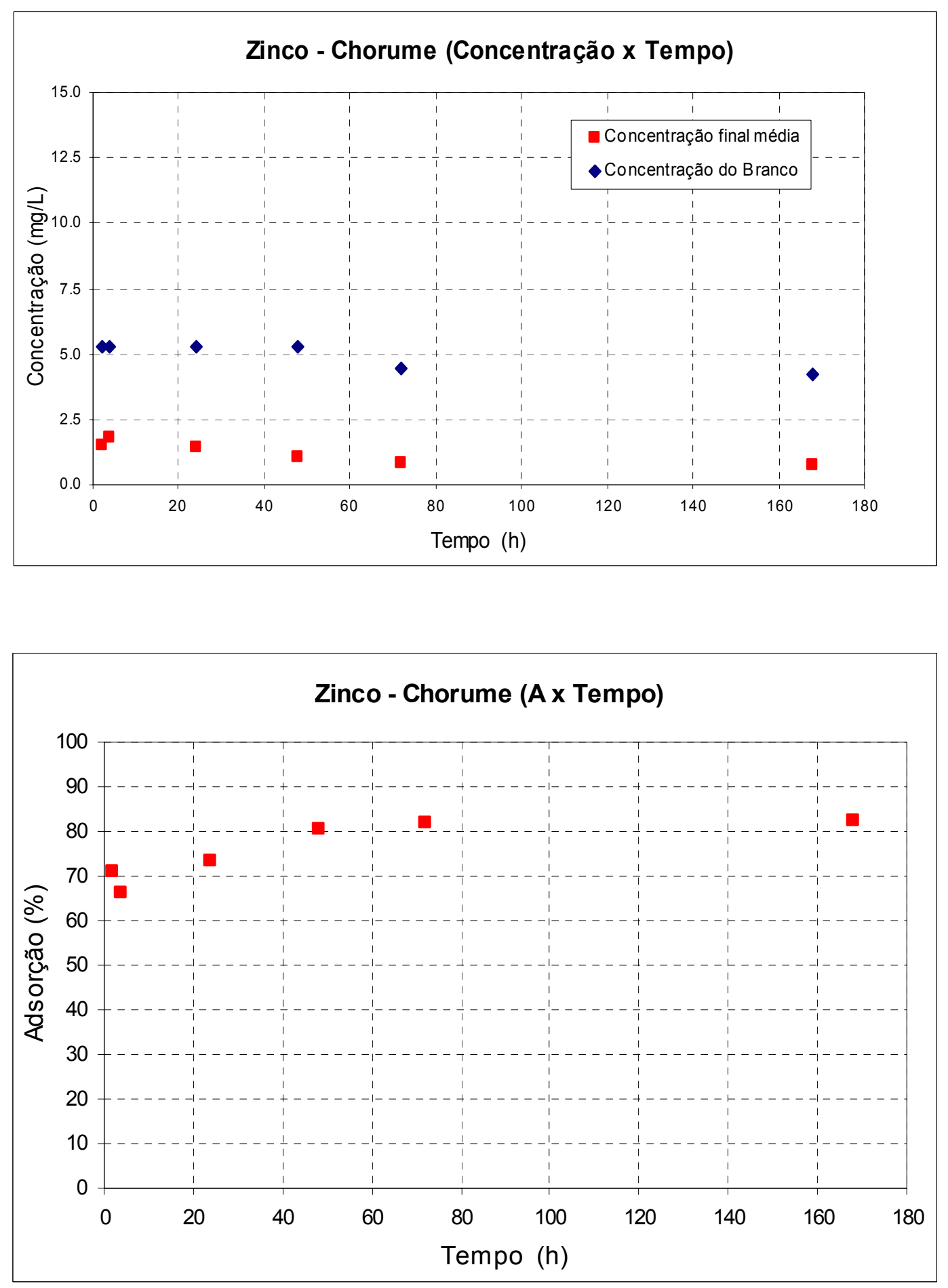
Cádmio:

\begin{tabular}{|c|c|c|c|c|c|c|c|}
\hline Amostra & Tempo (h) & $\begin{array}{c}\text { Concentraçã } \\
(\mathrm{mg} / \mathrm{L})\end{array}$ & $\begin{array}{l}\text { oConcentração } \\
\text { média }(\mathrm{mg} / \mathrm{L})\end{array}$ & $\begin{array}{c}\text { Psolo } \\
\text { (g) }\end{array}$ & \begin{tabular}{|c|} 
Psólido \\
(g)
\end{tabular} & \begin{tabular}{|c|} 
A \\
$(\%)$
\end{tabular} & \begin{tabular}{|c|} 
A média \\
$(\%)$ \\
\end{tabular} \\
\hline 2h B1 & \multirow{5}{*}{2} & 4.13 & \multirow{2}{*}{4.13} & & & & \\
\hline 2h B2 & & 4.14 & & & & & \\
\hline $2 \mathrm{~h}$ a & & 2.05 & \multirow{3}{*}{1.96} & 25.04 & 24.73 & 50.44 & \\
\hline $2 \mathrm{~h} \mathrm{~b}$ & & 1.84 & & 25.03 & 24.72 & 55.61 & \\
\hline $2 \mathrm{~h} \mathrm{c}$ & & 1.99 & & 25.01 & 24.71 & 51.84 & 52.63 \\
\hline 4h B1 & \multirow{5}{*}{4} & 4.08 & \multirow{2}{*}{4.14} & & & & \\
\hline 4h B2 & & 4.21 & & & & & \\
\hline $4 \mathrm{~h}$ a & & 2.23 & \multirow{3}{*}{2.15} & 24.98 & 24.68 & 46.28 & \\
\hline $4 \mathrm{~h} \mathrm{~b}$ & & 2.02 & & 24.97 & 24.66 & 51.25 & \\
\hline $4 \mathrm{~h} \mathrm{c}$ & & 2.21 & & 24.99 & 24.69 & 46.62 & 48.05 \\
\hline 24h B1 & \multirow{5}{*}{24} & 4.01 & \multirow{2}{*}{4.02} & & & & \\
\hline 24h B2 & & 4.04 & & & & & \\
\hline $24 \mathrm{~h}$ a & & 1.43 & \multirow{3}{*}{1.51} & 25.00 & 24.69 & 64.54 & \\
\hline $24 \mathrm{~h} \mathrm{~b}$ & & 1.48 & & 25.02 & 24.72 & 63.27 & \\
\hline $24 \mathrm{~h} \mathrm{c}$ & & 1.61 & & 24.96 & 24.66 & 59.92 & 62.58 \\
\hline 48h B1 & \multirow{5}{*}{48} & 4.05 & \multirow{2}{*}{4.02} & & & & \\
\hline 48h B2 & & 3.99 & & & & & \\
\hline $48 h$ a & & 1.36 & \multirow{3}{*}{1.44} & 25.00 & 24.69 & 66.27 & \\
\hline $48 \mathrm{~h} \mathrm{~b}$ & & 1.59 & & 25.04 & 24.73 & 60.40 & \\
\hline $48 \mathrm{~h} \mathrm{c}$ & & 1.36 & & 24.98 & 24.68 & 66.07 & 64.25 \\
\hline 72h B1 & \multirow{5}{*}{72} & 2.13 & \multirow{2}{*}{2.12} & & & & \\
\hline 72h B2 & & 2.11 & & & & & \\
\hline $72 \mathrm{~h}$ a & & 0.75 & \multirow{3}{*}{0.73} & 25.02 & 24.71 & 64.47 & \\
\hline $72 \mathrm{~h} \mathrm{~b}$ & & 0.76 & & 25.03 & 24.72 & 64.14 & \\
\hline $72 \mathrm{~h} \mathrm{c}$ & & 0.67 & & 25.04 & 24.74 & 68.20 & 65.61 \\
\hline $\begin{array}{c}1 \text { semana } \\
\text { B1 }\end{array}$ & \multirow{5}{*}{168} & 1.69 & \multirow{2}{*}{1.77} & & & & \\
\hline $\begin{array}{c}1 \text { semana } \\
\text { B2 }\end{array}$ & & 1.85 & & & & & \\
\hline 1 semana a & & 0.74 & \multirow{3}{*}{0.70} & 25.04 & 24.74 & 58.03 & \\
\hline 1 semana $b$ & & 0.66 & & 25.03 & 24.73 & 62.99 & \\
\hline 1 semana $\mathrm{c}$ & & 0.71 & & 25.03 & 24.73 & 60.11 & 60.38 \\
\hline
\end{tabular}



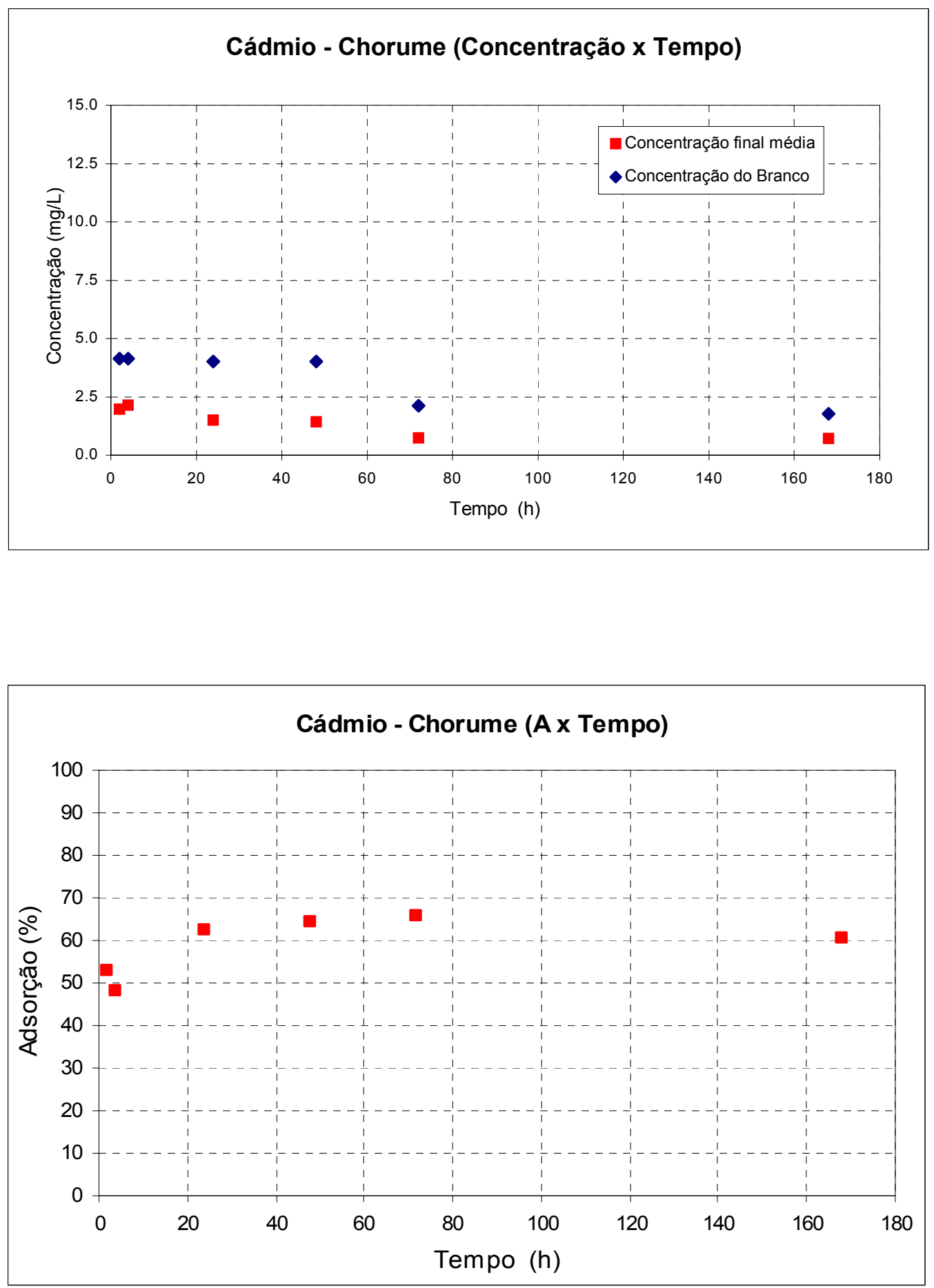
Chumbo:

\begin{tabular}{|c|c|c|c|c|c|c|c|}
\hline Amostra & Tempo (h) & \begin{tabular}{|c|} 
Concentração \\
$(\mathrm{mg} / \mathrm{L})$ \\
\end{tabular} & $\begin{array}{l}\text { Concentração } \\
\text { média }(\mathrm{mg} / \mathrm{L})\end{array}$ & $\begin{array}{c}\text { Psolo } \\
\text { (g) }\end{array}$ & $\begin{array}{c}\text { Psólido } \\
\text { (g) }\end{array}$ & $\begin{array}{c}\text { A } \\
(\%)\end{array}$ & \begin{tabular}{|c|} 
A média \\
$(\%)$ \\
\end{tabular} \\
\hline 2h B1 & \multirow{5}{*}{2} & \begin{tabular}{|l|}
6.63 \\
\end{tabular} & \multirow{2}{*}{6.64} & & & & \\
\hline 2h B2 & & 6.64 & & & & & \\
\hline $2 \mathrm{~h}$ a & & 2.89 & \multirow{3}{*}{2.62} & 25.04 & 24.73 & 56.47 & \multirow[b]{3}{*}{60.58} \\
\hline $2 \mathrm{~h} \mathrm{~b}$ & & 2.28 & & 25.03 & 24.72 & 65.58 & \\
\hline $2 \mathrm{~h} \mathrm{c}$ & & 2.67 & & 25.01 & 24.71 & 59.70 & \\
\hline 4h B1 & \multirow{5}{*}{4} & 6.66 & \multirow{2}{*}{6.87} & & & & \\
\hline 4h B2 & & 7.07 & & & & & \\
\hline $4 h$ a & & 3.06 & \multirow{3}{*}{2.95} & 24.98 & 24.68 & 55.50 & \multirow[b]{3}{*}{57.04} \\
\hline $4 \mathrm{~h} \mathrm{~b}$ & & 2.79 & & 24.97 & 24.66 & 59.40 & \\
\hline $4 \mathrm{~h} \mathrm{c}$ & & 3.01 & & 24.99 & 24.69 & 56.23 & \\
\hline 24h B1 & \multirow{5}{*}{24} & 6.13 & \multirow{2}{*}{6.11} & & & & \\
\hline 24h B2 & & 6.09 & & & & & \\
\hline $24 h a$ & & 1.52 & \multirow{3}{*}{1.75} & 25.00 & 24.69 & 75.09 & \multirow[b]{3}{*}{71.41} \\
\hline $24 \mathrm{~h} \mathrm{~b}$ & & 1.73 & & 25.02 & 24.72 & 71.67 & \\
\hline $24 \mathrm{~h} \mathrm{c}$ & & 1.99 & & 24.96 & 24.66 & 67.48 & \\
\hline 48h B1 & \multirow{5}{*}{48} & 6.14 & \multirow{2}{*}{6.11} & & & & \\
\hline 48h B2 & & 6.08 & & & & & \\
\hline $48 \mathrm{~h}$ a & & 1.15 & \multirow{3}{*}{1.26} & 25.00 & 24.69 & 81.15 & \multirow[b]{3}{*}{79.33} \\
\hline $48 \mathrm{~h} \mathrm{~b}$ & & 1.49 & & 25.04 & 24.73 & 75.60 & \\
\hline $48 \mathrm{~h} \mathrm{c}$ & & 1.15 & & 24.98 & 24.68 & 81.26 & \\
\hline 72h B1 & \multirow{5}{*}{72} & 4.73 & \multirow{2}{*}{4.68} & & & & \\
\hline 72h B2 & & 4.64 & & & & & \\
\hline $72 \mathrm{~h} \mathrm{a}$ & & 0.52 & \multirow{3}{*}{0.54} & 25.02 & 24.71 & 88.89 & \multirow[b]{3}{*}{88.42} \\
\hline $72 \mathrm{~h} \mathrm{~b}$ & & 0.58 & & 25.03 & 24.72 & 87.63 & \\
\hline $72 \mathrm{~h} \mathrm{c}$ & & 0.53 & & 25.04 & 24.74 & 88.75 & \\
\hline $\begin{array}{c}\text { semana } \\
\text { B1 } \\
\end{array}$ & \multirow{5}{*}{168} & 4.55 & \multirow{2}{*}{4.71} & & & & \\
\hline $\begin{array}{c}1 \text { semana } \\
\text { B2 }\end{array}$ & & 4.87 & & & & & \\
\hline 1 semana a & & 0.47 & \multirow{3}{*}{0.41} & 25.04 & 24.74 & 90.00 & \multirow[b]{3}{*}{91.38} \\
\hline 1 semana $b$ & & 0.40 & & 25.03 & 24.73 & 91.61 & \\
\hline 1 semana c & & 0.35 & & 25.03 & 24.73 & 92.53 & \\
\hline
\end{tabular}



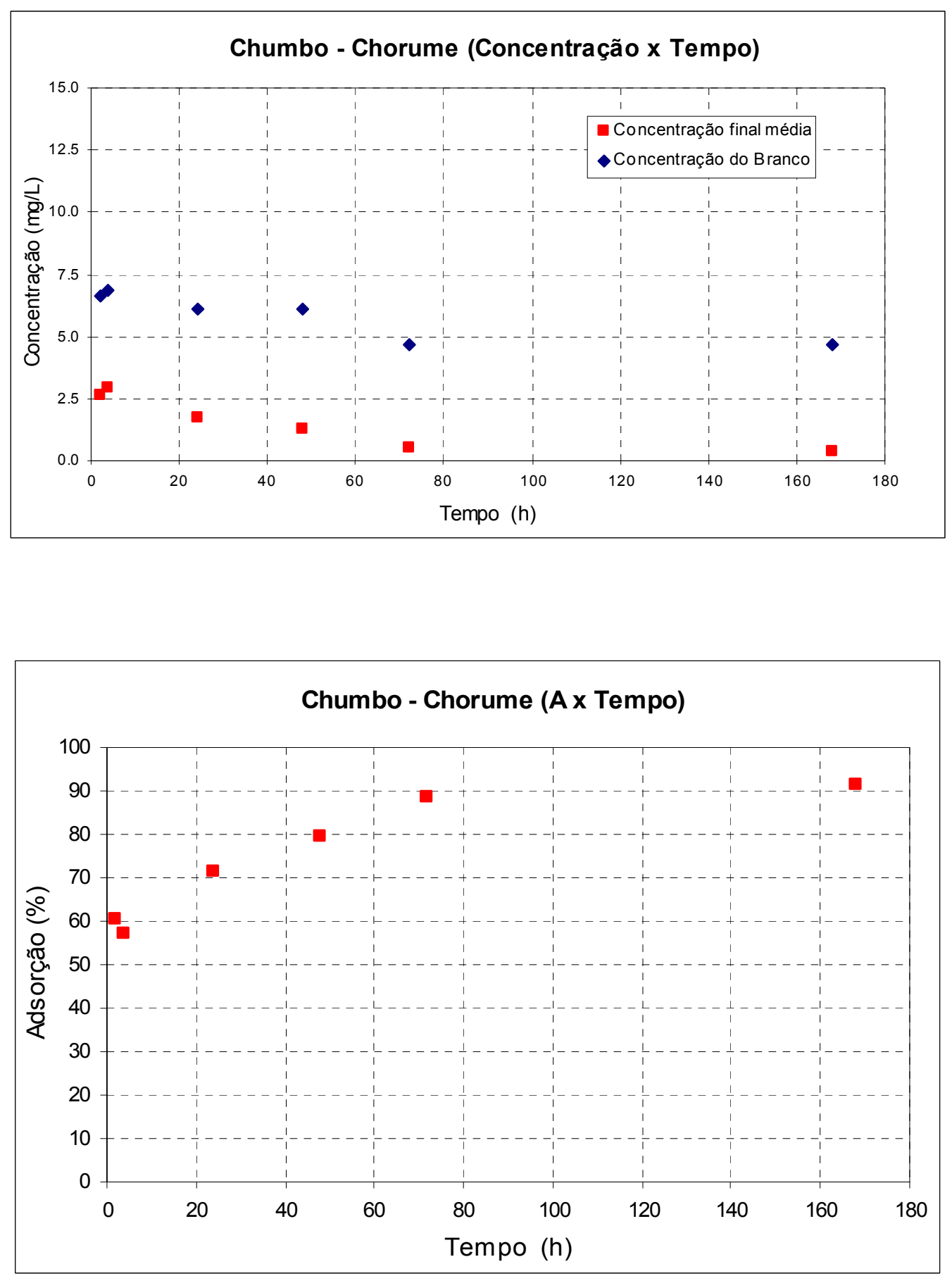
ISOTERMAS DE ADSORÇÃO TIPO ECL (Environmentally Conservative
Isotherms RSS)

Solução de Metais: 
- Teor de umidade do solo seco ao ar e passado na peneira 40: $1.20 \%$

- Tempo de Equilíbrio: 1 semana (168 h)

\section{Níquel:}

\begin{tabular}{|c|c|c|c|c|c|c|c|c|}
\hline \multirow{2}{*}{ Amostra } & \multirow{2}{*}{\begin{tabular}{|c|} 
Concentração \\
$(\mathrm{mg} / \mathrm{L})$ \\
\end{tabular}} & \multirow{2}{*}{$\begin{array}{l}\text { Concentração } \\
\text { média (mg/L) }\end{array}$} & \multirow{2}{*}{$\begin{array}{c}\text { Psolo } \\
\text { (g) }\end{array}$} & \multirow{2}{*}{$\begin{array}{c}\text { Psólido } \\
\text { (g) }\end{array}$} & \multirow{2}{*}{\begin{tabular}{|c|}
$\mathrm{S}$ \\
$(\mathrm{mg} / \mathrm{g})$ \\
\end{tabular}} & \multirow{2}{*}{\begin{tabular}{|c|}
$\mathrm{S}$ \\
$(\mathrm{mg} / \mathrm{g})$ \\
\end{tabular}} & \multirow{2}{*}{$\begin{array}{c}A \\
(\%)\end{array}$} & \multirow{2}{*}{$\begin{array}{c}A \\
(\%)\end{array}$} \\
\hline & & & & & & & & \\
\hline B1 & 8.51 & \multirow{2}{*}{8.55} & & & & & & \\
\hline B2 & 8.58 & & & & & & & \\
\hline $1: 4 a$ & 1.97 & \multirow{3}{*}{2.01} & 24.99 & 24.69 & 0.03 & \multirow[b]{3}{*}{0.03} & 76.91 & \multirow[b]{3}{*}{76.47} \\
\hline $1: 4 b$ & 2.10 & & 24.94 & 24.64 & 0.03 & & 75.44 & \\
\hline $1: 4 \mathrm{c}$ & 1.96 & & 24.91 & 24.61 & 0.03 & & 77.06 & \\
\hline B1 & 8.51 & \multirow{2}{*}{8.55} & & & & & & \\
\hline B2 & 8.58 & & & & & & & \\
\hline $1: 10 a$ & 3.87 & \multirow{3}{*}{3.91} & 10.05 & 9.93 & 0.05 & \multirow[b]{3}{*}{0.05} & 54.66 & \multirow[b]{3}{*}{54.24} \\
\hline $1: 10 b$ & 3.96 & & 10.05 & 9.93 & 0.05 & & 53.68 & \\
\hline $1: 10 c$ & 3.90 & & 10.04 & 9.92 & 0.05 & & 54.37 & \\
\hline B1 & 8.51 & \multirow{2}{*}{8.55} & & & & & & \\
\hline B2 & 8.58 & & & & & & & \\
\hline $1: 20 a$ & 5.03 & \multirow{3}{*}{5.11} & 5.03 & 4.97 & 0.07 & \multirow[b]{3}{*}{0.07} & 41.14 & \multirow[b]{3}{*}{40.20} \\
\hline $1: 20 b$ & 5.17 & & 5.03 & 4.97 & 0.07 & & 39.50 & \\
\hline $1: 20 \mathrm{c}$ & 5.13 & & 5.06 & 5.00 & 0.07 & & 39.96 & \\
\hline B1 & 8.51 & \multirow{2}{*}{8.55} & & & & & & \\
\hline B2 & 8.58 & & & & & & & \\
\hline $1: 50 a$ & 6.15 & \multirow{3}{*}{6.14} & 2.05 & 2.03 & 0.12 & \multirow[b]{3}{*}{0.12} & 28.03 & \multirow[b]{3}{*}{28.18} \\
\hline $1: 50 \mathrm{~b}$ & 6.25 & & 2.09 & 2.07 & 0.11 & & 26.86 & \\
\hline $1: 50 \mathrm{c}$ & 6.01 & & 2.05 & 2.03 & 0.12 & & 29.67 & \\
\hline B1 & 8.51 & \multirow{2}{*}{8.55} & & & & & & \\
\hline B2 & 8.58 & & & & & & & \\
\hline 1:100a & 6.63 & & 1.08 & 1.07 & 0.18 & & 22.41 & \\
\hline $1: 100 b$ & 6.53 & 6.60 & 1.07 & 1.06 & 0.19 & & 23.58 & \\
\hline $1: 100 \mathrm{c}$ & 6.65 & & 0.98 & 0.96 & 0.20 & 0.19 & 22.18 & 22.72 \\
\hline B1 & 8.51 & 855 & & & & & & \\
\hline B2 & 8.58 & 8.55 & & & & & & \\
\hline $1: 200 a$ & 6.83 & & 0.51 & 0.50 & 0.34 & & 20.07 & \\
\hline $1: 200 \mathrm{~b}$ & 6.88 & 6.81 & 0.51 & 0.50 & 0.33 & & 19.49 & \\
\hline $1: 200 \mathrm{c}$ & 6.73 & & 0.50 & 0.49 & 0.37 & 0.35 & 21.24 & 20.27 \\
\hline B1 & 8.51 & 855 & & & & & & \\
\hline B2 & 8.58 & 8.55 & & & & & & \\
\hline $1: 500 a$ & 7.19 & & 0.20 & 0.20 & 0.67 & & 15.86 & \\
\hline $1: 500 b$ & 7.13 & 7.21 & 0.20 & 0.20 & 0.70 & & 16.56 & \\
\hline $1: 500 c$ & 7.30 & & 0.20 & 0.19 & 0.64 & 0.67 & 14.57 & 15.66 \\
\hline
\end{tabular}



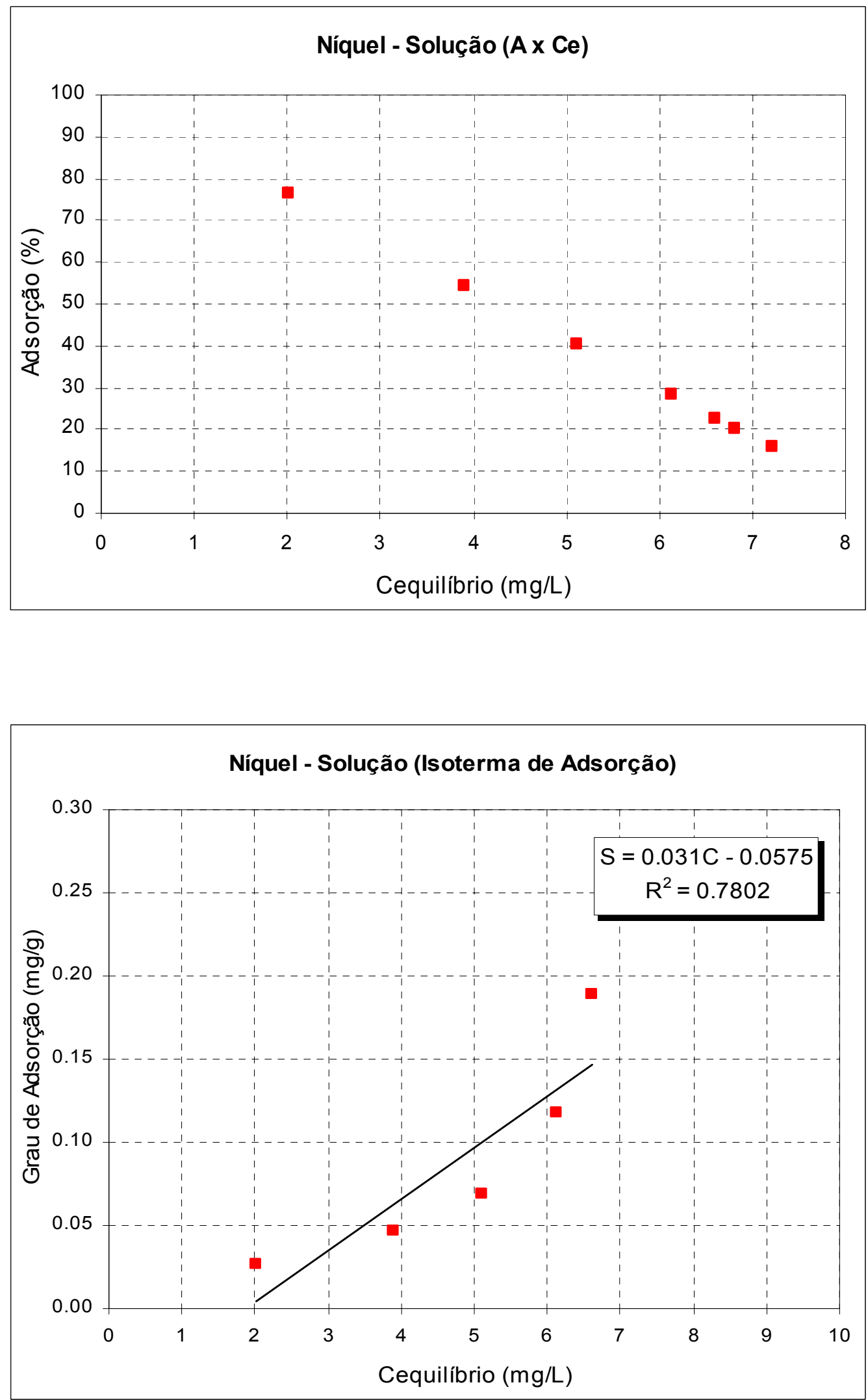
$\underline{\text { Zinco: }}$

\begin{tabular}{|c|c|c|c|c|c|c|c|c|}
\hline \multirow{2}{*}{ Amostra } & \multirow{2}{*}{$\begin{array}{c}\text { Concentração } \\
(\mathrm{mg} / \mathrm{L})\end{array}$} & \multirow{2}{*}{$\begin{array}{l}\text { Concentração } \\
\text { média }(\mathrm{mg} / \mathrm{L})\end{array}$} & \multirow{2}{*}{$\begin{array}{c}\text { Psolo } \\
\text { (g) }\end{array}$} & \multirow{2}{*}{$\begin{array}{c}\text { Psólido } \\
\text { (g) }\end{array}$} & \multirow{2}{*}{\begin{tabular}{|c|}
$\mathrm{S}$ \\
$(\mathrm{mg} / \mathrm{g})$ \\
\end{tabular}} & \multirow{2}{*}{$\frac{\mathrm{S}}{(\mathrm{mg} / \mathrm{g})}$} & \multirow{2}{*}{\begin{tabular}{|c|}
$A$ \\
$(\%)$ \\
\end{tabular}} & \multirow{2}{*}{$\begin{array}{c}A \\
(\%)\end{array}$} \\
\hline & & & & & & & & \\
\hline B1 & 6.17 & \multirow{2}{*}{5.98} & & & & & & \\
\hline B2 & 5.79 & & & & & & & \\
\hline $1: 4 a$ & 1.66 & \multirow{3}{*}{1.67} & 24.99 & 24.69 & 0.02 & \multirow[b]{3}{*}{0.02} & 72.32 & \multirow[b]{3}{*}{72.09} \\
\hline $1: 4 b$ & 1.77 & & 24.94 & 24.64 & 0.02 & & 70.45 & \\
\hline $1: 4 c$ & 1.59 & & 24.91 & 24.61 & 0.02 & & 73.49 & \\
\hline B1 & 6.17 & \multirow{2}{*}{5.98} & & & & & & \\
\hline B2 & 5.79 & & & & & & & \\
\hline $1: 10 a$ & 3.16 & \multirow{3}{*}{3.20} & 10.05 & 9.93 & 0.03 & \multirow[b]{3}{*}{0.03} & 47.19 & \multirow[b]{3}{*}{46.56} \\
\hline $1: 10 b$ & 3.27 & & 10.05 & 9.93 & 0.03 & & 45.27 & \\
\hline $1: 10 \mathrm{c}$ & 3.16 & & 10.04 & 9.92 & 0.03 & & 47.21 & \\
\hline B1 & 6.17 & \multirow{2}{*}{5.98} & & & & & & \\
\hline B2 & 5.79 & & & & & & & \\
\hline $1: 20 a$ & 4.05 & \multirow{3}{*}{4.11} & 5.03 & 4.97 & 0.04 & \multirow[b]{3}{*}{0.04} & 32.32 & \multirow[b]{3}{*}{31.34} \\
\hline $1: 20 b$ & 4.11 & & 5.03 & 4.97 & 0.04 & & 31.32 & \\
\hline $1: 20 \mathrm{c}$ & 4.16 & & 5.06 & 5.00 & 0.04 & & 30.37 & \\
\hline B1 & 6.17 & \multirow{2}{*}{5.98} & & & & & & \\
\hline B2 & 5.79 & & & & & & & \\
\hline 1:50a & 4.80 & \multirow{3}{*}{4.82} & 2.05 & 2.03 & 0.06 & \multirow[b]{3}{*}{0.06} & 19.68 & \multirow[b]{3}{*}{19.37} \\
\hline $1: 50 \mathrm{~b}$ & 4.83 & & 2.09 & 2.07 & 0.06 & & 19.31 & \\
\hline $1: 50 \mathrm{c}$ & 4.84 & & 2.05 & 2.03 & 0.06 & & 19.11 & \\
\hline B1 & 6.17 & \multirow{2}{*}{5.98} & & & & & & \\
\hline B2 & 5.79 & & & & & & & \\
\hline $1: 100 a$ & 5.29 & & 1.08 & 1.07 & 0.06 & & 11.54 & \\
\hline $1: 100 b$ & 5.17 & 5.23 & 1.07 & 1.06 & 0.08 & & 13.55 & \\
\hline $1: 100 \mathrm{c}$ & 5.24 & & 0.98 & 0.96 & 0.08 & 0.07 & 12.37 & 12.49 \\
\hline B1 & 6.17 & & & & & & & \\
\hline B2 & 5.79 & 5.98 & & & & & & \\
\hline $1: 200 a$ & 5.04 & & 0.51 & 0.50 & 0.19 & & 15.72 & \\
\hline $1: 200 \mathrm{~b}$ & 5.06 & 5.02 & 0.51 & 0.50 & 0.18 & & 15.38 & \\
\hline $1: 200 \mathrm{c}$ & 4.96 & & 0.50 & 0.49 & 0.21 & 0.19 & 17.11 & 16.07 \\
\hline B1 & 6.17 & 598 & & & & & & \\
\hline B2 & 5.79 & 3.90 & & & & & & \\
\hline $1: 500 a$ & 5.06 & & 0.20 & 0.20 & 0.46 & & 15.38 & \\
\hline $1: 500 b$ & 4.89 & 5.01 & 0.20 & 0.20 & 0.54 & & 18.19 & \\
\hline $1: 500 \mathrm{c}$ & 5.07 & & 0.20 & 0.19 & 0.47 & 0.49 & 15.22 & 16.27 \\
\hline
\end{tabular}



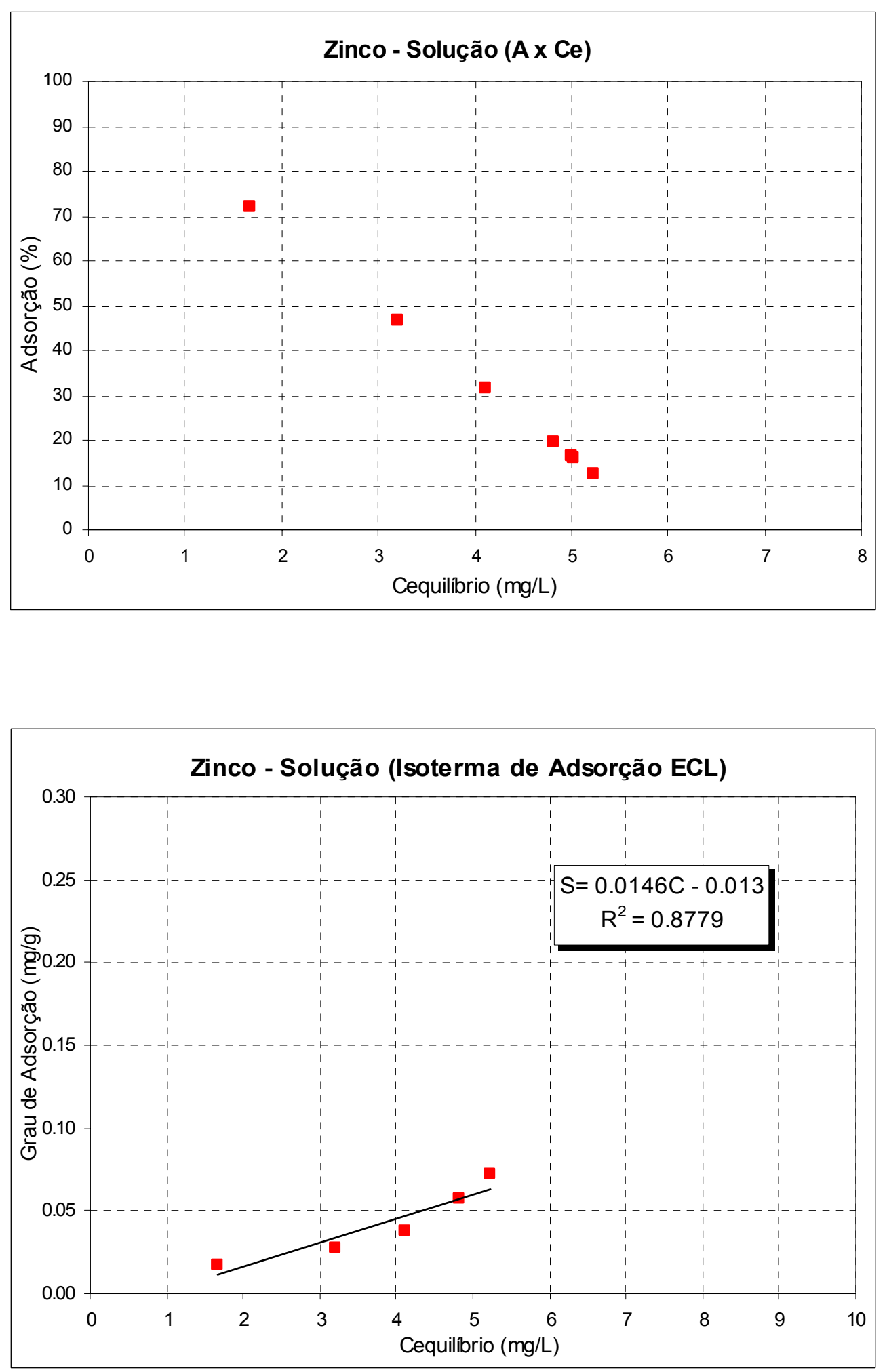
Cádmio:

\begin{tabular}{|c|c|c|c|c|c|c|c|c|}
\hline \multirow{2}{*}{ Amostra } & \multirow{2}{*}{\begin{tabular}{|c|} 
Concentração \\
$(\mathrm{mg} / \mathrm{L})$
\end{tabular}} & \multirow{2}{*}{$\begin{array}{l}\text { Concentração } \\
\text { média }(\mathrm{mg} / \mathrm{L})\end{array}$} & \multirow{2}{*}{$\begin{array}{c}\text { Psolo } \\
\text { (g) }\end{array}$} & \multirow{2}{*}{$\begin{array}{c}\text { Psólido } \\
\text { (g) }\end{array}$} & \multirow{2}{*}{\begin{tabular}{|c|}
$\mathrm{S}$ \\
$(\mathrm{mg} / \mathrm{g})$
\end{tabular}} & \multirow{2}{*}{$\frac{\mathrm{S}}{(\mathrm{mg} / \mathrm{g})}$} & \multirow{2}{*}{\begin{tabular}{|c|} 
A \\
$(\%)$ \\
\end{tabular}} & \multirow{2}{*}{$\begin{array}{c}\text { A } \\
(\%)\end{array}$} \\
\hline & & & & & & & & \\
\hline B1 & 8.23 & \multirow{2}{*}{8.44} & & & & & & \\
\hline B2 & 8.64 & & & & & & & \\
\hline $1: 4 a$ & 2.03 & \multirow{3}{*}{2.09} & 24.99 & 24.69 & 0.03 & \multirow[b]{3}{*}{0.03} & 75.89 & \multirow[b]{3}{*}{75.19} \\
\hline $1: 4 b$ & 2.19 & & 24.94 & 24.64 & 0.03 & & 74.05 & \\
\hline $1: 4 c$ & 2.06 & & 24.91 & 24.61 & 0.03 & & 75.63 & \\
\hline B1 & 8.23 & \multirow{2}{*}{8.44} & & & & & & \\
\hline B2 & 8.64 & & & & & & & \\
\hline $1: 10 a$ & 4.06 & \multirow{3}{*}{4.08} & 10.05 & 9.93 & 0.04 & \multirow[b]{3}{*}{0.04} & 51.89 & \multirow[b]{3}{*}{51.57} \\
\hline $1: 10 b$ & 4.12 & & 10.05 & 9.93 & 0.04 & & 51.17 & \\
\hline $1: 10 \mathrm{c}$ & 4.08 & & 10.04 & 9.92 & 0.04 & & 51.67 & \\
\hline B1 & 8.23 & \multirow{2}{*}{8.44} & & & & & & \\
\hline B2 & 8.64 & & & & & & & \\
\hline $1: 20 a$ & 5.18 & \multirow{3}{*}{5.27} & 5.03 & 4.97 & 0.07 & \multirow[b]{3}{*}{0.06} & 38.59 & \multirow[b]{3}{*}{37.56} \\
\hline $1: 20 \mathrm{~b}$ & 5.31 & & 5.03 & 4.97 & 0.06 & & 37.05 & \\
\hline $1: 20 \mathrm{c}$ & 5.31 & & 5.06 & 5.00 & 0.06 & & 37.05 & \\
\hline B1 & 8.23 & \multirow{2}{*}{8.44} & & & & & & \\
\hline B2 & 8.64 & & & & & & & \\
\hline $1: 50 a$ & 6.25 & \multirow{3}{*}{6.29} & 2.05 & 2.03 & 0.11 & \multirow[b]{3}{*}{0.11} & 25.90 & \multirow[b]{3}{*}{25.47} \\
\hline $1: 50 \mathrm{~b}$ & 6.41 & & 2.09 & 2.07 & 0.10 & & 24.01 & \\
\hline $1: 50 \mathrm{c}$ & 6.20 & & 2.05 & 2.03 & 0.11 & & 26.50 & \\
\hline B1 & 8.23 & \multirow{2}{*}{8.44} & & & & & & \\
\hline B2 & 8.64 & & & & & & & \\
\hline $1: 100 a$ & 7.15 & & 1.08 & 1.07 & 0.12 & & 15.23 & \\
\hline 1:100b & 6.90 & 7.06 & 1.07 & 1.06 & 0.15 & & 18.20 & \\
\hline $1: 100 \mathrm{c}$ & 7.12 & & 0.98 & 0.96 & 0.14 & 0.13 & 15.59 & 16.34 \\
\hline B1 & 8.23 & 844 & & & & & & \\
\hline B2 & 8.64 & 8.44 & & & & & & \\
\hline $1: 200 a$ & 7.74 & & 0.51 & 0.50 & 0.14 & & 8.24 & \\
\hline $1: 200 \mathrm{~b}$ & 7.92 & 7.85 & 0.51 & 0.50 & 0.10 & & 6.11 & \\
\hline $1: 200 \mathrm{c}$ & 7.89 & & 0.50 & 0.49 & 0.11 & 0.12 & 6.46 & 6.94 \\
\hline B1 & 8.23 & 844 & & & & & & \\
\hline B2 & 8.64 & 8.44 & & & & & & \\
\hline $1: 500 a$ & 8.61 & & 0.20 & 0.20 & -0.09 & & -2.07 & \\
\hline 1:500b & 8.40 & 8.58 & 0.20 & 0.20 & 0.02 & & 0.41 & \\
\hline $1: 500 \mathrm{c}$ & 8.72 & & 0.20 & 0.19 & -0.15 & -0.07 & -3.38 & -1.68 \\
\hline
\end{tabular}



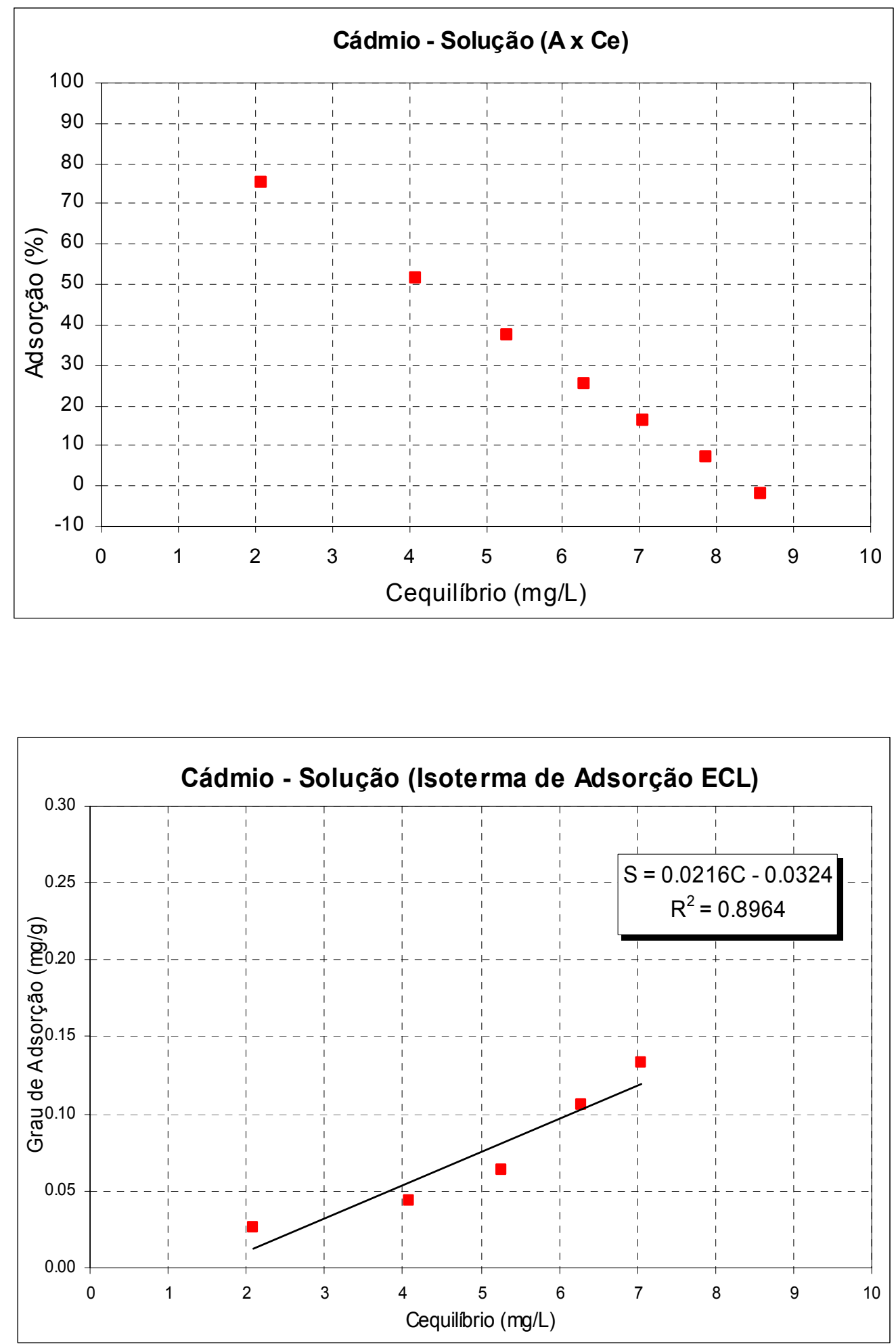


\section{Chumbo:}

\begin{tabular}{|c|c|c|c|c|c|c|c|c|}
\hline \multirow{2}{*}{ Amostra } & \multirow{2}{*}{\begin{tabular}{|c|} 
Concentração \\
$(\mathrm{mg} / \mathrm{L})$ \\
\end{tabular}} & \multirow{2}{*}{$\begin{array}{l}\text { Concentração } \\
\text { média }(\mathrm{mg} / \mathrm{L})\end{array}$} & \multirow{2}{*}{$\begin{array}{c}\text { Psolo } \\
(\mathrm{g}) \\
\end{array}$} & \multirow{2}{*}{$\begin{array}{c}\text { Psólido } \\
\text { (g) }\end{array}$} & \multirow{2}{*}{\begin{tabular}{|c|}
$\mathrm{S}$ \\
$(\mathrm{mg} / \mathrm{g})$ \\
\end{tabular}} & \multirow{2}{*}{$\begin{array}{c}\mathrm{S} \\
(\mathrm{mg} / \mathrm{g}) \\
\end{array}$} & \multirow{2}{*}{$\begin{array}{c}\mathrm{A} \\
(\%) \\
\end{array}$} & \multirow{2}{*}{$\begin{array}{c}\text { A } \\
(\%) \\
\end{array}$} \\
\hline & & & & & & & & \\
\hline B1 & 0.06 & \multirow{2}{*}{0.07} & & & & & & \\
\hline B2 & 0.09 & & & & & & & \\
\hline $1: 4 a$ & 0.13 & \multirow{3}{*}{0.18} & 24.99 & 24.69 & 0.00 & \multirow[b]{3}{*}{0.00} & -84.28 & \multirow[b]{3}{*}{-140.69} \\
\hline $1: 4 b$ & 0.23 & & 24.94 & 24.64 & 0.00 & & -212.51 & \\
\hline $1: 4 c$ & 0.16 & & 24.91 & 24.61 & 0.00 & & -125.29 & \\
\hline B1 & 0.06 & \multirow{2}{*}{0.07} & & & & & & \\
\hline B2 & 0.09 & & & & & & & \\
\hline $1: 10 a$ & 0.50 & \multirow{3}{*}{0.51} & 10.05 & 9.93 & 0.00 & \multirow[b]{3}{*}{0.00} & -589.00 & \multirow[b]{3}{*}{-602.03} \\
\hline $1: 10 b$ & 0.56 & & 10.05 & 9.93 & 0.00 & & -664.18 & \\
\hline $1: 10 \mathrm{c}$ & 0.48 & & 10.04 & 9.92 & 0.00 & & -552.90 & \\
\hline B1 & 0.06 & \multirow{2}{*}{0.07} & & & & & & \\
\hline B2 & 0.09 & & & & & & & \\
\hline $1: 20 a$ & 0.81 & \multirow{3}{*}{0.87} & 5.03 & 4.97 & -0.01 & \multirow[b]{3}{*}{-0.02} & -1004.58 & \multirow{3}{*}{-1086.60} \\
\hline 1:20b & 0.91 & & 5.03 & 4.97 & -0.02 & & -1146.75 & \\
\hline $1: 20 \mathrm{c}$ & 0.88 & & 5.06 & 5.00 & -0.02 & & -1108.48 & \\
\hline B1 & 0.06 & \multirow{2}{*}{0.07} & & & & & & \\
\hline B2 & 0.09 & & & & & & & \\
\hline $1: 50 a$ & 1.23 & \multirow{3}{*}{1.24} & 2.05 & 2.03 & -0.06 & \multirow[b]{3}{*}{-0.06} & -1585.58 & \multirow{3}{*}{\begin{tabular}{|}
$\mid$ \\
-1590.59 \\
\end{tabular}} \\
\hline $1: 50 b$ & 1.30 & & 2.09 & 2.07 & -0.06 & & -1673.07 & \\
\hline $1: 50 \mathrm{c}$ & 1.18 & & 2.05 & 2.03 & -0.05 & & -1513.12 & \\
\hline B1 & 0.06 & \multirow{2}{*}{0.07} & & & & & & \\
\hline B2 & 0.09 & & & & & & & \\
\hline 1:100a & 1.17 & & 1.08 & 1.07 & -0.10 & & -1502.19 & \\
\hline $1: 100 b$ & 1.07 & 1.09 & 1.07 & 1.06 & -0.09 & & -1362.75 & \\
\hline $1: 100 c$ & 1.03 & & 0.98 & 0.96 & -0.10 & -0.10 & -1310.80 & -1391.91 \\
\hline B1 & 0.06 & 007 & & & & & & \\
\hline B2 & 0.09 & 0.01 & & & & & & \\
\hline $1: 200 a$ & 0.98 & & 0.51 & 0.50 & -0.18 & & -1243.81 & \\
\hline $1: 200 b$ & 1.00 & 0.98 & 0.51 & 0.50 & -0.18 & & -1262.95 & \\
\hline $1: 200 \mathrm{c}$ & 0.95 & & 0.50 & 0.49 & -0.18 & -0.18 & -1202.80 & -1236.52 \\
\hline B1 & 0.06 & 007 & & & & & & \\
\hline B2 & 0.09 & 0.01 & & & & & & \\
\hline 1:500a & 1.10 & & 0.20 & 0.20 & -0.51 & & -1405.13 & \\
\hline 1:500b & 0.69 & 0.91 & 0.20 & 0.20 & -0.30 & & -836.43 & \\
\hline $1: 500 \mathrm{c}$ & 0.93 & & 0.20 & 0.19 & -0.44 & -0.42 & -1174.09 & -1138.55 \\
\hline
\end{tabular}



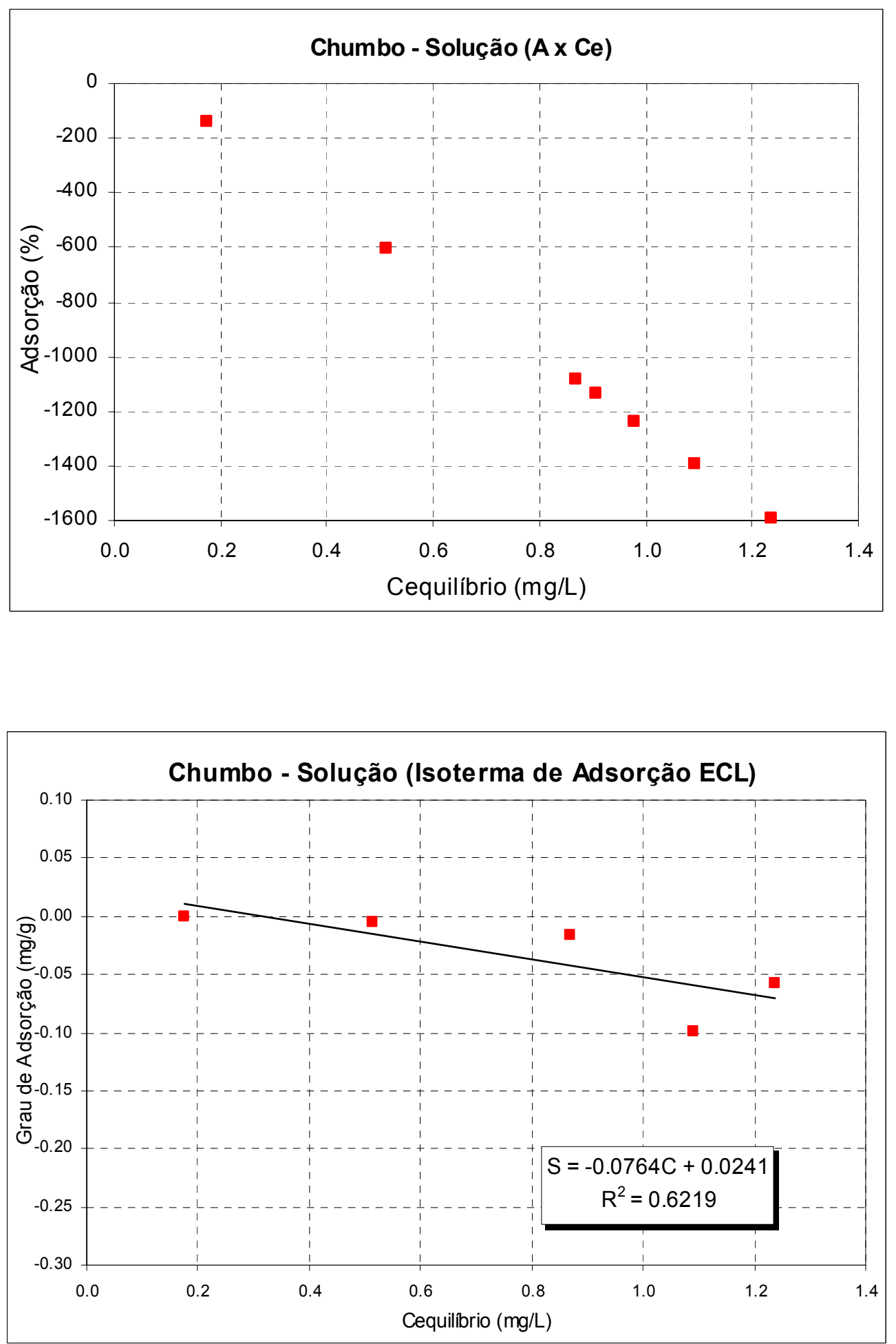


\section{Chorume mais Metais:}

- Teor de umidade do solo seco ao ar e passado na peneira 40: $1.20 \%$

- Tempo de Equilíbrio: 1 semana (168 h)

Níquel:

\begin{tabular}{|c|c|c|c|c|c|c|c|c|}
\hline \multirow{2}{*}{ Amostra } & \multirow{2}{*}{\begin{tabular}{|c} 
Concentração \\
$(\mathrm{mg} / \mathrm{L})$ \\
\end{tabular}} & \multirow{2}{*}{$\begin{array}{l}\text { Concentração } \\
\text { média }(\mathrm{mg} / \mathrm{L})\end{array}$} & \multirow{2}{*}{$\begin{array}{c}\text { Psolo } \\
\text { (g) }\end{array}$} & \multirow{2}{*}{$\begin{array}{c}\text { Psólido } \\
\text { (g) }\end{array}$} & \multirow{2}{*}{\begin{tabular}{|c|}
$\mathrm{S}$ \\
$(\mathrm{mg} / \mathrm{g})$ \\
\end{tabular}} & \multirow{2}{*}{$\frac{\mathrm{S}}{(\mathrm{mg} / \mathrm{g})}$} & \multirow{2}{*}{$\begin{array}{c}\text { A } \\
(\%)\end{array}$} & \multirow{2}{*}{$\begin{array}{c}\mathrm{A} \\
(\%)\end{array}$} \\
\hline & & & & & & & & \\
\hline B1 & \begin{tabular}{|l|}
8.63 \\
\end{tabular} & \multirow{2}{*}{8.78} & & & & & & \\
\hline B2 & 8.93 & & & & & & & \\
\hline $1: 4 a$ & 3.90 & \multirow{3}{*}{3.84} & 25.03 & 24.74 & 0.02 & \multirow[b]{3}{*}{0.02} & 55.55 & \multirow[b]{3}{*}{56.29} \\
\hline $1: 4 b$ & 3.98 & & 24.93 & 24.64 & 0.02 & & 54.72 & \\
\hline $1: 4 \mathrm{c}$ & 3.63 & & 25.07 & 24.77 & 0.02 & & 58.61 & \\
\hline B1 & 8.63 & \multirow{2}{*}{8.78} & & & & & & \\
\hline B2 & 8.93 & & & & & & & \\
\hline $1: 10 a$ & 5.09 & \multirow{3}{*}{5.10} & 9.92 & 9.80 & 0.04 & \multirow[b]{3}{*}{0.04} & 42.03 & \multirow[b]{3}{*}{41.91} \\
\hline $1: 10 b$ & 5.18 & & 9.98 & 9.86 & 0.04 & & 41.00 & \\
\hline $1: 10 \mathrm{c}$ & 5.03 & & 10.06 & 9.94 & 0.04 & & 42.71 & \\
\hline B1 & 8.63 & \multirow{2}{*}{8.78} & & & & & & \\
\hline B2 & 8.93 & & & & & & & \\
\hline $1: 20 a$ & 6.41 & \multirow{3}{*}{6.36} & 4.93 & 4.87 & 0.05 & & 26.99 & \multirow[b]{3}{*}{27.56} \\
\hline $1: 20 b$ & 6.36 & & 5.09 & 5.03 & 0.05 & & 27.56 & \\
\hline $1: 20 \mathrm{c}$ & 6.31 & & 4.97 & 4.91 & 0.05 & 0.05 & 28.13 & \\
\hline B1 & 8.63 & \multirow{2}{*}{8.78} & & & & & & \\
\hline B2 & 8.93 & & & & & & & \\
\hline $1: 50 a$ & 7.62 & \multirow{3}{*}{7.56} & 2.06 & 2.04 & 0.06 & \multirow[b]{3}{*}{0.06} & 13.21 & \multirow[b]{3}{*}{13.93} \\
\hline $1: 50 \mathrm{~b}$ & 7.58 & & 2.04 & 2.02 & 0.06 & & 13.67 & \\
\hline $1: 50 \mathrm{c}$ & 7.47 & & 1.96 & 1.94 & 0.07 & & 14.92 & \\
\hline B1 & 8.63 & \multirow{2}{*}{8.78} & & & & & & \\
\hline B2 & 8.93 & & & & & & & \\
\hline 1:100a & 8.33 & \multirow{3}{*}{8.31} & 1.01 & 1.00 & 0.04 & & 5.13 & \\
\hline $1: 100 \mathrm{~b}$ & 8.24 & & 1.02 & 1.01 & 0.05 & & 6.15 & \\
\hline $1: 100 \mathrm{c}$ & 8.36 & & 1.03 & 1.02 & 0.04 & 0.05 & 4.78 & 5.35 \\
\hline B1 & 8.63 & 878 & & & & & & \\
\hline B2 & 8.93 & 0.10 & & & & & & \\
\hline $1: 200 a$ & 8.60 & & 0.51 & 0.50 & 0.04 & & 2.05 & \\
\hline $1: 200 \mathrm{~b}$ & 8.75 & 8.68 & 0.50 & 0.50 & 0.01 & & 0.34 & \\
\hline $1: 200 c$ & 8.68 & & 0.49 & 0.49 & 0.02 & 0.02 & 1.14 & 1.18 \\
\hline B1 & 8.63 & 878 & & & & & & \\
\hline B2 & 8.93 & 8.18 & & & & & & \\
\hline $1: 500 a$ & 8.84 & & 0.20 & 0.20 & -0.03 & & -0.68 & \\
\hline $1: 500 b$ & 8.88 & 8.94 & 0.21 & 0.21 & -0.05 & & -1.14 & \\
\hline $1: 500 \mathrm{c}$ & 9.10 & & 0.20 & 0.19 & -0.17 & -0.08 & -3.64 & -1.82 \\
\hline
\end{tabular}



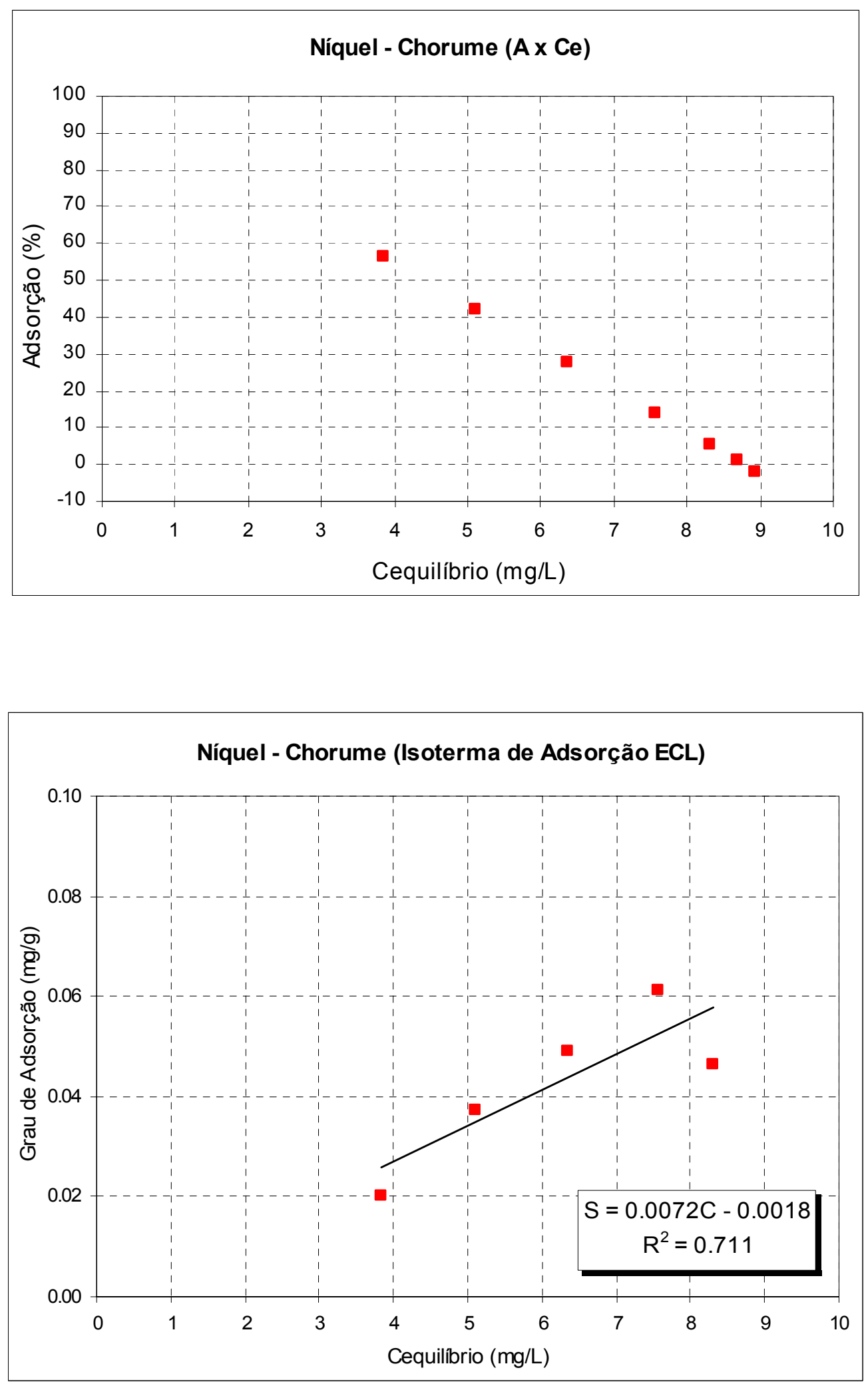
$\underline{\text { Zinco: }}$

\begin{tabular}{|c|c|c|c|c|c|c|c|c|}
\hline \multirow{2}{*}{ Amostra } & \multirow{2}{*}{\begin{tabular}{|c} 
Concentração \\
$(\mathrm{mg} / \mathrm{L})$ \\
\end{tabular}} & \multirow{2}{*}{$\begin{array}{l}\text { Concentração } \\
\text { média }(\mathrm{mg} / \mathrm{L})\end{array}$} & \multirow{2}{*}{$\begin{array}{c}\text { Psolo } \\
\text { (g) }\end{array}$} & \multirow{2}{*}{$\begin{array}{c}\text { Psólido } \\
\text { (g) }\end{array}$} & \multirow{2}{*}{\begin{tabular}{|c|}
$\mathrm{S}$ \\
$(\mathrm{mg} / \mathrm{g})$
\end{tabular}} & \multirow{2}{*}{$\frac{\mathrm{S}}{(\mathrm{mg} / \mathrm{g})}$} & \multirow{2}{*}{\begin{tabular}{|c|}
$A$ \\
$(\%)$ \\
\end{tabular}} & \multirow{2}{*}{\begin{tabular}{|c|}
$A$ \\
$(\%)$ \\
\end{tabular}} \\
\hline & & & & & & & & \\
\hline B1 & 4.98 & \multirow{2}{*}{5.11} & & & & & & \\
\hline B2 & 5.24 & & & & & & & \\
\hline $1: 4 a$ & 0.44 & \multirow{3}{*}{0.50} & 25.03 & 24.74 & 0.02 & \multirow[b]{3}{*}{0.02} & 91.42 & \multirow[b]{3}{*}{90.17} \\
\hline $1: 4 b$ & 0.70 & & 24.93 & 24.64 & 0.02 & & 86.38 & \\
\hline $1: 4 c$ & 0.37 & & 25.07 & 24.77 & 0.02 & & 92.71 & \\
\hline B1 & 4.98 & \multirow{2}{*}{5.11} & & & & & & \\
\hline B2 & 5.24 & & & & & & & \\
\hline $1: 10 a$ & 0.73 & \multirow{3}{*}{0.66} & 9.92 & 9.80 & 0.04 & \multirow[b]{3}{*}{0.05} & 85.78 & \multirow[b]{3}{*}{87.05} \\
\hline $1: 10 b$ & 0.66 & & 9.98 & 9.86 & 0.05 & & 87.13 & \\
\hline $1: 10 \mathrm{c}$ & 0.60 & & 10.06 & 9.94 & 0.05 & & 88.26 & \\
\hline B1 & 4.98 & \multirow{2}{*}{5.11} & & & & & & \\
\hline B2 & 5.24 & & & & & & & \\
\hline $1: 20 a$ & 1.01 & \multirow{3}{*}{0.99} & 4.93 & 4.87 & 0.08 & \multirow[b]{3}{*}{0.08} & 80.24 & \multirow[b]{3}{*}{80.64} \\
\hline $1: 20 b$ & 0.97 & & 5.09 & 5.03 & 0.08 & & 80.94 & \\
\hline $1: 20 \mathrm{c}$ & 0.98 & & 4.97 & 4.91 & 0.08 & & 80.75 & \\
\hline B1 & 4.98 & \multirow{2}{*}{5.11} & & & & & & \\
\hline B2 & 5.24 & & & & & & & \\
\hline 1:50a & 1.96 & \multirow{3}{*}{2.00} & 2.06 & 2.04 & 0.15 & \multirow[b]{3}{*}{0.16} & 61.57 & \multirow[b]{3}{*}{60.92} \\
\hline $1: 50 \mathrm{~b}$ & 2.21 & & 2.04 & 2.02 & 0.14 & & 56.86 & \\
\hline $1: 50 \mathrm{c}$ & 1.82 & & 1.96 & 1.94 & 0.17 & & 64.33 & \\
\hline B1 & 4.98 & \multirow{2}{*}{5.11} & & & & & & \\
\hline B2 & 5.24 & & & & & & & \\
\hline $1: 100 a$ & 2.84 & & 1.01 & 1.00 & 0.23 & & 44.51 & \\
\hline $1: 100 b$ & 3.00 & 2.99 & 1.02 & 1.01 & 0.21 & & 41.34 & \\
\hline $1: 100 \mathrm{c}$ & 3.14 & & 1.03 & 1.02 & 0.19 & 0.21 & 38.60 & 41.49 \\
\hline B1 & 4.98 & & & & & & & \\
\hline B2 & 5.24 & 5.11 & & & & & & \\
\hline $1: 200 a$ & 3.53 & & 0.51 & 0.50 & 0.31 & & 30.95 & \\
\hline $1: 200 \mathrm{~b}$ & 3.84 & 3.76 & 0.50 & 0.50 & 0.26 & & 24.83 & \\
\hline $1: 200 \mathrm{c}$ & 3.91 & & 0.49 & 0.49 & 0.25 & 0.27 & 23.56 & 26.45 \\
\hline B1 & 4.98 & 511 & & & & & & \\
\hline B2 & 5.24 & 5.11 & & & & & & \\
\hline $1: 500 a$ & 4.30 & & 0.20 & 0.20 & 0.41 & & 15.97 & \\
\hline $1: 500 \mathrm{~b}$ & 4.39 & 4.37 & 0.21 & 0.21 & 0.35 & & 14.07 & \\
\hline $1: 500 \mathrm{c}$ & 4.42 & & 0.20 & 0.19 & 0.36 & 0.37 & 13.46 & 14.50 \\
\hline
\end{tabular}



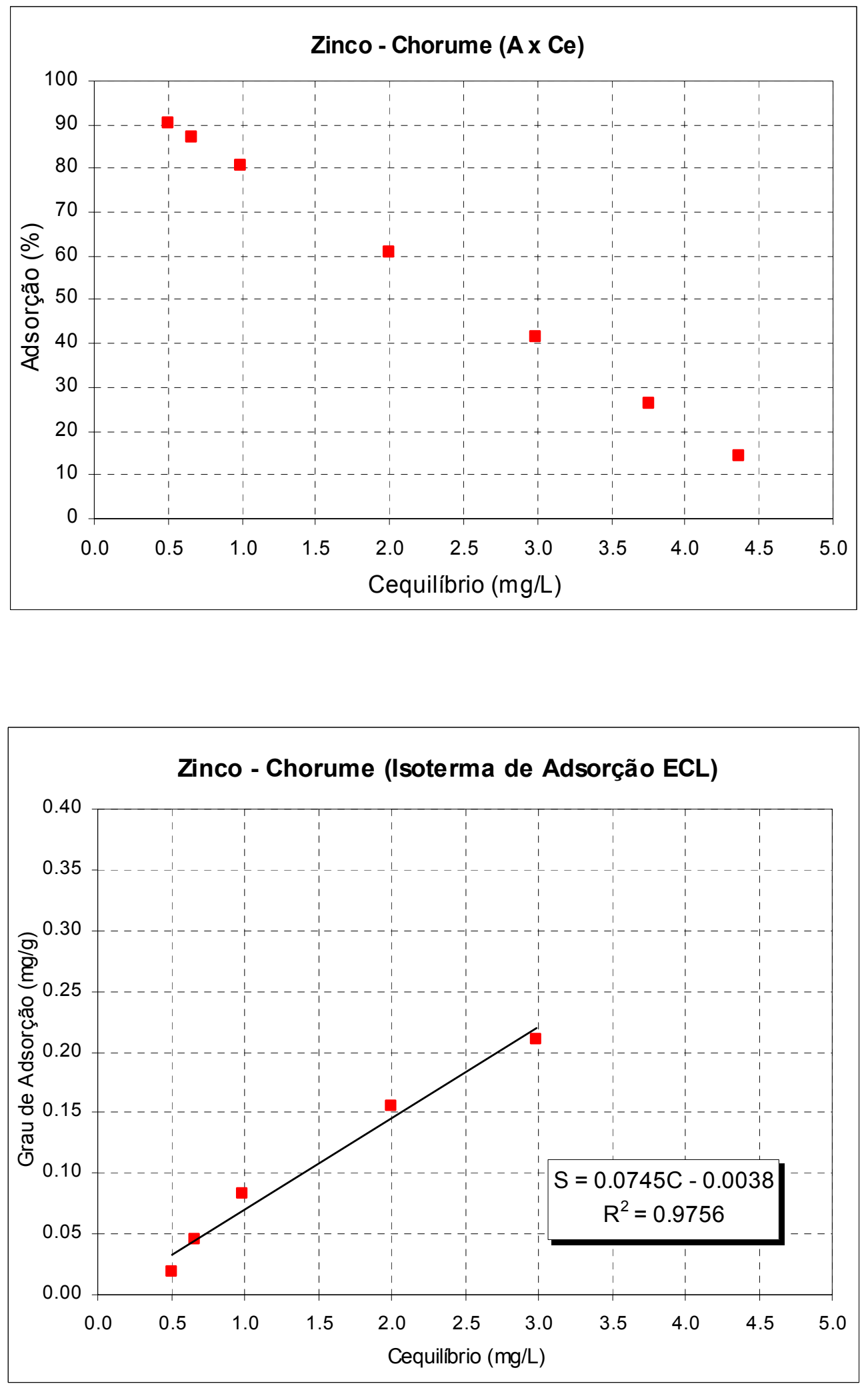
Cádmio:

\begin{tabular}{|c|c|c|c|c|c|c|c|c|}
\hline \multirow{2}{*}{ Amostra } & \multirow{2}{*}{\begin{tabular}{|c|} 
Concentração \\
$(\mathrm{mg} / \mathrm{L})$
\end{tabular}} & \multirow{2}{*}{$\begin{array}{l}\text { Concentração } \\
\text { média }(\mathrm{mg} / \mathrm{L})\end{array}$} & \multirow{2}{*}{\begin{tabular}{|c|} 
Psolo \\
(g)
\end{tabular}} & \multirow{2}{*}{$\begin{array}{c}\text { Psólido } \\
\text { (g) }\end{array}$} & \multirow{2}{*}{\begin{tabular}{|c|}
$\mathrm{S}$ \\
$(\mathrm{mg} / \mathrm{g})$ \\
\end{tabular}} & \multirow{2}{*}{\begin{tabular}{|c|}
$\mathrm{S}$ \\
$(\mathrm{mg} / \mathrm{g})$
\end{tabular}} & \multirow{2}{*}{\begin{tabular}{|c|}
$A$ \\
$(\%)$ \\
\end{tabular}} & \multirow{2}{*}{$\begin{array}{c}A \\
(\%)\end{array}$} \\
\hline & & & & & & & & \\
\hline B1 & 2.55 & \multirow{2}{*}{2.63} & & & & & & \\
\hline B2 & 2.71 & & & & & & & \\
\hline $1: 4 a$ & 0.72 & \multirow{3}{*}{0.71} & 25.03 & 24.74 & 0.01 & \multirow[b]{3}{*}{0.01} & 72.49 & \multirow{3}{*}{73.05} \\
\hline $1: 4 b$ & 0.75 & & 24.93 & 24.64 & 0.01 & & 71.39 & \\
\hline $1: 4 \mathrm{c}$ & 0.65 & & 25.07 & 24.77 & 0.01 & & 75.27 & \\
\hline B1 & 2.55 & \multirow{2}{*}{2.63} & & & & & & \\
\hline B2 & 2.71 & & & & & & & \\
\hline $1: 10 a$ & 0.81 & \multirow{3}{*}{0.83} & 9.92 & 9.80 & 0.02 & \multirow[b]{3}{*}{0.02} & 69.18 & \multirow[b]{3}{*}{68.59} \\
\hline $1: 10 b$ & 0.83 & & 9.98 & 9.86 & 0.02 & & 68.27 & \\
\hline $1: 10 \mathrm{c}$ & 0.83 & & 10.06 & 9.94 & 0.02 & & 68.31 & \\
\hline B1 & 2.55 & \multirow{2}{*}{2.63} & & & & & & \\
\hline B2 & 2.71 & & & & & & & \\
\hline $1: 20 a$ & 0.97 & \multirow{3}{*}{0.94} & 4.93 & 4.87 & 0.03 & \multirow[b]{3}{*}{0.03} & 62.98 & \multirow[b]{3}{*}{64.09} \\
\hline $1: 20 \mathrm{~b}$ & 0.92 & & 5.09 & 5.03 & 0.03 & & 65.04 & \\
\hline $1: 20 \mathrm{c}$ & 0.94 & & 4.97 & 4.91 & 0.03 & & 64.24 & \\
\hline B1 & 2.55 & \multirow{2}{*}{2.63} & & & & & & \\
\hline B2 & 2.71 & & & & & & & \\
\hline 1:50a & 1.35 & \multirow{3}{*}{1.43} & 2.06 & 2.04 & 0.06 & \multirow[b]{3}{*}{0.06} & 48.79 & \multirow[b]{3}{*}{45.77} \\
\hline $1: 50 \mathrm{~b}$ & 1.45 & & 2.04 & 2.02 & 0.06 & & 44.91 & \\
\hline $1: 50 \mathrm{c}$ & 1.48 & & 1.96 & 1.94 & 0.06 & & 43.62 & \\
\hline B1 & 2.55 & \multirow{2}{*}{2.63} & & & & & & \\
\hline B2 & 2.71 & & & & & & & \\
\hline $1: 100 a$ & 1.87 & & 1.01 & 1.00 & 0.08 & & 28.74 & \\
\hline $1: 100 b$ & 1.87 & 1.88 & 1.02 & 1.01 & 0.08 & & 28.89 & \\
\hline $1: 100 \mathrm{c}$ & 1.90 & & 1.03 & 1.02 & 0.07 & 0.07 & 27.79 & 28.48 \\
\hline B1 & 2.55 & 263 & & & & & & \\
\hline B2 & 2.71 & 2.63 & & & & & & \\
\hline $1: 200 a$ & 2.10 & & 0.51 & 0.50 & 0.10 & & 20.07 & \\
\hline $1: 200 \mathrm{~b}$ & 2.22 & 2.28 & 0.50 & 0.50 & 0.08 & & 15.66 & \\
\hline $1: 200 \mathrm{c}$ & 2.53 & & 0.49 & 0.49 & 0.02 & 0.07 & 3.75 & 13.16 \\
\hline B1 & 2.55 & 263 & & & & & & \\
\hline B2 & 2.71 & 2.63 & & & & & & \\
\hline $1: 500 a$ & 2.45 & & 0.20 & 0.20 & 0.09 & & 6.83 & \\
\hline $1: 500 b$ & 2.68 & 2.55 & 0.21 & 0.21 & -0.02 & & -1.96 & \\
\hline $1: 500 \mathrm{c}$ & 2.51 & & 0.20 & 0.19 & 0.06 & 0.04 & 4.43 & 3.10 \\
\hline
\end{tabular}



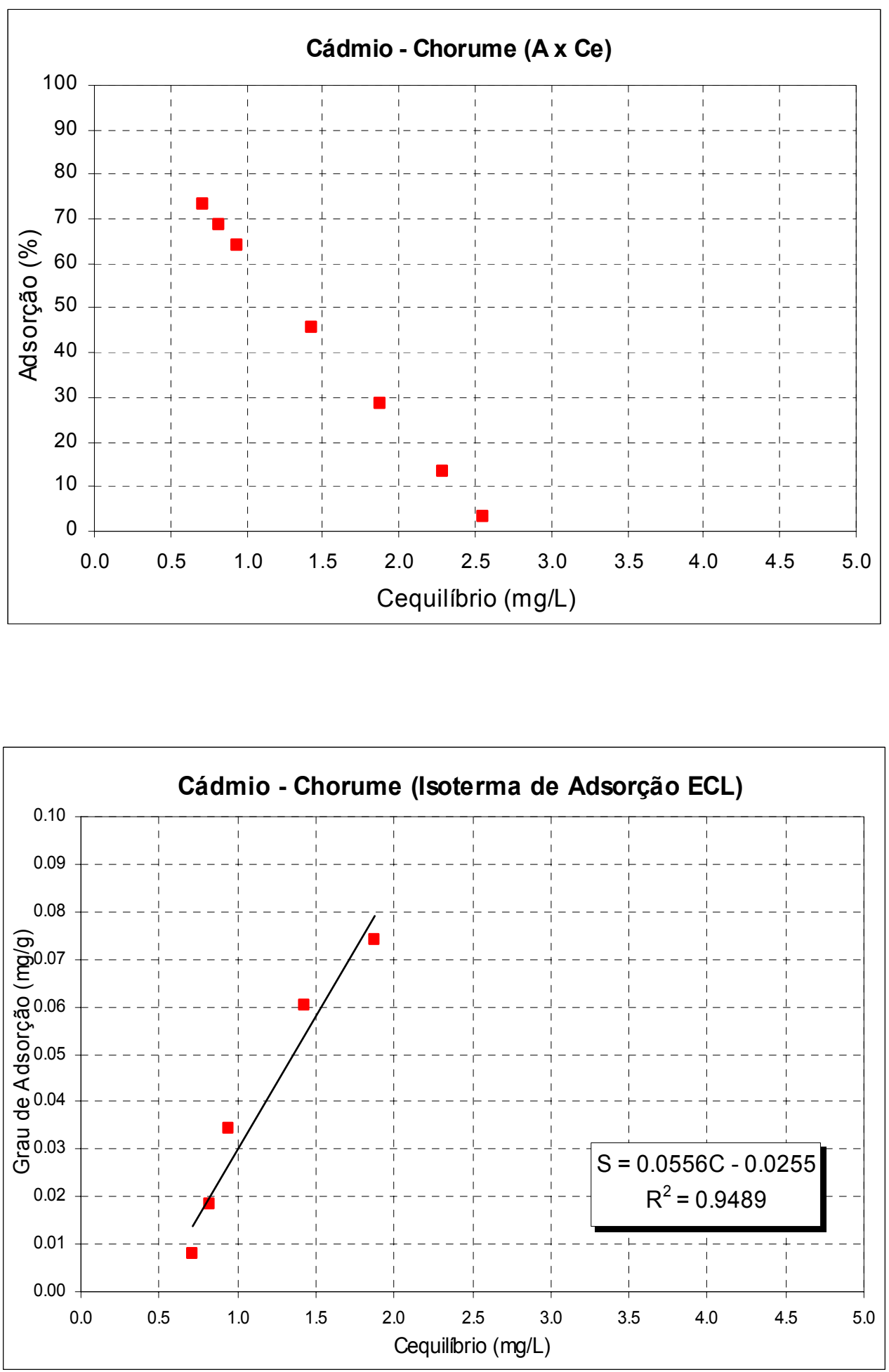
Chumbo:

\begin{tabular}{|c|c|c|c|c|c|c|c|c|}
\hline \multirow{2}{*}{ Amostra } & \multirow{2}{*}{\begin{tabular}{|c|} 
Concentração \\
$(\mathrm{mg} / \mathrm{L})$
\end{tabular}} & \multirow{2}{*}{$\begin{array}{l}\text { Concentração } \\
\text { média }(\mathrm{mg} / \mathrm{L})\end{array}$} & \multirow{2}{*}{\begin{tabular}{|c|} 
Psolo \\
(g)
\end{tabular}} & \multirow{2}{*}{$\begin{array}{c}\text { Psólido } \\
\text { (g) }\end{array}$} & \multirow{2}{*}{\begin{tabular}{|c|}
$\mathrm{S}$ \\
$(\mathrm{mg} / \mathrm{g})$ \\
\end{tabular}} & \multirow{2}{*}{\begin{tabular}{|c|}
$\mathrm{S}$ \\
$(\mathrm{mg} / \mathrm{g})$
\end{tabular}} & \multirow{2}{*}{\begin{tabular}{|c|}
$A$ \\
$(\%)$ \\
\end{tabular}} & \multirow{2}{*}{$\begin{array}{c}A \\
(\%)\end{array}$} \\
\hline & & & & & & & & \\
\hline B1 & - & \multirow{2}{*}{14.21} & & & & & & \\
\hline B2 & 14.21 & & & & & & & \\
\hline $1: 4 a$ & 0.33 & \multirow{3}{*}{0.29} & 25.03 & 24.74 & 0.06 & \multirow[b]{3}{*}{0.06} & 97.67 & \multirow[b]{3}{*}{97.94} \\
\hline $1: 4 b$ & 0.33 & & 24.93 & 24.64 & 0.06 & & 97.71 & \\
\hline $1: 4 \mathrm{c}$ & 0.22 & & 25.07 & 24.77 & 0.06 & & 98.44 & \\
\hline B1 & - & \multirow{2}{*}{14.21} & & & & & & \\
\hline B2 & 14.21 & & & & & & & \\
\hline $1: 10 a$ & 0.42 & \multirow{3}{*}{0.44} & 9.92 & 9.80 & 0.14 & \multirow[b]{3}{*}{0.14} & 97.08 & \multirow[b]{3}{*}{96.91} \\
\hline $1: 10 b$ & 0.39 & & 9.98 & 9.86 & 0.14 & & 97.23 & \\
\hline $1: 10 \mathrm{c}$ & 0.51 & & 10.06 & 9.94 & 0.14 & & 96.43 & \\
\hline B1 & - & \multirow{2}{*}{14.21} & & & & & & \\
\hline B2 & 14.21 & & & & & & & \\
\hline $1: 20 a$ & 0.81 & \multirow{3}{*}{0.74} & 4.93 & 4.87 & 0.28 & \multirow[b]{3}{*}{0.27} & 94.31 & \multirow[b]{3}{*}{94.79} \\
\hline $1: 20 b$ & 0.67 & & 5.09 & 5.03 & 0.27 & & 95.26 & \\
\hline $1: 20 \mathrm{c}$ & 0.74 & & 4.97 & 4.91 & 0.27 & & 94.79 & \\
\hline B1 & - & \multirow{2}{*}{14.21} & & & & & & \\
\hline B2 & 14.21 & & & & & & & \\
\hline 1:50a & 1.83 & \multirow{3}{*}{1.93} & 2.06 & 2.04 & 0.61 & \multirow[b]{3}{*}{0.61} & 87.12 & \multirow[b]{3}{*}{86.42} \\
\hline $1: 50 \mathrm{~b}$ & 1.90 & & 2.04 & 2.02 & 0.61 & & 86.64 & \\
\hline $1: 50 \mathrm{c}$ & 2.06 & & 1.96 & 1.94 & 0.63 & & 85.50 & \\
\hline B1 & - & \multirow{2}{*}{14.21} & & & & & & \\
\hline B2 & 14.21 & & & & & & & \\
\hline $1: 100 a$ & 3.47 & & 1.01 & 1.00 & 1.07 & & 75.55 & \\
\hline $1: 100 b$ & 3.62 & 3.55 & 1.02 & 1.01 & 1.05 & & 74.51 & \\
\hline $1: 100 \mathrm{c}$ & 3.56 & & 1.03 & 1.02 & 1.04 & 1.05 & 74.94 & 75.00 \\
\hline B1 & - & 1421 & & & & & & \\
\hline B2 & 14.21 & 14.21 & & & & & & \\
\hline $1: 200 a$ & 4.39 & & 0.51 & 0.50 & 1.95 & & 69.09 & \\
\hline $1: 200 \mathrm{~b}$ & 5.88 & 5.62 & 0.50 & 0.50 & 1.68 & & 58.62 & \\
\hline $1: 200 \mathrm{c}$ & 6.58 & & 0.49 & 0.49 & 1.57 & 1.73 & 53.69 & 60.47 \\
\hline B1 & - & 1421 & & & & & & \\
\hline B2 & 14.21 & & & & & & & \\
\hline $1: 500 a$ & 8.51 & & 0.20 & 0.20 & 2.84 & & 40.11 & \\
\hline $1: 500 b$ & 8.79 & 8.89 & 0.21 & 0.21 & 2.63 & & 38.14 & \\
\hline $1: 500 \mathrm{c}$ & 9.36 & & 0.20 & 0.19 & 2.50 & 2.66 & 34.13 & 37.46 \\
\hline
\end{tabular}



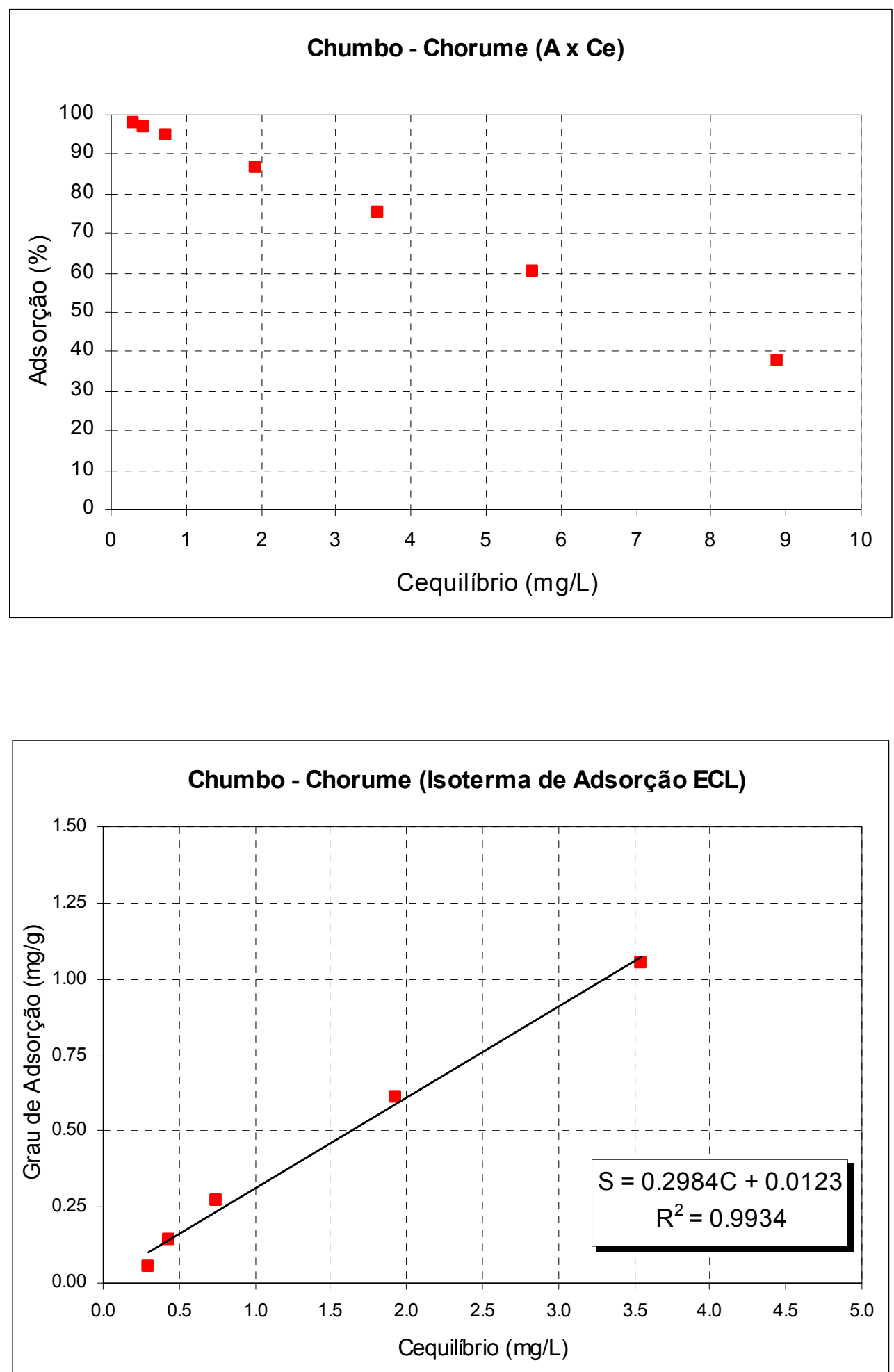